\title{
DISCOLPA DI SOCRATE
}

Benché per tutto il corso della mia vita franco et inatterito nell'affrontare l'accozzamenti et incorsioni della fortuna mi sono ad altrui dimostrato, negare non posso che l'accusa hora intentatami da miei malevoli habbia, come caso a me inaveduto et inopinato, alquanto stordito il mio intendimento. E chi harebbe giamai stimato che la sospensione del giudicio, retentione dell'assenso, il seguire nelli affari della vita il semplice e sincero probabile, et il rendermi ossequioso a cenni e taciti susuri delli dei sugeriscano materia a' caluniattori di lacerare la mia fama e deturpare il mio nome?

Essendo io perciò accusato al vostro spetabile tribunale, come se atrocissima sceleragine, non meno che li tempii delli dei e loro altari diruppato comesso havessi, m'attentino questi novelli Aniti e Meliti ciò che vogliono contra il concetto che la libertà del mio animo nella mente de' virtuosi ha procaciato, ché per il certo vano è per riuscire ogni loro conato e maligna intrapresa. Anzi di più hora mi avego che per tale loro querela, maggiormente a retenire l'assenso inclinare mi persuade, [14] ren|dendomi questa loro ingiuriosa accusa molto più che prima probabile, che nel nostro animo giamai alcuna indubitabile certezza allogii. E hora molto più di prima mi rimane probabile, che niuna opinione si trova appo l'homo di tal ferma esistenza, che al tormento del nostro importuno discorso alla fine non ceda e si pieghi, e che non vi sia oggetto rappresentato all'intelletto, che non prenda quel visaggio et apparenza, che egli li somministra e sugerisce.

Onde perciò li apprensibili in tanto essistano, in quanto che dalla nostra mente l'è prestato formalità et apparenza, il che grandemente si conforma con quello è solito il nostro Protagora pronontiare, che l'homo sia la misura delle cose che nel mondo ci appariscono, e di quelle che non sono nella maniera che ci spariscono, occorendo lo stesso alli oggetti da noi appresi, che a nostri vestiti e drappi, stimati da noi falsamente principali cagioni di quel calore, che da noi derivando, da essi ci è solamente reflesso e rimandato, così fors'erroneamente crediamo che quelle rimostranze, che nelli oggetti esterni scorgiamo, siano di loro germani imagini, mentre che per la verità, da noi in gran parte procedendo, ne siamo di esse originarie cause. E l'oggetto che concorre a produrli ci li regetta e rimanda, a guisa di spechi che reflettono l'imagini che incontrano, ma però conforme la diversità della conditione, figura, e compositura di essi spechi disguisano e variano li simulacri che ribattono. 


\section{SOCRATES'S DEFENCE}

Throughout all my life, I have demonstrated to others that I am courageous and unafraid of dealing with the adversities of fortune. Yet I cannot deny that this charge, brought against me now by my ill-wishers, confounds my understanding, since I find it abrupt and unexpected. Who would ever have assumed that my suspension of judgment, my constrained assent, my following of the simple and sincere probable as the only guide in life, and my obedience to the signs and silent whispers of the gods could have offered my slanderers enough reasons to tear my fame and disfigure my name?

Since for these reasons I am accused by your respectable court as if I had committed the most atrocious wickedness, comparable to robbing temples and the altars of gods, these newcomers Anytus and Meletus may attempt to say whatever they wish against the concepts that my freedom of spirit has produced in the minds of virtuous people, ${ }^{32}$ because I am sure that their every effort and malicious undertaking will be vain. Rather, I now realise that their complaint has persuaded me to constrain my assent [14] even more; their injurious charge makes it more probable than before that no indubitable certainty has ever been placed in our minds. And now I find it more likely than ever that no opinion has such a stable existence within human beings that it will not finally surrender and submit to our rash discourse, and that there is no object represented to the intellect that does not assume the aspect and appearance that the intellect itself provides and suggests.

Therefore, everything that is perceptible only exists because our mind gives it a form and appearance. This complies perfectly with what our Protagoras used to say: ${ }^{33}$ that a human being is the measure both of things [that are to the extent that they] appear to him in the world and also of those things which are not to the extent that they do not appear to him. ${ }^{34}$ The same [thing] happens to the objects that we apprehend: we wrongly consider our robes and coverings to be the source of that heat which, on the contrary, derives from ourselves and is merely reflected in them and sent back to us. Hence, we are used to believing, perhaps mistakenly, that those manifestations of external objects that we see are their true images, while in fact, we are their original cause, since most of them come from us. Furthermore, the objects participate in producing them by ejecting them and sending them back to us, like mirrors that reflect the images of the object in front of them. However, the ejected simulacra differentiate and diversify from one another in accordance with the different conditions, figures, and compositions of these mirrors. ${ }^{35}$ 
Da quindi aviene che la sospensione del giuditio, da me oltre modo salutare e giovevole al nostro genere giudicata, ad altrui, come tuttavia accade a questi miei accusatori, apparisca in eccesso pernitiosa e danevole, giudicandosi ciò da essi e da me con diversa dispositione d'animo.

Ma inanzi che io intraprenda la mia difesa, conviene che io spenga dall'animo di alcuno certa meraviglia, che per occasione di questa mia discolpa forse turbare lo potesse, et è, che professando io apatia e severissima alienatione di qualunque affetto, e che ad ogni urto e scossa di fortuna [15] sempre mi dimostrai indiferente, inalterabile, e non curante, a segno tale che già con il mio costante e libero ragionare, ma qual si conveniva al decoro filosofico, la cicuta affrapai da mani delli mali affetti giudici, e come che da me stesso mi dannai, nondimeno al presente, per conservarmi la popolare aura e concetto delli homini, cotanto io sia solecito et affanatto. Ma nondimeno, mentre che sarano advertiti et osservati, quali furno sempre in me l'incentivi e fini, che ressero le mie attioni, acquietarassi in altrui ogni stupore.

$\mathrm{Fu}$ sempre il mio proponimento non essere solamente nato economo de una privata famiglia, né patritio de particolare republica, ma cittadino dell'universo, stimando il publico servigio del comune delli homini il più proprio e decente esercitio che nel corso della mia vita adoperare mi potessi. Da quindi è che non mi lece trascurare punto la difesa dell'openione che il mondo tiene della mia virtù, dipendendo da ciò la stima delle dottrine, che per felicitare il nostro genere divolgai, havendomi l'osservatione delli humani affari dimostratto, che il valore e pregio di amaestramenti affatto dipende dalla openione che si ha de loro autori. Per il che riesce impossibile, che dannato et infamatto Socrate, che li suoi documenti siano osservati et eseguiti. Ma che li miei insegnamenti siano tali che tranquillare l'animo humano possino e che dispongano altrui a divenire felice, da ciò probabilmente giudicare si può, che essendo le impetuose perturbationi che agitano et infestano l'animo humano nelle false opinioni fondate, e radicate, il proprio e germano rimedio di sedare tali flutuationi è lo sbarbicare da noi questi tali openioni. Né altrimente ciò si può eseguire, se non con lo far sortire evidente, che incerto sia il concetto che tenimo del vero e falso, da cui dipendono le openioni de' quali siamo tanto tenaci e partiali.

Per il che in ciò ho pratticato il costume de perito medico, ché affrontandomi alla radice del male, ho procurato affatto dal nostro animo eliminare e [16] detru|derlo, non come sogliono li volgari fare, che con semplici refrigeranti sedare e temperare l'ardore della febre attentano, trascurando il fomite d'onde essa prende origine e vigore, ché perciò l'instituto mio fu il dimostrare che mentre non è diretta da 
Thus, the suspension of judgment, which I considered extremely salutary and favourable to humankind, is now considered pernicious and harmful by others, particularly by my slanderers, since they and I judge it with different mental frameworks.

Yet before starting my defence, it would first be worth extinguishing a certain astonishment in the minds of some who might perhaps be upset by the occasion of my exculpation. Since I profess apathy and the most severe alienation from any affection, I have always been indifferent, changeless, and heedless of any adversity of fortune, [15] to such an extent that as an expression of my constant and free reasoning, which is proper to philosophical decorum, I snatched the hemlock from the malevolent judges' hands. I did this as though I had banished myself from myself, at least for the present time, in order to preserve the popular favour and esteem that I had been solicitous and industrious to achieve for so long. However, all the astonishment of those others will be appeased as soon as the ever-present incentives and goals of my actions are acknowledged and observed.

My purpose was always to be born not a mere administrator of a private family, nor a patrician of a particular republic, but a citizen of the universe, ${ }^{36}$ since I considered being publicly at the disposal of the common people to be the most proper and decorous practice that I could have carried out throughout my life. This is why I cannot fail to defend myself against the world's opinions about my virtue, because the respect for the doctrine that I disseminated in order to bring happiness to humankind depends on it. Indeed, the observation of human affairs has demonstrated to me that the value and merit of any teaching depend on the general opinion that one has of its authors. For this reason, after Socrates's condemnation and defamation, it will be impossible for his teachings to be observed and followed. However, my teachings are able to appease the human mind as well as to dispose others towards happiness. In force of this, one may judge that since the impetuous perturbations that usually upset and infest the human mind are founded on and rooted in false opinions, the proper and true remedy for soothing this wavering is to eradicate these opinions in ourselves. The only way to accomplish this is to show that our concept of right and wrong, on which the opinions of which we are such tenacious and partisan supporters depend, is uncertain.

Therefore, in this respect, I practised the art of an expert doctor, because I dealt directly with the root of the evil in order to remove it from our minds and destroy it. ${ }^{37}$ [16] This was contrary to the custom of the common people, which attempts to soothe the ardour of a fever only by refreshing the body, disregarding the source where it takes its origin and strength. Hence, my task was to demonstrate that our minds 
Occasione della sospensione dell'assenso.

Racconto di openioni diverse circa li principii delle cose. superiore lume la nostra mente nulla di fermo, constante, et indubitabile apprende. Né perciò stimare dobbiate, che io affatto abbandoni le attioni della vita al forsenatto caso, ma sappiate che per mia scorta tengo il barlume del probabile, stella polare del viaggiare nel corso della mia età, né crediate parimente, Signori Giudici, che reprobando io la contumacia dell'assoluto assenso, overo dissenso, che talmente mentecatto io sia divenutto, che pertinacemente io nieghi, che da miei nemici mi sia hora intentatta gravissima querella, che voi, Signori Accademici, assistiate alla discussione della causa, e ch'io trattando mia discolpa disperi l'ottenerne assolutione, ché se talmente fossi disposto, non mi accingerei hora ad informarvi della mia innocenza per conseguirne favorevole sentenza.

Ma acciocché l'affare sortisca conforme la mia probabile aspettatione, conviene che esatamente con ogni maggiore puntualità vi racconti l'avenimenti che mi occorssero inanzi ch'io capitassi a tanta stupidità e codardia nell'affermare overo negare alcuno dogma. Dal che spero scorgerete, che non vana ambitione, come fingono li miei adversarii, cagionò nel mio animo tal sospensione di giuditio, ma piuttosto ragionevole e probabile discorso a ciò m'indusse et impulsò.

Stimo non esservi affatto occulto, Signori Giudici, con quanta applicatione et urgenza d'animo, nella mia giovenile età m'impiegai nelli esercitii della filosofia, non trascurando n'anco quelle arti che in maggior pregio e stima appo noi Greci si ritrovano, come la pittura, scultura, aritmetica, musica, e simili, onde progredendo in queste et in quella, diverso anzi contrario successo incontrai. Nell'arti predette quanto più m'inoltravo, tanto maggiormente profitavo, ma nella filosofia, alquanto in essa internandomi, [17] in difficoltà inestricabili mi conducevo, onde a tal segno divenne la mia mente confusa e turbata, che la vertigine delle irreconciliabili altercationi e contraposte et equilibratte opinioni il lume del discorso di essa mi abbagliò, e quasi affatto spense. Il che tanto più mi turbò, osservan do io che circa li primi principii dell'universal esser delle cose, tanto varii e repugnanti ritrovansi li pareri delli più insigni cultori della filosofia.

Cratilo e suoi seguaci, sempre paralitici, e tremanti, che si milantano trarre il loro dogma d'insino Omero, in continuo motto et agitatione ponevano l'universo, non admettendo in esso cosa che in flusso e flutuattione non si ritrovasse, apportandoci però con tal parere tanto di bene, che non resta a noi homini di che lagnarci del cangiamento del nostro stato dalla fortuna continuamente sconvolto, correndo tal disaventura anco l'universale di tutte le cose, dalla inevitabile fatalità sempre alterato e perturbato. 
cannot apprehend anything stable, constant, and indubitable when they are not led by superior light. ${ }^{38}$ You must not believe that I am abandoning the actions of my life into the hands of frenzied Chance, but you should know that my guide is the light of the probable, ${ }^{39}$ which is the North Star in my journey through life. Yet you must not even believe, Lord judges, that by reprimanding the obstinacy of absolute assent or dissent I have become so half-witted as to unceasingly deny the very serious complaint that my enemies are now proceeding against me. You, Lord Academicians, by attending the discussion of my case, must not expect me to despair of obtaining my absolution during my defence, for if I was so well-disposed towards it, I would not now be intending to inform you of my innocence in order to obtain a sentence in my favour.

However, in order to conclude the affair in accordance with my probable expectation, it would be worthwhile to tell you about the events that occurred to me before I ended up in the stupidity and cowardice of affirming or denying any dogmata in more detail. Therefore, I hope that you will realise that this suspension of judgment was not caused in my mind by vain ambition, as my opponents claim it to be, but rather that I was induced to it by reasonable and probable discourse.

I think that you well-know, Lord judges, that in my youth I devoted myself to the exercise of philosophy with much diligence and solicitude, without of course disregarding those arts such as painting, sculpture, arithmetic, music, and the like, which are held in high regard and esteem by us Greeks. But while I was advancing in the latter, I obtained different, rather contrary success in the former. The more I entered into the above-mentioned arts, the more I profited from them, but the deeper I delved into philosophy, [17] the more I encountered inextricable difficulties which made my mind so confused and upset that the vertigo produced by the irreconcilable conflicts ${ }^{40}$ and opposed and balanced opinions blinded the light of my reason and almost extinguished it. I was even more upset when I observed that the opinions of the most distinguished experts in philosophy concerning the first principles of the universal being of things are various and opposing.

Cratylus and his followers, ${ }^{41}$ perpetually paralytic and trembling and boasting of their doctrine dating back to Homer, considered the universe to be in continuous motion and everything in it to be flowing and fluctuating. However, this opinion brought us something positive: that we have no reason to complain about our condition being continuously upset by fortune, since all things universally have the same misfortune, namely to be always altered and perturbed by their inevitable fatality.
Cause of suspension of assent.

Account of different opinions concerning the first principles of things. 
Non lontano da Cratilo si trovava Protagora, che non solamente asseriva conforme l'openione del detto, che il tutto fosse in sempiterna agitatione, ma di più aggiungeva, che quello che apprendiamo altro non sia che motto, rapportamento, e relatione ad altrui, non ritrovandosi nell'ambito dell'universo cosa che per se stessa diffinitamente tale sia, ma ad altra sempre relata si riferisce, stimando egli che non vi sia per se stesso, né mobile, né mottore fissi e permanenti, ma il tutto in rispetto, e congresso ad altrui constituito. Siccome aviene al maggiore, equale e minore, che per loro stessi tali non sono, ma solamente in paragone ad altrui, in tal maniera anco diceva accadere all'imagini che ne corpi politi si veggono, che nel medesimo punto, e nel stesso tempo differenti apparenze rappresentano rispetto a diversi oggetti che colà mandano li loro simulacri e d'indi a varii organi visivi sono inviatti e reflessi.

Ma Xenofane e Melisso assiderati et intorpediti, per il contrario si lagnavano, che [18] l'uni|verso di languido e cadaveroso aspetto se li rappresentava, sospetando essi, che invece della Sapienza, nella monstruosa testa de Medusa si havessero incontrato, e che d'indi contratto havessero il suo letale veneno, per il che tutto ciò che miravano se li impetriva, et in immobile sasso convertiva. Per il che furno indotti ad asserire che quello veramente è, d'ogni motto fosse casso e privo.

Et a ciò Parmenide con suoi Eleatici aggiungevano che non solamente l'universo che veramente partecipa di essere fosse affatto otioso e scioperatto, ma di più privo d'ogni vaghezza e varietà, e tutto conforme, et a se stesso equabile sia, non essendo altro la promiscua diversità che in esso il senso scorge, che sogno de' vigilanti e delirio di sani.

Ma d'altra parte Eraclito con voce quasi inarticolatta et affanosa, dirottamente piangeva, ché non meno in sé, che in altrui, osservava un febrile calore, che se incaminava ad una grave accessione et incendioso parasismo, che in progresso di tempo era per incenerire l'universo, tenendo egli per indubitabile dogma che il tutto di fuoco fosse construtto, e che in esso doppo lungo deviamento, convertire si dovesse.

Anasimene vociferava che sebbene Eraclito non affatto dal vero deviava, attribuendo al fuoco la vita delle cose e la energia et efficacia delle attioni naturali, nondimeno il primo esordio loro dall'aria derivare, non essendo altro il fuoco che collisione e stropiciamento della istessa aria, che in se stesso esercitandosi e dibattendosi produce il calore, e genera la luce. Onde aria elaborata, secondo il suo parere, il fuoco nominare si deve. Ma tuttavia dalla openione de Eraclito non si discostava nel cominare l'arssione all'universo, aggiungendo sola- 
Not far from Cratylus, there was Protagoras. He not only affirmed in accordance with the above-mentioned opinion - that everything is in eternal restlessness, but he added that motion is only known insofar as it is connected with and related to others. For it is not possible to find something in the universe which is definitively so in itself, but rather everything is always connected to something else. He considered that no mover, whether mobile or fixed and permanent, existed in itself, but that everything existed in relation to and in connection with others.

As the concepts of major, equal, and minor do not exist in themselves but only in comparison with others, so it is, he said, with every image that can be seen in polished objects. They represent different appearances of different objects at the same point and the same time, which send out their simulacra. From there, the simulacra are sent to various visual organs and reflected from them.

Yet Xenophanes ${ }^{42}$ and Melissus, ${ }^{43}$ frozen and numb, complained on the contrary that the universe appeared to them with [18] a languid and cadaverous aspect. Indeed, they suspected that they had met the monstrous head of Medusa instead of Wisdom and had contracted her lethal poison, ${ }^{44}$ because everything that they looked at turned to immobile stone. They were therefore induced to assert that what truly exists is lacking and devoid of motion.

Besides this, Parmenides, ${ }^{45}$ along with his Eleatics, added that the universe that truly participates in existence was not only indeed idle and lazy, but moreover was lacking in any diversity and variety. Furthermore, [he believed that] the whole conforms with and is equal to itself, since the promiscuous diversity perceived by the senses is nothing but a dream for the awake and delirium for the sane. ${ }^{46}$

On the other hand, Heraclitus wept copiously, ${ }^{47}$ and in an almost inarticulate and laboured voice, he said that he had observed - in himself as well as in others - a febrile heat increasing to a grave conflagration and inflammatory paroxysm that, over time, would incinerate the universe. He considered it an indubitable dogma that everything was made of fire and that after a long deviation, everything must return to it. ${ }^{48}$

Anaximenes vociferated that Heraclitus was indeed not far from the truth in attributing the life of natural actions to fire, as well as their energy and effectiveness, ${ }^{49}$ since [he believed that] their first beginning derived from the air. Indeed [according to his ideas], fire is nothing but collision and friction of the air itself, which, by shaking and struggling in itself, then produces heat and light. Therefore, in his opinion, fire should have been called processed air. Yet [Anaximenes], in threatening the arson of the universe, was not so distant from Hera- 
mente, che l'ultima e finale ressolutione delle cose all'aria se redurebbe.

Contra questi Talete insurgeva occorendo, et apponendo a tal fantastico e chimerico abbrugiamento non solamente l'Eridano, che estinse già l'incendio che per l'arogante ardire di Fotonte, come dicono [19] li poeti, seguì, ma con il vasto oceano e coluvie di tutti li fiumi, procurava spengere et ammorzarlo, affermando egli che l'acqua havesse sugerito e prestato origine a tutto il contenuto del mondo, e che perciò piuttosto di universale diluvio temere conveniva.

A questi seguiva Orfeo con suoi giocosi poeti che non meno abhorivano la somerssione della acqua, che la sorpresa et assalto del fuoco, per il che alla terra se attenivano, fermo e constante elemento, né giammai a noi nocivo, se non che da maligne et aliene esalationi fosse turbatto e sconvolto, decantando la terra fecondissima madre e cortese altrice della sua prole.

A tutti questi semplici elementisti, si opponeva Empedocle, delle siciliane muse cultore, reclamando egli, che non conveniva ad un solo elemento raccomandare sì gran machina, ma che tutti li quattro detti elementi siano necessarii a tale construtione, aggiungendo de più, che soministrando questi solamente inerte materia, era bisognoso assignare alla struttura universale delle cose industrii ministri et efficaci agenti, che insieme accopiassero tali elementi, e che finito e terminato il periodo della loro compositione e congresso, di novo li disuniscano e separino. Per il che all'amore assegnò la fontione dell'ammassare, et all'odio del dividere e disgiungere.

Né di ciò si contentava Democrito et a tutti li predetti repugnava, affermando che né uno, né tutti li quatro volgari elementi fossero sufficienti a soministrare materia sempiterna al sublunare universo, e che li predetti né primi, né anziani appellare si devono, poiché, facilmente cangiandosi l'uno nell'altro, havevano bisogno di precedente e comune materia, che sottogiacesse impermutabile a tale conversione che perciò convenisse capitare a' primi ad inderivatti, et originarii elementi, talmente constanti e fermi, che renitenti fossero ad ogni alteratione, et incontro di violenza, e che giamai in altrui non si transformassero, quali secondo lui sono certi corpuscoli atomali et indivisibili, [20] onde per li urti e scosse che casualmente dall'uno all'altro perviene si amassano, e con l'intermedio del vacuo poi in diverse forme si configurano, e che per loro vario congresso riescono le loro compositioni dotatte di varie qualità e conditioni. 
clitus's opinion; he only added that all things are finally dissolved into the air.

Thales $^{50}$ rose up vehemently against them, not only contrasting such fantastic and chimeric burning with the river Eridanus, which had already extinguished the fire caused by the arrogant impudence of Phaeton, ${ }^{51}$ as the poets [19] said, but also attempting to smother and extinguish it with the vast ocean and all the rivers together. $\mathrm{He}$ affirmed that water furnished and gave rise to the whole content of the world, and therefore that it was necessary to be more afraid of a universal flood [than of fire].

Orpheus, ${ }^{52}$ with his playful poets who abhorred water's submersion as well as fire's surprise and assault, followed them. Hence he preferred to comply with the earth, as [he saw it as] a fixed and constant element, never harmful to us unless upset by malignant and exterior exhalations. He exalted the earth as the most fecund mother and courteous wet nurse of its offspring.

Then Empedocles, ${ }^{53}$ who was devoted to the Sicilian Muses, opposed all of these simple elemental philosophers. He claimed that it was not appropriate to attribute such great agency to only one element, but rather that all the elements were necessary for such construction. He further added that since these four elements provided only inert matter, it was necessary to designate some industrious ministers and effective agents for the universal structure of things, who would combine such elements together and then, once the time of their composition and union was ended and concluded, separate them again. For this reason, he assigned the task of amassing them to love, and that of dividing and separating them to strife.

Democritus was not satisfied by this, and he rejected all the above-mentioned [ideas]. ${ }^{54} \mathrm{He}$ affirmed that neither one sole [element] nor the four vulgar elements were sufficient to give sempiternal matter to the sublunary universe. Furthermore, those above-mentioned [elements] should not be called either prime or primaeval; indeed, as they easily changed into one another, they needed an underlying previous and common matter unalterable through this change. Therefore, [he stated that] it was sensible to proceed from the prime to the underived and original elements, so constant and fixed that they withstood any alteration or violent collision, as well as never turning into one another. According to him, these were certain atomic and indivisible corpuscles [20] which were accidentally grouped together because of shocks and collisions passing from one to another, as well as taking different forms by means of the vacuum. [He furthermore affirmed that] because of the various ways in which they could combine with one another, the resulting compositions were endowed with various qualities and conditions. 
Il che Democrito contemplando, di riso, osservai, che s'ismascelava, scorgendo, come egli diceva, un ludicro spettacolo, che il caso nel teatro del mondo gratis li rappresentava, cioè una zuffa e pugna che vertiva tra pigmei, quali sono l'atomi, e vastissimi giganti cioè le portioni maggiori dell'universo, rimanendo questi da quelli alla fine vinti e debelatti, poiché tali corpuscoli minimi et indivisibili invadendo con valida aggressone li piú nobili membri e portioni del mondo, prima alterando e doppo depravando e corrompendoli in progresso di tempo, poi alla fine li distrugono et aboliscono. Aggiongeva egli che siccome la fortuna prende gioco della turba delli homini, così reciprocamente il sapiente tratteniva il suo otio, con l'osservare li vanegiamenti che il forsenato et insano caso comette nell'administrare il terrestre globo.

Contra de costui Pitagora, benché del silentio amico, romoregiava, dicendo che l'introdurre corpo indivisibile implicava manifesta contradittione, ché essendo questo di trina dimensione, li ripugnava l'atomalità, e che perciò alla unità conveniva ritrarsi, principio semplice, et anziano, asserendo egli che fosse non meno essa origine dell'universo, che del numero, onde riassonta in diverse guise, havesse prodotto la moltiplice varietà e congerie delle cose.

A tali positioni contrastava Anasagora Calzomeno, fieramente invehendo contra loro autori, che affatto pazza prosontione fu la loro, intraprendendo essi dedurre da tali meschini principii tanta diversità di enti, fra essi repugnanti e contrarii, e che riusciva insano proponimento assignare al cieco et inosservante caso la struttura e compositione del tutto, e che giamai intelletto da ragionevole discorso moderato [21] po|teva assentire, che l'accidentale e fortuito incorso di atomi, overo d'altri elementi, producesse il mondo in cui riluce costante e regolata dispositione, ornata compositione, et ordinato collocamento de' cose, e che questi autori inanzi che a tal dogma capitassero dovevano esprimentare, se continuando per molto tempo in gettare a sorte li caratteri del greco alfabetto, se il caso, loro opefice dell'universo, l'havesse giammai potuto formare un paio de' versi della Iliade di Omero.

Per il che asseriva Anasagora che ritrovava più convenevole l'affermare, che nell'antico cahos vi erano confuse le essenze similarie delle cose, e che per lunghissimo tratto di tempo fra esse si agittassero, et in varie guise accozandosi, diversamente insieme s'ammasassero e ne risultasse da ciò differenti figure e varie construttioni, alle fiatte decentemente, e più sovente in maniere strane, assorde et insusistenti si accopiassero. Onde ritrovandosi al cahos coasistente una divina mente del tutto inspetrice, osservò li convenevoli congressi di 
Hence I observed that Democritus, as he was contemplating, roared with laughter while attending, ${ }^{55}$ as he said, to the ludic play which was performed gratis by Chance in the [great] theatre of the world..$^{56}$ Namely, [he said] it was like a fight and battle between pygmies - as the atoms are - and enormous giants - as the major parts of the universe are - which was ultimately won and carried by the former. Indeed, these minuscule and indivisible corpuscles aggressively invaded the noblest members and parts of world, at first altering them, then, as time went by, depraving and corrupting them, and finally destroying and eliminating them. He continued that while Fortune mocks the human rabble, the wise man idly observes the changes made by insane Chance in administrating the globe.

Despite Pythagoras being a lover of silence, he clamoured against him [i.e., Democritus]. He said that the introduction of an indivisible body implied an evident contradiction, because it was contrary to atomicity since this was of three dimensions. Therefore, it would be worthwhile to return to unity as a simple and primaeval principle. Hence he affirmed that this was at the origin of the universe as well as of numbers, and so, summarised in different ways, it produced a wide variety and congeries of things.

Anaxagoras of Clazomenae opposed such positions, ${ }^{57}$ proudly inveighing against their authors that theirs was indeed a mad presumption, because they believed that such a great diversity of beings could have been derived from those meagre principles, so opposite and contrary to one another. He further said that it would be insane to attribute the structure and composition of the whole to blind and disobedient Chance, and that the intellect even by rational discourse could not [21] agree with the idea that the accidental and fortuitous course of atoms, or rather of other elements, would produce this world [that is so] characterised by constant and regulated disposition and by the ordered composition and regulated placement of things. Besides, these authors, before ending up at this dogma, must have tested whether Chance - as the author of the universe, in their opinion - had ever produced at least two verses of Homer's Iliad by repeatedly casting lots with the letters of the Greek alphabet. ${ }^{58}$

Hence, Anaxagoras asserted that he found it more appropriate to affirm that the original Chaos contained a confused mix of those homogeneous essences of things, which, over a very long time, by shaking and clumping together in various ways, grouped themselves together in different combinations, resulting in various figures and constructions, since they sometimes combined themselves together decently, but more often in a strange, absurd, non-existent way. So a Divine Mind, inspecting the whole and coexisting with the Chaos, ${ }^{59}$ observed the pleasing 
quelle portioni e loro più permanenti strutture, e ne formò in se medesima di queste ferme e stabili idee, onde poi ad imitatione di esse, segregando poi quelli minutti fragmenti di essenze che nel cahos risedevano, ne construì varii et innumerabili semi originarii di tutto quello che nel mondo inferiore giornalmente si produce. E sebbene a noi tali semi sono insensibili, alla natura non sono punto ignoti, che più di Argo riesce occhiuta in scorgere ogni minutia di materia che al suo operare riesce proficua e giovevole.

Contra l'antedetti machinationi urgeva Platone, asserendo che nella mente divina insistevano certe idee che le servivano per norme e direttrici nell'operare, ma non come Anasagora sognava, che dal caso fossero primieramente construtti l'essemplari delle cose, ma stimava che l'idee d'una interna necessità residente in essa mente fossero sortite, a tali attribuivagli la efficientia della essentialità delle forme e spetii, non negando però [22] che vi fossi certa rude materia che soggiacesse alla impressione di dette idee.

Non mancava Aristotele, benché per anco giovane, di addurre in sì importante contesa alcuna novità, divolgando egli con gran acclamatione del suo fidele satelitio, che tre siano li principii anziani delle cose naturali: la privatione, che precede a qualunque che di novo si genera et è come di esso previa dispositrice et introdutrice, la materia in cui si produce, e la forma che constituisce et arreca perfetto essere al generato. La qual positione altretanto che manca di sodo fondamento, abbonda di solertia et aveduto accorgimento, essendosi il suo autore, per sfugire l'instanze et argomenti che da adversarii li sarebbero stato opposto, occultato e nascosto nelle latebri, et oscurità del niente, ché perciò constituì principio la privatione, che a mio credere è l'istesso niente, la materia, per se medesima destituta e spoliata di qualunque forma et è come pura potenza e vana capacità, e perciò ad esso niente contigua, e la forma in essa materia instalatta e sostenuta, e per questo dal niente non molto discosta e lontana.

Et arrivò a tal termine il litiggio, che insino li affumicati chimici, dalla fucina alla scola trapassatti, caluniavano acramente tutti l'antedetti sapienti come troppo indulgenti e codardi in constituire et esaminare la natura, milantandosi che solamente essi in tal affare riuscirono sufficienti, ché osservandola ritrosa e renitente in confessare e scoprire li suoi primi natali et esordii, al tormento del fuoco havendola posta, al suo dispetto l'havevano estorto tal verace confessione, che 'l solfore, mercurio, e sale fossero li veri e germani principii et elementi del tutto, 
encounters of those parts and their more permanent structures and then formed fixed and stable ideas of them in itself. Then, in imitation of them, and by separating the minute fragments of the essences that were in the Chaos, it constructed the various and innumerable original seeds of all that is daily produced in the inferior world. While we cannot perceive such seeds with our senses, Nature knows them very well: namely, it results as more all-seeing than Argus in catching every minutia of matter, ${ }^{60}$ which is useful and beneficial for its work.

Plato reacted to the above-mentioned machinations by affirming there were some ideas in the Divine Mind that were useful as rules and guidances of its action. Yet he believed that the exemplars of things were not originally made by Chance, as Anaxagoras envisioned, ${ }^{61}$ but rather that these ideas were produced by an internal necessity inside this Mind. He attributed the efficiency of the essentiality of forms and species to them, but without denying [22] that there was some unrefined matter underlying the impression of the above-mentioned ideas.

Aristotle, although [he was] still young, also brought some novelties to these important disputes. To the great acclamation of his faithful followers, he disclosed that there were three ancient principles of natural things. Privation, which precedes anything newly generated and predisposes and introduces every generated thing, the matter in which it is produced, and the form which composes and perfects its being. ${ }^{62}$ This position lacks a solid foundation, much as it abounds with diligence and prudent caution. Indeed, its author cloaked and hid himself in darkness and the gloom of nothingness in order to elude instances and arguments which would have been addressed to him by his opponents. Therefore, he made privation the principle [of the whole] (which in my opinion is nothingness itself); [he made] matter, deprived and stripped of any form in itself, a pure potency and vain capacity; and, since there is nothing that is contiguous to it, [he made] form, as it is settled and maintained in such matter, not so different and distant from the nothingness.

The quarrel proceeded towards the conclusion that even the blackened alchemists, passing from the laboratory into the school, had harshly defamed all the aforementioned wise men by considering them to be too indulgent and cowardly in constituting and examining Nature. They boasted of being the only ones able to manage this affair. For although they found nature to be bashful and reluctant to confess and disclose its ancient origin and beginning, nevertheless, by subjecting it to the torment of fire, ${ }^{63}$ they extracted the following true confession: that sulphide, mercury, and salt were the true and genuine principles and elements of the whole. 
Dubita Socrate.

Deliberatione di

Socrate in scandagliar se stesso.

Litigio fra li oggetti, sensi, intelletto e sapere circa la preminenza. esenze visibili, palpabili, non fantastiche e chimeriche come sono quelle che da primieri furono pronuntiati.

Altre assordità circa tal proposito da scioperatti furono promulgate, che troppo importuno riuscirei se hora reassumerle attentassi, ma dall'osservatione di tali litigi e controversie circa li [23] prinlcipii delle cose presi a sospettare della imbecilità dell'humano sapere, onde probabilmente argomentai, se tali e tante sono le repugnanze intorno li principii, che maggiormente siano per riuscire inestricabili le difficultà nel progresso del discorso, a guisa de linee che dal centro escono per inviarsi alla circonferenza che vicino al loro principio puoco l'una dall'altra si dilunga, ma progredendo sempre più si divertiscono.

Da quindi parimente cominciai a dubbitare che noi homini non siamo altrimente provisti de organi e facultà sufficienti ad apprendere e riconoscere la verità e che le prime basi e fondamenti, sopra li quali si erge l'edificio della humana sapienza, non siano altrimente fermi e stabili, ma arbitrarii e posti da noi a capricio, come accadere suole ad alcuni giochi et in particolare di scachi, che altro tanto che le dedotioni e consequenze riescono necessarie, le prime positioni sono affatto contingenti e volontarie.

Da tal sospetto adunque eccittato, risolsi rinonciare a qualunque altra speculatione, ma con diligente incombenza impiegarmi a riconoscere me stesso, et al maggior segno possibile scandaligiarmi, dedicandomi tutto in meditare ciò che sia questo nostro sapere che ci rende così pretendenti e fastosi, qual siano li suoi primieri fondamenti, li mezi e criterii con che si conseguisce, et insomma a qual grado possa egli arrivare, e sormontare.

Ma non sì tosto che acciò mi applicai, mi si attraversò ostacolo tale, che quasi totalmente distornò tal mio attentato, e ciò fu un grave litigio che nel mio animo mi si rappresentò. Rasembravami che le cose esterne, overo li oggetti che dire le vogliamo, sensi, intelletto, e l'istesso sapere insieme acramente contendessero, quale di essi precedere dovesse nell'esame e discusione da me instituita. Parevami che romoreggiassero li oggetti, che a tutti in tal esame conveniva fossero anteposti, urgendo che da essi prende esordio e norma il sapere nostro, rimproverando in particolare [24] all'in|telletto la sua meschina nudità, e nativa rudità mentre si trovi privo dell'ornamento de loro suppelletile, non apparendo egli ad essi altro che pura e mera potenza, habile solamente a ricevere l'impressioni de' loro influssi. 
These elements were visible and palpable essences, not fantastic and chimeric like those presented by the first philosophers. ${ }^{64}$

Some idle people have promulgated other absurdities concerning this [i.e., the original principles of the world], but it would be too inopportune now to attempt to summarise them. Yet in observing these arguments and controversies about the ancient [23] principles of things, I began to have suspicions about the imbecility of human knowledge. Following the probable, I therefore argued that if the disagreements concerning the principles were so complex and numerous, then the difficulties in the development of the discourse would be even more inexplicable. Just like lines that go from the centre to the circumference, when they are close to their origin, there is only a little distance between them, but as soon as they advance, they increasingly shift in different directions.

Hence I likewise began to suspect that as human beings we were indeed not endowed with sufficient organs and faculties to apprehend and acknowledge the truth. Besides, the early bases and foundations from which the edifice of human knowledge rises are indeed not fixed and stable, but arbitrary and laid at our whim, as is usually the case with games, especially with chess, where similarly, while deductions and consequences are necessary, the first positions are indeed contingent and voluntary. ${ }^{65}$

Motivated by such suspicions, I decided to renounce any other speculation and to diligently pursue the task of acknowledging and scrutinising ${ }^{66}$ myself as much as possible. Therefore, I completely devoted myself to meditating on this knowledge that makes us so pretentious and ostentatious: what its early foundations were, what were the means and criteria whereby one could attain it, and in conclusion, how far it could go and [even] surmount.

However, as soon as I began to pursue my work, I encountered an obstacle that almost completely diverted me from my purpose, and this was a serious argument that appeared in my mind. It seemed to me that external things - or objects, as we want to call them - the senses, the intellect, and knowledge itself were harshly quarrelling about which of them should precede the others in the examination and discussion I had instituted. It appeared to me that the objects were clamouring that it would be appropriate to put them before all the [others], insisting that our knowledge had its origin and derived its rule from them. They especially reproached [24] the intellect because of its poor nudity, native roughness, and lack of ornament and instruments, which they themselves possessed. Indeed, it appeared to them to be nothing other than a mere simple potency, only able to receive the impressions of their influences.
Socrates begins to doubt.

Socrates's decision to analyse himself.

Argument between objects, senses, intellect, and knowledge about supremacy. 
Onde quando essi fossero ignoti, riesce parimente impossibile l'apprendere qual sia tal sua potenza, e habilità, essendo necessario ad informarsi di ciò, riconoscere prima quelle cose a quali egli si ritrova disposto a ricevere, siccome che l'informarsi se un palaggio sia idoneo ad allogiarvi personagio di stima dipende dal riconoscere la qualità e conditione di tal hospite, e nell'istesso modo qualunque continente è riconosciuto dalla quantità del contenuto, così parimenti giammai non si potrà sapere qual sia la potenza e dispositione dell'intelletto, se non si apprendano prima le inteligibili che in lui s'introducano et instalano.

Ma l'intelletto parevami che gagliardamente di ciò si risentisse,

Risposta dell'intelletto.

Oggetti replicano. non potendo tolerare che semplice dispositione, capacità, e potenza

fosse appellato, difendendosi che non solamente teniva esistenza soda e reale, ma che egli da per sé di molte nuove inventioni senza l'adminicolo d'oggetti fosse sofficiente autore, e che il comporre, dividere, ordinare, permettere varie propositioni, e dedurne inopinate conclusioni, siano offitii suoi speciali, che trascendono et oltra passano di gran lunga alla inertia et inefficacia di semplice e languida dispositione, e potenza, esposta solamente a ricevere li colpi et impressioni d'altrui.

Ma li oggetti, mi si rappresentava che di nuovo repigliassero, denegando all'intelletto tali suoi vanti, sogiongendo, che mentre esso si trova privo della cognitione de' oggetti, non può né anco possedere, né tenere in sé norma alcuna di regolare et ordinare, permettere e dedurre alcuno concetto, né formare alcuna propositione, siccome se renderebbe anco impossibile a Zeus il saper egregiamente ordinare e temperare li colori, mentre che non havesse appreso ciò che sia il nero et il bianco, il rosso e [25] verde, e che l'esperienza l'havesse appieno instrutto il modo di decentemente insieme temperarli et anco dimostratali la riuscita di tali compositioni. E né anco il cuoco, quando assagiatto non havesse giamai il dolce, garbo, acre, e falso, tanto separatamente com'insieme mescolati, riuscirebbe perito nella professione di convenevolmente condire li cibi.

Onde concludevano essi, che l'intelletto per se medesimo si trova inetto all'esercitio delle antedette fontioni, mentre che del tutto da oggetti non fosse stato instrutto, informato, e diretto. Dal che finalmente raccoglievano che tutto quello d'inventione, che l'intelletto humano a se medesimo attribuisce, fosse delibato e preso dalla inspettione delle cose et oggetti che la natura esteriormente li offerisce, la quale non fu meno liberale all'huomo nell'ornarli la mente, di che li fu cortese di tanti altri commodi, e piaceri per trattenire giocondamente la sua vita. Per il che quelli che derivarono l'uso dell'aratro dall'im- 
Hence, if the objects were unknown, it would be similarly impossible to understand the potency and ability of the intellect. Indeed, in order to know them, one would first need to know those things that it is disposed to receive, just as asking whether a building is appropriate to receive an esteemed person depends on recognising the quality and condition of such a guest. And similarly, every container is known [only] by the quantity of its content, so we may never know the potency and disposition of the intellect without first learning the intelligibles which enter into it and settle there.

However, it seemed to me that the intellect felt greatly affronted by this, because it could not tolerate being called simply disposition, capacity, and potency. It defended itself not only by affirming its stable and genuine existence, but also [by affirming] that it alone was the sufficient author of many new inventions, without the support of objects. It further said that its particular tasks were combining, dividing, putting in order, and permitting various propositions, as well as deducing unexpected conclusions. Besides, [it claimed that] they considerably transcended and exceeded the inertia and ineffectiveness of a simple and languishing disposition and potency, which were only intended to receive blows and impressions from others.

Yet I imagined that the objects reacted once more, denying these merits of the intellect, adding that as long as it lacked cognition of objects, it could neither have nor hold in itself any rule in order to regulate, put in order, permit or deduce any concepts, nor form any propositions. It would be similarly impossible for Zeus to know how to organise and temper colours perfectly without having learned to distinguish black and white, red and [25] green, if experience did not completely instruct him concerning the correct way to temper them together or show the result of such compositions. And even a cook, if he had never tasted sweet, unripe, sour, and debased flavours, separately or mixed together, would not be an expert in the profession of appropriately seasoning food.

Therefore, they [i.e., the objects] concluded that the intellect was not able to carry out the above-mentioned functions by itself when it was not instructed, informed, and directed by objects concerning the whole. Hence, they finally deduced that every invention that the human intellect attributed to itself had been seized and taken from the observation of things and objects that nature had externally offered to it. Indeed, Nature was as generous to human beings in decorating their minds as it was courteous [in providing] them with many other comforts and pleasures to joyfully entertain their lives. Hence, like those who derived the use of the plough from immund animals, ${ }^{67}$ the
Answer from the intellect.

Answer from the objects. 
mondo animale, e l'arte tesitoria dal ragno, e bombice, e la edificatoria dalla nidificatione delli uccelli, con sincera et ingenua confessione refferirono l'origine di tali professioni a suoi primieri autori. E di più apportavano l'oggetti che non dovrebbe parer istrano all'intelletto, che essendo essi materiali, e come dice egli insensati, pretendessero l'esser stimati l'origine di tanti solertissimi ritrovamenti, che falsamente egli si usurpa, poiché siccome professava esser diligente osservatore delli avenimenti naturali, dovrebbe considerare qual fosse l'accuratezza et acume che tiene la natura loro direttrice nel suo operare, ché di facile scorgerebbe quanto di gran lunga è da essa avanzato, e superato nelle proprie sue fiache e tarde attioni.

Qual celebre pittore giammai rappresentò imagine così al vivo come che eseguiscono li oggetti visibili nelli corpi politi e tersi, eppure dalla semplice natura normati sono? Qual finto risalto di chiaro, e profondo di scuro può compararsi alla spicatura e ribalzi che [26] ap|parisce in spechi materiali? Ma quello che accresce la meraviglia è la celerità e prestezza del loro operare: si rafigura in spechio, conforme la grandezza e dimensione dell'oggetto, imagine, che agiustatamente lo rappresenta, a caso si spezza lo spechio et in minuti fragmenti si divide, in quell'istesso instante in cadauna di quelle picciole portioni apparisce il primiero ma impiciolito simulacro con simetria, proportione, e similtudine tali, che peritissimo pittore con li adminicoli di graticole, compassi, e dispendio di lungo tempo, alla perfettione di tale operatione non potrebbe giammai arrivare. Nel ritrovare il centro della gravità de' corpi è parimente la natura così aveduta che il più speculativo mecanico non potrebbe giamai ad essa egualiarsi, accorgendosi essa instantaneamente ove il centro si ritrova in qualsivoglia corpo per irregolare che egli sia, ciò che solertissimo ingegno appena nelli regolari con stentatte dimostrationi può conseguire.

Dal che resta evidente che l'intelletto nella esatezza e celerità dell'operare rispeto alli oggetti, è meno che scimia comparata all'huomo, il che risulta, devisavano questi, dall'havere essi la necessità maestra, a cui il tutto rende ossequio et obedienza. Ma l'intelletto dalli altrui influssi nelle sue operationi dipendente, et essendo semplice osservatore di ciò che fuori de lui accade, riesce sempre tardo, imbecile, et imperfetto nelle sue intraprese.

Onde, concludevano li oggetti che conveniva all'intelletto rinontiare ad essi ogni inventione, essendosi necessario sempre insistere nelli vestigii delle loro instruttioni, e che contentare si dovesse di esercitarsi circa la servile, sterile, e conditionata imitatione, fontione sua propria, 
art of weaving from the spider and the silkworm, and the art of building from the nesting of birds, they attributed the origin of such professions to their early authors with a sincere and ingenuous confession. The objects furthermore added that it should not seem strange to the intellect that, although they were material and - as the intellect said insensible, they demanded to be considered the origin of many very clever findings, which it had falsely usurped. Since this one [i.e., the intellect] declared itself to be a diligent observer of natural events, it should rather consider the accuracy and acumen of Nature as their director in its action. In this way, the intellect would easily realise that it was far exceeded by Nature and surpassed in its weak and slow actions. $^{68}$

What famous painter has ever represented an image so vivid as that which visible objects produce on polished and clear bodies, though they are ruled by simple Nature? What false contrast of light and dark may be compared with the mirroring and reflection [26] that appear on a material mirror ${ }^{69}$ However, what increases our astonishment is the rapidity and promptness of their working: the image is represented in the mirror, which accurately reproduces it according to the size and dimension of the object. If by chance the mirror breaks, dividing into minute fragments, in that instant the original - but smaller - simulacrum appears on each small shard, with such symmetry, proportion, and similarity that even the most expert painter, with his instruments, wire grills, ${ }^{70}$ compasses, and the expenditure of a long time, would never reach the perfection of such an operation. Likewise, Nature is so sagacious in finding the centre of gravity ${ }^{71}$ of bodies that even the most speculative mechanic could never equal it. Indeed, it instantaneously finds the centre of any body, even if it is irregular, and this is something that the cleverest intellect may barely achieve with laborious demonstrations.

Hence it is evident that if one compares the intellect with objects as regards exactitude and promptness, [one can see that] it is less than a monkey compared with a human being. And they devised that this results from the fact that they have necessity, to whom the whole pays respect and obedience, as a teacher. ${ }^{72}$ Yet the intellect, depending on other influences for its operations and as a simple observer of what happens outside itself, always turns out to be slow, imbecilic, and imperfect in its undertakings.

Hence, the objects concluded that it would be appropriate for the intellect to attribute all invention to them, since it was always necessary to insist on the vestiges of their instructions. And they said that it should be satisfied with only exercising itself in servile, sterile, and conditioned imitation, which was its proper function, 
Pretesta di sensi per la precedenza.

Pretesa di sensi, intelletto, sapere. e che oltra i limiti di essa non osasse progradire, raccogliendo pertanto ch'essendo l'intelletto destituto da simulacri dall'oggetti inviatoli et essendo spogliato di loro supeletile, rimane a se stesso inattengibile et incomprensibile, esimendosi perciò da qualunque esame, mentre però che non li [27] prece|desse la disquisitione di essi oggetti. E non solamente queti contra l'intelletto tenzonavano, ma con li sensi esterni parimenti intrapresero l'istesso litigio di precedenza, pretendendo che non essendo conoscenti essi sensi di loro stessi, alla classe di esterni oggetti redurre si devono, poiché né le membrane, umori, nervi, figura, sito e positura dell'occhio in altra maniera si osservano e riconoscono, che per mezo della disecatione anatomica in altrui administrata, ché perciò come oggetti esterni esaminare si debbano, e l'istesso alli altri sensi accadere per tale instanze da oggetti addotte.

Non cessavano li sensi, l'intelletto e l'istesso sapere contra essi oggetti insurgere, denegandoli tale prerogativa di prelatione, divisando che impossibile riesce appieno discuttere ciò che siano li oggetti se primieramente essi non siano esaminati e riconosciuti, adducendo che siccome nella administratione della publica giustitia prima si stabiliscono l'auttorità de' magistrati, le formule del progresso del giuditio, l'ellettione di giudici sinceri e sapienti, e la approbatione di testimonii che superano ogni eccettione, e poi che tutto ciò egregiamente fosse eseguito, s'introducono i litiganti, si agita la causa, e ventilatta che sia, alla ultima decisione si diviene, così nel presente caso, havendosi posto in dubbio o per dir meglio in sindicato, il giudice qual è l'intelletto, sospettandosi della fede di testimonii, cioè de' sensi, et altrecandosi della forma del giuditio ch'è il saper humano, resta per consequenza impedito il giuditio che circa li oggetti si attenta, che tengono le veci de quelli che a magistrati s'appresentano per essere giudicati.

Ma qual giusta sentenza, in tal stato ridotto l'affare, si può aspettare circa l'oggetti pretendenti l'anzianità nell'esame mentre il giudice si trova per anco imputato d'inscitia? Li testimonii, di falsità? Il modo di ordinare il progresso della giustitia e proferire la sentenza dubbioso e perplesso?

Né qui si terminò la contesa che fra l'intelletto e sensi sortì nuova

Protesta di sensi. gara e scisma. Pretendevano i [28] sensi sopra l'intelletto precedenza in tale esame, contendendo essere i primierii a ricevere le impressioni d'oggetti, et anziani referendarii delli esterni avenimenti, standosi l'intelletto sequestrato nel suo secreto gabinetto, ignaro per se 
and that it must not dare to go beyond the limits of this. They gathered that the intellect, once deprived of the simulacra sent by the objects and thus stripped of their furnishing, remained unattainable and incomprehensible to itself, and therefore exempted itself from any examination if it was not preceded [27] by the disquisition of an object. And they strove not only against the intellect, but even similarly argued against the external senses [by claiming that] since they were not able to know themselves, they must be reduced to the class of external objects. Indeed, just as membranes, humours, nerves, shapes, and the placement and position of the eyes must be examined like external objects, as they can be observed and acknowledged in the same way as anatomical dissection executed in others, the same should be done for the other senses because of this instance that the objects had adduced. The senses, intellect, and knowledge itself constantly revolted against the objects, denying them the prerogative of pre-emption. They devised that it was impossible to fully discuss the objects' nature without having first examined and acknowledged it. Furthermore, they adduced that just as in the public administration of justice, the authority of magistrates, the forms of development of judgment, the election of sincere and wise judges, and the approbation of the witnesses, which must pass every exception, have to be established first, and [only] after having excellently executed all of this may the disputants be introduced and the case be discussed and pondered, may one come to the final decision, so in the present case, since doubt was cast on the judge, as the intellect is, or better to say, it [i.e., the intellect] has been submitted to judgment, the trustworthiness of the witnesses - namely of the senses - suspected, and the form of judgment - which is human knowledge - discussed, consequently the same intended verdict of the objects, who take the place of those who step forward before the magistrates in order to be judged, was obstructed.

However, the senses concluded, once the case was reduced to this state, what just sentence about the objects' claim of ancestry could be expected from such an examination, considering that even the judge was accused of ignorance, the witnesses of falsity, and the means to organise the advancement of justice and pronounce the sentence of being doubtful and perplexed?

Yet the dispute, which produced a new contest and schism between the intellect and the senses, did not even end here. The senses [28] demanded precedence over the intellect in this examination, arguing that they were the first to receive impressions from objects, and [hence] the primaeval referents of external events, while the intellect was confined to its secret cabinet, unaware in itself of all the occurrences hap-
The senses claim to have precedence.

Claim of senses, intellect, and knowledge.

Protest of the senses. 
stesso di tutte l'emergenze che al di fuori accadono, attendendo egli solamente a quello che da essi gli è sugerito. Onde se faliscono con loro raguagli, affatto precipitarebbono tutti l'aerii edificii di esso intelletto, per il che concludevano che siccome l'architetto impiega primieramente il pensiero alla stabilità di fondamenti, che alla erettione dell'edifitio, così era decente che precedere dovesse l'esame intorno li sensi a qualunque altra consideratione instituita circa il saper humano:

Lucret. Denique ut in fabrica si prava est regula prima

Normaque si fallax rectis regionibus erit

Omnia mendose fieri atque obstipa necessum est

Prava cubantia, prona, supina, atque absona tecta

Iam ruere ut quadam videantur velle, ruantque
Prodita iudicis fallacibus omnia prima
Sic igitur ratio tibi rerum, prava necesse est
Falsaque sit, falsis quecumque ab sensibus orta est.

E fra sensi, il senso visivo particolarmente reclamava dicendo:

"E chi non osserva che dalla varietà de membrani, humori, nervi, configurationi, sito dell'occhi, risulta la diferenza dell'apparenza che si tiene di oggetti visibili?".

Per il che deducevano, che dalla inspettione et esame d'organi sensitivi

Protesta principiare si dovesse tale indagine, per seguire poi alla tratattione e dell' intelletto. disquisitione delli altri pretendenti.

Replicava l'intelletto che temeraria ricercata era di tutti loro l'attentare di esser anteposti, mentre si ritrovavano di conditione materiale, a quali è negato il riflettere e ragirarsi sopra loro stessi e divenir di loro medesmi giudici. Onde ritrovandosi a ciò [29] inha|bili conveniva che si appresentassero al suo spettabile tribunale, non vi essendo altro giudice ch'esso nell'huomo idoneo a riconoscerli, e che tal giuditio effetuare non si poteva, se prima non fosse riconosciuto la propria sua sufficienza et idoneità nell'esercitare questo affare. Per il che raccoglieva che prima di qualunque altra speculatione, esaminare si doveva qual fosse la prestantia dell'istesso intelletto nel riconoscer e giudicar le cose esterne, che se l'appresentano.

A tal instanza parevami che di nuovo fosse dalli suoi adversarii opposto, e ricercato, da cui esso giudicare si dovesse, e qual fosse il tribunale al quale incombeva tal impego.

Ma l'intelletto mi rassembrava che intrepidamente a ciò occoresse dicendo, che tal giuditio a se stesso apparteniva, e questo per privile- 
pening outside, attending only to what was suggested by them, so that if they were to fail in informing it, all the airy edifices of that same intellect would indeed collapse. Hence they finally concluded that just as an architect would consider the solidity of the foundation before erecting a building, so it would be fitting that the examination of the senses would precede any other instituted consideration concerning human knowledge:

Lastly, as in a building, if the original rule is warped, if the

Lucret.

Square is faulty and deviates from straight lines, if the level is a trifle

Wrong in any part, the whole house will necessarily be made in a

Faulty fashion and be falling over, warped, sloping,

Leaning forward, leaning back, all out of proportion, so that some parts seem about to

Collapse on the instant, and some do collapse, all betrayed by false

Principles at the beginning. So therefore your reasoning about

Things must be warped and false whenever it is based upon false

Senses. $^{73}$

And amongst the senses, vision especially demanded:

"Who may not see that the different appearance of visible objects is drawn from the variety of membranes, humours, nerves, configuration, and the position of the eyes?"

Hence, they deduced that one should begin this inquiry with the inspection and examination of the sensory organs and then follow the treatise and disquisition of the other claimants.

The intellect replied that all of their attempts to take precedence Protest of the intellect. were temerarious, since they were in a material condition and so were denied the opportunity to reflect, revolve, and become judges of themselves. Since they found themselves unable [29] to do this, the intellect said that it would be appropriate for them to appear before its honourable court, because there was no judge in a human being which would be suitable to acknowledge them other than itself. However, it was not possible to give such an assessment without first recognising its self-sufficiency and suitability for dealing with such an affair. Hence, it deduced that before any other speculation, one must first examine the ability of the intellect itself in acknowledging and judging the external things that present themselves to it.

It seemed to me that this instance was once more contradicted by its opponents, ${ }^{74}$ who were searching for the one who should judge it and the court which should be responsible for such a task. Yet it seemed to me that the intellect reacted intrepidly by saying that this assessment was 
gio speciale dalla natura concessoli, mercé della sua immaterialità, per il che in causa propria li è permesso di esser legitimo giudice, ritrovandosi egli agile a riflettere e rivolgersi sopra se stesso e divenire legitimo riconoscitore di se medesimo.

Replica di contendenti.

Contro di ciò insurgevano di novo li antedetti contendenti, dicendo che li pareva inadmessibile a qualunque si sia giudicare et apprendere se medesimo, e che ciò se li dimostrava tanto impossibile, quanto che il motore et mobile, l'agente et il patiente, il continente et il contenuto, e che il sugello e la materia impressa siano lo stesso. Oltra di ciò aggiungevano, che se tal riconoscimento e giuditio si permettesse, ne seguirebbe che per tutto il corso della humana vita continuarebbe questa speculatione, non potendo alcuno altro alieno oggetto tanto oltre insinuarsi, che detruda e spichi la mente da se medesima, non ritrovandosi oggetto più interno e prossimo quanto è la mente conoscibile, a se stessa conoscente. Oltre di ciò se tale cognitione reflessiva conceduta fosse, sortirebbe la più agevole e verace di tutte le altre che la mente intraprende, essendo l'oggetto tanto penetrante, presente e radicato alla facultà che lo riceve, eppure riesce fra le [30] ardue la più dificoltosa, ché perciò forse dall'oracolo al pari della duplicatione del suo cubico altare la propose, per eccitare et esercitare li greci ingegni alla contemplatione di più reconditi et astrusi quesiti.

Ma l'intelletto a ciò protestava, che se non li fosse admesso tal prerogativa d'esaminare e giudicare se medesimo, si rendeva affatto perplesso e dubbioso il sapere humano, e che perciò l'elaborate machine delle dottrine crolorebbero e forsi affatto rovinarebbero.

Rispondevano essi, che siccome alla giustitia comutativa è interdetto lo sbilanciarsi, per la meschinità che ne seguirebbe ad alcun de' litiganti, per cagione della giusta sentenza, così parimente riesce decente, che rimanga nella speculatione prohibito il deviare dalla verità e norma del ragionevole discorso, benché da ciò fosse per sortire qualsivoglia pregiuditiale nocumento al saper humano, e che sì bene dalle comuni leggi si trova impedito che si divenga di se medesimo homicida, nondimeno è conceduto al discorso humano che destruga se stesso, piuttosto che admettere alcuna falacia.

A questi pretendenti s'opponeva l'istesso sapere attentando ancor Pretesa del sapere. egli la degnità di tale anzianità, apportando a ciò non lieve ragione: divisava che molto disonante et assordo risultarebbe l'anteporre l'esame di qualunque cosa ad esso sapere, poiché discorrendo circa l'altri contendenti, infinite fiatte converebbe valersi del sapere e non 
its prerogative because of a special privilege granted by nature. Thanks to its immateriality, it was permitted to be the legitimate judge of itself concerning its own cause, since it was swift in revolving and reflecting on itself as well as in becoming a legitimate recogniser of itself.

The above-mentioned opponents [i.e., the senses] reacted to this once more, saying that it seemed inadmissible to them that anyone, whoever he might be, could judge and know himself, and this appeared to be as impossible for them as to consider the mover and the mobile, the agent and the patient, the container and the content, or the seal and the impressed matter, to be the same thing. They furthermore added that if such an acknowledgement and judgment had been permitted, it would follow that this speculation would continue throughout all human life, since no other extraneous object could penetrate that far without expelling or detaching the mind from itself. Indeed, it was impossible to find an object nearer and more internal to it than the knowable mind, the knower of itself. ${ }^{75}$ Furthermore, if such reflexive cognition were permitted, it would turn out to be the agilest and truest of all the others undertaken by the mind, since the object is so internal, present, and deep-rooted in the faculty which receives it. Nevertheless, it remains the most difficult of all the arduous [tasks]. [30] Hence, perhaps the Oracle could have suggested it, similarly to the duplication of the cubic altar, ${ }^{76}$ in order to excite and exercise the Greek intellects in the contemplation of the most recondite and abstruse questions.

Yet the intellect protested that if it was not permitted the prerogative to examine and judge itself, then human knowledge would become confused and doubtful, and thus all the elaborated machination of doctrines would collapse, or perhaps they would indeed become spoilt. They [i.e., the senses] answered that just as corrective justice was forbidden to lose the balance because [it must attain] the correct sentence and thereby [avoid] the misery which would befall one of the disputants, ${ }^{77}$ so it was appropriate to forbid deviation from the truth and from the rule of rational discourse in speculation, even if this would result in prejudicial harm to human knowledge. And although common rules prevented a person from becoming his own murderer, nevertheless human discourse was permitted to destroy itself rather than to acknowledge any fallacy.

Knowledge itself opposed these pretenders by once more supporting the dignity of its seniority, adducing not-so-feeble reason in favour of this. She thought that placing the examination of anything before [the examination of] knowledge itself would be extremely dissonant and absurd. The reason for this was that in debating about the other opponents, it would have been infinitely more useful to take advan-
Answer of the opponents.

Knowledge's claim. 
sapere, il che seguirebbe senza tenire di tali vocaboli contezza et informatione alcuna, e che perciò bisognarebbe supporre la cognitione di ciò che fosse sapere, mentre che per anco si trova ignoto, e sebbene che tale instanza fosse insuperabile, tuttavia, invece di risolverla et appianarla, attentarno piuttosto li adversarii addurre nuova difficoltà.

Contendevano essi che impossibile fosse riconoscere ciò che sia sapere, se prima che se imprenda tal affare, non fosse posto in chiaro ciò che sia il conoscente et il conoscibile, essendo il sapere un certo raportamento e relatione che tra questi si ritrova, tanto è a dire, prole [31] che prende li suoi natali dal congresso et accopiamento delli doi antedetti cioè, lo sciente e scibile, sopra li quali sostiene la sua fiaca e debole conditione.

Siccome anco restarebbe occulto ciò che sia amore, se prima non si tenesse cognitione di quello che fosse l'amante e l'oggetto amabile, di più soggiungevano che tanto era assordo il pronuntiare sapere del sapere, quanto il dire moversi il motto, vedersi la visione, et udire l'udito, ma che ben decentemente si proferirebbe, moversi il mobile, vedersi l'oggetto colorato, et udirsi il suono, come anco convenevolmente si pronontiarebbe sapere lo scibile. La cagione di tale assordo procede per essere tali relationi e raportamenti di natura tanto fievole et imbecile, che non possiede energia di causare in altrui alcuna impressione, et imagine, che li rapresenti, e di più sono parimente tali relationi anco di conditione tanto labile e fugace, che non può per causa di essempio il posteriore sapere afferare et apprendere l'anteriore sapere, che tiene la vice dell'oggetto apprensibile, che non sia di già questo spento et estinto, et a guisa di onda marina, che seguendo l'antecedente non la può ragiungere, e quando essa alla ripa si ritrova, quella che la precede è già franta e spenta, il che apunto accade al nostro sapere, quando intraprende venire in cognitione dell'istesso sapere:

Credule quid frustra simulacra fugacia captas.

A questa obbiettione aggregavano de più quello fu di già all'intelletto opposto, cioè che non solamente delle leggi humane rimane prohibito che alcuno in causa propria non potesse esercitare la carica di giudice, ma che l'istessa impossibilità reclamava contra tal intrapresa, dovendo sempre il giudice tenire alcuna prerogativa sopra il giudicabile, ché altrimenti non li conveniva assumersi autorità di giudicarlo. Per il che anco riusciva indecente al sapere l'intraprendere il giuditio circa ciò 
tage of knowing and not-knowing. [Yet, on the contrary], this would occur without it having any cognition or information about such terms. Therefore, one would have to be aware of what knowledge was while it was still unknown. Furthermore, although such an instance was insuperable, nevertheless the adversaries rather adduced new difficulties instead of solving and overcoming it.

They contended that it was impossible to acknowledge what knowledge was without first clarifying what the knower and the knowable were, since knowledge is a kind of correspondence and relation between them. It may be said that [knowledge is like] an offspring [31] born of the union and match of the two mentioned above, namely the knower and the knowable, on which it [i.e., knowledge] supports its feeble and weak condition, just as what love is would remain hidden if one did not first have cognition of what the lover and the lovable object were.

They furthermore added that claiming to know knowledge was as absurd as saying "to move motion, to see vision, and to hear what is heard," but that it would be correct to say "moving the mobile, seeing the coloured object, and hearing the sound," as well as it being appropriate to say "knowing the knowable." The cause of this absurdity was drawn from the fact that the nature of these relations and connections was so weak and incapable that it did not have enough energy to cause any impression or image which represented them in others. Furthermore, these relations were of such a transient and fleeting condition that the subsequent knowledge could not catch or apprehend the previous knowledge via analogy, which would take the place of the apprehensible object, since it would already be extinguished and extinct. Indeed, it was like a marine wave which, coming on the heels of the one that precedes it, never catches up; and when that wave strikes the shore, the one before it has already broken and ebbed away. The same indeed occurs to our knowledge when it undertakes to attain cognition of knowledge itself:

O fondly foolish boy, why vainly seek to clasp a fleeting image ${ }^{78}$

To this objection, they furthermore added what had already been opposed against the intellect, namely that not only was it forbidden to be a judge of one's own case, according to human rules, but that this was even impossible. Indeed, the judge must hold the prerogative in respect of the one who is judged, otherwise it would not be appropriate to assume the authority to judge him. Therefore, it would also turn out to be inappropriate for knowledge to attempt to judge what knowledge 
Nuova replica dell'intelletto.

Dubbietà di Socrate.

Principia dalli oggetti l'esame. che sia sapere, [32] essenldo il giudice et il giudicato della medesima conditione, anzi l'istesso.

Ma il sapere parevami che contro l'intelletto di novo risurgeva, protestandoli, che se ad esso era interdetto il riconoscere ciò che sia sapere, non potendosi stringere et afferare tal fievole e fugitivo oggetto, che anco all'intelletto restarebbe impedito il riconoscere ciò che sia motto, attione, passione, alterattione, generatione, coruttione, sensattione, contatto e tutto quello che si riduce al genere della relatione, portione grandissima e quasi totale del scibile, e se la opinione di Cratilo e Protagora giammai si admetesse, che a tal classe tutte le cose dell'universo riducono, sarebbe esso intelletto casso e privo d'ogni intelligenza e sapere. Rimasero perciò attoniti et affrontati l'intelletto, sensi et oggetti, ma non perciò sviluppò et appianò lo sapere le difficoltà che li suoi emuli l'opponevano, onde restarno tutti li predetti l'uni dalli altri illaqueati et impediti.

Ma io, osservatore di tal pugna e tenzone che nel mio animo s'agitava, tanto mi resentii dalle equelibrate e contraposte addotte instanze, che giudicandole tutte di simile et egual peso, non mi poteo risolvere a qual di esse prestare l'assenso dovessi, et a qual di pretendenti la precedenza convenisse concedere. Onde, nuovo Tantalo divenuto, in tanta copia di ragioni ad alcuna di esse appigliare non mi era permesso:

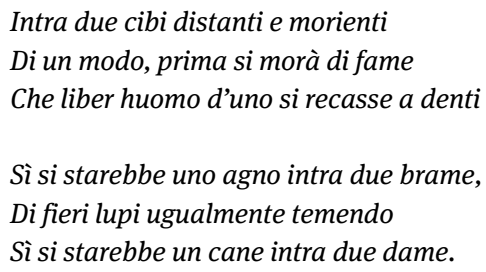

Per tale perplesità dunque mi rimaneva impedito il progresso alla propostami discussione, dovendo suporre sempre la cognitione di alcuni di questi contendenti alla [33] di altrui, né a tutti insieme nel medesimo tempo applicare mi potevo, repugnando a ciò la loro diversità, essendo impossibile che una sola facoltà, nel stesso instante, a differenti speculationi addattare si possa. Onde perciò, come dissi, mi restava affatto interclusa la strada ad oltrarmi con il discorso in tal inchiesta, ma per non abbandonare proponimento con tal fervore d'animo dal principio da me abbraciato, determinai, disimulando per allhora l'antedette difficoltà, all'oggetti primieramente applicare il mio discorso, ritrovandomi casualmente in quel tempo circa essi vagante et impiegato. Da 
is, [32] since the judge and the judged are of the same condition, or rather they are one and the same.

Yet it seemed to me that knowledge revolted against the intellect once more. It protested that just as it was prohibited from acknowledging what knowledge was - because it is impossible to grasp and catch such a feeble and fugitive object - so also the intellect would be prevented from acknowledging what motion, action, passion, alteration, generation, corruption, sensation, and contact were, along with everything that could be reduced to the genus of relative, ${ }^{79}$ as this is a very great part and almost the totality of the knowable. If one had ever accepted Cratylus's and Protagoras's opinion, which reduced all the things of the universe to such a category, then the intellect would be empty and lacking in intelligence and knowledge. Thus, the intellect, the senses, and the objects remained astonished and offended, but knowledge did not disentangle or smooth out the difficulties raised by its opponents. Therefore, they all remained in the above-mentioned ensnared condition and obstructed each other.

Yet as a spectator of these fights and contentions agitating my mind, I was so struck by the opposing instances that all of them were equally advancing that, judging all of them to be of similar and equal value, I could not decide to which of them I should give my assent and to which of the opponents it would be worthwhile to concede the priority. ${ }^{80}$ Thus, with such an abundance of reasons, I was not allowed to hold on to any of them, like a new Tantalus: ${ }^{81}$

Between two dishes, equidistant from him

And equally attractive, a man would starve

Of his own free will, before he ate one of them;

So would a lamb stand still between the greeds

Of two fierce wolves, fearing both equally;

So would a dog stand still between two deer. ${ }^{82}$

Then, because of this perplexity, I was prevented from developing the proposed debate, since I always had to suppose the cognition of some of these opponents before that [33] of the others. Likewise, I could not apply myself to all of them at the same time, since their own diversity opposed it: indeed, it was impossible that only one faculty at once could pursue different speculations. Hence, as I said, the way to continue with the discourse in such an inquiry was indeed obstructed. Yet in order not to abandon the purpose which I had initially fervently embraced, I decided - by dissimulating the above-mentioned difficulties for the moment - to first dedicate my discourse to objects, since by chance I was wondering about them and committed to them;
Socrates's doubts.

The examination begins with the objects. 
Ricerca se vi sia un oggetto universale.

Stima da principio che sia il vero.

Rigetta tal oggetto.

Congresso con Gorgia leontino. questi dunque prendendo li primi auspicii della mia speculatione, il primo attentato circa di essi fu, che osservando la loro varietà e moltiplicità, presi a considerare, se vi fosse un tal oggetto universale che sia adequato impronto, e sugello, che s'agguagliasse alla ampla capacità della nostra mente, a guisa del colore che serve alla vista per suo oggetto proprio, et universale, et il suono all'udito.

Ma contemplando io circa ciò, mi si appresentò in primo loco il vero, apparendomi che egli fosse quel tale che tenga simile facoltà di corispondere alla contenenza della mente. Ma considerando ciò piú acramente, mi s'affaciò che la verità piuttosto fosse una risultanza dipendente dal nostro intendimento, che oggetto, che precedentemente mova l'intelletto e l'informi, consistendo l'esser del vero in certa posteriore relatione, e raportamento, cioè in la corispondenza e similitudine che verte fra l'oggetto, e l'imagine che l'intelletto di esso concepisce. Per il che tralasciando il vero come non idoneo al mio proponimento, invece di lui all'istesso essere over ente, che dir lo vogliamo, mi appigliai. Il qual stimai che con suoi vastissimi amplessi abbracciasse tutto l'ambito del sensibile et inteligibili, non potendo la mente humana, fuori delli di lui difusi termini, ritrovare che di apprendere e riconoscere. Per il che giudicai che sotto il vessilo dell'ente, incaminar dovesse sempre l'intelletto il traino de [34] tutte le sue speculattioni.

Ma mentre che circa ciò ruminavo, nella nostra città Gorgia leontino capitò, celebre non solamente per certa copia et effluvio di universale eloquenza, flessibile et indiferente insino alla difesa di ambi li contraditorii, ma anco famoso per lo studio della reale sapienza. Costui fra le altre sue intraprese, lo rese insigne l'espugnatione dell'ente, da esso attentata, al niente riducendolo. Per il che si accese in me desio di seco trattare, e di questo da me asserto universal oggetto e sugello della mente devisarne. Non mi riuscì difficile contrahere seco amicitia, ritrovandolo di conditione molto humana et urbana, onde una fiatta, accadendoci esser ambi alquanto otiosi, l'interrogai del suo parere circa questo mio pensamento, et egli in tal maniera mi favellò:

"Se il mio sentimento intorno l'esser over ente ricerchi, talmente io verso lui mi ritrovo abbacinato, che nulla di certo in ciò arrecare ti potrei. Il comune ragionare, il generale intendimento delli homini, e la lunga loro consuetudine affermano che vi sia fuor di noi certa cosa soda e di massicia consistentia che ci tenga compagnia e società, ma gagliarde instanze movono e persuadono la mente mia a ciò rifiutare, e mi rendono oltre modo circa tal esser dubbioso e perplesso. Troppo lungo sarei se le contraposte ragioni di tal speculatione hora raccontare ti volessi, ma ti rimetto a miei scritti, da quelli restarai circa ciò appieno, a mio credere, satisfatto. Ma se hora, conforme la corrente openione affermi ritrovarsi fuori di noi tal esser per se stesso susistente, e procuri sapere, 
hence, I began my speculation with them. The first attempt concerning them was that seeing their variety and multiplicity, I kept considering whether a universal object existed.[This should be] an appropriate imprint and seal, able to match the extensive capacity of our minds, like colour, which is used by the eyesight as both its own and a universal object, or like sound for hearing.

Yet while I was contemplating this, at first the truth appeared to me like one who similarly had a faculty to correspond to the contents of the mind. However, after having considered it more carefully, I realised that the truth was a simple result depending on our understanding, rather than an object which has previously moved and informed the intellect. Indeed, the essence of the truth consists of a certain subsequent relation and connection, namely of a correspondence and similarity between the object and the image [of the object] that the intellect conceives. So, after having dismissed the truth as unsuitable for my proposal, I instead settled on being itself, or ens, whatever it might be called. Since the human mind cannot apprehend or acknowledge anything outside of its wide limits, I thought that with its vastness, it [i.e., being or ens] could embrace the whole field of the perceptible and the intelligible. Thus, I judged that the intellect must always direct [34] the sequence of all its speculations under the banner of ens.

Yet while I was ruminating on this, Gorgias of Leontini, famous not only for the abundance and diffuseness of his universal eloquence [which was] sufficiently flexible and indifferent to even defend two contradictory opinions - but also for the study of genuine wisdom, arrived in our city. Among his other undertakings, what had made him famous was the conquest of ens that he had attempted and his reduction of it to nothingness. ${ }^{83}$ Thus, this aroused a desire in me to meet with him and to think on this universal object, as I have asserted, and seal of the mind. It was not difficult for me to befriend him; indeed, I found him very human and sociable. Then it once happened that we were both very idle, so I asked him about his opinion concerning my thinking and he spoke to me in the following way:

"If you seek my opinion about being or ens, I may not give you any certainty about it, since I am so involved in it. The common way of reasoning, the general understanding of human beings, and their long consuetude demonstrate that there is something with a solid and massy consistency outside us which maintains us together and in society. Yet strong instances have moved and persuaded my mind to deny this and have also made me extremely doubtful and perplexed about this being. I would be dwelling on it too much if I told you the opposing reasons for this speculation now; therefore, I refer you to my writings, ${ }^{84}$ whereof I believe you will be fully satisfied concerning this matter. Yet if you affirm now, in accordance with the current opinion, that there is such a self-subsistent being outside us and that you are attempting to know whether
Research about the existence of a universal object.

First consideration of what the truth is.

Rejection of such an object. 
se decentemente egli sia stabilito adequato oggeto della mente humana, diroti quello, che conforme tal suposito mi rassembra”.

\section{Al che risposi:}

"Giacché tuoi dotti scritti mi offerisci, di quello che contengono per hora non chiedo, ma solamente ti dimando che mi raguagli, s'esso ente conforme il comune parere, sia l'oggetto adequato et universale della nostra mente".

\section{Al che sogionse egli:}

"In troppo angusto termine e [35] stretto recinto, o Socrate, attenti rachiudere l'innumerabili schiere de' inteligibili, mentre che nelli limiti dell'ente intraprendi sequestrare e confinarle. E troppo breve cariera proposto haresti alla humana curiosità, avida non solamente d'abbraciare l'infinito, ma trapassarlo se possibile le fosse".

\section{Repigliai io:}

"Non è l'ente quello che con suoi larghi dilatamenti include in sé tutto l'apprensibile? E ciò che da esso non è abbracciato, nell'anientato niente s'incontra e concide?".

\section{Ma egli a me:}

Ricerca circa l'univocatione dell'ente.

"Dimmi, diletto Socrate, quando tal esser, over ente come oggeto universale della mente apprendi, lo consideri come una tal cosa terminata, homogenea, similare, et equabile, over piuttosto si ti rappresenta una faraginosa moltitudine, varia, ilimitata, sciolta, heterogenea, dissimilare, e di differenti e contrarie portioni construtta et amassata?”.

\section{Risposi:}

"Per il certo negarti non posso, che mi rassembra scorgere una tal cosa limitata, similare, che tenga facoltà di fermare, e terminare la mente. Et in qual maniera, prestante Gorgia, potrei giammai admettere che mente humana, nel medesimo momento di tempo, diversi e varii oggetti apprendere potesse?"

\section{Al che Gorgia:}

"Egregiamente divisasti, et in breve ti sei condotto ove che con molto giro Riprende stimavo che appena capitar dovessi. Per il che siccome admiro la perspicacità gnanza et accozamento del tuo dogma con la quottidiana apparenza de' sensi”. 
it can be appropriately established as an adequate object of the human mind, I will tell you what seems to me to be in compliance with this premise.”

\section{Hence I answered:}

"As you are offering me your learned writings, for the moment I will not ask you about their content, but will only ask you whether this ens, according to the common opinion, is the adequate and universal object of our minds.”

\section{Thus, he continued:}

"You are attempting to enclose the innumerable arrays of intelligibles into too narrow a term and too tight a corral, oh Socrates, [35] when you undertake to sequester and confine them into the limits of ens. And you would have put forth too brief a course for human curiosity, [which is] eager not only to encompass the infinite, but also to go beyond it, if this were possible."

\section{I continued:}

"Ens includes all of the apprehensible in its wide extension, does it not? And those things which are not encompassed by it, they match the annihilated nothingness and [even] coincide with it, do they not?"

\section{And he replied to me:}

"Tell me, dear Socrates, when you apprehend this being, or ens, like a universal object of the mind, do you consider it as limited, homogeneous, similar, and equable, or do you rather represent it as a jumbled multitude, various, unlimited, free, heterogeneous, and dissimilar, built and muddled up of different and opposite parts?”

\section{I answered:}

"Certainly I cannot deny that it seems to me to be a limited and similar thing, which has the ability to set and delimit the mind. And how, oh excellent Gorgias, could I ever admit that the human mind could apprehend different and various objects at the same time?"

\section{Hence Gorgias [said]:}

"You have made an excellent examination and you have quickly led yourself to somewhere that I thought it would take you a long time to reach. Therefore, just as I admire the perspicacity of your intellect, so on the contrary I wonder that you do not recognise the opposition and contrast between your dogma and the appearances [perceived by] the senses every day."

Research on uniqueness of ens.

Gorgias reproaches

Socrates for his

carelessness. 
Rumore che pose

Parmenide circa

l'ente.
Considerationi circa

l'ente difficile.

Circa il non ente move difficoltà.
Et io ad esso:

"Per il vero il sommo dell'ignoranza stimarei che fosse, il ritrovarsi irretito et invilupato nelli errori, e tutavia non avedersene, per il che pregoti che mi rendi avisato di tale mia inadvertentia, e schiochezza”.

Et egli:

"Il pregio del desio di emendarti che tieni supera di gran lunga la difalta della tua ignoranza. La difficoltà dunque in che sei incapato è tale: se l'universo d'un solo essere fosse construtto, e come che tal uniforme et universale oggetto si ti appresentasse, il tuo dogma forse admettere [36] si poltrebbe, ma essendo esso universo come ci si mostra di dissimili e contrarie portioni amassatto, e di varii visaggi construtto, riesce impossibile, che tal oggetto homogeneo e similare contenga tutti li sensibili et intelligibili tanto fra essi repugnanti e contrarii. Dal che si deduce che ambe queste tue assertioni insieme complicate, cioè che l'essere sia l'adaquatto oggetto della mente, e parimente che egli sia homogeneo e similare, repugnano con la moltiplice e repugnante diversità che nell'universo apparisce, ché se pure ambe le predette tue positioni sostenere vogli, conviensi capitare al parere di Parmenide, che havendo primieramente comosso Elea sua patria, non poco di turbatione poi fra sapienti di questa città concitò. Affermò egli che le differenze, e contrarietà delle cose che nell'universo osservamo, siano mere illusioni, e fallacie del senso, overo vane apparenze della fantasia, ma che l'esser della mente appreso, sia tutto unito, equabile, e similare, e ch'egli solo tenga del vero e reale".

Ringratiai Gorgia del lume che in tal proposito mi sugerì, ma di nuovo lo richiesi se altro circa ciò di recondito e pregiato nelli tesori della sua mirabile sapienza ritenesse.

$\mathrm{Al}$ che egli soggionse che, a confessarmi il vero, che di qualunque altra inchiesta piuttosto desiderava esser ricercato che di ciò che all'ente appartenesse, non vi essendo, conforme il suo parere, quesito che maggiormente rimproveri la nostra inscitia e sciochezza, ché dovrebbe pur l'ente, come il primiero che ci si affaci et essendo fondamentale delle altre ricercare, riuscire il più piano e spiegato. E nondimeno praticando circa esso la speculatione, sortisce il più arduo e dificoltoso, e ciò non solamente circa l'ente accade, ma maggiormente intorno il non ente occore simili inviluppi, ché pur senza la cognitione di questo, pervenire non si può all'apprensione dell'ente, come si dirà.

"Primieramente mi si attraversô", diceva egli, "che del non ente, o niente che appellare lo vogliamo, conforme il calcolo di tutti li [37] sapienlti non si può di lui tenirne concetto, openione, e sentimento alcuno, non possedendo egli efficacia et energia tale, che produca di sé in altrui vestigio di alcuna impressione, riuscendo affatto sterile di potere generare simulacro et imagine che lo rappresenti e rafiguri. Ma per altro verso, se di esso non potemo haverne cognitione 
And I [said] to him:

"Truly, I consider the greatest ignorance to be becoming entangled and ensnared in mistakes and nevertheless to be unaware of it. Therefore, please inform me of my inadvertence and foolishness.”

And he [said]:

"The value of your desire to be corrected far exceeds the fault of your ignorance. Hence, the difficulty that you have encountered is such that if the universe were composed of only one being, and it represented itself to you as a uniform and universal object, your dogma could perhaps be [36] admitted. Yet since this universe shows us that it is a heap of dissimilar and opposite parts, and composed of different faces, it turns out to be impossible that such a homogeneous and similar object may contain all the sensibles and intelligibles, which are so opposite and conflicting with each other. One may deduce from this that both of these statements mixed together - namely that being is an adequate object of the mind and likewise that it is homogeneous and similar - conflict with the multiple and opposing diversity appearing in the universe. Thus, if you want to support both of your aforesaid positions, it would be worthwhile to ask the opinion of Parmenides, who firstly upset Elea, his fatherland, and then caused no little disturbance among the wise men of this city. He stated that the differences and contradictions of the things that we behold in the universe are merely illusions and fallacies of the senses, namely vain appearances of fantasy, while being, apprehended by the mind, is completely unified, equable, and similar, and the only true and real thing.”

I thanked Gorgias for the enlightened advice that he had offered me concerning this, but I asked him again whether he had some other hidden and refined thing in the treasury of his admirable wisdom.

So he added, to tell me the truth, that he wished to be sought for any inquiry except for that which concerned ens. Indeed, according to his opinion, there was no question that could reproach our ignorance and foolishness more, because ens should turn out to be the easiest and the clearest, as it appears to us first and is the ground for examining everything else. Yet in speculating on it, it turns out to be the hardest and the most difficult. And this does not only happen regarding ens, as similar tangles have especially befallen non-ens, because without cognition of this, it is impossible to come to apprehend ens, as will be explained.

"My first obstacle," he said, "was that according to the considerations of all wise men, one cannot have any concept, view, or opinion of non-ens, or nothingness, as we want to call it. [37] Indeed, it does not have the efficacy or energy to produce any vestiges or impressions of itself on others, and thus it turns out to be unable to generate any simulacrum or image that could represent and illustrate itself. However, on the other hand, if we may not have any cog-
Uproar caused by Parmenides about ens.

Considerations about the difficulties of ens.

New difficulties about non-ens. 
Ricerca circa l'univocatione dell'ente.
Riprende Gorgia

Socrate

di inavvertenza. et apprensione, in che maniera si rappresentamo e formalizamo le privationi, negationi, e di più le diferenze e distinzioni delle cose, che pur sopra le dette negationi e privationi si fondano? Oltra di ciò, li delirii di frenetici, sogni di addormentati, e tanti errori che vessano la mente dell'ignaro volgo, che non tengono alcuna realtà et esistentia esterna, che pur movono il nostro sentimento e di loro si formalizamo? Il che reproba affatto l'autorità delli sopra detti sapienti”.

\section{Al che repigliai:}

"Non crederei giammai che la mente humana dal non ente si movesse e sogiacesse alli di lui impulsi e scosse, ché essendo egli nulla, non tiene alcuna attività in causare in altrui sentimento. Per il che al parere di sapienti aderisco et applaudo".

\section{Ma egli continuò:}

"Stimi forsi che non vi sia alcuna diversità tra l'esser e non essere?"

Et io ad esso:

"E qual inditio di tanta stupidezza arrecato t'ho, che a tal interrogatione ti indusse? E qual è colui così scioco che non riconosce fra questi non dirò diversità, ma estrema repugnanza?"

\section{Di novo sogionse egli:}

"Gran ardire è il tuo, o Socrate, che asserisci contrario e nemico ad altrui quello di cui non tieni alcuna scintilla di cognitione et aviso. Ricordomi che più fiate tu meco ragionando, mi attestasti l'interno et arrabbiato odio che contro te tengono Anito e Melito, e che pigliasti argomento di ciò dalla conoscenza che tieni di essi, et in particolare della prava e pessima inclinatione che professano contro la virtù e cultori di essa".

\section{$\mathrm{Al}$ che risposi che:}

"Bene mi accorgo ove colpisce il tuo ragionamento, rimproverandomi che havendo io affermato che solamente dell'esser sia la mente humana capace, escludendo dal [38] con|tenuto di essa il non ente, hora sortisce per la instanza da te esposta, che anco esso non ente, overo niente ch'appellare lo vogliamo, sia comprensibile et intelligibile, affermandolo io contrario e repugnante all'ente”.

Ma egli seguì, addimandandomi, se diversamente io mi ritrovava

Dimanda di Gorgia. disposto quando sopito nel sonno, over affatto scioperava, da quello mi aveniva, quando circa il non ente con il discorso mi esercitava. 
nition or apprehension of it, how may we represent and conceive privations, negations, and moreover differences and distinctions of things, based also on the aforementioned negations and privations? In addition to this, how may we represent the deliriums of frenetics, the dreams of sleepers, and other errors vexing the minds of the oblivious common people? Indeed, even if they do not have any reality or external existence, they move our feelings and we conceive them. This indeed reproaches the authority of the aforementioned wise men."

Thus, I replied:

"I would never believe that the human mind was moved by non-ens and subjected to its impulses and collisions, because it is nothing and cannot cause any emotion in others. Therefore, I agree with the opinion of the wise men and I applaud it."

\section{Yet he continued:}

"Do you perhaps think that there is no difference between being and non-being?"

\section{And I said to him:}

"What sign of such stupidity did I give you that led you to this question? And who is so stupid not to recognise, I will not say the difference, but the extreme repugnance between them?"

He continued again:

"Yours is a great impudence, oh Socrates, since you define something whereof you have not a glimmer of cognition or opinion as contrary and enemy of another. I remember that you told me a few times when we were reasoning together about the deep and furious hatred that Anytus and Meletus feel towards you, and that you learned about it merely by knowing them, especially through the bad and poor inclination which they professed against virtue and its estimators."

\section{Hence I answered:}

"Well, I realise now where your reasoning leads. You have reproached me for having affirmed that the human mind can apprehend being, but [38] not nonens, by defining it as contrary and repugnant to ens. It follows now, from the example you provided, that this non-ens, or nothingness, as we want to call it, is also comprehensible and intelligible."

However, he continued by asking me whether my disposition while I was asleep or indeed in a state of inactivity was different from that which occurred while I exercised my discourse about non-ens.
Research on uniqueness of ens.

Gorgias corrects Socrates for his carelessness.

Gorgias's question. 
Non si può haver cognitione dell'ente se non s'apprende il non ente.
Replica di Socrate.
Risposeli senza punto pensarvi, che grandissima diferenza io scorgeva tra il non meditare cosa alcuna, dal speculare circa il non ente, e quasi tanto io trovava in ciò varietà, quanto tra l'esser e non essere.

\begin{abstract}
"Riesce dunque", sogionse egli, "necessario che il non ente tenga anco egli alcuna attività et efficacia in movere et informar la nostra mente, e che tal non ente da noi appreso non sia affatto totale privatione et annientato niente, poiché si trova bastante a produrre di sé alcuna impressione. Dal che ne segue, che piuttosto con la voce lo esprimiamo per assoluto niente, che con la mente tale lo concepimo, e perciò appare che esso non ente dell'esser in certo modo partecipi e tenga con esso comunicatione et allianza."
\end{abstract}

\section{Di più sogionse:}

"Stante l'assertione antedetta delli sapienti, non saprei imaginarmi in che maniera si potesse dell'ente haverne cognitione, mentre che del mero et assoluto non essere non siamo informati, havendo la natura, benigna reconciliatrice del tutto, constituito tal legge, che anco li contradittorii l'uno all'altro si apprestino lume, e chiarezza, onde tanto d'informatione apporta l'apprensione dell'assoluto non ente all'ente, che quasi ardirei affermare, che senza la cognitione del non ente, divenire non si potesse alla vera apprensione dell'essere, a guisa dell'ombre che soministrano risalto e sbalzo a più chiari, et illuminati colori. Onde non meno l'esser è mezo di farci riconoscere il niente, di quello è questo adminicolo di renderci conoscibile quello. Da ciò ne segue anco altro inviluppo che dipendendo l'apprensione dell'uno di questi, [39] dalll'informatione dell'altro, e riuscendo impossibile che ambi nell'istesso istante di tempo si riconoscono per cagion della loro repugnanza, onde non saprei rappresentarmi in che maniera di cadauno di essi formalizare si potiamo, essendoci interdetto, et impedito il devenire in cognizione dell'uno prima che dell'altro non siamo informati, et essendo impossibile ad un tratto ambi apprenderli. Per consequenza qualunque di essi ci sortisce incomprensibile”.

\section{Al qual ragionare replicai:}

"Negare non posso che meravigliato io non rimanga, e che non mi tinga di erubescentia riconoscendo quale fu da principio la mia temerità, che così arditamente nell'essordio del mio ragionare, proposi et affermai, che l'ente fosse quel massimo oggetto, che possiede ampla facoltà di adempire la vasta capacità della mente, mentre che tante e tali siano le ambagie et arduità che circa di esso emergono. Per il che mi disuade che io prenontii e pubblichi altri miei pensieri che circa ciò nell'animo ritengo, dubbitando di non rendermiti affatto ridicolo e sbeffatto". 
I answered him, without thinking much about it, that I saw a very great difference between not meditating on anything and speculating on non-ens, and that I found it almost as different as being and non-being.

"Then it turns out to be necessary," he continued, "that non-ens can also move and inform our minds. And thus this non-ens which we apprehended is indeed not complete privation and annihilated nothingness, because it is sufficient to produce some impressions. Thus, it follows that we express it like an absolute nothingness with the voice, rather than conceiving it so with the mind. Therefore, it seems that this non-ens somehow participates in being and has communication and alliance with it.”

Furthermore, he said:

"By considering the aforementioned assertions of the wise men, I could not imagine how we may have cognition of ens if we are not informed about mere and absolute non-being. Indeed, Nature, as a benign conciliator of the whole, established the law that contradictories also throw light and clarity upon each other. Therefore, the apprehension of absolute non-ens brings so much information about ens that I would almost dare to state that without the cognition of non-ens, it is impossible to come to the true apprehension of being, like shadows which bring out the brightest and most shining colours. ${ }^{85}$ Thus, being is as much of a means to allow nothingness to be known to us as this one [i.e., nothingness] is instrumental to making that one [i.e., being] knowable to us. There also follows another tangle from this, namely that since the apprehension of one of them [39] depends on information from the other, and since it is impossible to acknowledge both of them at the same time because of their opposition, then I would not know how we might conceive each of them. Indeed, we are forbidden and prohibited to come to the cognition of one before being informed of the other, since it is impossible to apprehend both at once. Consequently, both of them turn out to be incomprehensible to us."

\section{I replied to this reasoning:}

"I cannot deny that I remain astounded and embarrassed when I acknowledge my temerity from the beginning. Indeed, at the debut of my reasoning, I proposed and stated that ens was the ultimate object, which has the faculty to fulfil the wide capacity of the Mind, although there are so many complications and difficulties arising from it. Thus, this dissuades me from uttering and spreading some of my other thoughts concerning it, which I have kept in my mind until now. Indeed, [if I do this,] I am not sure whether I will make myself appear ridiculous before you or be mocked by you."
It is impossible to have cognition of ens without apprehending non-ens.

Socrates's reply. 
Tre saggi circa il riconoscere la verità.

\section{Rispose egli:}

"Anzi, pregoti che liberamente quello che in simile proposito nel pensiero per anco indigesto ritieni mi espongi, ché se al saggio e cimento della ragione non potrà resistere, almeno da inutile peso e faticosa sarcina, per la nostra discus-

Risposta di Gorgia. sione rimanerà il tuo animo sgravato".

Seguii io:

"Giacché la tua humanità mi assicura che le mie sciochezze ti palesi, spero da te piuttosto corettione, che scherno conseguirne. Per il che spiegaroti quello che hora mi soviene, per isfugire alquante delle difficoltà da te motivate, avisandoti primieramente che stimare non devi che tale io sia, che più riverisca l'autorità di maggiori, che la veneranda verità, e che parimente tanto codardo io sia, che tenga a me stesso rispetto e riverenza nel ritrattare quello che erroneamente una fiata havessi asserito, e divolgato. Giudicarei hora dunque, persuaso dalle tue instanze, che tanto dell'esser quanto del non ente si possa [40] ottener|ne cognitione, essendo l'apprensibilità comune tanto all'uno quanto all'altro. Onde perciò l'apprendimento piuttosto nostro resentimento interno che imagine di oggetto esterno riuscirà. Pensiero assai diverso da quello già inavedutamente stimavo, tenendo per inanzi in troppo veneratione l'autorità delli antichi sapienti, mentre pronontiai, che l'ente solamente fosse l'aggiustato oggetto, che all'ampla continentia della mente corispondesse. Ma hora parmi ragionevole l'affermare che anco fuori di limiti di esso ente può la mente vagare e spatiare, aggiungendo questo però, (havendo rispetto all'illusioni che accadono all'intelletto incontrandosi nel non ente), che all'hora ci potemo quasi che accertare della verità dell'apprensione:

- Primieramente, quando si trova essa accompagnata e corroborata dall'attestatione de' sensi esterni, et in particolare del tatto, sincero raguagliatore di ciò che al fuori di noi accade.

- Secondariamente, così anco la lunga e continuata duratione di tali apprensioni ci le rende oltre modo certe.

- Come parimente anco, in terzo loco, quando dal concorso del comune delli homini o della maggior parte di sapienti fossero asentite et applaudite.

Onde per il primo cimento non solamente le falacie dell'intelletuale discorso, ma l'inganni anco della vista quando stima mendacemente duplicati, slocati, e distorti l'oggetti, rimangono dal tatto robate. Anco per il secondo saggio, le frenesie de' infermi, e sogni di dormienti, per la loro breve perseveranza sono dalla ragione con buon fondamento reggetti. Come anco, per la terza prova, le scioche openioni del volgo, per esser dall'universale de' sapienti abhorrite, riescono schernite et abolite".

Ma mentre che io tal maniera divisava, osservai, che Gorgia alquanto sorise. Per il che qual ne fosse di ciò la cagione lo ricercai. 


\section{He answered:}

"Rather, I beg you to freely erase what you still consider unacceptable concerning it. Indeed, if it will not resist the examination and challenge of reason, at least your soul, thanks to our discussion, will be lightened of a senseless weight and laborious burden.”

\section{I continued:}

"Although your humanity reassures me that I may show you my foolishnesses, nevertheless I hope to receive some correction from you instead of derision. Therefore, I will explain to you what now comes into my mind in order to elude some of the difficulties you have raised. Firstly, I will inform you that you should not think that I am one to revere the authority of the most important people more than the venerable truth. Likewise, [you should not think] that I am so cowardly that I respect and revere myself [so much as to not] retract what I have previously erroneously asserted and divulged. Now, therefore, persuaded by your instances, I would judge that it is possible to obtain cognition [40] of being as much as of non-ens, since apprehensibility is common to both of them. Thus, apprehension will turn out to be our internal affection rather than the image of an external object. This is a very different thought from the one that I so rashly had before, when I held the authority of the ancient sages in too much veneration: indeed, I uttered that ens was the only object that correctly matched the wide content of the mind. Yet it now seems reasonable to me to state that the mind can also wander and range beyond the limits of this ens, though (considering the illusions that the intellect experiences when it encounters non-ens) I would add that we may then ascertain the truth of the apprehension only:

- Firstly, when it is followed and strengthened by the testimony of the external senses, especially that of the sense of touch, as honest informers of what happens outside us.

- Secondly, when these apprehensions are known to be certain from their long and continuous duration.

- Likewise, thirdly, when they are accepted and applauded by the common people or by most of the wise men.

Thus, according to the first proof, the sense of touch strengthens not only the fallacies of intellectual discourse, but also the deceptions of the eyesight when it mendaciously considers objects to be duplicated, moved, and distorted.

From the second proof, the frenzies of the sick and the dreams of sleepers are rightly rejected by reason on account of their short duration.

Likewise, from the third proof, the foolish opinions of the common people end up being derided and abolished, because they are abhorred by all wise men.”

Yet while I was thinking in this way, I beheld that Gorgias was smiling somewhat, so I asked him the reason for this.

Three proofs for acknowledging the truth.
Gorgias's answer. 


\section{Risposemi:}

"Li usi dell'amicitia dispensano e permettono il potere con modesta irrisione l'amico alla emenda admonire. [41] Adverltii", diceva egli, "nel tuo favellare, che nulla ti cale del parere di tanti sapientissimi homini, che affatto denegano al non ente l'energia di poter imprimere di sé nella mente carattere alcuno, ma che verso di lui stimanno che siamo disposti, come quando si troviamo da profondo sonno sorpresi, over che con la mente neghitosi a nulla abbadiamo. Per il che punto non mi aggrada la tua positione, stimando tu che l'apprensibilità sia comune e promiscua tanto al non ente, come all'ente. Non mi piace, redico, tale comunione, ritrovandosi questi talmente discosti e distratti l'uno dall'altro per infinito intervallo, che impossibile rassembra, che rinvenire si possa cosa, cioè l'apprensibilità che l'uno e l'altro abbracci, ricusando anco la volgare scola che la sostanza et accidenti tenghino un superiore genere che li comprenda. Onde secondo la tua assertione che del non ente tenimo concetto e cognitione, ci converebbe affermare che dell'essere non si possa haverne apprensione alcuna. Onde, se l'apprensibilità non può essere comune al non ente et all'ente, ne segue che del non ente non ne potiamo haverne apprendimento, perché se di lui ne tenissimo cognitione l'ente riuscirebbe incomprensibile et affatto ignoto.

Oltre di ciò s'alla tua positione assentissimo, in grande hazardo e pericolo si esponerebbe l'humano sapere, non essendo più l'apprensibilità cimento e saggio della vera esistentia d'oggetti esterni, ritrovandosi essa comune anco alli falsi e putatitii, come asserisci. Onde in qualunque nostra speculatione restaressimo perplessi, se a guisa di Endimione, nube pregna di vanità invece di cosa consistente nell'amplessi della mente preso havessimo. Et il primo saggio in quanto che attenti conseguire per mezo di sensi et in particolare del tatto, stimo

Riggetta il primo saggio di sensi e particolarmente del tatto. riuscire insufficiente ad arrecarci certezza circa l'apprensioni della mente. Ma prima de' sensi in universale diroti quello mi rassembra, cioè che non appariscano bastevoli a ministrarci certa evidenza delle cose, non instruendoci [42] la vista d'altro, che il semplice colore, l'udito il suono, l'olfato l'odore, il gusto il sapore et il tatto alcune qualità come il caldo, il freddo, il mole e duro e simili, ma non giammai ci informano dell'essentialità interna delle cose, ma né anco di altri accidenti più esterni, come della grandezza, numero, sito, distantia, motto, quiete, similitudine, proportione, diversità e contrarietà et infinite altre cognitioni de' quali sono construtte le humane dottrine e più egregie arti, le quali cose sono dalla mente solamente apprese e riconosciute, come in breve si dimostrarà.

Ma, amico Socrate, non osservi qual sarebbe il discapito dell'intelletto circa le cognitioni antedette, quando la certezza del suo sapere d'altrui dovesse mendicare, cioè da sensi esterni? E che essi solamente fossero li periti saggiatori della verità? Onde risultarebbe che non derivando da sensi tali cognitioni non ci accertaressimo giamai della loro verità.

Ma lasciamo ciò a parte, voglio per hora proporti la stimata appo volgari, la più certa apprensione, cioè quella che per mezo del senso del tatto conseguimo, dico quella che per suo raguaglio tenimo della esistentia de' corpi esterni, mediante la renitenza che sentimo ostarci, che tuttavia scorgerai ciò dal 


\section{He answered:}

"Friendship customarily provides and permits the right to correct friends through little mockeries. [41] I recognised in your speech," he said, "that you disregard the opinion of many very wise men who indeed deny that non-ens has the energy to impress any mark of itself upon the mind. Yet they think that we are inclined to this [i.e., non-ens] when, for example, we fall deeply asleep or when, with an indolent mind, we pay no attention to anything. Therefore, I do not appreciate your stance, because you consider that apprehensibility is common and belongs indistinctly to both non-ens and ens. I say again, I do not like this commonality, since they are so different, separated from one another by an infinite interval, that it seems to be impossible to find something, namely this apprehensibility, which encompasses both of them. Indeed, the common school also denies that substance and accidents could be included in a superior genus. ${ }^{86}$ Thus, following your assertion - namely that we have conception and cognition of non-ens - we should state that one cannot have any apprehension of being. Therefore, if apprehensibility cannot be common to non-ens and ens, it follows that we cannot apprehend non-ens, because if we had cognition of it, then ens would turn out to be incomprehensible and indeed unknown.

"In addition to this, if we assented to your stance, then human knowledge would be exposed to great peril and danger, since apprehensibility would no longer be a test and proof of the true existence of external objects. Indeed, it would also be common to false and alleged [objects], as you assert. Thus, we would remain perplexed in all of our speculations if we seized a cloud pregnant with vanity (as Endymion $\mathrm{did}^{87}$ ) instead of a consistent thing among the embraces of the mind. And concerning the first proof - namely that you attempt to achieve it [i. e., the acknowledgement of the truth] through the senses, especially through the sense of touch - I consider them insufficient to give certainty concerning the apprehensions of the mind. Yet I will first tell you how the senses seem to me in general; namely that they seem to be insufficient to provide us with certain evidence of things. Indeed, [42] the eyesight does not instruct us in anything other than simple colour; hearing in sound; olfaction in smell; taste in flavour; and the sense of touch in some qualities such as heat, cold, softness, hardness, and the like. However, they have never informed us about the inner essentiality of things, nor even about other more external accidents, such as size, number, position, distance, motion, rest, similarity, proportion, diversity, contrariety, and infinite other cognitions which make up human doctrines and the most distinguished arts. These things are apprehended and acknowledged only by the mind, as will be demonstrated shortly.

"Yet, dear Socrates, do not you behold how damaging it would be for the intellect concerning the aforementioned cognitions if it had to beg others, namely the external senses, for the certainty of its knowledge, if they alone were the expert essayers of the truth? Thus, it would result that if we do not derive these cognitions from the senses, then we will never ascertain the truth of them. However, let us leave this aside: for the moment, I want to propound to you the apprehension considered to be the most certain among the common people, namely that which we achieve by means of the sense of touch; I mean the one which informs us of the existence of external bodies through the resistance that we feel opposing us. Nevertheless, you will see that it does not derive from the
Refutation of the first proof of the senses and especially of the sense of touch. 
tatto non derivare, ma dal discorso dell'intelletto in gran parte dipendere, non havendo esso tatto appena che minima portione in tale cognitione.

Fu definito che corpo sia ciò che possiede longhezza, larghezza, e profondità, altri vi aggiunsero la resistentia che ad altrui fa. Primieramente dico essere molto evidente, che tali dimensioni siano piuttosto dall'intelletto che da sensi apprese, non conseguendo li sensi altro che li sopra nominati oggetti. Ma la recognitione delle dimensioni dipende dall'advertire con la mente certa continuata successione di diverse portioni del tangibile, insieme ordinate et unite, essendo da quella solamente osservata per certo passagio e flusso dell'organo tangente sopra al tangibile overo al converso. Al che vi concorre [43] anco l'apprensione del tempo che si consuma in tale successione, e parimente la conoscenza della continuità la quale non si può rafigurare senza l'apprendere ciò che sia unità, e numero, non essendo altro il continuo che l'unione di due estremità, che in un punto concidono e s'accopiano. Da tutto questo discorso, devenimo in cognitione della grandezza e dimensioni del corpo, e di più essendo questo uno aggregato di tre dimensioni, tale accopiamento e compositione non appartiene punto al senso esterno materiale, e semplicemente passivo, m’a facoltà compositiva di lui più egregia.

Oltre che il riconoscimento della resistentia agiunta da alcuni, come fu detto, alle dimensioni per farne sortire il corpo, non conviene al tatto attribuirlo, poiché noi per mezo di questo, altro non sentimo che una certa interna nostra compressione, facendo perciò poi giuditio con il discorso della mente, che tale compressione ci avenga per cagion di ostacolo et impedimento che ci contrasti l'oltrapassare e c'opprime. Al che concludere fa di mestiere alla mente, che alquante propositioni construisca.

Primieramente, li fa bisogno asserire che vi sia motto mentre che in noi si sente tale compressione, et in altrui renitentia che ci vieta lo progredire, benché Parmenide, Zenofane, Mellisso, e Zenone rifiutavano tal motto. Che parimente giudichi la mente che l'organo del tatto si risenta, per cagione della oppositione causata dall'esterno oggetto, et è necessario che concepisca et admetta che vi sia causalità, materia involta da tante difficoltà, che non mancarno fra sceptici che affatto negarono qualunque causalità, e senza dubbio l'asserire che vi sia, alla mente, e non al senso ciò appartiene. Di più sarebbe temerario trascorso l'affermare che per mezo del tatto si riconosce l'esistentia delle cose esterne, mentre che fosse ignoto ciò che foss'esso tatto, come in breve vi sono per esporre. E di più, se nel genere delle relationi e rapportamenti essa causalità e tatto si riducono, chi può dubbitare che alla mente non incomba [44] quelsto riconoscere?

Ma di più risorge altra difficoltà: in che maniera per mezo del tatto capitamo in cognizione delle cose per se stesse esistenti, s'egli nella classe de relativi è compreso? In qual guisa accidente tanto fievole quanto è la relatione, che non pochi li negarno il reale essere, ci può indicare e rappresentare il da per sé stante, e da niuno dependente? Ma che direbbe il nostro Aristippo, che severamente ci sequestra e restringe nel recinto delle nostre passioni, e che ci interdice il far passagio fuori de loro limiti? Per il che conforme tal suo benché falso dogma, l'asserire, che vi sia cosa fuori di noi riesce arditezza et inconsiderato partitto, onde quando che presumiamo con il concetto formalizarci di esterno oggetto fuori di noi esistente, e circa esso con il discorso ritrovarci, secondo 
sense of touch, but depends mainly on the discourse of the intellect, since the sense of touch plays only a marginal part in this cognition.

"The body is defined as something with length, width, and depth; others have also added resistance to other bodies.$^{88}$ Firstly, I say that it is very evident that these dimensions are apprehended by the intellect rather than by the senses, since the senses gain nothing more than the aforementioned objects. However, the acknowledgement of the dimensions depends on bearing in mind a certain continuous succession of different tangible parts, arranged and joined together. That one [i. e., the mind] alone may behold it through a certain course and flux of the sense of touch over the tangible, or vice versa. The apprehension of time, [43] which consumes itself in this succession, should also be added to this, and likewise the knowledge of continuity, which cannot be represented without apprehending what unity and number are. Indeed, the continuum is nothing other than the union of two extremities coinciding and matching on one point. From all this discourse, we come to the cognition of the size and dimensions of the body. Furthermore, since the body is an aggregate of three dimensions, this match and composition indeed does not belong to the external and material senses, which are simply passive, but to a composing faculty more excellent than them.

"Besides, the acknowledgement of resistance, as has been said, added by others to the dimensions that make up the body, should not be attributed to the sense of touch, for by means of this we feel nothing other than a certain internal compression. Then, through the discourse of the mind, we judge that this compression occurs us because of an obstacle and impediment which prevents us from proceeding further and oppresses us. Hence, it is necessary to conclude that the mind can build up several propositions.

"Firstly, it needs to assert that there is a motion when we feel the compression in ourselves and the resistance in others which prevents us from proceeding further, although Parmenides, Xenophanes, Melissus, and Zeno do not accept this motion..$^{89}$ Likewise, the mind judges that the organ of touch reacts because of the opposition caused by the external object. And it is necessary that it conceives and admits that there is causality. This [i.e., causality] is a matter entangled in so many difficulties that even amongst the Sceptics there were those who indeed denied causality, ${ }^{90}$ and asserting that it exists is undoubtedly [the task] of the mind and not of the senses. Furthermore, it would be a reckless mistake to state that one acknowledges the existence of external things by means of touch while it is unknown what that sense of touch is, as I will shortly expound. Besides, if this causality and sense of touch are reduced to the genus of relatives and connections, who may put it into question that the mind has the task [44] of acknowledging it?

"However, another difficulty arises: by means of the sense of touch, how may we come to the cognition of things that exist by themselves if it [i.e., the sense of touch] is included in the class of relatives? How can an accident as feeble as the relative, whose real existence is denied by many people, show and represent what is by itself and not dependent on anyone else? What would our Aristippus ${ }^{91}$ say, since he sequesters and strictly confines us into the prison of our passions, preventing us from going beyond their borders? Hence, according to his dogma, although it is false, asserting that there is something outside us turns out to be a reckless and inconsiderate stance. Thus, when we think we conceive an external object that exists outside us and we reason about it, in 
Aristippo, inavedutamente in noi medesimi insistemo, a guisa di mobile che si move circolarmente e benché continuamente rivolge, nondimeno nell'istesso loco sempre si ritrova. Dal discorso dunque conclude l'intelletto, e non il senso del tatto, che ci siano fuori di noi oggetti resistenti, e renitenti all'organo tangente, ché negandosi alcuno delli detti hippotesi, rimanerebbe affatto eliminato il fondamento più sodo della credenza che si tiene circa l'esistentia delle cose esterne.

Né voglio tralasciare di teco comunicare quello che circa la resistentia tengo nell'animo, benché per hora alquanto indigesto, apparendomi che essa non sia altrimenti segno tanto efficace in dimostrarci l'esistentia corporale di oggetti, osservando io, che l'impeto che acquista il corpo mobile per la celerità del motto tenga una gagliarda resistentia con li corpi che incontra, che non solamente impedisce ad essi il progresso, ma anco li smove, spezza e frange. Il qual impeto non può esser corpo generandosi dal semplice motto comunicato dal motore al mobile e dal proicente al proietto, augumentandosi anco l'acceleratione et impeto dal motto procedente nell'istesso mobile receputo. $\mathrm{E}$ l'insinuarsi tal impeto nelli [45] intimi recessi del mobile parimente dimostra non esser egli corpo, perché se tale fosse, denegato li sarebbe la penetratione. Dal che si raccoglie, che la resistentia, essendo effetto dell'impeto generato dal motto, non ci può indicare et accertare che derivi da cosa soda e massicia, non potendo l'effetto ch'è la resistentia trapassare la conditione del motto suo progenitore, che non è cosa esistente.

Ma oltre di ciò addurre ti potrei, per renderti sospetto questo tale tuo contatto al quale tanta fede attribuisci, altra instanza, rappresentandoti ciò che sovente nel sonno accade a crapuloni e bevoni, che li rassembra esservi chi li comprime restandoli perciò impedita la respiratione e qualunque loro motto, che dalli ignari delle cagioni naturali a demonii Incubi è ciò attribuito. Onde ci resta sospetto che può rassembrarci alcune fiate nell'animo esservi resistentia, benché non vi sia renitente esterno che ci si opponga.

Di più anco si può addurre in dubbitatione di ciò, che se al Sagittario celeste fosse permesso che la saetta che tiene nelle mani fuori dal convesso dal cielo scoccasse, restarebbe nondimeno essa impedita, non per oppositione di resistentia esterna di corpo, ma per mancamento di loco, mentre però che supponessimo, come che asserisce la comune credenza, che fuori del cielo non vi si ritrova pieno, né loco vacuo. Apportare anco potrei in corroboratione di questo li dolori artetici e colici che le loro punture d'acuti ferri esterni derivare rassembrano, eppure non tengono fuori di noi esistenti cause.

Dalle cose da me insino hora divisate, amico Socrate, si può agevolmente raccogliere, che quando l'intelletto da sensi dedurre li convenga le sue dottrine, et essi accertarli la verità, ad estrema inopia e meschinità egli si ridurebbe, e poco o nulla di sufragio può sperare dal tatto, stimato da te la più sicura norma e stabile base delle sue speculationi. Anziché se all'intelletto di più li fosse rimproverata una certa tal massima inavedutamente da lui a suoi danni e nocumenti prodotta e divolgata, e hora da te [46] alquanto con il tuo discorso applaudita, cioè che niuna cosa in lui ritrovare si può se prima non 
Aristippus's opinion, we are actually rashly standing still in ourselves, like a mobile thing moving around in circles which, although it is continuously rotating, nevertheless always remains in the same place. From this discourse, the intellect, not the sense of touch, concludes that there are objects outside us which are resistant and refractory to the sense of touch. [On the contrary,] by denying even one of the aforementioned hypotheses, we would indeed eliminate the most solid basis of the belief that we have concerning the existence of external things.

"I do not want to neglect to tell you what I keep in my mind concerning resistance, although it is a very unacceptable thing so far, because it seems to me such an ineffective way of demonstrating the bodily existence of objects. Indeed, I behold that - thanks to the impetus gained through the speed of motion - a mobile body exerts a strong resistance against the bodies that it encounters and not only prevents them from proceeding further, but also stirs, breaks, and shatters them. This impetus cannot be a body, since it is generated by a simple motion communicated from the mover to the mobile thing and from the projicient to the projectile. ${ }^{92}$ Besides, it also increases the acceleration and impetus received into the same mobile thing from the earlier motion. And this impetus, by intruding itself [45] into the inner recesses of the mobile thing, similarly demonstrates that it is not a body, because if it were, it would have been stopped from penetrating [into the other bodies]. We gather from this that resistance, which is the effect of the impetus produced by the motion, cannot indicate or ascertain that it comes from a firm and solid thing; indeed, the effect, which is [that same] resistance, cannot go beyond the condition of motion, which is its progenitor and a non-existent thing.

"In addition to this, I could put forth another instance to arouse your suspicions about your sense of touch that you consider so faithful. When you think about what often happens to drunk and greedy people during their sleep - namely that it seems to them that something is compressing them in such a way as to prevent them from breathing or moving - this is attributed to incubus demons by people who are unaware of natural causes. ${ }^{93}$ Therefore, we remain suspicious of the resistance that we sometimes seem to feel in our minds, although there is no resistant object opposing us.

"One may furthermore put forth, in order to support the doubts about this, that if the celestial Sagittarius were allowed to shoot the arrow in his hands outside the vault of the heavens, it would be hindered not by the external resistance of a body, but because of a lack of space. Hence, we should rather suppose, in accordance with the common belief, that there is no space outside the heavens, not even a vacuum. ${ }^{94}$ In order to strengthen this I could also cite the pain produced by arthritis and colic, which seems to be derived from the pricks of sharp instruments, yet does not have any external cause.

"From the things that I have examined up to now, dear Socrates, one may easily gather that if the intellect needed to deduce its doctrine from the senses and they ensured it of the truth, then it would reduce itself to a state of extreme poverty and meanness. And it may hope to receive little or no help from the sense of touch, which you considered the most certain rule and stable basis of its speculation. And moreover, if the intellect had formerly been reproached for a certain maxim which it had rashly produced and disclosed, causing its own damage and detriment, and which you now [46] have greatly applauded in your speech - namely, that nothing can be found in it which has not previ- 
sia passata per la condotta de' sensi esterni, a qual disagio e mendicità egli si condurebbe? E se interrogato fosse d'onde prese sì copiosa supeletile di tante cognitioni già accennate per lo acquisto de' quali si stima tanto arichito, che pur giammai per l'adito et uscio di sensi trapassorono, a qual confusione e turbamento capitarebbe? Non sapendo d'onde tanta farragine de' cose in esso sia pervenuta.

Ma di più se anco admettessimo che il senso del tatto insieme con li altri suoi congeneri somministrassero sufficientemente all'intelletto materia circa di che si potesse largamente esercitare, non si è veduto per anco qual certezza potressimo con l'aiuto di questi ottenere circa l'esistenze delle cose esterne, perché oltre il divisato apparisce di più, che il tatto non è per anco noncio verace e certa norma dell'apprensioni dell'intelletto, non essendo anco egli privo di sospetto di falsità. E quello che mi rende in ciò flutuante è che alcuno delli esterni non esercita la sua fontione senza il toccamento del sensibile, overo la di lui imagine. E la vista giudicata la più spirituale fra tutti li altri sensi, anco essa del tatto si serve, faciasi ciò per mezo dell'effluvio de raggi visivi che dall'occhio uscendo insino all'oggetto arivino, overo che la imagine dall'oggetto spicandosi ferisca nell'organo visivo, accada ciò nell'una maniera, overo nell'altra, sempre la sensatione con l'intervento del contatto s'eseguisce. Argumento di ciò anco è che la dimensione di qualunque corpo nell'istesso modo si misura con il tatto che con la vista, et è ragionevole che l'istesso effetto sortisca della medesima causa:

Sed atque etiam minima haec fateri necesse est

Corpora quae feriant oculos visumque lacessent, etc.

Praeterea quoniam manibus tractatta figura

In tenebris quaedam cognoscitur esse eademque

[47] Cernitur in luce et claro candore necesse est

Consimile causa tactum visumque movere

Nunc igitur si quadratum tentamus, et id nos

Comovet in tenebris in luceque poterit res

Lucret. $\quad$ Accidere ad speciem; quadrata nisi eius imago?

Onde da ciò si deduce che se falace riesce sovente l'aviso della vista che per mezo del tatto risulta, che altro tanto bugiardo ci può riuscire parimente il comune tatto, al quale s'appogiano tutte le nostre speranze in conseguire la verità delle cose, e se per evadere ciò, dicessimo, che l'esame e recognitione delli tatti adoperati nelle sensazioni all'intelletto appartenire, dunque ridondarebbe in lui la certezza del giuditio che si tiene delle cose, e non nel tatto, divenendo perciò tanto l'intelletto quanto il tatto sospetti di mendacio, mendicando l'uno dall'altro la certezza delle loro apprensioni. Per il che rimanerebbe dubbiosa ogni nostra apprensione, riuscendoci il testimonio al pari del giudice sospetti di falsità.

Oltre di ciò, chi accertare ci può che, siccome il tatto comune è stimato da te verace testimonio e sincero esploratore alla vera esistenza delle cose e che ci accerta delle altre apprensioni, che anco nella vastità della contingenza, e possibilità non si possa rinvenire altro tatto, molto più di lui esatto et esquisito 
ously passed through the external senses - to what difficulty and mendacity would it be led? And if the intellect was asked from whence it took such an abundant supply of the many aforementioned cognitions - which did not come from or pass through the senses and by whose purchase it considers itself to be so enriched - what confusion and upset would occur? Indeed, it is not known whence so great a medley of things came to it.

"Furthermore, even if we admitted that the sense of touch, along with its congeners, did provide the intellect with sufficient matter upon which it could perform a wide variety of tasks, nevertheless, we have not yet seen what certainties concerning the existence of external things we could obtain with their help. Thus, beyond what has already been considered, it is furthermore evident that the sense of touch is not a truthful messenger or certain rule for the intellect's apprehension, since it is also not free from the suspicion of falsity. Besides, what makes me waver about this is that none of the external [senses] can exercise their function without touching the sensible, or the image of it. And also, the eyesight, judged the most spiritual of all the other senses, uses the sense of touch. It does this either through the effluvium of visual rays going out from the eye and then coming to the object, or through the image detaching from the object and striking the visual organ. In whichever manner this occurs, the sensation is always executed through the sense of touch. The argument of this [stance] is that the dimension of any body is always measured in the same way, namely by the sense of touch rather than by sight, and it is reasonable that the same effect comes from the same cause:

Therefore, again and again I say you must confess

Bodies which strike our eyes and vision, etc. ${ }^{95}$

Besides, since a shape handled in the dark is

[47] Recognized to be the same which is seen in the clear light by day, It must be that touch and sight are moved by a like cause.

Now, therefore, if we take hold of something square and it excites our feeling in the dark, In the light what square thing can fall upon our vision, if not an image of it? ${ }^{96}$

Lucret.

Therefore, one may deduce from this that just as the eyesight may often be misled by means of the sense of touch, so then the common sense of touch, on which all our hopes of achieving the truth of things rest, will likewise turn out to be a liar. If, in order to avoid this, we said that the examination and acknowledgement of the sense of touch used for sensation belonged to the intellect, then the certain judgment of things would be derived from this and not from the sense of touch. Thus, both the intellect and the sense of touch would be suspected of mendacity by their begging each other for the certainty of their apprehensions. Hence, all of our apprehensions would remain doubtful, since both the witness and the judge would seem to us to be equally suspicious of falsity.

"In addition to this, although you generally consider the sense of touch a truthful witness and sincere explorer of the true existence of things and [able] to ascertain the other apprehensions, nevertheless, who may ascertain that one may not also discover another sense of touch in the vastness of contingency and possibility, more exact and thorough than this [i.e., the first sense of touch] is? And [who may ascertain that one may not also discover] that this might be 
che sia sofficiente a manifestare le di lui frodi et inganni, e che convinca evidentemente le sue falacie, siccome egli ti rivela e palesa l'illusioni della vista?

E di più mi arreca ansa di ciò dubbitare, l'osservare che ad alcuni animaletti e vili insetti la natura molto più egregio tatto che al nostro genere distribuì. Il ragno tessittore di quella predatrice sua tella senza dubbio possede palpitamento più risentito e risvegliato del nostro, esercitandosi circa quelli sotilissimi filli a noi inattingibili, et impalpabili. Né diversamente del bombice artefice della seta giudicar si deve. Né d'altronde scaturì quella insana openione delli huomini volgari, che li ucelli [48] siano avisatti dalli dei de' future emergenze humane, overo almeno per mezo di questi ne siamo dalli dei raguagliati, se non che per essere tali animali di sentimento molto acuto, e perciò di qualunque alteratione d'aria osservanti, onde riescono presaghi delle mutationi di tempi che seguire devono. Dal che l'ingegni plebei di più dedussero, che di qual si sia evento futuro benché non naturale siano conscii, dipenda ciò dal caso overo dalla nostra volontà, quasi che li dei fossero più liberali a comunicare li arcani del tempo avenire alli bruti che alli huomini, a cui tali successi appartengono.

Ma ritornando al tatto humano, diroti non esser io fuori di sospetto che egli al pari di altri sensi ci frodi et inganni, il che si osserva circa l'apprensione del caldo e freddo, del grave e lieve, onde la mano giudica freddo o caldo l'oggetto per tanto solamente che in una di queste qualità l'eccede, e il peso del nostro corpo benché grave, non lo sentimo per esser noi acciò avezzi, et un lieve drappo alle fiatte ci affatica, et affanna”.

\section{A ciò replicai:}

"Stimo che circa dette qualità l'affare riesca conforme il tuo avisamento, ma intorno la restistentia di oggetti dificilmente l'animo mio si può acquietare, e ridurmi a dubbitare che il tatto il falso ci referisca, né posso formalizarmi in che maniera avenga che ciò ch'esterno mi apparisce sia solamente passione in me internamente instalata".

\section{$\mathrm{Al}$ che egli replicò:}

"Stimarei abbastanza haverne circa ciò divisato, ma tuttavia volendo affatto compiacerti, e satisfare a questo tuo contumace pensamento, rappresentaroti alcuni avenimenti che comunemente c'ingannano, facendoci stimare l'interno esterno. L'humore giallo, che nelli occhi d'itericii s'annida, li fa apparire tutti li visibili esterni di tal colore infetti, e se d'altrui non fossero admoniti della loro infermità, cagione di tal errore, constantemente gialli li giudicarebbe. L'istesso accade alli vertiginosi, infestato il loro occhio da vapori che colà ascendono, e si ragirano, per il che li rassembra tutte le cose che mirano mobili et [49] agiltati, e li sani ancora nel nascere e tramontare del sole, verso lui affissando la vista, li pare che con veloce motto in se stesso si rivolge, il che avienne per il dilatare e restingersi della loro interna pupilla, onde comovendosi perciò li humori che circondano l'occhio, attribuiscono falsamente al sole tale terpidatione. E nella vista ordinaria quale è colui se non è di soda eruditione dotato, che non li ras- 
sufficient to show the frauds and deceptions of the [first] sense of touch, and that it may [even] convince us of the evidence of its fallacies, as well as how it discloses and shows us the illusions of the eyesight?

"And what provides me with a further pretext for doubting this is to behold that Nature bestowed a much more excellent sense of touch on some little animals and vile insects than on humankind. The spider, as a weaver of its predatory web, undoubtedly has a more reactive and alert sense of touch than ours, since it busies itself on those very fine threads, intangible and impalpable to us. And the worm, as a maker of silk, should not be judged any differently. Thus, the insane opinion of common people - namely that the birds [48] are warned about future human occurrences by the gods, or at least that we are informed by the gods by means of them ${ }^{97}$ - results only from the fact that these animals have very keen senses and thus notice all alterations in the air. For this reason, they have a presentiment of any future change. Hence, the plebeian intellects have furthermore deduced that their being aware of any future events, except for natural ones, depends either on Chance or on our will, as if the gods were more liberal in communicating the mysteries of the future to brutes than to the human beings whom these occurrences concern. Yet to return to the human sense of touch, I will tell you that I still suspect that it defrauds and deceives us like the other senses. That is evident in the perception of heat and cold or heaviness and lightness, because the hand judges the object as cold or hot only when it has an excessive amount of these qualities. And we do not feel the weight of our bodies, although they are heavy, because we are used to them, but sometimes even a light garment may tire and fatigue us."

\section{I replied to this:}

"I think, concerning the aforementioned qualities, that the matter turns out to be as you say it is, but regarding the resistance of objects, my mind will hardly be appeased and will merely suspect that the sense of touch refers [only] falsehoods to us. Nor can I conceive how what appears as external to me is only a passion located inside me.”

\section{Hence, he replied:}

"I would consider that I have reasoned enough about this, but since I indeed want to gratify you and to satisfy your obstinate thought, I will show you some occurrences which commonly deceive us and lead us to consider what is internal as external. The yellow-coloured humour hidden in the eyes of those affected with jaundice makes all visible external things appear this colour, and if they were not warned by others of their infirmity being the cause of their error, they would constantly judge them to be yellow. ${ }^{98}$ The same happens to people affected with vertigo: their eyes are infested with rising and rotating vapours, for to them, everything seems to be mobile and agitated..$^{99}$ [49] Likewise, when sane people stare at the sun rising and setting, it seems to them that the sun is revolving through a fast motion, but this only happens because of the contraction and dilatation of their inner pupil. Thus, [since it depends on] the motion of the humours around the eyes, they wrongly attribute this vibration to the sun. And in ordinary eyesight, is there anyone, except for those who are endowed with solid erudition, 
sembra che la visione si esequisca circa li oggetti da noi remoti, e lontanissimi? Stimandosi volgarmente che con la vista si affera le stelle.

E tuttavia secondo la meno insana openione la visione entro dell'occhio nel più profondo recesso da lui si eseguisce, né altro apprende l'organo visivo che la cuspide radiale del cono, che dall'oggetto ci è inviato, onde dal dilatamento e ristrengimento di tal apice si apprende la distanza e grandezza, over picciolezza della cosa visibile. Da simile argumentatione anco concepimo la figura et altre attinenze di oggetti visibili, restando per tanto il comune delli huomini ingannati, stimando che il tutto fuori di loro avenga et anco quelli che sono conscii del modo che si eseguiscono tali apparitioni, negare non possono, che li rassembra che fuori d'essi nell'istesso oggetto remoto, e lontano ciò si faccia. Tanto può la consuetudine in stabilire nell'animo nostro opinioni (benché false) indelebili et irretratabili”.

Hor dunque havendo ciò esposto Gorgia, da tal ragionamento presi ardire di novo stuzicarlo con dirli, che sebbene alla mia età alquanto giovanile converebbe piuttosto rendersi attenta a ciò che sapientissimo huomo favella, che introdurre proponimenti, et apportare dogmi, nondimeno la curiosità et inquietudine del proprio genio mi stimola a conferirli quello che nell'animo in tal proposito io concepisca, significandol'io stimare che il tatto giammai s'ingannasse circa li suoi oggetti come né anco l'altri sensi, eseguendo ancor essi le loro fontioni per mezo del tatto, sempre infalibile, ma che se la vista ci rapporta [50] alle volte alcuna falacia, ciò sia causato dal comercio che tiene con l'intelletto di tali illusioni principale autore, e che per se stessa non si possa altrimente ingannare, può il medesimo accadere al tatto comune. Al che replicò egli:

"Non è come credi proprietà dell'età giovanile l'imparare, ma piuttosto è sua conditione la pretesa dell'insegnare, essendo naturale e proprio alla humana, et inaveduta ambitione la brama d'altrui instruire. Ma noi, provetti et avanzati nelli anni, riconoscendo quanto la verità ci sia contrastata, et impedita, siamo oltra modo desiosi d'imparare, e ritenuti nell'insegnare e dogmi asserire. Ma il tuo ragionare m'induce a chiederti che mi esponi, se stimi che quello decreto filosofico che vuole che sentimento alcuno eseguire non si possa senza il contatto, escluda et esima l'apprensione dell'intelletto, over piuttosto ancor lui di ciò non si trova immune et assoluto".

Risposi:

“Crederei che per la sua spiritualità restasse da ciò eccetuato”. 
who does not have the impression that the eyesight is acting on objects which are very far and remote from us, since it is a common belief that is possible to capture the stars via the eyesight?

"Nevertheless, according to the least insane opinion, vision is carried out in the deepest recesses of the eyes, and the visual organ perceives nothing other than the radial tip of a cone sent by the object; ${ }^{100}$ by dilating and contracting this tip, one perceives the distance and largeness or smallness of the visible thing. From similar arguments, we also conceive shape and other things pertaining to visible objects. Nevertheless, most people remain deceived, believing that everything happens externally to them. And even those who are aware of the way things appear to us cannot deny that it seems that this is carried out externally to them in the object itself. The custom may go that far by establishing indelible and irrevocable opinions in our minds (although they are false)."

Now, once Gorgias had explained this, from this reasoning I dared to provoke him once more by telling him that although it would be more worthwhile, at my very young age, to pay attention to the words of a very wise man than to suggest proposals and produce dogmata, nevertheless the curiosity and restlessness of my own genius stimulated me to tell him what I had in mind concerning this, ${ }^{101}$ indeed, by making it known that I considered that the sense of touch had never been mistaken concerning its objects, and nor had the other senses which carry out their functions by means of the always-infallible sense of touch. Yet if the eyesight sometimes [50] relayed us some fallacies, then this [must be] caused by its exchanges with the intellect, as the main author of these illusions. And since it indeed could not be mistaken by itself, the same could occur to the sense of touch common [to the external senses]. Hence, he replied:

"Learning is not, as you believe, a feature of youth; that is rather pretending to teach, since the longing to instruct others is natural and peculiar to rash and human ambition. Yet as experts and older [people], we acknowledge how much opposition and impediment there is on the path to the truth. For we are greately yearning to learn, but we refrain from teaching and asserting any dogmata. However, your reasoning induces me to ask you to expound whether you consider that the philosophical decree which claims that no perception may be carried out without contact excludes and exempts the apprehension [performed by] the intellect, or rather whether it is still not released and freed from this.”

\section{I answered:}

"I would believe that it is exempt from this because of its spirituality." 


\section{Replicò egli:}

"Ma il nostro comune amico Protagora a cui alcuni di sapienti del secolo presente adheriscono, pretende, che l'intendimento della mente altro non sia che sentimento, confessando però che tanto sia più delicato di quello delli altri sensi, quanto la vista si ritrova al di sopra delli quattro suoi congeneri. Onde stante ciò non sarà giammai l'autore di tal dogma per assentire che senza l'aiuto del tatto alcuna apprensione benché intellettuale eseguire si possa, conforme, che alli altri sentimenti necessariamente ciò accade. Ma approbi il parere di Protagora over lo rigetti, convienti confessare che alcuna imagine e simulacro dall'oggetto spicato et intruso nelli sensi esterni, e poi penetrando nell'interni, giunga insino all'intelletto e lo risvegli, facendo in lui, se non impressione almeno impulso, onde per via di certo lieve e spirituale contatto esercita ancor egli le sue fontioni. Ma se per modo di contatto, e di questo tale contatto sospettamo e dubbitamo, in che maniera sarà suo congenere il di lui cimento e [51] sag|gio? Dunque il dubbioso et incerto sarà prova a se medesimo?

Ma oltre di ciò s'accade che la vista, praticando con la mente, resti sovente delusa nelle sue apprensioni, perché siamo affatto fuori di dubbio che anco al tatto comune non li avenga l'istesso infortunio? Poiché la cognitione che tenimo dalla esistenza delle cose esterne per mezo della resistenza conseguimo, e dell'apprensione di questa la mente gran parte ne possiede, da che poi s'evince la esistentia delle cose esterne, come già fu detto. Ma soprattutto il cimento eseguito da sensi circa le speculationi dell'intelletto non mi aggrada, perché dall'intelletto istesso è tal giuditio ad essi delegato e rimesso, il che in causa propria non se li deve admettere, perché ponendosi dubbio nella sua sufficientia, anco tal remissione riesce incerta e perplessa. Onde, riducendo il discorso a quello che da principio devisavamo, riesce il tatto, stimato da te sincerissimo e leale saggiatore delle nostre apprensioni, non meno che li altri sensi, così interni come esterni, perplesso et all'inganni esposto. E siccome il cimento de' tatto ci sortisce hora invalido a farci riconoscere e rivelarci la verità, così anco quell'altro saggio che adducesti, dico la continovata duratione

Rigetta il saggio della duratione dell'apprensione. delle apprensioni, ci riesce al mio stimare parimente incerto e falace. E non poco ti sei allucinato nel tenere vere quell'apprensioni che sono di lunga perseveranza, e false le momentanee e transitorie, ché per il certo a troppo debole fondamento raccomandi et appoggi la verità, sopra qual altra cosa egregia e pregiata.

Dunque, o Socrate, per tua assertione le manie di melanconici che essendo radicate in humori contumaci, che perciò al pari della vita sovente continuano, veri giuditii per tuo parere stimare si devono? Ma che le frenesie de' colerici, insultorie e di breve esistentia, solamente mendaci siano? E così medesimamente dal tuo ragionare si raccoglierebbe che se li sogni continuassero ogni notte li stessi, non vani et illusorii li giudicaresti. Onde se Bible [52] l'imagi|ne del pravamente amato fratello in qualunque suo sonno li fosse apparso, conforme il tuo parere satolatta si sarebbe realmente dell'infame et incestuoso suo inamora- 
He replied:

"Yet our mutual friend Protagoras, who is followed by some wise men of the present time, claims that the mind's understanding is nothing other than a perception, though he confesses that it is much finer than that of the other senses, just as the eyesight is above its four congeners. Therefore, if so, the author of this dogma would never agree that it was possible to carry out any apprehension, albeit intellectual, without the help of the sense of touch, as also necessarily occurs with the other senses. Yet whether you accept or reject Protagoras's opinion, you should confess that any images or simulacra of objects, once they are detached from the objects themselves and have intruded into the external senses before penetrating the internal [senses], may arrive at the intellect and reawaken it, if not by making [a direct] impression on it, at least [by giving] an impulse. Thus, by means of a certain soft and spiritual contact, it [i. e., the intellect] may also carry out its functions. However, if we suspect and doubt both the way the contact [works] and the contact itself, how will its congener [i. e., visual touch] be [51] the proof and demonstration of it [i. e., the sense of touch]? Therefore, will the doubtful and the uncertain be proofs of themselves?

"However, in addition to this, it happens that the eyesight after having dealt with the mind, often becomes dissatisfied with its apprehensions, so why are we so sure that the same inconvenience does not also occur for the common sense of touch? Indeed, we achieve cognition of the existence of external things by means of resistance, and the mind perceives most of this [resistance]. Hence, we then gather the existence of external things, as was already said. Yet above all, the proof obtained by the senses concerning the speculations of the intellect does not satisfy me, because this judgment is delegated and commended to them by the intellect itself. But it should not refer to them for its own advantage, because by putting its self-sufficiency in doubt, even this compliance turns out to be uncertain and perplexed. So, to bring the discourse back to what we were examining at the beginning, the sense of touch, which you considered to be very sincere and a loyal essayer of our apprehensions, is revealed to be just as perplexed and exposed to deception as the other senses, the internal as much as the external. And just as the proof of the sense of touch now appears to us to be inadequate to make us acknowledge and disclose the truth, so also the other test that you put forward - I mean the continuous duration of the apprehensions - turns out to be, as far as I see it, likewise uncertain and deceptive. And you were not a little mistaken in considering those long-persisting apprehensions as true and the temporary and transitory ones as false, because certainly you place and lay the truth, which is more excellent and refined than all other things, on too weak a foundation.

"Well, oh Socrates, according to your assertion, must the manias of melancholics be considered to be true judgments, since they are rooted in resistant humours which often last throughout their whole lives? ${ }^{102}$ And perhaps the frenzies of choleric persons, which are desultory and short-lived, are only mendacious? Likewise, it would be gathered from your reasoning that if the same dreams occurred every night, then you would not judge them to be vain or illusory. Therefore, if the image of her perversely loved brother had appeared in all of Byblis's dreams, ${ }^{103}$ [52] then according to your opinion, she would actually have satisfied her infamous and incestuous love, and she would have

Refutation of the proof of the duration of perceptions. 
mento, e come vigilante goduto se l'harebbe, mediante la frequenza delle rapresentationi del desiato fratello:

Dumodum tale nihil vigilans comittere tentem

Sepè licet simile redeat sub imagine somnus

Testis abest somno, nec abest imitata voluptas

Pro venus et tener volucer cum matre cupido

Gaudia quanta tuli, quam me manifesta libido

Contingit? et iacui totis resoluta medullis

Ovidio Et meminisse iuvat? quamvis breve illa voluptas

Metamorphoseon.

Nox fuit praeceps, et ceptis invida nostris.

Né perché allhora si trovamo sopiti nel sonno, e con il corpo immobili, mendaci giudicare si dovrebbero tali apparenze. Mentre che l'istessi sogni ogni notte si reiterassero, anzi si argomentarebbe che al di sopra dalle apprensioni di vigilanti vere fossero, ritovandosi in quel tempo l'anima appartata nelli suoi proprii chiostri, e recessi, e che non essendo turbata da scosse de sentimenti esterni, imbrochi nel bersaglio della verità. E se la continuatione e durata d'una openione fosse bastevole cimento per accertarci della verità, già l'assorde openioni radicate et abbarbicate nell'animo di plebei e volgari per il tratto di migliaia di anni, verissime sopra tutte l'altre reputare si dovrebbero, come per il contrario li dogmi di sapienti che non sì tosto che sono pronontiati, dalla folla e turba di sciochi rimangono abbattuti e spenti, mendaci riuscirebbero.

Ma oltre di ciò, qual openione benché in buona lena perseverasse lungo tratto di tempo, mentre che alla fine conforme a tutte le altre cose humane le convenga terminare il loro periodo nella totale estintione, non riesce di momentanea durata rispetto al tempo infinito avenire, et [53] alla indifinente successiva posterità? Anzi quotidianamente esprimentiamo che molte openioni che si ritrovarno in stima e reputatione appo l'antichità, hora in favoloso figmento, e ridicolo racconto si sono convertite. Già l'adorato bue, con la caterva de brutti animali dalli Egittii deificati, appo noi Greci cominciano a sentire del forsenatto, e pazzo, il che può servire per documento circa le cose presenti, rispetto al venturo tempo. E permettesse Iddio che li avenimenti instantanei, falaci apparenze, privi de reale esistentia fossero. E li terramotti, e folgori, che in un momento principiano e finiscono i loro horrori, sarebbero conforme il tuo pronontiato, mendaci illusioni, e che la morte come si dice che per la sua subitanea conditione non appartenere né a vivi né à morti, fosse piuttosto spaventevole larva, che pena così grave et affanosa:

\section{Aut fuit aut veniet, nihil est prasentis in illa}

Ovidius Epistolaria. Morsque minus pena quam mora mortis habet.

Ma la verità è, per quello hora mi si appare, che tanto tenga le sue vere e germane cause, quello che per brevissimo tempo esiste, quanto ciò che per lunghissimo tratto di tempo dalla natura l'è permesso perseverare. $\mathrm{E}$ tanto possiede le vere cagioni di vita quell'animaletto e sgratiatto insetto, Efimero appelato, che nasce vicino le fornaci di Cipro, che si dice la mattina trahere li suoi natali, e che la sera li sopragiunge la naturale sua morte, quanto la cornachia che per alcuni secoli continua in vita. Per il che stimo che molto s'ingannasse Hero, che 
enjoyed it as if she were awake, because of the frequent representations of her desired brother:

If only when I am awake I make trial of no such thing, still may sleep often return with a dream like that! A dream lacks a witness, but does not lack a substitute joy. $O$ Venus and winged Cupid with thy soft mother, how happy I was! How real my joy seemed! How my very heart melted within me as I lay! How sweet to remember it! And yet 'twas but a fleeting pleasure, and night was headlong and envious of the joys before me. ${ }^{104}$

Ovid

Metamorphoses.

These appearances should not even be judged as mendacious when we are asleep, with motionless bodies. If the same dreams were repeated every night, one would rather argue that they were truer than the apprehensions of those who are awake. Indeed, during that time, the soul is used to being secluded in its own cloister and recesses, and since it is not upset by external emotions, it may reach the targeted truth. And if the continuity and duration of an opinion were sufficient evidence to ascertain the truth [of it], one should consider the absurd opinions which took root and settled in the minds of plebeians and common people for thousands of years as the truest of all. However, the dogmata of wise men would turn out to be mendacious, since they, as soon as they are uttered, are destroyed and extinguished by the crowd and mass of foolish people.

"However, in addition to this, is there any opinion that, despite having strongly persisted for a long time instead of ending its [53] life and dying out in accordance with all other human things, turns out not to be temporary in relation to the infinite future and the undefined posterity to come? Rather, every day, we experience that many opinions held in high esteem and consideration by antiquity nowadays turn into mere fabulous fantasies and ridiculous tales. ${ }^{105}$ The worshipped ox, deified by the Egyptians along with many other brutes, already begins to be considered as frenzied and mad by us Greeks. ${ }^{106}$ That may be a useful lesson for present things in respect of the future. God may grant that temporary occurrences are merely false appearances, without real existence. And earthquakes and lightning, which begin and end their horrors in single moments, would, according to your opinion, be mere mendacious illusions, just as death - because thanks to its sudden nature, it is said that it belongs neither to the living nor to the dead - would only be a frightful ghost rather than a serious and distressing suffering:

[Death] either was or is to come: nothing of the present is in her;

And death holds less of dole for me than the delay of death. ${ }^{107}$

Ovid Epistles.

"Yet the truth is, as far as it seems to me now, that both those [things] which exist for a very short time and those which nature permits to persevere for a very long time have their true and real causes. Likewise, the small animals and ungraceful insects called mayflies, ${ }^{108}$ native to the Cypriot kilns, of which it is said that they are born in the morning and die naturally in the evening, have their true causes of life just like the crow, which lives for several centuries. ${ }^{109}$ Hence I think that Hero was highly mistaken when, ${ }^{110}$ after dreaming of closely 
Rigetta il terzo cimento. sognando ritrovarsi in stretti amplessi con l'infelice Leandro, e havere carpito il sommo di piaceri amorosi, tuttavia si lagnasse che vani fossero stati tali diletti, poiché brevissimi li riuscirono.

Ovidio. [54] Me misera brevis est, et non vera voluptas.

Per il che, carissimo Socrate, hormai persuadere ti devi ch'il cimento, et evidenza della vera esistentia dell'oggetti non si conseguisce altrimenti dalla continuata apprensione che da essi tenimo, come in sinora vigilando sognavi. Né la terza prova che adducesti, cioè che il consenso del comune delli huomini, over della maggior parte de più sapienti probabilmente ci possa accertare della verità, stimo sortire di migliore riuscita, che il primieri saggi e cimenti. Li pareri del volgo sono per il più li meno sani, e veraci, ché essendo naturale del comune delli homini seguire la mediocrità, accade che sovente all'estremità più assorde si attenga. Per il che occorre, o che l'apparenza de' sensi seguiti, regettando affatto il discorso della mente, overo che all'estremo contrario appigliandosi, all'assertioni aerie et insusistenti che forma la imaginatione, assolutamente lontani del senso et anco sovente alieni all'istesso intelletto, inclini e s'appiglia, essendo anco proprio dell'astrusità interessare li ingegni nelli loro inviluppi, e di rendere li homini più curiosi in riconoscerle, e poi maggiormente tenaci in abbracciarle. Oltre che l'oscurità apporta certo tale decoro e maestà alli dogmi, e la chiarezza poco di stima e sovente molto dispregio. Né il conformarsi la moltitudine in una opinione apporta maggiore certezza della sua verità, di quello occorerebbe alle monete sospette di falsità, ché siccome la abbondanza e copia non accerterebbe altrui della loro sincera liga, ma piuttosto accrescarebbe il sospetto, così parimente accade circa l'opinioni, riuscendo per il concorso dell'approbatione piuttosto incerte, tanto è lontano che lo annidarsi in molte teste l'istessi concetti, argumenti che dal falso siano lontani et alieni.

Ma se al calculo di plebei rimettere non vogliamo affare cotanto importante, quanto è la recognitione della verità, ma sì bene al parere de' più saggi et [55] addottri|nati, ciò poco giovarebbe per divenire a capo di tal'inchiesta, perché converebbe di novo riconoscere prima, quali fossero li sapienti a quali rimettere ci dobbiamo in riconoscere la verità, onde di novo indagare ci bisognarebbe, se quelli che ci proponessero tali giudici, savii ovvero ignoranti fossero. Non appartenirebbe al sicuro il fare tale scielta alli volgari e plebei, essendo questi di già regetatti da tal fontione, ma s'a sapienti fosse delegata tal carica, convenirebbe ch'anco essi fossero posti all'esame per riconoscere e cimentare la loro sufficientia in eseguire simile elettione. Onde all'infinito si procederebbe.

Ma oltre di ciò mi soviene nuova difficoltà, non potendomi rappresentare in qual maniera giamai possa seguire retto giuditio nell'approbare over reprobare l'altrui parere, poiché li giudici che sono egualmente disposti come quelli che al giuditio si sottopongono, non riescono idonei ad esaminare loro pari et equali, ritrovandosi tutti essi nella istessa constitutione posti, ché tanto sarebbe come se cadauno di essi giudicasse se stesso. Li pesi affatto simili non puono l'uno all'altro apportare fede della legitima loro sincerità. Ma se diferente il giudice dalli giudicati, non riesce esso giudice per altro verso suficiente a tal fontione, poiché quello che diversamente si trova disposto, con diferente visaggio et apparenza se li rappresenta l'altrui openioni. Per il che non sortisce 
embracing her unfortunate Leander and grasping the greatest pleasures of love, she complained that these delights were vain because they were so brief.

\section{[54] Ah me! brief pleasures these, and not the truth. ${ }^{111}$}

Hence, my dearest Socrates, you must persuade yourself that the proof and evidence of the true existence of objects can only be achieved by our continuous apprehension of them, as you have so far dreamt while being awake. Nor do I consider the third proof that you have adduced - namely that the general agreement of common people or that of the majority of the wisest men will probably ascertain the truth - to be any better than the earlier evidence and proofs. The opinions of the common people are mostly the least sane and truthful; since it is natural for the common people to follow the mediocrity, it often happens that they support the most absurd extreme. Therefore, it occurs that they either follow the impressions of the senses by indeed denying the discourse of the mind, or that they hold the extreme contrary by appealing and inclining to the airy and unfounded assertions formed by the imagination which are entirely distant from the senses and often also dissimilar from that intellect itself. Indeed, it is also typical of the abstruse to lead the intellect's interests into their tangles and to make human beings more curious to know them and then more tenacious in embracing them. Furthermore, while obscurity gives decorum and majesty to dogmata, clarity [produces] little esteem and often much disdain. Nor can the multitude's compliance with an opinion be proof of a greater certainty of the truth of it. Indeed, just as abundance and great quantity are not proof of a genuine alloy in money suspected to be counterfeit, but rather increase suspicion of it, so likewise is the case for opinions which turn out to be rather uncertain [precisely] because many people accept them. Indeed, the settlement of the same concepts in many minds is far from proving that they are distant and distinct from falsehood. ${ }^{112}$

"Yet if we do not want to assign so important a matter as the acknowledgement of the truth to the reckonings of plebeians, but rather to the opinion of the wisest and most learned people, [55] nevertheless it would not be very helpful for solving this question, because we should first acknowledge the identity of these wise men to whom we must refer in acknowledging the truth. Therefore, we should verify whether those who put themselves forward as judges are wise or ignorant. Certainly, this decision should not rest with the common people and the plebeians, since they have already been dismissed from this duty. However, if one were to entrust the wise men with such a task, even they should be evaluated in order to recognise and test their ability to carry out such an election. Thus, one can continue to infinity. ${ }^{113}$

"Yet in addition to this, another difficulty comes into my mind, because I cannot imagine how one could ever express correct judgment in approving or rejecting others' opinions. The reason for this is that the judges have the same aptitude as the people being judged; namely, they are not able to examine their peers and equals. Since all of them are in the same situation, it would be as if each of them were judging himself. Those who carry a similar weight cannot give each other proof of their lawful sincerity. However, if the judge is different from the ones being judged, he will in any case not be suitable for this duty, because a person with a different disposition will represent other people's opinions with a different aspect and appearance. Hence, this would not be helpful
Ovid.

Refutation of the third proof. 
al proposito in fare giuditio della disposizione dell'altri, ché tanto sarebbe come se giudice circa cosa ad esso ignota attentasse proferire sentenza.

Onde siccome sempre mi rassembrò come impossibile, che il sano riuscisca habile a giudicare delle apparenze del frenetico, essendo diferentemente disposti, e constituiti, così anco stimai che il reputato da noi savio, le stoltitie dell'ignorante sincermente giudicare non potesse. Il che oltre che la ragione ciò me l'additava, li volgari tintori mi lo dimostrano, ché volendo essi assagiare due porpore, dell'istesso panno prendono due portioncelle, ché se altrimente [56] fa|cessero, restarebbero delusi in tale loro prova. Pertanto, amico, riuscendoci li cimenti e caratteri da te addotti per riconoscere la vera esistenza delle cose insuficienti et impediti da sì gravi difficoltà, rimanemo come prima, nell'informarci circa l'esser over non essere d'esse cose, confusi et ignari”.

\section{Ma io ad egli di novo li soggionsi:}

"Punto non mi difido che circa tal materia mi sei per apportar alcun maggiore e più chiaro lume, e ben scorgo qual sia la tua modestia in dissimulare inscitia circa ciò che meglio di qualunque altro ne sei adottrinato. E per il certo non poco di giovamento mi arrecò tale discussione teco tenuta, havendomi purgato l'animo di quelle sciochezze, che mi harebbero conteso l'adito a quelle dottrine che, motivato dalla innata tua benignità, hora sei per introdurre nel mio animo".

\section{Risposemi egli:}

"La facilità che scorgo in te nel retrattare le tue proprie openioni, mentre che non tengono apparenza de verità, m'invita a comunicare teco quello che circa tal affare, già una fiatta, seriamente forse vanegiavo, ché havendo in consideratione la tua indole e probità di costumi, stimo esporlo più alla tua censura e corettione che a derisione, e se alla copella del tuo intendimento non resisterà, almeno eccitarà in te desio di rinvenire in tal proposito quello che in sin'hora tanto ci abbandona, e sfuge".

\section{Et io ad esso:}

"Da tuoi primieri ragionamenti ben osservai a qual grado di eccellenza sormontava la tua scientia, ma hora assaggio qual sia la moderatione et urbanità del tuo egregio animo, proprio carattere di sì preggiata dottrina, emendando l'altrui arrogantia con la simulata da te inscitia. Ma segui hormai, ottimo homo, il tuo cortese proponimento". 
for judging other people's dispositions, because it would be as if a judge were attempting to pass sentence on something unknown to him.

Therefore, just as it has always seemed impossible to me that a sane person could judge a frenetic one by his appearance, since they have different dispositions and constitutions, so I also thought that a person whom we consider to be wise could not sincerely judge the foolishness of the ignorant. Hence it was not only my reason that pointed me to this, but also those common dyers who, wanting to test two different kinds of purple, take two small parts of the same cloth, because if they did [56] otherwise, they would be disappointed by the proof. Hence, my friend, the proofs and signs that you put forward in order to acknowledge the true existence of things turn out to be insufficient and impeded by such serious difficulties that we would remain in the same state as before in being informed about the being or non-being of things, namely confused and unaware."

\section{Yet I replied to him again:}

"I do not doubt that you will throw further and clearer light upon this matter, and I clearly see your modesty in simulating ignorance about it, although you are more learned about this than anyone else. And certainly, this discussion with you has given me a great benefit, as it has purged my mind of those foolishnesses which would have prevented me from gaining access to the doctrines that you, motivated by your innate benignity, are going to introduce into my mind."

\section{He answered me:}

"I behold that you have such ease in retracting your own opinions when they do not hold the appearance of truth that it encourages me to tell you what I already once perhaps seriously raved about this matter. Since I hold your natural disposition and honest manners in high esteem, I think I will submit it more to your censorship and correction than to your derision. Then, if it will not withstand the cupellation of your understanding, ${ }^{114}$ at least it will arouse in you the desire to find out what has so far deserted and escaped us.”

\section{And I [replied] to him:}

"From your early reasoning, I behold the excellent degree achieved by your knowledge; but now I am also essaying the moderation and fairness of your remarkable mind, as characteristics of such a fine doctrine that emends the arrogance of others by your simulated ignorance. However, oh excellent man, you should now continue your courteous proposal.” 
Nello ricercamento circa l'oggetti.

Che l'oggetti non sono alcuna delle quattro cause.

Socrate stima l'oggetto stampe.

Rigetta Gorgia il modo di stampa.

\section{Al che continuò Gorgia:}

"Credo esserti noto, che quattro siano comunemente stimate, le cause delle cose: la materia da cui sortiscono, forma che tali le constituisce, efficienti dal quale sono operate et il fine per cui l'efficiente si condusse alla loro facitura. L'oggetti esterni che sono stimati volgarmente cagione delle [57] nostre operationi, ad una overo a parte di queste quattro cause ridurre si devono, se però a tutte non li vogliamo riferire. Ma li oggetti non sono già altrimente cause materiali dell'apprensioni, ché sortirebbero l'istesso animo. E per la medesima ragione, né anco sono formali cause, poiché parimente altro non sarebbero che l'istesso animo, in tal modo e non era conformato, e constituito, non restando in tal guisa alli oggetti altra esistentia esterna e reale, fuori di noi disgiunta e separata. Non cause finali, non servendo queste se non, che ad impulsare la volontà dell'operante alla esecutione di quello l'è proposto dall'intelletto sotto imagine di bene, per il che non sortiscono sufficienti ad informare la mente della volontà primiera norma e scorta, oltre che la causalità del fine è piuttosto metaforica che reale.

Restaci solamente il ricorso alla causa efficiente, né a mio credere tal causa ci si dimostra bastevole a renderci informati delle conditioni di essi oggetti. Primieramente parmi che non essendo altro l'efficiente, che l'origine e principio d'onde deriva il motto esecutivo, et operativo dell'effetto, non può esso produrre nella nostra mente cognitione tale, che ci renda informati della sua vera essentialità, siccome quando miramo la stupenda testa di Giove Olimpico, non restiamo conscii delle conditioni e qualità proprie et essentiali dell'opefice di tal simulacro, e l'esperienza ci insegna che una puntura che sentiamo può derivare nella istessa maniera da diversi e varii efficienti. Nel medesimo modo ci afflige acuto ferro, spino appuntato, schieggia di pietra, e humori interni acri e mordaci, che nel nostro corpo sovente risiedono. Per il che ci si rende chiaro che l'interne passioni non riescono soficienti a palesarci la qualità e conditioni delli efficienti di esse”.

\section{A ciò replicai che:}

"Piuttosto stimarei che li oggetti esterni fossero non come semplici motivi et impulssori. ma che a guisa di tipo e stampa formassero nel nostro animo il loro modello et imagine, ché perciò [58] pre|sumere potiamo di riconoscere in certa maniera le condizioni reali di tali oggetti”.

Ma Gorgia immantinente a ciò occorse, et acramente mi redarguì, che con troppo resoluta confidenza ciò pronontiassi et affermassi, e che era immoderata prosuntione, che non havendo l'huomo giamai scorto tali pretesi, et asserti tipi, impressori de nostre interne passioni, non essendo giamai alcuno traboccato fuori di sé et afferato tali stampe, e tuttavia ardisca sententiare che vi siano, mentre che in altro modo salvare si possono li nostri risentimenti, come hora son per dirti: 


\section{Hence Gorgias continued:}

"I believe that you know that the causes of things are commonly considered to be fourfold: the matter from which they come; the form that constitutes them as they are; the efficient [cause] from which they are guided; and the final [cause] to which the efficient addresses its work. ${ }^{115}$ The external objects, which are commonly considered causes [57] of our actions, must then be reduced to one or part of one of these four causes, if we are not referring to all of them. Yet the objects are indeed not material causes of perceptions, because [in this case] they would merely be the mind itself. And for the same reason, they are not formal causes, since then they would be nothing other than the mind itself, which is not made up or constituted in this manner. In this way, the objects would not have any real or external existence, disjoined and separated from us. [The objects are] not even the final causes, which are only useful for giving an impulse to the will of the one who is acting to carry out what the intellect suggests to be good. Hence, they turn out to be insufficient to inform the mind of the will, which is the original rule and guidance. Furthermore, the causality of a purpose is metaphorical rather than real.

"We can only appeal to the efficient cause, but I think that not even this cause demonstrates to us that it is sufficient to inform us about the conditions of the objects. Firstly, the efficient seems to me to be nothing other than the origin and beginning from which the motion executing and operating the effect is derived. For this reason, it cannot produce cognition in our minds to inform us of its true essentiality. ${ }^{116}$ Just as we are not aware of the conditions and proper and essential qualities of the maker of the splendid head of the Olympian Zeus when we admire that simulacrum, ${ }^{117}$ and just as experience teaches us that when we feel a prick, it may come from different and various efficient [causes], in the same way, we are tormented by sharp instruments, pointed thorns, fragments of rock, and sour and caustic internal humours often located in our bodies. Hence, it becomes evident that the internal passions are not sufficient to disclose the quality and condition of their efficient [causes] to us.”

\section{I retorted to this:}

"Rather, I would consider the external objects not only as simple causes and impulses, but also as being able, like type and imprint, to form the exemplar or image of themselves in our minds. Therefore, [58] we presume to somehow acknowledge the real condition of such objects.”

Yet Gorgias immediately opposed this and bitterly reproached me for having uttered and affirmed it with too much confidence. And [he found] it an immoderate impudence that although no man had ever met these supposed and alleged types which impress our internal passions, because nobody has ever overflowed from himself and grasped these imprints, nevertheless someone would dare to establish that they existed while there was another way to maintain our affects, as I am going to tell you:
Making inquiries concerning objects.

Objects are not one of the four causes.

Socrates considers object to be imprints.

Gorgias refuses the manner of imprint. 
Tre maniere d'impressione di oggetti.

Confuta li tre modi proposti dell'operar d'oggetti.
"La verità non compatisce ardite congietture, et arischiatti trapassi la codardia, ad essa sortisce Virtù, e la tarda e lenta circonspettione le apporta commendatione. Tiene maggior nemistà con il verisimile, che con l'aperto falso, questo usa la forza per opprimerla, e quello l'inganno per tradirla. Ma acciò non ti resti che desiderare circa quello che in tal proposito tengo meditato, comunicare ti voglio ciò che una fiatta in tal affare nella mente mi capitò. Rassembravami che in tre maniere si potessero formare l'apprensioni che in noi si producono: primo modo, come hora divisasti, per mezo di stampa, e sugello fuori di noi esistente, cagionando in noi impressione simile ad esso oggetto, il qual impressore rimane in sé doppo l'haver fatto in noi incontro.

Seconda guisa, come quando con il motto e flusso del penello over scalpello, sortisce nella tella over pietra la figura che si attenta indurvi, onde dopo tal facitura, non rimane appresso l'efficiente alcun'imagine dell'effetto prodotto. In terzo modo può seguirne effetto simile, senza aiuto d'esterna efficiente, ma per mezo di certa coagmentatione et amassamento di varie portioni materiali d'onde risulti una tal figura, dal caso in certa maniera formata, come si racconta che appo il Re di Macedonia si ritrova agata nella quale appariscono le nove muse che circondano Apollo loro corifeo, e nelle pietre di minor pregio, ogni giorno si scorgono varii scherzi della natura che rassembrano effetti della più elaborata humana arte, causati solamente dal concorso di diversi humori fortuitamente [59] insieme congelati et impetriti.

Da questa tripartita effetuatione d'imagini, fui indotto a speculare quali di queste maniere fosse la più propria et addatibile alla produttione delle apparenze che in noi sentiamo. Non mi fu occulto che volgarmente si stima, come tu medesimo hora proponesti, che nella primiera guisa sortiscono, nondimeno oltre il già detto, non mi mancò motivo ragionevole che mi indusse a disentire dalla tale comune openione, e che me inclinasse l'animo alla seconda guisa accennata, stimandola non aliena dal nostro proposito, persuaso, dico, dall'osservare che le nostre apprensioni con certa misura di tempo si eseguiscono, benché erroneamente alle fiatte, subitanee ci appaiano, ché se per modo de stampa li oggetti ci causassero le loro impressioni, affatto instantanee si produrebbero. Né da ciò è alieno il dogma d'Eraclito e Cratilo, che stimano il tutto essere in continua agitatione, produttione, e flusso, onde qualunque impressione che si trova in noi è in alteratione, e successione, e che il dolce, amaro, nero, e bianco, derivino da un certo congresso che tengono li oggetti esterni con li nostri sensi, e che disciolto tal accopiamento, non rimanga fuori di noi esemplare di tal apprensione, e che non altro resti nel nostro animo che un tenue vestigio della prima impressione accadutaci.

Oltre che il moltiplicare senza urgente necessità idee, stampe, tipi, e sugelli riesce insano partito, havendo la natura nelle sue operationi non meno il superfluo che il difettoso e manchevole schifatto et abhoritto. Né la terza guisa da me proposta rimane affatto esclusa dal nostro proponimento, poiché sovente esprimentiamo, che li sogni, delirii, e false opinioni si producono in noi senza l'esistentia d'alcun esterno oggetto. E siccome è mendace il ritrovarsi fuori di noi opefici di tali illusioni, così è vero insistere nel nostro interno tali rassembramenti, et apparenze, il che in altra maniera non può accadere, che 
"The truth does not sympathise with daring conjectures, just as cowardice [does not sympathise] with risky events. Virtue comes from it, and belated and slow circumspection causes its commendation. [The truth] is more the enemy of what resembles the truth ${ }^{118}$ than of what is clearly false: the latter uses force to oppress it, while the former uses deception to betray it. Yet what you can do now is desire [to know] what I have considered about it. Thus, I want to tell you what once occurred in my mind. It seemed to me that the apprehensions produced inside us could be formed in three ways. The first way, as you examined just now, is by a print or seal, existing independently of us, which produces an impression in us that is like the object itself, while what impresses us remains in itself even after having encountered us.

"The second way is like when the shape one is attempting to produce appears on a canvas or rock through the motion or flow of a paintbrush or chisel; once the operation is finished, no image of the effect produced by the efficient [cause] remains. From the third way, there may follow a similar effect without the help of an external efficient [cause], but merely by combining and amassing together different material parts, whence results a shape made in a certain way by Chance. Just as it is recounted that the king of Macedonia owned a piece of agate in which the nine Muses appeared around Apollo as their coryphaeus, ${ }^{119}$ so every day one may catch several tricks of nature which seem to be the effects of the finest human art even in the least precious stones. However, they were only caused by different humours, [59] frozen and petrified together by chance.

"From this tripartite effectuation of images, I was induced to speculate about which of these ways was the most appropriate and suitable [to explain] the production of the appearances that we perceive inside us. I knew well that it is commonly considered that they are caused in the first way, just as you suggested now. Nevertheless, in addition to what has already been said, I had enough reason to disagree with this common opinion and to incline my mind to the aforementioned second way. I considered it no different from our proposal, persuaded, I say, by observing that our apprehensions are performed in a certain length of time, although they sometimes erroneously seem to us to be instantaneous. Thus, if objects caused their impressions in us by printing, they would indeed be produced instantaneously. Neither is the dogma of Heraclitus and Cratylus different to this, since they consider the whole as being in a continuous state of restlessness, production, and flux. Thus [according to them], any one of our impressions is [subject to] alteration and succession; furthermore, [they believe that] sweetness and bitterness and blackness and whiteness are derived from a certain combination of external objects with our senses, and also that once such a union is dissolved, no exemplar of this apprehension remains outside us, and what is left in our minds is a feeble relic of the first impression that occurred to us.

"In addition to this, the [theory of the] multiplication of ideas, printings, types, and seals, without urgent necessity, turns out to be an insane view, since in its operations Nature equally abhors and rejects what is superfluous and defective. ${ }^{120}$ Nor indeed does the third way that I suggested remain excluded by our proposal, since we have often experienced that dreams, [those] delirious and false positions, are produced in us without the existence of any external object. And just as it is mendacious to find the authors of such illusions outside ourselves, so it is true that these images and appearances persist inside us.
Three manners of the impression of objects.

Refutation of the three manners suggested concerning the way in which objects work. 
Asserire in continuo flusso, e perciò ignoto.

Esser immobile secondo Parmenide, e perciò ignoto.

Instanza per l'immobilità dell'essere. per cagione di certa compositione e construtione di imagini che [60] in noi, e non nell'esterno, tengono le loro radici e propagini.

Onde tali avenimenti ci rendono alquanto sospetto che alle fiate vigilando sognamo, e che ritrovandoci sani del corpo, deliramo con la mente, non tenendo tali apprensioni fondamenti reali fuori di noi ove si appoggiano e sostengono.

In queste difficoltà si ritroviamo, o Socrate, illaqueati speculando l'ente, stimato da te a tal segno evidente, che lo giudicavi il vero et adequato oggetto della mente, e che sotto la sua scorta il tutto se apprendesse e riconoscesse, eppure a tal flutuatione e perplesità siamo ridotti che dubbitamo della sua esistentia. A questo si aggiunge il parere d'Eraclito, Cratilo, e Protagora, che niegano all'ente la fermezza e stabilità, ma flussibile e successivo si lo rafigurano, non diverso dal tempo di esso misura, non dovendo, conforme il loro pensamento, il misurato di diversa conditione sortire, che la sua misura, siccome riesce anco impossibile che la grandezza d'una campagna con il semplice numero discretto si misuri. Per il che se il tempo, dell'ente misura, è flussibile, conviene che anco l'istesso ente, suo misurato, successivo sia.

Ma se di lui, in qualunque instante della sua duratione, non si può affermare che piuttosto sia, che non sia, mentre che in continua alteratione e mutatione si trova, riesce complicato e mescolato con il non ente, e perciò di contraditione composto egli apparisce. Dal che parimente anco ne segue che di esso ente giammai compita cognitione non posiamo ottonerne, essendo interditto alle cose che in motto si ritrovono l'esatamente esser apprese, ché siccome sono in loro stesse fugitive, così anco scansano l'altrui comercio et esser appresi.

Ma se Melisso e Parmenide ascoltare vogliamo, che il contrario affermano, nelle istesse ambagie ricademo, restandoci molto più l'essere ignoto se immobile e stabile lo supponiamo. E l'instanza, dedotta dalla consideratione del tempo a favore di Eraclito, punto non l'annoia, anzi [61] da quella prendono questi ansa di maggiormente confermare l'immobilità dell'ente, advertendo essi che la portione del tempo passato in quiete si ritrova come di già trascorsa. E la portione dell'avenire parimente, perché al motto non è per anco chiamata, in riposo se ne sta. Il presente anco in quanto egli è tale, non li conviene il motto, oltre che essendo egli estremo del passato et avenire, li conviene che immobile sia, siccome accaderebbe alle estremità di corpi, che solamente al motto di essi corpi si movono, non potendo questi esser stabili e quelle mobili.

Ma se l'ente fermo et immobile si trova, siccome alli primieri riusciva, conforme li fondamenti della loro positione, che l'ente ci fosse ignoto, così alli assertori della quiete et immobilità accade che ci rimanga sconosciuto, perché ritrovandosi secondo tal dogma quieto, riposato, immobile, tutto in se stesso raccolto, ritirato e sequestrato, perciò anco l'è prohibito il tenire con altrui famigliarità, alleanza et attività alcuna, né può in altrui fare di sé impressione e produrre imagine, onde ci riesce di novo incomprensibile et inattingibile.

Stante l'antedette difficoltà circa l'ente incontrate, meravigliare non si dobbiamo, se alcuni di sapienti a tal partito s'indussero, di affatto sbandirlo dalli humani ragionamenti, et invece di pronontiare "il corvo esser nero, il 
Hence this can only happen through a certain composition and construction of images [60] which have roots and shoots inside us and not on the outside.

"Therefore, such events lead us rather to suspect that sometimes we are dreaming while we are awake, and that even if we have sane bodies, we are raving in our minds, since these apprehensions do not have any real foundation for sustenance and support outside of our minds.

"Oh Socrates, we are ensnared in such difficulties when we speculate about ens, which you considered it so evident that you deemed it a true and adequate object of the mind and that everything is apprehended and acknowledged under its guidance. Nevertheless, we are reduced to such a wavering condition and state of perplexity that we doubt its [very] existence. In addition to this, there are the opinions of Heraclitus, Cratylus, and Protagoras, who deny the firmness and stability of ens by representing it as fluid and successive. [They represent it] as being no different from time, as a measure of it [i. e., ens]; indeed, according to their thought, what is measured must not have a different condition from its measure. Similarly, it turns out to be impossible that the size of a country may be measured with a simple discrete number. Hence, if time, as the measure of ens, is fluid, then that same ens as measured by it should be successive.

"Yet if one cannot state, in every moment of its duration, what is, or rather what is not, while it is in continuous alteration and change, then it turns out to be involved and mixed up with non-ens, and thus it appears to be composed of contradictions. Hence, it similarly also follows that we could never reach an exact cognition of this ens, since it is forbidden that things in motion may be accurately apprehended, being so fleeting in themselves that they avoid apprehension and relations with others.

"If we wished to listen to Melissus and Parmenides, who affirm the contrary, we would once more fall into the same difficulties, since being would result as much more unknown if we supposed that it is motionless and stable. The instance deduced from the consideration in favour of time put forth by Heraclitus does not undermine it, but rather [61] they use it as an opportunity to confirm the immobility of ens even more strongly. And they warn that the part of time that is past is in a state of rest, since it has already elapsed; similarly, the part that is in the future is in a state of rest, because it has not yet been called to be in motion. Motion also as such does not concern the present time, which is the extreme border of both the past and the future and thus should be motionless like the extremities of the body. Indeed, they only move with the motion of the bodies themselves, because the latter cannot be stable while the former are movable.

"However, if ens is still and motionless, just as according to those [we mentioned] first [i.e., the opinions of Heraclitus, Cratylus, and Protagoras] and the principles of their position, ens turns out to be unknown to us, so it also remains unknown for those who asserted its immobile and resting state. According to this dogma, it is still, at rest, immovable, completely withdrawn, retired, and secluded into itself. Therefore, it is forbidden to have any relation with others or any alliance or business, nor can it impress itself and produce an image; thus, it results as incomprehensible and inaccessible to us.

"Because of the aforementioned difficulties that we have encountered concerning ens, we must not wonder why some of the wise men decided to ban it from human reasoning, and why instead of uttering 'the crow is black,
Asserting continuous flux means asserting the unknown.

\section{According to \\ Parmenides, being \\ is motionless, and consequently unknown.}

Instance for being's immobility. 


\section{Platone nel Sofista.}

cigno bianco, il sole è corrente," proferivano "corvo negro, cigno bianco, e sole corrente."

Et altri per rimpatriarlo introdussero in sua compagnia il diverso, l'istesso, il moto, e la quiete, siccome d'uno hospite eleate intesi divisare, quasi che questi quattro generi, dall'esser diversi e distinti, fossero idonei ad operare in esso e qualificarlo. In tali mostruosità et assordi si riducono quelli, che sottilmente presero a ventilare e discuttere ciò che sia l'essere, stimato già da sé l'unico sole che apporta lume a tutti li altri intelligibili oggetti, ma quello che oltre di ciò non mediocremente offende il saper humano è, che a tali termini ridottaci circa [62] l'essere, ci resta impedito l'adito di oltrapassare a qualunque altra speculatione, essendo noi destituti della cognitione di cui è fondamento di tutte le cose mondane, e base di qualunque nostra speculazione”.

\section{Al che soggiunse io:}

"Non picciola portione di dottrina fu quella che in tal proposito circa l'ente divisando meco, apportato mi hai, ritrovandomi purgato l'animo di molte sciocchezze che sode e vere scientie per inanzi reputavo, non essendo meno giovevoli le medicine purgative a corpi infermi che li utili alimenti a sani”.

\section{$\mathrm{Al}$ che repigliò egli:}

"Volesse Iddio che ciò fosse avvenuto, ma dubbito che tutto il discorso teco consumato ci riesce perplesso e dubbioso".

\section{E quale di ciò sia la cagione, l'interrogai.}

\section{Rispose egli:}

"L'haverci noi per tutto il tratto del nostro ragionamento, ventilando e discuttendo l'essere, servitosi del verbo 'è' e 'non è', e che mentre indagavamo ciò che egli sia, come di cosa già conosciuta et appresa nelli nostri parlamenti l'adoperavamo. Per il che tal nostro favellare ci riesce simile al fuoco che distruge non meno se stesso che altrui".

\section{E seguì egli:}

"Non mi rimane per hora altro che amichevolmente avisarti, che ritrovandoci noi in tali roversciati meandri, et invilupati laberinti, restandoci smarita la via di proseguire et afferare la verità circa l'esistentia universale delle cose, che per l'avenire da qualunque resoluta assertione affermativa, over negativa ti asten-

Persuasione di Gorgia fatta a Socrate per la retentione del giuditio. ghi, havendo ambe queste bisogno di tali dittioni 'è non è', il che tu esequendo, probabilmente stimo presagire, che doppo lunghi contrasti et importune oppositioni, che da malevoli ti saranno intentate, riuscire devi per tal circonspetta modestia, e cautelosa ritrosità, non solamente appregiato da molti di tuoi coe- 
the swan is white, and the sun is moving,' they said 'the black crow, the white swan, and the moving sun.'

"And others, in order to repatriate it, stated that it is accompanied by difference, sameness, motion, and rest, as I heard from the Elean Stranger, ${ }^{121}$ as if these four kinds, different and distinct from being, were suitable to work in it and qualify it. ${ }^{122}$ Those who subtly began to examine and discuss what being was - which was already considered to be alone, like the sun, and thus the only one able to provide light to all other intelligible objects by itself - were reduced to this monstrosity and absurdity. Yet what causes no little harm to human knowledge in addition to this is that [62] we are reduced to this extent concerning being, namely that we are prevented from turning to any other speculation. Indeed, we are deprived of the cognition that is the foundation of all worldly things and the basis of all of our speculations."

\section{Hence, I continued:}

"By conversing with me concerning ens, you have provided me with no small amount of doctrine. Indeed, I find my mind purged of many foolishnesses that I had originally considered to be solid and true sciences, because purgative medicines are beneficial for infirm bodies just as food is useful for healthy people." ${ }^{123}$

\section{Hence he replied:}

"May God grant this to have happened, but I suspect that the entire discourse [that I have] carried out with you will turn out to be uncertain and doubtful.”

\section{And I questioned him about the reason for this.}

He answered:

"Throughout our argument, in examining and discussing being, we have used the verbs 'is' and 'is not,' and while we were investigating what it is, we used it in our discourses as if it was something that is already known and acknowledged. Therefore, our conversation is turning out to be like a fire which destroys itself as well as others."

\section{And he continued:}

"All I can do now is to amicably warn you that since we are in such reversed meanderings and tangled labyrinths, we are straying from pursuing and catching the truth about the universal existence of things. In future, you should abstain from any resolute affirmative or negative assertion, since they both require the expression 'is' or 'is not.' If you follow this [advice], I foresee that after the long obstructions and rash oppositions that will be attempted by your ill-wishers, thanks to your careful modesty and cautious discretion you will not only be appreciated by many of your contemporaries and
Plato in the Sophist.

Gorgias persuades

Socrates to withhold his judgment. 
tanei e comendato dalla indifinente posterità, ma oltre modo grato alli dei, che dalli tesori della sapienza, ad essi solamente riserbati, ti astenesti, e no ardisti porvi profana mano, né con sacrilega lingua osasti vanamente milantarti di possedere la sincera verità, che ad essi è appropriata”.

Qui hebbe fine la [63] confe|renza che passò tra Gorgia e me, la quale gettò nel mio animo li primi fondamenti di quella retinenza di giuditio, tanto da miei adversarii calunniata, et al Vostro spettabile tribunale acramente hora accusata, ma dal sapientissimo Gorgia lodata e comendata. Hor dunque ritrovandomi dal ragionare di Gorgia in tal maniera affetto, e disposto, essendo per allhora destituto dalla norma di sapienti, al mio fiaco e proprio sapere mi abbandonai, proponendomi nell'animo tralasciare affatto ogni speculatione, et ad un pigro otio e volontaria ignoranza mi condannai, persuadendomi a ciò la Socrate si dà all'otio. rimembranza de' saggi documenti del prudente Gorgia, che a guisa di nuova, ma benigna Circe, con salutifero incantesmo in lenta testugine mi transformò, ché siccome questa, mentre che ristretta e raniciata nel suo teschio, e naturale armatura si riduce, dalle esterne offese si trova sicura, così, mentre che li miei giuditii nel recinto e continente delle proprie passioni si ristringessero, e che fuori de loro limiti non trabocassero né ad oggetti putatitii si affidassero, mi stimarei affatto cancellato di non attoppare et offendermi nelli diruppi delle falacie, e di non rendermi a me stesso deluso, et ad altrui ridicolo. E seppur il caso inavedutamente ad essi oggetti nel favellare mi facesse trapassare, con l'antidoto del 'così mi si rappresenta, e rassembra', coreggere et emendare tal ardito divagamento et inconsiderato passagio dovrei. In tal stato di scioperatezza et inerte accidia mi tratteni alquanto di tempo.

M'annoiato dalla otiosità et infastidito dalli stimoli del proprio genio e dall'oracolo finalmente admonito a non continovar in sì neghittoso stato di vita, admonendomi che ad ogni modo dovessi in me stesso discendere, facendomi a me medesimo teatro, intrapresi finalmente di penetrare con il discorso nelli più interni miei recessi, e con ogni maggior diligenza et esatezza intrapresi di esatamente scandalgiarmi, reputando tal speculatione non men nobile di quella che per inanzi circa [64] og|getti esterni esercitai, ché se l'universo è di intelligenza dottato, come li pitagorici asseriscono, non havendo fuor di sé che osservare e scorgere, ad altro per il certo non s'impiega che alla contemplatione di se medesimo. Da tali motivi dunque persuaso, essendo di già da oggetti spicato, rivocai li vaganti miei pensieri alla interna speculatione di me stesso. 
commended by indefinite posterity, but you will also greatly please the gods. [The reason for this is that] you will have abstained from the treasures of wisdom, reserved only for them, and you will not have dared to put your profane hand on them, nor will you have dared to vainly boast, with your sacrilegious tongue, of owning the sincere truth, which belongs only to them."

The conversation [63] between Gorgias and me ended here. It laid the first foundations in my mind for the withholding of judgment, so defamed by my opponents and harshly accused now by Your respectable court, but praised and commended by that most wise Gorgias. Thus, following Gorgias's argument, I found myself affected and disposed in this way, and as I was not following the usage of wise men at that time, I indulged in my own weak knowledge by proposing in my mind to leave aside any speculation and to sentence myself to indolent leisure and voluntary ignorance. The memory of the wise teachings of the prudent Gorgias persuaded me to do this. Like a new but benign Circe, ${ }^{124}$ he transformed me into a slow tortoise through a salvific enchantment, ${ }^{125}$ because when it [i. e., the tortoise] is withdrawn and crouched in its shell and natural armour, it is safe from external attacks. Similarly, if my judgments were restricted to the enclosure and field of their own passions and did not overflow from their limits or rely on alleged objects, I would indeed consider myself safe from being pushed into the precipices of fallacies and being affected by them, from being disappointed by myself, and from being considered ridiculous by others. And even if Chance rashly allowed me to come to talk about objects, nevertheless I should correct this daring deviation and hasty step thanks to the antidote of "this is how it seems and appears to me." I remained in this condition of idleness and indolent sloth for some time.

Yet bored with idleness and annoyed by the stimuli of my genius, ${ }^{126}$ I was finally warned by the Oracle not to continue this lazy state of life. She advised me that I should nevertheless retreat into myself. I therefore made myself into a stage and finally undertook to penetrate into the innermost meanderings of myself through discourse, and to perform a more diligent, exact, and accurate scrutiny of myself. I considered this speculation as noble as that which I had carried out at the beginning concerning the external objects. [64] Indeed, if the universe is endowed with intelligence, as Pythagoreans assert, and since there is nothing to see and behold outside it, all that it can pursue is the contemplation of itself. Then, persuaded by these reasons and having already distanced myself from objects, I addressed my wandering thoughts to an internal speculation on myself.
Socrates indulges in idleness. 
Dubbio circa il numero di sensi.
Avvenimento occorso con Critone cieco che negasse il senso della
Nel primo adito che a tal inchiesta mi s'apparì, furno li sensi esterni, circa quali primieramente presi ad esaminare, se bastevoli siano a raguagliarci di tutte l'emergentie che al di fuori di noi accadono. Osservai che cinque sono stimati dal comune delli homini tali sensi, la vista, udito, odorato, gusto, e tatto, ma che questi solamente ad avisarci di tutte le conditioni e visaggi delle cose a noi esterne fossero sofficienti, molto ne dubbitai. E ridicoli affatto giudicai coloro che arditamente pretendono evincere tal quinario dal numero de' generi di sensibili, quasi che questi per altra via e mezo che da sensi, ci si rendano conosciuti e manifesti et altre fiate poi, divenuti obliviosi della loro propria dottrina, deducono vicendevolmente il numero di sensibili da quello de' sensi. Ma lasciando la di costoro instanza e fievola argomentatione, stimai che tenisse molto dell'ardito l'affermare che li antenominati cinque sensi fossero soficienti ad avisarci tutte le condizioni delle cose esterne, e perché noi non ci possiamo formalizare delli altri sensibili a noi occulti, né delle maniere di sensi di quali si ritroviamo privi, tuttavia temerariamente si arisichiamo di affermare la loro impossibiltà.

Mi accrebbe gagliardamente il sospetto l'avenimento occorsomi con Critone di nascita cieco, ma di intelletto molto erudito, ché ritrovandomi seco, in compagnia de alcuni comuni amici, furno raccontati alcuni mirabili spettacoli che Pericle al popolo già alcuni mesi rappresentò. Da che fu preso occasione di favellare della eccellenza della vista che sopra tutti li altri sentimenti prestante [65] fosse, sugerendoci piaceri sinceri, non come li altri, sempre con dolori mescolati, e che alla loro riuscita nocumenti ci apportano, oltre che estendendosi essa vista ad oggetti lontanissimi, ci arreca egregie dottrine. Ma dubitando io che Critone da tal discorso prendesse alcuna noia, ritrovandosi egli di lume destitutto, attentai di consolarlo con dirli che altro tanto che la natura li si mostrò poco amica in renderlo cieco, il proprio genio li riuscì favorevole, con eccitarlo al studio della sapienza, ché tanto trapassa il diletto che da questa si trahe, quanto che il piacere della vista supera le altre volutà del corpo.

Ma egli soridendo replicò, che non occorreva che io prendessi briga a sedare il suo animo, reputando egli l'antedetta narratione de spettacoli, come tutto ciò che circa la vista fu da noi ragionato, favoloso racconto e chimerico discorso, e che ciò da noi per altro non fosse stato introdutto, che per attentare la sua credulità, et esprimentare se nella filosofia profitato havesse, ma ch'egli non era tanto ignaro, et imperito, che non riconoscesse quanto di assordo e disonante alla filosofia apportasse l'admissione di tal incredibile senso. 
At the beginning of this inquiry, the external senses crossed my mind: firstly, I began to examine whether they were sufficient to inform us about all the events happening outside us. I beheld that the common people considered these senses to be five [in number], namely eyesight, hearing, smell, taste, and touch. However, I greatly doubted that they would be sufficient in themselves to inform us of all the conditions and appearances of things external to us. I furthermore judged ridiculous those who daringly claimed to infer this quintet from the amount of kinds of sensible things, as if they might make themselves known and manifest to us through other ways and means than the senses; some other times, they became forgetful of their own doctrine and mutually deduced the number of sensible things from that of the senses. Yet leaving aside their instances and their weak argumentation, I considered it very daring to state that the aforementioned five senses were sufficient to inform us about all the conditions of the external things, because we cannot conceive of some sensible things which are unknown to us, nor of other means of perception which we do not have, yet nevertheless, we recklessly try to state that they are impossible.

$\mathrm{My}^{127}$ suspicion strongly increased following what occurred to me with Crito, ${ }^{128}$ who was born blind, but with a very erudite intellect. I was with him and some other mutual friends when we were told about some admirable plays that Pericles had had performed for the people a few months before. This gave rise to talk about the excellence of the eyesight, which was superior to [65] all the other senses because it offers us sincere pleasures, not always mixed with pain or eventually causing harm to us like the others. In addition to this, as the eyesight may reach objects which are very far away, it provides us with excellent doctrines. However, since I suspected ${ }^{130}$ that Crito, as he lacked light, might become irritated because of this discourse, I tried to console him by saying that although Nature had not been so friendly to him by making him blind, it had been favourable to his genius by inciting it to the study of wisdom. Indeed, the delight it [gives] is as great as the pleasure brought by the eyesight, which exceeds all the other sensual pleasures of the body.

Yet he smiled and replied that I should not worry about calming him down, since he considered the above-mentioned account of the plays to be the same as everything we had examined concerning the eyesight, namely like a fabulous tale and chimeric discourse. [Crito furthermore said] that we had only introduced this [i.e., the discourse on the eyesight] to test his credulity and to verify whether he had gained anything from philosophy, but he was not so unaware and inexpert as to not recognise how much absurdity and contradiction the acknowledgement of this incredible sense has brought to philosophy.
Doubt concerning the number of senses.

Experience with Crito who, blind, denied the sense of vision. ${ }^{129}$ 
"Qual comunicanza”, diceva egli, "può esservi tra l'occhio e le stelle che, come favolegiate, per quasi immenso intervallo si trovano distanti, se è vero che qualunque sensatione, come si tiene comunemente, per mezo del contatto del sensibile et organo sensitivo si eseguisce? Ma forsi dall'occhio, come alcuni per rendermi alquanto più probabile tal loro menzogna mi affermano, escono alcuni raggi visivi, e con incomprensibile celerità all'oggetto remotissimo slanciandosi l'incontrano e l'afferano? Ma qual è colui nel numero delli homini così insano, che credesse che dall'occhio di così angusto recinto et ambito, sortiscano tali raggi, che insino alle stelle fisse giongono? Ove è nell'occhio tanta copia di materia, benché tenuissima, che soministrare possa effluvio tale? Qual vigore et energia nell'occhio si trova, che soficiente [66] sia ad eiaculare per tanto tratto di spatio e massime materia così sottile e lieve non obediente alla proiettione? Qual languidezza e fiachezza nell'organo visivo esprimentarissimo doppo tale evacuatione? Ma concesso tutto ciò, in qual maniera permettere si può, che fuori di noi per tanta lontananza si eseguisca la sensatione? E che li raggi visivi siano de vita e sentimento dottati, mentre che passando per regioni algenti, overo ferventi, non sentano dolore alcuno? $\mathrm{E}$ che interrotti e divisi non patiscono alcuna tormentosa passione? Per il certo ciò trapassa tutte le meraviglie.

Né meno mi si rende ridicola l'altra esplicatione da alcuni amici narratami, che dall'oggetto esterno visibile egualmente verso tutte le sue circonstantie a quali si affacia siano difuse alcune lievi imagini, onde incontrandosi tali tenui simulacri nell'organo visivo e facendo in esso certa impressione, resulti la visione e scorgimento del visibile ogetto. Ma qual maggiore poetica fintione et impersuasibile assordo si può imaginare, che d'incredulità tal dogma superi? $\mathrm{E}$ per il certo stimo che ciò fu inventato ad onta dell'humana credulità, et insana sua semplicità. Sono queste imagini corporali over piuttosto immateriali? Se corporali, ove abbonda nelli ogetti tanta quantità di spoglie che continuamente si diffondono et insino a lochi remotissimi l'inviano? Ma se essi oggetti sono immobili, con qual forza per linea retta insino alli occhi le sospingono?

Qual sarebbe l'evidente detrimento che in essi oggetti si scorgerebbe per una tal continua et incessabile evacuatione? In che maniera, essendo questi imagini corporali e sovente l'una con l'altra incontrandosi, et insieme accozzandosi, non restano impediti li loro digressi e viagiamenti? E per qual cagione tali simulacri dalli occhi non sono appresi, ma invece di essi li oggetti che li producono, tenendo quelli non meno di questi facoltà di movere et imprimere l'organo sensitivo? E chi crederebbe che ritratto facesse apparire il suo originale [67] rimanendo egli occulto et invisibile? Come trapassano dall'oggetto all'occhio tali imagini? E benché l'aria fosse da impetuosi venti infestata, con tutto ciò lunga serie di simulacri non è disturbata et interotta, et all'occhio ordinatamente giunge e s'insinua?

Nell'istesso punto de' aria nel medesimo tempo s'incontrano diverse imagini di contraria natura come il nero e bianco, l'obliquo e retto, e senza alcuna repugnanza e loro diformità felicemente arrivano a lochi che da loro progenitori oggetti sono destinati et inviati. Ma chi admettarebbe ben anco 


\section{He said:}

"If it is true that according to the common opinion, all sensation is carried out through contact between the sensible thing and the sensory organ, what kind of relation may exist between the eyes and the stars, which, as you fantasise, are separated from each other by an immense distance? Do some visual rays perhaps go out from the eye at an inconceivable speed and reach and grasp objects which are very remote, ${ }^{131}$ as some state in order to make this lie of theirs much more likely? However, who among the multitude of people would be so insane as to believe that these rays, which travel as far as the fixed stars, might emerge from such a narrow enclosure and space as the eye? Whereabouts in the eye is there such an abundance of matter that might provide this effluvium, even if it is very subtle? What strength and energy is there in the eye to be sufficient [66] to eject [an effluvium] for so wide a stretch of space, and above all so subtle and light a matter which does not comply with the projection? What languidness and feebleness would we experience in the visual organ after such an ejection? And even given all of this, how might it be possible that this sensation may be carried out outside us over such a long distance? And if the visual rays are endowed with life and senses, [how might it be possible] that they may go through icy or fervid regions without feeling any pain? That once they are broken up and divided, they might not suffer any tormenting passions? Certainly, it goes beyond all marvels.

"Nor does the other explication told to me by some friends seem less ridiculous to me, namely that some feeble images spread from the external object, which is equally visible in all the places where it is displayed. Therefore, the sight and view of the visible object result from the visual organ's encounter with these feeble simulacra, which make a certain impression on it. ${ }^{132}$ Yet could we imagine a greater poetical fiction or unconvincing absurdity that could overcome the incredibility of this dogma? And certainly, I think that this was invented to offend human credulity and its insane simplicity. Are these images bodily, or rather immaterial? If they are bodily, where might so great a quantity of images that continuously spread themselves and are sent up to the most remote places be found inside the objects? However, if these objects are motionless, what force pushes them [i.e., the images] up to the eyes in a straight line?

"What evident damage would we behold in these objects because of this continuous and endless ejection? Since these images are bodily and often encounter each other as well as clumping together, how do they not turn out to be impeded in their deviations and movements? Furthermore, why do the eyes not apprehend these simulacra, but only the objects responsible for producing them, if [we consider that] both of them [i.e., the simulacra and the objects] have the faculty to move and impress the sensory organ? And who would believe that a portrait could show its original [67] if it was hidden and invisible? How do these images move from the object to the eye? And although the air is infested with impetuous winds, nevertheless, how may the long series of simulacra not be disturbed or interrupted by all of this and neatly reach the eye and penetrate into it?

"Different images of an opposing nature, such as black and white or oblique and straight, encounter each other in the same point in the air and at the same time; and without any hindrance or divergence among them, they successfully reach the places where they are intended and sent by their progenitors, the 
che il limitare della filosofia non fosse trapassato che li contrarii nell'istesso soggetto e nel medesimo instante di tempo, insieme sogiornare potessero? Ma oltre di ciò chi non osserva altro e notabile inconveniente, cioè che l'imagine che dall'oggetto si dipartisce, et all'occhio s'incamina, produrre dovrebbe in lui diversa figura di quella che nell'oggetto si ritrova? Esprimentando noi che le prominentie del sugello nella cera impresse divengono cavità, come per il contrario le profondità di quello riescono in questa risalti e rilievi, il che per apunto circa l'impressione dell'imagini che sognano l'autori di tal openione accadere dovrebbe.

Ma se tali simulacri over specii, come essi li appellano, sono immateriali, per la qual positione stimano sfugire molte di dette oppositioni, in che maniera ci si rendarà persuasibile che oggetto affatto corporale produca effetti spirituali et immateriali? Tanto più de esso oggetto nobili et egregi? Ma in che modo tali imagini riuscirano rappresentatrici al vero di oggetti materiali tanto da essi diverse di conditione, e natura? Né però scansano et evitano tali autori, con l'immaterialità d'imagini da essi introdotta, molte delle oppositioni da me contra l'assertori di simulacri corporali intentate, non essendo permesso a qualunque ente, sia corporale over immateriale, si esimerà e liberarà da qual decreto inviolabile dalla necessità constituito, che li contrari nell'istesso [68] sogget|to, nel medesimo tempo stantiare non possono, non tenendo in ciò alcuno spetiale privilegio l'immateriale sopra il corporale che possa in sé tal complicatione di contrarii admettere. $\mathrm{E}$ tale contrarietà non solamente nell'aria esterna accade, ma nel tempo della visione, nell'occhio l'istesso assordo avienne, concorrendo nel medesimo punto, et apice del cono visibile la rafiguratione e rappresentatione di quanto nel vasto hemispero si contiene, onde conforme tale positione, converebbe che raccolta in tal punto vi fosse faragine innumerabile di colori, benché contrarii, et infinite e diversissime figure, mandate da varii oggetti in diferenti lochi esistenti che in sì amplo tratto sono contenute.

Ma di più mi espongono li assertori di simulacri, tanto materiali come immateriali, in qual maniera si riconosce la grandezza dell'oggetto, se l'imagine che lo rappresenta è così minima che trapassa in picciolezza l'acume del cuspide del cono visibile? In qual modo apprende l'occhio la distantia dell'oggetto, se lui non è impresso dall'oggetto distante e lontano, ma invece di esso dalla sua imagine, tangente l'istesso organo? In qual guisa s'accorge l'occhio della situatione dell'oggetto se il simulacro è in lui medesimo intruso?

Il ricorrere a linee e triangoli, che si fanno in detto cono, et a deduttioni matematiche per mezo de' quali si informiamo della grandezza, distantia, sito dell'oggetto trascende la capacità dell'organo materiale del senso, e ripugna parimente alla tardità del discorso intelletuale, che non poco di tempo consuma e dispende nel formare tali teoremi e raccoglierne conclusioni che di ciò instruire lo possa. Tanto più ciò riesce incredibile che anco li fanciullini e bruti privi di discorso, del sito e grandezza dell'oggetto sono informati, il che esclude tali machinationi e dedottioni geomatriche.

E siccome li apportatori di tali menzogne ridicoli mi appariscono, così quelli che attentano de calcare certa mediocre via non si trovano meno ancor essi da critica, e rigorosa [69] cen|sura vessati, e travagliati. Questi per evitare l'oppositioni che accadono alli antedetti, tanto quelli che asseriscono, che l'imagini da oggetti all'occhio inviati siano, come quelli che introducono l'eiaculatione di raggi visivi, nuovo figmento inventarno: cioè che tali raggi visivi 
objects. However, who may admit, without overcoming the limits of philosophy, that contraries may dwell together in the same subject and at the same time? ${ }^{133}$ And in addition to this, who would not behold another remarkable problem, namely that the image departing from the object and entering the eye should produce a different shape in it from that of the object? We experience that the protrusions of a seal, when it is pressed into wax, become recesses. ${ }^{134}$ However, the recesses of the former turn out to be protrusions and projections in the latter. Hence, this should also happen for the impressions of the images dreamt by the authors of this opinion.

"Yet if these simulacra - or species, as they called them ${ }^{135}$ - are immaterial, as they believed them to be in order to avoid many of the aforementioned oppositions, how may we be persuaded that a bodily object may produce spiritual and immaterial effects which are much nobler and more remarkable than the object itself? How may these images succeed in truly representing the material objects that are so different from them in condition and nature? Neither will these authors, thanks to the immateriality of the images they have introduced, elude or avoid many of the oppositions I put forth against the supporters of bodily simulacra, because no ens, whether bodily or immaterial, is allowed to be exempt or free from that inviolable decree issued by necessity: namely that contraries cannot remain in the same [68] subject at the same time and an immaterial thing cannot have any more special privilege than a bodily thing that might allow it to admit the combination of contraries in itself. And this contradiction does not only happen in the external air, but the same absurdity also occurs with vision inside the eye, because the images and representations of what is contained in the wide hemisphere come to the same point, that is the tip of a visual cone. ${ }^{136}$ Therefore, according to this position, a medley of innumerable colours should be gathered into this point, although they are contraries, and likewise infinite and very different shapes sent by various objects in different places which are normally contained in so wide an interval of space.

"However, furthermore, how may the supporters of the theory of simulacra, material and immaterial, explain how one may acknowledge the size of an object if the image which represents it is small enough to overcome the smallness of the [same] tip of the visual cone? How does the eye apprehend the distance of an object if it is not impressed by the long distance or faraway object, but rather by the image of it which touches the organ itself? How does the eye observe the position of the object if the simulacrum has intruded into it?

"To make use of lines and triangles as we do as far as the aforementioned cone is concerned, and of mathematical deductions whereby we become informed of the size, distance, and location of an object, goes beyond the capacity of the material sensory organ and likewise is in opposition to the slowness of [our] intellectual discourse, which indeed consumes and spends a lot of time forming these theorems and gathers some conclusions from them by which it may be instructed. This is much more incredible [if we consider] that even children and brutes, lacking the capacity for reasoning, are aware of the location and size of objects; this indeed excludes machination and geometrical deductions.

"And just as the supporters of these falsities appear ridiculous to me, so those people who attempt to follow a specific middle way must be criticised and [69] oppressed, as well as tormented by strict censure. They invented a new pretence in order to avoid the oppositions to both the aforementioned [things], ${ }^{137}$ those who assert that the images are sent from the objects to the eye as much as those who raise the subject of the ejection of visual rays: namely that these 
Raccoglimento di

Socrate dal ragionare

di Critone circa il

numero di sensi.

Eccellenza di sensi di animali bruti. si uniscono e complicono con il lume esterno, contrahendo con esso certa famigliarità, et allianza, che poi, fatto tal congresso e compositione, giungono insino all'oggetto e ci informano della qualità di essi oggetti esterni visibili.

E per il vero né anco ciò poté atrahere il mio assenso, anzi che stimando io non solamente tal dogma soccombere a quasi tutte l'oppositioni antedette, ma di più anco parmi esposto ad altre e nuove dificoltà. Qual può essere tal subitaneo comercio e comunicanza, che li raggi visivi con il lume esterno conseguiscono, ritrovandosi di genere tanto diverso, l'uni sensitivi e visivi, e l'altro affatto privo di vita? Influiscono quelli al lume il sentimento, over resta egli nella primiera conditione, e qualità insensato? S'eseguisce la sensatione circa il contatto dell'oggetto con il prolungato raggio, overo nella continuatione, e congiuntione del raggio visivo con il lume esterno o piuttosto nell'istesso occhio?

Ché se nel primo modo, repugna a ciò l'assordità che segue nel admettere fuor di noi in parte tanto lontano la sensatione, e massime per mezo del lume per se stesso privo de' sentimento. E nella seconda maniera, ci contrasta di più la disgiuntione del oggetto dal raggio visivo. Nella terza guisa, ci s'oppone la celerità della sensatione che non permette tante subitanee attioni cioè l'effusione di raggi, l'accoppiamento con il lume esterno, il progresso all'ogetto, et ultimamente il regresso insino alli portioni interni di noi. Da questi e da altri motivi che addurre potrei rimango certissimo, che tutto quello circa la visione narrato m'havete sia piuttosto [70] giochevole tentativo e burlevole scherzo, che seria instruttione e vero racconto. Anzi debbo stimare che tal narratione fra la nenie puerili, et annili deliramenti annoverare si convenga".

Questo ragionare di Critone, tanto constante e contumace contra la visione, instillò nel mio animo non lieve sospetto, che siccome ad esso riusciva come che impossibile che si ritrovasse nel catalogo delle cose il senso della vista, uno de' più egregi che noi possediamo, così anco potrebbe avenire, che nel vasto ambito della possibilità potrebbonsi rinvenire molte altre maniere di sentimenti, benché noi alcuna contezza de esse non ottenimo. Et a ciò persuadermi non mancarono altri probabili inditii: vi sono alcuni vili animali che tanto al di sopra di noi sono dotatti di egregio sentimento che si potrebbe affermare che da' nostri i loro siano affatto diversi. Il cane con l'odorato riconosce l'amico dall'alieno, e non meno si serve di quello in viaggiare, che noi del discorso in dirigere il nostro camino, il che accade anco a tutti quasi li generi di pesci et uccelli che trapassando ampi mari, al destinato loco senza alcun errore pervengono, benché destituti siano di adminicoli di quadranti, magneti e mappe hegrafiche overo idrografiche, li quali animali, essendo da noi stimati privi di ragione e discorso, ci conviene confessare che per il mezo di alcun senso materiale ciò eseguiscono. Non vi mancorno alcuni filosofi, fra quali fu Empedocle celebre per 
visual rays match and combine with the external light by obtaining such an acquaintance and alliance with it that once they have accomplished this union and composition, they then reach the object and inform us about the quality of these external visible objects.

"Furthermore, not even this could truly obtain my assent; rather, I considered this dogma not only to be falling [under the blows of] almost all of the aforementioned oppositions, but also that it seemed to be exposed to other new difficulties. What instantaneous relation and exchange might the visual rays achieve with the external light if they are of such a different nature, namely that the former are sensitive and visual while the latter is indeed lacking in life? Do they instil the sensory faculty in the light, or does it remain in its original condition and [thus] without any sensibility? Is the sensation carried out by the contact between the object and the extended ray, or by the continuation and conjunction of the visual ray with the external light, or rather in the eye itself?

"If the first manner were the case, it would be refuted by the absurdity which follows from assuming that sensation happens outside us, in a very remote place, and above all [that it happens] by means of light, which lacks a sensory faculty in itself. In the second manner, the disjunction of the object from the visual ray hinders us [from believing it]. In the third manner, the quickness of the sensation, which does not allow many instantaneous actions, such as the effusion of rays, combination with external light, advancement up to the object, and finally regression into the internal parts of us, prevents us [from believing it]. Because of these and other reasons I might put forth, I remain extremely certain that everything you have told me concerning vision [70] is a playful attempt or humorous joke rather than a serious lesson or true account. I would even consider including this tale among puerile complaints and senile frenzies."

Crito's argument, so obstinate and persistent against the eyesight, instilled a great suspicion in my mind: as he considered it impossible that the eyesight, one of the greatest senses that we have, could be counted in the catalogue of things, so it might also happen that we could find many other ways of perceiving, although we cannot have cognition of them. And there were other probable clues which persuaded me of this. There are some vile animals which are endowed with a much greater sensory faculty than ours, ${ }^{138}$ to such an extent that we could state that their [senses] are indeed different from ours. A dog distinguishes a friend from a stranger with its sense of smell, and just as it uses this in travelling, so we [use] reason to direct our path. This also happens for nearly every kind of fish and bird, which, in crossing wide seas, arrive at the intended place without any mistakes, even while lacking instruments such as quadrants, magnets, and geographic and hydrographic maps. ${ }^{139}$ Although we consider that these animals lack reason and discourse, nevertheless we should admit that they carry this out [only] with their material senses. There were also some philosophers - among them Empedocles, who was famous for his

\section{Socrates's}

conclusions drawn from Crito's argument about the number of senses.

The excellence of brute animals's senses. 
Piante ornate del sentimento.

Magnete tiene anima sensitiva. sapienza et eruditione poetica, che asseriscono, che le piante siano di senso dotatte, benché del nostro assai diverso, e perciò a noi affatto ancora incomprensibile. Il che si conforma al racconto d'alcuni che all'atlantide regioni hanno navigato, che ci referiscono colà ritrovarsi alcuni arbori, le cui foglie benché spicate dal ramo, conservano per certo tempo vitale risentimento da se stessi movendosi, e compresse si ritirano.

Ma quello che ci apporta maggior meraviglia, e mi persuade a tal credenza [71] l'osser|vare le stupende qualità della magnete, hormai divenuta maestra d'una nuova e sensibile filosofia. Questa pietra, benché in apparenza si mostra inanimatta, nondimeno advertendosi li suoi instinti et inclinationi ci significa che di anima ornata sia, ché perciò dal sapiente Talete nella classe di animali li arrolò. Essa, a guisa de' viventi, atrahe dall'alito del ferro il suo nutrimento, e perciò lo desidera et a sé lo congiunge. Non li manca facoltà generativa, comunicando la sua virtù sì attratrice come versoria all'amico ferro. Possiede anco virtù progressiva come li altri animali, il che ci manifesta il girarsi da per sé al polo terrestre, suo famigliare amico. Non è priva de stimoli d'amore verso la sua patria attentando quando è posta in libertà, il ritornare a quella situatione che ottenne nella sua minera, né parimente è destitutta di risentimento di odio abhorrendo il polo magnetico settentrionale, il polo settentrionale d'altra magnete ad esso simile, ma per il contrario admette ne' suoi amplessi il contrario meridionale, al pari de' inamorati rivali che, al medesimo oggetto aspirando, professano fra loro aperta nemistà, et odio, dirimendo di più con tale attione questione acramente altercata fra sapienti, cioè se l'amore fra simili over dissimili si ritrova, adherendo essa magnete al parere del tragico poeta Euripide, che fra dissimili lo constituisce.

Ma non si dimostra tal pietra solamente sensitiva, ma in certo modo anco alquanto contemplativa e discorsiva, né affatto imperita di matematica scienza apparisce, sapendo da se stessa advertire la positura del polo terrestre, girandosi horizontalmente verso quella volta. Ma di più in ogni regione anco sa rivenire, e dimostrare l'elevatione del polo declinando il suo polo magnetico dal proprio horizonte, tanto quanto che il polo mondano si inalza sopra il terrestre horizonte, ritrovando anco con mirabile agevolezza la linea meridiana in qualunque [72] re|gione essa sia posta. Le quali cose eccelente matematico, privo d'instrumenti e non aiutato da reiterate osservationi, trovare non li è permesso.

Lasciamo la proportione della eiaculatione di suoi effluvii, ché la mente humana appena ne rimane capace. Ma per adempire tutti li caratteri che ad animale attengono, a guisa di quello invechiandosi, 
wisdom and poetical erudition - who stated that plants are endowed with senses, ${ }^{140}$ although they are very different from ours and thus still incomprehensible to us. This accords with the account of some who sailed to the Atlantic regions and reported back to us that they had found some trees there with leaves that retained a vital affect for a while even after being detached from their branches, as they were able to move by themselves and fold inward when they were compressed. ${ }^{141}$ Yet what most astonishes us and persuades me of this belief [71] is to observe the wonderful qualities of the magnet, which has already become the master of a new and sensory philosophy. Although this stone seems to be inanimate, nevertheless, having observed its instinct and inclinations, we consider it to be adorned with a soul; for this reason, the wise Thales includes it in the class of animals. ${ }^{142}$ Like living beings, it receives nourishment from the iron's breath, and therefore it desires and attracts it. It also does not lack a generative faculty; indeed, it communicates its own virtues to its friend the iron, both [that of] attraction and its ability to turn in all directions. It also has the virtue of moving from one place to another like the other animals, and it shows this by turning itself in the direction of its close friend the earth's pole. ${ }^{143}$ It does not lack the impulse of love for its homeland, since as soon as it is set free, it attempts to return to the location it occupied in its mine; similarly, it is not unaffected by hatred, since it abhors the magnetic north pole and the north pole of another magnet that is like it. However, it agrees to join with the opposite south [pole], like rivals in love longing for the same object and openly uttering their [mutual] enmity and hate. Through this deed, they furthermore settle a fiercely debated issue among wise men, namely whether there may be love between similar or dissimilar beings. This magnet behaves in accordance with the opinion of the tragic poet Euripides, who places it [i. e., love] among dissimilar beings. Yet this stone demonstrates that it is not only sensitive, but somehow also contemplative and discursive; indeed, it appears to be an expert in mathematical science, since it is able to recognise the position of the earth pole by horizontally rotating towards that direction. In addition to this, it is able to find its way in every region and to demonstrate the ground elevation of a pole by tilting its magnetic pole from the horizon, like the earth pole rises above the earth horizon. Thus, it also finds the meridian line [72] in any region in which it might be placed with admirable ease. Even an excellent mathematician cannot find these things without instruments or the help of repeated observations.

Let us leave aside the proportion of efflux that it ejects, because the human mind is barely able to do this. However, in order to fulfil all of the features of an animal, it ages like one and goes towards death
Plants are endowed with senses.

The magnet has a sensitive soul. 
Conclude la possibilità di altri sensi. alla morte si conduce, essendosi esalato quel spirito vitale autore di tante sue pregiate virtù et egregie operationi, rimanendo perciò cadaveroso sasso, il che parimente li accade quando gettata nel fuoco, quasi che come da morte violente assalita, l'è consumata dal fuoco lo spirito che sostiene la sua facoltà vitale.

Ma quale sia la qualità del suo sentimento e quanto avanza in perfettione a quello delli altri animali, ché perciò introdussi il presente ragionamento, da due insigni proprietà si può agevolmente comprendere, l'una che per tanta distanza quanta s'interpone tra noi et il polo artico terrestre, si risente delli amichevoli incentivi che dal polo ad essa famigliare li sono cagionati, ché perciò a conformare et aggiustarsi ad una medesima positura con esso la richiamano. L'altra egregia conditione di tal sentimento è, che di tanto resvigliato accorgimento si trova dottata, che niuno ostacolo per massicio e sodo che sia, può impedire che non si risenta della approssimatione del ferro, over altro polo magnetico ad essa amico overo adversario, in maniera che immediate non eseguisca la sua atrattione over verticità, ché se non fosse repugnante al principal axioma della filosofia naturale, che sentimento non si può eseguire senza il tatto del sensibile con lo sensitivo, ardirei affermare che senza d'esso contatto né anco spirituale, esercitasse tali suoi risentimenti.

Dalle antedette osservationi mi son imbevuto credenza tale, che nell'ambito e continentia della natura fosse possibile ritrovarsi varie maniere di sensi, non solamente diferentissime delle nostre, ma anco di più esatta [73] conditione, riuscendomi perciò anco per altro verso assai agevole lo stimare che caduno di oggetti possa possedere molti et infiniti visaggi e qualità, conforme il congresso e relatione che con diverse et innumerabili varie constitutioni di sensi potesse incontrare, sortendo diverse le apparenze della istessa cosa, conforme le diferenti dispositioni di organi sensitivi, variandosi quella per la diferente temperie, configuratione, compositione, e situatione di organi sensitivi.

E siccome il cubito paragonandolo alle sue portioni, che infiniti sono, sortisce in maniere innumerabili di proportioni e simetrie, così li oggetti esterni acquistano diverse apparenti conditioni, per le varie applicationi che con sensi diversi si abbatono, conforme appunto come occore a specchi, che sebbene li oggetti che dirimpetto li asistono rimangono inalterati, tuttavia cangiandosi li specchi in concavi, convessi, collonari, conici et altri diferenti maniere, parimente si disguisa e varia l'apparenza di tali oggetti. Ma che occorre a spechi ridursi per ciò evincere?

Il lume esterno alli animali comunemente vehicolo di colori, accieca la nottola, e la tenebre l'arreca la vista, el'esperienza quotidiana 
by exhaling that vital breath which was the maker of its many refined virtues and remarkable deeds and thus ends up a cadaverous stone. Likewise, when it is thrown into the fire, the spirit sustaining its vital faculty is consumed as though it has been violently killed.

Yet from two remarkable properties, one may easily comprehend the quality of its sensory faculty and how much its perfection overcomes that of the other animals: one [condition] is that despite the great distance between us and the Arctic earth pole, it [i.e., the magnet] is affected by the favourable incentives which are caused in it by the pole that is familiar to it, and thus they draw it to conform and adjust itself to the same position as it [i.e., the pole]. The other remarkable condition of this sensory faculty is that it is endowed with so much shrewdness that no obstacle, even if it is dense and solid, can prevent it from being affected by the proximity of iron or another magnetic pole, whether it is its friend or adversary, in such a way that it will not immediately activate its attraction or ability to turn. ${ }^{144}$ Thus, if it did not oppose the main axiom of natural philosophy, namely that perception cannot be carried out without contact between the sensible and the sensitive, I would dare to state that it is affected neither through this contact nor in a spiritual way.

From the aforementioned observations, I drew the belief that one may find various manners of sensory faculties in the field and range of Nature, not only very different from ours, but also more [73] exact. Therefore, it also seems easier to me to think that every object may have infinite appearances and qualities in conformity with the connection and relationship that it might have with the different and countless varieties of senses. This produces dissimilar appearances of the same thing according to the different dispositions of the sensory organs, since they change because of the various structures, configurations, compositions, and positions of these sensory organs.

Just as the cubit - with respect to its parts, which are infinite turns out to be of innumerable proportions and symmetries, ${ }^{145}$ so external objects receive different appearances because of the various ways they encounter the different senses. Similarly, this indeed occurs with mirrors: although the objects which are before them remain unaltered, nevertheless the appearance of these objects changes and varies, since mirrors diversify into concave, convex, columnar, ${ }^{146}$ conic, and other different shapes. Why should we restrict ourselves to mirrors in order to infer this?

Although external light is commonly a medium of colours for animals, nevertheless it blinds bats, and darkness rather allows them to see. ${ }^{147}$ Likewise, daily experience demonstrates the same to us con-
He concludes on the possibility of other senses. 
Ragionando di un specchio in dimostrar l'eccellenza de' sensi humani. parimente nelli altri sensi non altrimente ci dimostra, osservandosi che l'assintio incontrando nel nostro palato, rassembra amarissimo, et ad altri animali di giocondo gusto, il sale ci offende, et alle pecore riesce di somma delitie, come per il contrario il zucaro a noi tanto saporito, ad essi non punto aggradevole, li escrementi e le carogne da noi in estremo abhoriti, al cane, benché di esquisito odorato, non offensivi, per il contrario il muschio, zibetto et ambra, a noi tanto fragranti e così dilettevoli, ad esso non piacevoli, la musica, sopra modo alettatrice del nostro orecchio, alla lepre che trapassa qualunque altro animale nell'udito, non osservabile, ma pure la tarantola vilissimo insetto, per quello si racconta, senza instruttione di maestro et esercitio di alcuna disciplina dilettevole, [74] e la melodia e harmonia della voce aggrada.

Per il che sovente mi diedi a dubbitare che siccome accade a cibi, che quelli che per loro natura sono insipidi, agevolmente ricevono tutti li sapori, e li panni che sono privi per se stessi di qualunque colore, indiferentemente di tutti facilmente si tingono, e noi, mentre che dell'amore di alcuno non siamo di già sorpresi, verso tutti egualmente ci mostriamo essere bene inclinati. L'istesso anco giudico al nostro proposito, che quell'oggetto che tutto può rassembrare, niuna cosa realmente è di quelle che dimostra et apparisce essere. Per il che stimai che li oggetti esterni potendo in modi infiniti rappresentarsi, niuna apparenza che in essi si scorge essentialmenete sia.

Hora dunque havendo io tali divisamenti sovente con li amici comunicati, avenne, che una fiatta ne feci di ciò ragionamento nella officina d'un maestro di specchi, che stimando io che alla sua arte abbadasse, improvvisamente in tal maniera verso di me pigliò a dire:

\footnotetext{
"Non poca ingiuria verso te li tuoi calunniatori, o Socrate, comettono in riprenderti che invece di versare fra libri, e praticare nelle scuole di filosofi, per le officine di artefici divaghi, e che sempre con il comune d'idioti conversi, poiché le vere e sode scientie dalla esperienza tragono i loro natali. Noi artefici siamo le loro ostetrici, e voi filosofi siate poi li aii et educatori. Et al contrario di quello accade al nascimento delli homini, occorre alla produttione della sapienza: quelli, non riconoscendo i loro padri, come del volgo figliuoli sono infami stimati, ma questa, non le conviene riconoscere alcuno autore spetiale, et appropriato, ma da qual si sia genere d'homini deve derivare la sua origine, cioè riportarne instruttioni e documenti, onde prole del comune decentemente appellare si deve, non ritrovandosi homo così inetto, che in alcuno particolare non avanzi e prevaglia ad altrui, benché per altro egregio et eccellente sia.

Onde per hora, amico [75] Socrate, in ciò che io ti son per conferire non tenire a sdegno se io presuma, che discepolo mi divenghi, poiché non al di sopra della mia professione io sono per ragionarti, né stimo incontrar in quel volgare rimprovero, che il calzolaio oltre la scarpa non deve altrui emendare. È verissimo, come divisasti, che per la varia configuratione di specchi e corpi
} 
cerning the other senses: one may behold that absinthe seems to be very bitter to our palate, while it is of a pleasant flavour to [those of] other animals. While salt irritates us, it turns out to be highly delightful to sheep, and likewise sugar is very tasty to us and entirely unpleasant to them. While we completely abhor excrement and carcasses, the dog, although it has a fine sense of smell, is not irritated by them; on the other hand, musk, civet, and amber are very fragrant and pleasant to us and not delightful to it. Music pleases our ears above all, while it is not remarkable to the hare, although its hearing surpasses [that of] any other animal. Concerning this, it is also said that the tarantula, the vilest insect, appreciates the melody and harmony of a voice without [74] receiving instruction from any teacher or practising any delightful discipline. ${ }^{148}$

Since foods are naturally very insipid but then easily absorb flavours, clothes originally lack colour in themselves but can then easily be dyed any colour, and we - if we are not already in love with someone - show ourselves to be equally well-disposed to all people, I also deemed the same regarding this matter. Thus, I often doubted that an object which seemed to be many things was actually any of those things it looked and appeared to be. Therefore, I considered that since the external objects may be represented in infinite ways, none of their appearances that we perceive displays their essences. ${ }^{149}$

Now, therefore, as I had often recounted such thoughts to some of my friends, it once happened that I was arguing about this in a mirror maker's workshop. I thought that he was merely minding his work, but suddenly, he said to me:

"Your slanderers, oh Socrates, insult you so much, reproaching you for wandering into artisans' workshops and for continuously conversing with uneducated people instead of applying yourself to books and attending the philosophical schools. This is because the true and solid sciences are born from experience. We, the artisans, are their obstetricians and you, the philosophers, are their pedagogues and educators. What happens at a human being's birth is the contrary of what happens when wisdom is produced: [those among] the former who do not know their fathers are considered infamous sons of common people, but the latter should not acknowledge any particular author as its own, but must derive its origin from all kinds of people, namely it must obtain instruction and teaching [from all of them]. Thus, it should correctly be called the offspring of the community, because there is none so inept that he will not overcome or surpass another person in something, although the latter is excellent and distinguished in other things.

"Thus, now, dear Socrates [75], regarding what I am going to tell you, I hope you will not take offence if I presume that you will become my disciple. The reason for this is that I do not want to reason with you about my profession, nor do I want to go along with that vulgar reproach that the shoemaker should not judge beyond the shoe. ${ }^{150}$ It is absolutely true, as you noted, that thanks to the various configurations of mirrors and polished bodies, the reflection and
Argument about mirrors in order to show the excellency of human senses. 


\section{Risposta di Socrate al} specchiaio.

Tre ragioni per la debolezza de' sensi addotte da Socrate. politi, diversificandosi la riflessione e ribatimento dell'imagini over raggi visivi (sia come si voglia) si suole variare l'apparenza delli aspetti circa la figura, numero, distantia, sito delli oggetti visibili, ma tuttavia in fra questi specchi vi si trova il piano, che al naturale rappresenta l'imagine dell'oggetto, aggiustandosi con lui in tutte le sue vere germane conditioni et attinentie.

E siccome infiniti sono le spetii di specchi curvi, et irregulari, così unica è quella de' piani. Per il che stimarei che il simile accada circa le sensationi, ché havendo la miglior natura impiegato ogni sua cura nel formare e constituire l'homo, havendoci posto nel mezo dell'universo soli inspettori delle sue bellezze, ragionevolmente perciò credere si deve, che ci habbia proveduto di facoltà et organi tanto esatti et egregi, che a guisa di specchi piani ci riferiscono sinceramente le vere qualità delle cose esterne, e che li organi sensitivi che nelli animali bruti che diversi da quelli del nostro genere osserviamo, si rassomigliano a specchi curvi, distorti, et irregolari”.

\section{Al che replicai:}

"In quanto alla peritia che tieni della tua professione ti stimo al di sopra di molti filosofi, che essendo professori delle sette più nobili arti, cotanto si affanano per mantenersi, e sovenirsi e tu, con una solamente, honorevolmente sostenti la tua numerosa famiglia. Ma circa quello appartiene al presente trattato, non voglio contendere se hai trapassato i limiti dell'arte specularia, ma ben diroti che hai supposto molti dogmi per verissimi, che per anco al giudice sogiaciono, e di gravi contese sono vessati, et a guisa di degenere gallo anticipatemente contra di me hai la vittoria cantato. E giudico per [76] il certo, che senza l'havere fatto conferenza tra li altri animali et il nostro genere hai donato la palma a' sensi humani, non essendoti sovenuto il tatto del ragno, il gusto delli uccelli, l'odorato del cane, l'udito della lepre, e la vista dell'aquila e linceo e soprattutto l'acre sentimento della magnete, onde con precipitato giuditio, e con lubrica partialità, sententiasti circa li sensi a favore nostro.

Né mi move molto l'instanza da te dedotta dalla egregia dispositione o attitudine che tenimo circa le speculazioni propria fontione dalla mente, con che concludere tentasti la perfettione de' nostri esterni sensi, perché ciò facilmente scansare si potrebbe in più maniere. Primieramente, che da quella provida causa raggente del tutto, fu scarsegiato all'homo la perfettione di sensi esterni e rintuzzato il loro vigore riducendoli al di sotto delli animali bruti, acciocché maggiormente con sensi interni s'essercitassimo per suplire alla difalta di esterni. Overo piuttosto vogliamo dire, a fine che non fosse impedito e deviato l'intelletto dalla contemplatione, divagando dietro oggetti sensibili alieni a tal esercitio, havendo l'opefice universale praticato con noi quello sogliono usare li strucieri con loro predatori falconi, cioè l'atturarli li occhi, acciocché la vista loro non si distraga, così a noi l'opefice del tutto ci rese ottusi li sensi corporali esterni, acciocché l'interni da quelli non siano distratti, e che per causa di essi non stiamo in continua agitatione. 
repulsion of images or visual rays (whichever you prefer) varies, [and thus] usually the appearance of the shape, number, distance, and location of visible objects also varies, but among these mirrors, it is possible to find a plane that naturally represents the image of the object by conforming to all its true and authentic conditions and the things appertaining to it. ${ }^{151}$ And just as there are infinite species of curved and irregular mirrors, so there is only one plane one. Hence, I would consider that something similar happens with the sensations: since great Nature took so much care in forming and constituting man, placing us in the middle of the universe as the only spectators of its beauty, it is thus reasonable to believe that it must have provided us with such exact and excellent faculties and organs that, like plane mirrors, they sincerely show us the true qualities of external things. Furthermore, the sensory organs of brute animals, which we see as being different to those of humankind, look like curved, bent, and irregular mirrors.”

\section{Hence, I replied:}

"As far as the expertise you have in your profession is concerned, I esteem you above many philosophers, who, professing the seven noblest arts, exhaust themselves with great labour in order to sustain and support themselves, while you honourably sustain your large family with only one [art]. However, as far as what we are currently dealing with is concerned, I do not want to discuss whether you have exceeded the limits of the art of mirror making, but I will tell you that you have assumed many dogmata to be absolutely true while they are still in the course of proceedings and the subjects of serious disputes. And you, like a useless cock, have declared victory over me too early. I judge it certain [76] that you gave the palm of victory to the human senses without making a comparison between animals and humankind. Therefore, you decided, with rash judgment and impertinent partiality, on behalf of the human senses without thinking about a spider's sense of touch, a bird's sense of taste, a dog's sense of smell, a hare's hearing, and an eagle or lynx's eyesight, and above all the fine sensory faculty of the magnet.

"Nor am I very convinced by the instance you deduced from our excellent disposition or aptitude to speculate, as this is a characteristic function of the mind, thanks to which you attempted to come to the conclusion that our external senses are perfect. This might indeed be easily rejected in many ways. Firstly, because the provident cause ruling the whole made man's external senses imperfect and reduced their strength to less than that of brute animals, so we have mainly trained our internal senses in order to compensate for the deficiency of the external ones. Or we may rather say, in order not to impede or divert the intellect from contemplation by wandering towards sensible objects that are extraneous to this practice, that the universal maker did with us what trainers do with their predator hawks, namely covering their eyes so that their sight cannot distract them. Likewise, the maker of the whole made our external bodily senses dull so that the internal ones would not be distracted by them and so would not be continuously agitated by them.
Socrates's answers to the mirror maker.

Three reasons for the senses' weakness put forth by Socrates. 
E non vi mancò nell'ordine di noi filosofi che volontariamente si acciecasse, per potere meglio con la mente alla speculatione applicarsi, e da tal discorso parimente si mossero alcuni di sapienti a sospettare, benché ciò a mio giuditio sia falso, che a molti di animali brutti non li manchi la facultà del discorere, ma che da essi non fosse esercitata per la perfettione de' lor sensi esterni, supplendo questi con più agevolezza e celerità a loro bisogni, di quello li riuscirebbe servendosi della discorsiva facultà, pigra stentata e sovente fallace [77] nelli suoi impieghi, alla quale, secondo essi, l'homo per necessità riccorre, per il mancamento et imperfettione di sensi esterni. In ristretto dicoti, che la natura che tanto si diletò della varietà del suo operare, volse che alcuni animali valessero in una spetie di sentimento, et altri in diversa: a noi sortì l'eccellenza de' sensi interiori, alli altri l'esquisitezza d'esteriori.

Oltre di ciò si potrebbe in altra maniera occorrere a tal suo argomento, che ritrovandosi la nostra temperatura tanto delicata et alterabile, e li nostri spiriti così tenui e passibili, che se li sensi esterni fossero maggiormente apprensivi, over più numerosi, saressimo fuor di modo soggetti alle perturbationi dell'animo, et a fieri assalti di horribili invasioni esposti, aprendosi l'adito per mezo di oltre modo apprensivi sensi alli oggetti esterni ad affatto occupare, et opprimere il nostro animo.

$\mathrm{Ma}$, amico artefice, ciò teco hora devisai conforme la tua, mia, e comune openione, che l'homo fra tutti li altri animali sia appo il sommo opefice delle cose il più favorito, havendolo voluto colmare di tutte quelle gratie che lo formò disposto e capace a ricevere. Ma quelli che a parere contrario s'appigliano, e benché rustici, e fieri verso il loro genere appariscono, poco di ciò si curano, e temerariamente asseriscono esser li homini non solamente nulla al di sopra delli altri animali, ma che in alcuna parte ad essi siano inferiori, essendo et a pericoli, e necessità del corpo al di sopra di essi sottoposti et apparati, et in quanto a vessationi et infestamenti dell'animo assai più di quelli turbati $\mathrm{e}$ sconvolti.

Né punto a questi tali, di noi spregiatori, li move l'esercitio dell'humano intelletto circa li più astrusi et occulti oggetti, ché anzi da ciò prendono occasione di calunniare tal vano impiego stimando essi, che havendocili la natura nascosto, perciò conieturare si deve, che l'applicarsi ad apprenderli derivi dalla nostra depravata non naturale incombenza, a cui non siamo dalla natura chiamati, havendoci essa con facilità [78] e liberalmente offerto quello stimò a noi, sua prole, necessario e giovevole. Onde perciò questi ingiuriosi al loro proprio genere, né anco il pane et altri elaborati cibi stimano che a noi siano assolutamente proprii e naturali, per il che non mancano d'attentare con loro discorsi di ridurci alle antiche ghiande, et alla semplice acqua, che senza nostro stento copiosamente già una fiatta (come dicono essi) con sanità e satietà di vita ci nutrivano. Onde li medesimi (tornando al proposito) stimano, che le dottrine ci siano faticose e ponderose sarcine, che c'incurvano l'animo, e sovente ci accorciano la vita.

Onde li autori di tal dogma punto non li calerebbe di tue instanze, ma agevolmente permetterebbero, che li nostri sensi esterni, e l'istesso stimo che temerariamente affermarebbero della humana mente, che fossero a guisa di quelli spechi curvi, et irregolari che stravolgono l'imagini et apparenze di oggetti, havendosi così compiaciuto la natura scherzare con li homini, con farli travedere, siccome noi ci pigliamo diletto di formare tali spechi per defrodare la vista 
"And among us philosophers, there was one who voluntarily blinded himself in order to better apply his mind to speculation. ${ }^{152}$ And likewise, from this discourse, some wise men began to suspect - although in my opinion this is false - that many brute animals do not lack a rational faculty, but rather do not exercise it because of the perfection of their external senses. These indeed meet their needs more quickly and easily than the discursive faculty does, since it is lazy, reluctant, and often [77] deceptive in its works. They think that man appeals to it out of necessity, [namely] because of the lack or imperfection of the external senses. Simply, I will tell you that Nature, which greatly delighted itself in producing such variety, decided that some animals were skilled in some senses and others in different ones: we happened to receive excellence in our internal senses, while others [received] keenness in their external ones.

"In addition to this, one may reply to his argument in another way, namely that since our temperature is so delicate and alterable and our spirits are so feeble and sensitive, if the external senses were more perceptive, or more numerous, we would be greatly subjected to the perturbations of the mind and exposed to the intrepid assaults of horrible invasions. Thanks to these extremely perceptive senses, the external objects would be allowed to occupy and oppress our minds.

"Yet, my dear artisan, what I have now devised with you conforms to your, my, and the common opinion that among all the other animals, the human being was the one most favoured by the Supreme Architect of things, since he wanted to overwhelm him with all kinds of graces by making him disposed and able to receive them. However, those who cling to the contrary opinion, although they appear to be uncouth and proud that they are human beings, nevertheless do not care about this very much and recklessly assert not only that human beings have nothing more than animals do, but that in one respect they are inferior to them. Indeed, they [i. e., the animals] are subjected and exposed to more dangers and bodily necessities and to much more troubled and upset mental oppressions and afflictions than they [i.e., human beings] are.

"These people, who despise us, are not even moved by the exercise of the human intellect towards the most abstruse and hidden objects; on the contrary, they rather take from this the opportunity to calumniate such vain undertakings. Indeed, they consider that as Nature has hidden them, one must therefore suppose that attempting to apprehend them is a depraved, unnatural task. For Nature, which has easily [78] and freely offered us, as its offspring, what it considered necessary and useful for us, has not designed us for this. Thus, those who insult their own kind do not even consider bread and other processed foods as completely appropriate and natural for us. Hence, they also attempt to bring us back to the ancient acorns and simple water which, they say, once easily, copiously, and healthily fed us to satiety. ${ }^{153}$ Therefore, (returning to this topic) the same people think that doctrines are like hard and heavy sacks, which bend our minds and often shorten our lives.

"Thus, the authors of this dogma would not be interested in your instances, but they would easily allow that our external senses - and, in my opinion, they would recklessly state the same concerning the human mind - were like curved and irregular mirrors which distort the shapes and appearances of objects. Just as Nature enjoys joking with human beings by deceiving their perceptions, so we enjoy making this kind of mirror in order to mislead the eyesight 
S'applica Socrate a considerare ciò che sia l'istesso senso.

Racconta avenimento occorso con Democrito. de' più creduli e semplici. E se benché tal parere, come di già ti accennai, sia alieno dell'intendimento del comune delli homini, tuttavia la sua assordità non riesce tale, che subito appreso, da se stesso si regetti et abbati, simile a quelle propositioni, che essendo repugnanti a primi principii, rimangono immediate per la propria et interna loro contradittione reprobate, come che la parte sia eguale over maggior del tutto, et altre simili. Ma ad eliminare l'antedetta openione ci converebbe servirci di copia d'argomenti et evidenze de esperienze, dedotti da' sensi, et apprensioni dell'intelletto. Per il che ci bisognarebbe, mentre che li autori di tal parere ci contendono la sufficienza di nostri sentimenti et interno intendimento, di questi servirsene per regettar il loro parere e supporre per certo, quello per anco sta in litigio. Onde la reiettione di tal falso parere in gran parte da divini oracoli dipende”. [79]

Inteso ciò il maestro speculaio, a strisciare et appianare suoi spechi si applicò, et io tralasciando in disparte l'indagare se possibile sia il ritrovarsi maggior numero di sentimenti e spetii di sensibili, mi rivolsi ad esaminare ciò che sia l'istesso sentimento, e qual certezza promettere ci potiamo de' raguagli che ci apportano essi sensi circa le conditioni et avenimenti di oggetti esterni. Nell'ingresso di tal incombenza, mi sovenne la difficoltà che nel principio, quando ricercando ciò che fosse sapere, mi si attraversò, che siccome allhora mi riusciva quasi impossibile, che si potesse admettere sapere di sapere, in tal guisa parimente mi s'appariva malagevole il riconoscere ciò che sia sentire, sortendomi come che impossibile che simili relationi, e raportamenti l'uno l'altro apprendere potesse, come già fu devisato. Ma nondimeno deliberai per alhora scansare tal ostacolo, poiché mi prohibiva il progredire l'intrapreso esame, e per tanto mi resi affatto conivente a questo assordo. Ma non sì tosto che ciò scansai, risorse nel mio animo altra dificoltà circa li nostri sentimenti che ritardò il mio discorso.

E ciò fu che mi ramentò certo avenimento occorsemi con Democrito, mentre egli appo noi dimorò, ritrovandosi esso allhora di età assai provetta, et io per anco alquanto giovane. Questo prestante homo, come bene stimo esservi noto, fu nella scientia naturale oltre modo versato, non solamente per l'esercitio dell'intelletto, ma per una accurata esperienza che molti anni haveva praticato, ma quello che mi lo rendeva più mirabile fu una certa franchezza di animo che teniva, non solamente in sopportare li travagli humani, ma anco in patientare li dolori del corpo, e sebbene che giunto alla decrepità fosse, nondimeno sempre giolivo e ridente appariva. Ma io fui più curioso di sapere la cagione di tale sua constanza e tranquilità, che di aricchirmi di qualsivoglia sua altra pregiata dottrina. Onde, ritrovandolo una fiatta con Anasagora che divisava della cagione della immobilità della terra, 
of the simplest and most gullible people. And although this opinion, as I have already mentioned to you, is unrelated to the common people's understanding, nevertheless its absurdity does not turn out to be such that, once apprehended, it is immediately rejected and demolished. It differs from those propositions which - because they are unacceptable from their first principles - are immediately rejected because of their own internal contradiction, such as the part being equal to or greater than the whole, and so on. ${ }^{154}$ However, in order to cancel out the aforementioned opinion, we should use an abundance of arguments and evidence from experience, deduced by the senses and intellectual apprehensions. Thus, while the authors of this opinion quarrel about the sufficiency of our senses and internal understanding, we should use them to reject their opinion and believe the object of the current dispute to be certain. Therefore, the denial of this false opinion depends mostly on the divine oracles.”

[79] Once the mirror master had understood this, he applied himself to smoothing and flattening his mirrors, while I decided to leave aside the inquiry into the possibility to discover a greater number of senses and species of sensible things. Thus, I turned myself to examining what a sense itself was and what certainty we might wish to obtain from the information concerning the conditions of external objects and events provided to us by these senses. With the arrival of this undertaking, there came to my mind the difficulty I encountered at the beginning when I was looking for what knowledge was. At that time, I found it almost impossible to admit to knowing that one knows, ${ }^{155}$ and in this way, it seemed to me similarly difficult to acknowledge what perception was. Then, it turned out to be impossible for me to apprehend the relationships and connections of both of them [i.e., knowledge and perception], as I have already debated. However, I decided to leave this obstacle aside for the moment, because it was preventing me from advancing the examination I had undertaken, and so I decided to agree to this absurdity. Yet as soon as I had left this aside, another difficulty concerning our senses arose in my mind which delayed my discourse.

This was the memory of an event that had occurred to Democritus and me while he was dwelling with us; at that time, he was elderly and I was still very young. This excellent man, as I think is known to you, was well-versed in naturalsciences, notonly thanks to theexercise of hisintellect, but also to the accurate experience that he had gained over many years. However, what made him more admirable to me was his ease not only in bearing human hardships, but also in undergoing bodily pains. Indeed, although he was near to decrepitude, nevertheless he always looked cheerful and smiling. Yet I was more curious to know the cause of this constancy and tranquillity of his than to enrich myself with any of his other refined doctrines. Hence, I once found him debating with Anaxagoras over the cause of the earth's immobility:
Socrates applies himself to considering what a sense itself is.

He recalls the event that occurred with Democritus. 
Socrate ricerca Democrito della causa del suo animo.
[80] che essendo nel centro dell'universo sospesa e pendola, dal rapidissimo motto et agitatione di cieli, et aria circonvicina non sia smossa e sconvolta, e massime incontrandosi nelle prominentie de' monti, e rendendo di ciò ognuno di questi certa ragione, dall'altro diversa, io, volgendomi verso a Democrito, in tal guisa li favellai:

"Non della constanza e fermezza della terra io prendo meraviglia, giudicando che come corpo pesante e pigro nel loco ove si ritrova facilmente si posi, e per la sua semplice materialità si renda renitente all'altrui scosse et impulsi, ma ben mi stupisco che il tuo animo per se stesso di natura tanto flessibile e mobile, a colpi e vessationi della fortuna rimanga imperturbato e persista constante e fermo, e che con continuata allegria sempre perseveri, il che certo in homo sapientissimo, qual stimo che sei, non deve da sciocchezza e stupidità ciò risultare".

\section{Rispose egli:}

"Se tu, Socrate, con accurata deligenza havessi praticato li principii della mia dottrina circa le cose naturali, agevolmente penetrato haresti, d'onde si origina in me tanta stabilità e fermezza di spirito, trascurando io perciò tutte le offese che la fortuna imprendere contra di me attentasse”.

\section{Replicai:}

"Molto celebri sono li tuoi dogmi circa il primordio delle cose, ma giammai non saprei da ciò dedurne nelli travagli e dolori imperturbatione d'animo, et insensibilità, se però non fosse che l'occuparsi la tua mente in tal dottrina la divertisce dal risentimento di humani incommodi, oppur anco talmente è grande il diletto, che prende in rinvenire proprie, e vere cagioni di mirabili effetti della natura, che ricompensa di gran lunga a qualunque altro dolore et angoscia che il tuo animo infestasse. E tanto più si accresce in te il piacere, essendone celebrato autore di tal mirabile dottrina, ruminando in te stesso l'applauso universale che sei per conseguire da sapienti del secolo presente, ingiuntatovi la ferma speranza che tieni di raccomandare la fama della tua virtù alla indifinente e ventura posterità".

\section{A ciò [81] soggiunse egli:}

“Anzi, il riconoscere le vere cause de' mondani eventi sugerisce piuttosto noia e vessatione di mente, che diletto e piacere, rappresentandosi all'intelletto l'inesorabile fatalità che il tutto regge, over lo stolido et assordito caso, che li affari humani sossopra rivolge, riconoscendosi perciò non potersi apportare alcuno facile e salutare rimedio per impedire tal precipitoso et inevitabile corso, onde li volgari, ingannati dalla propria inscitia, e lusingati da folle speranza, con molti agevoli e poco dispendiosi mezi stimano scansare l'incontro di venturi mali, e procaciarsi facilmente li beni. E di più anco non 
[80] suspended and dangling in the centre of the universe, it is not moved or upset by the rapid motion and agitation of the skies or by the surrounding air, which can mostly be encountered at the summits of mountains. While each of them was giving certain reasons, but each of them different from the other, I turned to Democritus for this and spoke to him in this way:

"I am not astonished by the earth's constancy and stability, since I judge that it is a lazy and heavy body, easily resting in the place where it currently is and resisting the blows and impuleses of others through its simple materiality. Rather, I am stunned by your mind itself, of so flexible and adaptable a nature that it persists, constantly, firmly, and imperturbably through Fortune's blows and oppressions. Furthermore, you always persevere with a continuous cheerfulness that in a very wise man, as I think you are, must certainly not be regarded as foolishness or stupidity."

\section{He answered:}

"If you, Socrates, had practised the principles of my doctrine about natural things with accurate diligence, you would easily have grasped where the origin of such stability and strength of mind, [thanks to which] I avoid all the damage that Fortune attempts to cause me, is located in me."

I replied:

"Your dogmata about the origin of things are well-known, but I would not be able to deduce the mind's impeturbability from them, or insensibility in the context of hardships and pain, were it not for the fact that your mind is diverted from the affections of human troubles while it is pursuing this doctrine, or even that the delight it experiences in discovering the real and true causes of Nature's admirable effects is so great that it far recompenses any pain or anguish affecting your mind. And you will take much more pleasure from being the lauded author of such an admirable doctrine; you will dwell on the universal applause you will obtain from the wise men of the present time, together with the fervent hope you have of entrusting the fame of your virtue to indefinite and future posterity."

\section{[81] He replied to this:}

"Rather, acknowledging the true causes of mundane events ails and oppresses the mind instead of delighting and pleasing it. Indeed, the intellect, seeing the inexorable fatality ruling the whole, or dull and stupid Chance turning human matters upside down, thus acknowledges that it cannot provide an easy or useful remedy to avoid such a rash and inevitable course. Therefore, the common people, deceived by their own ignorance and swayed by their insane hopes, believe that they will avoid an encounter with future mishaps and effortlessly obtain good things through very easy and economical means. In addition to this,
Socrates looks for the cause of the fortitude of Democritus's spirit.
Knowledge causes pain. 
Espone Democrito la cagione della sua allegria.

Lucretio. sono offesi dall'angore, che suole arrecare la prescientia de' mali, per il che non li patiscono se non quando effetivamente sono da essi assaliti et invasi. Né l'acclamatione del secolo futuro punto mi raconsola, antivedendo io che mancando con la vita, il patrocinio delle mie dottrine, che hora con qualche diligenza la loro stima e credito sostengo, devineranno un giorno alla gente ventura ridicole favole, et anili delirii, non essendo le dottrine meno che l'altre cose mondane esposte a colpi della inconsiderata fortuna, e variante caso. Oltre che, le dicerie che di me doppo la morte saranno decantate, riuscirano a me inattinenti come, che se inanzi il mio nascimento fossero state divolgate e celebrate, che allhora sentimento alcuno di esse non ne teniva.

Ma la tranquilità e quiete, che scorgi nel mio animo, deriva piuttosto da peculiare proprietà che hanno li miei dogmi, circa li primi essordii delle cose da me promolgati, cioè che havendo io molto tempo invigilato in ritrovare principii tali dell'universo, che sofficienti fossero per conservare la di lui incolumità e fermezza, alla fine capitai a tali principii che da niuno disastro de strano accidente si potessero depravare, et alterare. Questi furono li atomi, et il vacuo. Li primi essendo incapaci della divisione, perciò inalterabili et impassibili li stimai. Il secondo per sua natura affatto imperturbabile lo giudicai [82] ritrovandosi egli di ogni essenza privo, e perciò non soggetto alle alterationi e variationi, a guisa di meschino, che non havendo che perdere, s'esime delle ingiurie di furatori. Questi, dico li atomi et il vacuo, in varie guise mescolandosi, producono infinite configurationi, condizioni e qualità di cose, l'uni le rendono sode e vigorose, e l'altro permeabili, e che con amichevoli congressi, tenessero insieme comercio e famigli. Oltre che il moto privo del vacuo, restarebbe affatto impedito, essendo dal pieno interdetto et ostato l'oltra passar e progredire:

\section{Tum puro locus ac spacium quod inane vocamus \\ Si nullum foret haud usquam sita corpora possunt \\ Esse neque omnino quoquam diversa meare.}

Essendo dunque tali li principii delle cose mondane, qual dunque, amico Socrate, affronto del caso, o che fiero avenimento offendere ci può, mentre che noi come anco tutte l'altre cose dell'universo, di tal impassibili elementi siamo composti e construtti? Per il che non dobbiamo tenire cagione di punto affligerci di qualunque apparente disastro che ci rassembra offendere, poiché le vere reali e primordiali portioni che ci constituiscono sono affatto inoffensibili, et inalterabili. E nulla o almeno poco molestare ci deve la slocatione accidentale, e fortuita positura de' atomi che nel similare et indiferente vacuo accada in questa situatione over in quella, restando sempre illesi quelli fondamentali principii che ci compongono, onde il dolore il più formidabile inimico che tenga la nostra natura, riesce piuttosto fantastica larva, parto della falace openione, che cosa reale et esistente, poiché ci si dimostra chiaro che il pieno che in noi si ritrova, si oppone et è renitente a ricever in lui ciò che lo penetri et offenda, essendo decreto inevitabile della necessità, che qualunque cosa per tenue che sia repulsi da sé l'altrui insinuatione e [83] penetratione, essendoli imposto che insino alla ultima estintione s'opponga a qualunque interna invasione, che d'altrui li fosse intentata. 
they are not ailed by the anguish usually caused by knowing evils beforehand; for this reason, they undergo them only when they are actually assaulted and invaded by them. Nor, indeed, may the approval of future centuries console me, because I foresee that after my death, I will not be able to advocate my doctrines, whose esteem and merit I now diligently support. Yet one day, they will become ridiculous tales and senile frenzies for people in the future. Indeed, doctrines, like the other mundane things, are exposed to the blows of rash Fortune and changeable Chance. Furthermore, the rumours that will be put forth about me after my death will be as insignificant to me as if they had been spread and celebrated before my birth, when I could not have taken any notice of them.

"Yet the tranquillity and rest you observe in my mind derives rather from a peculiar property of my dogmata concerning the very first origins of the things I have displayed. Namely, since I had attempted for a long time to discover principles of the universe that could be sufficient to maintain its integrity and stability, I finally ended up with these principles, which could not be corrupted or altered by any strange accident. These were atoms and the void. Since the former were incapable of being divided, I therefore considered them unalterable and impassive. I judged the latter to be imperturbable by its own nature, [82] since it lacks essence and so is not subject to alteration and variation, like a poor man who, having nothing to lose, is safe from the assaults of thieves. These - I mean atoms and the void - produce infinite shapes, conditions, and qualities of things by mixing themselves in different ways. The former make them solid and vigorous, the latter [makes them] permeable, and thanks to amicable combinations, they have connection and familiarity. Besides, motion would indeed be impeded without the void, since the plenum prevents it from advancing and going further:

Then further, if there were no place and space which we call void, bodies could not be situated anywhere nor could they move anywhere at all in different directions. ${ }^{156}$

"Since such are the principles of mundane things, dear Socrates, then what affront by Chance or ferocious event might hurt us, since we are composed and constructed of these impassive elements like all the other things in the universe? Hence, we must not have any reason to ail ourselves about any apparent disaster that seems to harm us, because the true, real, and primordial parts constituting us are indeed not damageable or alterable. And we must not be bothered by the accidental relocation of atoms or the accidental positioning of atoms that occur in this or that place in the same indifferent void. Those fundamental principles which constitute us are always unharmed. Therefore, pain, the most formidable of our natural enemies, turns out to be an imaginary ghost, the product of a false opinion rather than something real and existent. Indeed, it is clearly demonstrated that the plenum in us opposes and resists receiving into itself that which penetrates and harms it. The unavoidable decree made by necessity establishes that all things, even if they are very feeble, reject the intrusion and penetration [83] of other [bodies], since they must oppose any internal invasion attempted by others until the end of their lives.
Democritus expounds on the reason for his cheerfulness. 
Gioco di Anasagora preso di Democrito.
Dal discorso di Democrito rimane Socrate dubbioso del modo della sensatione.
Et insino l'aria benché facilissima alla divisione, se non fosse la sua fugace lubricità, si difenderebbe al pari di qualunque altro corpo sodo, e conservarebbesi immune da qual si sia compressione e penetratione. E parimente anco il vacuo che in noi si ritrova, schernisce qualsivoglia colpo che aventato li fosse, onde penetrando egli altrui overo essendo penetrato, senza alcuna dificoltà et oppositione non si risente punto di tal offesa”.

Ma in questa maniera discorrendo Democrito con la mente, e progredendo con piedi, avenne che inavedutamente s'attoppò in certa prominentia, per il che fu sforzato a terra dare, con non mediocre offesa di una delle gambe, restando per tal caduta molto contusa. Onde del gran dolore risentendosi, non poté far di meno che con la voce non lo significasse, e che in dupplicati “ohimè!” non prorompesse. M' Anasagora che come dissi con esso si ritrovava, con maniera derisoria accorendolo li diceva, che li rassembrava che vigilando sognasse, ovvero che conforme il concetto che di esso tenivano li suoi Abderiti, fortemente delirasse, havendosi in un subito dimenticato di suoi proprii prononciati e dogmi. Onde instantemente l'interrogava che li esponesse in qual portione di lui havesse riceputo tal offesa, nelli atomi over nel vacuo? Nel pieno, over nelli intervalli di fori d'ogni essere privi?

"Li attomi secondo il parere tuo", diceva egli, "sono indivisibili, et il pieno medesimo impenetrabile ché perciò non possono patire dolore alcuno, né meno il vacuo si trova disposto al dolore, essendo non solo di vita, ma di qualunque essere destituto".

Ma Democrito ricercando con stentati e fievoli distintioni evadere tali instanze, compresi che non meno l'affligeva la doglia del corpo, che la molestia dell'animo, divenendo egli eversore della propria sua dottrina. Onde io ciò [84] osservan|do, procurai divertire il ragionamento ad altro proponimento, et a fomentarli l'offeso membro me impiegai. Ma siccome rimase Democrito convinto piuttosto dall'avenimento occorseli, che da ragionevole evasione che sciogliesse la sua argomentatione, così io confuso et ignaro mi ritrovai nel riconoscere il modo che nell'animale la sensatione si produce.

E sebbene che la quottidiana esperienza purtroppo mi instruisce che in noi si generi il dolore, havendo io tante volte assaggiato la sua ferocità, e per il certo egregie ragioni furno ritrovate da sapienti per sedare e renderci facile la morte, così anco per render vani alcuni oggetti che molestano l'anime, le quali a questo si riducono in dimostrare che non sono reali ma arbitrarii e fititii dalla nostra fallace openione prodotti, ma li dolori del corpo che sono cagionati dalla dissolutione del continuo, non riuscì ad alcuno con discorsi mentali annularli e renderceli insensibili. Nondimeno tornando al proposito mentre che mi 
"And even the air, which is very easily divisible, were it not for its fleeting viscosity, would defend itself as well as any other solid body and preserve itself from any external compression or penetration. Likewise, the void, which we find in ourselves, also mocks any blow rashly hurled at it, because as it penetrates the other [body], or is penetrated without any difficulty and resistance, it is not affected by this harm."

Yet as Democritus was reasoning in this manner, he rashly tripped over something that was protruding from the path as he walked. Therefore, he fell down and injured one of his legs, which was badly bruised after the fall. Thus, affected by a strong pain, he had no other option but to express it, and he burst out into multiple cries of "Oimè!" However, Anaxagoras, who was with him, as I said, rushed to his aid and derisively told him that he seemed to be daydreaming, or that he was intensely raving in the manner that his fellow citizens of Abdera believed of him, since he had immediately forgotten his own statements and dogmata. Hence, he asked him which exact part of him had received this injury: the atoms, or the void? The plenum, or the intervals lacking any being?

"According to your opinion" - he said - "the atoms are indivisible and the plenum impenetrable; therefore, one cannot suffer any pain, nor is the void exposed to pain, since it not only lacks life, but is also deprived of any being."

Yet while Democritus was trying, with difficult and feeble distinctions, to refute these instances, I realised that he was affected as much by bodily pain as by mental annoyance, because he had subverted his own doctrine. Thus, beholding this, [84] I tried to turn the conversation to another topic, and I applied myself to caring for his injured limb. Yet Democritus remained more convinced by the event that had occurred to him than by the rational deflection [I had attempted] to dispel his arguments, so I ended up confused and unaware of how to acknowledge the way in which perception is produced in animals.

Furthermore, daily experience unfortunately teaches me that pain is generated in us, because of the many times I have tasted its ferocity. Certainly, while wise men have discovered great methods to relieve [us from pain] and render death easy for us, as well as to nullify some objects which torment our souls by simply demonstrating that they are not real but are arbitrary and fictitious products of our false opinions, bodily pains, which are caused by the dissolution of the continuum, have never been relieved or rendered imperceptible through rational discourses. Nevertheless, to return to my proposal, as the way in which
Anaxagoras mocks Democritus.

From Democritus's discourse, Socrates remains doubtful about sensory perception. 
Openione d'Archita tarentino circa le qualità. rimane occulta et astrusa la maniera che si produce la sensatione, non mi rassembra convenevole, che per mezo di essa io ardisca di accertarmi delle vere conditioni di oggetti esterni, parendomi gran assordo che l'ignoto mi conduca all'apprensione di altro per anco sconosciuto, come se per le tenebre attentassi ricercare cosa che oscura fosse.

Ma avenne che, mentre io vacilava circa tal dificoltà, che Dione, da Italia partitosi, verso noi navigasse, della dottrina di Archita tarentino molto disciplinato, ché di costui la fama molto celebre appo noi suonava. Occorse che havendo egli inteso dalli miei amici qual fosse la mia titubazione circa la sensatione, con non mediocre allegria m'incontrò et in tal modo favellomi:

"Stimarei, o Socrate, haverti arrecato ciò che per acquietare affatto il tuo animo circa il riconoscere la maniera che in noi la sensatione si genera, et è, che Archita tarentino gloria della nostra Italia, considerando la innumerabile farragine di cose che [85] nell'universo si ritrova, che perciò sfugiscono la nostra apprensione, il tutto raccolse et arrolò in due classi e distinti generi, nell'uno di essi vi rachiuse le più nobili e vigorose essentie, suficienti da se stesse senza l'appoggio altrui con il proprio essere sostentarsi, e queste appellò sostantie. Nell'altra vi accumulò una turba di cose di tanta fievole et imbecile conditione, che non potendosi da se stesse con il proprio essere reggersi e mantenersi, le conviene alla sostanza attenere et appigliarsi, e da questa mendicare il loro essere, e quelli accidenti nominò, li quali poi in nove minori classi distinse. Fra questi vi si ritrova il genere della qualità, del quale si serve la sostanza in esercitare in altrui le sue fontioni, la quale sostanza a guisa di maestoso Prencipe ritirata se ne sta da per sé nella sua reggia, e per mezo di ministri et emmissarii eseguisce con altrui li suoi attentati et intraprese. Onde quella in disparte dimorando con il ministerio della qualità in altrui penetrando et operando prima l'altera, e poi affatto corrompendolo lo riduce a sé simile. Così il fuoco adopera il calore, l'acqua il freddo, et in tal maniera parimente ogni altra sostanza si diporta.

Il che accade anco all'animale sensitivo, che incontrandosi nel fuoco non lo riceve altrimente essendo questo corpo e sostanza materiale, a cui è interdetto l'introdursi nelli intimi ricessi di altra sostanza, ma sì bene al calore, suo ministro, come immateriale qualità li è permesso et aperto l'adito ad insinuarsi e penetrare nell'interno dell'animale. La qualità dunque è quella che ci cagiona il sentimento, e che nel pieno di noi non li è intercluso l'adito et ingresso, onde se tal qualità si trova confacevole alla nostra natura produce la volutà e piacere, s'adversa offesa et il dolore.

Per il che ci si rende manifesto che questa, a guisa di ambasciatrice, ci espone e ci fa riconoscere l'istessa sostanza, ché, senza la communicatione dell'idioma della qualità, ci restarebbe [86] quella affatto occulta et incomprensibile, a guisa appunto che accade a nostri corpi che benché siano infagotati e ricoperti de' vestiti, nondimeno agevolmente per mezo di questi si comprende la costitutione e positura di quelli”. 
sensory perception works was still hidden and abstruse to me, it did not seem appropriate that I should dare to use it to ascertain the true condition of external objects. It seems to me a great absurdity that the unknown could lead me to apprehend something else that was still unknown, as if I was attempting to look for an unknown thing in the dark.

While I was vacillating in this difficulty, it happened that Dion left Italy and sailed to us. ${ }^{157}$ He was well-acquainted with Archytas of Tarentum's doctrine, ${ }^{158}$ the fame of which resounded among us. It happened that since he had heard about my indecision concerning perception from some friends of mine, he thus met me with great cheerfulness and began talking to me in this way:

"I would consider, oh Socrates, giving you this in order to indeed appease your mind towards the acknowledgement of the way in which perception may be generated in us. To wit, Archytas of Tarentum, the glory of Italy, considered the innumerable medley of things [85] which are in the universe and thus escape our apprehension. He listed the whole and divided it into two classes and different kinds. In one of them, he included the noblest and most vigorous essences, sufficient to sustain their own being by themselves without the support of anything else, and he called them 'substances.' In the other, he grouped a mass of things of such a feeble and powerless condition that they were unable to bear or maintain themselves on their own, and thus they needed to seize and depend on a substance and beg it for their being. He called them 'accidents,' and distinguished them into nine minor classes. ${ }^{159}$ Among them, there is the kind of quality, which a substance uses in carrying out its functions over the other things. The substance, like a majestic prince, withdraws into its palace alone, and by means of its ministers and emissaries, it carries out its attempts and undertakings towards the other things. Therefore, even if it dwells apart, thanks to its minister, the quality, it penetrates the other things and acts on them, first by altering them and then, after having indeed corrupted them, by making them like itself. Thus, fire uses heat, water [uses] cold, and every other substance similarly behaves in this manner.

"This is also the case when animals, as they are endowed with sensory faculties, enter into contact with fire; indeed, they do not perceive it otherwise, because it is a bodily and material substance and cannot intrude itself into the recesses of another substance, while for heat, its minister, the access to slip and penetrate into the animal is allowed and open, as it is an immaterial quality. So quality is that which causes perception in us, to which access and entrance into us is not prohibited. Thus, if this quality agrees with our nature, it produces delight and pleasure; if it is opposed [to our nature], [it produces] harm and pain.

"Therefore, it is evident that, like an ambassador, it shows us the substance itself and allows us to acknowledge it, which would indeed remain hidden [86] and incomprehensible without notifying us of the quality's peculiar properties. It is the same for our bodies that, even if they are well-bundled up and covered by clothes, one may nevertheless easily comprehend their constitution and posture."
Archytas of

Tarentum's opinion

concerning qualities. 
Ma havendo Dione posto fine al ragionamento, del cui favellare non Replica di Socrate. punto restandone io satisfatto, in tal maniera repigliai:

"Non così fu appo tarentini pregiato il volo della materiale colomba d’Archita construtta, quanto che il volo della fama della sua dottrina da noi Greci è admirato. E volesse Iddio che io mi potesse impennare alle tali, che ad esso mi apportassero, onde mi fosse lecito in alcuna parte arichirmi della sua mirabile et acclamata sapienza, et in particolare mi appianasse alcune dificoltà che in tale sua positione, da te esposta, mi si attraverssano, ché essendone egli il primier autore, stimo che meglio che qualunque altro ciò eseguirebbe. E per il vero, amico Dione, molte assertioni suppone egli che tengono bisogno di lunga discussione et accurato essame, per il che di parte di essi il ventilare tralascio. Ma per hora parmi strano, né posso facilmente digerire in qual maniera cosa priva in se medesima di essere, in altrui lo ritrovi. L'arbore si sostiene sopra le radici, e lo edificio si posa alla base e fondamento, ma l'uno e l'altro possegono proprio essere, sebbene non hanno per loro stessi solievo et erettione. Ma questi tali accidenti per loro stessi, sono cassi di esistentia, et in altrui l'accattano, ma l'esser è tanto intrinseco alle cose che fuori di esse il ritrovarlo parmi arduo.

Ma lasciamo ciò in disparte, teco voglio esaminare quello che solamente appartiene alla mia particolare inchiesta: rassembrami oltre modo assordo che enti di così grama e fievole conditione, che il proprio essere d'altrui li conviene mendicare, tengono per altro verso facoltà di informarci et additarci l'imagine della sostanza vigorosa, potente, e che possiede non solamente virtù di esistere da [87] per sé, ma ad altrui prestarlo e communicarlo. Il che molto più mi riesce mirabile, che se il simulacro d'animale dipinto pretendesse rappresentare l'interna essentia del suo vivo originale, non possedendo quello altro che il colore e lineamenti di contorni esterni. Oltre di questo, si aggiunge che conforme tal positione ci resta impedito il riconoscere tanto la sostanza quanto l'accidente, divenendo noi dubbiosi e perplessi da quali di essi prendere dovessimo l'esordio della nostra indagine, non dalla sostantia essendo quella imbrogliata et affatto ricoperta dalli addobamenti et invogli di accidenti, il che d'Archita non è altrimente preteso.

Ma in che maniera dall'accidenti è possibile pigliare il principio della disquisitione, se il loro essere dalla sostantia assolutamente dipende? Et essendo essa ignota, in qual maniera si possono quelli apprendersi? E come vogliamo pretendere che l'essentia delli accidenti sia riconosciuta, mentre che il fondamento della loro esistentia, quale è la sostanza, ci è per anco occulta? Oppur diremo che l'esser dell'accidenti sia distinto dalla loro essentialità? Non essendo il ciò affermare privo di irreconciliabile litigio e spinose dificoltà. $\mathrm{O}$ piuttosto per evitare tal instanza approbarasi che ad un medesimo tratto et instante la sostanza e suoi accidenti dalla nostra mente siano osservati et appresi, senza che essa mente rimanga confusa et implicata in speculare oggetti tanto varii e diversi?

Ma all'admissione di ciò non mi permette acconsentire il mio genio. Et in quanto appartiene alla maniera che il sentimento in noi sortisce, dico, ch'asserendo l'antedetto dogma, che per mezo di accidenti e penetranti qualità d'oggetti nell'interno del nostro animo si eseguisca la sensatione, ché perciò 
Yet as soon as Dion had concluded his argument, since I was not satisfied by what he had said, I continued in this way:

Socrates's reply.

"The flight of the wooden dove built by Archytas was less appreciated by the citizens of Tarentum than the flight of his doctrine's fame is admired by us Greeks. ${ }^{160}$ God granted that I might rise ${ }^{161}$ to this [doctrine] which could bring me to him [i. e., Archytas] so that I could be allowed to somehow enrich myself with his admirable and acclaimed wisdom, in particular so that he could smooth out some difficulties that I found in his position according to the way you have expounded it. Indeed, I think that as he was the original author of this, he would accomplish it better than any other. In reality, dear Dion, he supposes many assertions which need to be extensively debated and carefully examined; therefore, I will avoid discussing some of them. However, for the moment, it seems strange to me and I cannot easily accept how something which lacks being might find it in others. A tree stands on its roots and a building is based on the ground and its foundations, but both of them have their own being, although they cannot stand or be upright by themselves. Yet these accidents are lacking in existence in themselves and take it from others, but being is so intrinsic to everything that it seems to me to be difficult to find it outside of them.

"However, let us leave this aside, [because] I only want to examine what truly pertains to my particular inquiry with you. It seems extremely absurd to me that beings of so meagre and feeble a condition that they need to beg another for their own being nevertheless have the faculty to inform us and show us the image of the vigorous and powerful substance, which not only has the virtue of existence [87] per se, but also of lending it [i.e., existence] and communicating it to others. This seems to me even more admirable than if a simulacrum of a painted animal claimed to represent the internal essence of the original living one, since it has nothing other than the colour and features of its external outlines. Furthermore, one must add that according to this position, we are impeded from acknowledging the substance as much as the accident. [Consequently,] we become doubtful and perplexed concerning from which of them we must begin our investigation, but it must not be from the substance, since it is entangled and covered in adornments and a cloak of accidents, and this is no different from what Archytas supposes.

"Well, how is it possible to find the beginning of the disquisition from accidents, if their being completely depends on substances? And since this is unknown, how might they [i. e., accidents] have been apprehended? And how do we want to suppose that the essence of accidents may be acknowledged if the foundation of their existence, which is the substance itself, is concealed from us? Or may we rather say that the being of accidents is distinct from their essentiality, although stating this involves irreconcilable controversy and thorny difficulties? Or rather, in order to avoid this instance, should one accept that the substance and its accidents are observed and apprehended by our minds at the same time, without the mind being confused or involved in speculation on such various and different objects?

"Yet my genius cannot allow me to accept this. Furthermore, as far as the way in which sensory perception occurs is concerned, I say, by asserting the aforementioned dogma, that sensation is carried out through the accidents and qualities of objects penetrating into our minds. For this reason, you put forth 
adducesti l'essempio de' ministri de' Prencipi. Non volendoti io negarti il vero, dicoti che a tal dottrina io non inclino, né l'essempio di ministri reggii parmi che punto s'addatti al proposito che alle mani habbiamo. Anzi, da questo parmi scaturire maggiormente dificoltà circa il tuo e di [88] Ar|chita divisamento. Se alli ministri di Prencipi non fosse lecito di giamai dipartire e spicarsi da' loro Signori, e che ad essi fossero talmente anessi e congiunti, come sono l'accidenti alle sostanze che si trovano talmente ad esse uniti che loro essere da queste dipende, giamai appo altrui eseguirebbero alcuna agenda, et affare, senza la coasistenza de' loro padroni e comittenti, et ove che a questi non fosse lecito capitare, né anco a quelli si permetterebbe penetrarvi”.

A tal favellare s’acquietò Dione, né altro in difesa di Archita attentò. Onde siccome prima circa il modo che s'eseguisce in noi la sensatione rimasi flutuante, e perplesso, a ciò mi s'aggiunse altro dubbio e fu se il sentimento nell'organo esterno si eseguisce, instalandosi in esso facoltà di risentirsi dell'incontro dell'oggetto o della sua imagine, overo che per mezo di irradiatione della parte più principale del nostro animo, a guisa di luce emanante da corpo lucido, nelli organi al sentire destinati con subito influsso è dimandata facoltà che li cagiona divenire sensitivi, come contendono li medici, overo piuttosto che l'organo esterno altro non presta che adito e condotta alli simulacri di oggetti, in modo che possano penetrare alla più interna facoltà, a cui attiene il resentirsi di tale impressione, essendo probabile che ad un modo et all'altro ciò possa avenire, apparendoci la prima maniera probabile per la celerità e velocità che si eseguisce la sensatione nell'organo esterno. Ma per altro verso il discorso ci addita, che nelli più retirati ripostigli della mente ciò avenga, osservandosi che ritrovandosi essa occupata in alcun importante impiego, non si risentiamo punto di ciò che alle mani habbiamo, e che sotto l'occhi teniamo:

Dante Canto 4.

Quando per dilettanza over per doglie

D'alcuna virtù nostra comprenda

L'anima ben ad essa si raccoglie

Par che nulla potenza più intenda

[89] E questo è contra quell'error che crede

Che l'un'anima sovra altra in noi s'accenda.

Ma chi dubbitare può, ch'avenendo la sensatione nell'una over altra maniera oltre modo se disguisa la certezza che si tiene di oggetti esterni? Poiché se nell'interno dell'animo riceviamo l'imagine dell'oggetto, inanzi che in noi s'eseguisca la sensatione, conviene che l'imagine s'inoltri insino alli ultimi penetrali dell'animo. Per il che, l'acca- 
the example of princes' ministers. I do not want to deny you the truth, so I will tell you that I am not inclined to this doctrine, nor does it seem to me that the example of royal ministers is suitable for the purpose we have in hand. Rather, it seems to me that greater difficulties are arising concerning your thought and [88] that of Archytas. The princes' ministers are never allowed to depart or take distance from their lords, and they are very close and connected to them, just as accidents are so united with substances that their being depends on them. They [i. e., the ministers] will never accomplish any task or business without the assistance of their own lords and principals; and thus, a place where the latter are not allowed to be is also forbidden to the former.”

In the face of this discourse, Dion calmed down, without trying to defend Archytas in another way. Therefore, I remained wavering and perplexed about the way in which perception may be carried out in us. Yet in addition to this, another doubt emerged, and this was whether perception may be carried out in the external organs, as the faculty to be affected by the encounter with an object or the image of it was settled in them; or even [whether it may be carried out] through an irradiation [coming] from the main part of the mind which, like a light emanating from a shining body, instantaneously influences the sensory organs, and to which is attributed the faculty to make them sensible, as doctors argue; or rather that the external organ offers nothing other than access and a duct through which the simulacra of the objects can penetrate up to the most internal faculty, which is affected by these impressions. It is probable that it may happen in one or other of these ways: on the one hand, the first way appears to us to be probable because of the quickness and speed of sensation being carried out in the external organs; on the other hand, the discourse indicates that this happens in the most hidden meanderings of the mind. Indeed, it might be observed that when the mind is busy with some important work, we are not affected by what we have in our hands and is there for all to see:

When as a result of pleasure or pain,

Which any faculty of ours experiences

The soul withdraws itself into that faculty,

It seems to notice none of its other power;

Dante Canto IV.

[89] And this is contrary to that error which holds

That, in us, one soul lights up above another. ${ }^{162}$

Who may [not] doubt that if sensation happens in one or other of these ways, then the certainty that we have of external objects may also change dramatically? Because we receive the image of the object into our minds before sensation is carried out inside us, the image should advance into the deepest meanderings of the mind. Therefore, since it 
Esami particolari

di sensi.

Esame del tatto. derebbe non mediocre alteratione, e depravatione dovendo scorrere per meati tanto angusti et inviluppati, il che non avenirebbe se nell'organo esterno la sensazione occorresse, oltre che si divolverebbe il tutto al senso interno et all'istesso intelletto, né li sensi esterni apportare potrebbero fede al discorso dell'intelletto, non havendo essi parte nelle sensationi, ma il tutto appartenerebbe all'intelletto. Onde, stimando noi apportare attestationi a favore del senso, all'intelletto arrecaressimo in prova lui stesso a se medesimo.

Da questa consideratione (o per dir meglio) flutuatione, et attentamento universale che fu da me pratticato circa la sensatione come preludio di particolari speculationi, mi ridussi all'esame di nostri spetiali sensi, ma per più facile et agevole espediente, feci scelta di doi d'essi, quali furno il tatto e la vista, circa di quali intrapresi instituire la destinata da me disquisitione. Elessi il tatto, non solo per esser il più universale delli altri, non potendosi l'animale senza di esso reggere et esistere, ma perché come già fu detto, egli è riputato il fondamento delli altri suoi congeneri sensi, non potendosi eseguire alcuna sensatione senza l'intervento di certo contatto fra il sensitivo, e sensibile. E la vista parimente fu da me scelta per esser fra sensi il più nobile $\mathrm{e}$ maggiormente informativa dell'intelletto, e di lui non poco famigliare.

Dal tatto dunque pigliai l'essordio dell'esame, e benché nel devisamento tenuto con Gorgia alcune cose di non poco rilievo furno circa esso discusse, nondimeno non satisfatto di ciò a [90] pie|no, deliberai attentarlo con nuova ricercata più della primiera esquisita et esatta. Per il che ad Archelao ricorsi nelle materie fisiche (come sapete) assai versato e celebre, e lo richiesi che mi esponesse la vera esplicatione del contatto, mezo efficacissimo alla produttione delle cose naturali et a noi informativo delle cose esterne.

Risposemi egli che tale contatto sortiva quando l'estremi di doi corpi insieme si ritrovino, non intermezandosi fra essi altra cosa, a differenza del continuo che li estremi uno si fanno.

Non restai punto satisfatto di tale dichiaratione non potendomi formalizare, in che maniera due superficii, linee over punti insieme toccare si possino senza che seguisca la di loro unione. Onde non comprendevo diversità fra il contatto e la continuatione, dovendo sempre con la unione delli estremi eseguirsi tanto l'uno quanto l'altra, non potendosi imaginare contatto senza certa coniuntione, né questa senza unione, dal che si raccoglie, che il contatto sia una certa tal continuità in quanto che diversi punti, linee, overo superfitii ad un comun termine accorrono. 
would have to go through such narrow and tangled ducts, it would be greatly altered and corrupted, but this would not happen if sensation occurred in the external organs. Furthermore, if everything was to be transferred to the internal senses and the intellect, reventing the external senses from taking any part in sensation but letting everything belong to the intellect, they would not be able to trust the intellect's discourse. Thus, while we are considering putting forth testimonies in favour of the senses, as far as the intellect is concerned, we might provide it as proof of itself.

From this consideration, or better to say wavering, and the universal attempt I undertook concerning sensation as an introduction to specific speculations, I decided to turn to a detailed examination of our senses. And in order to do this in an easier and simpler way, I chose two of them, the sense of touch and the eyesight, and decided to focus my disquisition on them. I chose the sense of touch not only because it is the most universal of them - indeed, no animal can rule itself or exist without it - but also because, as was already said, it is considered the foundation of the other congener senses, since no sensation can occur without a certain contact between the sensitive and the sensible. Likewise, I chose the eyesight because it is the noblest of the senses, the most capable of informing the intellect and closely acquainted with it.

Some very relevant things about the sense of touch with which I began the examination were discussed during the debate held with Gorgias. Nevertheless, [90] not being fully satisfied with this, I decided to pursue it thanks to a new search, finer and more exact than the first. Therefore, I appealed to Archelaus, ${ }^{163}$ who was, as you know, wellversed in physical matters and renowned [for them]. I asked him to give me a true explanation of contact as an extremely effective means for the production of natural things and very capable of informing us about external things.

He answered me that such contact was the result of a direct encounter of the extremities of two bodies without anything between them, unlike continuity, in which [two] extremities become one alone.

I was not fully satisfied by this statement, because I could not conceive how two surfaces, lines, or points could touch each other without this resulting in their unity. Thus, I could not comprehend the difference between contact and continuity, as a union of extremities ${ }^{164}$ always accomplishes both of these. It is impossible to imagine contact without a kind of conjunction, and not even this without union. From this, one may gather that contact is a kind of continuity insofar as different points, lines, or surfaces converge on a common end.
Specific examinations of senses.

Examination of the sense of touch. 
Ma evinto che ciò hebbi, di nuovo ad esso Archelao attendendo, li dissi che havendo rispetto alle cose antedette, riesce che la diversità che vertisce fra la continuità, e contatto sia la facilità, overo malagevolezza che accade nella divisione e separatione, ché il contatto agevolmente permette la distrattione, e separatione, ma che il continuo a ciò riusciva più renitente.

$\mathrm{Al}$ che egli soggionse che per il certo la verità lo constringeva a confessare che ambo li tangenti in un punto, e comune superficie concorrono, ma che di ciò non molto si curava havendo dall'istessa verità anco ottenuto esser diverso il contatto dal continuo in quanto alla facilità overo malegevolezza della divisione.

Ma io continuvai:

"Poiché l'unità dalli esterni di tangenti è comune al contatto, et al continuo, gravi difficoltà mi s'attraversano, amico Archelao, admettendo tale unione per mezo del contatto over del continuo: in qual [91] maniera due superficie o per dir meglio estremi toccandosi over continuandosi, in una si transformano, e convertono? Ove una de quelle estremità e superfitie capitò, essendosi ambi fatti una? E come tale unione avenire può senza insieme confondersi? Onde l'aria tocando l'acqua et in uno comune termine accozzandosi, riesce necessario che si faccia certa mescolanza di diverse cose di contrarie qualità dotatte, così parimente l'oggetto sensibile per mezo del toccamento divenendo uno con il tangente sensitivo. Ma qual unione può ritrovarsi tra questo vivo e di sentimento dotatto, e quello privo di vita et insensatto? E qual sincera certezza potiamo conseguire delle conditioni dell'oggetto esteriore, mentre che per mezo del contatto con altra a sé diversa natura si confonde e diviene uno? E se così è che mescolandosi li tangenti riescano l'estremità dell'uno e l'altro l'istessa cosa, in qual guisa può l'uno esser agente, e l'altro patiente insieme essendosi confusi e divenuti uno?

Et oltre ciò toccandosi due superfitii orbicolari mentre l'una entro l'altra posta sia, converrà, che tal contatto in una comune superfitie si termini. Ma qual gagliarda imaginatione può giamai digerire, e rappresentarsi che superfitie concava, cioè quella dell'orbe continente et altra concava, qual è la superficie orbicolare esteriore del contenuto, in una superfitie indivisibile concorano et una sortiscano? E che il convesso e concavo nel medesimo si confondano? Ma a questo si aggiunge che impossibile apparisce, che doppo eseguito il contatto $\mathrm{e}$ che già l'estremità de' tangenti sono riusciti uno indivisibile, si possino di novo disgiungere et in due convertirsi, in modo che l'uno indivisibile in duoi si cangi.

Et insomma mi appariva che il contatto e continuità nel modo che tu, Archelao, hai esposto, a cui consente il comune di fisici, altro non sia che implicatione di contrarii et assorde repugnanze, all'intelletto humano affatto indegestibili, et inattingibili. Tralascio per hora altre instanze, dalle speculationi [92] mate|matiche dedotte, che oppugnano affatto tal contatto, come la linea che si genera da punti indivisibili per la revolutione di circolo, over sfera sopra il piano di superfitie. Oltre di ciò l'angolo, che producono due linee rette 
Yet once I had inferred this, I turned to Archelaus again, and I told him regarding the aforementioned things that the difference between continuity and contact consisted in how easy or difficult it was to divide and separate things; indeed, while contact easily allows division and separation, continuity turns out to be more reluctant in this.

Therefore, he added that the truth certainly compelled him to confess that both of the tangents converged on one point and a common surface. Yet he was not very concerned about this, because from the same truth, he also obtained [the idea] that contact is different from continuity as far as the ease or difficulty of division is concerned. However, I continued:

"Since the unity of external tangents is common to both contact and continuity, whether I admit that such unity happens by means of contact or of continuity, dear Archelaus, some serious difficulties are opposing me. How [91] may two surfaces, or better to say extremities, transform and convert into only one [surface] merely by touching or continuing themselves? Where does one of those extremities or surfaces end up, since they are both turned into one? How may this union happen without mingling them? Thus, just as when air touches water they mix together into a common point and it is necessary that a certain mixture of different things provided with opposite qualities must follow, so the sensible object, by means of touch, becomes one with the sensory tangent. Well, what kind of unity may one find between the latter, which is a living being endowed with senses, and the former, which lacks life and senses? And what sincere certainty of the conditions of the external object may we achieve when it mingles with another of a different nature by means of contact and becomes one [with it]? Furthermore, if it is so that in mixing the tangents each of their extremities becomes the same thing as those of the other, how may one be the agent and the other the patient, they being mingled and having become one?

"In addition to this, if two orbicular surfaces touch each other while one of them is inside the other, it should follow that this contact may be defined by a common surface. Yet what strong imagination may accept and represent that a concave surface, like that of the containing orb, and another that is also concave, like the orbicular surface outside the content, will converge on one indivisible surface and result as only one [thing]? Furthermore, that the convex and the concave may mingle into the same [surface]? And in addition to this, it seems to be impossible that after the contact is carried out and the extremities of the tangents have become one and indivisible, they can be separated and turned into two, so that their being one and indivisible may convert into two.

"Well, Archelaus, the way you have expounded contact and continuity, to which the physicists commonly assent, appears to me nothing other than a combination of contraries and absurd oppositions, unacceptable and unattainable to the human intellect. For the moment, I will overlook some other instances, deduced from mathematical [92] speculations, which are indeed not supportive of this contact, such as a line generated by indivisible points because of circular revolution, or a sphere on the plane of a surface. In addition to this, [there is also the case of] the angle produced by two straight lines 
insieme incontrandosi e toccandosi in uno punto, e tutta volta detto angolo all'infinito appresso li geometri si può dividere. $\mathrm{E}$ di più l'angolo che risulta dal toccamento di linea retta con circolare, il qual angolo è già divenutto celebre autore di incredibili paradossi e stranissime consequenze".

Ma non tenendo Archelao ciò che replicare presi d'esso congedo non

Conclusione di Socrate circa il senso del tatto. punto di lui satisfatto. Da simili ambagie dunque io soprafatto, presi a dubbitare che altro non fosse il tatto de una certa compressione, ovvero distrattione, dico una passione a noi assolutamente interna, e circonscritta, senza saperne altro di certo circa quello che fuori di noi avenga. E questo sia quel tanto che il senso realmente ne apprende, e può delibare, e che tutto quello vi aggiunse Archelao fosse ardita e capriciosa fabrica et accessione, che sopra vi forma e construisce l'intelletto, avido sempre di traboccare fuori di noi, non saprei dire per vana e propria sua ambitiosa curiosità, over che ciò li avenga da satietà et abborrimento che tenga di seco coabitare e dimorare.

Ma havendo io tali miei esercitii mentali a miei amici comunicati, irritai acramente contra me il comune delle genti, reputando molti tali discorsi piuttosto vaneggiamenti e delirii che dottrine sode, e fondate speculationi. Ma in particolar si stimarno molto offesi li professori di scientia, havendo io ardito di porre la falce insino alle radici del saper humano mettendo in dubbio l'istesso tatto, tenuto in sin hora la più sicura norma e fedele scorta che li speculativi nel derigere, et accertare li loro discorsi tenissero. Da questi ne derrivò poi l'odio, e dispregio dell'homini volgari verso di me, che sempre come ombra seguono il parere di quelli che stimati sono li più sacenti. Et a tal segno inoltrarsi il livore, che insino li otiosi amanti [93] contro di me conspirarno, essendoli stato imbevutto da miei malevoli, che ritrovandomi per cagione della mia senile età esautorato dalla militia di Venere, et essendomi li suoi piaceri a me interdetti, come d'essi amanti invidioso mi fossi indotto a screditare il tatto, portione così principale anzi fondamento delle loro carnali volutà:

Quem iam praesagit gaudia corpus

Atque in eo est Venus ut muliebria conserat arva

Adfigunt avide corpus iunguntque salivas

Oris et inspirant praestantes dentibus ora

Ne quicquam quoniam nihil inde abradere possunt

Lucretio 385. Nec penetrare et abire in corpus corpore toto. 
encountering and touching on one point; indeed, the aforementioned angle may be infinitely divided according to scholars of geometry. ${ }^{165}$ Furthermore, [there is also the case of] the angle resulting from a straight line touching a circle; indeed, that angle has already become the well-known author of incredible paradoxes and very strange consequences." ${ }^{166}$

Yet since Archelaus had nothing to reply and I was not satisfied by him, I bade him farewell. Then, overwhelmed by these difficulties, I began to wonder whether the sense of touch was nothing other than a certain compression or expansion; I mean an exclusively limited internal affection, without certain knowledge of any other thing concerning what is happening outside us. [I began to wonder] whether this was as much as the sense could really apprehend and taste of it. All the things that Archelaus had added were a daring and capricious production and addition which the intellect, always eager to overflow from us, shapes and builds. I cannot say whether this happens because of its own vain and ambitious curiosity or because it is fed up with itself and abhors dwelling and remaining with itself. ${ }^{167}$

However, since I had recounted my mental exercises to some friends of mine, the common people had been fiercely roused against me; indeed, many of them judged my discourses to be frenzies and deliriums rather than solid doctrine and well-founded speculation. And especially those who claimed to have knowledge of the sciences felt very offended, because I was daring to scythe the roots of human knowledge by putting into doubt the sense of touch itself, which was, indeed, considered by speculative people as a trustworthy guidance and rule in leading and ascertaining the discourses they held. From this, there resulted the hatred and disregard of the masses towards me, since it always follows the opinions of know-it-alls like a shadow. The spite spread to such an extent that even the idle lovers ${ }^{168}$ [93] began conspiring against me. They were convinced by my detractors that I had been induced to discredit the sense of touch - which was the main part, or rather the foundation, of their sensual pleasures - because I was envious of lovers, since my old age deprived me of the service of Venus ${ }^{169}$ and excluded me from her pleasures:

At the moment when the body foretastes its joy

And Venus is on the point of sowing the woman's field, ${ }^{170}$ they cling

Greedily close together and join their watering mouths and draw

Deep breaths pressing teeth on lips; but all is vanity, for they can

Rub nothing off, nor can they penetrate and be absorbed body in body. ${ }^{171}$
Socrates's conclusion concerning the sense of touch.

Lucretius 385. 
Ma delle costoro detrattioni poco curare mi dovevo, ché siccome l'amore sovente l'accieca la vista, così facilmente può riuscire che l'istesso l'havesse depravato il tatto, facendoli apparire quello veramente non è, e stimare di palpitare reale sodezza, mentre che forse si abbattono in ombre e vane larve. Questo fu quello che a tardità della mia mente apprese e delibò circa il tatto, fondamento e base d'altri nostri sensi. A ciò si aggiunse anco l'instruttione della esperienza che parimente mi lo rese non poco sospetto di falsità. Mi si appresentò che il sangue arterioso che nel cuore dell'animale s'anida, sia tanto fervente che la mano non lo può tolerare, eppur dal cuore che per altro è tanto sensitivo che per un istante non può patire offesa che mortale non sia, non è sentito. Dal che si comprende che l'organo del tatto non osserva se non quello che a sé riesce peregrino et alieno, così il ventre de pesci mentre vivono e massime nella stagione più algente riesce al nostro tatto fredissimo, eppur conviene che non mediocre calore li sia dalla natura donato, digerendo cibi crassisimi e semplicemente ingoiati, che il nostro ventricolo giammai in chilo [94] convertirebbe. Così anco il grave et il lieve, rispetto alla nostra dispositione over consuetudine sono da noi giudicati.

Celebre è quello avenimento che ad una delle nostre contadine occorse, che havendosi assuefatta a portare quotidianamente un vittelino mentre che per anco cresceva, avenne che, divenuto bue, agevolmente lo solevava, essendole insensibilmente augumentata la carica. E non mancò fra sapienti chi stimò che la cagione del starsi pendula e ferma la terra nel mezo del circostante aere derivasse dalla lunga et antica consuetudine che prese di situarsi in quella positura:

Terra ut in medio mundi regione quiescat

Evanescere paullatim et decrescere pondus

Convenit atque aliam naturam subter habere

Ex inuente aevo coniunctam atque uniter aptam

Partibus aerus mundi quibus insita sedet

Lucretio 452.

Propterea non est oneri neque deprimit auras.

Ma dubbito, Signori Accademici, che con noiosa satietà io sia troppo trattenuto circa l'esame del tatto, senso materiale, e volgare, non degno sogetto a consumarvisi il cotanto di voi pregiato tempo, che al di sopra delli ingegni plebei oltra modo vi solevate. Per il che tralasciandolo, al senso della visione egregio nontio, et accurato raguagliatore della nostra mente a divisare applicaromi.

Esame del Negare non posso le sue egregie qualità, e conditioni, poiché senso visivo. non solamente ci rapporta l'emergentie et affari humani, ma ci avisa et 
However, I must not care so much about their slanders, because love so often blinds their eyesight as easily as it may corrupt their sense of touch by causing something that does not really exist to appear to them. Therefore, [love makes them] think that they are touching a real firm body while they perhaps merely end up with shadows and vain spirits. This was what my mind had learned and thought in old age concerning the sense of touch, the foundation and basis of our other senses. In addition to this, the teaching of experience also raised the suspicion that it was false. It came into my mind that the arterial blood dwelling in the hearts of animals is so fervent that although the hand cannot bear it, nevertheless the heart does not perceive it, despite being so sensitive that any harm, even for a moment, might turn out fatal to it. Hence, it is understood that the sense of touch only pays attention to what is foreign and strange to itself: indeed, although the stomachs of living fishes, especially during the coldest season, turn out to be very cold to our sense of touch, nevertheless one should think that Nature endowed them with enough heat to be able to digest very fatty food and to simply swallow it, ${ }^{172}$ while our stomachs would convert it into chyle. ${ }^{173}$ [94] Likewise, light and heavy things are judged so according to our disposition and habit.

There is a well-known event that occurred to one of our peasants: every day, she would carry a calf, which was still growing, and even once it became an ox, she could still lift it easily without perceiving the increased weight. ${ }^{174}$ There were also some among the wise who considered that the Earth remains tilted and motionless in the middle of the ether because of its long and ancient habit of being located in that position:

That the earth may rest in the middle region

Of the world, it is proper that the weight should vanish away by

Degrees and grow less, and that it should have another substance

Beneath, joined together with it from the beginning of its life and

United into one with the airy parts of the world on which it is

Engrafted and lives. This is why it is no burden and does not

Depress the air. ${ }^{175}$

Lucretius 452.

Yet I wonder, Lord Academicians, whether I have dwelled too long on the examination of the sense of touch, a material and vulgar sense, which is not a subject worthy of consuming your valuable time, since you are far above the plebeian intellects. Thus, I will leave this aside and pursue the examination of the eyesight, a distinguished messenger and careful informer of our minds.

I cannot deny its illustrious qualities and conditions, because not only does it inform us about human events and matters, but it also

Examination of the eyesight. 
instruisce d'avenimenti della celeste regione, contrahendo noi per mezo di questo certa famigliarità, e domestichezza con quelli nobilissimi corpi, benché tanto remoti e lontani da noi posti siano, e massime doppo che fu sufragato dall'egregio adminicolo del cannachialo, che dimostrò l'errori e falacie, che l'antichità normata dall'humano discorso giudicava vere e sincere [95] dottrine.

Stimò questa che la Via Lattea fosse sublunare, e terestre esalatione, ma l'occhio aiutato da tal criterio et instrumento, hora ci insegna che sia una congerie di minutissime stelle fisse, nelle più sublime parti del cielo esistenti. Crese quella che la luna fosse corpo terso e polito, ci instruisce questo che de molte cavità e prominentie sia imgombrata. Ci persuase facilmente quella che solamente alla luna avenga diversità di apparenza, ci dimostrò questo che Venere parimente apparisce, intiera, dimezzata, e falcata. Stimò quella che l'istessa Venere e Mercurio attorniassero la terra, come fanno li altri pianeti, ci avisò questo che non la terra, ma il sole come loro centro questi circondono et intorno ad esso si ravolgono. Giudicò quella che sette fossero li erranti pianeti, ci accertò questo che all'intorno di Giove, con loro periodi particolari, si rivolgessero quattro altri globi, benché da esso circa il zodiaco siano traportati e rivolti, et anco ci insegnò che Saturno non solamente uno pianeta sia, ma certo consortio di tre corpi, che in anni trenta con moto conforme la terra circuiscono. Approbò quella che il sole, autore del mondano calore, ne fosse egli privo, ci informò questo che il globo solare fosse occupato da molti Mongibelli e Vesuvii, che vomitando fuochi, et oscure esalationi, a vicenda le sue apparenze si alternino e disguisino.

Ma se tutte le altre degne osservationi che per mezo dell'occhio furno apprese adducessi, troppo tedioso et importuno vi riuscirei. Ma a questi egregii suoi effetti mi conviene anco contraporre le sue frodi et inganni, che equilibrati con le sue lodevoli conditioni riusciranno queste soprafatte da suoi vitii e difalte, facendosi sovente apparire il grande piciolo, l'agitato immobile, l'uno duoi, il superiore inferiore, il sinistro destro, il quadro tondo, il piano profondo, il propinquo lontano, e tante altre fallacie che quottidianamente egli ci suggerisce, che come notorie tralascio.

Ma nell'ingresso di tal esame mi s'affaciò non [96] dis|pregiabile difficoltà intorno la diversità di pareri che circa la visione fu da sapienti pronunciato. 
informs and teaches us about occurrences in the celestial region. By means of it, we have become familiar and acquainted with those very noble bodies, although they are so remote and far away from us, especially once it was supported by that illustrious instrument the telescope, ${ }^{176}$ which has demonstrated to us the mistakes and falseness that antiquity, ruled by human reason, judged as true and sincere [95] doctrines.

It [i.e., antiquity] considered the Milky Way to be sublunary and an exhalation of the earth, ${ }^{177}$ but the eyes, aided by this tool and instrument, can now teach us that it is a mixture of tiny fixed stars existing in the most sublime parts of the sky. It believed that the moon was a clear and polished body, and then the telescope taught us about the many caves and protuberances occupying its surface. The former easily persuaded us that only the moon changes its appearance, while the latter has demonstrated to us that Venus may similarly appear as full, half, or curved. The former considered that Venus and Mercury surrounded the earth, like the other planets do, while the latter has told us that they surround and revolve not around the earth, but the sun as their centre. ${ }^{178}$ The former judged there to be seven wandering planets, while the latter has ascertained for us that four other globes, according to their particular orbit, are revolving around Jupiter, although it carries and points them towards the Zodiac. ${ }^{179}$ Furthermore, it has taught us that Saturn is not a single planet, but a combination of three bodies which revolve around the earth over thirty years following a uniform motion. ${ }^{180}$ The former accepted that the sun, the author of the earth's heat, was itself lacking in this, while the latter has shown us that the surface of the solar globe is occupied by many Mongibellies ${ }^{181}$ and Vesuviuses which alternatively change and modify their appearances by erupting in fire and obscure exhalations. ${ }^{182}$

Well, if I were to put forth all the other relevant observations apprehended by means of the eyesight, I would be too tedious and inappropriate. Yet I should counter its frauds and deceits with its illustrious effects. As soon as they are compared with them, its praiseworthy conditions will turn out to be overwhelmed by its vices and errors. Indeed, it often makes a big thing appear small, a moving thing [appear] motionless, one thing [appear as] two things, a higher thing [appear] lower, a left thing [appear] right, a square [appear] circular, a plane thing [appear] deep, a close thing [appear] distant, and many other falsities that it reports every day, which I will omit because they are well-known.

However, at the beginning of this examination, I encountered a [96] considerable difficulty towards the diversity of opinions held by wise men concerning vision: 
- Alcuni, come già da Critone fu divisato, stimarono che la visione con l'effusione di raggi insino all'oggetto se esequisca.

- Altri, non admettendo così remota eiaculatione, stimano che li raggi unendosi con il lume esterno, et insieme consolidandosi insino all'oggetto si estendono.

- Et altri, opponendosi a tal emissione di raggi, piuttosto asseriscono che nell'occhio vi si introduchino l'imagini, e simulacri da oggetti spicati, e questi in due classi si dividono.

- Alcuni giudicarno che tali imagini siano spoglie materiali di corpi visibili che per la virtù et efficacia del lume dall'oggetto si stachino.

- Altri che immateriali siano ma però idonei mezi per farci riconoscere l'oggetti materiali loro progenitori, ancorché essi simulacri per loro medesimi insensibili siano.

- Altri vi furono che stimano che la visione senza l'intromissione di simulacri, né emissione di raggi possa ciò avenire, essendo a ciò bastevole la presenza dell'oggetto all'incontro della facoltà visiva posto.

Non minore repugnanze di partiti, e pareri accade circa il loco interno ove in noi si faccia la visione se pure per modo d'intromissione di simulacri ciò avenga.

- Credettero alcuni che questo occorre nel mezo della cristallina ovvero glaciale lenticola.

- Altri abhorrendo che in semplice humore privo de vita, nonché di sentimento, ciò si eseguisca, alla membrana rettina, che nelli più secreti recessi dell'occhio è colocata, attribuirno tal sentimento, poco curandosi questi tali, che in tanto oltre penetrando le imagini, sia necessario che incrociandosi insieme, il destro divenga sinistro, et il superiore inferiore.

- Altri di ciò anco meno curanti, tengono che insino alla unione di nervi optici convenga che s'introducano l'imagini, accioché per la duplicità delli occhi non ci si rendono anco l'oggetti duplicati, come ad ubriachi e deliranti sovente accade, non facendo questi stima della depravatione dell'imagini che necessariamente occorerebbe, passando esse per l'anfratti [97] d'an|gustiosissimi meati.

- Altri non assentirno ad alcuna portione solida dell'occhio rimettere tal fontione, ma ad un spirito permabile per tutto l'occhio ciò assignarno, quasi che il spirito di conditione tanto tenue e fluido 
- Some of them, as Crito already singled out, considered vision to be carried out by the effluvium of rays extending to an object. ${ }^{183}$

- Others did not accept this remote ejection and considered that the rays would first match the external light and then, once consolidated together, extend as far as the object. ${ }^{184}$

- Furthermore, others argued against the emission of rays and rather asserted that some images and simulacra, once detached from the objects, would enter into the eyes and that they were divided into two classes: some people thought that these images were the material remains of visible bodies, detached from the objects by the virtue and effectiveness of light; others thought that they were immaterial but proper instruments for leading us to acknowledge material objects, as they were their progenitors, although these simulacra were insensitive by themselves. ${ }^{185}$

- There were others who considered that sight could be carried out without the intromission of simulacra or the emission of rays, but that the presence of the object was sufficient for it to be able to encounter the visual faculty.

The location in which vision occurs in us, and whether this also happens through the intromission of simulacra, encounters a similar opposition of opinions and views:

- Some believed that it happens in the middle of the crystalline or glacial lens. ${ }^{186}$

- Some others could not bear the idea that it could be produced in a simple humour [i. e., the glacial humour] lacking in life and perception and believed that it is carried out in the retinal membrane, located in the innermost secret meanderings of the eye. Nevertheless, they attributed perception to this without paying enough attention to the fact that the images penetrating into it meet and cross, so that the right [image] becomes the left and the higher [image] becomes the lower. ${ }^{187}$

- Others who cared even less about this believed that the images intruded as far as the optic nerves in order to avoid objects being duplicated because of the duplicity of those same eyes, as often happens to drunk and delirious people. They indeed did not consider the alteration of images which would necessarily result if they passed through these very narrow [97] meanderings [i.e., the nerves].

- Others did not agree with attributing this function to any solid part of the eyes, but rather [attributed it] to a spirit permeating the whole eye. ${ }^{188}$ [They supposed] that this spirit, which is of a very feeble and fluid condition, could stop and halt images, an [action] 
potesse in sé arrestare e fermare l'imagini, ché né anco all'acqua di natura più consistente è ciò permesso, ma che dico l'acqua, né anco al christallo ciò lece.

- Altri attentando compiacere a tutti li predetti contravertenti, pronontiarno, che la visione si faccia per l'incontro delli simulacri nella congerie di membrane, humori, nervi, spiriti, che nell'occhio si trovano. Onde, stimando essi di generosamente satisfare alli comuni amici, si contentarno di tolerare tutte le oppositioni che a cadauno dalle antedette openioni incontravano.

Altri dogmi crederei che circa il modo della visione sia per produrre l'humana curiosità, spinta da naturale desio sempre inclinato non meno alle contradittioni che alle novità.

Ma qual sia la più vera delle antedette opinioni poco al mio proponimento importa, non havendo io apportato tali pareri per discutterli, ma ciò solo pretendo dedurre da tal raccolta di varie openioni: che avenga la visione in una di tali maniere ovvero nell'altra, grandissima diversità conviene che accada circa l'apparenza rispetto la vera realtà di oggetti. E chi può negare che oltre modo sia per variare la rapresentatione del visibile, faciasi per emissione di raggi insino all'oggetto, over per accopiamento di questi con il lume, o piuttosto per intromissione d'imagini, overo per la semplice presenza dell'oggetto? E così anco, eseguendosi ciò nel centro del glaciale o membrana rettina, overo nell'unione di nervi optici, overo nelli spiriti, overo nell'amassamento di tutti questi?

Et evidente documento di tal disguisamento di apparenza ci arrecono li spechi che, sebbene della istessa materia construtti siano, un poco di varietà che nella loro figura accade diversificano non poco l'imagini da essi riflesse. Per il che l'imagini che dall'istesso oggetto prodotti sono, stimare dobbiamo che [98] abbattendosi in varie figure di occhii, amassati di diverse materie, ci sortiscono refratti e per consequentemente di apparenza assai differente di quello è l'oggetto loro originario et efficiente, e con strani dislocamenti e positure.

Il che ci rende anco documento, l'osservare che li animali bruti non sono altrimente capaci della vaghezza di colori, simetria, e bellezza de' corpi. Il che stimo che da altra cagione ciò non proceda, che dalla diversa construttione del loro occhio, variando dal nostro nella configuratione, situatione, qualità d'humori, membrane, e nervi, e non già per mancamento di senso interno. La ragione che a ciò m'induce è l'advertire che il lusignolo, canoro musico della campagna, non mediocre 
that is not even possible for water, naturally more solid than this, though it is wrong of me to mention water - indeed, it would not even be possible for a crystal to do this.

- Others tried to accommodate all of the aforementioned opponents' opinions and they said that vision works through the simulacra's encounter with the heap of membranes, humours, nerves, and spirits located in the eyes. ${ }^{189}$ Thus, they thought to generously satisfy their mutual friends and were content with merely tolerating all the oppositions encountered for each of the aforementioned opinions.

I believe that human curiosity will produce other dogmata concerning the way in which vision works, because it is pushed by a natural desire always inclined more to contradictions than to novelty. Yet which of these aforementioned opinions is the truest does not really concern my proposal. The reason for this is that I did not put forth these opinions to debate them, but I want to infer from this collection of various opinions only this: regardless of whether vision happens in this way or in other ways, it is necessary [to point out] that there is a great diversity between the appearance of objects and their true reality. ${ }^{190}$ Who may deny that the representation of what is visible would dramatically change if it happened through the emission of rays as far as the object, or by these [rays] mingling with the light, or rather by the intromission of images, or by the simple presence of the object, as well as whether it was carried out in the middle of the glacial or the retinal membrane, or throughout the optic nerves, or in spirits, or in all of them clustered together?

Furthermore, an evident lesson about this distortion of appearances is provided by mirrors, which are generally made of the same matter, but even a small difference in their form may consistently diversify the images reflected in them. Hence, we should consider that images produced by the same object [98] strike different forms of eyes, which are masses of various matters. Therefore, they are reflected, and consequently have very different appearances from that of the object, as their origin and efficient, and also strange dislocations and positions.

We also learn this by observing that brute animals are not able to perceive the agreeableness of colour, symmetry, or the beauty of bodies. I think that the reason for this comes only from the different structure of their eyes, since they vary from ours in terms of configuration, position, quality of humours, membranes, and nerves, but not because of a lack of internal sense. ${ }^{191} \mathrm{I}$ am induced to this [thought] because I realised that the nightingale, the country's songbird, is endowed with great 
peritia tiene della proportione del suono, da che risultano quelle sue cantilene piene di melodia tale, che l'humani concerti appena aguagliarlo possono.

Così della tarantola abietto insetto si racconta, che sciente sia della modulatione di armonici suoni, come anco il merlo et il papagalo divengono nostri discepoli in apprendere li canti che l'insegnamo. E perché non si può negare che maggior applicazione e peritia sia necessaria nell'osservare et apprendere l'armonia de' suoni, che in giudicare la vaghezza de' colori e proportioni di membri, questi da più volgari e plebei ingegni sono osservati, quella appena da esercitati e professori dell'arte riconosciuta et appresa. Onde se per difetto di sentimenti interni e mancamento di discorso li animali sono ignari della bellezza, molto più si renderebbero inetti circa li suoni, ché nell'advertire le loro qualità è necessario più esatto e risvegliato intendimento, ma essendo li organi visivi di bruti dalli nostri grandemente diversi, ciò che non accade alli organi dell'udito, risulta che nel vedere vi sia notabile diferenza tra essi e noi, ma nell'udire mediocre similitudine e corispondentia.

E probabilmente giudicarei anco, che più esatta sia la visione de' molti animali bruti, che la nostra. Segno di ciò che [99] non si lasciano così agevolmente ingannare e fraudi della pittura, come a noi accade, né ciò ad essi per mio giudicio occorre per stupidezza, ma per la buona construttione de' loro organi visivi, non agevoli ad esser fraudati et allucinati come li nostri. E ciò mi move l'osservare che essi animali circa la distantia et intervallo delle cose, al di sopra di noi sono informati e periti, il che si argomenta da loro aggiustati salti, che quasi giammai non faliscono. E tuttavia da scorciamenti, e finte lontananze, benché da scienti pittori elaborati non si lasciano punto circonvenire, et ingannare. E se una fiatta occorse ad un uccello che da un grappo d'uva dipinta fosse colto, ciò fra li miracoli fu annoverato, dal che si raccoglie che la perfettione del loro organo li defenda da tali fallacie. Motivato io dunque da tal discorso publicai, che colui il quale a fare giuditio delle cose belle si propone, sempre con la cautela del 'così appare alla construttione del mio senso', dovrebbe ciò pronontiare, poiché il nostro occhio che l'oggetto esterno apparende, è piuttosto efficiente del bello overo difforme, che di esso recetivo e da lui impresso.

Divolgossi tal mio ragionare, et alle orecchie di Diotima si fece udire, che nell'arte lenonia o del rufianesimo che dire vogliamo

Riprensione fatta da Diotima rufiana a Socrate. alquanto di nome nella nostra città si acquistò, et io per inanzi conoscendola quanto valeva nell'introdurre e risvegliare amistà nelli animi humani, et insieme raconciliarli, procurai la sua pratica, per appren- 
expertise in the harmony of sounds, from which result its songs [that are] so full of melody that human concerts can hardly equal them. ${ }^{192}$

Likewise, it is said that the tarantula, a despicable insect, knows the modulation of harmonic sounds, and also that blackbirds and parrots may become our disciples and learn the songs that we teach them. Furthermore, one cannot deny that observing and learning the harmony of sounds requires more diligence and ability than evaluating the agreeableness of colours and the proportion of parts. Indeed, the most vulgar and plebeian intellects may observe the latter, while some very experienced people and professors of art may barely acknowledge and apprehend the former. Thus, if animals are unaware of beauty, because their internal senses are insufficient and their reason lacking, they should be even more incompetent concerning sounds, because to perceive their qualities it is necessary to have a quick and exact understanding. Well, although the visual organs of brutes are very different from ours, this cannot be said concerning the organs of hearing: indeed, while there is a remarkable difference between us and them in terms of sight, in hearing there is some similitude and correspondence.

I would probably even consider that the vision of many brute animals is more exact than ours. A proof [99] of this is that they do not allow themselves to be easily deceived by the illusions and tricks of painting, as often happens to us. In my opinion, this does not happen to them because of their stupidity, but rather because their visual organs are well-constructed, since they are not easily deceived or victims of illusions like we are. And I am inclined to [state] this through observing that animals are more informed and expert in the distance and intervals of things than we are, and this is why they almost never fail [when calculating] their well-measured jumps. They are not deceived or mislead by partial views and false distances, even when they are elaborated by expert painters. It was counted among miracles when a bird was once attracted by a painted bunch of grapes; hence, one may gather that the perfection of their organs defends them from these fallacies. Motivated by this argument, I said that anyone who propounds to judge beautiful things should always state this with a cautious "as it appears to my senses, "193 because our eyes, in apprehending external objects, are rather the efficient [cause] of the beauty or deformity [of the object] than receptive [of it] or impressed by it.

My argument spread and attracted the attention of Diotima, who had gained high esteem in our city thanks to the art of panderism, ${ }^{194}$ or procuring, as we prefer to say. Since I already knew her capacity to introduce and awaken benevolence in human souls and to reconThe panderer Diotima's reproach to Socrates. cile them together, I pursued her practice to learn from her the way 
dere da essa la maniera di maneggiare e disporre l'humane passioni, in modo che ne rissultasse quiete et unione nella civile società, stimandola a questo molto più idonea, che coloro che di ciò aeriamente ne favellano, senza mai haverne effetivamente in tal fontione essercitati. Onde Diotima, essendosi dal mio divisare risentita, in tal guisa mi rimproverò:

"Molto diverso mi riesci, o Socrate, da quello che nel mio animo di te concepiva, né giammai harei creduto che tanto ingrato verso di me dovessi riuscire, che [100] havendoti comunicato e rivelato li più reconditi arcani della mia arte, a cui incombe l'eccitar amore nel nostro genere, sedare li odii e riunire li animi nemici, dal qual apprendimento et esercitio hai acquistato tanto di stima nella tua republica, che al sommo dell'autorità sei giunto, ma tuttavia hora come sconoscente di tanto benefitio attenti di levarmi quel poco di guadagno che per mezo della mia professione giornalmente mi procaccio".

L'interrogai qual ne sia la cagione di tale sua reclamatione. Soggionse essa:

"Non parti havermi gravemente offeso, mentre che il vago e bello che tormentano gli amanti, e che per il cui conseguire ansiosamente a me ricorrendo, con larghi premii riconoscono la mia industria, che ad essi tenghi persuaso, nel proprio loro occhio se annida; e che le rose confuse con gigli dico la vaghezza di colori, e la gratia che dalle simetrie de' membri risulta, nelli proprii occhi di amanti risiedono, essendo questi opefici di quella bellezza che nelle loro amate donne falsamente stimano ritrovarsi, e che con tanto travaglio e dispendio ricercano possedere, e godere, e che l'oggetto amabile piuttosto ben aventurato che bello giudicar si deve, che incontrò in organo visivo, che con benefica qualità lo rende dell'altrui amore attrativo?”

$\mathrm{Al}$ che risposi io che molto stimavo haver ricompensato all'obligo che con essa tenivo, per la instruttione che da lei appresi circa lo praticare l'humani affetti, mentre che procurai abbattere il saper humano tanto ad amore adversario, et inimico, onde screditando quello, arrecava vigoria e forza a questo. Ma alla per fine io dal probabile discorso indotto, dal genio stimolato, e dall'oracolo comandato, non haver potuto far di meno di non palesare circa la visione quello che sentiva, ma che di ciò punto turbare non si dovesse, ché quelli fiachi animi, che ad amore sono fuori di modo proclivi e disposti, tali miei discorsi non al di sopra che cicalamenti di garrulo vecchio, e vano sofista stimati farebbero.

Restò di ciò [101] alquanto satisfatta Diotima, ché la pratica del mondo molto prudente renduta l'haveva, et io seguendo il mio principiato proponimento, dall'organo visivo al colore suo oggetto mi tras- 
to manage and arrange human passions for the peace and unity of civil society. I considered her much more skilled in this than those who only spoke about it without ever having concretely exercised this function.

Thus Diotima, offended by my examination, reproached me in this way:

"Oh Socrates, you seem to be very different than I expected you to be in my mind, and I would never have believed that you might be so ungrateful to me. [100] Indeed, I communicated and revealed to you the most hidden secrets of my art, which must arouse love in humankind, calm hatred, and bring enemy souls back together; and thanks to such learning and exercises, you have gained so much esteem in your republic as to reach the highest authority. Nevertheless, by now denying this great benefit, you are attempting to take away from me that little profit that I earn every day from my profession."

I asked her the reason for her reproach. She replied:

"Do you not realise that you have seriously offended me? As the delightful and the beautiful usually torment lovers, they normally anxiously turn to me in order to gain them, and generously reward me for my industry. Indeed, you have persuaded them that they only exist in their eyes; that roses put together with lilies - I mean the beauty of colours - and the grace resulting from symmetrical members dwell only in their eyes when they are in love. They [i.e., the eyes] are the makers of that beauty that they [i. e., the lovers] falsely believe to be found in their beloved women, whom they try to possess and enjoy with so much work and effort. Furthermore, [you have persuaded them] that the object of love must be considered lucky rather than beautiful, because it has encountered a visual organ which, through its beneficial qualities, has made it attract the love of others.”

Hence, I answered that I believed that I had rewarded the obligation that I had to her regarding the way she had instructed me in dealing with human affects while I was attempting to defeat human knowledge, as such an enemy and opponent of love: thus, by discrediting the former, I gave strength and force to the latter. However, led by the probable, incited by my genius, and guided by the Oracle, I could do no differently than to explain my opinion about the eyesight. Yet [I thought that Diotima] should not be worried about this, because those weak minds who were extremely inclined and disposed to love would consider my discourses no more than the vain chatter of a talkative man or vain sophist.

[101] Diotima, made prudent by her wide experience in the world, was very satisfied with this, and I, following my original purpose, 
Esame del colore. ferii, il qual mi s'apparì piuttosto fititio che consistente e reale. Stima il volgo di savii che li colori siano permanenti anco quando del lume sono privi, apportando esso lume piuttosto la visione alli occhi, che l'esser a colori. Ma il parere di più eruditi e sensati ingegni è, che, ritrovandosi senza dubbio alcuni colori di temporanea durata, intanto perseverando che dal lume sono irradiati come quelli che nell'aeria iride, prisme triangolari di christalli, e collo della colomba appariscono. Da ciò si può convincere che universalmente tutti li colori siano lumi riflessi, e che da certa positura e configuratione di corpuscoli fissi, e permanenti nelli corpi ove insistono siano ributati, ché se altrimente li colori fossero, non così facilmente dedurre si potrebbe la necessità che tengono del lume acciocché alli occhi appareschino. Per il che probabilmente conieturano li autori di tal parere, che nella superficie dell'oggetto si ritrovino alcuni minutissimi corpuscoli, in varie figure construtti secondo la differenza di soggetti ove insistono, che incontrati dal lume in varie guise riflettendolo, ci fanno apparire le diversità e varietà de colori.

Onde vi fu alcuno che stimò, che il nero si generasse da una minuta congerie di sferule sode con l'intersfero vacuo, dal lume incontrata. E per il contrario il bianco comporsi dalla adunanza di molti orbi vacui, e l'interstitio pieno, come appar nell'acqua ridotta spiumosa che apparentemente imbianchisce. Ma tali colori di lunga durata, da primi transitorii sono diversi, per cagione che tali corpusculi sono fissi e permanenti in loro soggetti, se però da alcuna violenza o gagliarda alteratione non siano smossi e tramutati, come aviene quando tali corpi sono lisciati et imbruniti et affatto divenuti tersi, che mirando la semplice loro superficie non vi si scorge colore alcuno se non certa [102] fiacca lucidezza e diminuto splendore, essendo contuse quelle figurine e picciolissimi corpuscoli, che concorrendo con il lume generavano tal particolar colore. Né per altra cagione la superficie di qualunque corpo colorato gagliardamente percuote il senso visivo, che per l'inequalità di esso, cagionandosi per li infranti riflessioni del lume che in tali inequalità incontra, e d'esse sono ribatutte. E l'arte distilatoria rivelatrice di più reconditi arcani della natura, ci ha insegnato la maniera di separare et estrahere tali corpuscoli che insieme con il lume sono del colore progenitori. Ma che all'occhio nostro distintamente non appariscono mentre che sono nelli loro soggetti insinuati, non ci deve annoiare, essendo alla natura più che linceo di acutissima vista dottato, benissimo esposti e patenti; ché anco li pori e fori che nel vetro over altro transparente insistono, dalla nostra vista sfugiscono, 
turned my attention from the eyesight to its object, colour. This seemed fictitious to me rather than solid or real. The mass of sages considers Examination of colours to be permanent even without light, as if light provides the eyes with sight, but not colours with being. Yet the opinion of the most erudite and reasonable wits is that there are definitely some temporary colours which endure as long as they are illuminated by light, such as those appearing in a rainbow, ${ }^{195}$ a triangular prism, ${ }^{196}$ or a dove's neck. ${ }^{197}$ One may establish from this that all colours universally are reflected light and that they are merely ejected by a certain position and configuration of fixed corpuscles, which permanently constitute all bodies. For if colours were something different, one would not easily deduce how light was necessary to make them appear to the eyes. This is probably the reason why the authors of this opinion suppose that there are some tiny corpuscles on the surfaces of objects, made in many different ways according to the various subjects where they are. These corpuscles, in encountering the light, reflect it in different ways and cause the diversity and variety of colours [that are] visible to us.

Therefore, there were some who considered the colour black to be generated by the encounter of light with a tiny congeries of small solid spheres and an empty inter-sphere. However, the white colour was [believed to be] composed of an aggregation of many empty spheres and a full interstice, as it appears in the case of water, which appears to be white once it is turned into foam. Yet these enduring colours are different from the aforementioned momentary ones. The reason for this is that these corpuscles remain lasting and permanent in their own subjects when they are not moved or upset by any violent or strong alteration. This indeed happens when these bodies are polished and darkened, and so become fully clear. Thus, when we observe their simple surfaces, we do not see any colour, but only [102] a feeble lucidity and a diminished brightness. The reason for this is that these little shapes and tiny corpuscles are damaged, and they, together with the light, [are responsible for generating] this particular colour. There is no other reason why the surface of any coloured body should strongly strike the eyesight except because of its inequality. Indeed, it [i.e., the eyesight] changes because of the fragmentation of the light reflected on these inequalities and ejected by them. Furthermore, the art of distillation, by revealing the most hidden mysteries of Nature to us, has taught us how to separate and extract these corpuscles as the progenitors, together with light, of colour. ${ }^{198}$ Yet we must not hesitate if they [i.e., colours] do not distinctly appear to our eyes once they have intruded into their subjects, because they are well-exposed and more sensitive to Nature than a lynx endowed with very sharp eyesight. The pores and holes in glass or any other transparent material cannot be perceived by our eyesight, 
ma il lume da essa natura guidato in un momento di tempo li ritrova et espeditamente li trascorre.

E per il certo un caso avenuto alli giorni passati a Calicle oltre modo mi persuase della inesistentia e vanità di cotesti colori. Occorse che essendo stato egli percosso nella fronte vicino all'occhio, mentre che dal chirurgico li fu gagliardamente premuta la ferita, riferì Calicle d'haver scorto internamente non mediocre splendore. Dal che presi ragionevole conietura, che essendo il loco ove si generò tal luce impedito in maniera, che il lume esterno non vi poteva havere ingresso, che tal apparenza di luce si generasse da certo spetiale motto di quelle membrane overo nervi, che parimente anco si muovono e risentono dalla scossa over introduttione di certa tal cosa che lume appelliamo. Onde concludevo che il lume che ci apparisce, e così anco li colori da esso generati, non tenessero in loro stessi alcuna realtà et esistentia, ma che altro non fossero che certa commozione alteratione dell'organo visivo. Et a ciechi forse accaderebbe simile accidente che a Calicle occorse, se in quelli [103] non fosse depravato tale interno istrumento che alla visione della luce serve, e che fosse mosso in quella maniera come a Calicle avenne.

Da queste ragioni, et instanze rimasi alquanto admonito, che li colori non siano altrimente fuori di noi permanenti nell'oggetti ove appariscono, ma che sortiscono dalla irradiatione del lume nella superfitie di essi oggetti, overo che forse anco fuori di noi non tengono essi né il lume alcuno essere, ma ch'altro non siano che esso motto et alteratione dell'organo visivo, come hora ho divisato. Onde li colori secondo ciò riescono prole di corpusculi che risiedono nella superfitie dell'oggetto visibile, e del lume che in essi riflette, over effetto di certa agitatione dell'organo visivo.

Non dissimile de' colori sono li suoni non durando questi se non quel tanto di tempo che persevera la colisione dell'aria che dal precedente percuotimento de' corpi risulta. Ma cessata quella non rimane vistigio alcuno dell'isvanito suono. Per il che non poeticamente pronontiò egregio poeta trattando di colori:

Virgilius. Rebus nox abtulit altra colorem.

Ma tale fu la mia disgratia - e chi lo harebbe mai conieturato? - che non poco di sdegno apportò alli oppulenti avari tal mio discorso, onde avenendomi in Critia fra li trenta tiranni il più rapace, et inhumano, e verso di me suo precettore maggiormente ingrato, in tal guisa mi assalì: 
but the light led by Nature rapidly finds them and quickly goes through them.

Certainly, what recently happened to Callicles convinced me even more of the nonexistence and vanity of these colours. ${ }^{199}$ It happened that he received a blow on his brow, next to his eye, and when the surgeon pressed hard on his injury, Callicles reported having seen a great inner brightness. I reasonably inferred from this that the place where this light was generated was obstructed in such a way that external light could not have access to it. Furthermore, this apparent light was produced by the particular motion of those membranes or nerves, because they are also moved and affected by the blows and intrusions of this thing we call light. Hence, I concluded that the light that appears to us and the colours generated by it have no reality or existence by themselves, but are only a commotion and alteration of the visual organ. The same accident that occurred to Callicles would [103] perhaps also happen to blind people, if this inner instrument, designed for seeing light, was not damaged or moved in the same way as had happened to Callicles.

From these reasons and instances, I was well-advised that colours do not permanently exist outside us in the objects where they appear, but rather result from the irradiance of light towards the surfaces of these objects. Alternatively, perhaps neither they nor light even exist outside us, but are only a motion and alteration of the visual organ, as I was considering just now. Therefore, colours turn out to be the offspring of corpuscles dwelling on the surfaces of visible objects and of the light reflecting on them, or the effect of a certain agitation of the visual organ.

Sounds are no different from colours, since they only last as long as the collision of air from an earlier percussion of bodies. Yet once that has stopped, there is no trace of the vanished sound. Thus, a distinguished poet unpoetically stated referring to colours:

Black Night has stolen from the world her hues. ${ }^{200}$

Virgil.

Yet my misfortune was such - who may have supposed it? - that my discourse produced much disdain among the wealthy misers. ${ }^{201}$ Thus, I met Critias, ${ }^{202}$ one of the cruellest and most inhuman of the thirty tyrants, and especially ungrateful to me, his preceptor. Critias assailed me in this way: 
Risposta di Socrate a

Critia.

\begin{abstract}
"Non meno che li notturni incendiarii meriti, malitioso Socrate, severissimo et essemplare castigo, poiché non sei come li ladri che si procacciano con il nocumento altrui il proprio utile. Ma tu da scelerato talento e pernicioso instinto, il danno altrui solamente procacci, havendo intrapreso con vani e cavilosi ragionamenti levare il concetto e stima allo splendore e bellezza dell'oro, vaghezza delle margherite, e scintilare delle gemme, persuadendo altrui [104] che queste siano vane apparenze e putatitie rimostranze, e che prive dal lume, e dall'icontro della visiva facoltà, si estinguono, et isvaniscono, e che l'oro e le gioie in vili carboni e tenebrosi corpi si cangiano. Del qual tuo attentato rimane non solamente offeso il privato, ma oltre modo dannificato anco il publico, divenendo di niuno pregio li tesori che nelli erarii per urgenti occasioni tiene raccolto, e tanto piư", giocosamente soggiongeva, "meriti di essere severamente castigato di tale tua sceleragine, che né con custodia de’ vigilanti guardiani, né difesa di ferrato scrigno può essere impedita”.
\end{abstract}

Onde perciò mi admoniva che retrattassi tal nocivo dogma come everssore dell'humano comercio e civile società, ché dal pregio che si ha fra li homini dell'oro e gemme riesce il mondo comunicabile, e che perciò li avari rilasciano ad altrui le cose proficue e buone, per l'acquisto delle belle ma inutili.

Al cui ragionare con filosofica licentia risposi che giammai d'avari oppressori dalle ricchezze al di sopra di selaii feci alcuna stima, ché questi benché periti siano in formare le selle, tuttavia si ritrovano affatto ignari del maneggio di cavalli, come anco di arcolaii, ché sapendo essi li archi ottimamente operare, nondimeno dell'arte del saettare non sono punto addottrinati. Il che per appunto a mio credere, accade ad essi avari, che informati appieno di tutte le maniere e modi di accumulare richezze, tuttavia della guisa de usarle e decentemente servirsene sono assolutamente sconoscenti et imperiti.

E seguii che poco mi curava dell'ingiurie et offese che da questi mi fossero intentate, perché l'avaritia opposta alla virtù, sempre quella soccombe, anzi rimane per il più abbattuta dalla propria pusilanimità e dappocagine, riuscendo l'avaritia più efficace ad impedire lo progresso alla virtù, levandole l'alimenti e commodi, che a resisterle quando si trova già adulta e di generosa resolutione armata, e che in quanto a ciò che esso mi riprendeva circa il privare l'oro del suo splendore et alle [105] gioie de loro bellezze, li replicai che in ciò non poco s'ingannava, ché anzi con tal mio dogma admoniva a loro possessori, che scarcerandoli se li restituirebbero le perdute vaghezze de' colori, che per malignità di avari con le continue tenebre erano estinte, avenendo a tali ricchezze quello che accade al corallo, che stando nell'acqua sepolto, è 
"Malicious Socrates, you deserve as strict and exemplary a punishment as a night arsonist. Indeed, you are not like a thief, who harms others in the course of looking for what is useful for himself. As you are endowed with wicked talent and pernicious instinct, you only wish to harm other people. Indeed, through vain and quibbling arguments, you have undertaken to deprive gold of its brilliance and beauty, mother of pearl of its grace, and the glittering of gems of its high consideration and esteem; you are trying to persuade [104] others that they are vain appearances and apparent manifestations, which, in the absence of light and an encounter with the visual faculty, fade and disappear, and thus gold and jewels turn into mean coal or dark bodies. Not only does your purpose offend the private [sphere], but the public [one] will also be extremely threatened, because the treasures preserved in the treasury for emergencies will become worthless." And he playfully added: "As such, you deserve to be strictly punished for your wickedness, which will be not prevented either by the custody of vigilant guardians or by the defence [ensured] by an iron chest."

Hence, he exhorted me to retract this harmful dogma as it subverted human relationships and civil society, because thanks to human beings' high esteem for gold and gems, the things of the world may be shared [among all people]; indeed, misers leave good and useful things to other people in favour of the acquisition of those which are beautiful, but useless.

With philosophical licence, I answered his argument [with the fact] that I had never considered misers, who oppress wealth, [to be] different from saddlers. Although the latter have expertise in making saddles, nevertheless they do not know how to train horses. Likewise, bowmakers know how to make excellently functioning bows, but they are not at all aware of the art of shooting an arrow. I think that the same happens to these misers, who are so well-informed about all the ways and manners to accumulate wealth, but do not have any knowledge or expertise concerning the way to make use of it or properly employ it.

Furthermore, I continued that I did not really care about their insults and offences, because avarice always succumbs when it is opposed to virtue, or rather most of the time it is defeated by its own pusillanimity and ineptitude. Avarice is more effective in preventing the progress of virtue by depriving it of nourishment and comfort than in resisting it when it is mature and well-equipped with the capacity for generously deliberating. As far as the reproach he made to me for having deprived gold of its brilliance and jewels of their beauty was concerned, [105] I replied to him that he was very wrong about this, and the reason was that my dogma was rather meant to advise their owners that they would restore the lost beauty of their colours by releasing them. Indeed, the misers' malignity had extinguished it into continual darkness: their wealth also experiences what happens to coral,

Socrates's answer to Critias. 
Esame universale circa li sensi interni. frale e vile arbuscello, ma emerso, et all'aria apparito, in consistente e non dispregiabile gemma si converte.

Rimase dal mio ragionare confuso Critia, et insino qui giunse la instituita disquisizione circa alli sensi esterni, e sebbene che infelicemente il mio attentato sortì, non perciò mi si arestò la curiosità di non più inoltrarmi in tal proponimento, lusingando me stesso che forse li sensi interni per la allianza e famigliarità che tengono con la mente si renderebbono maggiormente patenti e conoscibili. Hor dunque nel primo ingresso di tal discusione con certo trascorso universale osservai, che li sapienti che circa tali sensi si travagliarno dalli governi civili trassero la ordinatione del reggimento interno del nostro animo, havendo essi instituiti in noi li istessi magistrati che nelle republiche per il governo politico furono eretti. La qual uniformità siccome al comune delli homini sommamente arride, così per il contrario a me riuscì oltremodo sospetta di falacia, rassembrandomi ragionevole che il regimento delli homini piuttosto deve essere normato dall'originale della natura, che questa da quello ne prenda essempio.

E chi non scorge per il più la moltiplicità di tribunali appo noi non tanto fu instituito per la copia d'affari, quanto che per trattenire l'otio over satiare l'ambitione di cittadini? E la subhordinatione di magistrati per corregere li errori de' giudici over rafrenare la loro rapacità? Onde la natura immune e libera da tali difalte e depravationi, non li è necessario tali gierarchie e subgradationi di iusdicenti. Ma tornando al proposito, dalli predetti savii dunque fu [106] instituito che li sensi esterni servissero al comune regimento e governo della nostra interna republica, a guisa d'esploratori che ci informano di tutto quello che al di fuori di noi accade; il senso comune pedaneo magistrato e di prima instanza, al qual riferiscano promiscuamente li detti sensi esterni loro avisi e raguagli, riconoscendo esso, come si dirà, le diferenze di loro sensationi. L'imaginationi che sia referendaria dell'intelletto, che raccolge e construisce ciò che sciolto e sparso ritrova nel senso comune, ché essendo questo destituto di facoltà compositiva, quella insieme unisce l'imagini e le rapporta alla mente.

Alcuni aggiunssero la potenza estimativa, alla quale incombe a guisa di giudice criminale il riconoscere li odii et amori, meriti e demeriti, et altri oggetti più tosto intelligibili, che sensibili, ma che tuttavia risultano in certa maniera dalle apprensioni che nel comune insistono. $\mathrm{Fu}$ eretto parimente in noi una tale celebre cancellaria, ove sono registrate le nostre apprensioni, questa memoria è appellata, onde alcuni 
which is a small, fragile, and insignificant bush when it is underwater, but turns into a solid and considerable gem once it has surfaced.

Critias was confused by my argument. The disquisition I had instigated about the external senses reached this point and although my attempt had not succeeded, it had nevertheless not prevented my curiosity from going further with my proposal. I let myself be swayed by the idea that perhaps the internal senses would be more manifest and knowable because of the alliance and familiarity they had with the mind. Therefore, as soon as I began this new discussion, I beheld a certain universal mistake, namely that the wise men who had worked on these senses had modelled the structure of our minds' system after that of a civil government. Indeed, they have instituted in us the same magistrates that were designated for political government in the republics. Although the common people are greatly amused by this similarity, nevertheless, in my opinion, it turns out to be extremely dubious. It seemed to me to be reasonable that the behaviour of human beings should rather be ruled according to the model of Nature, not that the latter should take example from the former.

Furthermore, who does not notice that most of the many courts that we have were established not because of an abundance of business, but to preserve leisure or to satisfy the citizens' ambition? And was the subordination of magistrates [meant] to correct the judges' mistakes, namely to refrain their rapacity? For Nature, which is immune to and free from these mistakes and depravities, does not need such hierarchies or ranks of judges. However, to return to my purpose, the aforementioned wise men established that [106] the external senses are useful for the common ruling and government of our inner republic, like explorers who inform us about everything happening outside of us. Common sense [is] the judge of minor cases and the first court of appeals to whom the aforementioned external senses indiscriminately refer their advice and suggestions, where this one [i.e., common sense] acknowledges, as we will say, the differences in their sensations. The imagination is the intellect's referendary, ${ }^{203}$ gathering and arranging that which may be found disseminated and scattered in common sense; indeed, while the latter lacks a composing faculty, the former combines the images together and brings them to the mind.

Some added the estimative power [to this list], ${ }^{204}$ which, like a judge of crimes, has the task of acknowledging loves and hates, merits and demerits, and other objects which are intelligible rather than sensible, but which somehow result from common sense's apprehensions. Likewise, an extremely renowned chancery has been established inside us where all our apprehensions are recorded, and this is called the memory. Therefore, as some were not content to have only one
Universal examination of the internal senses. 
Non esser necessario moltiplicare li sensi interni. non contenti di una sola cancellaria, la distinsero in publica e secreta, la prima dedicata alle apprensioni della imaginatione, la seconda al registrarvi le apprensioni dell'intelletto. A tale potenza vi aggiunsero l'intelletto consultore maggiore, e di maestosa autorità nelli humani affari dottato, a cui sopra li altri magistrati si presta assoluta fede.

A tutti questi è sopraposta la volontà libera principessa di tutte le agende, ma per il più reggere si lascia dalli consigli di esso intelletto. A' cenni di questa si rendono ossequenti li spiriti interni, ché con prontezza e mirabile agilità scorrendo questi per tutto l'ambito del nostro corpo movono li membri, conforme li decreti di essa volontà. Fra suoi principali vassali annoverati sono l'irascibile e concupiscibile, che con efficace energia eseguiscono li suoi comandi, ma non resta però che alle fiatte movono gravi seditioni contra la loro dominante et imperatrice volontà, con soversione e sconvolgimento del stato della interna [107] republi|ca. Vi sono ultimamente li membri organici e corporali che distratti da ogni conditione d'imperio, a guisa di più vili officiali li appartiene solamente il semplice obedire, et eseguire. Bene intesa ordinanza, se l'opefice del sistema humano prendesse documento de' nostri instituti, sovente come dissi piuttosto inventati per sostenere la plenipotenza e somma autorità di più vigorosi, che a difendere l'indemnità di più deboli et imbecilli.

Ma per quello che io osservai non vi scorsi copia di emergentie et affari né diversità di negotii, né insoficientia di ministri, che apportino necessità alle numerosità di tanti tribunali, se pure non indusse tali sapienti a fingere in noi tanti e tali curiali, una certa admiratione che l'humanità tiene verso le sue proprie inventioni, ché le rassembra irregolato et enorme, tutto ciò che non si aggiusta con il nostro uso, e costume, e tanto più li fu facile introdurre in noi tali magistrati e numerosa famiglia, che senza alcuno dispendio e spesa, li manteniamo e sosteniamo.

Et oltre di ciò non sono fuori di sospetto che la mente humana, come che accortissima nelli suoi affari, sostituì tali e tanti ministri et agenti nella sua curia, per solievo e discolpa di proprii errori, e delitti, a guisa che sogliono alcuni imperanti erigere magistrati, conferirli autorità quasi regia, adoperandoli nelli più rigorose e fiere esecutioni e tirannici trattamenti, per irritare il publico odio sopra tali ministri, scaricandosene essi che pur furno del tutto primi impulssori. Onde sovente li semplici esecutori sono sacrificati al popolare sdegno e plebeo furore, restando intanto li dominanti non solamente illesi, ma acclamati giustissimi vendici delle comuni offese. 
chancery, they distinguished between a public and a secret one, the first designed for the apprehensions of the imagination and the second for recording the apprehensions of the intellect. They furthermore added the intellect to this faculty as the major adviser endowed with majestic authority within human affairs, trusted absolutely above all the other magistrates.

Above all of these is free will, the princess of all actions, although it is mostly led by the intellect's advice. The inner spirits, which flow through our whole body with promptness and admirable agility, moving each member according to the decrees of the will, are obedient to its signals. Among its main vassals are numbered the irascible and concupiscent [faculties]. They accomplish its orders with effective energy, but sometimes they also generate serious seditions against their ruler and emperor, the will, by subverting and upsetting the internal state of [107] the republic. Finally, there are the organic and bodily members, which are deprived of any possibility of dominion, and which, like the vilest officers, must simply obey and execute. If this order were well-understood, the maker of the human system would learn from our institutions, which, [however,] are often rather invented, as I have said, to support the plenipotentiary and highest authority of the strongest people instead of defending the safety of the weakest and feeblest ones.

Yet as far as I observed, I did not see any abundance of occurrences or businesses, variety of activities, or insufficiency of magistrates that could justify the necessity of the many courts. The only reason that induced the wise men to picture all these members of the court inside us was a certain admiration that humanity has for its own inventions. Indeed, it considers everything that does not conform to our purpose and custom to be irregular and outside the law, and thus it is much easier to suggest these magistrates and this large family inside us, since we maintain and sustain them without any expenditure or expense.

In addition to this, it is also suspicious that the human mind, so careful in its activities, has substituted so many ministers and agents in its court only to relieve and exonerate its own mistakes and crimes. Similarly, some rulers are used to designating magistrates and giving them almost royal authority. They use them in the cruellest and most rigorous performances and tyrannical treatments in order to arouse public hatred towards these magistrates and exculpate themselves, although they were the first to push them [to act in this way]. Therefore, often the mere executors are sacrificed to popular scorn and plebeian rage, while the rulers are not only unhurt, but are even acclaimed as the most just avengers of a common offence.
It is not necessary to increase the internal senses. 
Fiaca difesa dell'ignoranza.

Manilius Lib. 4.

Nell'istesso modo tiene machinata essa mente humana di riversciare sopra altrui le proprie colpe e difalte, ché perciò si fornì e provide di copia di agenti et assessori, per incaricar questi e liberare se stessa dalle calunnie che per cagione delle sue deliquenze le potessero seguire. Onde peccando essa, rimangono [108] da lei accusati li sensi come fallaci testimonii, il senso comune pigro et inetto, la imaginatione menzognera et ingannatrice, l'estimativa fantastica e chimerica, testarecia et ostinata la volontà, indomito e feroce l'irascibile, dissoluto e sfrenato il concupiscibile, vaganti, et incapaci di intendimento li spiriti, materiali e ponderosi li membri. Ma che essa mente sempre retta e sincera nelli suoi giudicii riesce, onde seguisca ciò che si voglia, non le mancano subterfugi e scapatoii, da scansare le censure, e ribattere le colpe che a sé veramente appartengono, e che tuttavia essa sugerisce la prima scossa al motto, l'impulso all'esecutioni, sì del bene come del male.

Et a tal segno arrivò la sua solertia, che quando essa manifestamente è nelli misfatti colta, e che ad altri regettarli non può all'asilo e franchigia dell'ignoranza ricorre, e si ricovra per riparo de' sue difalte, quasi che questa sufficientemente difendere la potesse di qualunque delitto che le fosse imputato. Onde se per il contrario musico over pittore nella loro professione per ignoranza errassero, sono ispediti, et inescusabili, ma se volontariamente deviano dalli precetti dell'arte, punto non discapitano della loro stima, e reputatione. Ma l'intelletto per inscitia nelli morali affari dal retto deviando, riesce discolpato et innocente:

Nec tamen haec ratio facinus defendere pergit
Virtutemve suis fraudare in premia donis
Nam neque mortiferas quisque minus oderit herbas
Quod non arbitrio veniunt, sed semine certo
Gratia nec levior tribuetur dulcibus escis
Quod natura dedit fruges, non ulla voluntas
Sic hominum menti tanto sit gloria maior
Quod coelo gaudente venit, rursusque nocentes
Oderimus magis in poenam culpamque creatos.

Ma havendo io tutto ciò osservato, da quindi presi occasione di sempre intonare nell'orecchie delli amici, contra il [109] co|mune parere, che dall'intelletto dipende in maggior parte sì il bene come il male, publicando io che le virtù morali mere scientie, e li vitii ignoranze siano. Onde Medea come forsenata e di giuditio depravato, falsamente per sua difesa pronontiò: 
Likewise, the human mind has a strategy for making all its faults and mistakes fall on others: thus, it has supplied and provided itself with many agents and councillors in order to free itself from any calumny which might follow because of its delinquencies. Therefore, when it sins, [108] it accuses the senses of being untrustworthy witnesses, common sense of being lazy and inept, the imagination of being lying and deceitful, the estimative [faculty of being] fantastic and chimerical, the will [of being] stubborn and obstinate, the irascible [faculty of being] indomitable and fierce, the concupiscent [faculty of being] dissolute and uncontrolled, the spirits [of] wandering and lacking understanding, and the members [of being] material and heavy. Therefore, the mind will always result as honest and sincere in its judgments, because whatever it pursues, it does not avoid subterfuges or loopholes in order to avoid censure or deny the faults which actually belong to it. Nevertheless, it provides the first thrust to motion, the impulse to carry out as many good things as evil ones.

Furthermore, it is so diligent that when it is manifestly caught committing crimes and cannot place the blame on others, it appeals to the aid and exemption of ignorance, which shelters it from its mistakes as though it might sufficiently defend it from any crime charged to it. For, if a musician or a painter were mistaken through ignorance, they would be doomed and inexcusable, but if they voluntarily diverted from the rules of art, they would not harm their esteem or reputation. Yet if the intellect strays from the path because of ignorance of moral issues, it turns out to be excused and innocent:

\footnotetext{
Not that this reasoning goes so far

As to defend crime or deprive virtue of the gifts that are its reward.

For no one will hate poisonous plants the less because they grow

From their appointed seed and not by their own choice, nor will

Tasty food find less favour because the crops are nature's bounty and

Not given us by any decision of their own. Let man's merits,

Therefore, possess glory all the greater, seeing that they owe their

Excellence to heaven; and, again, let us hate the wicked all the

More, because they were born for guilt and punishment. ${ }^{205}$
}

Yet after having considered all of this, I then took the chance to speak constantly in my friends' ears against the common opinion [109] that both good and evil depend mostly on the intellect. I said that moral virtues were mere sciences and that vices were products of ignorance. Therefore Medea, ${ }^{206}$ mad and corrupted in her judgment, in order to defend herself, falsely stated:
The weak defence given by ignorance.

Manilius bk. 4. 
Esame di sensi interni in particolare.
Sed trahit invitam, nova vis, aliud cupido

Ovidio. Mens aliud suadet, video meliora proboque, sed peiora sequor.

Ma essa medesima prima di ciò riconoscendosi insana di mente disse:

Excute virgineo conceptas pectore flamma

Si potes infelix, si possem sanior essem.

Ma posto da banda tal preludio universale, circa li interni sensi, hormai l'opportunità mi chiama a dimostrarvi in particolare la insofficientia di questa tale chimerica e superflua curia, da comune de savii in noi instituita. Primieramente mi se affaciò il senso comune, ritrovato da sapienti per l'esercitio di due fontioni a quali riescono inhabili li esterni sensi affatto materiali, et inetti a qualunque attione, soggetti solamente al patire, et a ricevere l'esterne impressioni disposti.

Primo officio dunque che a tal senso comune fu attribuito è l'apprendere la diversità che verte tra le sensationi che da differenti sensi li pervengono, dico fra l'apprendimento del colore, da quello del suono, sapore e simili, non essendo il senso esterno ad altro idoneo che all'apprendere il semplice suo proprio oggetto, cioè l'organo visivo del colore, l'udito del suono, e così li altri. Onde fu detto che il senso comune fosse come centro di circolo, che essendo uno, ad esso concorrono infinite linee, che dalla circonferenza si l'inviano, così il comune ricevendo in sé l'apprensione di cinque sensi, riconosce le loro diversità.

Ma internandomi alquanto in considerare tal esercitio al senso comune attribuito, mi si apparirno non lievi difficoltà. In primo loco mi s'appresentò che cadauno da sensi [110] este|riori, possiede un organo proprio affatto diverso, di quello tengono li altri sensi, con il quale apprende li oggetti che se li incontrano, et appartengono, onde perciò qualunque d'essi riesce inhabile et impotente ad esercitare la fontione dell'altro. Da ciò presi argomento che impossibile sia il ritrovarsi in noi tal senso comune, poiché s'egli tiene organo simile ad uno di essi sensi, li conviene rinontiare il nome di comune, e sortisce senso particolare e perciò di egual fontione a cui è simile.

Ma s'è construtto e amassato di tutti li organi che a sensi esterni servono, oltre che ciò sia falsissimo, non apparendo tal cosa nella anatomica inspetione, ne seguirebbe anco di più, che le sue apprensioni fossero oltremodo diverse e varie di quelle che cadauno di sensi 
But some strange power draws me on against my will.

Desire persuades me one way, reason another. I see the better and

Approve it, but I follow the worse. ${ }^{207}$

Ovid.

However, before acknowledging her insanity, she said:

Come, thrust from your maiden breast these flames that you

Feel, if you can, unhappy girl. Ah, if I could, I should be more

Myself. ${ }^{208}$

Yet leaving aside this universal introduction, regarding the internal senses, I now have the opportunity to show you the insufficiency of this chimeric and unnecessary court in detail, which most of the sages have conceived in us. Firstly, common sense ${ }^{209}$ came forward, [which was] discovered by wise men thanks to the exercise of two functions that cannot be carried out by the external senses because they are material. Indeed, they are inept in all action, as they are only disposed to passively undergo and receive external impressions.

The first function attributed to this common sense was the apprehension of the diversity of sensations coming from the different senses; I mean from the apprehension of colour, sound, flavour, and the like. The external senses can indeed only apprehend their own simple objects, namely colour through the visual organ, sound through hearing, and so on for the others. Therefore, they said that common sense was like the centre of a circle, which is one alone and on which infinite lines [which may be] drawn from the circumference converge. ${ }^{210}$ Indeed, common sense, on receiving the apprehensions of the five senses into itself, can acknowledge the differences between them.

However, when I went deeper in considering the activities attributed to common sense, I encountered great difficulties. The first was that each of the exterior senses [110] has its own organ which differs from that of the other senses, and through this, each of them apprehends the objects that it meets or in which it is interested; for this reason, each of them is inept at and incapable of performing the function of another. From this, I took the argument that this common sense cannot be found inside us, because if it has an organ like one of the other senses, it must renounce being called common, for it is rather a particular sense and thus [endowed] with the same function as the one which it resembles.

However, if it was a construction and combination of all the organs used by the external senses, it would not only be a great falsehood - since it does not appear in the anatomical examinations ${ }^{211}$ but it would also follow that its apprehensions would be extremely varied and different from those affecting each sense. Indeed, while

Particular examination of the internal senses. 
risente, essendo questo di un organo semplice dottato e quello, dico il comune, di una congerie, e mescolanza di moltiplicità d'instrumenti construtto. Ma se di qualunque d'organi di sensi esterni egli è privo, tanto meno riesce incapace d'apprendere né tutte né qualunque delle sensationi da esterni già apprese. Onde dovendo egli essere constituito in una delle antedette maniere, riesce insuficiente ad apprendere le sensationi di tutti li sensi esterni, e per consequenza non si trova idoneo a riconoscere le loro diferenze e diversità, essendo impossibile riconoscere la diferenza di cui si trova ignoto et inappreso.

Per altra via parimente mi si mostrò la sua invalidata circa tale recognitione, non sapendo io discernere in qual modo s'eseguisce tal giuditio circa le diferenze delle esterne sensationi, non mi rassembrando convenevole, come già dissi, che il simile giudichi il simile, non tenendo l'uno sopra l'altro facoltà e prerogativa di giuridittione, e tanto sarebbe come l'admettere che uno di se stesso fosse giudice. Onde se il senso comune è simile all'esterno riesce inetto in giudicare le sue diferenze, ma se dissimile le constituimo, non potrà giamai il comune tenire in sé apprensione simile a quella dell'esterno a sé diverso, e vario. $\mathrm{E}$ [111] per|ciò non restando appieno informato del risentimento di quello, li è parimente prohibito il pronontiare retto giuditio e sincera sentenza circa le diversità dell'esterne sensationi.

Alli antedetti intoppi vi si aggiunse altro attraversamento, ché giamai non mi poteva formalizare in qual modo il senso comune potesse effetuare tal giuditio circa la diversità delle sensationi, parendomi che né come un sol giudice, né come in molti diviso potesse ciò eseguire. Perché se egli è semplice et indiviso, in che maniera può nell'istesso instante di tempo apprendere due sensationi diverse? Ché giamai giudice alcuno nel medesimo momento ascoltò duoi litiganti che non confondesse il suo giuditio. Ma se non come uno ma distinto in più portioni si impiega all'osservatione di tali sensationi, riesce parimente impossibile il pronontiarne retta sentenza, siccome accaderebbe a duoi giudici, che caduno di essi separatamente havesse udito le ragioni d'uno di contravertenti. Restaci solamente per autenticare tal giuditio il dire, che il senso comune essendo uno indivisibile, in diversi instanti di tempo apprenda tali sensationi, e doppo ne formi il giuditio delle loro diferenze. Ma tal scansatoio poco giova, ricadendo noi nelle antedette ambagie, riuscendo nell'istesso modo assordo l'apprendere in diversi tempi diferenti oggetti, come che se doi giudici in disparte giudicassero doi litiganti, non essendo diferente la diversità di 
the latter is endowed with a simple organ, the former - I mean the common one - is composed of a congeries and mixture of multiple instruments. Yet if it were lacking any of the external sense organs, still less would it be able to apprehend any or all of the sensations that had already been perceived by the external [senses]. Thus, since it must be constituted in one of the aforementioned manners, it turns out to be insufficient to apprehend the sensations of all the external senses. And consequently, it will not be capable of acknowledging their differences and diversities, since it cannot acknowledge a difference whereof it is unaware and has no knowledge.

Likewise, its incapacity in this acknowledgement has been shown to me in another way, as I did not know how to discern how the judgment of the differences between the external sensations works. Indeed, I did not find it plausible - as I said - that the similar judges the similar, ${ }^{212}$ since none of them has any faculty or prerogative of jurisdiction over the others. This would even lead us to accept that one was the judge of oneself. Therefore, if common sense was like the external [senses], it would turn out to be unable to judge its own differences. However, if we supposed that common [sense] was dissimilar [to the other senses], it would be unable to have apprehensions like those of the external senses, because they are unlike and different from it. Thus, [111] as it is not well-informed about the affections of the latter [i. e., the external senses], it is not permitted to give the diversities of the external sensations a correct judgment or sincere sentence.

I encountered another difficulty in addition to the aforementioned obstacles: I could not conceive how common sense could express a judgment concerning the diversity of sensations, as it seemed to me to be unable to do this either as a single judge or divided into many. If it was simple and undivided, how could it apprehend two different sensations at the same time? No judge has ever listened to two litigants at the same time without confusing his judgment. Yet if it pursued the observation of these sensations not as a single person, but as [if it were] divided into multiple parts, it would likewise be impossible to give the correct sentence, as would be the case for two judges if each of them had separately heard the reasoning of one of the litigants. In order to validate this judgment, we may only say that as common sense is one and indivisible, it apprehends these sensations in different moments and then forms a judgment on their differences. Yet this deflection does not benefit us, because we encounter the aforementioned difficulties; namely it turns out to be equally absurd that we may apprehend different objects at different moments, as if two judges were separately judging two litigants. There would be no discrepancy between the different 
Antistene pretende scioglier il dubbio motivato contra il senso comune.

Regetta Socrate l'evasione di Antistene. tempi all'istesso giudice applicato a diversi oggetti, che se fossero doi separati che nel medesimo instante apprendessero cose varie.

Ma mentre che tal oppositione fu da me motivata circa il senso comune, e che gravemente mi molestava, poiché non solamente sturbava ciò che atteniva al riconoscimento di esso senso comune, ma offendeva qualunque altra conferenza che dal nostro discorso fosse attentata, non restando perciò più loco all'apprendimento di alcuna contrarietà, similitudine, diferenza, proportione, maggioranza, egualità, e minorità, e tutto ciò che [112] al genere relativo appartenga, portione sì grande dell'intelligibile, per evitare tale difficoltà accorsemi Antistene, mio famigliar amico, e stimò rincorarmi con dire, che non m'isgomentassi da tale benché in apparenza importante difficoltà, che agevolmente si potrebbe evitare, e che sebbene fosse indubbitabile che nell'istesso instante di tempo da un solo apprendente non si potesse advertire et osservare cose diverse, siccome riesce anco impossibile che nel medesimo momento l'istesso marmo ricevesse in sé la figura di Ercole e di Bacco, nondimeno succedendo immediatamente nel senso comune l'apprensioni di tali diverse sensationi, vale tanto come che se nel medesimo tempo l'occorsero, avenendoli a guisa di fiaccola di fuoco che ragirata, una compita e perfetta circonferenza ci rassembra.

$\mathrm{Al}$ che mi opposi con dirli, che non posso se non comendare il zelo che tiene verso l'humano sapere, procurando sfugire sì importante ostacolo, che impedisce lo progresso a qualunque speculatione che circa la conferenza delle cose accade, per il che rimarebbe per tal attraversamento la nostra mente come che legata et immobile circa le sue fontioni, ma che tuttavia non rimango di meravigliarmi che l'affetto che tiene verso la sapienza lo rendesse tanto immemore et oblivioso di suoi proprii dogmi, che se il genio non mi faliva, transmessi alle posterità, lo renderanno illustre e celebre alla ventura gente.

Risposemi:

"Conviene che io ti confessa la propria tardità ché anco da te eccitato, non mi soviene a qual di miei dogmi il tuo ragionare acenna".

Et io ad esso in tal guisa li dissi:

"Ricordare dunque ti devi, che fra tuoi famosi decreti dal volgo paradossi appellati, vi si annovera anco quello che difende tutti li peccati esser eguali, e dell'istesso peso, poiché tanto trapassa il segno quello che un ditto fuori di meta si ritrova, quanto colui che per molte parasanghe si discosta. Onde al nostro pro- 
moments in which a single judge would judge different objects and two separate [judges] apprehending various things at the same time.

Yet this objection that I expounded against common sense was seriously annoying me, because it not only prevented us from acknowledging this common sense, but also impeded any other comparison attempted by our discourse. Indeed, there was no space left to apprehend any opposition, similarity, difference, proportion, superiority, equality, or inferiority, and everything belonged [112] to the category of relative, ${ }^{213}$ which is such a considerable component of the intelligible. In order to avoid this difficulty, Antisthenes, ${ }^{214}$ a close friend of mine, came to help me. He thought to reassure me by saying that I must not be dismayed by this difficulty, even if it was apparently important, because it could easily be avoided. It is evident that one person apprehending alone cannot perceive or observe different things at once, just as it is also impossible that the same [block of] marble may simultaneously receive both the image of Hercules and that of Bacchus. Nevertheless, for common sense, the apprehension of these different sensations happens so immediately that it appears as if they are occurring at the same time, like a rotating torch that appears to have accomplished a perfect circumference.

Then, I objected to this by saying that I could only praise him for being a zealous [proponent of] human knowledge, as he was trying to evade such an important obstacle encountered in the comparison of things that prevents the development of any speculation. Because of this difficulty, it would be as though our minds were tied and motionless in respect of their functions. Nevertheless, I could only be astounded that his love of knowledge had made him so forgetful and oblivious towards his own dogmata, which - if my genius was not mistaken - would make him illustrious and renowned to future generations when passed on to posterity.

He answered me:

"I must confess to you that I have a slow mind, because despite being your spur, I cannot remember to which of my dogmata you are referring in your argument.”

And I replied to him in the following way:

"You must remember that among your famous assertions, called 'paradoxes' by the common people, there is also that which states that all sins are the same and carry the same weight, ${ }^{215}$ because both one who only departs from the line by an inch and one who departs from it by several parasangs are overstepping the mark. ${ }^{216}$ Thus in this respect, I will tell you that whether the sensations are carried
Antisthenes supposes to leave no doubt concerning the sense.

Socrates refutes Antisthenes's deflection. 
Secondo offitio del senso comune. posito dicoti che quando le sensationi in diversi tempi dal senso comune overo d'altro apprensivo, [113] sono conseguite, poco vale che immediatamente l'una all'altra succede, siccome circa li peccati parimente tieni affermato, essendo assolutamente diversa l'identità, dalla immediate successione, e la transmutatione sostantiale conforme la volgare opinione in un istante senza intermedio di tempo accade, e così la luce alle tenebre succede, benché tanto diverse siano una dell'altra. Per il che, amico Antistene, riesce hormai vana cotesta tua evasione, e restiamo come prima hesitanti circa le conferenze dal senso comune e d'altre facoltà interne praticate".

Non replicò altro Antistene e da me cogitabondo si dipartì. Ma né anco l'esempio del centro già addotto punto mi acquietò l'animo, essendo non meno esso centro, che il senso comune implicato da inestricabili et insolubili ambagie: il ponto indivisibile non può esser d'alcuno tocato, essendo egli l'istessa estremità che con il tangente uno riesce, tantomeno apprendere si può il contatto d'infinite linee da diversi lati ad esso centro inviati. Per il che, lasciandolo ne suoi inviluppi involto, a sciolgere l'altrui nodi non conviene chiamarlo et affaticarlo.

All'antedetta primiera fontione del senso comune vi fu aggionto altro officio, e questo fu: che apprendendo l'organo visivo solamente il semplice colore, il senso comune vi aggiunge l'accorgimento della sensatione che in noi si eseguisce, osservando egli certa tal passione che l'incontro del sensibile nel sensitivo cagiona, al che apprendere non si trova bastevole l'esterno, mancando egli di facoltà reflessiva idonea a far regresso sopra al suo proprio apprendimento.

A confessar il vero, alquanto di tempo fui oltremodo fautore di tal fontione attribuita al senso comune, siccome nel Carmide di Platone $\mathrm{fu}$ da egli riferito. Ma poiché stimolato dal genio fui indotto a risaggiare li miei dogmi, e di nuovo scandalgiarmi, circa ciò mi si affrontò il dubbio, che se al senso comune appartiene il riconoscere la passione et il resentimento di ciò che già apprese [114] l'esterno senso, altro ciò non sarebbe che se Clinia fosse da Aristarco battuto, e stafillato, e che di ciò se ne risentisse Agatone. Ma se dire vogliamo che il senso comune apprende il colore, et anco la passione, come facoltà apprensiva dell'altrui incontro, e riflessiva sopra la propria passione, riuscirebbe la sua apprensione molto diversa da quella del senso esterno, essendo esso comune di tanta diferente conditione, e qualità, e perciò non idoneo a giudicar le diferenze delle sensationi esterne. Oltre che non apprenderebbe se non le proprie sensationi, non di esterni. 
out in different moments by common sense or by another sense, [113] it is not important that one immediately follows the other, as you similarly stated about sins. Indeed, the identity is completely different from the immediate sequence, and according to common opinion, substantial transmutation happens in a single moment without an interval of time. Likewise, the light follows the darkness, although they are so different from each other. Therefore, dear Antisthenes, your deflection turns out to be vain, and we are hesitant, as before, about comparisons performed both by common sense and by other internal faculties."

Antisthenes did not reply and, pensive, he took leave of me. However, my mind was not even appeased by the aforementioned example of the centre, since this centre, like common sense, was implicated in entangled and insoluble difficulties. An indivisible point cannot be touched by anyone, because it is like an extremity that becomes one with the tangent; least of all may one apprehend contact between infinite lines sent from different sides to the centre. Hence, in leaving it [i.e., common sense] to be so enveloped in its difficulties, I found not useful to appeal to it [i.e., common sense] and tire it in order to untie those knots made by others.

To the aforementioned first function of common sense, another task was added, and this was that since the visual organ apprehends only simple colour, common sense adds the awareness of the sensation occurring in us. It observes a specific passion caused by the encounter between the sensible and the sensitive, while the external [senses] are not sufficient to apprehend it because they lack the reflexive faculty appropriate to return to their own apprehensions.

Admittedly, for a long time, I was a supporter of this function attributed to common sense, as was described in Plato's Charmides. Yet incited by [my] genius, I was induced to review my dogmata and to scrutinise myself once again. In this respect, I was struck by the following doubt: if common sense can acknowledge the passion and affection of what has already been apprehended by [114] the external senses, it would merely be as if Cleinias ${ }^{217}$ had been defeated and flagellated by Aristarchus, ${ }^{218}$ but then Agathon ${ }^{219}$ was affected by it. However, if we want to say that common sense apprehends colour and also passion namely as if it was an apprehensive faculty towards others and a reflexive [faculty] towards its own passion - its apprehension would turn out to be very different from that of the external senses. Indeed, common [sense] is of so different a condition and quality [from the external senses] that it is thus unable to judge the differences between the external senses. Moreover, it would only apprehend its own sensations and not those of the external [senses].

Second function of common sense. 
A ciò se aggiunge, che intopparebbe in quell'inconveniente tante volte da me replicato, di concedere sentire del sentire, non meno dissonante che admettere vedere il vedere, udire l'udire, e moversi il motto. Ma quello che oltre modo mi annoiava admettendo tal senso comune, $\mathrm{fu}$ che giammai potei riconoscere il loco spetiale della sua dimora, e residenza, benché da suoi partigiani fosse curiosamente indagato.

- Alcuni stimano che la sua stanza sia internamente fra li occhi.

- Altri fra le membrane del celabro.

- Altri lo constituirno in uno delli ventricoli dell'istesso celabro.

- Altri nel cuore lo sequestrarno.

- Et altri in tutto l'ambito del corpo li concessero larga habitatione.

E havendo cadauno delli autori di detti pareri addotte valide instanze alla sua particolare opinione, io non volendo ad alcuno di essi con la mia assertione pregiudicare, con cautelosa neutralità, giudicai che in niun loco del nostro corpo si ritrovasse, stimandolo putatitio e vano.

Dalla disquisitione di questo primiero magistrato mi sono con-

Esame circa l'imaginatione.

Prima espositione circa l’imaginatione. dotto al tribunale della imaginatione, facoltà celebre non solamente per li suoi fantastichi ritrovamenti, e falacie, ma per esser acclamata feconda madre d'egregie dottrine e professioni. Da questa scaturì la poesia, nobile ristoro del nostro animo, e destra riformatrice di costumi, quando decentemente è usata. Parimente è lodata l'imaginatione, come ottima maestra dell'arte oratoria, timoniera della republica, [115] e moderatrice di nostri affetti, né sdegna la detta di riconoscere per sua legitima prole la pittura, e scultura, della natura imitatrici et emulatrici. A questa potenza imaginativa parimente fu attribuito che a guisa d'ape raccolga et amassi quello che diviso e sciolto ritrova nel senso comune e decentemente poi, con benigna qualità condendo e migliorandolo, all'intelletto lo rappresenta e riferisce.

Ma inanzi che io disquirisca le sue fontioni, stimai necessario indagare ciò che sia. Primieramente persuaso dal significato del suo nome giudicai, che a guisa di mollissima cera fosse pronta a ricever l'imagini che per via di sensi esterni le derivano. Ma contra tal suposito insurgevano grandissimi ostacoli, e repugnanti alla conditione del spirito, ché tale comunemente si stima il soggetto di tal facoltà, che potesse raffigurarsi in tali imagini, ritrovandosi egli di conditione oltre modo tenue, e lubrica. E che se alla acqua di natura molto più crassa e consistente, non lece né anco per un istante conservare in sé alcuna 
In addition to this, it would end up with that inconvenience that I have already repeated many times; namely to permit perceiving perception, which is no less discordant than to admit to seeing sight, hearing hearing, and moving motion. Yet what was really annoying me concerning this common sense was that I could never identify the special place where it lives and dwells, although it had been inquisitively investigated by its proponents:

- Some considered that it was located internally, between the eyes;

- Others among the membranes of the brain;

- Others placed it in one of its [the brain's] ventricles; ${ }^{220}$

- Others secluded it in the heart; ${ }^{221}$

- Still others accepted that it dwelled comfortably throughout the whole body.

Furthermore, since each of the authors of the aforementioned opinions had put forth valid instances for each individual opinion, I did not want to jeopardise any of them with my assertion; therefore, with careful neutrality, I considered common sense to be nowhere in our body, since it is presumed and vain.

From the disquisition of this first magistrate, I came to the court of the imagination, a faculty renowned not only for its wonderful discoveries and falsities, but also for being acclaimed as a fertile mother of distinguished doctrines and statements. From it arose poetry, as a noble relief for our minds and a skilful reformer of our customs, when it is appropriately used. The imagination is equally commended as a great master of the oratorical art, a helmsman of the republic, [115] and a moderator of our affects. The aforementioned one [i.e., the imagination] does not refuse to acknowledge painting and sculpture, imitators and emulators of Nature, as its own legitimate offspring. Likewise, this imaginative power was attributed the bee-like ability to collect and cluster together what is still divided and unconnected in common sense. Then, after having properly spiced and improved it, it presents and refers it to the intellect. ${ }^{222}$

Yet before discoursing on its [i.e., the imagination's] functions, I considered it necessary to investigate what it was. Firstly, persuaded by the meaning of its name, I thought that it was disposed to receive images by means of the external senses, like a very soft wax. ${ }^{223}$ Yet great obstacles and oppositions to the condition of the spirit - which is commonly considered [to be] the subject of this faculty and to have such a nature that may be represented in these images, as it is of a very feeble and slippery condition - were raised against this supposition. Furthermore, I thought that if water, much thicker and more solid [than the spirit], was not permitted to maintain any

Examination of the imagination.

First exposition concerning the imagination. 
apparenza di simulacro che le sia impresso, tantomeno ciò al spirito è permesso.

Ma anco quando questo li fosse conceduto, mi riusciva incomprensibile che varie e quasi infinite imagini in sì poco di spirito tanto aggiustamente, senza che punto l'una l'altra diformi, vi potessero fare giusta impressione. Oltre di ciò, repugna ad ogni retto discorso che li simulacri visibili insino alli recessi di essa imaginativa arivino senza punto guastare e depravarsi, e massime dovendo passare per angustissimi meati quanti sono l'invisibili cavità di nervi optici. Di più se a guisa di pittura in tella, sono nella imaginatione rafigurate tali apprensioni, essendo quelli penetrali di lume privi, in che maniera si possono apprendere e riconoscere? E tanto più se il lume come fu detto, è di colori l'essentiale fondamento?

Ma oltre di ciò, se dicessimo che nell'imaginatione vi fossero simulacri corporalmente impressi, accaderebbe che le prominentie dell'oggetto in esse [116] sortissero cavità, come fu advertito da Critone circa il senso della vista, onde diverse sarebbono le apprensioni dalla constitutione e realtà de' oggetti esterni. Oltre che non saprei formalizarmi in quel modo si possano dall'intelletto spirituale et immateriale apprendere tali imagini esistenti nella imaginatione, essendo esse construtte di risalti e profondità.

Né anco si può evadere tal instanza con dire che la imaginatione, a guisa di specchio, non ricevendo in sé l'immagini le riflette e ribatte all'intelletto, perciò che ripugna ciò alla natura e conditione del spirito soggetto senza dubbio della imaginatione, non essendo esso corpo duro e terso a cui solamente è conceduto tale riflessione et eiaculatione, oltre che nulla operarebbe la facultà imaginativa circa li simulacri, ma tali quali li ricevesse da sensi li rifleterebbe all'intelletto.

Ma di più, se per modo di rapresentatione di simulacri eseguisce la imaginatione le sue fontioni, in qual maniera li odori, sapori, e suoni per mezo di essa imaginatione ci appariscono e si fanno sentire? In qual guisa l'imagine, che solamente alla facultà visibile overo tangente appartiene, ci può dimostrare ciò che in semplice alteratione, come li altri sensibili, consiste? Ma quello che affatto espulsa tale espositione è, che il sentimento che a noi veramente appartiene è affatto distinto dalla imagine, ché se altrimente fosse, il marmo scolpito, la cera impressa, e la tella dipinta sarebbero di sentimento dottati.

Per il che conviene piuttosto dire che quello che si apprende, sia

Secondo modo dell'imaginatione. certa comottione che in noi sentiamo, che imagine impressa et affigurata, ché perciò capitai a giudicare, che tali apprensioni che attribuirno alla fantasia siano comotioni di nostri interni spiriti, causate dall'impulso e scossa ch'i sensi esterni hanno da oggetti receputo che insino 
appearance of the simulacrum impressed on it for even a moment, much less was this permitted to the spirit.

However, even if it was permitted, I could not understand how such different and almost infinite images could impress themselves so correctly on such a small amount of spirit without deforming one another. In addition to this, every correct discourse would abhor that visible simulacra could reach the recesses of this imagination without changing or deteriorating themselves, still more since they would have to go through the very narrow meanders of the invisible caves of optic nerves. Furthermore, if these apprehensions were pictured in the imagination like a painted canvas, since those inner parts were lacking in light, how could we apprehend or acknowledge them? All the more so if light, as you said, was the essential condition of colours?

Yet in addition to this, if we assumed that simulacra are bodily impressed in the imagination, it would be the case that the reliefs of the objects in them would turn out [116] to be cavities. This was already noted by Crito concerning the eyesight; ${ }^{224}$ therefore, the apprehensions would differ from the constitution and reality of external objects. Besides, I would not be able to conceive how the images existing in the imagination could be apprehended by the spiritual and immaterial intellect, since they are formed of relief and depth.

It would not even be possible to evade this instance by saying that the imagination, like a mirror, does not receive the images into itself, but reflects and returns them to the intellect. This opposes the nature and condition of the spirit, a certain subject of the imagination, because it is not a solid polished body to which only this reflecting and ejecting [of images] is granted. Furthermore, the imaginative faculty would not work on the simulacra, but would reflect them to the intellect as it received them from the senses.

However, if the imagination carries out its functions by representing the simulacra, how do smells, flavours, and sounds appear to us and how do we perceive them by means of the imagination? If the image belongs only to the visible faculty or the sense of touch, how may it demonstrate to us that it consists in a simple alteration, like the other sensibles? Yet what indeed refutes this exposition is that the sensory faculty, which truly belongs to us, is distinct from the image. If it was otherwise, then sculpted marble, impressed wax, and painted canvases would be endowed with sensory faculties.

Hence, we should rather say that what is apprehended is a specific alteration perceived inside us and not an impressed or pictured image. ${ }^{225}$ For this reason, I began to think that these apprehensions that we were Second manner of the imagination. used to attributing to fantasy were alterations of our internal spirits, caused by impulses and blows received from objects via the external 
Terzo modo dell'imaginatione. ad essa imaginativa arrivano, a guisa di tesa corda che commossa da un capo, tremola e vibra anco nell'altro estremo, et a guisa di acqua che se vi fosse pietra caduta, si produrebbero in essa molte circolazioni per [117] distante intervallo.

Mi piaceva al principio questa seconda esplicatione, rassembrandomi in apparenza molto avenente al proposito, nondimeno in quanto aspettava alla certezza che tenimo di oggetti, et informatione delle loro reali conditioni, non mi riuscì al proposito e di mia compita satisfatione. E non dipartendomi punto dalli essempii addotti, siccome la corda può essere scossa da infiniti impulsori di diversa conditione, e le circolationi dell'acqua da varii agitanti di diferenti qualità, così anco parimente può avenire al senso interno che le sue agitationi da promottori di conditione affatto diversissima siano cagionati, benché l'apparisce sempre l'istessa comotione.

Oltre di che riesce tal agitatione inetta a significarci la realtà vera dell'oggetto non essendo la cagion d'essa propria e peculiare dell'agitante e motore, né di lui cosa interna et essentiale come né anco la comotione penetrante nell'agitato e comosso, come che divisando, della causa efficiente fu da Gorgia dimostrato. Onde per ciò riparare, alla alteratione feci ricorso, conieturando che lo spirito interno incontrando nell'oggetto, over imagine da esso mandatali, internamente si altera e ciò esser il resentimento che in noi apprendiamo. Ma havendo sopra ciò alquanto ruminato, parevami non isfugire l'antedetta difficoltà, ricapitando di novo all'istesso assordo, potendosi anco parimente nel medesimo modo alterare lo spirito da diversi alteranti, con tutto che la sensatione fosse simile et uniforme.

Ma oltre di ciò, qual assomigliatione e corispondentia può esservi tra l'oggetto stabile, e l'alteratione flussibile e fugitiva? Tra il permanente per sé stante, et il sentimento privo in se medesimo di essere, e che d'altrui lo richiede e mendica? Il dolore e piacere sono le principali alterationi che ci occorrono, ma in noi solamente circonscritte e terminate né in modo alcuno rapresentative di oggetti esterni, non possedendo questi in sé né dolore né piacere. Per il che, se il nero, [118] e bianco, il dolce et amaro, alterationi sono, non al di sopra del dolore e piacere stimarei che ci rappresentassero il vero visaggio di esterni oggetti.

Ma di più contra tal esplicatione mi si appresentò altra difficoltà, che essendo ogni alteratione previa preparatione alla estintione della essentia del loro sogetto, la imaginatione se alteratione fosse, condurebbe il suo soggetto alla coruttione, il che non accadendo, mi persuadeva che l'imaginare per modo di alteratione non si eseguisca. 
senses and reaching as far as the imagination. It would be like a taut string which, when moved from one end, also shakes and vibrates at the other, or like many concentric circles produced at intervals in water when a stone falls [117] into it.

At first, I liked this second explication, considering it apparently most suited to this matter, but as far as the certainty we have of objects and the information about their real conditions was concerned, it turned out to be inappropriate and was not completely satisfactory to me. Therefore, without departing from the adduced examples, as the string may be shaken by infinite impellers of different conditions just as the circles of water [may be created] by various forces of different qualities, so similarly this may happen to the internal senses, whereof agitations may be caused by promoters of very different conditions although it always seems to be the same alteration.

Besides, this agitation seems to be unable to express the true reality of an object, since its cause is not appropriate or peculiar to the agitator and mover, nor is it something internal and essential to it, and it is not even the alteration which penetrates into the agitated and altered, as Gorgias demonstrated during his examination of the efficient cause. ${ }^{226}$ Therefore, in order to resolve this, I appealed to alteration, and I supposed that when the internal spirit encounters the object or the image sent by it, it changes itself internally: this is the affection we perceive in ourselves. ${ }^{227}$ Yet although I had ruminated on this a lot in my mind, nevertheless I seemed to be unable to avoid the aforementioned difficulty. Indeed, I ended up with the same absurdity again, since the spirit could also be likewise altered by different altering agents, while the sensation always remained unvarying and the same.

Yet in addition to this, what kind of similarity and relationship could there be between a stable object and a transient and fleeting alteration? Between what is permanent in itself and perception, which lacks being in itself and asks and begs it from others? Pain and pleasure are the main alterations that we experience, but they are not only restricted or limited to us, as well as being in no way representative of external objects. Indeed, they lack pain and pleasure in themselves. Therefore, if black [118] and white and sweetness and bitterness are alterations, I would consider them as able to represent the true faces of external objects as pain and pleasure are.

Yet I also encountered another difficulty with this explication: as an alteration is a prior preparation for extinguishing the essence of its subject, then if the imagination was an alteration, it would lead its subject to corruption. However, since this was not the case, I was persuaded that the imagination does not work by means of alteration. To
Third manner of the imagination. 
Raccogliendo dunque il mio divisamento, non apparendo che in niuno di tre maniere racconte possa eseguirsi l'imaginare, né altre guise non potendo rinvenire la mia tardità, mi restava intercluso il discorrere circa tal facoltà, e più oltre progredire, essendo verisimile che ignorata l'essentia di qualunque cosa, resti parimente impedito il discorso e la via di riconoscere le sue conditioni e qualità.

Nondimeno per non lasciar angolo vacuo al destinato esame, applicai il mio talento ad indagare quali siano le attioni che comunemente se li attribuiscono: fu assignato, come già accennai, a tale facoltà imaginatrice il construire insieme le apprensioni, che ritrova nel senso comune sparse e divise, over anco separare quelle che fossero insieme anesse, et all'intelletto poi ciò rapportare, per il che refferendario dell'intelletto s'appellò. Dal che ne segue, che essendo tal potenza dall'intelletto distinta, sovente complichi insieme cose che affatto disgionte e repugnanti sono, come per il contrario disunisce quelle che realmente congiunte si ritrovano.

Prole di costei sono li centauri, harpie, pegasei, et altre chimeriche compositioni, di che ci assordiscono li poeti con lor copiose dicerie, e li pittori ci spaventano con loro stravaganti rapresentationi. Al primo aspetto, l'essempio del refferendario preso dalla pratica della curia civile, introdotto tal offitio per facilitare il progresso delli affari in modo che al supremo magistrato si rendono più agevoli e trattabili, molto parevami [119] che al proposito della imaginatione rispetto all'intelletto si aggiustasse, e che assai dilucidasse qual fosse il ministerio di essa. Ma mi ramentai alla fine del parere del nostro Euclide megarese, ch'affatto reprobava nel praticare le speculationi più importanti, l'uso di essempii e similitudini, stimando egli che se l'essemplare affatto riesce simile all'essemplificato, diveniva tal conferenza inutile, e superflua, essendoci ambi egualmente noti over occulti, ma se punto fra essi variano, conviene che sortisca ingannevole tale comparatione.

Per il che cominciai a dubbitare che l'esempio del referendario non riuscire idoneo al trattato della imaginatione, e quanto più che rassembrava che li apportasse chiarezza, tanto maggiormente sospettai che in alcuna circostanza li fosse diverso, il che facilmente riflettendovi sopra, mi accorsi della falacia. Il referendario non è privo di ragionevole discorso, anzi di egregio giuditio conviene che sia dottato nel saper discernere ciò che nel processo confusamente si contiene, e smedolandolo farne poi un ordinato construtto, componendo insieme quelle cose che fra loro coherentia tengono, il che addattare non si può 
summarise my consideration, since the imagination did not seem to be working in any of the three manners described [above], and since I was not able to find other ways because of my slow wit, I was prevented from discoursing on this faculty and from going further. Indeed, it is likely that when one is ignorant of the essence of a thing, any discourse or way of acknowledging its conditions and qualities is likewise hindered.

Nevertheless, so as not to leave my examination incomplete, I applied my talent to investigating which actions were commonly attributed to it [i.e., the imagination]. As I have already mentioned, this imaginative faculty was given [the ability] to combine the apprehensions that it finds scattered and separated in common sense, as well as to separate those which were already joined together, and it then reports this to the intellect. Because of this, it was called the intellect's referendary. It follows from this that this force, which is distinct from the intellect, often combines things together which are indeed disjointed and opposite, as on the contrary it divides those which are actually joined together.

The offspring of the imagination are centaurs, harpies, pegasi, and other chimerical compositions with which poets stun us through their abundant falsehoods and painters frighten us through their whimsical representations. At first sight, it seemed [119] to me that the example of the referendary was well-suited to [describing the role of] the imagination in relation to the intellect and clarified its ministry very well. It was taken from the office of the civil court, ${ }^{228}$ whose role was introduced to facilitate the course of businesses in order to make them easier and more manageable for the supreme magistrate. Yet finally, I remembered the opinion of our Euclid of Megara, ${ }^{229}$ who indeed disapproved of the use of examples and similitudes in dealing with the most important speculations. He believed that if the exemplar turned out to be like what was exemplified, such comparison became merely senseless and superfluous, since both would be equally known or unknown to us. However, if they diversified from one another, this comparison should be considered deceptive.

Therefore, I began to doubt that the example of the referendary was appropriate to address the imagination. Furthermore, the more it seemed to be clarifying it, the more I began to suspect that it was somehow different from it. Hence, after I had thought about it, I easily realised the mistake. The referendary is not lacking in rational discourse; rather, it must be endowed with an excellent faculty of judgment in discerning what is confusedly included in a process. Then, after having clarified it, it makes an orderly construction out of it by combining together those things which are consistent with one another. This cannot work for 
alla imaginatione mentre che disgiunta e separata dall'intelletto la suponiamo.

Onde se la facoltà imaginativa, in tal guisa dementicata et ignara fingere se la vogliamo, riesce piuttosto una inaveduta aggregatrice che perita referendaria, e con la memoria la confondaressimo, e l'istessa devinirebbe. Per il che ci conviene dire che ancor essa capace sia di ragionevole discorso, né perché construisse heteroclite e strane compositioni, perciò affatto insana e pazza stimare la dobbiamo. Perché se forma centauri, di figura humana e beluina composti, construisce tal imagine per dimostrarci homini che possedendo il discorso della ragione, tuttavia tengono alle volte affetti, che li rendono simili a bruti, et oltremodo alla concupiscibile et irascibile soggetti.

E se ci rafigura le harpie, ci rappresenta li adulatori che tenendo apparenza affabile, e sempre ridente, [120] posse|dono nondimeno le mani adunche e grifagne. E tale facoltà imaginativa, instruendo il pittore al rappresentare varii simulacri, li regge la mano così perfettamente nel disegno et apprestamento de' colori, che rasembrano a chi mira tali effetti, dall'istessa natura trahere li loro natali. La poesia parimente giudiciosa apparisce, e capace di esquisito discorso, e se snoda la lingua a proferire overo la penna a scrivere menzogne, le sugerisce anco tali artifitiose figure di dire, agiustato decoro a colui che la rappresenta, aggradabili documenti a chi instruisce, che lo affermare priva di ragione l'imaginatione, madre di tale professione, sarebbe pronunciato oltremodo assordo.

E sebbene volgarmente si stima che non vi sia ciò che più offenda tali nobili impieghi, che il comercio et intervento dell'intelletto, onde se con sue sacenterie e sottigliezze troppo in simili affari si ingerisce, et impiega, non fra le mediocri censure, che a queste professioni si oppone, è la calunnia di pennello stentato, e maniera elaborata, ché perciò, a certo subitaneo et improviso furore si attribuisce l'egregio di tal imaginarie arti, nondimeno dico che non resta però, che l'imaginatione di retto discorso sia destituta, ma si vuole inferire che tali esercitii desiderano piuttosto efficacia et urgentia di spirito, benché peraltro non oltremodo grave, che fiacchezza, accurata, et immoderatamente circonspetta, e perciò languida e cadente.

Ma lasciamo la poesia e pittura a parte, ché purtroppo la rendono evidente di facoltà ragionevole dottata. Ma li sogni, per non dire li stessi delirii, che senza dubbio riconoscono l'imaginatione per loro madre, benché il loro principal fondamento sia vano, e che al 
the imagination if we suppose that it is disjointed and separate from the intellect.

Therefore, if we wanted to claim that the imaginative faculty is like this, namely forgetful and unaware, it would turn out to be a rash collector rather than an expert referendary. Besides, we would confuse it with the memory, and they would become one and the same. Hence, we should still say that it is endowed with rational discourse, and we must not consider that it is indeed insane and mad only because it forms heteroclite and strange compounds. ${ }^{230}$ For when it forms centaurs as compounds of human and animal shapes, it builds up these images in order to demonstrate to us that human beings, although they have reason, are nevertheless sometimes led by affects, which makes them like brutes and extremely subject to the concupiscent and irascible [faculties].

Furthermore, when it depicts harpies, it represents flatterers, who have affable and perpetually cheerful appearances [120], but nevertheless also hooked and clawed hands. This imaginative faculty instructs the painter in representing various simulacra and leads his hand so perfectly in drawing and giving colour that to those who observe these effects, they seem to have been generated from Nature itself. Likewise, poetry seems to be judicious and capable of refined reasoning: indeed, when it moves its tongue to speak or its pen to write falsehoods, through these affected figures of speech it also inspires the appropriate decorum of the one who represents them and agreeable lessons for those whom it instructs. Therefore, it would be absurd to state that the imagination, the mother of this art, was lacking in reason.

Furthermore, it is commonly thought that there is nothing that damages these noble arts more than their relationship with the intellect and its intervention. Indeed, when it interferes in such businesses and excessively pursues them with its arrogance and quibbles, among the harsh criticisms that it opposes to these arts are the slanders of hesitant brush strokes and a too-affected manner. As the excellence of these imaginative arts is attributed to a sudden and unexpected fervour, nevertheless, I say that this does not lead to the fact that the imagination is deprived of rational discourse, but that with this [argument], it should rather be inferred that these [imaginative] exercises need an effectiveness and promptness of spirit, which is however extremely light, instead of careful and immoderately circumspect weakness, which is thus languid and feeble.

Yet let us leave poetry and painting aside, which unfortunately make it evident that it [i.e., the imagination] is endowed with a rational faculty. However, dreams, not to mention the deliriums themselves, undoubtedly acknowledge the imagination to be their own mother. Although their main ground is illusory and they are not 
di fuori di noi non tengono oggetti reali che li sostengano, non è tuttavia il filo e serie delle loro apparenze affatto privo di retto discorso, e ragionevole giuditio. Onde rappresentando essa imaginatione horridi avenimenti, et atroci casi prima si attrista, e spaventa, e doppo li compassiona come se la mente istessa l'osservasse, come per il [121] contra|rio di dilettevoli e giocondi spettacoli se ne rallegriamo e compiacemo, il che non d'insano discorso può risultare.

Ma di più, se alcuna dishonesta et infame ma voluttuosa apparenza nel sogno ci sorprende, e che la concupiscenza ci stimoli ad essequire alcuna attione indecente, nondimeno il rispetto delle comuni leggi, e riguardo dell'honesto in certa guisa ci raffrena, benché allhora la sola imaginatione distratto l'intelletto, come comunemente si dice, tenga il regimento interno del nostro animo, et in sua balia affatto si ritrovamo posti, come a Bible occorse del fratello inamorata:

Placida resoluta quiete

Saepe videt quod amat visa est quoque iungere fratri

Ovidio Met. Corpus erubuit, quamvis sopita lacerat.

E tal instruttione per il certo dall'intelletto pervenire non può, ché se alle fantastiche machinationi di sogni asistesse, affatto reprobarebbe tutto quel vano spettacolo, e fallaci apparenze che ci si rappresenta, che pur in quell'istante al pari di qualsivoglia seria verità li apprestiamo assoluta credenza, stimandoli affatto reali et esistenti. Oltre di ciòché se la imaginatione priva di giuditio e discretione congiungesse le apprensioni di sensi insieme, amassarebbe sempre faragine di compositioni e construttioni affatto incomplicabili, onde troppo importuno tedio seguirebbe alla mente in sciogliere da tal coluvie di impertinenti amassamenti quello che essa approba e che al suo proposito serve.

E quante fiatte restarebbe delusa la sua diligenza non havendole l'imaginatione sugerito ciò che li aggrada. E l'istesso intelletto in tali casi scorgerebbe non tanto il poco che elegesse, quanto il molto incondito, mendace e superfluo che l'imaginatione li raccolse e soministrò, il che non esprimentando in noi, ci rende probabile che non priva di giuditio sia tal facoltà imaginativa, come volgarmente è decantato, ché in [122] quan|to poi all'apprendimento delle propositioni universali, che né a tempo e loco sono affissi e circonscritti, che comunemente alla imaginatione vengono denegati, in breve sono per dimostrare la inesistentia di tali asserti concetti universali. 
supported by any real objects outside of us, the thread and series of their appearances is nevertheless not lacking in right discourse or rational judgment. Therefore, when the imagination represents horrible events and dreadful cases, [we] first feel sad and frightened, and then it arouses compassion for them [in us], as though the same mind was observing them, as on [121] the contrary pleasant and cheerful performances delight and please us, and this cannot result from an insane discourse.

Moreover, if some deceitful and shameful yet voluptuous appearances surprise us in dreams and concupiscence spurs us to perform some indecent action, nevertheless respect for the common laws and a sense of honesty somehow restrain us. However, the imagination alone, once it has distracted the intellect, as it is commonly said, holds the inner control of our minds and we are at its mercy, as happened to Byblis, in love with her brother:

But when she is relaxed in peaceful slumber,

She often has visions of her love: she sees herself clasped in her brother's arms And blushes, though she lies sunk in sleep. ${ }^{231}$

Ovid Met.

Furthermore, it is certain that the intellect cannot give this instruction, because if it paid attention to the fantastic machinations of dreams, it would indeed reprove all of this vain spectacle and the fallacious appearances presented to us. ${ }^{232}$ [And this would occur] even if we firmly believed in them in that moment as though they were any other serious truth, considering them indeed to be real and existing. In addition to this, [it is certain that the intellect cannot give this instruction] because if the imagination combined the senses' apprehensions without judgment or the ability to discern, it would always group them into muddled compounds and entangled constructions. Hence, the mind would undergo too much trouble in extricating what it likes and needs for its purpose from this jumble of incoherent groupings. Besides, its diligence would be disappointed so many times by not receiving what it likes from the imagination. Furthermore, the intellect itself would not see the little that it selected, but the confused, mendacious, and superfluous lot that the imagination collected and provided to it. As we do not experience this in ourselves, this makes us consider it probable that the imaginative faculty is not lacking in judgment, as is commonly claimed. Therefore, as far as [122] the apprehension of universal propositions is concerned, which are not defined or circumscribed by time and space and from which the imagination is commonly [considered] to be excluded, I will soon demonstrate the inexistence of these alleged universal concepts. 
Esame circa la facoltà estimativa.

Esame circa la memoria.
Da queste e simili instanze, probabilmente giudicai che di qualche intendimento fosse anco essa donata. Ma doppo finita l'antedetta discusione, alla facoltà estimativa applicai l'esame, alla qual quasi tutte l'oppositioni occorrenti alla imaginatione parimenti l'incontrano. Ma di più mi accadeva nuova difficoltà, che essendo ad essa estimativa attribuito l'apprensione di alcuni oggetti che non cadono sotto a' sensi esterni, come l'odio, amore, honore et infamia, e simili, mi riusciva non poco disdicevole che li soggetti che sostengono l'attributi di amanti et amabile siano da sensi esterni et imaginatione appresi, e l'amore dalla estimativa solamente ciò riconosciuto. Onde convenga alla estimativa, quando vuole inferire che questo sia amante e quello amato, ricorrere alla imaginativa che li presti e sugerisca soggetti a quali attribuire possa tali suoi intentionali oggetti. E così l'imaginatione mentre attenti formalizarsi che Paride fu di Helena amante convenga dalla estimativa mendicare tale amore, essendo ad essa ignoto.

Oltre di ciò parevami assordo lo admettere che tenissero titoli di oggetti, cioè efficienti d'impressione, l'amore et odio, semplici passioni e perturbationi, ché, come ho divisato molte fiate, che essendo queste relationi, per la loro fievolezza, e flussibilità non sono bastevoli di mover alcuno di nostri sentimenti sì esterni come interni. Oltre che se questi tenissero facoltà come di oggetti, di movere l'estimativa, dunque inanzi che fossero appresi hebbero esistentia, dovendo il mottore e l'efficiente precedere al movimento et all'effetto.

Ma da onde tali oggetti insensibili scaturirno? Da chi presero la loro origine? Non dalli oggetti esterni che sarebbero da sensi riconosciuti et appresi, non dalla [123] ima|ginatione parimente, mentre che distinta dalla estimativa la constituirno. Da tali divisamenti dunque raccolsi che tal facoltà estimativa fosse parimente putatitio e chimerico magistrato, e che non tenisse appo noi reale, e vera residentia.

Espeditomi dunque da questa, altro non mi rimaneva di esaminare inanzi che alla reggia dell'intelletto giungessi, che la memoria, onde colà transferendomi con il discorso, disposimi circa di essa travagliarmi. E per il certo restai alquanto attonito, considerando le sue stupende facoltà, ché perciò la stimai al di sopra di tutti li altri ministri, all'intelletto serventi, degna et egregia e che ragionevolmente nominare si dovesse tesoriera del tempo, e refertissima depositaria delle spoglie dell'universo, poiché in quella come che in sicurissimo archivo, sono riposte l'imagini di tutto ciò che giammai occorse, e successe, ritrovandosi essa capace non solamente di ciò che l'universo 
Because of these and similar instances, I considered the imagination to be also endowed with a kind of understanding. Yet after having concluded the aforementioned discussion, I devoted my examination to the estimative faculty, where one may find almost all the contradictions that recur in the imagination. However, I encountered yet another difficulty: the apprehension of some objects which are not perceived by the external senses, such as hate, love, honour, infamy, and the like, is attributed to this estimative [faculty]. Therefore, it seemed improper to me that the subjects that held the attributes of lover and beloved should be apprehended by the external senses and imagination while love was acknowledged only by the estimative [faculty]. Thus, when the estimative [faculty] wishes to infer that this one is the lover and that one the beloved, it needs to appeal to the imaginative [faculty], which will provide and suggest someone to whom it may attribute these supposed objects. Similarly, when the imagination attempts to conceive that Paris was the lover of Helen, it needs to beg the estimative faculty [for help to conceive] this love, which is unknown to it.

In addition to this, it seemed absurd to me to admit that love and hate, simple passions and perturbations, ${ }^{233}$ were considered to be objects, namely to be efficient causes of impressions. Indeed, as I have maintained many times, they are relations, which are so feeble and transitory as to be insufficient to move any of our internal or external senses. Moreover, if they were to have the same capacity to move the estimative [faculty] as the objects, then they must have existed before they were apprehended, because the mover and the efficient must precede the motion and effect.

Yet where do these insensible objects come from? What gave rise to them? Not external objects, which would be acknowledged and apprehended by the senses, and not even [123] the imagination, since it was constituted separate from the estimative [faculty]. Therefore, I gathered from these considerations that this estimative faculty was likewise a fictitious and chimerical magistrate and that it had no real or true dwelling in us.

Departing from this, then, there was still nothing but the memory to examine before reaching the royal palace of the intellect. ${ }^{234}$ Thus, I turned my attention there and I began to work on it. Certainly, I was most astonished when considering its incredible faculties, for I deemed it more worthy and excellent than all the other ministers serving the intellect. Besides, [I considered] that it should be reasonably appointed as a treasurer of time and a depositary filled with $^{235}$ the relics of the universe, because the images of everything that has ever occurred and happened are placed in it, as though in a very secure archive. It turns out to hold not only what the universe
Examination of the estimative faculty.

Examination of memory. 
contiene, ma di tutto quello che per il passato in esso soggiornò, e hora si trova estinto, et abolito, e che a ciò contenere et abbraciare angusto e deficiente riuscirebbe.

E quello che maggior meraviglia mi areccò fu il fermo ordine, e stabile collocamento, che mantengono l'imagini che in essa sono constituite, e talmente riescono constanti, che il rodimento del tempo per il tratto d'un secolo sovente un minimo di quello non deprava né sloca. Come anco non l'assalti di contumaci affetti, et incursioni di fiere infermità, né anco le travagliate vessationi di rea fortuna sono bastevoli a sconvolvere e sregolare così ordinata serie di simulacri. Onde, da queste notabili conditioni admonito, fui io il primo fra Greci a sostenere l'immortabilità della nostra anima, non potendosi dedurre dal caldo, freddo, humido e secco la tenacità della memoria in conservare per lungo tratto di tempo tanta copia di imagini distinte et inconfuse. Onde per il certo da altri principii trahe tal facoltà memorativa il suo esser e divina virtù, ché perciò il [124] distin|guere tal facoltà memorativa dall'intelletto non poco mi molestava, per il che insino allhora procurai di ritrovare instanze che la indentificassero con l'istesso intelletto.

Hor dunque proposimi a considerare che li sapienti la rafiguravano a guisa di biblioteca, overo cancellaria interna, nella quale doppo che li sensi esterni, il comune, l'imaginativa et estimativa esercitato havessero le loro fontioni, eran ad essa rimesse le reliquie di tali apprensioni, restando però esposte al servigio dell'intelletto overo imaginatione, al che tanto più si rendono idonee, quanto che con esquisito ordine conforme il successo di tempi, proprietà di lochi, et altre circonstantie di avenimenti, fossero disposte. Il che succede a guisa di noi Ateniesi che osservamo nelli nostri archivi di collocare le materie urbane, dalle esterne distinte, e così anco con decente ordine separamo li affari di Persiani, Macedoni, Tebani, et Argivi.

Tale fu l'esplicatione divolgata da sapienti circa la facoltà memorativa. Ma altrettanto che l'esempio mi si appariva avenente et aggiustato tanto maggiormente presi sospetto, come già circa l'imaginatione, della sua fallacia. Onde ventilando io tal dottrina, e ponendola al cimento della esame, osservai che noi Ateniesi oltre la cancelleria tenimo per nostro commodo et uso un cancelliere assai perito e versato circa li affari della cancellaria, a cui esatamente è noto l'ordine, e regolato colocamento delle scritture, che nell'archivo si contengono. Onde perciò nell'urgenti occasioni, ad un tratto capita a pigliare quello che al proposito convenga, trascurando l'impertinenti ché, se altrimente avenisse, l'una scrittura per l'altra prenderebbe, e rare fiate se non a caso coglierebbe quella che procurasse ritrovare. 
contains, but also everything that dwelled in it in the past and is now extinct and abolished, because the universe would be too narrow and insufficient to contain it.

Furthermore, what astounded me most was the firm order and stable position maintained by the images which are constituted in it. Besides, they are so consistent that the deterioration caused by time will often not corrupt or change even the slightest amount of them in the space of a century. Neither the assaults of obstinate affects nor the incursions of strong infirmities nor tormented oppressions, for which Fortune is responsible, would be sufficient to upset or disorder such a well-ordered series of simulacra. Therefore, advised by such considerable conditions, I was the first of the Greeks to assert the immortality of our souls. ${ }^{236}$ Indeed, it was not possible to deduce the memory's tenacity in everlastingly preserving such a quantity of distinct and separate images from heat, cold, dampness, and dryness. Thus, this mnemonic faculty undeniably obtains its being and divine virtue from other principles. For this reason, it was quite irritating [124] to me to have to distinguish this mnemonic faculty from the intellect. Hence, I have so far tried to discover instances which could identify it with the intellect.

So, I proposed to consider that the wise men had represented it like a library or internal chancery, where the external senses, common sense, and the imaginative and estimative faculties, after having carried out their functions, would put the relics of these apprehensions, which nevertheless remain at the intellect's or the imagination's disposal. Thus, the more suitably they are made, the more orderly they are disposed according to the temporal sequence, characteristics of places, and other circumstances of events. Likewise, this happened to us Athenians when we took care to separate urban and foreign matters in our archives, as well as having arranged Persian, Macedonian, Theban, and Argivian businesses into good order.

This was the explanation for the mnemonic faculty spread by the wise men. Yet the more suitable and adequate that example appeared to me, the more I started suspecting it of fallacy, as I had already done about the imagination. Therefore, by analysing this doctrine and subjecting it to examination, I observed that we Athenians, besides the chancery, also have a chancellor at our disposal and use. He is an expert and is well-informed about the chancery's businesses; he knows the precise order and regulated classification of every writing contained in the archive. Thus, in urgent circumstances, it is possible to immediately seize what is necessary in this respect, leaving aside what is not pertinent. Otherwise, one would take one writing instead of another, and would catch only rarely or even by chance what one needed to find. 
Questo istesso fermandoci sopra il rigore dell'essempio addotto, conviene constituire nella nostra interna cancellaria memorativa, cioè un massaio che eserciti la fontione del cavaliere, e sia ricordevole dell'ordine di ripostiglii dell'avanzi [125] del|l'apprensioni, da che ne seguirebbe che tal interno canceliero overo bibliotecario egregiamente memorativo fosse, ché se altrimente, riuscirebbe inetto a simile carica, ma di tal sua memoria di novo si ricercarebbe chi ne fosse il massaio, in maniera tale che all'infinito si procederebbe. Onde che ci converebbe caricare di innumerabili cancelarie, e massaii.

Il che m'indusse a probabilmente giudicare che tal biblioteca overo cancellaria, in quanto almeno aspetta alla mentale, non sia altrimente distinta e separata dall'intelletto e che l'intelletto da per sé sufficiente sia, senza il suffragio d'altrui rappresentarsi le proprie apprensioni. Si può anco per l'inesistentia di tale cancellaria addurre la momentanea celerità con che l'intelletto si ramemora delle cose già conosciute, ché per il certo evidentemente apparisce che non fuori di lui ricerca e mendica li fondamenti della sua intelligenza, oltre che se tal biblioteca in noi si trovasse distinta dall'intelletto, inanzi che egli capitasse a quella imagine che ricerca, e che procura addattare al suo discorso, in altre infinite che non l'appartengono incontrarebbe.

Il che anco accade nelle bene disposte librarie et ordinate cancellerie, che prima ad un ripostiglio ch'all'altro si perviene conforme l'ordine della positura delle scritture, il che in noi non occorrendo, ci mostra l'inesistentia di tale aeria e vana separata cancellaria. Oltre di ciò mi si rendeva impersuasibile che in tal angusto e coartato loco, qual è il ristretto ambito dalla memoria, si conservassero per tanto corso di tempo così copiosa coluvie e faragini d'imagini diverse et infra loro repugnanti, e massime abbraciando la memoria non solamente li simulacri delle cose che esistono m'anco di quelli che il tempo di già estinse et annientò, ma di più come già accennai discorrendo circa la imaginatione, oltre li simulacri di oggetti visibili vi si dovrebbero ritrovare in tal servatoio le reliquie di suoni, odori, gusti, e toccamenti, il che non mi saprei formalizare in che maniera questi esistono, essendo [126] questi semplici passioni et alterationi, repugnando alla loro conditione lo conservarsi lungo tempo. E parimente, non capisco in che modo per intervallo di tempo tali passioni ci riescono insensibili et inosservabili, ché per il certo ritrovandoci noi con l'animo affatto scioperatto, dovressimo sentire di esse alcuna scossa.

Da tali oppositioni et instanze io impulsato, presi ad abbattere e demolire tale biblioteca interna, stimando che l'esercitio del ramentare appartenga al semplice intelletto, senza bisogno di ricorrere ad altrui. 
Stopping at the example I have adduced, we should rigorously establish in the court of our internal memory a custodian ${ }^{237}$ responsible for its administration who would exercise the function of a judge $\mathrm{e}^{238}$ and remember the classification order of the relics of these apprehensions [125]. It would follow from this that this internal chancellor or librarian should have an excellent memory, otherwise he would turn out to be incompetent at this task and thus we would have to look for another custodian of his memory, and this would continue to infinity. $^{239}$ In that case, we would have to appoint innumerable chancellors and custodians.

This led me to think that this library or chancery, as far as the mental one was concerned, was probably not distinct or separate from the intellect and that the intellect was sufficient by itself to represent its own apprehensions, without help from anything else. In support of the idea that this chancery does not exist, one could still put forth the intellect's quickness in remembering things that it already knows. This certainly makes it evident that it does not look or beg outside itself for the grounds of its intelligence. Moreover, if this library was positioned separately in us from the intellect, it would encounter infinite other unsuitable [things] before ending up at the one it was seeking.

This is also the case for the well-disposed libraries and ordered chanceries where, following the way in which the writings are organised, we come first to one place, then to another. As this is not the case for us, it demonstrates the inexistence of this immaterial and vain separate chancery. In addition to this, I could not accept that such a large quantity of jumbled and muddled images, different and opposite from one another, could be lastingly collected in such a narrow and compressed place as the limited space of the memory. Furthermore, above all, the memory collects not only the simulacra of existing things, but also those that Time has already extinguished and destroyed. Moreover, as I mentioned before when I was debating about the imagination, besides the simulacra of visible objects, one should find in this container the relics of sounds, smells, flavours, and touches. Yet I could not conceive how they could exist: as they are [126] simple passions and alterations, it would be contrary to their own condition to preserve themselves for a long time. Similarly, I do not understand how these passions may result as imperceptible and unobservable, because when we are at rest in our minds, we should feel some tremors of them.

Spurred by these oppositions and instances, I began to destroy and demolish this internal library, as I considered that the exercise of remembering belonged only to the intellect, without appealing to the help of anything else. Furthermore, I was persuaded by the fact 
E mi persuasi che punto ciò non lo degradi, anzi che riuscendo egli di se stesso dipendente non li conviene da altrui mendicare suoi alimenti. Oltre che mentre da se medesimo si ramenta le proprie apprensioni, havendo perciò se medesimo in assoluta balia e potestà, può agevolmente emendare due difalte che non poco l'offende, stimando havere la facoltà memorativa da sé distinta.

L'una è l'esser oltre modo tenace delle ricevute offese, e labile e lubrico de' beneficii conseguiti, ma hora moderando l'intelletto se stesso, riconoscendo in se medesimo fondati tali vitii, si può rendere da questi immune, e purgato, avisandosi parimente che delle ingiurie conviene ramentarsi, non per vendicarsene ma per solamente osservare la conditione di chi l'offese per evitare la reiteratione, e replica di affronti, ma de' beneficii sapersene dimenticare, insino tanto solamente, che la fortuna li porge occasione di ricompensarli, perché il continuo oggettare li favori ricevuti genera prima erubiscentia e poi turbatione, et alla fine dispetto et odio, non solamente verso il beneficio, ma sovente anco contro il benefattore. Onde per scansare tal angore, con l'aperta inimicitia si procura levare lo stimolo del debito, e rompere la sferza dell'obligo, che flagella e tormenta.

L'altra difalta della memoria è, che ci rende troppo tenaci et abbarbicati a questa vita mortale, onde occorrendoci abbandonarla, chiamati a ciò dal servigio della patria, o dalla [127] fatalità della natura, con importuno contrasto a tali instanze et urgenze si opponiamo, e ciò non d'altra cagione procede, che dal dispiacere che sentimo in perdere la memoria delle cose già da noi apprese. Onde se nel corso della vita ci avenisse una totale et assoluta oblivione, senza alcuno angore si reputaressimo come se all'hora nati fossimo, e havessimo acquistato un nuovo essere, e ciò accadarebbe senza alcun fastidio della perdita della vita passata.

Onde la mente, hora con la sua egregia intelligenza può moderare in se stesso tale eccessivo affetto che tiene circa la tenacità e ricordanza dell'avenimenti passati, ché siccome li oggetti che questi causarno sono di già estinti, così anco può patientare che in essa siano aboliti li loro fievoli e vanide imagini, et a migliore conditione di vita aspirando, con alacre comiato dal suo corporale hospitio, licentiarsi e sviluparsi. Né della destruttione del suo domicilio e construttione deve punto attristarsi, mentre osserva che la migliore natura, da principio terminò e limitò la materia del mondo sublunare, e come giustissima distributrice decretò, che con alternanti vicende, caduna portione di essa materia fosse per alcun tempo impressa dalla più nobile e vile forma che nella sua idea si trovava. 
that this did not degrade the intellect at all; rather, in turning out to be dependent on itself, it would not have to beg others for its nourishment. Moreover, as it would remember its own apprehensions by itself, being at the mercy of itself and its own power, in considering that it had a faculty of memory distinct from itself, it could easily emend two failures that are very damaging to it.

One [failure] is to be extremely tenacious [in preserving] the damage it has received and weak and feeble concerning the benefits it has acquired. Yet now the intellect, by moderating itself, may acknowledge these vices to be grounded in itself and may exempt and purge itself of them. Likewise, it should remember the affronts not to take revenge for them, but only to consider the condition of the one who had offended it in order to avoid a reiteration or repetition of the affronts. However, one should be able to forget the benefits as long as Fortune offers the opportunity to reward them. Indeed, the continuous pointing out of received favours causes first blushes, then embarrassment, and finally annoyance and hatred, not only towards the benefit, but often also towards the benefactor. Therefore, in order to avoid this anguish, one should remove this feeling of being indebted with open enmity and erase this obligation as a source of affliction and torment.

The other failure of the memory is that it makes us cling too tenaciously to this mortal life. Thus, when we have to leave it, called by our homeland to do military service or by [127] the inevitability of Nature, we rashly oppose these instances and urgencies. Furthermore, this only happens because we regret losing the memory of the things we have already apprehended. For if during our lives it happened that we were to completely lose our memories, we would think, without any anguish, that we had been born in that moment and had acquired a new existence, and this would happen without worrying about the loss of our past life.

Therefore, the mind, with its great intelligence, can now moderate this excessive affect in itself regarding the tenacity and memory of past events. As the objects which caused them are already extinguished, the mind may expect that their light and feeble images will also disappear from it. Besides, aspiring to a better life, it will promptly take leave of its bodily dwelling, and thus it will release and disentangle itself. It must not be saddened because of the destruction of its dwelling and construction if it observes that great Nature originally defined and limited the matter of the sublunary world. Furthermore, as it is a most fair provider, it established that each portion of this matter should be alternately impressed by the noblest and vilest forms which were found in its idea. ${ }^{240}$ 
Instanza di Protarco a favor della memoria.
Onde a guisa di convitati che doppo l'esser satolati cedono il loco, a quelli che l'hanno serviti e regalati, così conviene all'animo humano, rinontiare ad altrui li piaceri della presente vita, siccome altri adesso li lasciarno:

\section{Nam si grata fuit tibi anteacta priorque \\ Et non omnia pertusum congesta quasi in vas \\ Commoda perfluxere atque ingrata interiore \\ Cur non ut plenus vita conviva recedis?}

Tale fu il mio divisamento circa la memoria, ma devolgata la mia openione circa essa, offese non poco Protarco, che certa arte memorativa che locale si appella [128] pro|fessava, rassembrandoli che attentassi distrugere il soggetto e fondamento di quella sua arte, che lo rendeva celebre alla nostra città.

Onde avenendomi, rimproveromi che facile fu sempre l'opporsi a qualunque dottrina, ma che l'inventare ciò che alli homini fosse giovevole riuscì in ogni tempo oltre modo arduo e malagevole, e seguendo disse, che la sua arte memorativa locale ben dimostrava, che vi fosse posto in noi un archivo nel quale insistono l'imagini dell'impressioni seguite, e con mirabile ordine distinto e collocato e che l'aggravare l'intelletto di tal sarcina, lo renderebbe non meno impedito nelli suoi mentali discorsi, di quello accade a donna di più embrioni pregna, che ad ogni attione della vita riesce impedita et inetta, ma la mente ritrovandosi agile et espedita nelle sue attioni, ciò argomenta, che di tale gravidanza e peso sia affatto scarca e libera. Oltre di ciò adduceva che l'istessa natura pareva ci additasse tal distintione tra l'intelletto e la memoria, havendole costituito nel celabro loco appartato a guisa che assegnò alle altre facoltà interne serventi ad esso intelletto.

$\mathrm{Al}$ che io che egregiamente divisava, ma che disideravo che pacatamente ascoltasse altra maggior novità che in tal proposito io l'era per dire.

“E quale sarà”, replicò egli, “Tal nuovo assordo che sei per narrarmi?”.

\section{Soggionsi:}

\footnotetext{
"Non solamente niego che non si trova ripostiglio e cella assignata alla memoria, e che vi sia facoltà diversa dall'istesso intelletto, ma di più arditamente io propongo che non so formalizarmi abbastanza, che vi sia in noi alcuna ricordanza d'avenimenti passati. E benché insino con il latte habbiamo imbevuto che quella conoscenza che rimembranza appellamo, sia di fatti e casi già
} 
Thus, just like guests who, once satisfied, give their own seats to those who have served and honoured them, so the human mind should assign the pleasures of the present life to others, as the others have now left them:

For if your former life now past has been to your liking, if it is not true That all your blessings have been gathered as it were into a riddled Jar, and have run through and been lost without gratification, why Not, like a banqueter fed full of life. ${ }^{241}$

This was my consideration concerning the memory, but as soon as I had spread my opinion of it, Protarchus, ${ }^{242}$ who taught the art of memory that was called [128] "local," ${ }^{243}$ was quite offended. It seemed to him that I was attempting to destroy the subject and ground of his art, which had made him well-known in our city.

Therefore, he came to me and reproved me that it was always easy to object to a doctrine; however, it was always extremely arduous and difficult to invent what was useful for humankind. Moreover, he continued by saying that his local memory art aptly demonstrated that there was an archive inside us where all the images of past impressions were located in an admirable order. Furthermore, [he said that] to increase the intellect's burden with this would certainly impede it in its mental discourses. This would be like what happens to a woman who, pregnant with more than one embryo, is hindered and incapable in all daily actions. Yet he argued that as the mind is fast and quick in its actions, it must be relieved and free of such a pregnancy. In addition to this, he put forth that Nature itself seemed to point out this distinction between the intellect and the memory by having constituted a secluded place for it [i. e., the memory] in the brain, as it allocated the other internal faculties at the intellect's disposal.

Hence, I [told him] that his argument was remarkable, but that I wished that he would calmly listen to the other main novelty I was going to say in this regard:

“And what," he replied, "is this new absurdity that you are going to tell me?"

\section{I continued:}

"Not only that I deny that there is any lumber room or cellar allocated to the memory and that there is any faculty that is different from the intellect itself, but, even more daringly, I put forth that I cannot easily imagine that there is any memory of past events inside us. Furthermore, although even though from a very early age, we imbibe along with our mother's milk that that knowledge that we call 'memory' is made up of events and cases that are already extin-
Lucret. 3. 282.

Protarchus's instance in favour of the memory. 
Nuova instanza di Socrate contra la memoria.

estinti e preteriti, nondimeno il fiaco mio discorso diversamente mi persuade, $\mathrm{e}$ m'instruisce che ciò sia inganno et illusione del nostro falace intendimento, riuscendomi assolutamente assordo che di quello che non tiene alcuna esistenza, si possa haverne di lui openione, concetto e [129] sen|timento alcuno, né ad esso si può attribuire relatione e rapportamento immaginabile.

Al che quasi tutti li sapienti assentirno, siccome nel divisare che con Gorgia hebbi si è dimostrato. Ma volgarmente allhora diciamo ramentarci del passato, quando che con pronta agevolezza ritrovamo in noi una serie e filo di imagini, ottimamente coherenti et amassate il che seguisca senza consumare alcuno spatio di tempo in ammassarle, et insieme ordinarle, onde conieturamo, che se non fossero impressioni di avenimento preterito non si trovarebbero nel nostro animo con tale regolata dispositione. Per il che se il caso overo altra sopra naturale virtù, formasse in noi momentaneamente senza nostro accorgimento un ordinato concatenamento di simulacri, lo stimaressimo rappresentatione di trapassati avenimenti, e scorse emergentie, siccome accade a freniticanti che li appaiano strani avenimenti giammai non successi”.

\section{A ciò soggionse Protarco:}

"In qual modo deduci che di quello non è, la memoria non si può ricordare, mentre ch'io mi ramento di Tebe mia patria che per anco esiste, e forse contra il volere di voi Ateniesi per molto tempo perseverarà in prospero e felice stato?”.

$\mathrm{Al}$ che mi opposi con ricercarlo in che maniera di Tebe si ricordava.

Risposemi egli della veduta di essa città, di piaceri e travagli in essa accadutili, et in particolare dell'arti ivi apprese.

Ma io lo rincalciai con dirli:

"Non ti accorgi, ottimo Protarco, che tutto quello ch'hora hai narrato, e conservi memoria di Tebe come tue attioni overo passioni, essere del già estinto et abolito?”.

\section{A tal discorso replicò di novo Protarco:}

"Dunque se non admetti ricordanza che si riferisca al passato, da che procede tale impensato ordine di eventi che nell'animo ci si rappresenta?”.

Risposi io:

"Conietturo, amico Protarco, che la facoltà rappresentativa che esercita l'intelletto che memoria nominamo, altro non essere, che certa inclinatione e proclività, che egli tenga al ritornare a quelle guise e [130] constituitioni che già altra fiata hebbe, essendo ciò legge come che fatale a tutte le cose mondane di rimettersi nel pristino stato, e conditione. Onde conseguito che tenga la cosa un 
guished and past, nevertheless my weak discourse is convincing me of a different opinion. It is teaching me that this is a deception and illusion coming from our fallacious understanding, as it seems to me to be completely absurd to have an opinion, concept, or [129] perception of what does not exist, or to attribute any imaginable relationship and connection to it.

"Almost all the wise men agree with this, as I have demonstrated by debating with Gorgias. Yet then we commonly say that we are remembering the past when we quickly and easily find a thread or series of images inside us that is very consistent and well-grouped together. As this is accomplished without spending time clustering or ordering them together, we suppose that they are so orderly disposed in our minds only because they are impressions of past events. Hence, if Chance or another supernatural virtue temporarily shaped an ordered concatenation of simulacra inside us without us realising it, we would consider it a representation of past events and previous occurrences, as happens to frenzied people who see strange events which have never happened.”

\section{Protarchus continued:}

"How do you deduce that the memory cannot remember what does not exist? Indeed, I remember Thebes, my homeland, which still exists, and which perhaps, against the will of you Athenians, will live for a long time to come in prosperity and happiness.”

I countered this by asking him how he remembered Thebes. He answered me that [he remembered] the view of this city, the pleasures and troubles that had occurred to him there, and especially the arts he had learned there.

However, I retorted to him:

“Don't you see, oh excellent Protarchus, that everything you have told me now, [namely] that you preserve the memory of Thebes in your deeds or passions, is already extinguished and destroyed?"

To this argument, Protarchus replied again:

"Well, if you do not admit any memory of the time that is past, where does this unthought order of events appearing in our minds come from?"

\section{I answered:}

"I suppose, dear Protarchus, that the representative faculty practised by the intellect that we call memory is nothing more than its inclination and tendency to go back to the ways and [130] conditions that it once had. It is a fatal law of all worldly things to return to their original status and condition. Therefore, when a 
Boetio lib. 3 Metro 2.

sito mentre da questo è rimossa, purché si trova libera, fa regresso e ritorna a quella volta. E se il proietto non fosse impedito dalla oppositione dell'aria, perseverebbe sempre nell'istesso motto e direttione che in quel poco di tempo che fu unito con il proicente acquistò. Il che potrebbe accadere a cieli che havendo una fiatta riceputo il motto da Iddio loro impulsore, per non ritrovare essi in ciò impedimento, senza altra scossa et urto in esso motto perseverano. Ma che occorre da cieli tanto a noi remoti trarre di ciò argomento, il ferro stando per alcun tratto di tempo fermo in una positura, rimosso da tal situatione e poi posto in libertà, ritorna da se stesso al primiero sito. Che la magnete tenga parimente anco essa tal impulso è superfluo l'addurne prova. Ma ben ciò stimo riuscire osservabile al nostro proposito, che qualunque corpo flessibile essendo con alcuna violenza piegato e rivolto, e poi in libertà ritrovandosi, da se stesso ritorna alli primieri spiri e ravolgimenti:

\section{Validis quondam viribus acta}

Pronum flectit virga cacumen

Hanc si curuans dextra remisit

Retro spectat vertice coelum.

Et in ogni momento esprimentamo nelli nostri membri, che da se stessi si movono in quelle maniere che per alcun tempo si sono essercitati, non essendo né anco da noi advertito il loro motto, nemmeno sappiamo in qual maniera le loro fontioni eseguiscono. Da ciò ne segue che punto non ci deve arrecare meraviglia, se l'intelletto di maggior perfettione dottato di qualunque altra cosa mondana, conservi in se stesso talento e dispositione di ritornare a quella guisa [131] che già una volta fu constituito. Il che tanto più agevolmente accade, quanto che nella primiera impressione perseverò per alcuna duratione di tempo, il che habito volgarmente si appella, ma non resta però che ciò da principio fu detto che la memoria tenga rispetto o relatione a cosa passata, ma sia solamente una certa tal facile constitutione dell'animo nostro in tal maniera, per così dire, configurato e disposto.

Né li ventricoli da te adotti che osservano l'anatomici nelle loro dissecationi punto mi move, havendoli io sempre stimati piuttosto destinati a ricevere l'escrementi del celabro che a contenere in sé facoltà che s'esercitasse in servigio della mente. Da ciò che teco tengo divisato stimarei che satisfatto rimanessi di quello che circa la memoria mi opponevi, né devi punto lagnarti che perciò rimanga la tua mirabile arte discreditata, anzi stimare devi che più degna e pregiata divenga, instruendo hora l'intelletto istesso più egregia portione di quante concorrono ad integrarci, né annoiare ci deve che molti vagliano nel discorso della mente e sono difettosi di memoria, e così parimente per il converso, poiché la finezza dell'ingegno non consiste solamente nel regresso alli primieri motti, siano in qualsivoglia modo seguiti, ma nell'essere con regolati e decenti ordini disposti”.

Ma Protarco essendosi renduto taciturno al mio ragionare, né altro aggiungendo, stimai che affatto convinto rimanesse, et io da tutto ciò raccolsi, che superflua fosse al servigio della mente tal facoltà memo- 
thing is removed from the place it has reached, although it is free, it turns and goes back in this direction. ${ }^{244}$ Furthermore, if a projectile was not hindered by the resistance of the air, it would always persevere in the same motion and direction that it acquired during the short time that it was joined to its projicient. ${ }^{245}$ This might be the case for the skies, which once received motion from God as their mover: as they have not found any obstacles, they persevere in this motion without any other propulsion or strike. Yet we should not appeal to the skies, so distant from us, in order to argue this. Indeed, when [a piece of] iron is removed from a place where it has been resting for a while and is made free, it returns to its original location by itself. Likewise, a magnet is also endowed with this impulse, but it is not necessary to put forth proof of this. Yet I consider it to be easily observable for our purpose that every flexible body, after being folded or strongly turned and then let free, returns to its original spirals or windings by itself:

Bend now, with all your strength,

A sapling's top to the ground:

But if the right hand bowing it let go

Its top again points straight up to the sky. ${ }^{246}$

Boethius

bk. 3 metre 2.

"Furthermore, at any time, we may experience in our limbs that they move by themselves in those manners that they have practised for a while. As we do not even perceive their motion, we do not know how they carry out their functions. It follows from this that we should not be astounded if the intellect, as it is endowed with more perfection than any other worldly thing, preserves in itself the talent and disposition to return to the way [131] it was originally constituted. This happens more easily the longer it has persevered in this original impression. This is commonly called 'habit,' but there remains only what was said at the beginning, namely that the memory does [not] hold a connection or relationship with a past thing, but that it is only an easy constitution of our minds, which may be said to be so configured and disposed.

"Even your adduction of the ventricles - which are observed by anatomists during the dissection [of bodies] ${ }^{247}$ - cannot convince me. I have always considered them to be designed to receive the excrements of the brain rather than to have capacities in themselves to practise at the mind's disposal. From what I have debated with you, I would consider myself satisfied by that which you have objected to me concerning the memory. Furthermore, you must not complain that your excellent art will therefore be discredited; rather, you must consider that it will become worthier and more valuable. Indeed, now the intellect itself is instructing one of the most excellent of the parts which compose us. Besides, we must not be irritated that many who are talented in the discourse of the mind are [endowed] with a defective memory, and similarly the other way around. Indeed, finesse of wit does not consist only in reverting to the original motions, however they are carried out, but in disposing them according to orders that are ruled and appropriate."

Yet Protarchus became taciturn in face of my argument and did not add anything. I thought that I had convinced him, and I gathered from all of this that this faculty of memory, distinct from the intellect and at its 
Esame circa l'intelletto. rativa da esso distinta, non meno che l'altre, che al suo ministerio li sapienti del secolo destinarno.

Ma progredendo nella primiera inchiesta, ritrovomi alla fine giunto all'estremo grado della interna curia et al sommo magistrato di essa penetrato, cioè all'intelletto arrivato, né altro mi rimaneva di esaminare che l'istessa mente. Ma però con non mediocre cautela a tal impiego mi applicai, dubbitando che l'identità che tiene la mente con se stessa non mi [132] traviasse in riconoscerla dal tramite del vero. Onde per evitare tal errore deliberai circa ciò in questa maniera diportarmi, che se a favore dell'intelletto riesce tal sindicato, non immediate con peremptorio giuditio a prò di esso terminare dovessi, poiché nel proprio interesse potrebbesi ingannarsi il mio giudicio. Ma se per il contrario in tal disquisitione convinto di inettia et insufficientia esso intelletto rimanesse, senza alcuno altro rispetto e scrupolo non idoneo ad esser giudice della verità delle cose stimare si dovesse, havendo egli se medesimo condannato. Hora dunque havendo proposta una rigorosa inquisitione circa l'intelletto, o per dire meglio contro me stesso, attentai per venirne a capo li seguenti quesiti:

Primo, indagare ciò che sia l'intelletto.

Secondo, se uno overo molti al timone del nostro regimento risiedono.

Terzo, qual sia la propria sua attione et officio.

Quarto, circa che esercita le sue operationi.

Quinto, in qual loco di noi sogiorna e dimora.

Sesto, quanto di tempo consuma ne suoi ordinarii esercitii.

Settimo, con qual istrumento esequisce le sue attioni.

Ottavo, con qual ordine regola e pratica li suoi discorsi.

Nono, in che maniera s'eseguiscono le sue deliberationi.

Decimo, ciò che sia il fine di tanto suo travagliare, e che attenta di conseguire et ottenere.

Hor dunque applicandomi a snocelare il primo quisito, tosto mi accorsi et avertii, quanto infelicemente succedere mi dovesse tal mia intrapresa, e che non dissimile avenimento succedere mi dovesse, da quello mi occorse nelli antecedenti essami. Inditio di ciò mi fu che nel ricercare ciò che fosse l'essentia dell'intelletto da cui dipendono tutte le altre sue conditioni, non incontrai in meno difficoltà, di che mi avvenne già, trattando circa li anziani principii delle cose, non ritrovando meno li pareri [133] repugnan|ti e discordi intorno a quello che circa questi, affermando li autori tale esser l'anima quali sono li loro asserti principii delle cose.

- Anzi di più vi fu chi stimò che altro non fosse che tenue e sottilissimo spirito, cioè elaborato sangue con aria mescolato. 
disposal, was unnecessary, like the others which the wise men of [our] time considered to be under its ministry.

However, by going further into this first inquiry, I finally found myself at the highest degree of this internal curia and before its supreme magistrate; namely, I had reached the intellect. Thus, the only thing I still had to do was to examine the mind itself. Yet I applied myself very carefully to this task, suspecting that the mind's identicalness with itself could prevent me [132] from recognising the truth of it. Therefore, in order to avoid this mistake, I decided to proceed in this regard as follows: if this scrutiny was to be in favour of the intellect, I must not form a peremptory judgment that was immediately favourable to it, because my judgment could be misled by its own interest. However, if, on the contrary, such a disquisition were to prove that the intellect was guilty of ineptitude and incapacity, then without any respect or scruple, it should be considered inapt to judge the truth of things, as it would be as if it had sentenced itself. So now, since I have put forward a rigorous inquiry concerning the intellect, or, better to say, against myself, I attempted to work out the following questions:

First, to investigate what the intellect was.

Second, whether there was one or many at the helm of our government.

Third, what its actions and functions were.

Fourth, to what it addressed its operations.

Fifth, in which part of us it resided and dwelled.

Sixth, how much time it needed for its ordinary actions.

Seventh, by which means it carried out its actions.

Eighth, by which order it ruled and practised its discourses.

Ninth, in what way it carried out its decisions.

Tenth, the goal of so much work, and what it was attempting to achieve and obtain.

As soon as I had begun to enucleate the first question, I immediately realised and recognised how unsuccessful the outcomes of such an endeavour would have been and that it would not have been different from what I had already experienced in the previous examinations. The proof of this was that when I searched for the nature of the intellect's essence, on which all its other conditions depend, I encountered the same difficulties that had already arisen when dealing with the ancient principles of things. I found [133] opposing and discordant opinions as much towards the former as towards the latter; indeed, the authors asserted the soul to be like their asserted principles of things. Rather, there were:

- $\quad$ Those who considered it a feeble and thin spirit, namely a compound of blood mixed with air. ${ }^{248}$
Examination of the intellect. 
- Altri un fragmento dell'anima universale del mondo, che ad esso soministra vita:

His signis atque exempla secuti

Esse apibus parte divina mentis et haustus

Virgil. IV Georg. Aetarios etc.

- Altri semplice potenza sostenuta d'organo interno materiale.

- Altri con parole generali pronontiarno che fossi certa tal egregia facoltà instalatta in certa perfettione di corpo organico, anima appellata.

- Ma d'altri fu divolgato che a guisa di auriga nel carochio, overo nochiero nella nave asista e regga la sua mobile stanza e portabile domicilio.

- Altri dissero che fosse un rampolo di un certo tale intelletto agente, non affatto di lui diviso né con esso identificato.

- Altri pubblicarno ch'altro non sia che una portione di eccellente magnete, indotti a ciò dire, da certe corrispondenze di aversioni et inclinationi che accadono all'animo e la magnete.

Ma troppo riuscirei prolisso, se io esatamente riferire volessi il tutto.

- E per ultimarla non vi manca chi che con ardita temerità promolgò l'intelletto essere nome senza soggetto, e che altro non sia che semplice esercitio delle reliquie di sensationi già apprese, che hora insieme s'uniscono, e hora si disgiungono.

- Ma altri con più sodo giuditio stimarno che fosse un'essentia immortale, nel corpo come in hospitio residente.

Le quali tutte openioni ho raccolto et addotto, non perché io inclini ad assentirle, ma per dimostrare, quanto sia conspiqua l'imbecillità del nostro intendimento in riconoscere qual sia la sua propria et essentiale natura, e che tuttavia ardisce rinvenire quali siano le più recondite e [134] remote cause dell'universo.

Ma oltre di ciò da tal controversia questo voglio anco dedurre, che siccome divisando io circa il senso della vista raccolsi, che dalla varietà dell'openioni intorno tal senso ne seguiva parimente grande diversità circa apprendere la verità di oggetti che vi facevano impressione, l'istesso avenire circa l'intelletto che secondo il parere di caduno di antedetti altercanti si differentiava parimente oltre modo il visagio et apparenza dell'intellegibili oggetti, essendo necessario che incontrandosi caduno di questi in diverse constitutioni e nature di intelletti, sortiscano medesimamente in strane rappresentationi e varie apparenze di cose. 
- Others [considered it] a fragment of the World's universal Soul, ${ }^{249}$ a source of life for it:

Led by such tokens and such instances, some have taught that the bees have received a share of the divine intelligence, and a draught of heavenly ether; $; 50$

Virgil Georgics 4.

- Others [considered it] simply to be power borne by an internal material organ. . $^{21}$

- Others generally said that this illustrious faculty called the soul was perfectly placed in a part of the body.

- Yet others spread around that it was like a coachman in a chariot ${ }^{252}$ or the helmsman of a ship, ${ }^{253}$ who assist and lead their mobile abode or portable dwelling.

- Others said that it had originated from a certain agent intellect; [that the soul was] not separate from it, but also not identical to it.

- Others declared that it was nothing other than a portion of that excellent magnet, ${ }^{254}$ induced to say this by the correspondence of aversions and inclinations between the mind and the magnet.

But I would be too prolix if I wanted to meticulously refer to all [the opinions]. And, in conclusion:

- There was also someone who, with daring recklessness, declared that the intellect was a name without a subject and merely a simple activity produced by the combination and separation of the already perceived relics of sensations.

- Yet others considered, with more grounded reason, that it was an immortal essence dwelling in the body. ${ }^{255}$

I have collected and presented all these opinions not because I am inclined to assent to them, but in order to demonstrate the scale of the deficiency of our understanding in acknowledging its own essential nature, while on the contrary it attempts to discover the most hidden and remote [134] causes of the universe.

However, in addition to this, I would like to deduce something else from this discussion. Just as from my previous reasoning on the sense of sight I gathered that from the different opinions towards this sense there similarly follows a wide diversity [of opinions] towards the truth of the objects impressed on it, so the same happens to the intellect. Indeed, according to the opinions of each disputant, the aspects and appearances of intelligible objects were likewise different. Since each of them encounters diverse constitutions and natures of intellects, it is necessary that strange representations and various appearances of things would follow at the same time. 
Risolutione del secondo quesito circa il numero d'intelligenti.

Instanza a favor della moltiplicità d'intelligenti.
Hor dunque ritrovando tali intoppi di irreconciliabili litigi circa l'interno essentiale dell'intelletto, inchiesta che primieramente mi proposi di rinvenire, non arrestai però la mia curiosità, e progredii e continovai l'indagare la resolutione delli altri propostomi quesiti, et al secondo mi condussi, e ricercai se uno solo e singolare fosse quello che come monarca reggesse il sistema humano, overo molti, che a guisa di republica da ottimati governata e retta sia la nostra construttione. Non mancarno di quelli che questo ultimo partito stimarno assai probabile. Per il che pronontiarno che a modo di governo civile, molti fossero li comandanti che a vicenda l'uno all'altro nel prendere il dominio sopra di noi succedesse, al che pare che s'accostasse preclaro poeta mentre che descrivendo una certa flutuatione e perplesità di animo di egregio heroe in tal modo disse:

At pater Eneas casu concussus acerbo,

Nunc huc ingentes, nunc illuc pectore curas

Virgilius V. Mutabat etc.

Dove mostra che non nell'istesso loco dell'interno le cure et i pensieri si mutavano, ma in diverse parti ciò accadeva, [135] et io parimente inanzi ch'affatto sterile divenissi e che per anco con indifferente aversione non regettavo qualunque dogma, a tal parere alquanto inclinavo. A ciò mi moveva, primieramente il rassembrarmi assordo che uno solo regente a guisa del favoloso Proteo e cangiante camaleonte, momentaneamente in tanti diversi e repugnanti modi si mutasse, e che come in uno instante s'accendesse di fervente ira o di cocente amore, e poi in un subito si cangiasse in fredda gelosia overo algente timore. Al che stimare alquanto mi confortava l'osservare che nel sogno si presta l'assenso a molte assertioni che tengono evidenti instanze contrarie e di ciò punto il sognante non se ne avede. Il che io credevo che risultasse, perché quello che riserba in sé la memoria di tali instanze si trova nel sonno sopito, e perciò non s'oppone a tale falsa illusione, ma poi risvegliato abbattendo la fallacia nel sogno concepita, si rimane informato della verità e mendacità del chimerico sogno.

Non altrimente pensavo avenire a delirii di frenetici restituiti alla sanità. Oltre di ciò mi rese proclivo a tal parere l'advertire che doppo l'essere da noi riconosciuta la fallacia di qualche nostra assertione e ch'evidentemente rimane reprobata, nondimeno persevera in noi chi persiste contumacemente in affermarla, né punto si rende pieghevole a regettarla e refiutarla. Da quindi è che mentre carocciamo over navigamo ci appare benché falsamente, che li arbori over i lidi si muovano e da noi si dilunghino: 
Thus, although I had found these difficulties - the consequences of irreconcilable disagreements about the internal essence of the intellect, which was my previous inquiry - I did not restrain my curiosity. I proceeded and continued investigating in order to resolve the other questions that I intended [to consider]. And I turned my attention to the second one and investigated whether there was one sole ruler of the human system, like a monarch, or whether there were many, meaning that our construction was like a republic governed and ruled by optimates. There were those who considered this last position to be very probable. Therefore, they said that like a civil government, there were many commanders who followed one another in exercising control over us. An illustrious poet seemed to come close to this in describing a certain wavering and perplexity in the mind of a distinguished hero. He spoke in the following way:

But father Aeneas, stunned by the bitter blow, now this way, now that, within his heart turned over mighty cares, etc. ${ }^{256}$

Here, he shows that worries become thoughts not in the same internal place, but in different parts. [135] Likewise, before becoming sterile and coming to reject all dogmata with indifferent aversion, I was much inclined to this opinion. What first motivated me was that it seemed to me to be absurd that there was only one ruler who, like the legendary Proteus or an iridescent chameleon, ${ }^{257}$ could temporarily change into many different and opposite semblances, instantaneously lit up with ire or ardent love, and then suddenly turning to cold jealousy or algid fear. Hence, what greatly comforted me was observing that by dreaming, one assents to many assertions which have evidently contrary instances and which the dreamer does not notice. I believed that the reason for this was that the person who retains the memory of such instances is asleep, and therefore he cannot oppose these false illusions; yet once awake, he demolishes the falsity conceived during the dream and becomes informed of the truth or mendacity of the chimeric dream.

I thought that a similar thing occurred with the deliriums of frenetics once they had become sane again. In addition to this, what made me incline to this opinion was to realise that although we recognise the fallacy of some of our assertions, which are evidently refuted, nevertheless there is still someone in us who obstinately persists in asserting them, without being inclined to reject or refuse them. Hence, when we travel in a chariot or ship, it appears to us, although falsely, that the trees or coasts are moving and becoming distant from us: ${ }^{258}$
Resolution of the second question concerning the number of intellects.

Virgil 5.

Instance in favour of the multiplicity of intellects. 
Virgil. III. Provehimur portu terraeque, urbesque recedunt.

Né può quel tale in noi intrinseco a cui tal illusione li rassembra vera, per qualunque efficace persuasione desistere da tal inganno benché ciò si riconosca dal miglior giuditio che in noi si trova, al qual non solamente è manifesta la falacia m'anco la cagione et essordio di essa, cioè che risulta [136] da una tal quale nostra arbitraria suppositione di attribuire ad altrui il motto et a noi la quiete e stabilità. Né vale il rimetter tal fallace openione al senso esterno, poiché questa mendace credenza, non è in esso fondata ma installata in una facoltà discorsiva a cui incombe riconoscere il motto e la quiete delle cose, e come in breve si dirà.

E simile errore parimente ci accade mentre che caminando siamo dal sole illuminati, causandosi perciò ombra sopra la terra, onde ci rassembra moversi l'ombra, ma anzi la luce è quella che progredisce overo retrocede, ch'essendo l'ombra privatione non se li può attribuire né motto né attione alcuna. Altra fallacia anco accade quando miramo la luna offuscata da nube che le sottogiace che ci appare questa ferma stare, e quella velocemente viaggiare e sviluparsi da tal involgio, ché senza punto dubbitare il contrario aviene. Ma la cagione di tal fallacia accade per altro nostro arbitrario supposito, cioè di attribuire la stabilità e fermezza a quello che ci rassembra più d'apparente grandezza, apparendoci continente, e perciò fisso, et il motto assignare al contenuto come minore, onde rappresentandosi la nube maggiore per la sua prossimità e la luna minore per la lontananza, crediamo erroneamente che questa velocemente si move, e quella ferma se ne stia.

E sebbene siamo capaci et informati della cagione di tale illusione, pure rimane in noi, non saprei dire quale contumace assertore, che repugna a tale disinganno, e vuole perseverare nella fallacia. Dal che raccoglievo che non sia l'istesso colui che riconosce l'errore, e quello che ostinatamente l'acconsente, ma che differenti siano, e che l'uno all'altro non comunichi li proprii concetti et openioni. Mi si rendeva anco ciò mediocremente ragionevole dall'osservare, che in molte attioni che tengono bisogno di non poca advertenza nell'esercitarle, la mente principale reggente ad altro abbadi, et in particolare mentre che caminiamo, stando noi eretti sopra un solo [137] piede, dovendosi in tal stato rinvenire nel nostro corpo il centro della gravità sopra il quale egli eretto si sostiene, ritrovamento tanto arduo, benché non pensamo né anco moverci divertendosi la mente ad altri affari. 
Nor will that person inside us to whom this illusion seems to be true desist from believing in this deception through any effective persuasion, although it is acknowledged by the best of our judgments which recognises not only the deception, but also its cause and beginning, namely [136] that it results from our arbitrary supposition of attributing motion to others and quietness and stability to ourselves. It is not even worth attributing this fallacious opinion to the external senses, because this mendacious belief is not grounded in them, but placed in a discursive faculty which has the task of acknowledging the motion and stillness of things, as I will say very soon.

And a similar mistake likewise happens to us when the sun shines on us as we walk and thus causes shadows on the earth. Therefore, the shadow seems to us to be moving, but it is rather the light that moves forwards or backwards. Indeed, since a shadow is privation, we cannot attribute any motion or action to it. Another similar mistake happens when we watch the moon darkened by an underlying cloud: it appears to us that the latter is fixed, while the former is rapidly moving and disentangling from the [cloud's] grasp, when undoubtedly the contrary is what happens. Yet this mistake happens because of another arbitrary supposition that we make, namely that we attribute stability and firmness to what seems to us to be bigger, which appears to be like a container and thus fixed, while we assign motion to what is contained, as [we believe] it is smaller. Therefore, by representing the cloud as bigger because of its proximity [to us], and the moon as smaller because of its distance, we wrongly believe that while the former is moving rapidly, the latter is fixed.

And although we are aware and informed of the cause of this illusion, nevertheless there remains I could not say what kind of obstinate assertor inside us who opposes this disillusion and wants to persevere in error. I gathered from this that the one who acknowledges the mistake and the one who obstinately agrees with it are not the same [person], but that they are different and do not communicate their own concepts and opinions to one another. Also, it hardly seems reasonable to me from beholding that the mind, which is the principal ruler, turns its attention to other things during some actions that usually require a lot of care to perform. Especially when we walk, as we stand on one [137] foot [after the other], the centre of gravity towards which it [i. e., our body] can be sustained must be found in this condition in our body. Although this is very difficult to discover, nevertheless we do not even think about moving, diverting our minds to other businesses. 
Terentius Eunuc.

Openione di Stoici circa la moltiplicità dell'intelletto.

Regetta il parere della moltiplicità di reggenti.
Parevami anco favorire tal dogma la quotidiana esperienza apparendoci, che nell'istesso tempo siamo distratti in varii pareri che insieme contendono per il dominio di noi e sovente nell'istesso instante alla sensualità, et alla riverenza dell'honesto ci chiamano e rapiscono:

\section{Quid igitur faciam? non eam ne nunc quidem \\ Cum accersor ultro? en potius ita me comparem \\ Non perpeti meriticium contumelias? \\ Exclusit: revocat: redeam? non si me obsecret.}

E perciò inclinavo anco a quella openione che per un tempo celebre $\mathrm{fu}$, e doppo divenne ridicola, cioè che qualunque virtù e vitio over openione, che in noi insista fosse animale appartato, per il che seguendo io tal parere stimavo che in noi fosse constituita republica tale, che variando la nostra età cangiasse ancora essa forma e maniera di governo. Onde nel tempo della pueritia e gioventù in guisa popolare fosse retta, non vi essendo né vitio over virtù che alle fiate non tenga nel dominarci la sua alternata vicenda, anzi sovente accade che tutti ad un tratto tumultino per occupare l'imperio di noi, ma poi nella età consistente e virile alla aristocratia overo oligarchia il nostro stato si riduce, havendo il costume già fatto alquanto di presa, perdominandoci alcune virtù over vitii.

Ma non senza alcuna oppositione et altercatione ciò accade, ma ultimamente nella vecchiezza havendo già l'inveterato habito pigliato in noi lo scetro e l'assoluto regimento, ad una totale monarchia over tirannide si [138] divolve il governo, osservandosi l'età senile, constante et affatto retinente d'alcun costume et openione particolare, e tanto nel bene come nel male contumace et inflessibile, essendo per il continuo uso depressi et estinti quelli capi di seditioni che solevano inquietare l'interno stato della nostra vita.

Questo fu quello che in altro tempo circa tal proponimento giudicai alquanto ragionevole, ma doppo che infecondo divenni, mi occorse ciò che accadere suole alli animali bruti, che devenuta la loro prole adulta, di essa punto non li cale. Onde tanto in tal soggetto come circa altri miei dogmi, a guisa di alieni li trattai, spogliandomi verso di loro d'ogni paterno affetto. Anzi come si favoleggia dell'antico Saturno, di essi fui uccisore. Per il che anco l'openione antedetta come contraria alla ragione regettai et espolsi, rassembrandomi molto strano, che noi a guisa di gabbioni e seraglii di varii e feroci animali fossimo constituiti. E per il vero a troppo continue turbolenze sogiacerebbe il nostro genere, tenendo caduno di noi in se stesso una masnada di tanti sediosi e tumultuanti animali. 
It also seemed to me that daily experience was in favour of this dogma, as it shows us that we are simultaneously distracted by various opinions that compete with each other for control of us, which often call to us and captivate us with sensuality and reverence for honesty at the same time:

So what am I to do? Should I not go, not even now, when she invites me of her own accord? Should I rather take myself in hand and refuse to endure the insults of courtesans? She shut me out, she calls me back: shall I go? No, not if she implores $m e .{ }^{260}$

Therefore, I also inclined to that opinion - famous for a while, but later viewed as ridiculous - that every virtue, vice, or opinion was a secluded animal existing inside us. ${ }^{261}$ Hence, by following this opinion, I used to think that there was a republic inside us, constituted in such a way that it could still change its form and manner of governing at different ages. Thus, during childhood and youth, it would be ruled by the people, since vices and virtues alternate with each other in dominating us and rather it often happens that they all rise up at once to take control of us. However, when we are of a firm and virile age, our state is reduced to an aristocracy or oligarchy, since custom has already prevailed, causing some virtues and vices to predominate. Yet this cannot happen without objection or dispute; indeed, only finally in old age does inveterate custom take possession of the sceptre and absolute power, when the government changes into an absolute monarchy or [138] tyranny. Senility appears to be constant and to resist any particular custom or opinion, as well as being obstinate and inflexible, for better or for worse, while those promoters of seditions, who used to upset the internal state of our lives, are depressed and extinguished by continual use.

I judged this as very reasonable in the past, ${ }^{262}$ but as soon as I became unproductive, there happened to me what usually occurs among brute animals, namely that they no longer care for their offspring once they become adults. Thus, I treated this topic like some of my other dogmata, as though they were foreign, ridding myself of any paternal love for them. Rather, I even killed them, as is fabled of ancient Saturn. ${ }^{263}$ Therefore, I also rejected and excluded the aforementioned opinion as contrary to reason: it seemed to me so strange that we could be like great cages or serails of different ferocious animals. ${ }^{264}$ In fact, if each of us kept such a large group of seditious and turbulent animals inside us, humankind would continuously be subjected to excessive tumultuousness.
Terence, The Eunuch.

Opinion of the Stoics about the multiplicity of the intellect.

The opinion of the multiplicity of rulers is rejected. 
Né crederei che nel spettacolo che già alcuni mesi per trattenimento del popolo ateniese, rappresentò il nostro Alcibiade, vi si ritrovasse tanto numero di ferigni animali quanto che nel nostro interno, conforme tal parere si annidarebbe, essendo appo la natura diffinite le spetii di animali, ma non giammai si ha potuto terminare li generi di vitii, come anco le strane openioni che nella mente humana possono capire. Oltre che se conforme la antedetta openione si ritrovassero rachiusi in noi tanta varietà di animali, non mi saprei rassembrare che ad un istante si potessero ridurre sotto l'imperio d'uno dominante, e massime non essendo questi capaci di retta ragione e non potendo passare, come fu detto, li discorsi dell'uno, all'intendimento dell'altro.

Ma n'anco stimarei che tal obedienza fosse prestata per violenza e sforzo, non potendomi imaginare con [139] quali arme, organi, et adminicoli il vittorioso sottoponesse li oppressi e vinti. Ma nondimeno havendo riguardo alle primiere instanze addotte per tale parere, non poteva io admettere in noi un solo dominante e despotico arbitro, onde a guisa di Euripo in continuo influsso e reflusso di contrarie instanze agitava il mio animo. Ma mentre che io pendente fra questi repugnanti pareri flutuavo, occorsemi Archelao, che pretendeva introdurre certa transatione fra le due estreme opinioni, giudicando egli probabile che tre rettori principali fossero proposti al nostro governo, la ragione, l'irascibile, et il concupiscibile, e che fossero construti et insieme annodati a guisa di portentoso tricipite Cerbero, in maniera che questi tre capi siano fondati e radicati ad una comune stirpe, onde l'irascibile e concupiscibile fossero a guisa di rami, e la ragione di tronco e l'animo del tutto la fondamentale radice:

Nascenti cui tres animas feronia mater

Horrendum visu dederat terna arma mouendo

Virgilius. Ter laeto sternardus erat.

Tal dogma posto dunque alla censura, parevami, che calcando una mediocre via per scansare l'inconveniente che alli altri dogmi accadevano, piuttosto partecipasse delli assordi di ambi li pareri. Né mi sapeva parimente bene formalizare in che maniera il concupiscibile fosse distinto della ragione, se l'oggetto di quello sovente è la bellezza, la gratia e proportione di motti, la destrità del conversare, et apparenza di buoni costumi, non potendomi raffigurare in che maniera tali oggetti ad altra facoltà che alla intellettiva appartenessero, né che potessero esser appresi. Non sortisce la bellezza dalla simetria di membri e temperie di colori come anco la gratia da un aveduto e modesto modo di attegiare? Ma che forse ciò [140] dalla dissoluta e pazza concupiscenza 
Nor would I believe that one could find as many feral animals in the exhibition that Alcibiades presented to the Athenian people a few months ago as there would have to be inside us according to this opinion. ${ }^{265}$ Indeed, while in Nature there is a definite number of species of animals, it is not possible to define every kind of vice or the strange opinions that the human mind may have. Furthermore, if, in accordance with the aforementioned opinion, there were so many different animals secluded inside us, I could not imagine how they could suddenly be submitted to the control of one dominant one, especially as they are not endowed with right reason ${ }^{266}$ and the discourses of one cannot be transferred to the understanding of another, as we said.

Yet I do not even think that they would obey through force and violence, because I cannot imagine [139] what weapons, devices, or instruments the winner would have to use to subjugate those he had oppressed and defeated. Nevertheless, because I was paying attention to the first instances put forth in favour of this opinion, I could not accept that there was only one dominant and despotic arbiter inside us. So, like Euripus, ${ }^{267}$ the continuous ebb and flow of contrary instances was agitating my mind. However, while I was oscillating between these contradictory opinions, Archelaus rushed to my aid by presuming to find an agreement between these two opposite opinions. He considered it probable that there were three main regents who ruled us, namely reason and the irascible and the concupiscent parts, ${ }^{268}$ built and tied together like a portentous three-headed Cerberus. In this way, these three heads were grounded and took root in the same lineage, so we should consider the irascible and the concupiscible as branches, reason as a trunk, and the soul as the fundamental root $^{269}$ of the whole:

Birth his mother Feronia had given (awful to tell!)

Three lives with threefold armour to wear -

Three times he had to be laid low in death; $;^{270}$

Virgil.

It seemed to me that although this censured dogma was following a middle path in order to avoid the same inconveniences that had occurred for the other dogmata, it nevertheless fell into the absurdities of both opinions. Similarly, I could not easily conceive how the concupiscent was separated from reason, since its object is usually beauty, grace, and proportion of motion, dexterity in conversation, and the appearance of morality. I could not imagine how these objects could belong to a different faculty from the intellective and be similarly apprehended. Beauty comes from a symmetry of limbs and a proportionate mixture of colours, just as grace comes from a careful and modest way of behaviour, does it not? Might it be possible that this [140] is beheld 
è osservato et appreso? Ma oltre di questo li solertissimi machinamenti, accorte stratagemme, che praticano li amanti per conseguire il bramato loro desio, non avanzano qualsivoglia pensamento militare che perito capitan per sorprendere et espugnare munitissima fortezza usare suole?

Arte cita, veloque rates remoque reguntur

Arte, levis currus, arte, regendus amor.

Né facilmente mi potevo persuadere che l'intelletto, principale corifeo e duce dell'humano sistema, ché questi tale lo fingono, e che per sua natura si oppone alle dissolutioni della sfrenata concupiscenza, inavedutamente tradisca se medesimo, soministrando alla istessa concupiscenza, non solamente l'oggetto, ma anco li modi di conseguire quello che tanto sfuge et abhorisce? Eppur è in sua balia il sottraherle il vigore e rendere ineficace tali sue intraprese e ridurla consternata et enervata. Non dissimile avenimento accade circa l'irascibile, essendo l'honore il principale impulsore di tale perturbatione. Ma l'honore da chi altro che dall'intelletto può essere ideato e riconosciuto?

Ma oltre di ciò giamai a sufficientia ho potuto riconoscere in qual maniera si accopiassero l'irascibile, concupiscibile e ragione insieme, ché havendo li doi primi antedetti per loro soggetto, tenue spirito, in che modo si congiungono che non si confondino? Le cose fluide si mescolono non si legano et insieme aggropano. Tanto meno ciò riesce admessibile rispetto alla mente di conditione molto più di essi spirituale, et affatto immateriale.

Per il che io non appagandomi di alcuno delli antenarrati pareri, altro da ciò non raccolsi se non la recognitione del nostro infelice stato, mentre da mente superiore non è illuminato, non sapendo né anco doppo una tal ventilata discusione et agitato dibattimento, discernere se il totale governo di noi sia retto da monarca [141] alle fiatte saggio, e sovente anco pazzo, et insano, overo piuttosto governato da una turba di diversi animali alcuni ragionevoli, et altri affatto dishumanati, oppure siamo soggetti ad un monstro moltiplice, e tricipite, essendo sorti fra le miserie vicina alla suprema, servire e non sapere a cui. Et a confessare il vero mi rassembra l'huomo mentre si trova assalito da alcuna gagliarda perturbatione, simile a colui che advertendo al buio nella propria casa il puzzo e noia del fumo, non accertandosi ove il fuoco si annida, se nella sua habitatione, overo nel vicinato, vi accorre con l'acqua, et a caso il tutto scialaquando, sovente riesce vana ogni sua fatica. Così 
and apprehended by dissolute and mad concupiscence? In addition to this, the very clever and careful machinations, the cautious stratagems practised by lovers in order to achieve their yearned-for desire, only put forth the same military device usually adopted by an expert captain in order to surprise and conquer a well-armed stronghold, do they not?

By skill swift ships are sailed and

rowed, by skill nimble chariots are driven: by skill

must Love be guided..$^{271}$

I could not even persuade myself that the intellect, the main coryphaeus and leader of the human system, as these people claimed it to be, and the natural opponent of the unrestrained dissoluteness of concupiscence, might imprudently betray itself by giving to that same concupiscence not only the object, but also the means to achieve what the intellect greatly avoids and abhors. However, it is in its power to remove its [i.e., concupiscence's] vigour and to make its enterprises ineffective, as well as to dismay and weaken it. This is also the case for the irascible, since honour is the main impulse to such perturbation. Yet who other than the intellect could conceive and acknowledge honour?

However, in addition to this, I have never sufficiently acknowledged how the irascible, the concupiscent, and reason might fit together. Since the aforementioned first two have a feeble spirit for their own constitution, how do they combine without merging with one another? Fluid things do not bind and entangle with one another, but meld. Least of all would this be acceptable for the mind, which has an even more spiritual and immaterial condition than these.

Hence, not satisfied by any of the aforementioned opinions, I gathered from this only the acknowledgement of our miserable state when it is not enlightened by a superior mind. ${ }^{272}$ After having put forth this discussion and fervent debate, I could not even understand whether our entire government was ruled by a monarch - sometimes wise, but often also mad and insane - [141] or rather by a crowd of different animals, some of them reasonable and others indeed inhuman, or whether we were subjected to a monster with multiple [faces] and three heads, having received by Chance the closest to the supreme misery: to serve without knowing whom we are serving. To be honest, it seems to me that a man assailed by a strong perturbation is like one who perceives a sudden smell of burning in the darkness of his home, and, without verifying where it is coming from, whether from his home or elsewhere in the neighbourhood, rushes in with water and throws it everywhere at random. Often, he exhausts himself in vain. Similarly, 
Esame circa l'attioni della mente.

Boetio Liber V, metro 4.

Parere di quelli che stimano l'intelletto attivo. noi sorpresi dall'ardore della concupiscenza over fervore dell'ira, vi si appresentamo con la ragione per amorzare tal incendio, eppur da noi non si conosce per anco, in qual facoltà accade l'incendio.

Da tal non sortita indagine, circa il numero di nostri interni reggenti e dominanti, mi applicai a riconoscere quali siano l'attioni della mente, il che stimai che riuscire mi dovesse non molto difficile, non sospettando, che ciò che tanto ci è famigliare ignorassimo. Ma in questa incombenza deliberai lasciare a parte, il considerare ciò che sia l'istesso sapere, havendomi a questo destinato particolare esame, onde il mio impiego fu circa l'universale delle sue attioni. Nel primo adito di tal discussione ritrovai, chi apertamente negava all'intelletto attione alcuna, affermando che fosse semplice potenza, pigra, et inerte facoltà, disposta solamente a ricevere li influssi che per mezo di sensi esterni da oggetti l'è distribuito, e mandato, non ritenendo altra potestà che di risentirsi di tali impressioni, le quali sono dalla natura così bene seriate e regolate, mentre l'invia, che non tengono bisogno che l'intelletto le congiunga et amassi, o le disgiunga e divida, assomigliandolo l'autore di tal dogma, ad ostrica marina, che stando affissa ad un sasso di altra facoltà non si trova dottata che d'aprirsi e rachiudersi: [142]

Quondam porticus attulit
Obscuros nimium senes
Qui sensus et imagines
E corportibus extemis,
Credant mentibus imprimi
Ut quondam celeri stilo
Mos est equore pagine
Quae nullas habeat notas
Pressas figere litteras.

Ma non rimasero perciò altri che di tal parere non poco si risero, stimando indecente che l'humana mente, inspetrice o per dir meglio giudicatrice dell'egregie e meravigliose bellezze dell'universo, destituta fosse d'ogni energia et attività. E tanto più mi riusciva ciò impersuasibile, quanto repugna a ciò l'esperienza, riconoscendoci dotati di efficace attione nel comporre, dividere et ordinare diverse propositioni e da essi raccogliere nuove et inopinate conclusioni, aggiungendole questi fautori della mente, la construttione di universali non a tempo né a loco alligati, la cui struttura non può da sensi esterni né interni derivare, e sortire, essendo questi corporali e materiali. Ma bene essi 
when we are surprised by concupiscence's ardour or ire's fervour, we represent it using reason in order to dampen the fire. However, we do not even know in which faculty this fire is burning.

After this unsuccessful inquiry concerning the number of our internal rulers and lords, I applied myself to acknowledging the actions of the mind, which I supposed to be not such a difficult task, without suspecting that we are mostly ignorant of what should be so familiar to us. However, I resolved to carry out my task, laying aside the inquiry into what that knowledge itself was, having in mind a particular test for it. Therefore, my commitment was about the universality of its [i.e., the mind's] actions.

At the beginning of this discussion, I encountered someone who openly denied any action of the intellect. He stated that it was a simple potency, ${ }^{273}$ a lazy and inert faculty, capable only of receiving influences sent and distributed by objects by means of the external senses. He acknowledged only the capacity to be affected by these impressions, which were so well-ordered and organised by Nature as it sent them that they did not even need the intellect to connect and group them or to disjoin and divide them. The author of this dogma considered the intellect like an oyster, ${ }^{274}$ which, staying fixed on a stone, was only endowed with the faculty of opening and closing itself: [142]

\author{
Sometimes the Porch has brought into the world \\ Some very obscure old philosophers, \\ Such as think sensible images \\ From bodies outside themselves \\ Are impressed upon men's minds; \\ As at times with swiftly-moving stylus \\ Men are used to print the blank space of a page \\ Which has no marks \\ With impressed letters. ${ }^{275}$
}

Yet there were others who greatly derided this opinion, considering it unacceptable that the human mind, the investigator or rather the judge of the excellent and marvellous beauties of the universe, should be relieved of all energy and activity. The more it diverged from experience, the less it convinced me, as it was evident that we are endowed not only with the effective capacity of combining, dividing, and ordering different propositions, but also of gathering new and unexpected conclusions from them. These supporters of the mind furthermore attributed to it the capacity to form universals, whose framework, as it is disjointed from time and space, cannot derive or result from the external and internal senses, as they are, on the contrary, bodily and material. Thus, [according to them,] the universals turned out to be
Examination of the actions of the mind.

Boethius bk. 5 , metre 4 .

Opinion of those who consider the intellect as active. 
Consequenza che risulta dalle dette due opinioni. universali riescono degno parto della mente spirituale, et immateriale, aggiungendo di più che la facoltà reflessiva che tiene la mente in ragirarsi sopra se stessa, bene indica, che di egregia e straordinaria conditione sia dottata, attione che a qualunque altro agente naturale è dinegato:

Sed mens si propius vigens
Nihil motibus explicat
Sed tantum patiens iacet
Cassasque in specula vicem
Rerum reddit imagines
Cernens omnia notis
[143] Quae vis singula prospicit
Aut qui cognita dividit
Qui divisa recolligit
Alternumque legens iter?
Nunc summis caput inserit
Nunc decidit in infima
Tam sese referens sibi
Veris falsa redarguit?
Haec est efficiens magis
Longe causa potentior
Quodque materie modo
Impressas patitur notas.

Da quali due contrarie openioni, diversità non disprezzabile risulta circa la sufficientia dell'homini, ché se l'intendimento è passione, l'animi maggiormente passibili e fievoli riusciranno li più intelligenti, e per consequenza meno attivi, ma s'egli è attione li animi più galiardi e vigorosi sortirano li più discorsivi, e perciò parimente anco più agili et esecutivi.

Non mancorno delli altri che procurando fra li estremi pareri destregiare, constituirno in noi nuovo e monstruoso hermafrodito, cioè una essentia che tenisse due facoltà, l'una maschile, et attiva, e l'altra feminile, patiente, e recetiva. Ma tuttavia questi tali transatori participavano dell'incomodi dell'uno et altro delli estremi dogmi, e benché stimassero di evitarli con li nomi di facoltà e potenza, stimando che sebbene contrarie fossero, nell'istessa essentia instalare e mescolare si potessero, nulla dimeno a mio credere poco giovarno.

Ma io non essendo difensore né oppugnatore di alcuno di detti pareri, non mi conviene che in ciò mi onoltri e trapassi. Solamente da tal racconto dedurre voglio, che a tal segno giunge l'inscitia dell'intelletto, che resta dubbioso e perplesso in terminare, se egli eserciti le sue 
worthy products of spiritual and immaterial minds. They furthermore added that the mind's reflective faculty amply showed, in folding upon itself, ${ }^{276}$ that it was endowed with an excellent and extraordinary condition denied to any other natural agent:

\author{
But if the mind, with the strength of its proper motions, \\ Nothing unfolds, \\ But merely passive lies \\ And like a mirror but reflects \\ The empty images of things, \\ Whence then this all-discerning common concepts? \\ [143] What power singulars perceives, \\ Or what power all things known divides? \\ Things thus divided what collects again, \\ And taking either way in turn \\ Now lifts its head to highest things \\ And now to lowest things descends, \\ Then to itself returning \\ Falsehood refutes with truth? \\ This is an efficient cause \\ More powerful by far \\ Than that which passively receives \\ Only the impressed marks on things material. ${ }^{277}$
}

From these two contrary opinions, there resulted substantial diversity about the capacities of humankind, because if understanding is a passion, then the weakest and most passive minds will turn out to be the most intelligent, and consequently the least active; yet if it is an action, then the strongest and most vigorous minds will result as the most rational and, consequently, the most agile and active.

There were also others who, in trying to find a solution between these opposite extreme opinions, devised a new and monstrous hermaphrodite, ${ }^{278}$ namely an essence with two faculties, one male and active, and one female, passive, and receptive. ${ }^{279}$ Nevertheless, these combinations dealt with the disadvantages of coming from these two opposite dogmata. ${ }^{280}$ Although they were convinced that they had avoided them through the definitions of faculty and potentiality indeed, even if they were contrary to each other, they could have been settled and mixed into the same essence - nevertheless, they hardly benefitted at all, in my opinion.

However, since I am neither a defender nor an opponent of any of the aforementioned opinions, it is not worthwhile for me to continue discussing this. From this story, I only want to deduce that the intellect's ignorance reaches such a level as to remain doubtful and perplexed in determining whether it carries out its

Consequence resulting from the aforementioned opinions. 
Esame di particolari offitii dell'intelletto. fontioni et operi over d'altrui è mosso, se mottore over mobile sia, [144] inscitia che supera ogni ignoranza et inettia. Ma di più inquirendo li suoi officii lo ritrovai circa essi tanto ignaro, e pravamente informato, a segno tale che le sue proprie fontioni ad altrui attribuisce e con indiretto giuditio defrauda se stesso dal pregio delle sue proprie attioni.

E per il vero non crederei giammai, che pittore tanto sciocco si ritrovasse che mentre egli con la propria mano disegnasse li primi rudimenti della futura pittura, che erroreneamente stimasse, che ciò fosse eseguito dal servo over fantesca. Ma che ciò intervenga all'intelletto lo rende manifesto l'apprensione di quelli oggetti che sensibili comuni volgarmente sono appellati. Principali fra essi sono la grandezza, figura, numero, motto, quiete, sito e distanzia, et altri simili, ché per esser questi volgarmente stimati che da sensi appresi siano, il nome di comuni conseguirno, e benché impropriamente ciò ottennero, tuttavia vario fu il parere di sapienti a cui appartenesse la loro recognitione.

Stimorno alcuni che conforme risuona il loro nome, a sensi esterni la loro apprensione incombesse, mossi a ciò dall'osservare che sentito che sia dall'occhio il colore, s'apprende la grandezza, figura, numero, motto, quiete, et altri simili conditioni che ad oggetti attengono, non infraponendosi alcuno sensibile interstitio di tempo osservabile nel quale s'eseguisce circa essi il discorso della mente. Ma perché li fautori di questa openione si ritrovano impediti da gravi difficoltà, fu openione di alcuni di sapienti benché non molti in numero, che la cognitione di tali oggetti fosse fontione del discorso intelletuale, e che l'organo, per essempio, visivo d'altro non sia capace che del colore suo proprio oggetto, e che la grandezza della dimensione, dalla sucessione continuata che fa il senso sopra l'oggetto visibile, benché ciò sia da noi inosservabile, il discorso interno deduce e riconosce.

E chi può di ciò dubbitare non essendo il motto e la successione appo noi apprensibile se non [145] per le sue portioni che li construiscono, cioè il già trascorso, e quello che è per trascorrere? Lapprensione di cui appartiene al senso interno, non all'esterno, che solamente dal presente oggetto si move e rimane impresso, riuscendo in tal affare parimente il senso del tatto simile al senso visivo, ché per il certo per mezo del flusso del tangente sopra il tangibile, il discorso apprende la quantità dell'oggetto. Così anco dalla cognitione che si tiene della dimensione di oggetti agevolmente alli altri asserti sensibili comuni il discorso interno progredisce. 
functions and works by itself or whether it is moved by someone else; whether it is motor or moved. [144] This ignorance exceeds any other ignorance or ineptitude. Yet by inquiring into its [i. e., the intellect's] functions, I found it to be so unaware of them and so poorly informed about them that it would attribute its own functions to others and, through an indirect judgment, defraud itself of the merits of its own actions.

In reality, I cannot believe that there is a painter who, when he draws the first sketch of a future painting with his own hand, ${ }^{281}$ would be so foolish as to erroneously consider this [action] to be being carried out by a servant or maid. Yet the apprehension of those objects which are commonly called common sensibles shows that this occurs to the intellect. ${ }^{282}$ The main ones are size, shape, number, motion, rest, position, distance, and the like. As they were commonly considered to be apprehended by the senses, they were given the name of "common." Furthermore, although they acquired this [name] improperly, nevertheless, the opinions of wise men differed concerning who was liable to acknowledge them.

Some considered them to have been appropriately named, as the external senses had the task of apprehending them. They were motivated to [think] this by observing that just as colour is perceived by the eyes, so they also apprehend size, shape, number, motion, rest, and other similar conditions pertaining to objects. Indeed, there is no observable space of time between them in which the discourse of the mind might be carried out. However, the supporters of this opinion were hindered by serious difficulties: the opinion of some wise men, albeit only a small number of them, was that the cognition of these objects was up to the function of the intellect's discourse. Furthermore, [they believed] that the visual organ, for example, was able to [acknowledge] only colour as its own object. Besides this, [they believed] that the internal discourse deduced and acknowledged the size of the dimension through the continuous passage of the senses over the visible object, even though we cannot observe this ourselves.

Furthermore, who may doubt this, as we cannot apprehend motion or sequences, [145] but only the portions constituting them, namely that which has already happened and that which will happen? Apprehension pertains to the internal senses and not the external ones, which are only moved and impressed by the present object. Likewise, in such a situation, the sense of touch turns out to be like the eyesight. Certainly, by means of the flow of the tangent over the tangible, the discourse apprehends the dimensions of the object. Similarly, once it knows the object's dimensions, the internal discourse will easily pass from it to the asserted common sensibles.
Examination of the particular tasks of the intellect. 
A questo parere assentiscono li prospetivi che havendo congionto le demostrationi matematiche alla esperienza naturale arrecano alcun peso a detta openione, benché forsi in ciò troppo alle matematiche attribuirono, poiché la quantità della dimensione, situationi e lontananze di oggetti visibili dalla dottrina di triangoli dedussero, scientia che oltre modo eccede la capacità di idioti, fanciulli, et animali irragionevoli.

Ma tornando all'inscitia dell'intelletto circa le sue proprie attioni, osservatione molto più notabile in tal proposito accade nel riconoscere la vera situatione delle parti del visibile, che intersecandosi nell'humore glaciale posto nel mezo dell'occhio, le linee dell'imagini che dall'oggetto sono inviate alla membrana rettina vero organo visivo, cangiando per cagione di tal incrociamento situatione nella detta membrana, riesce il destro sinistro, et il superiore inferiore. E nondimeno il retto discorso della mente non si lascia in ciò ingannare, ma con aveduto accorgimento emenda tal falacia e riconosce la vera positura dell'oggetto, nella quale realmente si ritrova.

Eppure tale osservatione a' sensi la mente attribuisce senza advertire di esserne essa l'autrice et opefice, credendo ciò non solamente la turba delli idioti, e volgari, ma anco molti che nella classe di sapienti sono annoverati, stimando essi che dall'organo [146] sensitivo e visivo ciò appreso sia. E quello che rende alquanto di stupore è, che della grandezza, numero, distantia, sito delli oggetti, non solamente li fanciulli, ma li sognanti, e deliranti, e di più li animali stimati da noi incapaci di ragione, appieno sono informati. Ma quello sopra ogni altro in tal proposito riesce mirabile, portentoso, e che maggiormente argomenti la inscitia dell'intelletto è, che egli esercitando un tale suo giuditio circa il sito e distantia di certo tale oggetto, che pur tuttavia giamai per anco con ogni solertia che vi s'habbia impiegato, non si ha potuto investigare d'onde li deriva tal giuditio, e da quali principii egli con sì ferma assertione lo deduce e raccoglie.

Questo è il riconoscimento della cagione per la quale esso giudica che il loco dell'oggetto nella visione riflessiva, si ritrova nell'intersecamento della linea della reflessione prolongata insino l'incontro del cateto over perpendicolo che dall'oggetto cade, onde perciò nel spechio concavo alcune volte occorre dietro di lui, alle fiatte nella sua superficie, et anco alcuna volta anteriormente fuori di esso verso l'occhio ribalza. E siccome nella visione diretta come si ha detto, non all'occhio appartiene la recognitione della distantia e sito dell'oggetto, così parimente nella riflessa ad esso ciò attribuire non si deve, ma sì bene che il discorso della mente solamente di tal finta apprensione ne sia opefice, 
The perspectivists ${ }^{283}$ were of this view; indeed, they agreed with the aforementioned opinion by combining mathematical demonstrations with natural experience. However, they perhaps attributed too much to mathematics, since they deduced the size of the dimensions, positions, and distances of visible objects from the doctrine of triangles, ${ }^{284}$ a science which considerably exceeds the capacities of idiots, children, and irrational animals.

Yet returning to the intellect's ignorance concerning its own deeds, we will have a more remarkable observation in this respect when the true position of the parts of the visible, which intersect in the glacial humour positioned in the centre of the eye, is acknowledged. ${ }^{285}$ The lines of the images sent by objects to the retina, the true visual organ, change their position in the aforementioned membrane because of this crossing, and thus what [appears to be] on the right turns out to be on the left, and [what appears] higher [turns out to be] lower. Nevertheless, rational discourse does not allow itself to be deceived concerning this, but carefully corrects this fallacy and acknowledges the true position in which the object is actually located.

However, the mind attributes this observation to the senses without realising that it is itself the author and architect of it. Not only does the crowd of idiots and common people believe this, but also many who are included among the category of wise men. Indeed, they consider that this is apprehended by [146] the sensory visual organ. Furthermore, what is rather astonishing is that not only children, but also dreamers and delirious people, and moreover animals, which we consider irrational, are fully informed of the size, number, distance, and position of objects. Yet what turns out to be admirable, wonderful, and most able to argue [in favour of] the intellect's ignorance above all other things in this respect is that although it practises its judgment on the position and distance of a specific object and diligently applies itself to it, nevertheless, it has never been able to investigate where this judgment comes from and what the principles are from which it may deduce and gather it with such firm assertion.

This is the reason why it judges the position of the object within the reflected view to be at the intersection of the line of reflexion extended up to the cathetus or perpendicular to the object. Therefore, with a concave mirror, this sometimes happens behind it, sometimes on its surface, and sometimes it bounces off it - from the front - to the eyes. Furthermore, just as in direct vision, as we have said, the acknowledgement of the distance and position of an object is not the task of the eye, so this must not be attributed to it during reflexion. However, the mind's discourse is the only author of this supposed apprehension, 
Democrito ribambito prezzato e lodato. e nondimeno egli non sa rinvenire qual sia la ragione che lo impulsa e che lo induce a ciò stimare, né per qual via si conduce a formar tal giuditio, ancorché sia credibile che mentre eravamo fanciulli e che principiavamo a discernere il sito e distantia delli oggetti, di tutto ciò fossimo affatto informati, et instrutti, ma per la lunga consuetudine ci siamo resi inadvertiti delle dedutioni et illationi che produssero in noi tal estimatione.

Per il che sovente ho giudicato che mentre noi scientemente operiamo alcuna cosa, non ne teniamo [147] per anco l'intiera peritia, ma sì bene quando che senza nostra osservatione la eseguimo. E di più ho stimato che il sapere operare altro non sia che uno accorgimento che segue immediate doppo la produttione dell'effetto, che advertimo riuscito e corrispondente alla idea che già si formò nella mente, come, quando non s'assomiglia, rimaniamo conscii della nostra inettia et imperitia, di modo che il continuato esercitio e perseverante habito è quello solamente che ci dispone et addestra nell'operare.

E perciò cominciai a dubbitare che lo stimare che il bene operare rissulti dalla cognitione che si tiene e che regge le attioni, fosse certa complicatione di contrarii, perché giudicando io allhora che il sapere fosse una spetie di risentimento e passione, io credevo anco per consequenza che con l'attione identificarsi et unire non si potesse. Onde secondo questo discorso appariva che la peritia dell'operare derivi dalla reiteratione dell'attioni, non dalla cognitione. Ma alquanto io sono dal mio proponimento digredito, onde ritornandovi dico che mi apparisce che solamente li fanciulli, che di tal consuetudine e habiti sono privi, stimare si devono riconoscitori di motivi che l'inducono a formare l'antedetti giuditii. Per il che il saggio Democrito essendo giudicato da suoi Abderiti pazzo, e perciò da essi per improperio appellato vecchio ribambito, egli ciò annoverò fra suoi elogi et encomii, stimando che la vera humana filosofia, altro non essere che ribambire e riassumere quelli primi principii che produssero in noi tante farragini di positioni che giudicandole noi affatto da sensi esterni derivare le giudicamo invincibili et indubitabili. Ma tale speculatione siccome non mi arrecò alcuni lume e chiarezza, circa la recognitione delle attioni dell'intelletto, così per il contrario mi suggerì non poco di modestia nello sopportare l'altrui errori et incogitanze.

Per il che divenii molto più facile a patientare li falli di [148] Xan|tippe mia moglie e le difalte della fantesca, né giammai più come solevo le rimproverai che non sapessero ciò che si facessero, ritrovandomi conscio che anco la mia mente benché per il corso di tanti anni 
but it cannot find the reason that spurs and induces it to consider it and how it comes to form its judgment. Moreover, it is incredible that when we were children and starting to discern the position and distance of objects, we were well-informed and instructed about all of this, yet because we have had this habit for a long time, we became unaware of the deductions and inferences responsible for having produced these considerations in us.

Therefore, I have often thought that when we undertake an action consciously, we do not have [147] as complete a knowledge of it as we have when we carry out [a deed] without being aware of it. Furthermore, I decided that being aware of acting is nothing more than the awareness immediately following the produced effect, as we notice that it results from and corresponds to the idea that we have already formed in our minds. As it does not look like it [i.e., the idea we have already formed in our minds], we remain aware of our ineptness and incapacity. In this way, only continuous exercise and a persevering habit dispose and train us to undertake actions.

Thus, I began to wonder whether considering that acting in the right way results from the cognition we have, which rules our actions, was rather a specific combination of contraries. As I judged at that time that knowledge was a kind of affect or passion, I consequently believed that it could not be identified as or connected with action. Therefore, in accordance with this argument, it seemed to be that expertise in acting was derived from the reiteration of actions and not the cognition [we have of them]. However, as I have greatly digressed from my proposal, in order to return to it I will say that it seems to me that only children, who lack these consuetudes and habits, must be considered able to acknowledge the reasons inducing them to form the aforementioned judgments. Hence, the wise Democritus, considered mad by his people in Abdera and insulted with the name of "foolish old man,"286 included this among the praise and commendation [he received]. Indeed, he was of the opinion that true human philosophy was nothing more than going back to being children and once more taking those first principles which produced such a jumble of opinions in us that we judged them incontestable and unquestionable because we believed them to be coming from the external senses. Yet this speculation did not provide me with any illumination or clarification concerning the acknowledgement of the intellect's actions, but rather substantial modesty in tolerating the mistakes and ignorance of others.

Hence, it became easier for me to tolerate the mistakes of my wife [148] Xanthippe and the errors of my maid. I did not reproach them for not being aware of what they were doing as I would have done before. Indeed, I realised that my mind, even if it had been well-trained in
The foolish Democritus appreciated and praised. 
Esame circa il loco ove risiede l'intelletto. esercitata fosse nelle dottrine, sovente non apprende ciò che si faccia, essendo ridotta a tal estrema imperitia, che non discerne né anco se nel speculare operi over patisca.

Hor dunque ritrovando l'indagine dell'intelletto tanto inviluppata et impedita, mi risolsi a guisa di giudice che in alcuna causa sia perplesso, che per prenderne maggiore informatione sopra il loco che verte la contesa si conduce, così anco io deliberai capitare al proprio domicilio ove tiene l'intelletto la sua residenza. Ma non essendone io di ciò troppo informato ne ricercai li sapienti, né da essi riportai alcun certo raguaglio:

- Alcuni pronontiarno che il suo hospitio fosse nel cuore, celebre officina del sangue più spiritoso, poco curandosi questi, della continua agitatione del continente cuore, et inquieta circolatione del contenuto sangue.

- Altri lo confinarno nelli ventricoli del celabro, loco piuttosto destinato a scaricarvi li escrementi di quella humida e fredda regione, che ad altro spiritual officio.

- Vi fu chi lo sequestrò nelle membrane che circondano il celabro fra quelli invogli di arterie, che la ordiscono.

- Altri a loco più particolar del capo fra le ciglia lo detrusero.

- Altri nella inquiete diaframma constituirno la sua stanza, contendendo che ove si origina la frenesia, collocare si deve anco il discorso della ragione.

- Vi fu chi ardì appropiarli loco nella bocca del stomaco admonito dalla isquisita e dolorosa sensatione di quella parte quand'è offesa.

- Altri in tutto lo spirito che per angustissimi meati di nervi scorre, lo distribuirno.

- Altri tutto per tutto il nostro corpo e tutto in qualsivoglia parte di noi lo constituirno.

- Finalmente vi furono alcuni di più temerario proponimento che anco fuori di noi havesse habitatione, non essendo dal nostro corpo affatto [149] circonscritto e terminato, forse a ciò persuasi dalla maniera che s'esercita la visione, che in parte tanto remota, secondo l'openione della eiaculatione di raggi, eseguisce il suo risentimento, oppur mossi dalla continua inspiratione dell'aria, che con il nostro animo si coniunge et amassa. Da tali controversie alcuni a maggior insania spinti per satisfare in parte a tutti li antedetti altercanti pronontiarno che, non potendosi ritrovare per le contraposte instanze nelli lochi già detti, che in niuno affatto 
learning over so many years, also often did not apprehend what it was doing and was in such extreme ignorance as to be unable to discern whether it was active or passive during speculation.

Then, as my inquiry into the intellect turned out to be so entangled and hindered, I decided to act like a judge who, perplexed about a charge, goes to the place where the dispute is being conducted in order to collect more information. So, I decided to address the domicile where the intellect ${ }^{287}$ has its dwelling. ${ }^{288}$ However, since I was not well-informed about this, I asked the wise men, but did not receive any certain information from them:

- Some said that its home was the heart, known as the workshop of the more spiritic blood, but they did not consider the heart's continuous agitation to also contain the restless circulation of the blood contained [in the heart]..$^{289}$

- Others confined it to the ventricles of the brain, a place more intended for depositing the excrements of humid and cold reason rather than for a spiritual function. ${ }^{290}$

- There were also those who secluded it in the membranes surrounding the brain, among those nets of arteries weaving around it. ${ }^{291}$

- Others placed it in a more particular part of the head, between the eyebrows. ${ }^{292}$

- Others constituted its place in the restless diaphragm, arguing that the discourse of reason must be located in the same place that frenzy originates. ${ }^{293}$

- There were also those who dared to consider the pit of the stomach $^{294}$ as the proper location for it, because they were inspired by the typical ${ }^{295}$ and painful sensation [generated by] this part when it is harmed.

- Others located it in the spirit flowing through the very narrow meanders of the nerves. ${ }^{296}$

- Others constituted it to be throughout the entire body and in every part of us. ${ }^{297}$

- Lastly, there were also some who recklessly [considered] it to have its dwelling outside us and not to be circumscribed or limited by our bodies. [149] They were perhaps persuaded of this because of the way in which the eyesight works: indeed, according to the opinion of the emission of the rays, it can reach very remote places. Alternatively, they were motivated [to believe this] by the continuous inhalation of air, which thus joins and connects our minds. ${ }^{298}$

- Some were spurred to a greater insanity by these controversies: in order to partly satisfy all the aforementioned disputants, they said that as it could not be found in the aforementioned places because of the contradictory instances, it dwelled nowhere and that [what
Examination of the place where the intellect has its location. 
Esame circa il tempo o circa l'intelletto nel discorso. dimorasse e che la mente altro non fosse che uno semplice esercitio delle reliquie delle sensationi.

Ma circa tal inchiesta anco deluso rimasto, seguii a considerare il tempo con che esercita esso intelletto le sue fontioni, circa di che, non meno che nelle antedette inquisitioni nulla profitai. Osservarno li speculativi la luce di consistentia molto spirituale, come che in un istante trascorre dall'estremo dell'oriente all'occidente, perciò si lasciarono persuadere che admettere si potesse momentaneo motto, che dal tempo misurato non fosse, da onde si trasse l'attribuire alle attioni della mente tale prerogativa di esercitarsi con subitaneo discorso, apparendoci, benché falsamente, che in momento indivisibile essa trapassasse con il discorso dalla terra insino all'ultima convesità del cielo. Ma io advertito dalle antedette fallacie, non così agevolmente prestai l'assenso a tal suppositione, stimando che con il nostro intelletto si habbiamo formato un certo minimo intelligibile, con il quale stimiamo di rappresentarci il vero e reale instante, che forsi la natura all'infinito divedere potrebbe, avenendoli non diversamente quello accade al minimo sensibile, che in innumerabile portioni si può distinguere.

Da ciò è proceduto che esercitando la mente le sue fontioni e praticando le sue speculationi, stima che alcune di esse siano momentanee, misurandole con il minimo ad essa famigliare, ma che tal minimo momento mentale et arbitrario [150] sia e che la retta ragione lo repugna e regetta. Da ciò si può dedurre, che sebbene ci si dimostra in un subito apprendere e riconoscere qualsivoglia oggetto, tuttavia conviene, inanzi che di ciò anco probabilmente se ne informiamo, che discorriamo circa molte delle sue differenze che verso altrui tiene, acciocché l'uno per l'altro non prendiamo, il che senza alcuno progresso e successione di tempo eseguire non si può.

E di più afferma la prospettiva che nelle apprensioni della distanza dell'oggetto cinque advertenze almeno conviene osservare inanzi che di essa ne teniamo esata informatione: si apprende la luce, la qualità spetiale del colore, la dimensione dell'oggetto, il sito che si trova rispetto alla positura del mondo, e doppo tali osservationi si diviene alla cognitione della lontananza in astratto, e doppo ultimamente di quello intervallo particolare che attentiamo accertarci. Il che anco per mezo d'alcune consequenze dedotte da triangoli si raccoglie, siccome che da prospettivi difusamente fu insegnato. 
we call] the mind was nothing other than a simple performance of the relics of sensations. ${ }^{299}$

However, disappointed by this inquiry, I continued by considering the time this intellect [invests] in carrying out its functions, but, as in the aforementioned investigations, I did not get anywhere with this. Speculative people have observed light to be of a very spiritual consistency, as in one instant it can pass from the extreme Orient to the Occident. Therefore, they were persuaded to admit that it was possible for a momentary motion [to exist] that could not be measured by time. Thus, we gathered from this that it was appropriate to attribute the prerogative of being carried out through instantaneous discourse to the actions of the mind: then it appeared to us, although it was wrong, that in an undivided moment it [i. e., the mind] could, thanks to its discourse, move from the earth up to the last concavity of the sky. ${ }^{300}$ Yet warned by the aforementioned fallacies, I did not trust this supposition so easily. Indeed, I considered that we form a certain intelligible minimum with our intellect, thanks to which we represent the very instant in which Nature may divide itself into infinity, as is also the case with the perceivable minimum, namely that it may be differentiated into innumerable parts.

It follows from this that as the mind carries out its functions and undertakes its speculations, it considers some of them to be momentary, measuring them by the standard of the minimum with which it is acquainted. Yet [the mind considers] this minimum amount of time to [also] be mental and arbitrary [150] and to be refuted and rejected by right reason. ${ }^{301}$ It can be deduced from this that although it demonstrates that we are able to immediately apprehend and acknowledge an object, it is nevertheless necessary that we first become informed of this by following the probable; namely, we should discuss the many differences it has in comparison with other [objects], so that we will not confuse one with another. Furthermore, this can only be accomplished over and in the course of time.

Moreover, according to [the rules of] perspective in apprehending the distance of the object, before we come to have exact information about this, we should observe at least five aspects: the light, the particular quality of the colour, the dimensions of the object, and the position where it is located with respect to the position of the world; and after these observations, we may come to the cognition of the distance in the abstract and then finally to the particular interval of time we are attempting to ascertain. This may also be gathered by means of some consequences deduced from triangles, as was taught at length by the perspectivists. $^{302}$ 
Tempo diviso conforme la sua duratione.

Esame circa il soggetto intorno al quale s'impiega l'intelletto.
Ma di più anco innanzi che alla intiera cognitione di qualunque oggetto visibile capitamo fa bisogno che le asse del cono visivo trascorra per tutto l'ambito della superficie dell'oggetto, il che parimente senza flusso di tempo non si può eseguire. Non lascio a parte il giuditio subitaneo che circa la bellezza over diformità dell'oggetto accade, ché dipendendo dalla cognitione della simetria di membri e proportionata mescolanza di colori, niuno per il certo ardirebbe di asserire che ciò senza successione di tempo avenga.

Né meravigliare ci dobbiamo che tal illusione accade alla nostra mente, poiché se quell'animallucio e vil insetto che Efimero si appella, che al matino la natura li donò l'essere, et alla sera seguente gli lo estingue, havesse tanta facoltà di discorrere circa la divisione del tempo della breve sua età, li suoi momenti li riuscirebbero molto più minuti, e ristretti che i [151] no|stri, determinandoli conforme la angustia del suo proprio essere e duratione, et il nostro giorno li rassembrarebbe un lungo intervallo di tempo. E se caduno di noi fosse presago del spatio particolare della propria vita, si formarebbe instanti proprii e peculiari dall'altri diversi.

Ma la natura, amica della equalità, come abstruso arcano ci occultò il termine del vivere, poiché tal spetiale distintione augumentarebbe over diminuirebbe il pregio e valore del tempo, il che apportarebbe senza dubbio pregiuditio alli humani affari, risparmiando alcuno e vendendo a maggior pretio il suo impiego. Non resta però che la virtù ad onta della natura non habbia a suoi cultori limitato più al minuto la misura del loro tempo, e siccome che a merci vili e triviali è constituito dalle leggi misura e peso uguale, ma alle gemme non fu ciò ordinato, riuscendo perciò qualunque gioia a se stessa peso e particolare misura, così a volgari la loro vita è dal comune tempo misurata con hore, giorni, mesi et anni. Ma quella di savii et egregi homini esimendosi da tali limitationi, conforme la di loro virtù si accresce il pregio di qualunque sua benché minima portione di tempo.

Ma essendomi io forsi troppo digredito circa il tempo, dubito d'havere abusato, Signori Accademici, il vostro tempo al pari di qualunque altro pretioso e valevole. Al primiero proponimento facendo dunque ritorno, alla consideratione di tali circonstantie all'intelletto attinenti, vi agiunsi il disquerire et esaminare ciò che sia il soggetto circa di che l'intelletto se stesso esercita e travaglia.

Invalse appresso il volgo di sapienti che egli intorno certi concetti che né a tempo né loco spetiale si restringono si affatichi, li quali comunemente universali appellati furno. Questi primieramente dall'istesso intelletto con l'aiuto di altro intelletto agente ad esso coasisitente sono 
Yet in addition, before we come to have complete cognition of any visible object, it is necessary for the axis of the visual cone to pass over the entire surface of the object; likewise, this can only be accomplished over time. I will not leave aside the instantaneous judgment which occurs concerning the object's beauty or deformity, as this depends on cognition of the symmetry of the components and the proportionate mixture of colours; certainly, no one would dare to deny that this happens over time.

We must not be astonished that this illusion occurs in our minds. Indeed, if those small and vile insects called "mayflies"303 - which Nature brings to life in the morning and extinguishes in the evening were able to think about the time division of their short lifetimes, their single moments would turn out to be much shorter and more minute than ours, [151] and as they would be determined according to the brevity of their own existence and duration, our day would appear to them to be a long period of time. Furthermore, if each of us could foresee the specific duration of his own lifetime, he would form individual and particular instants different [to those] of others.

However, Nature, a lover of equality, has concealed the end of our lives from us, like an abstruse arcane, because this special distinction would increase or diminish the worth and value of time. This would undoubtedly cause some prejudices in human businesses by making a person economise and sell his work for a higher price. Yet only virtue despite Nature - does not realise the way its estimators measure their time. Standard measurements and weights have been established by law for base and trivial merchandise, while they are not regulated for gems, so that any jewel may have its own weight and particular measurement. Likewise, the lives of the common people are measured by the common [concept of] time, by hours, days, months, and years, but those of sage and illustrious men are excluded from these limitations in accordance with their virtue, which increases the worth of even the least portion of their time.

Yet as I have perhaps made too long a digression on time, I hope I have not abused your time, Lord Academicians, as precious and valuable as that of anyone else. Then, reverting to the first proposal, namely to the consideration of circumstances pertaining to the intellect, I added a disquisition and examination of the nature of the subject towards which the intellect acts and works.

The masses of wise men became increasingly inclined to [the opinion] that it [i.e., intellect] would apply itself on specific concepts that are not limited by specific time and space, which are commonly called "universals". ${ }^{304}$ These are originally formed by the intellect itself, with the help of the other agent intellect coexisting with it. They are
Time is divided according to its duration.

Examination of the subject to which the intellect applies itself. 
Rigetta l'universali che né anco mentali siano. formati, et in tal modo prodotti che [152] apportan|do il senso alla mente una coluvie e farragine di individui simili di qualità e natura, che essendo recise da essa le conditioni particolari et individuali, ratiene solamente appo sé il loro comune et eguale. Onde havendone essa mente construtti alquanti di tali universali se ne serve poi in construire le machine silogistiche, deducendone conclusioni e deduttioni parimenti universali, che contrastando questi poi con il tempo deludendo li suoi insulti, in sempiterno illesi et inalterabili rimangono, lasciando che con l'individui eserciti esso tempo le sue fierezze et abbattimenti.

Presi a ventilare tal positione, primieramente incontrai irreconciliabili controversie e contumaci digladiationi fra li fautori di detti universali circa il modo della produttione di essi, ché ricorrendo tutti unanimi al suffragio dell'intelletto agente, divengono poi fra essi contrarii, altercando se diviso, over unito sia con il nostro passibile, e ricetivo se concorre a tal formatione come efficiente, overo estrahente, $o$ piuttosto a guisa di lume che faccia l'universale apparire. Ma troppo lungo devenirei se referire volessi ciò che in tal proposito fu detto e ridetto. Per il che lasciando per hora tale discussione a parte, mi risolsi solamente considerare ciò che in loro stessi tali universali siano.

Applicai dunque il mio primo impiego ad esaminare, se nella classe delle cose reali che fuori di noi esistono porre si devono, ma non sì presto che mi si appresentò tal quesito, fu dalla ragione e senso regetto e ributtato che nella classe di cose reali esterni si ritrovassero, essendo qualunque cosa da loco circonscritta e da tempo terminata, onde seguii a speculare se pure nella idea humana rappresentare si può tali universali. Ma questo anco non mi riuscì admissibile, ritrovandoli non solamente privi di soggetto esterno, ma anco destituto d'imaginabile interno concetto, e che tenga appo noi né anco lieve formalità.

Ma Platone, mio singolare amico, hora qui assistente, inteso che hebbe tal mia perplesità circa li universali come [153] di essi grande partegiano, accorrendomi, in tal maniera mi favellò:

\footnotetext{
"Qual offesa contro di te comisero le humane dottrine che con abbattere l'universali, attenti affatto eliminarle e distrugerle? Non ti accorgi, o Socrate, che mentre nieghi l'esistentia di tal universali, e che li detrudi non solamente dal mondo reale, ma anco mentale, che si distruggerebero le humane scientie, alli individui sempre alterabili e corutibili appogiate, ché giammai questi nell'i-
} 
produced in this way [152]: the senses provide the mind with a conglomeration and medley of particulars which are similar [to each other] in quality and nature; as it removes the particular and individual conditions from itself, it keeps only what is common and equal among them all. Thus, as the mind has constructed some of these universals, it adopts them in building syllogistic machines from which it may deduce equally universal deductions and conclusions. As they oppose time by nullifying its harms, they remain eternally unharmed and unchanged by allowing time to exercise its power and supremacy over the particulars.

As soon as I began to evaluate this position, I first encountered irreconcilable controversies and obstinate disputations among the proponents of the aforementioned universals concerning the way in which they are produced. Then, [I realised that] as soon as they are all agreed in appealing to the help of the agent intellect, they oppose each other, quarrelling about whether it is separate from or joined to our passive and receptive one [i.e., intellect]. [They also quarrel about] whether it participates in forming them as the efficient [cause] of these universals, or as the one which abstracts them, ${ }^{305}$ or rather as a light which reveals the universals. Yet I would be too verbose if I were to mention what has been said time and time again concerning this matter. Hence, for the moment, I left this discussion aside and decided to consider only what these universals are in themselves.

Then, I applied myself to examining whether they should be included in the class of real things existing outside us. Yet as soon as this question had been raised, reason and sense refuted and rejected that they could be found in the class of real external things, because everything is circumscribed by space and delimited by time. Therefore, I continued to speculate about whether these universals could be represented by the human mind. Yet this also turned out to be unacceptable, because I found them to be not only lacking an external subject, but also deprived of an imaginable internal concept which could have even a little formality in us.

However, as soon as Plato, a particular friend of mine who was there at that moment, ${ }^{306}$ heard my perplexity concerning universals [153], he came to me and addressed me in this way, as he was a great supporter of them:

"What kind of offence did human doctrines give you, if you are attempting to eliminate and destroy them by demolishing the universals? Don't you realise, oh Socrates, that if you deny the existence of these universals and chase them away not only from the real world, but also from the mental one, you will destroy human sciences, as they are dependent on the particulars, which are always changeable and corruptible and thus never
He denies that the universals are even mental. 
stesso modo permanenti e stabili non sono? E che riuscirebbero al pari di essi labili, e di niuna ferma esistentia sortire?”.

Al che io li risposi che non fuori del dovere egli prese la pretensione e patrocinio della scientia che tanto celebre lo ha renduto appresso il secolo presente, e se il genio non mi falliva che al venturo non è per riuscire di minor grido, ma che io havendo di già rinontiato ad ogni scientia, poco mi curavo se dalla destruttione di tali universali, sortisca l'eversione delle dottrine. Anzi, che havendo rivocato le mie contemplationi da cieli, e da qualunque altro oggetto alli affari humani, era parimente mia incombenza difendere la prudenza che li regge e governa, et espugnare e prostrare tali universali che ad essa tanto nuocono e dannegiano, non havendo io ritrovato, chi più d'essi infeliciti le nostre attioni. Onde li massimisti e formalisti senza l'inspettione e pratica di particolari, et individuali circonstantie di negotii, il tutto confondono e turbano. Per il che siccome questi tali nelli aringhi e publici ragionamenti acquistandosi credito appresso li imperiti, riescono vittoriosi, così nelle esecutioni e maneggio delle cose, sortiscono inetti, e ridicoli. Il che aviene dal non potersi giamai aggiustare et adattare l'emergentie che alle mani tengono a quelle massime che ritratte dalli avenimenti preteriti, e particolari, non hanno corrispondentia con le occorrenze presenti.

Da quindi è che li Persiani et altri che con il nome di barbari dilegiamo, aveduti et [154] osser|vantissimi del stato presente, non punto ogettando il tempo passato riescono prosperosi nelle loro intraprese, havendo occupato tutto l'Asia e tuttavia alla nostra Grecia minacciano. Ma noi Ateniesi che sopra tutte le altre nationi di tali axiomi universali per la cognitione delle istorie et eruditione delle dottrine siamo abbondantemente provisti, giammai fuori dell'Attica piciola et angusta provincia della Grecia non ci fu concesso protrahere e dilatare il nostro dominio. M'anco quando che alcuno danno non ci apportassero tali universali, essendo le admissioni di essi alla ragione repugnante, punto movere non mi deve il pregiuditio e nocumento che la loro eliminatione apportasse all'humano sapere, ché siccome la giustitia commutativa punto sbilanciare non si deve, per la meschinità che seguire potesse ad uno di litiganti per cagione della giusta sentenza che contra esso fosse pronontiata, così anco non lice al retto discorso deviare dalla verità, segue qualsivoglia danno all'humane dottrine. $\mathrm{Al}$ che replicò Platone: 
endure or remain in the same state? Therefore, [don't you realise] that the former would turn out to be fleeting and without any firm existence, just as the latter are?”

Hence, I answered him that it was his duty to endorse and defend knowledge, which makes him so renowned in the present century, and - if my genius was not mistaken - for which he would also maintain his fame in the century to come. Yet [I answered him] that I had already renounced all science and thus I did not care whether the destruction of the universals would result in the subversion of doctrines. Moreover, [I answered him] that since I had directed my contemplation away from the skies and all other subjects towards human matters, it was likewise my duty to defend the prudence that rules and governs them. Furthermore, [it was my duty] to conquer and defeat those universals which harm and damage it so much, as I had discovered that nothing is more responsible than these for our actions being unsuccessful. Thus, maximists and formalists, ${ }^{307}$ who do not examine or deal with the particular and individual circumstances of businesses, confuse and muddy everything. Hence, just as they turn out to be victorious, winning the trust of gullible people during speeches and public debates, so they result as incompetent and ridiculous in undertaking and managing things. This comes from the fact that they could never adjust or adapt the occurrences on their hands to those maxims which have no correspondence to present occurrences once they have been taken out of their specific context in the past.

Hence, then the Persians and others, whom we deride by calling barbarous, are careful [154] and very watchful of the present, and without bringing up the past, they have been successful in their endeavours, as they have occupied the whole of Asia and are threatening us throughout all of Greece. Yet although we Athenians are abundantly provided with these universal axioms for the cognition of past events and the erudition of our doctrines, nevertheless, we have never been permitted to expand or enlarge our supremacy beyond Attica, a small and narrow province of Greece. However, even if these universals do not cause us any harm, I should not be influenced by the prejudice and harm their elimination could cause to human knowledge, as the [simple] acceptance of them is repellent to reason. Just as commutative justice must not be unbalanced because of the misfortune that might follow for one of the litigants due to a correct verdict delivered against him, so also a correct discourse must not be allowed to divert from the truth, whatever damage will occur to human doctrines. Then, Plato replied to this: 
"Hor dunque a questo accingere ti devi, dico a dimostrare et evincere la falsità di tali universali, ché non meno di te sincero cultore della verità io sono".

\section{Al che ripigliai:}

"Stimi forse, o Platone, che di minor ambito sia il concetto universale non limitato da loco né da tempo benché estratto fosse da minutissime, et individuali formiche, che la dimensione d'un libico elefante, o vasta balena?".

Risposemi:

"E chi può dubbitare che più amplo sia l'universale cavato benché di picciole formiche, abbraciando esso quanti furno, sono, e saranno, che lo rappresentamento d'un elefante over balena per grandi che siano?".

\section{Soggionsi io:}

"Stimi tu forsi che nel formicaio, stantiare et addaggiare vi potesse tali smisurati animali?”.

E seguii che non fuori di proposito di ciò lo interrogai.

"Non certo", rispose egli.

Ma io li continovai:

"Molto avenentemente hai corriposto alla aspettatione che di te ho conceputo, essendo guidato dal retto discorso meco [155] affermi l'impossibilità di tali universali, e che anco dall'intelletto li convenga prendere comiato et esilio".

Ma replicò egli che qual ne sia di ciò la cagione li dimostrassi.

A che occorrendo li dissi, che esporre mi dovesse se stimava che l'humano intelletto nel qual sono dipinti tali universali, fosse cosa terminata, over che né a loco né a tempo alcuno fosse affisso e limitato.

Risposemi egli che ciò non crederebbe giamai, ma che indubitatamente cadauno di noi tenga il suo intelletto spetiale, in se stesso circonscritto, con suoi particolari concetti e singolari openioni ad altrui non comunicabili, e che a tempo e loco egli sogiacia.

Al che io continovai: 
"Well, you must prepare yourself for this, for I mean to demonstrate and deduce the falsity of these universals, as I am no less a sincere estimator of the truth than you."

Hence, I continued:

"Do you consider, oh Plato, that the universal notion, which is not limited by space or time, would be smaller than a Libyan elephant or a huge whale if it were extracted from very tiny and particular ants?"

He answered me:

"As the universal [notion] drawn from ants, despite their smallness, would include as much they were, are, and will be, well, who may doubt that it would be greater than the image of an elephant or a whale, despite how huge they are?"

\section{I continued:}

"Do you believe that these enormous animals could be settled and placed in an ant's nest?”

Besides, I continued that I was asking him this for a particular reason. He answered:

"Certainly not."

\section{Yet I continued:}

"You have answered very properly, as you are led by right reason, ${ }^{308}$ that you agree with me [155] that such universals are impossible and also that the intellect should take leave of them and keep its distance from them."

However, he replied that I should explain the reason for this, whatever it was.

Directly responding to this, I told him to expound to me whether he considered the human intellect - in which the universals are supposedly located - to be delimited, namely whether it was bound or restricted by any space or time.

He answered me that he would never believe this, but that undoubtedly each of us had his own individual intellect, delimited in himself, [endowed] with its particular concepts and singular opinions incommunicable to others and which was subject to space and time. And I went on to say: 
"Non advertisci, amico Platone, che sei sorpreso, e nella rete colti sono li tuoi universali, benché come li fingi per la loro difusione siano inattingibili, havendo tu stesso confessato che il tuo intelletto fondamento e soggetto che sostiene in sé tali universali, e nel qual si ricovrano, sia singolare, e da essi di conditioni affatto diverso, e parimente tieni asserito che picciol loco non possa capire dimensione molto di lui maggiore, et essendo l'universale molto maggiore in proportione, di quello sono li elefanti e balene resta anco parimente concluso che impossibile sia che l'idea et imagine dall'universale si rappresenti e rafiguri nell'intelletto".

Al qual mio ragionare riconoscendosi Platone convinto altro non replicò. Ma io instando la vittoria di nuovo l'invasi, dicendoli:

"Non osservi, o Platone, che admettendo l'universali introduci nella tua mente certa spetie di simulacri la più diforme, assorda, et incomprensibile, che l'istessa imaginatione decantata volgarmente genitrice delle fallacie et illusioni giammai non seppe fingere? Rafiguraci, o Platone, il colore in astratto, che non sia negro né bianco, né giallo né rosso, né verde né turchino, né di altro spetiale colore, che sarà egli? Et in che maniera ti rappresenti l'animale che non sia né homo, né cavallo, né bue, né leone e d'altri simili spetii?

Oltre che essendo il genere [156] universale e per dir così infinito, la spetie anco universale e perciò anco essa indeterminata et infinita in qual maniera il genere sarà di maggior continentia che la spetie, essendo ambi infiniti, tenendo questi per legge inalterabile, che l'uno infinito non possa l'altro avanzare? Onde Diogine nostro amico, non perché fosse di tardo e rude ingegno come alcuni di suoi adversarii finsero, pronontiò, che egli benissimo scorgeva Alcibiade, Agatone, Calicle e Clinia, e che discerneva quali homini fossero, ma che verso l'humanità over l'asinità affatto cieco riusciva".

Al qual ragionare replicò Platone che per il certo da mie ragioni rimaneva alquanto convinto, ma che nondimeno il discorso conveniva cedere alla evidenza del fatto, e che quotidiamente in noi stessi esprimentiamo le appresioni di tali universali, non meno che con il senso esterno li singolari individui.

Al che soggionsi che oltre modo circa tal pratica s'ingannava, stimando egli di riconoscere cosa universale, mentre che singolare a tempo, e loco circonscritto apprende, e che altro non fosse l'asserto universale da lui pronontiato, ma pravamente inteso, che un imperfetto abbozzo, che desidera l'ultima mano dell'artefice che lo riduca ad un distinto et elaborato dissegno. E siccome un rude tronco di legno già diramato a diverse figure che dall'opefice l'è imposto ubidisce, così anco l'universale essendo certa tal informe figura, può di esso sortire diversi individui, non resta però che in conformità dell'abbozzo e 
“Dear Plato, don't you realise that I have caught you, and that your universals have fallen into the trap? Although you suppose them to be unattainable because of their diffusion, nevertheless you have confessed that your intellect, as the foundation and subject holding these universals in itself and the place where they dwell, is particular and of different conditions to them. Likewise, you have asserted that a small space cannot contain something which has a much greater dimension, and, as the universals have much greater proportions than those of elephants or whales, we may similarly conclude that it is impossible that the idea or image of universals may be represented or illustrated in the intellect."

Plato acknowledged that he was convinced by my argument, and thus he did not say anything else in reply. Yet as I was pursuing victory, I addressed him again, telling him:

"Don't you see, oh Plato, that by accepting the universals, you are introducing a specific species of simulacra into your mind, so deformed, absurd, and incomprehensible that not even the imagination, commonly called the mother of all falsity and illusion, would ever be able to picture it? If, oh Plato, we represented colour in the abstract as neither black, white, yellow, red, green, turquoise, nor any other particular colour, then what would it be? Furthermore, how may you represent an animal as neither man, horse, ox, lion, nor another similar species?

"Besides, [156] if the genus is universal, and therefore infinite, the species is also universal, and thus also indeterminate and infinite, and so how will the genus have a greater ability to contain than the species, as they are both infinite and [both] follow the unchangeable rule that one infinite cannot exceed another? Therefore, Diogenes, our friend, who was not of a slow and rough wit (as some of his opponents supposed that he was), said that although he could see Alcibiades, Agathon, Callicles, and Cleinias perfectly, and he could discern which men they were, nevertheless he could not see humanity or asininity." ${ }^{309}$

To this argument, Plato replied that although he was certainly quite convinced by my reasons, nevertheless the discourse should bow to the evidence that we experience the apprehension of these universals as much as that of the particulars every day, [the latter] through the external senses.

Hence, I continued that he was extremely mistaken about this issue, because he believed he was acknowledging a universal thing when he was actually apprehending a particular one, circumscribed by time and space. Besides, the asserted universal - which he had stated, but had understood incorrectly - was nothing other than an imperfect draft needing a final coat from its architect, who would turn it into a distinct and completed drawing. Furthermore, just as a rough trunk of wood obeys the creator, who obliges it to branch off and form different figures, so also a universal is like a not-yet-moulded figure from which different particulars may emerge. 
tronco accenati, non sia singolare et individuo. Per il che tal universal di che tanto si milanta l'intelletto, ci riesce rudità et imperfetione o per dir meglio sconciatura et aborto della mente, ché per anco non ha receputo l'ultima et estrema lineatura. Per il che fu, a mio stimare, con gran pregiuditio e detrimento di esso intelletto da savii publicato, che alla mente appartengono l'universali, et al senso li singolari, essendo questi reali et esistenti, e quelli finti e putatitii.

Rimase affatto convinto Platone dal mio divisare, benché non poco impalidito, [157] scor|gendo esser abattuta la sua già cotanto pregiata scientia, che sopra le basi di tali universali si sostentava, ma tuttavia con generosa modestia confessò, che non poco di commodo haveva da ciò conseguito, essendosi scaricato dal grave preso di errori che per vere et infallibili dottrine stimava, rimanendo di gran lunga inferiore l'emolumento che da queste putatitie traheva, che li nocumenti che ne risultavano, e che hora esprimentava che il maggior grado al qual sormonta l'humano ingegno, caruisse stultitia e non acquisisse sapientiam, promettendomi che per l'avenire critico censore divenirebbe contro il suo proprio sapere, non come per inanzi, n'era cieco, et indulgente genitore.

Disciolto il favellare con Platone, mi riapplicai a soliti esercitii, e per non lasciare che d'intentato circa la mia principal inchiesta, alla consideratione alli altri mezi et instrumenti che sono ad esso intelletto più famigliari e che adopra per conseguire le sue contemplationi mi dedicai.

Fumi di alcuni pitagorici detto, che verisimile fosse, che quella miglior causa che ottimamente ci formò, non si rese parca et invidiosa all'intelletto humano, dedicato alla inspettione delle bellezze dell'universo, nel concederli idonei instrumenti, et aggiustate norme per il mezo de' quali esercitare potesse le sue fontioni e riconoscere la verità scopo e meta del suo mental camino. Per il che stimavano che nella mente humana dal principio del suo essere fossero stati inserti, et instilati alcuni semi, e primi essordii, mediante li quali esso ordinar e regolare dovesse la condotta e serie di suoi discorsi. Principali fra questi, è quella massima e propositione che nega li contradittorii

Contra li Pitagorici che affermano l'incomplicabilità de' contraditorii. insieme cohabitare possino.

Inteso ciò interrogai questi sapientissimi homini, s'estimassero ragionevole che giudice pronuntiasse sentenza peremptoria a disfavore di alcuno, inanzi che tenga appreso lo stato della causa contraversa. 
However, it cannot otherwise be particular and individual in conformity with the aforementioned draft and trunk. Therefore, this universal about which the intellect boasts so much seems to us rather coarse and imperfect, or better to say a deformity or distortion of the mind which has not yet had its last fine-tuning. For in my opinion, through great prejudice and to the detriment of the intellect, the sages have made it known that universals pertain to the mind, while particulars [pertain] to the senses, as the former are real and existent and the latter are fictitious and illusory.

Indeed, convinced by my argument, Plato [157] turned pale, seeing his refined science, based on these universals, being demolished. Yet he confessed with great modesty that he took a great benefit from this, because he could finally release himself from the heavy weight of the mistakes that he had considered true and infallible doctrines. Indeed, the reward he gained from those alleged [doctrines] was less than the [amount of] damage resulting from them. Besides, he experienced that the highest degree reached by human wit was to have got rid of folly ${ }^{310}$ and not to get wisdom. ${ }^{311}$ Then he promised me that in future, he would become a critical censor of his own knowledge, towards which he had once been a blind and indulgent parent.

Once I had concluded the conversation with Plato, I applied myself to the usual exercises once more. In order not to leave anything in my main inquiry incomplete, I devoted myself to the other means and instruments which are more familiar to the intellect and which it adopts in order to accomplish its contemplations.

Some Pythagoreans told me that it was likely that the best cause, which formed us in the best possible way, had neither spared nor envied the human intellect. As it [i.e., the human intellect] was devoted to inspecting the beauties of the universe, it [i.e., the best cause] granted it proper instruments and adequate rules to carry out its functions and acknowledge the truth, as is the aim and final goal of its mental path, for they believed that some seeds and first principles had been inserted and instilled into the human mind at the very beginning of its existence. By means of them, it must have ordered and ruled the course and series of its discourses. The main one among them was that maxim and proposition which denies that contradictories are able to coexist. $^{312}$

Once I had understood this, I asked these very wise men whether they considered it reasonable for a judge to peremptorily sentence someone before having completely understood the status of the controversy.
Against the Pythag. oreans, who state the impossibility of combining contradictories. 
Prontamente risposero che ciò riuscirebbe affatto ingiusto et iniquo giuditio, ma che prima conviene rappresentarsi le ragioni d'ambi li altercanti e formalizarsi della [158] qua|lità del litigio.

Replicai:

"Stimate dunque, ottimi homini, che dannare si devono per falsi li centauri, e hidre, e castelli volanti se prima non se li rafiguriamo almeno con la imaginatione?".

"A satietà”, replicarno, "ci affatichi intorno ciò, amico Socrate”. Al che soggionsi:

"Per il certo indecente e precipitata sentenza fu la vostra, mentre che per anco giammai non vi habbiate rafigurato duoi contradittorii insieme complicati, eppur havete ciò dannato, come falso et impossibile”.

A questa mia instanza replicavano dal non haversi giammai potuto tal complicatione di contradittorii apprendere, dedurre si può la sua impossibilità.

$\mathrm{Al}$ che soggionsi con dirli che tale consequenza et illatione punto non teniva del necessario, poiché moltissime altre propositioni riescono incomprensibili, né la mente se le può imaginare, ché tuttavia non solamente non sono [im]possibili, ma di più anco necessarie, quali sono che due linee benché vicine, prolongandosi all'infinito e sempre l'una all'altra accostandosi, nondimeno giamai insieme si possono congiungere, il che riesce repregante al discorso:

"Eppur la demostratione matematica dedotta da questi tali vostri primi principii, conclude che ciò avenga, che parimente infinite siano le parti d'ogni continuo, e che perciò l'uno maggior dell'altro non dovrebbe esser, escludendo l'infinito la maggioranza e minorità.

Nondimeno non tenimo sotto li occhi cosa più famigliare et evidente, che la disuguaglianza di corpi, et il motto fondamento di tutte le operationi sì naturali come humane, in qual guisa avenga affatto è incomprensibile et al discorso inattingibile, mentre che non si admetta la complicatione di contradittorii, poiché, ritrovandosi il mobile nel loco d'onde partì per anco non si move, se nel loco ove tende et aspira, di già il motto è finito e terminato. Per il che pare che ci convenga dire che continuando il flusso, e successione, che sia e non sia in tali lochi e termini. Eppure non si può repugnare al senso, con asserire, che [159] non si trovi il motto, ché rifiutandolo ci converebbe negare l'istessa natura, che comunemente è definita principio di motto. Per il che a torto fu dannata la coasistentia di contradittorii, se d'altra instanza che dalla incomprensibilità a tal 
They promptly answered that this would result in an unfair and unequal verdict, because one should first represent the viewpoints of both litigants and understand the nature of their argument.

\section{[158] I replied:}

"Then do you think, oh excellent men, that one must accuse centaurs, hydras, and floating castles of falsity, ${ }^{313}$ if we cannot first at least picture them in our imagination?”

They replied:

"Dear Socrates, you are greatly tiring us with this."

\section{Then I continued:}

"Certainly, your judgment was inappropriate and rushed, as you have never pictured two contradictories combined together. Nevertheless, you have accused this of being false and impossible.”

To this instance, they replied that as they would never be able to apprehend this combination of contradictories, one would deduce that it was impossible.

Hence, I continued by saying that this consequence and inference was not necessary at all. Indeed, many other propositions which are either unintelligible or unimaginable for our minds are not impossible, but rather necessary, as would be the case with two lines next to each other that would never touch each other even if they were prolonged to infinity, but would always stay alongside one another. ${ }^{314}$ This is reprehensible for this reason: ${ }^{315}$

"The mathematical demonstration deduced from these, your first principles, leads to the conclusion that it may also be the case that the parts of every continuum are infinite, and thus that one cannot be greater than another because infinity excludes the concepts of greater and lesser.

"Furthermore, although there is nothing more familiar or evident to us than the inequality between bodies and motion, which is the foundation of all actions, natural as well as human, nevertheless, the way in which it happens is indeed not understandable and intelligible to reason unless we allow the binding together of contradictories. Indeed, if a movable does not depart from its location, which is the place where it longs and wishes to be, then the motion will already be accomplished and finished. Therefore, it seems to be the case that we should say that in continuing the sequence and flow, it both is and is not within these places and boundaries. Nevertheless, we cannot oppose our senses by stating [159] that motion does not exist, because by refusing it, we would also be denying Nature, commonly considered to be the principle of motion. Hence, the coexistence of contradictories has been wrongly condemned 
sentenza pronontiare non siano motivati li autori di tal dogma, ma che piuttosto alla tardità della nostra insufficientia in apprender la detta complicatione ciò attribuire dovevano.

Ma se a contrarii vogliamo rivolgerci, li osservaremo parimente altrettanto pieghevoli a riceversi e concedere hospitio l'uno l'altro. La qualità rimessa del caldo e freddo, non è amichevole introduttione e penetratione dell'una nell'altra? La reatione parimente admessa comunemente fra le operationi della natura, che altro è che mescolamento di attione e passione nell'istesso soggetto? L'harmonia di suoni, la soave compositione di odori, l'aggradimento di cibi mescolandosi il dolce e garbo insieme non sono resultantie di interno mescolamento, e totale confusione di contrarii? Ma che, nell'istesso punto dell'aere non si ritrovano l'imagini del nero e bianco da diversi corpi coloriti ivi mandate? Anzi che nell'apice del cono che ferisce l'organo visivo, quanti diversi simulacri di colori e figure contrarii vi si uniscono? Il piacere ristoro di nostri affanni e lusinghevole trattenimento della vita, non è egli composto et unito con il dolor suo contrario? Indicio di ciò è che cessando questo si termina quello, ma nel contatto, quando accade che duoi contrarii l'uno l'altro si tocca risultando fra essi certa unione, non segue necessariamente che li contrarii si areccano fra loro benigno albergo?

Ma lasciamo hormai ciò a parte quando anco a tali oppositioni fossimo indulgenti, non mi saprei giamai risolvere, ottimi amici, di concedere a tal vostro principio e fondamental origine della nostra scientia, prerogativa di antianità sopra molte altre cognitioni, che a mio stimare lo precedono o almeno che circolamente l'un all'altro egualmente precede e segue, [160] poiché a raccogliere la impossibilità che li contraditorii insieme nell'istesso sogetto, e medesimo tempo si complichino, et uniscano, ci conviene prima rappresentare ciò che sia l'essere, e non essere, de' quali si compongano li contraditorii, concetti tanto ardui quanto dal ragionare di Gorgia si dimostrò. Parimente bisogna apprendere ciò che sia l'istesso et identità, che forse riesce delle più spinose dottrine che assagi la nostra mente, per la moltiplicità de' generi de' distinioni di novo ritrovati in che si abbagliorno li più acuti ingegni. Né anco ci deve esser occulta la natura della impossibilità e d'onde essa procede e prende forza la sua fatale renitenza, tutte quante speculationi delle più difficoltose che in sé habbia la filosofia.

E senza dubbio per altro verso ci occorerebbe grave assordo, apprendendo prima l'antecedenti cose, che la inessistenza de contraditorii, poiché ci converebbe molte fiatte servirsi di tal vostro principio cioè che l'essere e non esser insieme cohabitare nell'istesso soggetto nel medesimo tempo non possino, e converebbe inanzi che egli fosse appreso, riconoscerlo e per vero saperlo, come anco riesce impossibile tenire cognitione di alcuno composito qual è tal vostra axioma, se prima non si tenga cognitione de suoi componenti che sono li antecedenti concetti. Per il che si scorge che circolarmente tali apprendiamo.

Ma anco apparisce assordo per altra maniera il dire che tal principio ci sia dalla natura e non dal senso e discorso additato, poiché ciò repugna ad ogni sana ragione, che se la cognitione delli componenti che constituiscono tal massima non è altrimente in noi da essa natura inestata, ma per noi de' 
by the authors of this dogma, who were only motivated to utter this sentence by this instance of incomprehensibility. They must rather have attributed it to our slowness and insufficiency in apprehending the aforementioned binding.

"However, if we wish to address these contraries, we will notice that they are inclined to receive and offer hospitality to one another. The quality of heat and cold given off is not an amicable introduction and penetration of one into the other, is it? Likewise, the reaction commonly acknowledged among Nature's operations is nothing other than a mixture of activity and passivity in the same subject, is it not? The harmony of sounds, gentle composition of scents, and appreciation of food resulting from mixing sweetness and sourness result from an internal mixture and complete fusion together of contraries, do they not? And black and white images sent by different coloured bodies can be found in the same location in the air, can they not? Furthermore, how many different simulacra of contrary colours and figures will link together on top of the visual cone produced by the visual organ? Pleasure, as it is relief from our worries and our life's joyful entertainment, is joined and combined with pain, which is its contrary, is it not? The evidence for this is that the end of the former defines the limits of the latter, but concerning the sense of touch, when it happens that two contraries come into contact with each other, resulting in a specific unity, it does not necessarily follow that these contraries are benignly hospitable to one another, does it?

"Yet let us now leave this aside. Even if we were indulgent of these objections, my very good friends, I could never agree to grant the prerogative of seniority among the many other cognitions to your principle and fundamental origin of our knowledge, as I consider them either to have precedence or at least to be equally preceding and circularly following one another. [160] In order to accept the impossibility that two contraries can be bound and unified in the same subject at the same time, we should first conceive what being and non-being are. Indeed, they are essential components of contraries and are also very arduous concepts, as demonstrated by Gorgias's argument. Similarly, one must apprehend what sameness and identity are, as this turns out to be perhaps one of the thorniest doctrines experienced by our minds because of the numerous kinds of recently discovered distinctions which have dazzled the sharpest wits. Furthermore, we must disclose the nature of the impossibility and where its fatal reluctance comes from and gains its strength. These are the most difficult speculations in philosophy.

"However, we would undoubtedly run into a serious absurdity if we were to apprehend the preceding things first and then the inexistence of contraries. Indeed, we would have to use your principle - namely that being and non-being cannot cohabit in the same subject at the same time - many times. Furthermore, before this was apprehended, it would be worthwhile to acknowledge it and know that it was true. Likewise, it turns out to be impossible to have cognition of any compound, as with your axiom, without first having cognition of its components, which precede the concept. Hence, we may see that we are apprehending them in a circular fashion.

"Yet in other words, it also seems to be absurd to say that this principle has been shown by Nature and not by the senses and discourse, because it is contrary to every sane mind. If cognition of the components constituting this maxim is not settled in us by Nature, but rather we apprehend it through the 
Considera l'ordine che tiene l'intelletto ne suoi discorsi. sensi habbiamo ciò appreso, così parimente la incomplicatione di tali cose per l'istessa via e modo habbiamo ottenuta, essendoci interdetto di apprendere tali impossibilità senza la notitia de' soggeti a cui essa si attribuisce, et inferisce.

Per il che probabilmente stimar si deve che sebbene ottenga tal axioma peculiare dignità sopra l'altre cognitioni, ha comune con [161] esse l'istesso natale, et origine, ma che questo per la frequenza del suo uso sia giudicata sopra l'altre propositioni evidentissima et indubitabile. All'istanze antedette vi si aggiunge che alcuni di sapienti ardiscono di negare la sua certezza, fra quali fu il nostro amico Protagora, che perciò acquistò celebre grido havendo intrapreso di opporsi al comune concetto de tutti li homini”.

Ma li detti pitagorici di novo risorsero con protestarmi, che molto circonspetto doveva io procedere in tal affare, ché abbattendo tal principio e fondamento, pericolarebbero tutte le dottrine.

Et io li repplicai che anzi essi advertire dovessero di non erigere le machine de' loro scientie sopra fondamenti incerti e fievoli, et in tal maniera dissolvessimo il ragionare senza haver raccolto da essi cosa soda circa li mezi che adopra l'intelletto nelle sue speculationi. E non potendo riportare messe di alcun rilievo da tale disquisitione, mi transferii al considerare l'ordine che tiene l'intelletto nell'esequire li suoi mentali esercitii, né di ciò lo trovai punto meglio informato che degli altri suoi affari. Mi apparì che fra le controversie più irreconciliabili che l'istesso intelletto agiti, è, quale sia il primo conoscibile che al suo giuditio si appresenta. Ad alcuni rassembra che se li incontra il più universale e comune, ad altri il maggiormente singolare fosse l'anziano che li apparisce, ad altri e l'uno e l'altro, ma in diverse guise.

Oltre di ciò li resta dubbioso, se prima riconosce l'affermatione, che la negatione. Alcuni di sapienti preferiscono l'affirmatione, dovendo il positivo come fondamento precedere al privativo. Ad altri il contrario li aggrada, ché siccome è credibile che all'esser reale li sia anziano la privatione, così parimente occorrere deve al mentale, oltra che, dovendosi per esempio affermare che il cigno sia bianco, prima conviene riconoscere che il cigno e la bianchezza non siano l'istesso, perché se altrimente fosse non riucirebbe affermatione ma piuttosto tautologia e repetione dell'istesso.

Oltre di ciò si trova [162] l'intelletto come che instupidito nel sapere discernere qual primieramente se li rappresenta, la unità overo la moltitudine. Da un lato li appare che precedere dovesse l'unità come principio semplice e componente della moltitudine non essendo questa altro che riassunta unità, ma per altro verso, considerandosi che la definitione della unità consiste in non haver parti, conforme la definì il nostro Euclide, però rassembra che prima conviene riconoscere la mol- 
senses, we will similarly obtain detachment through the same path and way. Indeed, we are not allowed to apprehend these impossibilities without having information about the subject to whom it [i. e., Nature] speaks and refers.

"Hence, we should probably consider that although this axiom received a special dignity [161] above the other cognitions, it shares their origin, but because of its regular use, it is judged the most evident and indubitable among all the other propositions. In addition to the aforementioned instance, some wise men dare to deny its certainty, among them our friend Protagoras, who became very famous as he undertook to oppose the common opinion of all humankind.”

However, the aforementioned Pythagoreans again protested to me that I should proceed carefully in this inquiry, because if I demolished this principle and foundation, all doctrines would collapse. So I replied that they must rather be careful not to build the machine of their sciences on unsure and weak grounds. In this way, we concluded our discussions without me receiving anything concrete from them concerning the means the intellect uses in its speculations. As I could not gather any harvest that could be relevant from this disquisition, I turned to consider the order that the intellect follows in carrying out its mental exercises, but I likewise did not find that it was better informed about this than about its other affairs. It seemed to me that among the most unresolvable controversies which tormented the intellect was [identifying] the first knowable that it judges. According to some people, the most universal and common [knowable] is what it encounters first; according to others, the most particular is the first to appear to it; according to still others, they are both [encountered at the same time], but in different ways.

In addition to this, what is still uncertain is whether it [i.e., the intellect] acknowledges affirmation or negation first. Some wise men prefer affirmation, since the positive, as a foundation, must precede privation. Others prefer the contrary: just as it is credible that privation is the ancestor of real being, so the same must occur to mental [being]. Besides, for example, before affirming that a swan is white, one should first acknowledge that the swan and whiteness are not the same thing, otherwise no affirmation would result, but rather a tautology and repetition of the same thing.

In addition to this, the intellect [162] finds itself incapable of discerning which it should represent first, either unity ${ }^{316}$ or multiplicity. On the one hand, it seems to it that unity must come first, as it is a simple principle and component of multiplicity, which is nothing other than a summarised unity. On the other hand, the definition of unity consists in not having any parts, according to Euclid, ${ }^{317}$ although it seems to be appropriate to acknowledge multiplicity first rather
He considers the order respected by the intellect in its discourse. 
titudine che la unità. Et in non minore preplessità e flutuatione ritrovai involto l'intelletto circa quelle cose che ad altri si rapportano e referiscono, non sapendo egli, o forse non potendo discernere, a qual primo de' corelativi applicare si debba, dipendendo sempre la cognitione di uno d'essi, dall'apprensione dell'altro, non potendosi riconoscere ciò che sia amabile se non si apprende prima quello sia amante, e così per il converso.

E parimente del Signore non si può tenir cognitione, se prima del suditto non siamo informati, né di questo senza di quello si formallizamo, né ambi nell'istesso tempo si possono comprendere, mentre che confondere non vogliamo tali cognitioni, mescolandosi insieme diverse e repugnanti apprensioni. Da quindi risulta che de simili, diferenti, contrarii, proportionabili, eguali, cause, effetti, significanti, significati, sensitivi e sensibili, intelligibili et intelligenti, non può l'intelletto per molto che circa essi speculasse, conseguirne per cagione di tale impedimento perfetta cognitione, non potendosi terminare a quale prima di relativi impiegar si debba.

Da ciò forsi prociede che riesce preplessa et incerta la cognitione della relatione a segno tale che alcuni rifiutandola affatto, fra le chimere la aroralarno. E per il certo l'ingannarsi l'intelletto circa l'ordine e serie delle sue attioni, non puoco lo discredita e l'arreca biasimo. Qual è pittore da sì grave ignoranza oppresso, che non tenga appreso l'ordine della sua operatione? Forse si trova tale che non sappia che prima li convenga ordinare la tella over tavola, ove formare si deve [163] la pittura, macinar li colori e doppo maestevolmente temperarli, formar l'abbozzo, perfetionare il disegno, apprestare il colorito e doppo ritocandolo produrre li sbalzi e risalti, profondare le cavità et ultimamente poi dolcemente far isvanire li più duri e tagliati contorni? E qual è parimente architetto che non sia informato che prima convenga misurare il tereno sopra il quale attenta erigere l'edifitio e poi conforme il sito e capacità formare il modello, scavare li fondamenti, finalmente constituire la ideata fabrica?

Eppur l'intelletto humano che presume donare regola, misura, et ordine a tutte le cose, riesce tanto imperito della serie e seguimento delle sue proprie attioni, non sapendo qual di esse prima e qual

Considera

l'instrumenti che adopera l'intelletto. doppo esequisca. Ma havendolo io dunque trovato tanto ignaro circa se stesso e proprie operationi, non mi arrecò poi tanto di meraviglia rinvenirlo parimente affato cieco circa il riconoscere li suoi più famigliari e domestici ministri, et esecutori de' suoi consigli. E per il certo riesce stupendo che egli fondator de regni, instituitore de republiche, 
than unity. Furthermore, I found the intellect entangled in no less perplexity and wavering concerning things which refer and relate to others. Indeed, it does not know, or perhaps it cannot discern, to which of the correlatives it should apply itself first, ${ }^{318}$ as the cognition of one of them always depends on the apprehension of the other: one cannot acknowledge what the beloved is if one does not first apprehend what a lover is, and likewise the other way around.

Similarly, we cannot have any cognition of the Lord if we are not first informed of his subjects, nor we can conceive of the latter without the former, nor can one comprehend both at the same time if we do not want to confuse these cognitions by mixing together different and opposing apprehensions.

From this, it results that the intellect may not achieve a perfect cognition of similarity, difference, contrariness, proportionality, or equality, [or] causes [and] effects, signifier and signified, perceived and perceivable, or intelligible and intelligent, even if it were to speculate on them at length. The reason for this is that it cannot determine to which of the relatives it must apply itself first.

From this, it probably follows that cognition of this relation turns out to be so perplexed and uncertain that some have refuted it completely by including it among the chimaeras. Certainly, the fact that the intellect is mistaken about the order and sequence of its actions consistently discredits it and bring it into disrepute. What painter is so ignorant as to be unaware of the sequence of his procedures? Can there be anyone who does not know that he should first prepare a canvas or panel where he will produce [163] the painting, then mix the colours and masterfully blend them, draw a draft, perfect the drawing, provide the colour, and then, retouching it, produce nuances and contrasts, create depth, and then lastly softly tone down the most pronounced and defined contours? Likewise, is there any architect who does not know that he should first measure the ground where he aims to raise the building and then, in conformity with the location and its capacity, prepare a model, dig the foundations, and finally erect the projected building?

On the one hand, the human intellect claims to provide rules, measure, and order to everything; on the other hand, it turns out to be so unaware of the series and sequence of its own actions that it does not know which one comes first and which one follows. Yet as I found it so unaware of itself and its own procedures, I was also not very surprised to discover that it is likewise blind concerning the acknowledgement of He considers the instruments used by the intellect. its close and familiar ministers, as well as the executors of its advice. Certainly, it is astounding that as the founder of kingdoms, institutor of 
legislator de popoli, rimanga sconoscente de' suoi proprii agenti et astanti, che pur a meno che a cenno eseguiscono li suoi comandi.

È ben vero che di tanta sua inavedutezza difendendosi, rigetta l'administratione del sistema humano alla volontà, a cui egli come semplicemente consultante sugerisce il suo proponimento, dimostrandole il bene che si deve eleggere, et il male che conviene rifiutare, dovendo poi essa volontà a spiriti interni imporne la esecutione delle sue arbitrarie deliberationi. Ma nondimeno non se può all'intelletto ragionevolmente admettere tal discolpa e sfugatoio poiché rapportandosi egli alla volontà, e confessandosi ignaro de' ministri et esecutori di essa, ne segue non mediocre assordo, constituendo la volontà priva di cognitione come da esso disgionta, ché avenirebbe perciò alla nostra interna republica quell'assordo che ad Anacarsi Scita benché di natione barbara ma di ingegno non punto [164] incul|to osservò nella nostra republica, che governandosi allhora, con forma popolare, li fu addimandato quello che giudicasse di tale maniera di reggimento. Onde liberamente rispose che punto non li aggradiva tal maniera di publica admonistione, ove li savii quali erano li Areopagiti proponevano, e li pazzi cioè li volgari e plebei deliberavano. Tale veramente per il certo ci occorarebbe quando admetessimo la volontà dall'intelletto divisa e distinta, per il che si scorge che attentando l'intelletto sfugire una dificoltà in altra maggiore si conduce, ma se anco questa difalta dissimulare volessimo, affatto non si scolpa dalla propria inscitia e sciochezza, poiché se la volontà distinta di lui si ritrova, non sa né anco riferire in che maniera le propone li suoi consiglii, ché essendo la volontà di ragione priva in che modo li sugerisce suoi amaestramenti e documenti? Ma se non per modo di instruttione ciò eseguisce, con quelli mezzi la inclina a suoi insegnamenti et instruttioni? Forsi a guisa di pedagogo con le sferzate over altra simile violenza? Over come sugello l'imprime ciò che li aggrada? Ma s'è l'istesso la volontà con l'intelletto ci occorre la primiera assordità, cioè l'ignorare li suoi agenti e ministri. Et è notabile che nella inspiratione e respiratione e formatione della voce, vi concorrono al numero di ottantasei muscoli incirca li quali benché eseguiscono ciò che l'intelletto e volontà l'impongono, da quelli punto non sono riconosciuti, né osservati, ma sì bene doppo lunga osservatione di anatomica inspettione da pochissimi e peritissimi dell'arte, ciò è riconosciuto et advertito.

E quello è di maggior stupore, che anco nel tempo del sonno, si eseguisce l'inspiratione e comottione di sì gran turba di muscoli benché l'intelletto, principale rettore di nostri motti, alhora in se stesso sia raccolto et attratto, ché il rimettere ciò a semplice et inco- 
republics, and legislator of communities, it does not know its own agents and bystanders, who only require the smallest nod [from the intellect] to immediately cause its orders to be carried out.

It is true that it protects itself from this carelessness by laying the responsibility for the administration of the human system on the will, to which it refers its resolution like a simple consultant by showing it the good that must be chosen and the evil that must be rejected. Then the will forces the internal spirits to execute its arbitrary deliberations. However, one cannot reasonably allow the intellect this excuse and loophole. If it referred to the will and confessed itself to be unaware of its ministers and executors, we would be following a great absurdity in constituting the will as separate from it and lacking cognition. Therefore, the same absurdity that was observed in our actual republic by Anacharsis the Scythian, ${ }^{319}$ who was endowed with a cultivated intelligence although he was of [164] barbarian origin, would occur in our internal republic. As at that time it was a people's government, he was asked for his opinion of this way of ruling. Then, he freely answered that he did not appreciate the kind of public admonishment in which the wise Areopagites would propose and the mad, namely the commoners and plebeians, would deliberate. Certainly, we would experience the same if we admitted that the will is divided and separate from the intellect. For this reason, one may see that when the intellect is attempting to avoid one difficulty, it encounters another that is even greater. Yet if we wanted to dissimulate this failure as well, it would not be acquitted of its own ignorance and foolishness. Indeed, if the will was distinct from it, it could not even say how it [i.e., the intellect] could propose it [i.e., the will] its advice; as the will is lacking in reason, how could it suggest its teachings and instructions? Yet if it does not carry this out by way of instruction, how does it steer it towards its teachings and guidelines? Perhaps it does this like a pedagogue, with a whip or with other similar kinds of violence? Or like a seal, imprinting what it wishes? However, if the will and the intellect are the same, then we will incur the first absurdity, namely that it [i. e., the intellect] is ignorant of its own agents and ministers. Furthermore, it is known that approximately eighty-six muscles take part in inhalation, exhalation, and the production of the voice, which carry out what they are ordered to do by the intellect and the will, but they do not acknowledge or observe them. However, this was only acknowledged and noticed by a very small number of experts in this art after a long anatomical examination.

Besides, what is more surprising is that breathing and commotion are carried out by a great crowd of muscles during sleep, although the intellect, as the main director of our movements, has withdrawn and retreated into itself. Indeed, it would not be reasonable to ascribe this 
gitante natura non riesce ragionevole, essendo in balia dell'intelletto a suo talento il ritenere, ritardare, et acelerare la inaspiratione, ché perciò a [165] fa|coltà animale attribuire si deve tale attione. Per il che quando io vaneggiavo nell'affermare dogmi, stimai ciò non ineficace coniettura per condurmi ad affermare, che più d'uno regesse li nostri volontarii motti, et essendo l'uno occupato over sopito, l'altro come suo vicegerente eseguisce li offitii di quello.

E di più ciò che circa tal proposito è degno di osservanza, che l'intelletto unito con la volontà in un medesimo momento a diversi membri distinti e lontani l'uni dalli altri compartiscono spiriti talmente aggiustati e proportionati, che ad un medesimo tratto le fauci cantando, le mani suonando, li piedi danzando, con mirabile corrispondentia insieme si aggiustano, et accordano, e tuttavia rimane l'intelletto affatto ignaro del modo e guisa che tiene in ciò operare, et eseguire.

Ma lasciamo a parte tali attioni, ché pure si riconosce che l'intelletto in certo modo ne sia autore, ma l'esercitio del caminare che con tanta incognitanza dell'intelletto si eseguisce eppure da esso dipende, poiché non si potrebbe giammai il nostro corpo sopra un piede sostennersi come aviene nel caminare, se non fosse dalla mente ritrovato il proprio suo centro della gravità, sopra il qual bilanciato in positura retta si mantiene, come accade a tutti li altri corpi che equilibrati sopra il centrale loro punto insistono, e non vacilano. La cui inventione riesce molto malagevole nel corpo humano tanto irregulare, che anco nelle semplici superficii regulari il ciò ritrovare fu reputato da periti matematici, più che mediocramente arduo, eppur noi senza alcuna advertenza et ad altro pensando, e mentre operamo, lo serviamo, e non solamente li sapienti et addottrinati, ma l'idioti e fanciullini con somma prestezza et agilità ciò eseguiscono. Ma quello che trapassa la meraviglia che anco dormendo ci conservamo in tal equilibrio sopra il centro della nostra gravità, che vigilando ci siamo constituiti.

E non manca parimente di admiratione l'osservare che essendo li spiriti esecutori di consilii dell'intelletto, e decreti [166] della volontà non solamente privi di capacità di ragione, ma di vita, come afferma il comune di sapienti, che così prontamente et alacramente pongono in opera ciò aggradisce e piace a loro regenti e comandanti. Ma se altrimenti, con quali urti e scossi l'intelletto, over la volontà, tanto spirituali et immateriali movono et agitano tali ignari et insensati operarii? E per porre in esecutione le loro deliberationi, quali vetti, taglie, torchi, et altri mecanici strumenti appo loro tengono di mover corpi così gravi e ponderosi?

In che maniera l'imagine di un picciolo pesciolino, per trapassare anco fuori del nostro genere, riesce bastevole a movere vasta balena che velocemente accorre per ingoiare l'originale di tal imagine? Il 
to simple and irrational Nature, as it is at the mercy of the intellect's wish to withhold, delay, or accelerate breathing. Therefore, [165] this action must be attributed to an animal faculty. Thus, while I was still insane enough to advocate some dogmata, ${ }^{320}$ I considered this to be an effective conjecture to lead me to accept that our voluntary movements have more than one ruler, so that while the former was busy or sleeping, the latter, as vice-director, would carry out the former's function.

In addition to this, what is worth noting concerning this is that the intellect, joined with the will, simultaneously allocates proper and proportioned spirits to different parts that are distinct and distant from one another, so that the singing mouth, the playing hands, and the dancing feet suddenly harmonise and agree with admirable correspondence. Nevertheless, the intellect is not aware of the way or manner in which it makes this and carries it out.

Yet let us leave these actions aside, because one can still acknowledge that the intellect is their author, but as far as the practice of walking is concerned, which [seems to be] carried out without the intellect being aware, [one must acknowledge that] it is also dependent on it [i.e. the intellect]. One's body would not be able to stand on one foot if one's mind did not find its own centre of gravity on which it could balance in a standing position, as happens to all other bodies which keep their balance at their centre and do not vacillate. The task of locating this in the human body is very complicated, as it is so irregular. Indeed, while expert mathematicians considered it most arduous to discover where it is located even on simple regular surfaces, we obey it without being aware of it, thinking of it, or even by doing anything at all. Besides, fools and children, along with wise and learned men, can do this very quickly and ably. Yet what is even more surprising is that we also maintain this equilibrium in our centre of gravity - achieved while we were awake - while we are asleep.

It is likewise commendable to observe that spirits - which are the executors of the intellect's advice and the will's [166] decisions, although they are not only lacking in the capacity for reason, but also in life, as the majority of wise men have said - so quickly and rapidly accomplish what pleases and delights their rulers and leaders. However, if this were not the case, what blows and shakes would the intellect and the will use to move and agitate these unaware and imperceptible agents, as they are so spiritual and immaterial? Furthermore, what lever, tackle, press, or other mechanical instrument would they have to move such heavy bodies and thus to execute their deliberations?

How does the simple image of a small fish - to move away from humankind - turn out to be sufficient to get a huge whale moving so that it quickly rushes to swallow the original of this image? I considered 
Considera il fine del sapere. ricorrere per resolutione di tali difficoltà al patrocinio della simpatia, stata questa per un lungo tratto di tempo sicuro ricovro a negligenti investigatori della natura, stimarei vano sfugitolo. La magnete già asilo di tali pigri e scioperati esploratori delle cause di mirabil effetti, ha liberamente manifestato le germane cagioni della sua attrattione, e vertecità.

Per il che rimane vano il dire che li membri mentre che obediscono a cenni della parte dominante, non sia ciò, per semplice loro ossequio, o impulso che da quella ad essi pervengono, ma piuttosto ci accada per certa simpatia che tengono di conformarsi con quella serie d'imagini che nella mente e volontà allogia, onde tale ricovro riesce piuttosto nenia infantile e favola annile, che soda e consistente dottrina. Ma da tale discussione circa l'imperitia dell'intelletto circa li criterii et organi che adopera per essequire li suoi proponimenti di nuovo riconobbi e ritastai quanto sia grande l'humana ignoranza, e cecità. Mi rimaneva solamente scorrere affatto la mia cariera l'addatarrmi al considerare il fine e scopo a cui indrizza la mente tanto suo travagliare. Non ragiono hora di fini accessorii, et adventitii, come sarebbero le ricchezze, honori, autorità, et altri simili, ma parlo di quell'ultimo scopo e bersaglio a cui dirige [167] et incamina lo sapere humano.

Onde ritrovandomi in tal speculatione implicato, mi occorsero Diogene et Aristippo mentre che io per diporto, nel giardino di Alcibiade mi era condotto, godendo ad un tratto ivi della amenità della terra e vaghezza del mare, del corso di fiumi et erettione di montagne, compendio di tutto ciò che nell'ambito dell'universo si raccoglie. Ma soprattutto remanessimo non mediocramente admirati dall'osservare la notabile varietà di piante, così domestiche, come forestiere che il giardino, con maestevole ordine conteniva.

Onde per tal diversità di vegetabili fu preso a divisare Diogine, che siccome la natura riuscì diligentissima nel variare li generi delle stirpi, così anco molto industre fu nell'apprestare a qualunque di individui di medesimi generi l'istessa conditione e virtù, ma che il contrario pare che osservasse nella humana spetie, che di tal equalità punto non si curò, ritrovandosi cadauno homo, tanto diferente di virtù, conditione, costumi, et opinioni dall'altro, che rassembra che cadauno d'essi constituisca affatto diversa spetie. Onde se l'anatomia interna dell'animo si potesse praticare, come la disecatione del corpo, s'osservarebbero le più portentose monstruosità che giammai la imaginatione formalizare si potesse, né l'Africa di heterocliti parti fecondissima madre, né la licentiosa libertà di poeti e pittori, tali ne formarebbero e fingerebbero. Da che presero origine quelli tre celebri pronontiati che appo il volgo passano per adagii, homo homini Deus, homo homini lupus, 
it a vain loophole to find a solution to these difficulties by appealing to the support of sympathy, which for a long period of time was a safe haven for the negligent investigator of Nature. Magnets, which were already a refuge of these lazy and indolent explorers of the causes of incredible effects, have plainly shown the original causes of their attraction and their ability to turn. ${ }^{321}$

Thus, it is vain to say that when the components obey the signs of the dominant part, they do so not because of the respect they have [for it], or because of an impulse they receive from it, but rather because of a specific sympathy they keep in order to comply with that series of images located in the mind and the will. However, this haven turns out to be a ditty for children or an old wives' tale rather than a solid and grounded doctrine. Yet from this discussion of the intellect's incompetence concerning the criteria and organs it adopts to accomplish its purposes, I once more acknowledged and tested how great human ignorance and blindness are. Still, all I could do was to go back over my career and dispose myself to consider the goal and aim to which the mind addresses such intense labour. I am not thinking now about any secondary or accidental goals, such as wealth, honours, authority, and the like would be, but I mean rather that final aim and target towards which human knowledge [167] is directed and headed.

Therefore, while I was involved in this speculation, Diogenes ${ }^{322}$ and Aristippus joined me in Alcibiades's garden, where I had gone to distract myself. There, I immediately enjoyed the amenity of the earth and the beauty of the sea, as well as the flowing of the rivers and the altitude of the mountains, as they were a condensed representation of everything that one may find in the universe. Yet above all, we were highly impressed by observing the remarkable variety of plants, both cultivated and wild, displayed in the garden in such majestic order.

Therefore, because of this diversity of plants, Diogenes began to consider that while Nature was very diligent in diversifying the kinds of species and providing the same characteristics and virtues to all individuals of the same kind, it did not, however, observe this for humankind, as it did not ensure this equality. Indeed, every man has such different virtues, characteristics, habits, and opinions that each of them seems to constitute a different kind. Hence, if we could practise the anatomy of the soul as we do with the dissection of the body, we would observe the most extraordinary monstrosity that the imagination could ever conceive, and Africa, as a most fertile mother of heterogeneous variety, would not be able to give birth to them, nor would the licentious freedom of poets and painters be able to portray them. From this arose those three well-known expressions considered to be adages among the common people: homo homini Deus, homo homini lupus,
He considers the goal of knowledge. 
homo homini homo, ché forsi questo ultimo meglio espresse la fierezza dell'human genere.

Ma da tal discorso disentiva Aristippo, et opponendosi a ciò, prese a dire, che la natura non ci trascurò punto, havendoci construtti tanto fra noi varii e diversi, né che ciò da forsennato caso risultò, m'anzi, che da tal varietà si può argumentare che essa natura tenne di noi ottimo provedimento, ché havendo le piante come che a stampa gettate, delli homini come che se caduno di [168] appar|tata spetie fosse, con particolare idea et esata diligenza ne prese cura e patrocinio, acciocché per tal diversità riuscisse l'universo più vago et ornato.

Ma Diogine a ciò contradicendo replicò, che se tal varietà da accurata incombenza derivasse, doveva sortire in noi ciò che in quello giardino accadeva, che la diversità delle spetie che in esso vegetano lo rendevano di riguardevole e giocondissimo aspetto e visaggio:

"Ma per il contrario chi considera quali siano le diverse e strane conditioni, costumi, e openioni delli homini, infetti di tante assordità e sconvenevolezze, altro probabilmente stimare non si può che tali diversità altro non siano che errori che deviano dal vero tipo della humanità, né che ciò a malignità della natura et a sua difalta attribuire si deve, ma piuttosto ad insano et indiscreto caso derivare. E per non prendere da ciò lontani essempii dimostrarotelo con cinica libertà. Se il tuo animo, Aristippo, al senso visivo altrui si rappresentasse, siccome io con la mente mi lo rafiguro, in sembiante di monstruoso centauro e diforme harpia li apparirebbe".

$\mathrm{Al}$ che Aristippo alquanto alterato rispose:

“E qual impulso ti move a ciò pronontiare e in sì fatta maniera dileggiarmi?”.

\section{Sogiunse Diogene:}

"Mi move l'osservare che havendoti il piacere proposto per ultimo fine delle humane attioni e ciò sfaciatamente con non poco d'infamia della filosofia hai al mondo divolgato, onde con grande nostra ingiuria ci hai intruso nella classe di bruti, perciò sei in parte a questi simile. Ma d'altro verso osservandoti tanto solecito et anhelante all'indagare la verità e riconoscere le cagioni delle cose, oltre lo esser ornato di qualunque altra egregia morale virtù, non solamente homo ma semideo mi rassembri. Onde havendo advertito che il tuo animo di tal heterogeneo mescolamento sia composto, fui indotto a dire che mi rafiguravi in guisa di centauro". 
and homo homini homo; ${ }^{323}$ the last one is perhaps the best expression of humankind's pride.

However, Aristippus disagreed with this argument and objected to it by saying that Nature had not overlooked us at all, as it had made us so various and different from one another, and this could not be considered as resulting from mad Chance. Rather, from such variety, one could argue that Nature took the greatest care with us: indeed, while it made all plants the same, it took care of human beings and assisted them with specific ideas and precise diligence, as if every single one belonged [168] to a separate kind; thanks to this diversity, the universe has turned out more delightful and decorated.

Yet Diogenes denied this by replying that if this variety came from accurate commitment, there must have happened to us what had occurred in that garden, where the diversity of species growing in it had provided it with such a remarkable and delightful aspect and face:

"For on the contrary, if one considers the diverse and strange characteristics, habits, and opinions of human beings as they are, infected with so many absurdities and indecencies, he would probably consider this diversity to be nothing more than mistakes diverting from the true type of humanity. Besides, this must be attributed not to malicious Nature and its failure, but rather as having been derived from insane and immoderate Chance. Furthermore, in order not to adopt an example far removed from this, I will demonstrate it with cynical license. If your mind, Aristippus, were visible to others, it would appear to them, as I imagine it, in the form of a monstrous centaur or a deformed harpy.”

Then Aristippus, very upset, answered:

"And what is spurring you to say this and to mock me in this way?"

\section{Diogenes continued:}

"I am spurred to do so by observing that you have suggested pleasure to be the final goal of human actions, and you have defamed philosophy by insolently spreading this around the world. Thus, you have greatly insulted us by putting us in the category of brutes, and therefore you are partially like them. On the other hand, since I have observed that you are so prompt and eager to investigate the truth and acknowledge the causes of things, as well as being decorated with every other distinguished moral virtue, you seem to be not a mere man, but rather a demigod. Hence, as I had warned you that your mind was a compound of a heterogeneous mixture, I was induced to say that I imagine you to be like a centaur.” 


\section{$\mathrm{Al}$ che ripigliò egli:}

"Se mi riponessi nel rollo delli animali, anco che brutti da te stimati, gran caso di ciò non farei, ché tuttavia ancor essi dalla comune madre [169] natura sono prodotti et educati, e nella classe di enti reali sono riposti, ma che m'assegni loco fra portenti di poeti, et arditi capricci di pittori ciò patientare non voglio. Per il che desidero che rimanghi informato appieno di questo mio tal instituto. Conviene dunque che sappi, che il piacere non solamente al corpo, ma all'animo parimente appartiene, e se a tempo dedicato al servigio del corpo e suoi piaceri con ogni mia cura e conato m’impiego, altro tanto quando di ciò mi trovo satolato al diletto dell'animo tutto mi offerisco, refocilandolo con curiose speculationi e mentali tratenimenti. Onde io a guisa di economo diligente, all'uno e l'altro della mia famiglia al debito tempo presto quello se li deve, ché perciò riesco tenace sempre del mio principale proponimento, il piacer continuamente seguendo e tracciando. E per il vero con tanto maggior fervore il diletto dell'animo procuro, che la volutà del corpo, quanto che quello più durabile e privo di qualunque nocumento mi riesce”.

S'oppone che il diletto sia il fine del sapere.
A tal ragionare acquietosi Diogine, ma io stimolato dal proprio genio non potei rattenermi, et ad Aristippo volgendomi li dissi che ponendo egli l'ultimo fine e scopo delle attioni et attentati humani il piacere comune al corpo et all'intelletto, conveniva constituirlo a guisa del colore che contiene sotto di sé il nero, bianco, rosso, giallo. Per il che conviene che resti accordato fra noi che la voluttà sia un certo universale comune a tutti li piaceri e diletti particolari.

Accennò Aristippo a ciò assentire, seguendo io:

"Parimente stimarei anco, che fra noi fosse aggiustato che il piacer altro non sia che un nostro interno risentimento che ci accade per la restitutione che si fa in noi al primiero naturale stato".

Assentì egli. Et io:

"Ma se questa è la deffinitione del piacere pigliato in comune et astratto, bisogna che tanto si addati al corporale quanto all'intellettuale. Da ciò si deduce che tre siano li statti nelli quali si trovamo, indolenza, dolore, e piacere. L'indolenza quando [170] siamo senza alcuna alteratione, dolore mentre che si partimo dal statto naturale, piacere quando di nuovo ad esso restituiti siamo, cioè mentre che dal dolore alla indolenza facciamo passagio. E che esso piacere tale sia, potemo da ciò argomentare, che cessando in noi la sete e fame si estingue anco il piacere del bere e gusto del mangiare.

Hor dunque stando le predette assertioni in tal guisa stabilite ruminiamo di nuovo alquanto circa quello affermasti che il piacere sia il sommo bene ch'a noi s'aspetta. Primieramente parmi che non solamente non sia sommo, ma che né anco semplice bene egli sia. La ragione che mi move a ciò dire, è, ch'es- 
Hence, he continued:

"It would not be a problem for me if you included me in the category of animals, even if you considered them to be brutish, because they are also produced and educated from the common mother Nature [169] and included in the class of real beings. Yet I will not tolerate that you should place me among the marvels of poets and the daring caprices of painters. Therefore, I want you to be fully aware of my principles. Thus you should know that pleasure belongs not only to the body, but also to the mind, and I devote myself to paying great care and attention to the body and its pleasures as much as I apply myself to delighting my mind - once I have satisfied it - by first restoring it with interesting speculations and mental entertainments. Thus, like a diligent administrator, I invest due time in both sides of my family. For that reason, I always tenaciously pursue my main objective, namely to continuously pursue and follow pleasure. Furthermore, I will certainly try to promote the soul's delight more fervently than the body's sensual pleasure, as the former turns out to be more lasting and not harmful at all."

Diogenes was appeased by this argument, but, as I was spurred by my genius, I could not hold myself back, and, addressing myself to Aristippus, I told him that since he had set out that pleasure was common to both the body and the intellect as the final aim and goal of human actions and attempts, it was appropriate to conceive it like colour, which includes black, white, red, and yellow. Hence, we should agree among ourselves that sensual pleasure was a kind of universal common to every particular pleasure and delight.

Aristippus gave me a sign of his assent, so I continued:

"Similarly, I would consider that we agreed that pleasure is nothing other than an internal affection occurring to us when we are brought back to the original state of nature."

He agreed with me. Then I [spoke] again:

"However, if this is the common and abstract definition of pleasure, it needs to be suitable for both the body and the intellect. From this, we deduce that we may find ourselves in three different states: indolence, pain, and pleasure. [We are in a state of] indolence [170] when we do not experience any alteration; pain when we leave our natural state; and pleasure when we are brought back to it again, namely when we pass from pain to indolence. Besides, we may argue from this that pleasure is such that as soon as we are no longer thirsty or hungry, the pleasure of hearty eating or drinking is also taken away.

"Then, as the aforementioned assertions have been established in this way, we will ruminate again on that which you have stated, namely that pleasure is the supreme good intended for us. First, it seems to me to be neither the supreme nor a simple good. The reason for my statement is that

He argues that pleasure can be the goal of knowledge. 
Cagione del diletto che sentimo nel sapere. sendo il piacere posto fra il dolore et indolenza, cioè un progresso fra questa e quello, come fu hora detto, riesce un certo mescuglio dell'uno e l'altra. Per il che il nome di bene offerirli decentemente non se li può, non potendo esser bene colui che uno de' suoi componenti è male quale è il dolore, ma che questo tale sia, non crederei che né anco li pazzi ciò negassero, poiché con il timore del dolore si rendono alquanto mansueti. Ma né anco l'indolenza è meritevole dell'economio del bene, essendo essa anco alle pietre insensate comune, onde se l'esser privo di dolore bene fosse, mentre che ciò desiderassimo, bramaressimo di renderci alla conditione di freddi marmi.

Ma oltre di ciò se il piacere, come tenimo concertato, consiste nella restitutione al primiero naturale stato, non sarebbe per se stesso desiderabile, ché pur ciò si stima il proprio carattere del sommo bene, poiché giammai si bramò per se stesso il risanarsi, ma sì bene doppo che havessimo smarita la sanità, $\mathrm{e}$ di già incorso nella infermità. Ma di più avicinandomi al primiero nostro proponimento cioè al diletto che sentimo nella speculatione, ci converebbe dire che la scientia già appresa sia a guisa della indolenza, l'ignoranza simile al dolore e lo speculare eguale al piacere. Ma che l'ignoranza generi per se stessa il dolore non saprei in qual guisa ciò rassembrarmi, essendo essa ignoranza il più potente [171] nar|cotico che ci habbia proveduto la natura a renderci imperturbati a dolorosi colpi che ci sono dalla fortuna inviati.

E se sovente ci lagnamo della nostra ignoranza ciò accade per il riconoscimento che di essa tenimo, onde il contrario di essa, cioè il riconoscimento, è quello che ci molesta e tormenta, overo altra prava consequenza che da quella deriva, ad essa adventitia et accessoria come il sprezzo, e mala riuscita di nostri intraprese. Ma di più se il bene, come affermi, è il piacere che si conseguisce dall'atto dello speculare e ricercare la verità, doppo conseguita che questa fosse, rimarebbe terminato et estinto il bene, onde mentre che procacciamo e tracciamo la scientia ottenimo il sommo bene, ma acquistata che l'habbiamo estinguendosi esso piacere, ci svanisce il sommo bene.

Per il che sarebbe desiderabile per continuare nel diletto cioè nel bene, subito che havessimo conseguito la scientia dimenticarla acciocché di nuovo tenissimo occasione di reiterare il piacere che conseguimo nel riacquistarla, et infratanto ripossedere il bene del diletto che in ciò sentiamo, divenendo simili a quelle miserabili sorelle che attingendo con crivelli l'acqua, giù questa cadendo, li bisogna continuamente rinovare il loro vano impiego. Ma di più aggiungo, che dubito il piacere, che dal conseguire la verità prendiamo, non sortisce per cagione di essa verità, ma che il diletto risulta, a mio credere, perché fugimo con tal esercitio quel naturale timore che apporta seco l'admirabilità, mentre che ignoramo le germane e vere cause di stupendi effetti che inopinatamente nel mondo occorrono, riuscendoci sospeta qualunque novità che ci apparisce.

Onde quando che alla retta speculatione ci applichiamo, conoscemo tali novità essere semplici aborti e sconciature della gran madre natura, non feciali et alardi che c'intimano la guerra et all'arme come stima il volgo de plebei. Per il che riconoscendo noi le cagioni di tali fenomeni resta l'animo nostro quieto e tranquilato. Da questo procede ch'a guisa di cacciatori alli [172] speculatori accade, che siccome quelli mentre che tracciano vil lepre oltre modo pare che la pregiano, ma presa che l'hanno non più la stimano che vilissimo animale, così 
as pleasure is set between pain and indolence, namely an advancement from the former to the latter, as we have now said, it turns out to be a kind of mixture of both of them. Therefore, one cannot properly provide it with the name of good, because something which also has an evil component, as pain is, cannot be good. Yet if this were the case, I would not believe that it could be denied even by the insane, because they become quite docile before the fear of pain. However, not even indolence deserves to receive the praise of being called good, because it is also common to insensible stones. Hence, if to be lacking in pain is a good, then when we wished for it, we would also be longing to be in the same condition as cold marble.

"Yet in addition to this, if pleasure - as we have established together consists in a return to our original natural state, it would not be desirable in itself, although this is considered to be the proper feature of the supreme good. The reason for this is that no one has ever longed to be healed in himself, but he does so only after being no longer healthy and already in a state of disease. Yet in coming closer to our first objective, namely the pleasure that we feel during speculation, we should say that already apprehended knowledge is like indolence, ignorance is like pain, and speculation is like pleasure. However, I cannot imagine how ignorance may produce pain by itself, as ignorance is the most powerful [171] narcotic that Nature has given us in order to make us imperturbable to the painful blows struck by fortune.

"Furthermore, although we often complain about our ignorance, this happens after having acknowledged it; thus its contrary, namely acknowledgement, is what annoys and torments us, and another bad consequence deriving from it, which is accidental and secondary to it, is disregard for our undertakings and their failure. Besides, if the good, as you state, is the pleasure obtained from the act of speculating and searching for the truth, then once we had achieved it, the good would be over and extinguished. Therefore, when we see and pursue knowledge, we obtain the supreme good, but as soon as we have acquired it, then not only is the pleasure extinguished, but the supreme good also vanishes.

"Therefore, in order to continue to be in a state of pleasure, namely in a state of good, it would be desirable to forget knowledge once we had achieved it, so that we would have a new opportunity to repeat the pleasure we reach in acquiring it and in the meantime to once more possess the good [achieved by] the pleasure we feel in doing this. Thus, we would become like those miserable sisters drawing water with a sieve who had to ceaselessly perform this task as it would flow back out. Moreover, I will add that I doubt that the pleasure that we gather while we are achieving the truth is occasioned because of the truth itself. Rather, I believe that the delight results because through this, we escape that natural fear produced by the sense of wonder when we are ignorant of the true and original causes of the astounding effects unforeseeably occurring in the world. Indeed, any novelty we see ends up being suspicious to us.

"Thus, when we commit ourselves to true speculation, we come to know that these novelties are nothing other than a simple failure and deformity of the great mother Nature and not, as the masses of plebeians consider it, fetials ${ }^{324}$ or herald $\mathrm{s}^{325}$ who order us to go to arms and war. Thus, once we acknowledge the causes of these phenomena, our minds are appeased and reassured. Hence, it follows that speculators are like [172] hunters: just as the latter seem to esteem the hare while they are hunting it but consider it nothing more than a most vile animal

Cause of the pleasure we feel in knowledge. 
noi inanzi ch'habbiamo fatto acquisto della verità, la tenimo in gran stima, ma ottenuta che sia, poco o nulla la curamo:

Come segue la lepre il cacciatore.

Al freddo al caldo alla montagna al lido

Né più la stima poiché presa vede.

Et sol dietro a chi fugge affreta il piede.

Dal che ne siegue che l'animi maggiormente fiachi e deboli sono quelli che più delli altri riescono li più curiosi nel conseguire la scientia delle cause d'effetti naturali, essendo maggiormente da sospetti e timori vessati, ma l'animi per natura generosi, et inflessibili, poco o nulla da tal impiego ricevono diletto. Onde fermasi il cielo, sconvolgasi la terra, confondansi di nuovo li elementi, nulla li comove e paventa. M'anco, amico Aristippo, se l'antedette ragioni non ti appagassero, lo promulgare che il piacere sia l'ultimo scopo e mira delle nostre attioni, non mi pare che ciò apporti alcun utile alla humana società, anzi l'arrechi notabile nocumento.

Onde s'anco il tuo dogma vero fosse, riesce oltre modo dannevole. Et in qual modo si potrebbe giammai disuadere altrui l'abbandonare l'oscene volutà, mentre che da sapienti fosse publicamente asserito che l'acquisto del piacere sia il sommo bene? Né la distintione posta fra li piaceri corporali e spirituali può tal colpo affatto evitare, poiché già si è mostrato che in quanto ambi sono piaceri, sono simili e che concorrano nell'istessa definitione. Ma, carissimo amico, giacché il presente loco al piacere fu dal nostro amico destinato, non procuramo con nostre importune discussioni profugarlo, né contraveniamo al generoso volere di lui che [173] tanto largamente ci l'offerisce, ma prendiamo quelli diletti che la stagione et il loco ci stimola a ricevere”.

Qui hebbe fine il nostro discorso circa tal proponimento, dal quale questo solamente fu da me raccolto ch'il piacere non sia l'ultimo scopo della speculatione e ritrovamento della verità. Non mancai a ricercare altri sapienti circa tal fine ma doppo lungo divagamento di discorso e dubbiosa flutuatione, mi fu da alcuni di essi detto, che il fine della contemplatione era un scusabile fuggilotio et un honorato scanso dalla pernitiosa e dannata accidia e scioperatezza.

A questo segno approdò la mia lunga navigatione e continuato tra-

Pone fine Socrate al sindicato circa la curia interna dell'huomo. vagliare circa il riconoscere 1 a nostra interna curia e questo fu il fine del mio rigoroso sindicato. E per il certo da tal mio faticoso impiego altro non rapportai se non che dubbitai che li oggetti, primieri promotori del nostro sapere in folta caligine si ritrovassero, li sensi esteriori fallaci, l'interni vani e fititii, l'intelletto ignaro di se stesso, e di qualunque sua attinentia et attione. Dal che ne seguì che non poco spiacere sentii dalla frustatione di tanti miei laboriosi conati, ma maggior mole- 
once they have caught it, so we esteem the truth highly before having acquired it, but take little or no care of it as soon as it has been achieved:

Ev'n as the huntsman doth the hare pursue, In cold, in heat, on mountains, on the shore, But cares no more, when he her ta'en espies Speeding his pace only at that which flies. ${ }^{326}$

Hence, it follows that the weakest minds, as they are the most suspicious and frightened, are those who are more inquisitive than others to achieve knowledge of the causes of natural effects. However, minds [that are] more generous and inflexible by nature barely enjoy this activity, or do not [enjoy] it at all. Therefore, nothing affects or frightens them: the sky may stop, the earth may be shaken, and all the elements may be reshuffled again. However, dear Aristippus, even if you are still not satisfied by the aforementioned reasons, nevertheless, you cannot spread the opinion that pleasure is the final goal and aim of our actions, because it seems to me to be providing no advantage to human society, but rather only to be causing considerable harm.

"Thus, even if your dogma were true, it would turn out to be extremely harmful. Furthermore, how may one dissuade others from abandoning obscene sensual pleasure if the wise men have publically asserted that the supreme good consists in the achievement of pleasure? Not even a distinction between bodily and spiritual pleasures would avoid this issue, because it has already been demonstrated that as both of them are pleasures, [it follows that] they are similar and that they remain under the same definition. However, my dear friend, since our common friend [i. e., Alcibiades] designed this place for pleasure, I do not wish to chase it away because of our rash discussions, nor to contravene his generous will [173] in liberally offering it to us; thus, let us enjoy the delights that the season and location offer us here."

Here, our argument concerning this subject ended, from which I gathered only that pleasure was not the final goal of speculation and seeking the truth. I did not miss the opportunity to question other sages concerning this goal, but after a long meandering of the discourse and some doubtful wavering, some of them told me that the goal of contemplation was rather [to seek] an excusable pastime and a respectable avoidance of harmful and condemned sloth and idleness.

My long navigation and continuous striving to acknowledge our internal curia ended here, and this was the end of my rigorous assessment. Certainly, I gathered nothing from my difficult pursuit other than that I suspected that objects, which are the first promoters of our knowledge, were in a dense fog, the exterior senses were deceptive,

Socrates ends the assessment of the human internal curia. the internal ones were vain and fictitious, and that the intellect was unaware of itself and of any other thing related to it, as well as of its own actions. On the one hand, it followed from this that I felt a great regret because of the frustration coming from the many industrious attempts I had made, and what disturbed me most was to observe that 
Si ride Socrate della vana curiosità altrui.

stia mi arrecava l'osservare che l'administratione delle mie attioni, e regimento di me stesso era comesso ad ignoti et imperiti governatori.

Ma tal consideratione per altro verso eccitava in me non poco di riso rappresentandomi la vanità di coloro che mentre il loro intelletto si trova sconoscente di se stesso, e se da altro lume non fosse illuminato dubbitarebbe se uno overo molti siano coloro che governano il loro sistema, nondimeno con temerario ardire attentano con risoluta decisione definire:

- $\quad$ Se l'universo da spirito permeabile nelli suoi vastissimi membri retto sia, overo piuttosto trovasi causa dal mondo distinta e con esso punto non mescolata che con la propria energia et efficacia il tutto moderi e regga.

- Se li cieli si movono per impulso conferitoli da esterno motore, overo come soleciti amanti a volta si ragirano [174] per ossequioso corteggio verso loro amate separate intelligentie.

- $\quad$ Se le stelle e pianetti a guisa di pesci che nell'acqua guizzano nel puro ethere viaggino, o piuttosto come nodi in tavola affissi continuamente sono traportati.

- Se un primo mobile a tutti superiore rapisce li orbi ad esso inferiori e l'impulsa ad andare dall'oriente all'occidente, overo piuttosto caduno di essi tiene un proprio cielo che tal moto l'imprime contrario al di loro proprio dall'occidente all'oriente, overo conviene dire che caduno di cieli oltre il suo naturale moto, tenga propria propensione di conformarsi al motto universale di tutto il sistema. $\mathrm{O}$ piuttosto è ragionevole il risparmiare alla natura non solamente la moltiplicità delli orbi m'anco di motti et affermare che caduno di orbi dall'oriente all'occidente solamente s'indrizza, ma che il tardare nel lor corso chi più chi meno, ingannevolmente ci fa apparire che in contraria regione s'inviano cioè dall'occidente all'oriente.

- E non mancò chi per evitare la pluralità di motti, rapti, accelerationi, stattioni, retrogradationi nelli cieli, a maggior assordità assentì, cioè che le stelle fisse et il sole immobili se ne stassero, e che li pianeti e la terra circolarmente comettessero circa quelli, continua danza.

Ma lasciando io a parte tal ridicola consideratione, di nuovo invalse in

Socrate s'applica a discutere ciò che sia il

sapere. me l'antico mio talento di proseguire l'incominciato instituto, massime percorso tanto di spatio, che poco mi pareva rimanesse di progredire, e superare per compimento del destinato mio proponimento. E perciò circa l'istesso sapere mi applicai come ultima meta del mio mentale viaggio. E perché riconobbi la propria mia imperitia nelle antedette discussioni, deliberai ricercarne il parere di più sapienti. Il primo 
the administration of my deeds and my governing were being executed by unknown and incompetent rulers. On the other hand, this consideration caused me great amusement. Indeed, I thought about the vanity of those whose intellect is not aware of itself, who would wonder whether their own system of government is ruled by one or more [ruler] if it [i.e., their intellect] is not enlightened by another light. However, they recklessly dare to decisively define:

- Whether the universe is regulated by a spirit permeating the entire immense breadth of it $^{327}$ or rather whether there is a cause - distinct from the world and not at all mixed with it - that is able to moderate and rule the whole only through its own energy and effectiveness; ${ }^{328}$

- Whether the heavens are moved by an impulse given by an external mover or rather turn like attentive lovers [174] by obsequiously courting their beloved separate intelligences;

- Whether the stars and planets move through the pure ether like fish wriggling in water ${ }^{329}$ or rather are continuously carried like knots in a board; 330

- Whether a prime mover, superior to all the others, holds the orbs that are inferior to it and gives them the impulse to move from Orient to Occident; or rather whether each of them has its own heaven and the motion impressed is contrary to its own, from Occident to Orient; or rather whether one should say that all the heavens, in addition to their own natural motion, are inclined to conform to the universal motion of the whole system; or rather whether it is reasonable to say that Nature not only has a multiplicity of orbs, but also of motions, and to state that orbs are directed only from Orient to Occident, but that the greater and lesser delay of each of them allows us to appear to be going in a contrary direction, namely from Occident to Orient.

- Furthermore, there were also those who agreed with an even greater absurdity, namely that the fixed stars and the sun are static while the planets and the earth complete revolutions around them, like a continuous dance; ${ }^{331}$ and this is in order to avoid a plurality of motions, jerks, accelerations, stops, and reversals in the heavens.

Yet in leaving this ridiculous consideration aside, my original wish to proceed with my already started proposal re-eme rged. Although I had already walked a long path, it seemed to me that there was still a little to be done and to surmount in order to accomplish my intended proposal. Therefore, I applied myself to knowledge itself as the final goal of my mental journey. As I had acknowledged my incapability in the aforementioned discussions, I decided to look for the opinions of the wisest men.
Socrates laughs at the vain curiosity of the others.
Socrates applies himself to discussing what knowledge is. 
Prima espositione del sapere. che mi s'offerì fu Prodico, famoso sofista della nostra età e che per lo straordinario premio che di suoi documenti conseguiva divenne oltre modo stimato dal volgo della nostra città. Ad esso dunque ricorsi e lo richiesi che m'esponesse ciò che intendeva che fosse [175] l'humano sapere, e che Alcibiade li sarebbe malevadore di una mina s'egli ciò m'insegnasse.

Risposimi che tanto agevole li riusciva il satisfare il mio desiderio che non meritava tanto di remuneratione e seguendo disse che il saper humano, consisteva nella cognitione delle cose divine, naturali e humane.

Al che soggionsi che anzi meritava per tal grata instruttione assai maggior mercede che la da me offertali, poiché invece d'insegnarmi ciò che sia un solo sapere di molti mi haveva informato, ma che io havendo hora assaggiato la sua urbanità e cortesia, ardiva di nuovo circa altra mia richiesta occuparlo, ricercandolo che m'esplicasse qual fosse il parere suo circa l'essenza del colore bianco, havendone esso, tenuto intorno ciò con Democrito trattato.

Rispose egli che varii furno li pareri circa questo:

"Alcuni stimarno che non fosse altrimente colore ma semplice privatione di esso, esprimentandosi che purgato che sia il panno da qualunque altra tintura al bianco si riduce, né ad altro colore fa passagio.

Altri attribuirno il bianco a certi corpuscoli che nella superfitie del corpo si ritrovano, formati di figura orbicolare vuota con l'interstitio pieno percossi dal lume esterno siccome nella spiuma biancheggiante appare.

Non mancorno di quelli che con la solita tirannica dedutione, alle prime qualità ricorsero, attribuendo il bianco al freddo e humido. Ma il definire qual di questi pareri al vero più si aggiusti troppo lungo divinirei se hora ciò attentassi”.

Ma io lo rincalzai con dirli:

"Amico Prodico, per qual cagione cosí prestamente dimenticato ti sei del tuo primiero proponimento, non havendomi hora risposto come prima facesti, che la bianchezza fosse ciò che insiste nella cerussa, marmo pario, neve, e nel petto delle celebre sirene, siccome che nell'esplicare ciò che sia il sapere esponesti, cioè che fosse la cognitione delle cose divine, naturali, e humane”.

Ma io ridarguendolo osservai che nuova bianchezza nel suo volto apparì. Per il che confuso e convinto lo giudicai, riconoscendo egli che tal sua definitione [176] addotta circa il sapere non indicava l'essentiale interno di esso sapere ma piuttosto esponeva circa ciò egli si esercita et impiega, come se fossimo interrogati dell'arte della pittura respondessimo che travaglia circa li colori. 
The first one who came to me was Prodicus, ${ }^{332}$ a well-known sophist of our time, who became very highly esteemed by the common people of our city thanks to the extraordinary recognition he had achieved through his teachings. So I appealed to him and asked him to expound to me what he thought human knowledge was, [175] and [said that] if he taught me this, then Alcibiades would be the guarantor for a mina [with which I would reward him]. ${ }^{333}$

He answered me that it was so easy to satisfy my wish that he did not deserve such great remuneration, and he continued by saying that human knowledge consisted in the cognition of divine, natural, and human things.

Then I continued that he rather deserved much more remuneration than I had offered him for his welcome teaching, because instead of teaching only one kind of knowledge, he had informed me about many. However, as soon as I had tested his kindness and courtesy, I dared to make him commit to another of my requests, and I asked him to explain what his opinion was concerning the essence of the colour white, as he had already dwelled on this with Democritus.

He replied that there were various points of view about this:

"Some considered it to be not colour, but a simple privation of it, because they observed that after all the dye is bleached from a piece of cloth, the whiteness remains and does not change into any other colour.

"Others attributed the white colour to some corpuscles located on the surfaces of bodies, made of empty spherical figures with a full interstice, which are shaken under external light, as we may see appearing in white lather.

"There were also those who, through the usual tyrannical deduction, appealed to the first qualities, attributing the white colour to coldness and humidity. However, if I attempted to define which of these opinions was closer to the truth now, I would be dwelling on this too much.”

Yet I replied by saying:

"Dear Prodicus, why did you forget your first resolution so quickly? Indeed, [by saying that] whiteness is what exists in white lead, Parian marble, ${ }^{334}$ snow, and the breasts of the famous Sirens, you have not answered me now as you did before, when you explained to me what knowledge is; indeed, you expounded that it is the cognition of divine, natural, and human things."

However, as soon as I had reprimanded him, I noticed that he turned pale, and therefore I thought that he was disoriented, but persuaded. Indeed, he acknowledged that the definition [176] of knowledge that he had put forth did not really explain the internal essence of knowledge, but rather expounded on the area of its application and usage, as though if we were wondering about the art of painting, we answered that it works through colours.
First exposition of knowledge. 
Seconda espositione del sapere che sia risentimento.

Ma se da Prodico accomiatatomi inclinai la mia diligenza alli monumenti lasciatici dalla veneranda antichità, et in Omero primieramente m'incontrai, il quale parevami che in certi quali suoi versi decantasse ch'il sapere altro non fosse che un certo delicato risentimento che nell'interno dell'animo ci accade. Ma Protagora, che con maggior espressione lasciossi intendere, chiaramente afferma che il nostro sapere sia semplice passione dell'interno animo. Ma per esporre li motivi che indussero costoro a ciò stimare e le consequenze che da questo si deducono, conviene che alquanto mi dilunghi e che da lontano ordisca il mio ragionare.

Nell'introdurre nel marmo alcuna imagine conviene scalpellarlo, et in tal maniera riesce in esso il simulacro che s'attende farvi sortire, come anco la cera comprimendola il sugello, risalta in essa la figura che si ricerca formare, ma né questa né il marmo benché rappresentino tali imagini essendo di sentimento privi non riconoscono punto ciò che in essi il maestro ha indotto. Da quindi è che se di senso fossero dottati altro non apprenderebbero di più il marmo che la distrattione delle sue parti e la cera la compressione, onde conforme il parere di Protagora e suoi seguaci che il sapere altro non sia che sentimento, da noi non si apprenderebbe il vero simulacro et imagine che l'oggetto veramente, che realmente forma e rafigura nel nostro animo, ma solamente la semplice compressione over distrattione, che per l'incontro dell'oggetto overo della sua imagine, nel nostro animo si produce.

Onde se il nostro sapere altro non fosse che sentimento, noi apprenderessimo solamente certa interna alteratione né più oltre passarebbe il nostro intendimento, adducendo di più l'autore di tal dogma in prova che tenendo poi l'occhi aperti [177] in modo che si conceda libero adito all'imagini che s'introducono insino alli più intimi recessi del nostro animo e che vi facciano impressione, tuttavia mentre che con l'animo altrove ci divertimo non sono da noi advertite e osservate. Dal che parimente raccolgono che il sapere sia l'istesso che il sentimento. Apportano oltre di ciò che non può imagine di oggetto insensato complicarsi et identificarsi con la facoltà sensitiva, ma conviene che diverse siano. Per il che è di mistiero che altro sia il simulacro che il sentimento che s'apprende per la di lui impressione.

Si favoregiano di più dell'autorità del nostro Aristotele che pronontiò che intelligere est quodam pati sebbene che in altri suoi discorsi si dimostrò da ciò alieno. Ma esposti li fondamenti di tal opinioni, conviene che s'esplichi l'avantaggi che il saper humano da questa positione riceve, come anco li pregiuditii che ne derivano. Fra li avantaggi dunque s’annoverano la destruttione di concetti universali già da me 
However, after taking leave of Prodicus, I turned my attention to the records delivered by venerable antiquity, and first I met Homer, who seemed to me in some of his verses to be praising knowledge as nothing other than a delicate affection occurring in our minds. And Protagoras expressed himself openly and clearly stated that knowledge was a simple inner passion of our minds. However, in order to expound on the reasons motivating those people to state this, as well as the consequences to be deduced from it, I should dwell on this somewhat and plan my argument from the beginning.

In order to produce an image on marble, one must chisel it, and in this way, the simulacrum one expects to obtain will appear on it, just as by pressing a seal on wax, the figure one wishes to form will emerge. However, although both the latter and the marble display these images, nevertheless they do not remotely acknowledge what the master added to them, as they are lacking in sensory faculties. Hence, if they were endowed with senses, the marble would apprehend nothing more than the separation of its parts, or the wax [nothing more than] the pressure. Therefore, according to the opinion of Protagoras and his followers, namely that knowledge is nothing more than sensory perception, we cannot apprehend the true simulacrum or image of the object that is truly and genuinely formed and represented in our minds, but only the simple pressure and separation produced in our minds by encountering the object or its image.

Thus, if our knowledge was nothing other than sensory perception, we would perceive only a particular internal alteration, and our understanding would go no further. Furthermore, the author of this dogma provided as proof that, by allowing our eyes to open, [177] we thereby allow images to have free access to the most internal recesses of our minds and to impress themselves on them. However, we will not perceive or observe them when we turn our attention to something else. Thus, they gather from this that knowledge and sensory perception are the same. In addition to this, they put forth that the image of an object lacking in senses cannot be mixed or identified with the sensory faculty, but that they should be different. Hence, it is necessary that the simulacrum is different from the perception we apprehend through the imprint of the simulacrum.

They mostly stand firm on this by appealing to the authority of our Aristotle, who stated that understanding is a kind of passion, ${ }^{335}$ although in some of his other arguments he demonstrated that he did not share this opinion. ${ }^{336}$ Yet on the basis of this opinion, one should explain the advantages that human knowledge receives from this position, as well as the prejudices that follow from it. So among the advantages may be included the demolition of the universal concepts, which I have already contested because it is impossible that a passion located 
oppugnati essendo impossibile che passione in noi instalata divenga tale, che né a loco né a tempo sia alligata e ristretta. Secondo profitto che conforme tal dogma ne seguirebbe grande sollievo all'affari humani, ché per tal parere si levarebbero affatto le contradittioni e contese che seguono per la repugnanza delle openioni, poiché essendo queste semplici risentimenti in noi circonscritti e terminati, non può l'uno homo all'altro contradire, essendo una sensatione diversa dall'altra secondo la varia dispositione dal sensitivo e diferente applicatione dell'oggetto, benché questo l'istesso sia, com'accade a panni di diversa conditione che posti nella istessa caldaia di tintura emergono di variato colore.

Onde oltre modo evidente riesce che le facoltà sensititive che sono di egual dispositione e rispetto all'istesso oggetto e nell'istesso modo ad esso accomodate, affatto sortiscono corrispondenti e di egual impressioni. All'antedetti avantaggi che seguono alla predetta espositione dell' [178] huma|no sapere, e si contrapongono alcuni altri incongruità per li quali, tal dogma riesce oltre modo assordo.

Primieramente, non mediocramente rimanerebbe avvilita $\mathrm{e}$ depressa la nostra mente, mentre che ad altro non aspirasse che al patire e semplicemente risentirsi dell'altrui urti e scosse, priva per se stessa d'ogni efficacia et attività.

Di più secondariamente, se il sapere altro non fosse che sentire ci pervalerebbero alcuni animali bruti che di meglio sentimento di noi si trovano proveduti e massime ritrovandosi li loro sensi al di fuori esposti, non passando l'impulsi che da oggetti derivano per li anfratti di angustissimi et invilupati meati, come a noi accade, dovendo penetrare all'ultimi ripostigli del nostro animo.

Terzo assordo, che tanto li delirii de' frenetici, sogni di addormentati, e le sciochezze del pazzo volgo, quanto l'egregie et elaborate dottrine di sapienti egualmente vere riuscirebbero ché tutti uniformamente sono passioni e sentimenti dell'animo causati d'oggetti non vani ne' fititii.

Quarto inconveniente, ne seguirebbe da questa espositione, che siccome altre fiate fu da me detto, che non essendo altro il nostro sapere che sentimento, siccome il dolore e piacere li più vehementi risentimenti che incontramo in noi insistino e sono circonscritti, né giammai si trovò esterno oggetto che piacere over dolore fosse, così l'istesso seguirebbe circa tutte le altre nostre passioni. Onde il dolce et amaro, il nero e bianco, e qualunque altra apprensione 
in us may alter itself in order to become neither related to nor limited by space or time. According to this dogma, as a second advantage there would follow a great relief to human affairs; indeed, according to this point of view, it would end the controversies and disputes that are consequences of opposing opinions. As they are simple affections, restricted and limited to us, no one of them can contradict another. Indeed, every sensation is different from the others, according to the various dispositions of the one who perceives and the different ways he applies himself to the object, although it always remains the same. Likewise, it happens that if diverse cloths are put in the same cauldron, they will turn out to be of different colours.

Therefore, this turns out to be even more evident if [we consider that] the sensory faculties, which have the same disposition and attitude towards the same object and are adjusted to it in the same way, will turn out to correspond to and [produce] the same impressions. The aforementioned advantages following the previously mentioned exposition [178] of human knowledge may be countered with some other incongruities, which results in this extremely absurd dogma.

Firstly, the mind would be greatly despondent and depressed if it could only aim to undergo and simply be affected by the blows and shocks coming from others and to be lacking in effectiveness and activity by itself.

Furthermore, secondly, if knowledge was nothing other than sensory perception, we would be overcome by certain brute animals, as they are endowed with better sensory faculties, especially because their senses are exposed to the outside and thus the impulses they derive from objects do not go through very narrow and tangled meanders, as is the case for those of us who mean to penetrate as far as the most hidden parts of our minds.

The third absurdity is that the deliriums of frenetics, the dreams of sleepers, and the foolishnesses of the mad crowd would turn out to be as true as the illustrious and refined doctrines of wise men. This is because all of them are indifferent passions and perceptions of the soul caused by objects which are neither vain nor fictitious.

The fourth disadvantage resulting from the explication that our knowledge is nothing other than sensory perception - as I have said before at other times - is that just as pain and pleasure, which are the strongest affections we experiencein ourselves, are inside us and limited to us - indeed, we have never found an external object that is both pleasure and pain - so the same would follow for all our other passions. Therefore, sweetness and bitterness, black and white, and any other 
sensibile over intelligibile, denegare se li dovrebbe entità e realtà esterna, e così anco il concetto che forma l'intelletto della esistentia esterna delle cose, sortendo anco essa sentimento nostro interno, e mentre che ci pensamo d'apprenderla, e rittrovarsi con il discorso vagare circa li oggetti esterni, in noi stessi dimorarissimo, a guisa di sognanti che imaginandosi peregrinare e ritrovarsi in parte remota dalla patria, alla fine nel loro letto fissi et immobili giaciono.

Quarto assordo, ch'è come colorario dell'antecedente [179] si|ccome il dolore e piacere in noi sono temporanei e flussibili, né più tengono in loro stessi reale essistentia che mentre continua il risentimento che di essi tenimo, l'istesso parimente accadarebbe a tutti li sensibili et intelligibili che l'universo ci appresenta, producendosi la di loro apprensione per mezo del nostro semplice risentimento, onde divertendo da essi ad altro, rimanerebbero estinti. Per il che troppo crudeli contra li più cari oggetti della humanità diveniressimo, mentre che cessando noi di specularli et apprenderli, l'amici, la patria, e li figlioli si distrugessero. Né vale il dire che continuarebbe al di fuori quelli oggetti che produssero in noi tali apprensioni, perché già fu esposto, che secondo la predetta opinione qualunque cosa che da noi s'apprende essere sentimento, da che ne segue parimente, che anco tal imaginato efficiente del sentimento, in noi allogia e risiede.

Quinto inconveniente, che se il sapere non fosse altro che sentimento non già l'essentie delle cose, ma solamente si apprenderebbero leggiermente l'esterne membrane e cortecie dell'oggetto, non potendo il semplice sentimento più adentro penetrare e fare passaggio, siccome aviene quando di alcuna puntura rimaniamo offesi.

S’aggiunge a ciò per sesto assordo, che rassembra repugnare alla esperienza il negare alla mente l'attività e situarla nella classe delli semplicemente passibili, osservando noi le compositioni, divisioni e dedottioni che continuamente essa essercita, per il che nel rollo dell'attivi ci par che convenga includerla. E per il vero havendo io riguardo alli narrati assordi, m'arosisco d'inclinare a tal dogma.

Ma lasciando hormai queste spinosità riduciamoci a gente più

Terza espositione del sapere. festevole, che ci espone che il sapere sia reminiscenza delle cose che altra fiatta habbiamo apprese. Onde con ardito proponimento ci dissero che l'animo nostro, inanzi che nel corpo nostro sogiornasse, fosse stato delle cognitioni di tutte le cose mondane dottato, stimando alcuni che l'anime nostre siano come rami recisi da grande [180] tronco d'arbore. 
sensible or intelligible apprehension would have to be denied any external entity and reality. [And we must say] the same about the concept of the external existence of things formed by the intellect, as it also turns out to be a perception that is internal to us. Furthermore, when we believe that we are apprehending it and our reason is meandering around the external objects, we are [only] dwelling in ourselves, like dreamers who imagine themselves to be wandering and finding themselves far away from their homeland, but who are motionless and still lying in their beds.

The fifth absurdity, ${ }^{337}$ which is a corollary of the anteceding one, [179] is that just as pain and pleasure are temporary and fleeting but have real existence as long as we continue to be affected by them, so the same should occur to all the other sensible and intelligible things that the universe provides for us. Indeed, as their apprehension is produced simply by our being affected, then as soon as we turned from them to something else, they would be extinguished. Hence, we would become too cruel towards the most beloved objects of humanity; indeed, our friends, our homeland, and our offspring would be destroyed if we stopped to speculate about and apprehend them. It is not correct to say that they [i.e., sensible things] continue to exist outside the objects which have produced these apprehensions in us, because, as has already been expounded, according to the aforementioned opinion, anything that we apprehend is [nothing other than] sensory perception. Likewise, it also follows from this that the supposed efficient cause of sensory perception dwells and is located inside us.

The sixth disadvantage is that if knowledge was nothing other than sensory perception, we would not apprehend the essence of things, but merely the objects' external membranes and bark. Indeed, simple sensory perception cannot penetrate deeper or pass through things as happens when we are stabbed.

A seventh absurdity must be added to this:that it seems to be contrary to experience itself to deny the activity of the mind and to simply classify it among the passive things; indeed, if we observe the continuous combining, dividing, and deducting that it carries out, it seems that we should include it among the active ones. Truly, as I take the narrated absurdities into consideration, I blush to have been inclined to this dogma.

However, leaving these thorny things aside for now, let us address more cheerful people, ${ }^{338}$ who expound that knowledge is the recollection of things that we have already apprehended. Thus, they dared to affirm that our soul, before dwelling in our body, was endowed Third exposition of knowledge. with the knowledge of all mundane things; indeed, they considered our souls like branches cut from the great trunk [180] of a tree. ${ }^{339}$ 
Questo è l'anima dell'universo che regge con tanta sapienza li mirabili effetti della natura:

\author{
Principio coelum et ac terras compos liquentes. \\ Lucentemque globum lunae titaniaque astra \\ Virgil. $\quad$ Spiritus intus alit, tatamque infusa per artus \\ Mens agitat molem, magno se corpus miscet \\ Inde hominum pecumque genus viteque volantum.
}

Onde essendo poi tali animi congionti con li corpi humani a guisa di quello dicono li poeti con il beveragio del fiume Lete si dimenticano tutto il già conosciuto, ma doppo con l'occasione dell'incontro di oggetti esterni quasi destandosi da profondo letargo si ricordono delle cose di già sapute.

Da qui trassero il dire che il nostro sapere sia piuttosto remiscenza, che nuova cognitione. Crebbe la credenza di tal dogma per l'autorità di Pitagora ch'a tal parere dicesi che assentì. Non poco di stima parimente apportò appresso li miei Ateniesi ciò che in tal proposito giocosamente pronontiai, con l'occasione di un fanciullo affatto ignaro delle scientie matematiche, che proponendol'io certo difficoltoso teorema a dimostrare, per mezo delle mie semplici interrogationi, senza punto circa ciò instruirlo, egli ottimamente dedusse la ricercata da me demonstratione. Per il che come che giocando pronontiai ch'egli si ricordò ciò che si havea dimenticato, perché se altrimente fosse, non poteva condurre a fine così laboriosa demostratione.

Fu stimato appresso il volgo ciò seria mia opinione. E perché non fu mai così strano dogma a cui assolutamente mancasse patrocinio di huomini dotti, e che mendicasse visaggio di alcuna apparenza avenne che tale opinione fece tenace presa nella mente di molti, né rimase destituta di alcune apparenze e superficiali instanze. Onde fra li altri motivi fu apportato il bombice diligente artefice della seta, che senza instruttione conseguita da suoi [181] pro|genitori, né da maestri né da esperienza appresa esercita la sua laboriosa arte, tessendosi quel non punto ivvilupato convoglio e serraglio, acciocché senza alcuno disturbo et impedimento tenga commodo et agio di renontiare alla primiera vita di semplice serpibile e trasformarsi in alato animale, riuscendo perciò anco idoneo a perpetuare la sua spetie.

Onde non havendo tal animale imparato questa sua arte d'altrui, conviene che ciò li accada per ricordanza di quelle apprensioni che li fu transmessa da suoi parenti nel seme, dal quale fu prodotto, conservando questo in sé l'idea di tal operatione, come anco mantiene in sé il modello di varii membri e minutissime portioni de' quali l'animale 
This is the Soul of the Universe, ${ }^{340}$ which so wisely rules the admirable effects of Nature:

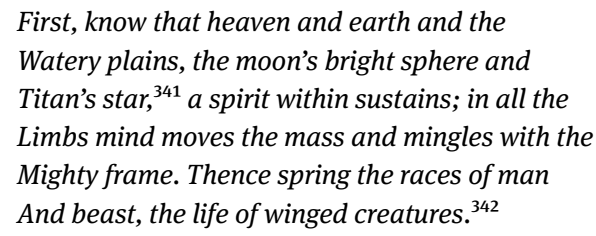

Virgil.

Thus, since these souls are unified with human bodies, after drinking the water of Lethe's river, they forget everything they know, according to what the poets say. ${ }^{343}$ Yet as soon as they meet with external objects, they remember the things that they knew before, almost like waking from a deep sleep.

From this, they drew that our knowledge was recollection rather than new cognition. This belief grew thanks to the authority of Pythagoras, who, they say, assented to this opinion. Likewise, something that I playfully uttered in respect of this - when I asked a young boy, who was indeed unaware of mathematical sciences, to demonstrate a very difficult theorem - was highly esteemed among my [fellow] Athenians: ${ }^{344}$ by means of my simple questions, without me teaching him anything about it, he perfectly deduced the requested demonstration. Hence, I playfully uttered that he remembered what he had forgotten, because otherwise he would not have been able to solve such a complicated demonstration.

The common people considered this to be a serious opinion of mine. And since it was never considered to be such a strange dogma that it lacked the support of learned men, and since it [did not need] to beg for any kind of attention, it happened that this opinion obtained great success in the minds of many people, although some interpretations or superficial instances could not be avoided. ${ }^{345}$ Therefore, one of the arguments put forth was that of the silkworm, as a diligent maker of silk which carries out its difficult art without being instructed by [181] its parents, masters, or any other previous apprehended experience. It weaves, wrapped up in its enclosure and serail, so that it may comfortably leave its original life as a simple slithering being without any bother or hindrance and turn into a flying animal, resulting thus as also being able to perpetuate its species.

Therefore, since this animal did not learn its art from anyone else, it is correct [to believe] that this only happens because of the recollection of those apprehensions given to it by its parents through the seed from which it was produced. This animal holds the idea of this operation in itself and maintains in itself the model of varied parts and tiny 
è composto, dipendendo tal distintione da sotilissimi spiriti che nel seme si contengono conservandosi la loro anatomia non meno immista inconfusa di quello che varii lumi, benché siano di conditione tenuissima, rimangono distinti, ancorché per angustissimo e ristretto foro insieme trapassano, così anco l'imagini visibili di contrarii colori per l'istessa aria viaggiano senza punto disordinarsi.

Per il che riusciva alli autori di tal dogma ancor persuasibile che anco le reliquie della memoria in tali spiriti siano impresse e che possono perseverare e continuare per alcun tempo. Dimostravano anco alcune infermità che in quarta età risorgono et appariscono, come la podagra, epilepsia et altre, né vale, dicono l'autori di tal openione, quello che alcuni pusilanimi investigatori della natura dicono, che tali effetti mirabili che si scorgono nelle operationi di alcuni animali, al semplice instinto naturale attribuire si devono, perché mentre essi non ci espongono con più chiara espressione ciò che sia tale instinto, senza loro ingiuria, et offesa della natura appelare si potrà, nome senza sogetto, inventato solamente per ricovro di pigri esploratorii delle cause di stupori dell'universo.

E chi crederebbe, che la natura occupata nel generare e corrompere tanta infinita coluvie di cose, sia attenta ad insegnare al bombice la maniera di fabricarsi il suo domicilio, et al ragno la insidiatrice sua [182] tella per cogliervi una mosca over zanzara et alle api l'edifitio della loro esagonale stanza acciocché dimorino più accommodati et agiati? Di più con quali modi esequisce la natura tale instruttione? Documenta li suoi figlioli come pedagoga? O piuttosto qual maestro che soprapone la sua alla mano del discepolo per avezarlo al scrivere? Qual giuditio tengono tali insetti e vili animalluci per apprendere l'insegnamenti che li sugerisce la loro madre natura? Overo quali idonei instrumenti possiede questa a guidare quelli alle operationi che essa attenta che eseguiscono? Ma di più come è credibile che la natura, o per meglio dire l'ottima causa che il tutto regge, fosse così cortese nelli bruti et alli homini d'essa speculativi, ne fosse cotanto parca et avara, che non li fu pronta con suoi instinti se non per mezo della reminiscenza eccitati dalli invitti et impulsi di oggetti esterni?

Hora dunque posti da banda l'instinti, alla memoria riduciamo l'operationi di tali animali, ché se la imaginatione humana non fosse aggravata, vanegiano questi poetici ingegni, da un mescuglio di molte discipline, senza l'eccitatione di oggetti esterni da se stessi l'homini al pari delli bruti delle preterite cognitioni si ramentarebbero, come ci aviene nel suchiare il latte, ché sebbene l'embrione nel ventre della madre per la sola via delle arterie umbelicali si nutrisce, tuttavia nondimeno immediate che sia uscito dal ventre materno riconosce l'uso 
portions whereof it is composed. Their distinction depends on the very thin spirits in the seed holding their clear and straightforward structure in the same manner as light. And although they are endowed with a very feeble condition, nevertheless, they remain separated even when they go through very tight and narrow holes, just as the visible images of different colours move in the air without losing their order.

Hence for the authors of this dogma, it was also still plausible that the relics of memory were impressed upon these spirits and could persevere and endure for a while. And they also demonstrated this [by referring to] some infirmities of the fourth age, such as gout, epilepsy, and others. The authors of this opinion say that the view of some fainthearted investigators of Nature that the admirable effects that one may behold in the actions of some animals must be attributed to natural instinct is also invalid. Yet as long as they do not explain more clearly what this instinct is, without insulting them or offending Nature it could be called a name without a subject, invented only as a refuge for lazy explorers of the causes of the universe's marvels.

Furthermore, who would believe that Nature, so busy with generating and corrupting such an infinite conglomeration of things, would pay attention to teaching the silkworm the way to produce its home, the spider [182] its insidious web to capture flies or mosquitos, and bees the hexagonal cells in which they may live in comfort and ease? Furthermore, how does Nature carry out these instructions? Does it teach its offspring like a pedagogue? Or rather like a teacher, who lays his hand upon that of his pupil in order to make him accustomed to writing? What kind of judgment do these insects and vile small animals have in order to apprehend the teachings suggested by their mother Nature? Or what proper instruments does it adopt in order to guide them in the operations that it wants them to carry out? And in addition to this, how might one believe that Nature-or better to say the ultimate cause that rules all-was so kind to brutes, yet so mean and sparing to the human beings who speculate on it that it did not provide them with instincts [that were] ready [to be used] except by means of the recollection activated by incentives and impulses from external objects?

Putting the question of instinct aside, we should trace the activities of animals back to the memory. These poetic wits raved that if the human imagination was not impregnated with a mixture of many disciplines, then human beings, like brutes, would be able to remember their past cognitions without receiving any input from external objects. The same happens to us when suckling breastmilk: although in the mother's womb the embryo is nourished only through the umbilical cord, as soon as it is outside the womb, it nevertheless knows how 
del mangiare e bere benché da esso prima non fu praticato in questo stato. Ma ciò accade dalla tenace retentione di memoria, dicono questi, del reiterato uso che da suoi progenitori fu frequentato, ché perciò ne segue nel seme e doppo in esso embrione impressione così gagliarda e contumace.

E chissà, seguono questi, se la cagione perché subito scapato che sia il bambino dall'alvo materno in pianto prorompe che da altro non proceda che dal ritrovarsi in esso vestigio e residuo delle passioni che così sovente infestavano li suoi parenti. Et alla fine tali facetissimi dogmatori [183] apportano corroboratione del lor parere quel volgare e tritto essempio del servo fugitivo, ch'essendo da principio al suo padrone ignoto e sconosciuto riesce impossibile che lo rinvenisca e che si accerti del suo ritrovamento, anzi che anco in lui incontrandosi non lo riconoscerebbe, non tenendo appo sé la di lui imagine. E né anco a ricercarlo si potrà impiegare mentre ch'ignora per qual via se ne sia sfugito et il loco ove si ricovrò.

Il che appunto, asseriscono questi, ci accaderebbe quando che pretendessimo investigare et accertarsi della verità delle cose mentre che non fosse la nostra nuova apprensione, reminiscenza. Ma queste tali instanze addotte da fautori di questa giocosa openione il mio intendimento punto non piegarno e che a tal segno prestasse assenso, poiché lo stimare che il nostro animo inanzi che nel corpo si ritrovasse teneva la cognitione di tutte le cose che nel mondo si ritrovano e che poi per il contagio del corpo se le smariscono e che ultimamente per l'occorso et incontro di oggetti di nuovo risorga la primiera cognitione, non poteva al mio intendimento riuscire punto digestibile.

Il che accadeva per molte oppositioni che il registrarle tutte compitamente stimo affatto superfluo. Il ricorrere all'anima del mondo cioè che l'anima nostra sia un rampolo over fragmento di quella non tiene meno del forsenato e chimerico. Qual sano giuditio può assentire ch'il mondo non tenendo le sue parti conesse et insieme legate possedesse tale permeabile spirito che lo constituisca un animale? Quali sono li meati e condotte di continuata consistenza che contengono tale spirito a guisa delle arterie, vene e nervi del nostro corpo che a tutta la vasta mole dell'universo lo distribuiscono? E s'essa anima del mondo di cognitione è capace, siccome questi tengono, di acutissimo senza dubbio sarà fornita. Ma a quali dolori essa sogiacerebbe, mentre che da noi il suo corpo fosse lacerato e discontinovato?

Ma perché non osservano l'assertorii di tal dogma nuova [184] e noiosa superstitione che l'interdica lavorare la terra, e penetrare con violenza di ferro nelle sue viscere? Tagliare le montagne, recidere le selve? Et insino calcare il suolo per non offendere tale anima 
to eat and drink even though it has never practised this in any way. And they say that it does this by retaining the memory of its parents' custom, from which such a strong and obstinate impression on the seed, and thereafter on the embryo, is derived.

In addition, who knows, as they go on to argue, whether the reason why a baby starts to cry once outside the womb is due to the fact that traces and residues of the passions so often affecting its parents are found within it? And finally, these very facetious dogmatists [183] strengthen their view by referring to the vulgar and trite example of the runaway slave. ${ }^{346}$ Since he is originally unknown and anonymous to his master, he [i.e., the master] cannot find him or ensure that he is found, and since he holds no image of him, he would not recognise him even if he encountered him. He cannot even search for him, because he cannot determine in which direction he escaped or where he might have found refuge.

And this indeed, these same men state, would happen to us when we supposed we were investigating and ascertaining the truth of things, if our new knowledge was not an act of recollection. However, my understanding was not persuaded by the instances put forward by the advocates of such a playful opinion, and I did not assent to them. Indeed, my understanding could not accept that our souls ${ }^{347}$ could already know all the mundane things before entering into the body and then lose them as soon as it came into contact with the body, and then finally that the original knowledge would rise again through contact and encounters with objects.

This happens because of many contradictions, which, in my opinion, do not need to be enumerated in full. To recall [the idea of] the Soul of the World, ${ }^{348}$ namely that our soul is a part or fragment of it, would also be mad and chimeric. What sane judgment would assent to the idea that the world may have a permeable spirit, making it like an animal without all its parts being connected or held together? What meanders and ducts have a sufficiently compact texture, like the arteries, veins, and nerves of our body, to contain such a spirit and then to be able to distribute it throughout the grand expanse of the universe? And if this Soul of the World were capable of cognition, as they [i.e., the poets] affirm, it would certainly be a very acute [faculty]. Therefore, what pains would it be subjected to, since we continuously tear and shatter its body?

Yet why do the supporters of this dogma not observe a new [184] and annoying superstition which would prohibit [all individuals] from working the land and violently penetrating into its bowels with iron tools? From tunnelling into mountains or cutting down forests? Even from treading on the ground, in order not to offend this 
mondana? Di più li richiedo se recondita et ascosa tiene a guisa della nostra, in domicilio appartato la sua principale residenza overo piuttosto per tutto l'universo ugualmente si trova difusa e vagante? Ma di più m'instruiscano, che se il nostro animo è congenere ad essa anima mondana derivando da questa quello, per il che conviene che ambi nell'istesso modo apprendono le cose, mi instruiscono ridico, in qual maniera essa apprese la cognitione delle istesse cose? Quali organi di sensi essa tiene? Per qual cagione l'animo nostro, di lei portione, inherendo al nostro corpo pur anco egli fragmento della universale materia diviene così dimenticato et immemore, eppur nondimeno esso animo congionto con il corpo dell'universo assai meno organizato del nostro ratiene l'apprensione delle cose senza alcuno detrimento? Ma di più, in qual modo l'oggetti eccitano nel nostro animo di nuovo le obliviate cognitioni? Se già sono estinte et abolite?

M'anco quell'altro sfugitoio cioè il ricorrere alle reliquie d'impressioni transmesse da progenitori nel seme da essi deciso non tiene meno del favoloso. Non nascono l'animi humani l'uno dall'altro a guisa di quelli di bruti, conforme la più sana openione. Ma di più, il riserbarsi l'occulti vestigi delle dottrine nel seme possiede molto del ridicolo, esprimentando noi che molti divengono addottrinati in scientie de quali per longa serie di successione loro progenitori furno affatto ignari di qualunque disciplina.

Anacarsi Schita dimorando appo noi, divenne celebre filosofo benché da suoi barbari parenti non traheva alcuno seme di dottrina. Et il nostro Fedone ancor egli di stirpe schiavo a pari di qualunque altro suo coetaneo, riuscì cotanto scientiato. Ma né anco l'esprimento praticato da me con quel fanciullo, che [185] senza alcuna antecedente disciplina, in un subito divenne eccellente matematico, punto di suffragio apporta a tal parere, perché tal fanciullo nel construire il teorema propostoli si rimembrò di quelli principii, che per mezo del senso giornalmente già apprese, come che il tutto sia della parte maggiore, e che le grandezze che ad una terza sono equali, fra esse parimente eguali siano et altri simili massime, non già che ciò proceda da dottrina che nel suo animo inanzi che con il corpo si accopiasse li fosse stato infusa.

Ma io per mezo delle mie interrogationi, insieme annodandoli quelli axiomi già da esso conosciuti, lo resi fecondo a generare conclusione tale, che da indi sortì la perfetta demostratione che io attentavo per mezo di esso dedurre. Nell'istesso modo si abbate l'instanza del servo fugitivo, riconoscendo noi per mezo della disciplina le istesse cose già da noi in questa vita apprese, ma separate e disgiunte l'una dall'altra, ma doppo per mezo del discorso insieme conesse e con 
World-Soul? Furthermore, I ask them whether this soul is secluded and hidden like ours, holding its main residence in a separate dwelling, or whether it is rather equally spread and wandering over the whole of the universe. And if our soul is of the same kind as the World-Soul, since the former derives from the latter, they should explain to me how both may apprehend things in the same way; I say again, they should explain to me how it [i.e., the World-Soul] may apprehend the same things [that also our soul apprehends]. What sensory organs does it have? Why does our soul, as a part of it ${ }^{349}$ that is attached to our body which is also a fragment of the universal matter, become so forgetful and oblivious? And why is this soul [i.e., the World-Soul] that is joined with the body of the universe, much less organised than ours, able to retain apprehensions of things without letting them fade? And yet how do objects reawaken the forgotten cognitions in our minds if they are already extinguished and abolished?

Yet the other loophole, namely appealing to the relics of impressions which are directly passed on to the seed from the parents, appears no less fabulous. According to the sanest opinion, human minds are not born one from another like those of brutes. Furthermore, attributing the unknown relics of doctrines to the seed is most ridiculous. Indeed, we experience that many become greatly learned in the sciences although their ancestors for many generations were not aware of any discipline. Anacharsis the Scythian, who dwelt among us, became a well-known philosopher although he did not gather any kind of doctrine from his barbaric parents. And our Phaedo, ${ }^{350}$ also of slave descent, turned out to have as much science as any other of his age. However, the experiment that I carried out with this young boy, who immediately became [185] an excellent mathematician without any previous discipline, could not even support this opinion. Indeed, this young boy formulated the theorem only by remembering those principles that he had already apprehended through his senses, namely that the whole is larger than the part and that [two] physical quantities, when like a third quality, are likewise also like one another, and other similar maxims. And this did not proceed from a doctrine infused into his soul before it was paired with his body. However, thanks to my questions and by knotting together those axioms that he [unwittingly] knew, he was able to reach the exact conclusion that I had intended to coax out of him through my perfect demonstration. We can refute the example of the runaway slave in this same way. Indeed, by means of a discipline, we come to know the same things that we have already apprehended in this life, except that [in life] they are separate and divided from one another. It is only through the aid of discourse that they are connected 
Quarta espositione del sapere. decente maniera congionte, essendosi già per inanzi con l'intervento della osservatione advertito anco il modo d'insieme accopiarle, come insegna la logicale dottrina.

Ma essendo da me in tal guisa prostrata l'antecedente espositione, sopra le rovine di questa sortì altro dogma che afferma, che non poteva mancare che il sapere fosse reminiscenza per alcune delle instanze da me hora apportate, ma che fosse essa rimembranza de' primieri principii e massime già per mezo di sensi appresi e di nuovo dal discorso decentemente insieme comessi et annodati, da quali scaturiscono poi le vere e nuove conclusioni, rassomigliandosi ciò alle figure di Dedalo che insieme unite furno di alcuno pregio l'una l'altra fermando, ma separate e divise, che per la loro leggierezza dal vento erano furate, di niun valore erano stimate. Onde l'istesso accade a tal principii e massime che sciolti improficui, et inutili riescono, ma insieme con modo decente construtti sortiscono idonei di produrre in apparenza [186] nuove et inopinate conclusioni.

Ma né anco questa espositione del sapere acquietò il mio animo, oltremodo essendo divenuto impatiente ad assentire et approbare ciò che con tutto li suoi numeri compíto non sia. E benché tal opinione trahesse li suoi natali dall'antedetto mio esprimento, e che per mia legitima prole la riconoscessi, non però mi sofrì l'animo pregiudicare alla riverenza che verso la veneranda verità tengo.

Per il che sottoponendola al mio solito esame parevami inconveniente l'admettere che il saper humano consistesse solamente nel legare li principii già appresi, rassembrandomi che tali principii benché siano con stretissimo legame anessi e più del nodo gordio avitichiati, arrecare non ci possono il vero conoscimento delle cose, né l'interne rapresentationi di oggetti che presumiamo conseguire, e non perché le figure che dal vento non si lasciano portare, per se stesse stimare si devono gran cosa, se peraltro non fossero degne d'essere pregiate, perché tanto l'imagine che nella cera s'imprime, benché agevolmente si depravi, quanto quella che nel marmo apparisce mentre che egualmente ci rappresentano l'effigie del loro originale, in quanto sono figure egualmente appregiare si devono, perché anco al nostro proposito la duratione della rappresentatione delle imagini in noi impresse non è inditio della corrispondentia che tengono con l'oggetti, ma sì bene nella di loro similitudine consiste la real e sincera verità delle nostre speculationi.

Et oltre di ciò non mi pareva convenevole attribuirre al coligamento di principii, tanto di honore, e che esso fosse l'istesso humano sapere, ché li spetiali che al di sopra di medici sono periti del comporre e mescolare l'ingredienti delle medicine, tuttavia si trovano affatto 
and properly conjoined together, since the way to combine them together had already been seen before it was observed, as the doctrine of logic teaches.

Yet even after I had defeated the former exposition in this way, another dogma arose from its ruins. And this stated that although it could not be overlooked that knowledge was recollection, according to some of the examples I put forth, it was nevertheless a recollection of primal principles, and especially of those which had already been apprehended by the senses and correctly recombined and knotted together by discourse. Then, from these, true and new conclusions were drawn, which were like Daedalus's figures. ${ }^{351}$ These, which only had a value when they were tied down together, were however esteemed of no value when separated and divided, since they could be carried away by the wind because of their lightness. ${ }^{352}$ Therefore, the same happens to these principles and maxims, which are fruitless and senseless when separated, but adequately produce apparently new [186] and unexpected opinions when properly combined together.

However, not even this exposition of knowledge appeased my mind, since I could not tolerate accepting and approving something that did not fulfil all the needed requirements. And although this opinion originated from my aforementioned experiment and I acknowledged it to be my legitimate offspring, nevertheless, my soul could not bear the idea of compromising the reverence I held for the venerated truth.

Therefore, I examined it as usual, and it seemed to be inappropriate to admit that human knowledge consists only in binding together already apprehended principles. Indeed, it seemed to me that even if these principles are very closely bound together, tighter than the Gordian knot, ${ }^{353}$ they can provide us neither with the true knowledge of things nor with the internal representations of the objects we believe we are attaining. Furthermore, the figures must be highly esteemed in themselves and not because they resist being carried away by the wind, [especially] if they have no other reason to be worthy of appreciation. Indeed, images impressed on wax, although they can easily be spoiled, represent the effigies of their originals to us as well as those which appear in marble, and thus, as they are both figures, they must be evaluated equally. Likewise, in our matter, the duration of the representations of images impressed in us is not a sign of the correspondence they have with objects, but rather the real and sincere truth of our speculations consists in this similarity.

In addition to this, it seemed inappropriate to me to attribute such great honour to the connection of principles and to identify it with human knowledge. Indeed, although apothecaries are even more expert than doctors in combining and mixing the ingredients for medicines,
Fourth exposition of knowledge. 
ignari della interna natura di semplici e del modo di applicarli all'infermità, né parimente il baiulo benché opportunamente lega e commette insieme le merci, riesce perciò punto informato del loro valore e pregio. La cagion di tutto ciò è, che l'esser [187] sciolto overo legato, unito overo separato non appartiene all'interna cognition delle cose che si ricerca sapere.

Ma di più interrogai Dionisidoro assertore di tal espositione se stimava che ogni plebeo e volgare ingegno fosse idoneo ad esercitare e praticare tal complicatione e ligamento di principii. Risposemi prontamente che a ciò eseguire conveniva tenirne alcuna peritia.

Di nuovo l'interpelai che intendeva che fosse peritia. Sogionse che intendeva una esata cognitione in sapere convenevolmente ciò eseguire, allhora io lo sorpresi:

"Dunque il sapere non risulta dalla conessione di tali principii, ma piuttosto questa da quello deriva. Ma stante la tua esplicatione il contrario ci converebbe affermare che il sapere inanzi che fosse nato, già fosse e tenisse energia di produrre la sua causa e produtrice, cioè la conessione di principii”.

Ma Dionisidoro benché molto caviloso egli fosse, punto non replicò,

Quinta espositione del sapere di

Empedocle.

Empedocle. dando perciò evidente segno di concedermi la vittoria. Non passò molto di tempo dopo il congresso antedetto, che capitò nella città d'Atene un hospite siciliano della dottrina di Empedocle non mediocramente imbevuto, con il quale contratto che hebbi alcuna pratica, lo richiesi se circa il saper humano cosa di rilievo ci havesse dalla sua patria rapportato.

Risposemi che il saggio Empedocle agrigentino ne suoi celebratissimi versi dottamente ne trattò:

Terram nam terra, limpha cognoscimus undae Aethera aethere sane, ignis dignoscatur igne Sic et amor amore, ac triste discordia lite.

E continuando egli divisava, che siccome per mezo della luce che risiede nell'occhio apprendiamo il lume e li colori suoi effetti, e con l'aria che si rachiude nel timpano dell'organo uditivo sentimo il suono, così anco l'animo riconosce qualunque oggetto esterno, per mezo di quella portione che appo sé ritiene, che s'assomiglia all'oggetto esterno e ciò che [188] non li corrisponde nega, che tale sia, contendendo Empedocle che l'animo nostro composto sia in certo modo di tutte le cose, overo almeno di quelli principii che constituiscono l'universo. 
nevertheless, they are not aware of the internal nature of simple [elements] or the way to apply them in diseases. Likewise, although a porter properly gathers and binds goods together, nevertheless, he does not know their value or worth. The reason for all of this is that [187] being untied or tied, [or] joined or separated, does not pertain to the internal cognition of the things we are attempting to know.

Moreover, I asked Dionysodorus, ${ }^{354}$ as he was the upholder of this exposition, whether he considered every plebeian and vulgar intellect to be adequate to carry out and practise this binding and connection of principles. He promptly answered me that it was necessary to have some expertise in order to carry this out.

I asked him again what he meant by expertise.

He continued that he meant an exact cognition of the way to properly carry it out. Then, I caught him:

\footnotetext{
"So, knowledge does not result from the connection of these principles, but rather the latter derives from the former. Yet as your exposition maintains the contrary, we should then state that before it was born, the knowledge already existed and had the energy to produce its cause and creator, namely the connection of principles."
}

However, Dionysodorus, although he was very argumentative, did not reply; in this way, he clearly showed that he had granted the victory to me. It was not long after the aforementioned encounter that a Sicilian guest, who was very keen on Empedocles's doctrine, ended up in the city of Athens. As I was acquainted with him, I asked him whether he had brought us anything from his homeland that was relevant to human knowledge.

He answered me that the wise Empedocles of Agrigentum had eruditely dealt with this in his well-known verses:

By Earth we see Earth, by Water Water,

By Air the divine Air, by Fire destroying Fire,

Love by Love, and Strife by bitter Strife. ${ }^{355}$

Furthermore, he continued by considering that just as we perceive brightness and colours by means of the light located in the eyes and we hear sounds by means of the air contained in the tympanum of the auditory organ, so also the mind acknowledges external objects by means of that part [that is] like the external objects that it retains in itself, while it denies the existence of what does not match [188] this correspondence. Indeed, Empedocles was of the opinion that our soul was somehow composed of all things, or at least of those principles constituting the universe.
Fifth exposition of knowledge made by Empedocles.

Empedocles. 
La novità di tal dogma piuttosto che la sua probabilità attrasse il mio animo ad applicarvi alcuna speculatione. Primieramente giudicai che l'openione di Empedocle fosse, che non la terra interna che ci constituisce, apprendesse la terra esterna che come oggetto ci si appresenta, né che nel medesimo modo l'acqua interna riconoscesse l'esterna, poiché la terra et acqua in quanto tali, di ragione e di sentimento prive sono. Di più conforme il dogma dell'istesso Empedocle sono parimente inalterabili benché nel misto insieme si ritrovano et insistono. Ma che forse egli stimava che l'animo nostro di tali principii et elementi si serviva a guisa di colui che certificare si vuole della dimensione di un panno che prende una misura a lui nota e con essa si assicura della quantità del misurato, così l'animo humano si vale delli elementi che li sono contigui e cogniti e domestici, e li adopera come misura a riconoscere l'esterni elementi e ciò che di essi è composto. Onde aggiustandosi l'oggetto alla terra interna giudica rettamente che tal oggetto sia parimente terra, ma se discrepa giudica che di diversa conditione sia. In tal modo dunque sebbene l'animo non tiene alcuna cognitione delli elementi esterni, nondimeno per mezo delli suoi ne conseguisce chiara informatione.

Ma essendo tale l'openione d'Empedocle intorno il sapere humano, in tal guisa circa essa m'esercitai. Mi si offerì principalmente che essendo l'animo humano capace di sentimento, e per consequenza alterabile, il che alli elementi empedoclei non accade, per necessità converebbe conforme alla sua positione che l'animo di diversa natura di essi elementi fosse. Onde siccome delli elementi esterni esso per se stesso si ritrova incapace di poterli apprendere, il medesimo occorrere li dovrebbe circa l'interni elementi che li coasistono e compongono il di lui corpo, [189] nonostante che prossimi e congionti li siano, mancando la prima misura per riconoscerli.

Ma di più mi molestava che ricercando io l'hospite ciò che fosse sapere, mi rispose che con la terra interna si riconosceva l'esterna così parimente li altri asserti elementi, non accorgendosi egli che il riconoscere è l'istesso sapere che io con tanta instanza procurava esserne informato, e che egli supponeva già appreso ciò di che io ansiosamente ne dubbitavo. Ma di più anco mi annoiava che non per mezo dell'assimigliatione noi conosciamo le cose, ma piuttosto per la diversità che con noi tengono. Se la mano possiede duoi gradi di calore et altri tanti l'oggetto esterno tangibile, non è appreso in esso da noi calore alcuno, ma s'egli ne tiene gradi tre, benissimo sarebbe sentito. Così mentre al 
The novelty of this dogma, rather than its probability, captured my attention for another speculation. Firstly, I considered that Empedocles's opinion was that the internal earth constituting us does not apprehend the external earth appearing to us as an object, just as the internal water does not acknowledge the external one. The reason for this is that earth and water, as they are, lack reason and sensory faculties. Moreover, according to the dogma of that same Empedocles, they are also unalterable, even if they always find themselves mixed together. Yet perhaps he might have thought that our minds use these principles and elements like someone who wants to test the dimensions of a piece of cloth by using a unit of measurement that is familiar to him. Just as he makes sure of the measured quantity by means of this, so the human soul uses the elements that are neighbouring, known, and familiar to it and adopts them as a unit of measure in order to acknowledge the external elements and what is composed of them. Hence, once an object is adjusted to the internal earth, it [i. e., the soul] correctly judges this object to be like earth, but if it differs from this, it judges it to be of a different condition. In this way, although the soul has no cognition of the external elements, it nevertheless attains some clear information about them by means of its own [elements].

Yet as this was Empedocles's opinion concerning human knowledge, I dealt with it in the following way. Firstly, it came to my mind that the human soul was capable of sensory perception, and consequently that it was alterable, but this was not the case with Empedocles's elements; thus it would be correct, according to his position, [to state] that the soul was endowed with a different nature from these elements. Therefore, as it would be incapable of apprehending the external elements by itself, the same should occur to it concerning the internal elements, which coexist with it and compose its own body. [189] Indeed, although they are close and connected to it, nevertheless it lacks the original unit of measurement to acknowledge them.

Yet what was irritating me most was that when I asked the guest what knowledge was, he answered me that just as one may acknowledge the external earth by means of the internal one, so [it happens] similarly for the other asserted elements. Indeed, he did not realise that this acknowledging was that same knowledge I was urgently seeking to be informed about and that he was supposed to have already apprehended that which I was anxiously doubting. Yet what was bothering me even more was that we do not know by means of similarity, but rather by means of their dissimilarity to us. If both our hand and an external tangible object are at two degrees of heat, we will not perceive any heat in it, but if it [i.e., the object] is at three degrees, then it will be very keenly felt. Likewise, if we move in the same 
Sesta espositione del sapere. pari dell'ogetto visibile noi ci moviamo, non vi discerniamo in esso motto alcuno, ma quando più velocemente di noi scorre all'hora, advertimo che si move. Dal che parimente risulta, che noi non osservamo il continuo et incessante flusso del nostro essere perché questo è commune all'esser di tutto l'universo che parimente con noi scorre e fluisse.

Ma di più se tale fosse il sapere come Empedocle lo rafigura, converebbe che fossimo composti di qualunque spetie di cosa che l'universo abbracia, non basta ridursi alli primi elementi e qualità, et insino li veneni entrarebbero come ingredienti della nostra construttione, tenendone noi a danno del nostro genere purtroppo curiosa cognitione. Con altre instanze potevo io abbattere tal parere che hora omettere voglio, rendendosi più laborioso il percuotere il vano che agitare le cose sode e massicie.

Dalle obiettioni intentate contra la predetta espositione dell'humano sapere si mosse Anasagora, nostro antico amico, a ricercarne di nuovo altra esplicatione. Onde alla fine pronontiò che il sapere sortiva mentre la mente si renda all'oggetto simile, il che agevolmente l'accade per una certa versatile habilità e naturalezza di conformarsi in ogni [190] gui|sa, che se l'offerisce, onde mentre che s'aggiusta con esso oggetto ne segue la verità, ma discrepando la falsità.

Inteso che io hebbi ciò, attentai abbattermi con il detto Anasagora e li dissi che per il certo da niuno poteva io sperare più ottima espositione circa il riconoscere ciò che sia il sapere che da esso primo autore et introduttore fra filosofi greci della mente disgregratrice dell'antico cahos, ché senza dubbio talmente con il suo ottimo sapere il tutto ottimamente distribuì, e con egregia ordinanza e concinità fu disposto, ma che nondimeno, havendo io udito la sopranarrata esplicatione del sapere ad esso attribuita aggradire non mi poteva.

Interrogomi qual di ciò, ne fosse la cagione.

Risposeli che se altro non fosse il sapere che assimigliatione dell'intelletto all'oggetto, già la cera impressa, il marmo scolpito, e la tavola dipinta e sarebbero di sapere dottati, paregiando essi in alcun modo al loro essemplare et originale.

Confessò egli immediate la difalta e mancanza di tal sua espositione, e cedendo alla mia censura di nuovo ripigliò che il sapere era bene una assomiglianza della mente con l'oggetto, ma di più anco un riconoscimento dell'istessa corrispondentia e similitudine, a guisa di colui che mirando il ritratto vi riconosce anco l'originale.

Ma io né anco di ciò punto rimasi satisfatto, ché sebbene in parte evitasse Anasagora alcuni che di assordo che ad Empedocle incontra- 
direction as a visible object, we will not discern any motion in it, but if this object moves at a greater speed than us, then we will notice that it is moving. Similarly, it results from this that we do not observe the continuous and restless flow of our being, because it is the same as the being of the whole universe, which runs and flows at the same rate as us.

Moreover, if knowledge was as Empedocles imagined it, we would have to be composed of every kind of thing embraced by the universe; not only the first elements and qualities, but even poisons - which unfortunately, and to the detriment of mankind, we are very desirous to know about - would be ingredients of our construction. I could demolish this opinion with further instances, but I would prefer to omit them now, because it is more industrious to rock vain [things] than to shake solid and stable ones.

Against the objection raised against the aforementioned exposition of human knowledge, Anaxagoras, an old friend of ours, intervened to search for another new explication. Therefore, he finally pronounced that knowledge emerged when the mind made itself like the object, and that this happened easily thanks to a specific versatility and natural ability to adapt to every [190] possible form. Thus, when it matched itself with the object, it would follow the truth, but when it differed [from the object, it would follow] falsity.

Once I had heard this, I attempted a discussion with the aforementioned Anaxagoras. Then, I told him that I could certainly not expect to find a better exposition concerning the acknowledgement of what knowledge was than the one given by him. Indeed, he was the first author and initiator among the philosophers [to state that] the mind broke up the primordial chaos. Through its great knowledge, it had undoubtedly distributed everything in the best possible way, as well as arranging it with great order and consistency. Yet once I had heard the abovementioned explication of [the nature of] knowledge that was attributed to him, [I told him that] I could not be satisfied by this.

He asked me the reason for this.

I answered him that if knowledge was nothing other than a similarity between the intellect and the object, then impressed wax, sculpted marble, and painted canvas would also be endowed with knowledge, as they would somehow be competing with their exemplar and original.

He immediately confessed the defeat and failure of his exposition, and, surrendering to my criticism, he continued again that knowledge was not only likeness between the mind and the object, but also an acknowledgement of this correspondence and likeness, as [occurs to] one who observes a portrait and also acknowledges the original in it.

However, I was also not satisfied by this: although Anaxagoras had avoided some of the absurdities encountered by Empedocles, 
vano, nondimeno con tal dichiaratione non iscansava altre difficoltà. Primieramente lo ricercai con qual certezza poteva affermare che nella mente humana siano impresse le vere e germane imagini delli esterni oggetti, non havendo né esso né alcuno altro mortale potuto giamai assaggiare l'istesso originale. In qual guisa ci potemo oggi assicurare ch'il ritratto di Ciro li sia simile, se non havessimo per attestatione di nostri antichi e suoi coetanei certezza che tale appunto egli fu, havendoli essi occulatamente osservato. E tanto più riesce ciò dubbioso perché ogni poco di varietà e discrepanza che tra l'imagine et ori|ginale [191] vertisca, apporta grandissima diferenza.

La causa di ciò è che pretendendo l'humana mente al di sopra che dipinti ritratti, rappresentare la germana et aggiustata imagine delle cose, et essendone molte di natura tale che in un minimo indivisibile eccedendo overo disminuendo si mutano di essenza, onde il loro massimo e minimo termine, insieme si complicano, perciò ogni picciola varietà può cagionare gravi errori nel nostro discorso, essendo l'essentie apunto come li numeri che l'unità solamente accresciuta over diminuita li cangia di spetie, ché insino quelle incomprensibili minutie appellate volgarmente irrationali che sono meno et al di sotto della unità, constituiscono varietà di generi di numero, tanto è il rigore della natura nel formare suoi effetti. Onde tornando al proposito, non essendo tali minime diversità da noi osservate restiamo defraudati nelli nostri giuditii, a guisa di giudice che da gemelli affato simili rimane ingannato mentre che uno di essi havesse receputo il deposito, e l'altro alla restitutione essendo citato, giurasse di non haverlo giammai riceputo, onde l'uno e l'altro ne rimanesse libero:

Si sunt nati filii duo gemini

Ita forma simul pueri est mater sua

Plauto. Non internosse possetque, etc.

Di più non mi si rendeva piano quel suo pronontiato che la mente humana si rendesse tanto flessibile quasi nuovo Proteo nel trasformarsi in tante guise e che all'oggetti si rendesse siffattamente ossequente divenendoli simile, poi se la fingeva di tenue conditione, e perciò obediente all'altrui impressione. Non poteva accadere in ciò aggiustata corrispondentia e similitudine, osservandosi che li più consistenti meglio rappresentano l'imagini che di tenui et aerii. Ma s'essa è affatto immateriale, stante quell'asioma tanto applaudito, che ciò che in altrui s'introduce, si accomoda alle [192] condi|tioni del recipiente, in qual maniera l'imagine del corpo materiale, e dimensionato potrassi nella mente incorporale imprimersi in modo tale, che le divenga simile, 
nevertheless he could not avoid other difficulties with this statement. Firstly, I asked him with what certainty he could state that the true and authentic images of external objects were impressed in the human mind, since neither he nor any other mortal could ever experience the original itself. How could we make sure today that a portrait of Cyrus resembled him, without having the certainty that he was as such from the testimonies of our ancients and his contemporaries, ${ }^{356}$ who had observed him very carefully? However, this would turn out to be even more doubtful, because every single disparity and incongruity between the image and the original [191] would constitute a great difference.

The reason for this is that the human mind claims to represent the true and correct image of things better than painted portraits. Indeed, as the nature of many [images] is such that they change their own essences only by increasing or diminishing an indivisible minimum, then their maximum and minimum components are mixed together and thus every small diversity can cause serious mistakes in our discourse. Indeed, their essences are like numbers, which change their species only by increasing or diminishing the unit. Even those incomprehensible minutiae commonly called irrationals, which are less than and below the unit, constitute different numbers: [this shows] how rigorous Nature is in forming its effects.

Thus, to return to our subject, as we cannot observe these minimal diversities, we are deceived in our judgments, like a judge misled by two twins who look alike if one of them receives a deposit and the other, who is taken to court to give it back, swears that he never received it. Therefore, neither of them may be charged:

Two twin sons were born to him, boys of

Such similar looks that their wet nurse [who gave them the breast]

Could not tell them apart, etc. ${ }^{357}$

Plautus.

Moreover, that statement of his - that on the one hand, the human mind could make itself very flexible, like a new Proteus, turning into many different forms, as well as being so compliant with objects as to become like them - was not clear to me. On the other hand, he imagined it to be of a tenuous condition and thus obedient to the impressions of the other [objects]. However, a proper correspondence and similarity could not occur, as one may observe that the most solid [things] can represent images better than tenuous and airy ones. Yet according to that most acclaimed axiom that whatever enters into others accommodates itself to [192] the conditions of its recipient, if it [i. e., the mind] is immaterial, how can the image of the material and dimensional body proceed through the incorporeal mind? And how can this [i.e., the material image of the body] impress itself in such 
e che l'oggetto con le sue proprie e germane conditioni sia rappresentato? Ma di più havendo Anasagora ingiunto alla positione di Empedocle la facoltà conoscitiva, accioché si produca in noi il sapere, mi si rendeva arduo in che modo potesse tal facoltà apprendere aggiustatamente le conditioni dell'oggetto, ché s'essa dalla imagine impressa è distinta, in qual modo l'apprende non attenendole tal impressione? Ma se l'istesso è, oltre che non ci potiamo formalizare in qual guisa ciò avenga apparendo impossibile complicare insieme cose affatto diverse cioè la facoltà conoscitiva, e l'imagine impressa, di più incontramo in altra difficoltà, che molto differente riuscirebbe l'imagine impressa di quello è l'oggetto e massime essendo questo cosa insensata, riuscendo tale imagine mentre si trova nella mente impressa, mescolata con la facoltà conoscitiva. Ma di più si confonderebbero insieme il giudicato, qual è l'imagine, et il giudice la cui vice sostiene la mente, onde perciò il giuditio, retto non sortirebbe. Ma oltre di ciò interrogai l'istesso Anasagora che intendeva per tal potenza riconoscitiva, se virtù attiva overo passiva.

Risposemi che l'uno e l'altro con alcun fondamento di ragione si poteva sostenere.

Replicai io che né l'uno nè l'altro agevolmente si poteva, ché se potenza solamente passiva e sensitiva fosse incorrerebbe in tutti l'assordi che a Protagora accadono, già da me racconti, ma se facoltà attiva la constituiva, correrebbe in gran pericolo di falsità l'humano sapere potendosi sospettare, che tutto quello che appartiene a tal facoltà sia effetto et opera da essa facoltà conoscitiva et attiva prodotto, e che non tengano in ciò la norma dell'oggetto che la move e guida.

Ma egli soggionse con dire, che per il vero le mie instanze gravemente l'oppugnavano, ché perciò inclinarebbe a dire, che la facoltà conoscitiva fosse insieme [193] attiva e passiva.

Al che replicai che al mirabile suo ingegno ciò poteva apparire riuscibile, ché già si accommodò a formalizarsi come ciascuna cosa si ritrovasse con qualunque unita e confusa, e che per anco participasse delle conditioni dell'antico cahos da onde trasse da principio origine, e che perciò anco se li rendeva digestibile il concepire nell'istessa facoltà complicate insieme l'attione e la passione.

Ma di più l'advertii che con tale sua esplicatione circa l'humano sapere incorreva in quel grave assordo che già si attopò l'hospite siciliano, cioè che mentre io mi ritrovo perplesso circa il riconoscere ciò che sia l'humano sapere, e che io l'insto ad espormelo, egli ricorrendo 
a way as to become like it [i.e., the mind] and to cause the object to be represented in its own authentic conditions? Furthermore, as Anaxagoras added to Empedocles's position that the cognitive faculty was needed to produce knowledge in us, it was difficult for me [to understand] how this faculty could correctly apprehend the conditions of the object. Indeed, if it is distinct from the impressed image, how does it apprehend them if this impression does not pertain to it? Yet if it is the same, not only can we not conceive how this may happen, as it seems to be impossible to combine two very different things, namely the cognitive faculty and the impressed image, but we also encounter another difficulty, namely that the impressed image would turn out to be very different from the object, above all because it is not endowed with a sensory faculty. Indeed, this image turns out to be mixed with the cognitive faculty when it is impressed in the mind. However, what is judged - as the image is - and the judge - whose function is embodied by the mind - would be mixed up, and then a correct judgment would not be pronounced. Yet in addition to this, I asked Anaxagoras himself what he meant by this cognitive faculty, whether it was an active or a passive virtue.

He answered me that both of them could be reasonably upheld.

I replied that neither of them could easily be held, because if it was only a passive and perceptive potency, then it would incur the same absurdities that had occurred to Protagoras, as I have already told you. However, if we considered it to be an active faculty, then human knowledge would be exposed to the great danger of falsity. Indeed, it would be allowed to suppose that everything that belonged to this faculty was an effect and effort produced by the cognitive and active faculty, without taking into account the object's disposition, which moves and leads it.

Yet he continued, saying that my instances actually seriously refuted his [argument] and therefore that he would be inclined to say that the cognitive faculty was [193] both active and passive.

Hence, I replied that this might appear acceptable to his admirable wit, which had already prepared to conceive how everything was linked and mixed up with everything else and also connected to the conditions of the ancient chaos from which it originally arose. Therefore, he could easily agree to conceive that action and passion were combined together in the same faculty.

Yet I warned him that he risked falling into the same serious absurdity that had occurred to our Sicilian guest because of his [i. e., Anaxagoras's] explication of human knowledge; namely that while I was perplexed concerning the acknowledgement of what human knowledge was and had committed myself to explicating it, he appealed to 
all'assimigliatione della mente all'oggetto, v'ingiunse il riconoscimento di tal assimigliatione che riesce quell'istesso che io ricercava senza punto esplicarmelo di più, che quando l'indagavo. Et oltre di ciò il rincalzai che dimostrare mi dovesse la maniera che tiene la mente, stante tale sua dichiaratione circa il sapere, in accertarci della verità, cioè che essa mente concepisca l'oggetto nel modo che realmente si trova, e qual ne sia di ciò il saggio e cimento?

Diss'egli:

“Che l'oggetto stia nell'istesso modo che lo comprese”.

\section{L'accors'io:}

"Et in qual maniera si accorge la mente che se ne stia in quella guisa, che lo comprende?”.

Rispose egli:

“Con il retto discorso della mente ciò si apprende e si accerta”.

Al che di nuovo replicai:

"Non osservi, amico Anasagora, che come il dannato Ixione con il tuo discorso ti raggiri, et a volta ti ravolgi? Alle fiatte attenti riconoscere la verità dall'esisitentia dell'oggetto che in noi cagiona tale impressione, et alle volte poi alla mente ricorri ch'essa ci accerti che tale sia l'esistentia delle cose?".

Procurò Anasagora scansare il colpo tentando referire e devolvere l'affare a sensi esterni, e particolarmente al tatto stimato volgarmente fedele riconoscitore di oggetti esterni, ma repetendo io tutto il discorso di Gorgia in tal proposito meco tenuto, e [194] dimo|strandoli non esser ciò fontione di sensi esterni l'affermare over negare, approbare over reprobare l'esistentia di oggetti esterni, ma che tutto ciò alla mente solamente appartenere.

Né envece di risolvere et appianare le difficoltà da me proposteli, Anasagora ad una critica censura s’appigliò, e verso di me in tal guisa prese à dire:

"Quanto, o Socrate, sei divenuto diverso da quello già eri, quando meco incombevi al studio della sapienza, essendo tutto dedicato alla esperienza delle cose, 
the resemblance between the mind and the object and [even] added the acknowledgement of this resemblance. This led to the same thing that I was looking for, but he did not offer any better explication of it than the one given by my investigation. In addition to this, I exhorted him to show me the mind's way of ensuring the truth according to his statement in respect of knowledge, namely: was the mind itself able to conceive the object as it really is, and was there any proof or evidence of this?

He said:

"[The proof is] that the object is as the mind has comprehended it to be."

I replied:

"And how does the mind realise that it is as it has been comprehended to be?"

He answered me:

"It may be apprehended and ensured by the correct discourse of the mind."

Hence, I replied again:

"Don't you see, dear Anaxagoras, that with your argument you are going round and round in circles, like the accursed Ixion? ${ }^{358}$ [Don't you see that] sometimes you are attempting to acknowledge the truth from the existence of the objects which cause this impression in us and other times you are appealing to the mind in order to guarantee the existence of the objects to us?"

Anaxagoras sought to dodge the blow by attempting to refer and address the matter to the external senses, and especially to the sense of touch, commonly considered to be that which faithfully acknowledges external objects. Yet I repeated the whole discourse that Gorgias had held with me in this respect, [194] as I demonstrated to him that affirming and denying were not functions of the external senses, nor were approving or refuting the existence of external objects. On the contrary, all of this belonged only to the mind.

Instead of resolving and smoothing out the difficulties that I had raised, Anaxagoras appealed to a critical censure, and he spoke to me in this way:

"Oh Socrates, how different you are now from the person you were before when you were pursuing the study of wisdom with me, as you were entirely devoted to experiencing things. At that time, you were focused on the relics 
onde insistendo allhora nelli vestigi della natura la stimava di molto più acuto accorgimento nell'eseguire suoi effetti, che noi nel contemplare et apprenderla. Per il che noi da essa instrutti si trovavamo più habili all'operare, che al disputare, omettendo queste quisquile con le quali hora non meno confondi te stesso che turbi altrui. Per il che seguendo l'usi di vani sofisti sovertisci l'humano sapere, et invece di riportare alla filosofia lume, caligine e tenebre ad essa arrechi, e somministri.

E mi stupisco che non ti ramenti che tanto sovente insieme si trastulavamo di Xenofane, Melisso e Parmenide che attentavano con cavilose consequenze ridurre l'universo, mirabile teatro di tante varietà, ad un solo et uniforme sembiante, ma di più anco che imprendevano fermarl'il motto con il quale si regge, governa, e si rende di sì gratioso aspetto? E nell'istesso modo sbeffavano Heraclito che non lasciando in esso universo cosa quieta e riposata, sturbava affatto la tranquilità di esso.

E quanto più di te, Pericle riuscì prudente, mio vero e germano discepolo, divenuto hora arbitro della Republica ateniese, il quale meco continuando li suoi studii, non si lasciò depravare dalla consuetudine di cotesti venditori di ventose parole e raccoglitori di massici denari, ché seguendo egli nelle cose naturali l'esperienza et il senso, e nell'humane il probabile, riuscì ad un tratto scientiato e prudente.

E perché antevedeva che a reggere la Republica li conveniva ammaestrarsi nel sapere moderare l'animi de' suoi cittadini, né ciò conseguire poteva se prima egli non [195] rimanesse a sufficientia informato della natura, e conditione dell'istesso animo humano, et in qual modo si producono in esso l'affetti e come l'uno dall'altro procede et a qual segno si può cadauno d'essi condurre, che in diverso e repugnante non degeneri e si cangi, et in qual maniera prodotti che siano, agevolmente manegiare si possino. Perciò al speculare circa l'animo humano e sue qualità tutto si dedicò, renuntiando a qualunque altro studio, et in questo solamente ogni sua incombenza impiegò. E non solamente applicossi alla compositione di circonflessi e rotondi periodi, equilibrati contraposti, hiperboliche amplificationi, tumide e solevate parole, ardite translationi, ornate e calmistrate dicerie praticate da semplicimente disciplinati oratori, che non ritrovando l'animo dell'auditorio disposto a riceverle, piuttosto l'annoiano e perturbano, che l'admoniscono e persuadono.

Come per il contrario la peritia che si tiene circa la generatione et estensione delli humani affetti sempre riuscì opportuna e proficua a chi la praticò. Da quindi è, che a Pericle giammai non accadé che il soverchio timore mosso dal suo ragionare nell'animo altrui, si cangiasse in desperatione, dalla quale poi ne successesse ardire et inavertita temerità, né giammai talmente s'inoltrò nel provocare e riscaldare l'ira, che affatto s'evaporassero li spiriti più sottili e furibondi, ché perciò rendesse l'animo altrui consternato e languido. Né parimente nel regimento suo proprio si lasciò da suoi offenditori talmente irritare l'animo più di quello si havesse sdegnato contra l'offesa della fervente stagione, overo dell'eccessivo freddo dell'inverno, formalizandosi della humanità come di certa cosa non dalla natura universale astratta et esclusa, ma in essa compresa, a cui non meno che alle altre cose mondane conviene accommodarsi e destramente reggere. 
of Nature, and you considered it to be much more attentive in executing its effects than we were in contemplating and apprehending it. Hence, as we are instructed by it, we are more capable of acting than of disputing thanks to omitting these trifles whereby you have now confused yourself and upset the others. Therefore, by complying with the customs of vain sophists, you will subvert human knowledge, and instead of shedding light on philosophy, you are hazing and obscuring it.

"Besides, I am surprised that you do not remember how we often mocked Xenophanes, Melissus, and Parmenides, who, through quibbling arguments, attempted to reduce the whole universe, as the admirable theatre of such variety, to a single and uniform appearance. Moreover, they undertook to stop the motion whereby it rules and governs itself and gives itself such a delightful appearance. In the same way, they derided Heraclitus, who disturbed the tranquillity of the universe by allowing nothing in it to be still or at rest.

"Furthermore, Pericles has turned out to be much more prudent than you, as he was a true and sincere disciple of mine. He has now become the arbiter of the Athenian Republic, and by continuing to study with me, he has prevented himself from being corrupted by the consuetude of these sellers of vain words and collectors of huge amounts of money. Indeed, as he decided to follow experience and the senses towards natural things, as well as the probable towards human matters, all of a sudden he became a scientist and a prudent man.

"He foresaw that in order to hold the Republic, it was necessary to learn how to moderate his citizens' spirits. Yet he could not achieve this without [195] becoming sufficiently informed of the nature and conditions of the human mind itself, of the way affections are produced in it, whether one [affect] may arise from another, to what extent each one may progress without degenerating and changing into a different and contrary one, and how they can be managed, however they were produced. Therefore, he applied himself completely to speculating on the human mind and its qualities by renouncing any other study, and he invested all his efforts in this alone. Furthermore, he applied himself not only to the composition of circumflex compositions and round periods, but also to the balanced [composition of] antithetical [elements], hyperbolic amplifications, pompous and comforting words, daring metaphors, and adorned and embellished ${ }^{359}$ speeches simply practised by disciplined orators, who, when do not find an audience whose minds are disposed to receive them, irritate and unsettle them rather than admonishing or persuading them.

"However, the attainment of expertise in the generation and extent of human affects is always opportune and useful for the one who practises it. Hence, it had never occurred to Pericles that the excessive fear that his arguing was causing other people could change into desperation, from which there could then result a rash and daring recklessness. He never went so far as to provoke and arouse rage; indeed, in this way, he quelled the most oversensitive and furious spirits by making other people's minds consternate and languid. Similarly, as far as control of himself was concerned, he allowed his soul to be as annoyed by those who were offending him as he was bothered by the harm of the fervent season or the excessive cold of winter. He conceived humanity not as something abstracted and excluded from universal Nature, but as something included in it that should comply with it and be ably ruled by it like the other mundane things. 
Né per aquistare amicitia si rese affatto di animo simile all'altrui, conoscendo che l'esata et assoluta simiglianza non produce amore, non possendendo l'uno d'amico, [196] cosa di avantagio sopra l'altro amico acciò l'alletti ad amarlo, né troppo dissimile per non offenderlo con la repugnanza e contrarietà, ma si rende moderato quale si conviene ad homo morale e civile. E havendo egli da me imparato il modo di medicare il corpo, molti assiomi d'inde trasse per il risanamento del suo animo. A tali impieghi attendendo, Pericle è divenuto così celebre appo l'età presente e forsi non oscuro è per riuscire alla ventura posterità. Ma tu invece di ciò, ti sei travagliato in oscuri affari cavilando con giovani et altercando con sofisti onde non tieni per anco acquistata fama di alcuno pregio, ma di più dubbito che ne sei per riportarne segnalato et essemplare detrimento".

Al che risposi che non la pratica di sofisti causò in me tal mutatione, né mi ritrasse dalla contemplatione delle cose, ma che admonito non solamente dall'oracolo, e spinto dal proprio genio, ma anco a ciò impulsato dalli editti del popolo ateniese e proposti dal medesimo Pericle, che vietano l'uso di qualunque misura e peso che dal magistrato non sia primieramente stato approbato e riconosciuto per sincero e legitimo. Per il che mi restò medesimamente impedito, che dovendo io con la mia mente assagiare e cimentare l'esser di tutte le cose che nell'universo appariscono, che ciò non attentasi, se prima essa mente non sia riconosciuta e cimentata per aggiustata misura di tutto l'intelligibile. Per il che rivocai a me stesso ogni mia speculatione et ad assagiarmi posi qualunque mio impiego. Et in quanto a Pericle attiene, benché al sommo delle sue virtù per anco non giungo, nondimeno la sua egregia conditione non occlude ad altrui l'adito ad alcuna mediocre comendatione:

"Nell'arte navigatoria sono distinti li carichi et impieghi: al nochiero appartiene nell'alto mare governare le velle, rasecondare li venti, overo opporseli. E ciò per apunto rincontra con l'offitio dell'oratore la cui fontione consiste nel concitare overo sedare l'affetti del popolo. Ma carica del pilota è riconoscere li terre|ni, [197] ritrovare le fauci de' porti e condurre la nave in sicura statione, e salutare ricovro, tale parimente è l'intrapresa del filosofo, che con vive ragioni, et efficaci documenti addita se non il porto del sommo nostro bene, almeno ci dimostra la spiaggia ove alquanto ancorare e tranquillare il nostro agitato animo si possa.

Ma di più diroti essere cosa volgare con il fuoco ammolire il ferro e con l'acqua poi amorzandolo renderlo indurito, ma l'introdurvi temperatura tale, che per l'eccesiva renitenza non si franga, e per la tenerezza cedendo non rimanga piegato, è proprio arcano della feraria arte. Così anco l'irritare l'animo nostro al furore come per il contrario con le lusinghe e blanditie enervarlo non 
"He did not make his mind resemble those of others in order to acquire friendship, because he was aware of the fact that an exact and absolute resemblance does not produce love, as in this way, one friend would not have [196] anything that would be profitable for the other friend which would thus entice one to love the other; nor did he [make himself] overly dissimilar [from another person], in order not to offend him by means of opposition and aversion, but he made himself moderate, as is proper for a moral and civil man. Moreover, having learned from me how to medicate his body, he gathered many axioms from this in order to cure his mind. As he is committed to these pursuits, Pericles has become very celebrated in these times, and he will perhaps also not be unknown in the future. Yet instead of this, you have been committed to obscure matters by quibbling with young people and debating with sophists. Therefore, you have not acquired any precious fame, but rather I suspect you will obtain remarkable and exemplary harm.”

Then I answered that this change in me was not caused by dealing with sophists, and that it had not even stopped me in my contemplation of things. On the contrary, I had not only been admonished by the Oracle and spurred by my own genius, but I had also been incited by the edicts of the Athenian people issued by Pericles himself. Indeed, they forbade the use of any unit of measure or weight which was not first approved and acknowledged by the magistrate as faithful and legitimate. Thus, I was likewise hindered from testing and proving the being of all the things that appear in the universe, and I could only attempt to do this if this mind was previously acknowledged and proven to be the correct measure of all intelligibles. For this reason, I had limited my speculations to myself only and had devoted all my efforts to testing myself. As far as Pericles was concerned, although I could not achieve his greatest virtues, nevertheless his excellent condition did not exclude the possibility that others could also have access to some little praise:

"In the art of navigation, there is a distinction between tasks and occupations: the helmsman must control the sails on the high seas; he must either go along with the winds or oppose them. This indeed is like the role of the orator, whose function consists in inciting or soothing affects in the populace. Furthermore, the pilot's duties are to recognise [197] land, to find the port's mouth once more, to bring the vessel to a secure station, and to turn towards a refuge; such is the undertaking of the philosopher, who, with acute explanations and effective proofs, shows if not the port of the supreme good, at least the beach where we may anchor and appease our unsettled minds.

"Moreover, I will tell you that while it is an ordinary thing to soften iron using fire and then to harden it by cooling it with water, on the contrary, heating it to such a temperature that it does not shatter from excessive tension or bend through excessive softness belongs to the mysteries of the blacksmith's art. Similarly, it is not such a renowned undertaking to arouse our mind's fury, or on the contrary to weaken it through adulations and blandishments. Yet only the 
è impresa oltremodo celebre, ma il ridurlo a segno tale, che spogliato d'affetto, dalle percosse della rea fortuna non si rompa, né che per favore della medesima non si amolisca, ma che sempre constante sia, appartiene al sapiente ciò solamente eseguire”.

A questo mio ragionare non replicò Anasagora, ma solo mi advertì, che sebbene egli rimaneva satisfatto del preso da me patrocinio de filosofi, nulla di meno stimava che il seguire l'apparente, e volgare verità, fosse sempre giovevole. Ma la esquisita et esata sempre apportò a suoi settatori noie e calamità, essendo la pura e sincera verità simile all'eccessiva luce, ch'alli deboli di vista nuoce mentre che in essa si affissano, et alli furatori arreca molestia, come rivelatrice de loro ribalderie. Cos'il lume della verità all'ingegni plebei che non possono li suoi raggi tolerare, gravamente offende, et alli sagaci e sinistramente accorti, oltremodo travagliare, dubbitando questi che non scuopra ad altrui le loro menzogne, et inganni. Per il che la lunga pratica sempre dimostrò che l'osservatori di humani costumi sono divenuti egregi nel destreggiare e maneggiare l'affetti del volgo, e nell'affari del mondo prosperi e felici riuscirno, e li troppo esatamente sapienti, e contumaci nelli loro benché fondati proponimenti, all'altrui [198] stra|pazzo s'offerirno.

Ringratiai Anasagora di tali ottimi avisi, dicendoli che permetta Iddio et il proprio genio che io tali documenti eseguisca, havendo l'esperienza insegnato ad esso Anasagora quanto può in simili affari la naturale propensione dell'animo, non essendosi egli autore di tal ammaestramenti, potuto astenersi di promulgare che il sole, tanto dalli Ateniesi riverito et adorato, che fosse, secondo il suo parere, insensato ferro overo macigno infocato et ardente. Con tali ragionamenti, da Anasagora mi dipartii.

M'avenne che doppo alcuni giorni in Eutidemo mi abbatei, in Eutidemo dico, homo di non mediocre grido non meno per la sua erudi-

Settima espositione del sapere. tione, che per strani dogmi che difendeva, al quale in questo modo la favellai:

"Non dubbito punto, o sapientissimo Eutidemo, a cui il naturale talento accompagnato da vigilante disciplina ha sugerito facoltà di reggere a tuo modo l'humani ingegni, e piegarli a qual verso ti aggrada e hora con sottilissime reti illaquearli, e quando anco ti piace sviluparli, et alla verità incaminarli, pregoti che amichevole officio meco hora eserciti instruendomi di ciò che sia l'humano sapere, rendendoti compassionevole la mia inettia e dapocagine, ché mentre voi homini valorosi et oltremodo addotrinati nell'alto della sapienza prosperamente vellegiate, io già invechiato, nel limitare e vestibulo di essa per anco dimorando, mi trovo tanto impedito". 
wise man can guide it [i.e., the mind] to such an extent that - once despoiled of any affects - it cannot be broken by the adversities of fortune or softened by its favour, but must always be constant."

Anaxagoras did not reply to my argument, but he warned me that although he was satisfied with my defence of the philosophers, he still considered it to be appropriate to always follow the apparent and common truth. However, the thorough and exact [truth] has always provided its proponents with troubles and misfortunes. Indeed, the pure and sincere truth is like the excessive light that harms those with weak eyes when they stare at it, as well as annoying thieves because it reveals their rogueries. Likewise, the light of the truth damages plebeian intellects, as they cannot tolerate its rays, and it greatly torments sagacious and ill-intentioned [intellects], because they suspect that it may disclose their falsehoods and deceits to others. Hence, long experience has always demonstrated that those who observe human customs become excellent at manoeuvring and manipulating the affects of the masses, and they turn out to be prosperous and successful in mundane matters. However, those who are indeed too wise and obstinate in their resolutions, although they are well-founded, are mistreated by [198] others.

I thanked Anaxagoras for this excellent advice and I told him that both God and my genius would allow me to follow these teachings. However, experience had taught Anaxagoras himself how much the natural inclination of the soul was able to do in these kinds of matters. Indeed, although he was the author of these teachings, nevertheless he could not abstain from declaring that the sun, which is so worshipped and adored by the Athenians, was in his opinion an insensitive [piece of] metal or an inflamed and burning boulder. ${ }^{360}$ With these arguments, I took my leave of Anaxagoras.

After a few days, I came across Euthydemus, and I mean the Euthydemus, as famous for his erudition as for the unusual dogmata he maintained. Then, I spoke to him in this way:

Seventh exposition of knowledge.

\footnotetext{
"Oh, most wise Euthydemus, I do not remotely doubt that your natural talent, combined with vigilant discipline, has led to the capacity to rule human intellects according to your will, to bend them to your wishes, and to enmesh them in a very fine net, as well as to free them when you want to steer them towards the truth. Therefore, I beg you to carry out this amicable task with me, to instruct me about what human knowledge is. I hope you will be compassionate towards my ineptitude and incompetence; indeed, while you valorous and highly learned men are sailing ahead from the heights of your wisdom, I am already old, but still dwelling at its [i. e., knowledge's] entrance and vestibule and finding myself hindered [from going further].”
} 
Al che Eutidemo accorendomi disse:

"Tengo dubbio, o Socrate, che hora pratichi meco delle tue solite ironie che simulando ignoranza, procuri con maggior sicurezza assaltare e sorprendermi. Ma sia come si voglia, satisfarti mi aggrada, ché se censurato da te sarà il mio parere, emendato e corretto riportarolo. Stimo dunque, o Socrate, che la mente humana in due fontioni si eserciti l'una in apprendere, e l'altra in giudicare l'appreso, e siccome il giudice prima si applica a riconoscere lo stato della causa, serbandosi intanto sincero et indeterminato, e doppo si conduce al secondo offitio, cioè à decidere e [199] deter|minare il giuditio, così apunto aviene all'intelletto circa la cognitione delle cose, che prima l'apprende semplicemente senza punto giudicarle. Ma il sapere non consiste altrimente in quella primiera apparitione, ma sì bene nella susequente applicatione, cioè nell'affermare over negare la real esistentia all'appreso. Onde il formalizarsi semplicemente e rappresentarsi il corvo con piume bianche et il cigno di nere vestitto, non si commette pertanto verità né falsità, ma sì bene quando con fermo proponimento da noi si afferma che tali siano, comettendo perciò la falsità, come per il contrario attribuendo il colore nero al corvo, et il bianco al cigno con asseveratione che tali siano si afferma la verità. E questo è il vero sapere che ricerchi e che con tanta industria indaghi”.

Ma io con tal espositione non rimasi punto con l'animo tranquillato, e l'interogai:

"O amico Eutidemo, stimi forse che quello che in noi giudica sia il medesimo che esercitò prima la semplice apprensione, overo piuttosto da esso distinto et appartato?”.

Risposemi egli che non ardirebbe giamai pronontiare che fossero distinti sogetti, perché non sapprebbesi imaginare in qual maniera colui potesse rettamente giudicare, che prima non fosse informato di ciò che al suo giuditio di già non si fosse sottoposto. Né diverso ciò sarebbe che se Agatone apprendesse la bellezza di Taide e che il cieco Critone la giudicasse degna di essere da qualunque giovane amata.

Ma di novo lo ricercai se stimava che nell'istesso tempo la mente esercitasse l'apprensione, et il giuditio, over in diversi momenti.

Prontamente mi rispose, che li rassembrava impossibile che nell'istesso instante l'accadesse l'apprensione et il giuditio, il che facilmente si esprimenta quotidianamente nelli publici giudicii, che prima alla semplice intelligenza della causa s'impiega il giudice, e poi alla discussione e giuditio si applica, ché se altramente facesse giamai non riuscirebbe il giudicio sincero et aggiustato, anzi affatto si confonderebbe. 
Thus, Euthydemus addressed me and said:

"I am unsure, oh Socrates, whether you are now practising your usual irony with me; indeed, by simulating your ignorance, you are trying to attack and catch me with more certainty. However, let us do as you wish; I will enjoy satisfying you, because if you censure my opinion, it will come back to me emended and corrected. I think, oh Socrates, that the human mind carries out two functions: one is to apprehend, and the other is to judge what it has apprehended. Just as the judge first applies himself to acknowledging the state of the case, adopting a sincere and impartial manner, he then comes to his second task, namely to decide and [199] determine the judgment. Thus, concerning the cognition of things, it happens that the intellect simply apprehends them without judging them. Yet knowledge does not consist in that first appearance, but in the following application, namely in affirming or denying the real existence of what we have apprehended. Therefore, simply conceiving and representing a raven with a white plumage and a swan with a black one does not intend either truth or falsehood. Yet when we resolutely state that they are this way, we are thus speaking falsely. However, when we attribute the colour black to a raven and the colour white to a swan, we are decisively stating that they are like this, and then we are speaking truly. This is the true knowledge that you are looking for and investigating so industriously."

However, after this exposition, my mind was not appeased, so I questioned him:

"My dear Euthydemus, do you think that whoever judges in us is the same [person] who simply apprehended at first, or rather that the former is distinguished and separate from the latter?"

He answered me that he would not dare to say that they were two distinct subjects, because he could not imagine how someone could give a correct judgment without being previously informed about what must be judged. This would be like saying that Agathon apprehended Thaïs's ${ }^{361}$ beauty while Crito the blind man judged her worthy of being loved by any young person.

However, I asked him again whether he was of the opinion that the mind carried out its apprehension and judgment at the same time or [that it did so] at different moments.

He promptly answered me that it seemed impossible to him that apprehension and judgment could happen at the same time. This was easily experienced each day in the public trials, where the judge first sought to simply understand the case and then applied himself to its discussion and judgment. If he did otherwise, the judgment would never turn out to be sincere and appropriate; rather, it would indeed become confused. 
$\mathrm{Al}$ che io replicai che havendomi [200] egli conceduto che diversi non possono essere l'apprensivo dal giudicante, con la sua ultima concessione, di nuovo si invilupamo nell'istesso assordo, cioè di asserire che altro in noi sia colui che apprende, che quello che giudica, perche i varii tempi all'istesso soggetto non è dissimile che diversi soggetti nell'istesso tempo, siccome che quando ragionai del senso comune fu da me espresso.

Ma oltre di ciò con altra simile instanza l'assaltai con dirli:

"Credi tu, Eutidemo, che l'apprensione sia cosa per se stessa esistente come il ferro, il marmo, overo piuttosto essendo una tal passione overo attione, ché ciò non fa caso al mio arguire, conviene che a guisa dell'altre sue congeneri, sia di conditione flussibile e labile, in modo tale che impiegandosi la mente nel giudicare l'apprensione già si trova questa estinta, ma se così è dunque, sapientissimo Eutidemo, a che tenirà essa mente riguardo nell'approbare over reggettare alcuno proponimento? Stimi forse giudice che dimenticato s'havesse il racconto della causa, a ragionevole sentenza, se non che a caso, capitare potesse?”.

Risposemi egli, che sebbene terminata et estinta fosse l'apprensione, tuttavia rimane nell'animo certo vestigio e reliquie di essa, sufficiente ad indrizzare il seguente giuditio come ci accade circa l'habiti delle dottrine, arti, e virtù, ché senza altro nostro accorgimento, et osservatione s'eseguiscono li primieri documenti, essendo noi solamente normati da quel tenue residuo che ci avanza delle già pratticate attioni.

A ciò io mi opposi con dirli, che non conviene dalli habiti dell'animo trarne consequenza favorevole al nostro proposito, ché questi sono piuttosto dispositioni e qualità che inclinano l'animo a reiterare quell'istesse attioni che altre volte esso esercitò, il che accade anco alle cose insensate come di già fu detto. Ma nel giuditio che eseguisce la mente nell'approbare l'apprensione over regettarla non replica l'istessa attione, ma una nuova ne esercita, per il che tal assomiglianza non si addatta al nostro proposito. Ma che l'introdurre tali vestigi e reliquie diversi dall'istessa [201] appren|sione, è piuttosto scansamento che vera resolutione che sviluppi la difficoltà, come riescono comunemente tali, tutte quell'evasioni a questa simili che fra li contradittorii propongono mezi e transationi.

Per il mio ragionare osservandosi Eutidemo fuori del suo solito nella rete colto soggionse: 
Hence, I replied that as he had [200] conceded that the one who apprehended and the one who judged could not be different [people], ${ }^{362}$ then with his last concession we were again entangled in the same absurdity, namely asserting that the one who apprehended and the one who judged were different. The reason for this was that there was no dissimilarity between saying that various different moments existed in the same subject and that different subjects existed at the same time, as I expressed when I was arguing concerning common sense.

Moreover, I attacked him with another similar instance, telling him:

"Do you believe, Euthydemus, that apprehension is something that exists by itself, like iron or marble, or is it rather a passion or action? However, if this does not fit what I am inferring, then it must be transient and labile like its other congeners, so that as soon as the mind begins to judge the apprehension, it has already disappeared. Yet if this is so, most wise Euthydemus, what will the mind take into account when it must approve or reject a resolution? Do you believe that a judge who has forgotten the account of the case could come to the correct sentence? Yet if he did so, it would be only by chance."

He answered me that although the apprehension was over and extinguished, nevertheless a kind of vestige and relic of it would remain in the mind. This would be sufficient to direct the subsequent judgment, as was the case when we dealt with the habitus of doctrines, arts, and virtues. Indeed, we would follow the first teachings without any further precaution or observation, since we were ruled only by that feeble residue left over from the actions we had already undertaken.

I objected to this by telling him that it was not necessary to draw any favourable consequences for our topic from the mind's habits, because they were rather dispositions and qualities which oriented the mind to repeat the same actions it had already carried out at other times. This also happened with insensitive things, as has already been said. However, when the mind judged by approving or rejecting the apprehension, it did not repeat the same action, but undertook a new one. Therefore, similarity was not pertinent to our matter. On the contrary, in presenting these vestiges and relics as different [201] from apprehension itself, instead of finding a true solution to this difficulty, this would rather be a way to avoid it, as was commonly the case for all those deflections which put forward a medium and agreement between the contradictories in this way.

Because of my argument, as Euthydemus realised that he had fallen into the trap - as was unusual for him - he continued: 


\begin{abstract}
"Molto fretolosamente mi diportai mentre ch'affermai che l'istesso fosse in noi colui che apprende con quello che giudica. Anzi che hora motivato da queste tue instanze m'è di mistiero retrattare il già inavedutamente asserto, e ripronontiare che diversi siano quelli che esercitano tali due fontioni, cioè l'apprendere e giudicare, che però nell'istesso tempo ciò eseguiscono. Ma per evitare l'assordo già da principio proposto, che seguirebbe se differenti fossero, fa bisogno dire, che nondimeno si ritrovano diverse facoltà destinate a tali due fontioni, ambe inestate et instalate nell'animo humano per se stesso uno e singolare, a guisa di rami, che ad uno tronco sono uniti, e che dalla istessa radice si alimentano".
\end{abstract}

A ciò replicai che poco al mio parere con tal sfugitoio si avanzò, non potendomi con la mente formalizare, che le cose che per se stesse e per loro propria natura sono distinte, per mezo altrui l'istesso divenire. Né il posarsi sopra il comune fondamento cagiona altrimente la loro identità, siccome anco nell'essempio di rami addotto ciò evidentemente apparisce, potendo l'uno di essi divenire infecondo et arido, e l'altro rimanere fronduto e vegetante, benché sopra l'istessa radice insistono et alignano. Onde stante ciò, essendo le già dette facoltà divise, s'incorrerebbe nella primiera difficoltà che colui che rende il giuditio non riconosce sopra che egli sententia e decide.

Intraprese di novo Eutidemo evadere la difficoltà con dire che sebbene l'istesso affatto non fosse l'apprendere che il giudicare, nondimeno perché tali offitii l'uno immediatamente l'altro segue, assordo alcuno da ciò non sortisce.

Ma io incontrando il suo tentativo con il discorso tenuto con Antistene siccome vi raccontai mi opposi [202] a tal sua evagatione. Al che per fine acquietosi Eutidemo.

Ma Tehetetto che presente si trovò a tal divisamento stimò scansare il colpo con dire che non siano diverse di spetie l'apprendere e

Ottava espositione del sapere. giudicare, ma solamente varii in quanto al più e meno, e che l'apprendere sia una lieve e volatile cognitione, et il giudicare una profonda e radicata intelligenza. E perciò avenendoci altra cognitione repugnante alla primiera ma più gagliarda e potente, si ritratta quella, e quando vicendevolmente l'una l'altra oppugna e discaccia, dubbiosi e perplessi ci rende.

Stimava Tehetetto con tale sua diceria havere collimato nel centro del bersaglio, ma io lo sorpresi, avisandolo che grandemente rimaneva per ciò offeso il nostro sapere, se per altro mezo e modo non si afferasse la verità che per la contumace permanenza dell'apprensione che nel nostro animo insiste. Onde ne seguirebbe che il cimento e saggio 
"I was very hurried when I stated that the apprehender inside us and the judge inside us were the same [person]. Rather, as I am now motivated by your instances, it is necessary for me to retract what I rashly asserted before, and thus for me to say that the ones who carry out these two functions, namely apprehending and judging, are different from one another, though they must execute them at the same time. Yet in order to avoid the absurdity mentioned at the beginning which would occur if they were different, one should rather say that there are different faculties designed for these two functions. Both of them are grafted and installed in the human mind, which is one and singular through itself, like branches joined to a sole trunk and nourished by the same root." ${ }^{363}$

I replied to this that in my opinion, he could not go much further through this loophole, because I could not conceive that a thing which was through itself and was by its own nature [two] different [things] could become the same [thing] by means of another. The fact of resting on a common foundation was not the cause of their being identical, as also evidently appeared in the example of the branches mentioned above. Indeed, one of them could become infertile and arid while another remained leafy and growing, although they existed and originated from the same root. Therefore, in these circumstances, since the aforementioned faculties were separate, the first difficulty would be raised, namely that the one who judged did not know the object of his judgment and decision.

Euthydemus again sought to avoid this difficulty by saying that although apprehending and judging were not the same, nevertheless as these functions immediately followed one another, no absurdity would follow from this.

However, I had already experienced this attempt during the discourse I had held with Antisthenes ${ }^{364}$ - indeed, as I told you, I objected to his [202] wandering from the point. Hence, Euthydemus finally was quietened.

Yet Theaetetus, who was present at this debate, thought to dodge the blow by saying that apprehending and judging were the same thing with some small variations. For that reason, apprehending was a light and volatile cognition, while judging was a deep and rooted understanding. Thus, as soon as we had another cognition contrary to the first, but which was more vigorous and strong, we would retract the first, and when they mutually opposed and excluded one another, then this would make us doubtful and perplexed.

Theaetetus thought that he had hit the centre of the target with his speech, but I caught him by warning him that if there was no other way or means of grasping the truth except through the obstinate persistence of the apprehension in our minds, then our knowledge would be greatly harmed. Therefore, it would follow that the only proof and evidence

Eighth exposition of knowledge. 
Nona espositione del sapere.

Dubbita Socrate

come accade al falso giuditio. della certezza delle cose altro non fosse che la lunga dimora della loro apprensione.

Ma io narrato che hebbi a Tehetetto il ragionare di Gorgia in tal proposito et a Voi già da me raccontato, rimase rintuzzato il dogma di Tehetetto. Ma non cessò egli per altro modo di risorgere con dire, che siccome rifiutava per la mia instanza che la sola perseveranza dell'apprensione fosse bastevole ad accertarci della verità, così anco stimava che la decente applicatione dell'attributo al soggetto over sconvenevolezza ci indicasse la verità over falsità del proponimento.

Ma io di novo lo risaltai dicendoli:

"Non ti accorgi, ottimo Tehetetto, che con tal conditione diversifichi e distingui maggiormente il giuditio dall'apprensione, e che perciò di novo cespiti nell'antedetto assordo? Ma di più il tuo ragionare eccita in me altra non lieve difficoltà, non potendomi rafigurare in che modo in noi il falso giuditio accade".

Et egli a me:

"In che maniera puoi dubbitare circa li falsi giuditii come quando al corvo s'attribuisce la bianchezza, et al cigno la negrezza? E chi può negare che ciò sia falsissimo mendacio?”.

Replicai:

"Per il certo mi [203] arrosisco di ciò dubbitare, ma il modo che ci avenga tal mendace giuditio mi si rende come che incomprensibile. Rassembrati, dilettissimo amico, che appo Prencipe grande si ritrovi una guardarobba ottimamente instrutta di varii vestiti per l'uso di diverse persone, e che conforme alla qualità della stagione variamente servire debbono, a questa vi sia preposto un dispensiere, che conforme la convenevolezza e bisogno di caduno de cortegiani a tempi e stagioni debiti distribuisca li drappi che in detta guardarobba si contengono, onde s'egli decentemente li compartisce, ottimo ministro riesce, come s'altrimente eseguisce che il vestito del cavaglier al stafiero e l'habito di questo a quello distribuisce e l'addobamento dell'estate nel verno appresta, inetto a tal carica senza dubbio riuscirebbe. Hor dunque nell'istesso modo quando la nostra mente accopia ad un soggetto l'attributo che se li deve la stimamo verace e che nel bersaglio colpisca, ma quando insieme aggrega cose repugnanti, et incomplicabili, mendace e fallace la giudicamo".

\section{Al che soggionse Tehetetto:}

“Per il certo essempio migliore al nostro proposito arrecare non potevi”. 
of the certainty of things would be nothing but the long persistence of their apprehensions.

Yet as soon as I had told Theaetetus Gorgias's argument in this respect, which I have already told you, Theaetetus's dogma was refuted. However, he did not hesitate to say that he was arguing against the view that the apprehension was sufficient to ascertain the truth solely by its persistence - which one could gather from my instance - as much as he was considering that the proper or improper application of an attribute to a subject might show us the truth or falsity of a resolution.

Yet I replied by telling him:

"Don't you realise, excellent Theaetetus, that in this situation you will separate and distinguish the judgment from the apprehension even more by again coming across the above-mentioned absurdity? Moreover, your argument causes me another sizeable difficulty, as I cannot imagine how the false judgment may occur in us."

And he [said] to me:

"How can you be doubtful concerning false judgments, such as when one attributes whiteness to a raven and blackness to a swan? Besides, who may deny that this is a very mendacious falsity?"

Socrates is doubtful concerning the way in which false judgment

I replied:

"Certainly, [203] I will blush to doubt this, but I find the way this mendacious judgment occurs to us to be incomprehensible. Imagine, my dearest friend, that among the princes there is a great wardrobe that is perfectly filled with various clothes available for different people and able to provide them according to the season. A steward is in charge of handing out the clothes stored in this wardrobe, conforming to the requirements and need of each courtier as well as to the time and season. Thus, if he distributes them properly, he will be an excellent minister; if he otherwise carries this out by providing an equerry with a knight's outfit and the latter's outfit to the former, or if he provides summer clothes in winter, then he will undoubtedly be unsuitable for this position. Likewise, we now consider our minds to be truthful and able to hit the target when it matches a subject and the due attribute, but when they cluster opposed and uncombinable things, we judge them to be mendacious and fallacious.”

Hereupon, Theaetetus continued:

“Certainly, you could not put forth a better example in this regard.” 


\section{Ma io continovando dissi:}

"Nondimeno importuno intoppo ci incontra, per il che esercitare in comune il tuo egregio intelletto mi conviene, ché forse il tutto ci appianarà. Stimi, o Tehetetto, che tal dispensiere tenendo cognitione di Critia, et Agatone questo proceroso di corpo e di notabile statura, e quello oltremodo macilente e quasi nano, ch'egli distribuisca ad Agatone il vestito che a Critia si addatta, et a questo quello che ad Agatone si assetta?”.

\section{Rispose egli:}

"Per il certo non cometterebbe tal difalta seppur a caso over per burla o piuttosto sorpreso di grave delirio ciò non operasse".

\section{Seguii:}

"L'istesso stimare dovresti dell'animo nostro, che giammai non fosse per comettere tal difalta di applicare conosciuto attributo, che disconvenga a non ignoto soggetto".

"Per il certo non”, affermò Tehetetto, e continovando disse: “Forse l'errore occorere ci potrebbe, quando il [204] di|spensiere riconoscendo Agatone e Critia e circa la conditione di vestiti imperito si trova, et in ciò ingannatosi assegna l'habiti indecentemente. E l'istesso avenirci quando l'intelletto giudica il falso, conoscendo un delli accoppiati, e l'altro ignorando". Ma a ciò accors'io:

"Né errore in questa guisa parmi poter avenire, ma siccome mi rassembra impossibile che la mente giudichi che la luce sia tenebre mentre che riconosce ciò che sia luce e tenebre, così appunto ancora non li può accadere che l'ignoto al da lei conosciuto attribuisca”.

Sollecitomi Tehetetto, che meglio li dilucidasse tal essempio. Et io ad esso:

"Rafigurati che Agatone sia dal dispensiere conosciuto, e che il vestito che li compartisce li sia ignoto, in qual modo potrà egli stante ciò affermare, che tal vestito sia il suo proprio e quello che agiatamente se li addatta? L'istesso ancora facilmente puoi applicare circa il giuditio della mente mentre che asserisce l'attributo convenire a tale soggetto”. 
However, I continued, saying:

"Nevertheless, it raises a bothersome obstacle; therefore, I should work together with your excellent intellect and then perhaps this will all be smoothed away. Do you think, oh Theaetetus, that one such steward who knew Critias and Agathon, the former slender and of remarkable stature while the latter is extremely scrawny and almost a dwarf, would provide Agathon with clothing suitable for Critias and him [i.e., Critias] something that was suitable for Agathon?"

\section{He answered:}

"Certainly, he would not make such a mistake, unless he did it by chance, or jokingly, or rather while he was utterly delirious.”

\section{I continued:}

"You should consider our minds, which would never make this mistake of applying a known attribute to a known subject which conflicts with the former, in the same way."

Theaetetus stated: "Surely not." And he continued: "Perhaps the mistake may occur if [204] the steward recognises Agathon and Critias, but has no expertise concerning clothes. Therefore, he provides them with unsuitable clothes by mistake. Furthermore, the same may happen to us when the intellect judges incorrectly because it only knows one of the two and is ignorant of the other." Yet I replied:

"It seems to me that a mistake cannot be made in this way, as I think that it is impossible that the mind can consider light as darkness if it knows what light and darkness are. Hence, it also cannot happen that it may apply an unknown attribute to something that is known to it."

Theaetetus urged me to clarify this example better. And I [replied] to him:

"Imagine that the steward knows Agathon, while he [i.e., the steward] does not know which clothing he is giving him. So, in these circumstances, how can it be possible that he [i. e., Agathon] will affirm that this clothing is his and that it fits him comfortably? You can easily apply the same to a judgment expressed by the mind when it asserts that this attribute is fitting to that subject." 
Ma di nuovo risorse Tehetetto con dire:

"Forse che il falso occorre quando ambi li accopiabili non sono da noi conosciuti, tanto il soggetto quanto l'attributo, siccome anco accaderebbe al dispensiere mentre che Agatone, e Critia, e parimente li vestiti li fossero ignoti”.

Al che mi opposi, che né anco ciò può avenire, ché in tal caso né il dispensiero né la mente possono cadere in tal fallacia, non potendosi con fondamento di alcuno apparente giuditio affermare che l'uno all'altro convenga e si addatti, essendo tutti egualmente ignoti, Agatone e Critia e li addobamenti, così anco li soggetti e l'attributi, siccome giamai alcuno non affermarebbe mentre le cose nelle tenebre si ritrovano, che l'una all'altra convenga, e punto sarebbe come se cieco dispensiere attentasse di eseguire decentemente la distributione di colorati vestiti a persone di diversa qualità e conditione. Onde restaci per anco occulto il modo con che opiniamo il falso. Anzi apparirebbe per tal discorso che sempre nel vero colpissimo. A ciò sogionse Tehetetto dicendomi:

"Ma tale buona ventura che [205] im|provisamente mi arrechi di sempre incontrare nel vero, mi si rende infortunio, diminuendosi perciò il pregio alla verità, facendone tu di essa tanta larga copia et abbondanza, appresentandosi, conforme il tuo divisare, spontaneamente alle mani di qualunque senza alcuna nostra laboriosa industria. E mi sortisce admirabile che tutti li altri beni con tanta ansietà e sudori li cieli ci vendono, e che la verità gratiosamente ci sia offerta. Ma in quanta confusione, o Socrate, sortirebbero tutti li humani affari, quando fosse levata la distintione del vero e falso, e che ogni fititia chimera l'elogio del vero si usurpasse? Ma in tali salebri et inviluppi ci conducemo per cagione dell'immoderato dibatimento che circa l'investigatione della verità praticamo.

Per il che ho sempre stimato che siccome intorno l'habiti morali dell'animo la mediocrità sia il più comendabile et ottimo, così in fatto delle dottrine et esercitii mentali temperatamente esercitar si deve, e che se l'intelletto rimane sovente irretito in tali ambagie e come da se medesimo illaqueato, non deve di ciò punto lagnarsi e reclamare, poiché tendendo egli insidie non solamente alli altri animali, ma sopra tutti al suo proprio genere, la natura giustissima vindice delle ingiurie contra la sua prole comesse, l'induce a cogliere, imbrogliare, et implicare se stesso. Ma giacché a tal flutatione ridotto mi hai, pregoti a compiacermi in esplicarmi ciò che in tal proposito intendi”.

Et io ad esso:

"Diroti quello, non saprei se sognando over vigilando, già una fiatta mi sugerì il discorso. Stimavo che la mente nell'istesso instante che giudica l'attributo al soggetto convenirsi, non havendo allhora rispetto a tutte le circostantie et 
Yet Theaetetus replied again, saying:

"Perhaps the falsehood occurs when both of the combinable ones - the subject and the attribute - are unknown to us, just as it would occur to the steward if Agathon, Critias, and the clothes were unknown to him.”

I objected to this because not even this could occur. Indeed, in this case, neither the steward nor the mind could make this mistake, since it could not be stated on the basis of any apparent judgment that one of them was suitable for and appropriate to the other. The reason for this is that they would all - namely Agathon, Critias, and the clothes - be equally unknown, as well as the subjects and attributes: indeed, no one would ever state that one [thing] was suitable for the other if this was taking place in the dark. Indeed, it would be as if a blind steward were attempting to correctly distribute the colourful clothes to different kinds and ranks of people. Therefore, the way in which we could deem something to be false also remained concealed to us. Rather, from this argument, it would seem that we always reach the truth. Theaetetus added to this:

"Yet this good luck, [205] which you are suddenly bringing me by saying that we always reach the truth, now becomes a misfortune, because it reduces the truth's value. Indeed, you make it seem as though it exists in a great amount and abundance, since, according to your consideration, it seems to be spontaneously offered to anyone without any great industry. Besides, I find it admirable that while all other goods are purchased from the heavens with the wages of our concern and hard work, the truth is generously offered to us. However, in what confusion, oh Socrates, would all human affairs end up if the distinction between truth and falsehood was removed and every false chimaera could usurp the praise of [being called] the truth? Because of the immoderate debate concerning the investigation of the truth, we come to these difficulties and tangles.

"Therefore, just as I have always thought concerning the moral habits of the mind that the happy medium ${ }^{365}$ should be considered the best and the most commendable, so it must be practised in moderation regarding doctrines and mental processes. Furthermore, if the intellect is often ensnared in such difficulties, as though it were tangled up in itself, it must not complain about this at all or protest against it. Indeed, as it sets traps not only for other animals, but above all for its fellow men, Nature, as a most fair avenger of the affronts to its offspring, induces it to be caught, deceived, and entangled in itself. However, since you have led me to this wavering, please gratify me by explaining what you mean in this respect."

\section{And I [said] to him:}

"I will tell you what reason suggested to me once before, although I do not know whether I was dreaming or awake. I considered that when the mind judges the attribute to be suited to the subject, as it takes care of all the circumstances and 
individuali attinentie dell'uno e dell'altro, sempre in certa guisa nella verità s'affronta, benché ciò inutilmente et importunamente seguisca, havendo solamente la mira a quelle conditioni e positure che per allhora se li appresenta. Ma poi diversificandosi le conditioni delle cose overo palesandosi all'intelletto altre e diverse qualità, e sovente [206] va|riandosi la dispositione dell'istessa mente se varia il giuditio. E falso e mendace si stima il primiero, non essendo pertanto da noi advertito et osservato che la mutatione del posteriore giuditio sia seguito per nuove avenentie che sono state da noi scoperte et osservate; ingannandoci che reputiamo sempre rimanere l'identità del primo oggetto, $\mathrm{e}$ della facoltà apprensiva stabili e constanti, credendo noi, che circa l'istesso oggetto habbian conceputo varii giuditii.

Appunto come se la fantesca capitasse al polaio per prendere una cotornice et invece di essa pigliasse una tortore, ché senza dubbio nell'istante della presa non teneva nella imaginatione la figura della tortore distratta dall'imagine della cotornice, ma un certo tal abbozzo addatabile all'una et all'altra, onde in quel momento non faliva mentre che pigliò l'una per l'altra, ma subito che fu eseguita la presa scorgendo più d'appresso e considerando minutamente il tutto, riconosce la difalta.

Quest'è quanto in tal proposito ho delibato non sapendo per anco se al vero mi sia molto avicinato, per il che alla tua sagace censura l'offerisco. Ma di più tornando al primiero proposito, tanto alla tua positione come a quella di Eutidemo mi rimane per anco difficoltoso che riducendosi il sapere al giuditio che si esercita circa la complicabilità over incomplicabilità delle cose l'una con l'altra, non si può eseguire senza riconoscere la convenienza over incongruità che le cose insieme tengono, il che incontra e concide con l'istesso sapere, per la cui intelligenza tanto si travagliamo a rinvenire e riconoscerlo, onde si troviamo in tal punto, che esponiamo il sapere con l'istesso sapere".

Al fine di tal mio ragionare osservai Eutidemo alquanto turbato, recandosi ad onta, ch'egli insino allhora vittorioso in tutti li mentali conflitti, al presente da me in dottrina tenuta da esso tanto volgare fosse stato da me ragirato e superato.

Ma Tehetetto di più nobile indole e generoso spirito dottato, deliberò meco affaticarsi circa tal inchiesta, e né volse per l'avenire aventurare [207] il suo giuditio in affermare o negare dogma alcuno, se prima non veniva a capo di tal indagine, stimando irragionevole pretensione presumere di conoscere la conditione di alcuna cosa, mentre che si ignorasse ciò che sia l'istesso sapere.

Ma io rincorato da tale compagnia, licentiatoci da Eutidemo determinassimo ambi ricorrere ad Erchelao, che tutto alla speculatione delle cose fisiche dedicato si era, stimando che havendosi egli con tanta assiduità a ciò impiegato, si fosse prima esatamente informato di ciò che sia il sapere, siccome che giamai nochiero al mare si aventurarebbe, se prima non riconoscesse quello che fosse l'arte navigatoria. 
individual connections between both of them, it always runs into the truth to some extent. However, it does this uselessly and rashly, since its only aim is those conditions and positions that it represents in that moment. Then, once the conditions of things have changed, different qualities will be disclosed to the intellect, or often [206] a change in the mind's disposition may change the judgment. However, the former is considered to be false and mendacious, because we do not realise or observe that the mutation of the subsequent judgment proceeds from new events that we have discovered and observed. Indeed, we are misleading ourselves when we consider the identities of the first object and the apprehensive faculty to be always stable and constant. Thus, [we are misleading ourselves] when we believe we have conceived different judgments concerning the same object.

"Indeed, it would be as if a maidservant went to the henhouse and took a rock partridge instead of turtledove. Undoubtedly, in the moment when she took it, she did not hold the figure of a turtledove distinguished from the image of a rock partridge in her imagination, but a kind of sketch fitting both of them. Therefore, she did not fail in the moment when she took one instead of the other, but if, as soon as she took it, she saw it more closely and considered the whole in detail, she would then acknowledge the mistake.

"This is what I have observed in this respect, although I did not even know whether I was very close to the truth, and therefore I submit it to your sagacious criticism. Moreover, to return to the original subject, I find your position, like that of Euthydemus, still very difficult. Indeed, as they both reduce knowledge to a judgment of the combinability or non-combinability of things, then it cannot be achieved without acknowledging conformity or incongruity between things, and this corresponds to and coincides with knowledge itself. Therefore, we work so hard in seeking and acknowledging it in order to apprehend it; hence, we are at a point where we are expounding knowledge through knowledge itself."

Once I had concluded my argument, I noticed that Euthydemus was rather upset, because he had so far [always] been victorious in all his intellectual disagreements, but now he had been tricked and overcome by me in a doctrine that he considered very simple.

Yet Theaetetus, endowed with a more noble nature and a generous spirit, decided to put effort into this inquiry with me. Besides, he did not want [207] his judgment to undertake [the challenge of] affirming or denying any dogma in future before he had completed this investigation. He considered it an unreasonable claim to suppose to know the condition of anything when one is ignorant of what knowledge itself is.

Yet being heartened by this company, we took leave of Euthydemus, and both of us decided to appeal to Archelaus, who had completely dedicated himself to speculation on physical things. As he worked on this so regularly, we thought that he already knew precisely what knowledge was, because no helmsman would venture into the sea without first knowing the art of navigation. 
Decima espositione del sapere.

Virgilius. $\quad$ Felix qui potuit rerum conoscere causas.

Ad esso dunque capitati lo ricercassimo che ci esplicasse quello che sia il sapere. Al che egli prontamente rispose, che fosse l'apprendere le cose per le lor cause, quali sono la materia, forma, efficiente, e fine. Fra molte ragioni che addusse in corroboratione di tal sua diceria fu, che allhora si acquieta in noi la brama del sapere, quando habbiamo conseguito la cognitione delle cause, rimanendo perciò la nostra curiosità affatto satolata, occorrendoci a guisa di pedota che doppo lungo travagliare con l'insulti del mare, in sicuro porto pieno di gaudio approdi et ancori, e che perciò egregiamente pronontiasse il poeta:

Ma io punto non mi allegrai per tal espositione, né questa satisfece punto al desio che teniva di conseguire tal cognitione. Primieramente m'abbatei in quella difficoltà che come fatale a tutte l'espositioni del sapere si oppone e contrasta eccettuando forse a quella di Protagora, cioè mentre che ignari si troviamo circa quello che sia il sapere, e che instantemente ricerchiamo di tenire novella, presumemo con lui stesso renderci di esso capaci et informati, nel qual inconveniente evidentemente incorse Archelao mentre pronontiò che il sapere fosse apprendere le cause delle cose, che [208] altro non è che l'istesso sapere.

Ma lasciando ciò a parte, altri non lievi assordi mi si attraversarno. Mi molestava primieramente che il riconoscere ciò che sia causa et in che consiste la sua efficacia et energia è forse delle più ardue dottrine che pratichi il saper humano. Onde non vi mancorno di quelli benché troppo temerarii ingegni e puoco riverente al comune intendimento delli homini, che negarno qualunque causalità. Ma siccome questa opinione, falsa dall'universale delli homini è reputata, nondimeno la sua falacia non è tanta manifesta che con la semplice evidenza a guisa de' primi principii si riconosce. Tiene tal fantasia settatori e seguaci, per il che è di mestiere confutarla con serie di argomenti e difuse dedottioni, per il che senza la cognitione di ciò che sia saper non si può attentare la sua regettione. Onde inanzi che fosse comprobato l'esistentia delle cause già sarebbe nato et adulto il sapere.

Oltre di ciò admessa la causalità come da per sé evidentissima, mi si oppone altra difficoltà non solo intorno il modo che tiene nel produrre il suo effetto m'anco circa il numero delle cause.

- Non mancano alcuni de sapienti che solamente la causa materiale admessero.

- $\quad$ Altri v'aggiunsero la formale. 
Well, since we had come across him, we asked him to explain to us what knowledge was. Hence, he promptly answered that it was apprehending things through their causes, which are the material, formal, efficient, and final [causes]. Among the many reasons that he put forth in order to strengthen this speech of his was that once we have acquired cognition of these causes, we then appease our longing for knowledge, having therefore satisfied our curiosity. This occurs to us exactly as it would to a helmsman, who, after being troubled for a long time by the assaults of the sea, [finally] docks and joyfully anchors in a secure port. ${ }^{366}$ Therefore, the poet excellently said:

Blessed is he who has succeeded in learning the causes of things. ${ }^{367}$

However, I was not pleased by this exposition, and it did not even remotely satisfy my desire to achieve this cognition. Firstly, I encountered that difficulty which fatally opposes and hinders all expositions of knowledge, except perhaps that of Protagoras, [which states] that we are unaware of what knowledge is, but as soon as we attempt to obtain information about it, we presume that we may be made aware and informed about it by itself. This inconvenience evidently also occurred to Archelaus when he said that knowledge consisted in apprehending the causes of things, which is nothing other than [208] knowledge itself.

Yet in leaving this aside, other serious absurdities hindered me. Firstly, what irritated me was that to acknowledge what the cause is and what its effectiveness and energy consist in were perhaps some of the most difficult doctrines pursued by human knowledge. Therefore, there were also some very reckless wits who were irreverent towards the common understanding of humankind because they denied any causality. ${ }^{368}$ However, although people universally consider this opinion to be false, nevertheless, its fallacy is not so manifest as to be acknowledged by simple evidence, such as first principles. This fantasy has sectarians and followers and hence it is necessary to confute it with a series of arguments and extensive deductions; nevertheless, it cannot be rejected without cognition of what knowledge is. Therefore, before the existence of causality was ascertained, knowledge would have already been born and grown into an adult.

Moreover, even if one were to admit that causality is very evident by itself, I encountered another difficulty, not only concerning the way it produces its effect, but also concerning the number of causes.

- $\quad$ There were also some wise men who only accepted the material cause;

- $\quad$ Others added the formal one;
Tenth exposition of knowledge.

Virgil. 
- Et altri anco l'efficiente introdussero.

- Et Anasagora asserendo la mente disgregatrice del confuso cahos alle predette la finale v'addatò.

- Non manca Platone di acramente contendere per la ideale.

Onde a risolvere e determinare il vero numero di esse, sforzati saressimo di valersi dell'istesso sapere, onde ci ridonderebbe l'antedetta dificoltà.

Ma di più mi annoiava altro intoppo, che se il sapere dipende dal riconoscimento delle cause o che ci converebbe all'infinito procedere, il quale per sua natura è incomprensibile né si può giamai con il discorso percorrerlo, et abbracciarlo, overo ci conviene fermare ad un segno e termine senza ricercarne più oltra causa alcuna, onde vano di novo riuscirebbe il nostro antecedente travagliare. Che valerebbe alla curiosità delli Egittii riconoscere la vicina [209] deri|vatione delli rivi, e canali che irrigano e fecondano le loro campagne, ritrovando che dal Nilo fluiscono, mentre che li resta occulto il primo origine e scaturigine dell'istesso Nilo, da cui prendono principio?

E per il certo Democrito in ciò è degno di grave censura, che havendosi affaticato al di sopra di ogni altro fisico in rendere le ragioni di qualunque benché minimo effetto naturale, e nondimeno la construttione universale del mondo al caso e cieco concorso delli atomi assignò. Da questi comuni esami, alla particolare disquisitione di cadauna di esse cause m'applicai, proponendomi indagare qual grado tenisse qualunque di esse nel sapere humano, e dalla causa materiale feci l'esordio. Mi riusciva tal causa oltre modo inetta e sterile a produrre in noi cognitione alcuna di vaglia, essendo essa in quanto tale indiferente et interminata. Per il che ad arrecarci la vera e speciale essenza delle cose, affatto insufficiente et inidonea mi si appariva, e perciò a riconoscere la simetria e formosità della testa di Giove olimpico poco ci vale il sapere che di bronzo o di argento, overo di altro metallo sia.

Nell'istesso modo parimente la forma non mi rassembrava causa che ci instruisca la conditione del suo effetto, ma piuttosto che sia l'istessa cosa che oggettamo. L'efficiente come all'effetto esterno, lo stimai, e che minimo di lume ci apporti nel rappresentarci li suoi effetti, siccome che riconoscendo Fidia, non si apprende punto le conditioni particolari di sue sculture, seppure non ci avenisse come accade all'i- 
- Still others introduced the efficient one;

- Besides, Anaxagoras, in stating that the mind breaks apart the confused chaos, added the final to the above-mentioned causes.

- And there was Plato, who strongly contended for the idea [as a cause].

Hence, if we tried to work out and determine the true number of them, we would be compelled to avail ourselves of knowledge itself. Thus, the above-mentioned difficulty would occur again.

However, in addition to this, what annoyed me most was that if knowledge depended on the acknowledgement of the causes, we would be led into an infinite regress, which is by its nature incomprehensible and could never be penetrated or embraced by reason, or we should stop at a certain point and extent without searching for other causes. Hence, our previous effort would again turn out to be vain. How would it help the curiosity of the Egyptians to discover that the rivers and canals irrigating and fertilising their land closely derived and flowed from the Nile if the first origin and source of the Nile itself where they arose was still unknown to them? Therefore, what would it have earned?

[209] Certainly, Democritus is worthy of serious censure in this respect, because he put more effort than any other physician not only into discovering the reasons for natural effects, even the most minor ones, but also into attributing the universal construction of the world to Chance and to a blind combination of atoms. From these common examinations, I applied myself to the disquisition of each particular cause. My proposal was to investigate the position each of them occupied in human knowledge, and I began with the material cause. This cause appeared to me to be too inept and sterile to produce any valuable cognition in us, since it was so indifferent and indeterminate. Hence, it appeared to me to be indeed insufficient and inadequate to inform us about the true and specific essence of things. Indeed, it was not important to know whether the head of the Olympic Zeus was made of bronze, silver, or any other metal in order to acknowledge its symmetry and beauty. ${ }^{369}$

Similarly, it seemed to me that the form could not be the cause that is able to instruct us about the condition of its effect, but rather that is the same thing that we present [to our understanding]. Then I considered the efficient [cause] to be like an external effect which provides us with the smallest possible light in showing us its effects. Likewise, when acknowledging Phidias, one does not remotely apprehend the particular conditions of his sculptures, unless we want to behave like those people who are unaware of the arts of painting and sculpture 
gnari dell'arte della pittura e scultura, che dal semplice conoscimento delli opefici, deducono la perfettione delle loro opere. Oltre ch'essendo l'efficiente solamente cagione della semplice essistenza delle cose non dell'interna loro ragione e conditione, non ci può altrimente suggerire cognitione di importante rilievo. Il legnaiolo forma tavola di quadrata misura. Egli è bene cagione che il legno in tal figura sortisca, non già che il diametro di essa sia al suo lato [210] incommensura|bile, né che i quadrati che emergono dalli doi suoi lati siano eguali al quadrato che dal diametro risulta, derivando tale proprietà da necessaria inevitabile et intrinseca causa, propria all'istesso quadrato non già dipendente da legnaiolo che fece apparire tal figura nel legno. Così il pittore appresta il disegno e soministra li colori, ma la bellezza che dalla proportione de' lineamenti, e temperatura di colori risulta, d'altro principio sortisce. Il musico medesimamente sugerisce la voce et il suono, ma la melodia dell'armonia, da numeri consonanti risulta.

Ma per confessarvi la mia ignavia né anco seppi intieramente imaginarmi, in che maniera dall'efficiente pervenga il principio del motto, che fontione sua propria è stimata, perché se trapassa alcuna cosa dal motore al mobile non so formalizarmi, parlando hora con termini usitati dalla scola, se tal cosa sia sostanza overo accidente. Non sostanza, poiché essendo il motto semplice accidente, e forsi non altro che l'istesso mobile, come stimano quelli ch'a nomi attribuiscono tali formalità, ricusa ogni retto discorso che sia sostanza. Né che sia accidente si può admettere, poiché a questo è interdetto lo spicarsi e fare passagio d'un soggetto all'altro, e perciò parevami che non potesse cosa alcuna transferirsi dal mottore nel mobile. Ma se non deriva da quello a questo né sostanza né accidente, che sarà quello che operarà il mottore nel mobile, e che renderà questo ossequente a quello?

E perciò alcuna fiatta adherivo al parere di coloro che l'offitio che si attribuisce al motore di movere il mobile, sia piuttosto certa concomitanza di motto che tiene con altrui, ché insieme accopiati si movono, che cosa che da esso al mobile pervenga. Ma né anco il fine benché preconizato causa delle cause e primo impulsore dell'efficiente, non mi riuscì bastevole a produrre in noi de' suoi effetti alcuna egregia cognitione. Chi non sa che il fine della guerra sia la vittoria? Della medicina la sanità? Del politico governo la tranquilità della [211] republica? Quanti pochi e rari si trovano che dalla administratione della militia, pratica della medicina, e reggimento di Stato siano periti, et in tali pro- 
who suppose to deduce the perfection of works simply from knowledge of their creators. Moreover, as the efficient is only the cause of the simple existence of things and not of their internal reason and condition, it cannot suggest any cognition to us that is remotely relevant. When a woodcutter makes a square table, he is surely the cause of the figure resulting from the wood, but not of the fact that its diagonal is incommensurable to its side, ${ }^{370}$ [210] nor that the squares emerging from its two sides are equal to the square resulting from the diameter. This property derives from the necessary, inevitable, and intrinsic cause, which is specific to the square itself and not dependent on the woodcutter who caused this figure to appear from the wood. In the same way, a painter prepares a drawing and provides the colours, but the beautiful proportions of the lines and the balance of colours result from another principle. Similarly, a musician suggests the voice and the sound, but the harmony of the melody results from consonant numbers. ${ }^{371}$

However, I will confess my sloth to you: in fact, I cannot entirely imagine how the principle of motion may come from the efficient, as this is considered to be its function. ${ }^{372}$ Indeed, when something proceeds from the mover to the movable, I cannot conceive - speaking now in terms used by the school ${ }^{373}$ - whether this thing is a substance or an accident. It cannot be a substance, because the motion is a simple accident and perhaps nothing other than the movable itself, as is believed by those who attribute forms to names, ${ }^{374}$ so that it is a substance is refuted by any correct discourse. Yet one cannot admit that it is an accident, because it is forbidden to be detached [from the subject] and to pass from one subject to another. For this reason, it seemed to me that nothing could transfer from a mover to a movable. However, if neither the substance nor the accident derives from the former to the latter, what will the mover enact in the movable that will make the latter subject to the former?

Therefore, I once agreed with the opinion of those [who believe that] the function of moving a movable usually attributed to the mover is a specific concomitance of motion held with another [thing], because they move once they are fixed together rather than [it being the case] that something comes from it [alone] to the movable. Yet not even the final [cause], although it has been predicted to be the cause of all other causes and the first to impel the efficient [cause], turns out to be sufficient, in my opinion, to produce any excellent cognition of its effects in us. Is there anyone who does not know that the goal of war is victory? Of medicine, health? Of political government, the tranquillity of [211] the republic? How few and rare are those who are experts in administrating the militia, practising medicine, and ruling the State and also 
fessioni di alcun grido? Per il che meravigliare non si deve che alcuni di filosofi hanno lasciato a parte la speculatione della causa finale nell'annoverare esse cause. Oltre che mai non mi potei rafigurare la maniera che tiene tal fine nell'impulsare l'efficiente.

Parevami impossibile, che il fine che per anco non è, tenisse facoltà et energia di movere l'efficiente alla esecutione dell'istesso finale effetto, ma se per evitare la predetta difficoltà dire vogliamo che tal causa finale che impulsa l'efficiente sia imagine di cosa che già essiste, se così fosse non moverà altrimente come fine, ma piuttosto a guisa di efficiente, onde giudicare si dovrebbe motore del motore over efficiente dell'efficiente. Ma di più ancora, a sufficientia formalizare non mi potei in qual maniera si può rappresentare l'uso della cosa che tanto sarebbe a dire il fine di essa, se prima informato non si sia della qualità e conditione di essa cosa, essendo l'uso accidente consequente e posteriore o piuttosto effetto di lei. Prima è l'occhio, e poi il vedere:

Lucret. Liber IV.

Nil ideo quoniam natura est in corpore, ut uti

Possemus: sed quod natum est id procreat usum.

Disse uno poeta anco peraltro troppo ardito e temerario. Ma io in ciò nulla affermando, solamente accuso circa tali speculationi la propria ignavia. Anzi tanto desioso mi trovavo in riconoscere la causalità et energia del fine, che se permesso mi fosse stato il rinvenirla, harei rinontiato alla speculatione et inchiesta di ogni altra causa, et ad apprendere il fine delle principali cose che nell'universo si trovano totalmente impiegato mi harei. E per certo Anasagora havendo alla mente attribuito il regolare et ordinare l'universo, nel progresso delle sue speculationi abbandonando la causa [212] finale, ricorse nel rendere ragione delli avenimenti naturali al caldo freddo, secco e humido, leggiero e grave, e simili.

Onde seguendolo li altri sapienti, chi mai di essi investigò e rinvenì il fine per cui alcuni regioni della terra sono a satietà irrigate da prolifico humore, et altre affatto di esso destitute, et altre dalle illuvioni di fiumi somerse? Chi ricercò perché alcuni paesi sono piani e commodi alli usi humani et altri alpestri e sterili? Chi indagò per qual oggetto il mare in alcuni lochi della terra con furioso flusso l'assalta, et immediate la rilascia come accade nel mare occidentale settentrionale, et in altri lochi con mediocri aggressi, regressi con essa scherza, et in altre positure, come nella lunghezza del Mare Mediteraneo, solamente con reciproco et alternante corso non crescendo né diminuendo la lambisce? 
famous [for their skills] in these occupations? Therefore, we must not be astonished that some philosophers overlooked speculation concerning the final cause when they enumerated these causes. Moreover, I could not figure out how this final [cause] gives the impulse to the efficient.

It seemed to me impossible that the final [cause], which does not exist yet, could have the faculty and energy to push the efficient to the execution of the final effect itself. However, if, in order to avoid the aforementioned difficulty, we mean that this final cause giving the impulse to the efficient is the image of something that already exists, then if this was so it would act not as a final [cause], but rather as an efficient [cause]. Thus, it would be judged to be the mover of the mover, or the efficient of the efficient. In addition to this, I could not sufficiently conceive how one may represent the use of something, namely its final [cause], if one is not first informed about the quality and condition of that thing. Indeed, the use is a consequent and posterior accident, or rather an effect of it; first there is the eye, and then sight: ${ }^{375}$

Since nothing is born in us simply in order that we may use it, but That which is born creates the use. ${ }^{376}$

Lucretius bk. 4.

This was said by a poet, who was also too daring and reckless. However, I could not affirm anything, and for this I blame my sloth concerning these speculations. Rather, I found myself to be so eager to acknowledge the causality and energy of the final [cause] that if I had been allowed to discover it, I would have renounced speculation and inquiry into any other cause. Likewise, I would have sought to completely apprehend the final [cause] of the principle things which are in the universe. Certainly, since Anaxagoras attributed [the capacity] to rule and order the universe to the mind, during the development of his speculations, he abandoned the final cause [212] and appealed to heat and cold, dryness and humidity, lightness and heaviness and the like to explain the reasons for natural events.

Therefore, who among the other wise men who followed him has ever investigated or discovered why some regions of the earth are sufficiently irrigated by a prolific humour while others are lacking in this and [still] others are submerged by floods? ${ }^{377}$ Who has ever investigated why some countries have a flat surface and are comfortable for human use while others are alpine and sterile? Who has ever inquired for what purpose the sea furiously assaults some parts of the earth and releases them immediately afterwards, as happens with the western-northern sea, ${ }^{378}$ or [why] it teases other places with little transgressions and regressions and only lightly touches yet other places, ${ }^{379}$ like the Mediterranean Sea, with a reciprocal and alternating flow, without growing 
Per qual scopo l'istesso mare nel lido della Soria termina, e non più oltre si estende, privandoci di agevole comercio con li popoli più interni della vastissima Asia?

Qual mira hebbe l'opefice universale nell'impedire la navigatione alla Grecia, Italia, et altre provincie mediteranee con l'infraporre quel stretto istmo e poco di terra fra l'Asia et Africa, in modo che ci rimane impedito lo transitare con vascelli alle ricche Indie? Come anco perché infrapose quel strettissimo tratto di terreno fra la Grecia e Poloponesso, con che fece ostacolo a doi mari Ionio et Egeo che insieme con tanto profitto di popoli non comunichino? Per qual cagione la natura congela la grandine così nociva e dannosa? Se per nostra pena e castigo, perché sovente la scarica in lochi affato sterili, e deserti senza l'offesa di alcuno? Per qual fine si accende il folgore, ultimo terrore del nostro genere? Se per abbattere il nostro orgoglio, perché tante fiatte il dorso di raminga montagna vanamente percuote?

Scilicet ipse petet Pholon? petet ignibus Oethen?
Lucano. $\quad$ Immeriteque nemus Rodopes? pinus minantes?

Ma la varietà di tanti animali non solamente a nostri usi [213] alie|ni, ma a noi oltre modo nocivi per qual causa esistono? Ma se li venenosi serpenti per nostro castigo spirano, perché nelle vastissime solitudini della inhabitata Africa son confinati? Le piante tanto dannose e mortifere a qual fine la natura de' suoi effetti custode, dal suo seno produce, e con sue poppe nutrisce? Infinite altre cose addurre potrei, che ometto, che a ricercarne le loro cagioni finali li sapienti, neghitosi, et intorpediti riescono, che pure fra tutte l'altre cagioni sono dalla curiosità del nostro intendimento oltre modo bramate.

Ma ritornando al primo nostro proposito, di più dico, in difalta di tali cause, che né anco le scientie matematiche che tengono fra le altre di certezza il principato, né di causa efficiente né finale nelle loro ferme demostrationi punto si servono, non potendosi render ragione per qual fine il diametro del quadrato sia al suo lato incomensurabile, e che tre angoli di caduno triangolo siano eguali a doi angoli retti, né meno si discorre in tali scientie circa la causa efficiente di simili proprietà. Ma quello che in tal proposito è notabile che nelle matematiche sovente si rendono evidenti alcuni teoremi senza l'aiuto et intervenimento di alcuna causa, come accade nel già detto celebre teorema fecondo di 
and diminishing? For what purpose does the same sea flow up to the Syrian shore but not beyond it, depriving us of the possibility of having easy trade with the people living in the innermost part of vast Asia?

What was the universal creator's aim when he prevented the navigation of Greece, Italy, and other Mediterranean provinces by placing such a narrow isthmus and small stretch of land between Asia and Africa, thereby making it impossible to travel by ship up to the rich Indies? Furthermore, why did he place such a very narrow stretch of land between Greece and the Peloponnese, whereby he made an obstacle between the Ionian and Aegean seas, which do not deal with each other, giving thus a great advantage to their people? Why does Nature freeze hail, which is so harmful and injurious? If it is for our punishment or chastisement, why does it hurl it onto some sterile or even deserted places without injuring anyone? What is the purpose of lightning bolts, which are so terrifying to humankind? If [they were made] in order to discourage our pride, why do they so often vainly strike lonely mountain ridges?

Shall he forsooth aim his fires at Pholoe and Oeta, at the

Pines of Mimas and the innocent forest of Rhodope? ${ }^{380}$

Lucan.

What is the reason for the existence of such a variety of animals which are not only unfamiliar to [213] us, but also extremely harmful? And if poisonous snakes hiss to chastise us, why are they confined to the immensely vast loneliness of uninhabited Africa? Why does Nature, the guardian of its own effects, produce such harmful and mortiferous plants from its bosom and nourish them with its breast? I could adduce infinite other things, which I am currently omitting, whose final causes are sought by wise, indolent, and torpid men. However, these causes are among all the other causes greatly yearned for by the curiosity of our understanding.

Yet to return to our original subject, I will moreover speak concerning the failure of these causes: indeed, not even the mathematical sciences, which have the supremacy of certainty amongst the other [sciences], use the efficient and final causes for their firm demonstrations. Indeed, they cannot explain for what purpose the diagonal of a square is incommensurable to its side or why the [sum of the] three angles of every triangle is equal to two right angles, ${ }^{381}$ and the efficient cause of similar properties is not even debated in these sciences. However, what is remarkable in this respect is that some theorems become evident in mathematics without receiving help or intervention from any cause. Similarly, this happens in the aforementioned famous theorem that was so fruitful as to bring forth many 
tante altre consequenze, cioè che li tre angoli di caduno triangolo sia eguale a doi retti, dimostrando ciò il nostro Euclide per mezo dell'angolo esterno di esso triangolo, il che ad alcuna delle antedette quattro cause ridurre si può.

Né punto mi move l'instanza apportata d'Archelao presa dal piacere che sentimo quando habbiamo conseguito la cognitione delle cause, avenendo ciò per certo nostro suposito, che la cognitione delle cause sia l'ultima linea dell'intelletuale discorso, come s'ingannarebbero coloro che posto havessero il loro ultimo fine nelle ricchezze o bellezza e simili oggetti che realmente non adempiscono la nostra volontà, se non tanto che da essi a ciò sufficienti li stimano. Potrebbe anco tale aggradimento derivare che mancandoci il modo di conseguire le cose per se stesse ci contentiamo di quello che per mezo delle loro cause ne [214] deli|bamo. A questo si aggiunge che tal contento ci accade non perché le cause ci sugeriscono sincera e perfetta cognitione delli effetti, ma perché sovente ci spingono dall'animo quelli sospetti che la novità et admirabilità ci apporta, come già fu detto trattando con Aristippo et egregiamente prononciò il poeta:

Virgilius. $\quad$ Felix qui potuit rerum cognoscere causas.

Seguendo egli immediate rendendo di ciò la cagione

Atque metus inanes et inevitabile fatum

Subiecit pedibus strepitumque Acherontis avari.

L'eclisse della Luna perfettamente si apprende da qualunque mentre che repentinamente la sua luce si estingue, ma il saperne la cagione perché tale oscurità procede, cioè che derivi dalla interpositione della terra fra essa et il sole, detrude dal nostro animo quell'horrore che ci arreca l'osservare che uno di principali ministri della natura patisca deliquio e detrimento, dubbitando noi che ciò in grande offesa e danno ridonda. Onde per tal ignoranza seguì l'eccidio dell'ateniese esercito che sotto Nicia in Sicilia militava. Da tutto ciò si rende chiaro che la cognitione delle cause di effetti non è l'ultimo conato dell'humano sapere anzi che meglio si conosce la cosa per se stessa che per altrui, siccome che giamai ritratto di pittura non ci farà meglio conoscere il suo originale di quello che esso originale per se medesimo. $\grave{E}$ ben vero che in difalta di questo di quello si servimo. 
other consequences, namely that [the sum of] the three angles of a triangle is equal to two right ones. Our Euclid demonstrated this by means of the external angle of this triangle, ${ }^{382}$ and hence it can be traced back to one of the above-mentioned causes.

I am not even convinced by the instance put forth by Archelaus, which originated from the pleasure we feel once we have achieved cognition of the causes. Indeed, this happens because of a specific supposition we have that cognition of the causes is the ultimate goal of intellectual discourse. Likewise, those who have placed their final goal on wealth or beauty or similar objects, which do not really fulfil our wishes - or at least only do so as long as they are considered to be sufficient to [fulfil] them - would be misleading themselves. This appreciation could also be derived from the fact that as we lack the way to achieve things in themselves, we are merely content that we may sample them through [214] their causes. In addition to this, we feel this contentedness not because the causes suggest a sincere and perfect cognition of the effects to us, but because they often remove those suspicions generated by novelty and wonderment from our minds, as was already said when I was dealing with Aristippus and when the poet excellently proclaimed: ${ }^{383}$

Blessed is he who has succeeded in learning the causes of things.

Virgil.

He [i.e., Virgil] went further and immediately gave the reason for this:

Has cast beneath his feet all fear and fate's implacable

Decree, and the howl of insatiable Death. ${ }^{384}$

An eclipse of the moon may be perfectly apprehended by anyone when its light is suddenly extinguished, but to know the reason why this darkness occurs, namely that it is derived from the earth's interposition between it and the sun, will remove from our minds the terror produced by observing that one of Nature's principle ministers is obscured and harmed. Furthermore, we suspect that this may turn out to cause great destruction and damage. Therefore, because of this ignorance, there followed the massacre of the Athenian army in a military expedition headed by Nicias in Sicily. ${ }^{385}$ From all of this, it becomes clear that cognition of the causes of effects is not the final aim of human knowledge; rather, a thing is better known in itself than through others. Similarly, a painted portrait will never allow us to know the original better than the original itself, although it is also true that we may use the former in the absence of the latter. 
Undecima espositione del sapere.

Hor dunque non havendo dall'antedetta esplicatione raccolto messe che mi satisfacesse, lasciando Archelao tutto implicato nella investigatione delle sue cause, a Teofrasto ricorsi, il quale di Aristotele era amicissimo e che per l'assenza di esso a Stagira ito, la vice di lui nel Liceo sosteneva, e con maggior instanza che io poteva [215] lo solicitai che spiegare mi dovesse quale fosse la mente di Aristotele circa l'humano sapere, tenendo io ferma speranza che circa ciò la mia curiosità estinguerebbe.

Tale è la celebrità dell'acume e solertia del suo ingegno, risposemi Teofrasto, che il comune amico circa ciò molto s’industriò per riportarne concetto di lui degno, ma che prima li conveniva narrarmi quello che circa il mio modo di discorrere, seco sovente favellò, il che stimava non alieno dal nostro proposito:

"Per il vero, diceva Aristotele, il nostro Socrate nel confutare l'altrui openioni, e rintuzzare il vano acume di sofisti, riesce admirabile, né meno è comendabile circa l'affari humani nel consigliare e dirigere altrui a suoi profitti. Ma nondimeno osservo in esso notabile penuria d'instrumenti e machine per oppugnare l'altrui dogmi, non havendo giamai alle mani altro che la semplice induttione tratta da legnaioli, selaii, calzolaii e simili, non affatto valevole a prostrare le contumaci openioni di protervi sofisti. $\mathrm{E}$ continuò di più dicendo, che giamai non intese che da te fosse formato demostrativo silogismo, che pure è il più formidabile ariete che sia stato escogitato per disrocare et atterrare il più munito et ostinato dogma, ma però confessava egli che se di tal organo ti fosse provisto, haresti esercitandolo renduta stupida l'istessa maraviglia".

$\mathrm{Al}$ che risposi che strano non doveva parere al nostro amico se io fosse destituto di tal silogismo, appropriato più che altri a ritrovare e fondamentare la vera scientia, non professando io alcuna scientia e dottrina, e che perciò incombeva ad esso Teofrasto esatamente instruirmi qual sia tal demonstrativo silogismo.

Seguì Teofrasto che:

\footnotetext{
"Secondo Aristotele altro questo non esser che construtione di due premesse et una conclusione, le quali premesse dalla definitione di una portione della conclusione che si ricerca riconoscere, scaturiscono, le quali conviene che siano affatto vere, immediate dipendenti da primi principii over che tengono da essi principii necessaria consequenza, e che [216] esse premesse contengano la causa della conclusione la quale è l'istessa scientia da te tanto bramata et ambita".
}

Inteso che hebbi ciò subito sospetai che la moltiplicità di conditioni non arrecassero al sapere maggior chiarezza, ma sì bene l'apportassero 
Now, as I had not gathered any satisfying harvest from the above-mentioned explication, I left Archelaus, who was completely focused on investigating the causes. Then I appealed to TheophrasEleventh exposition of tus, ${ }^{386}$ who was a very good friend of Aristotle and who went to Stagira because of his absence, where he acted at the Lyceum on his behalf. So, as insistently as I could, [215] I solicited him to explain Aristotle's opinion concerning human knowledge to me, as I had a strong belief that he would satisfy my curiosity in this respect.

Theophrastus answered me that the fame of his acumen and the cleverness of his wit were such that our common friend had worked hard on this in order to develop a concept [of knowledge] worthy of him. However, he deemed it necessary to first tell me what he [i.e., Aristotle] often said to him concerning my way of arguing, as he considered it to be not unrelated to our matter:

\begin{abstract}
"Aristotle said that in truth, our Socrates is as admirable because of the way he confutes the opinions of others and refutes the vain acumen of sophists as he is commendable in human matters, as far as his advising of others and his influencing of them for his own ends is concerned. However, I have noticed his remarkable lack of instruments and strategies to oppose the other dogmata. Indeed, he always has nothing more than simple induction in his hands, gathered from woodcutters, saddlers, cobblers, and the like, which is not sufficient to defeat the obstinate opinions of arrogant sophists. Besides, he continued by saying that he had never heard a well-made demonstrative syllogism from you. However, although this is the most formidable battering ram ever devised to scatter and defeat the most fortified and obstinate dogma, nevertheless, he confessed that if you had been provided with this instrument, you would have made wonder itself stupid by practising it.”
\end{abstract}

Hence, I answered that it should not seem strange to our friend that I had dismissed the syllogism, because I did not profess any science or doctrine and it was more suited to discovering and giving foundation to the true science than others. Therefore, Theophrastus had the task of instructing me in detail on what this demonstrative syllogism was.

Theophrastus continued:

"According to Aristotle, it is nothing but a construction of two premises and a
conclusion. Besides, these premises are drawn from the definition of a part of
the conclusion one is attempting to acknowledge. It is necessary that they are
indeed true [and that they] immediately depend on its first principles, namely,
that they necessarily follow from them. [216] [It is necessary that] these prem-
ises contain the cause of the conclusion, which corresponds to the very knowl-
edge you have yearned and longed for so much."

Once I had understood this, I forthwith suspected that a multiplicity of conditions could not provide knowledge with greater clarity, but 
maggior numero di contrarie instanze. Primieramente risorssero nel mio animo l'oppositioni hora contra Archelao intentate circa le pretese cause che producono in noi il sapere, pretendendo Aristotele che le premesse abbraciassero le cause della conclusione, oltre che nel scegliere quali devono esser le premesse idonee per fabricare tal silogismo dal quale si produca la conclusione, conviene già esser dottato di non mediocre sapere, onde la scientia inanzi li natali suoi, di già prodotta et adulta sarebbe. Ma perché non appieno della antedetta diceria da Teofrasto pronontiata, mi trovavo informato, cioè del modo che la difinitione d'una proportione della conclusione nelle premesse s'introducesse, lo pregai che ciò esatamente mi esplicasse.

$\mathrm{Al}$ che mi rispose che:

"Aristotele teneva per certo che dalla definitione conveniva auspicare e prendere l'essordio della demostratione, e da essa formarne il silogismo da cui si raccoglie e conclude la congiuntione del soggetto con il predicato over attributo, che dir lo vogliamo, che si attenta dimostrare. Ma se ricerchi da qual portione della conclusione, la definitione si deve prendere, benché l'amico ciò apertamente non habbia dichiarito, e crederei che fosse la definitione dell'attributo della conclusione, dalla quale per mezo della ordinatione silogistica si manifesta l'allianza et anessione che tiene con il soggetto della istessa conclusione”.

Il ricercai che di ciò alcuno essempio mi appressentasse. Il che egli cortesemente mi l'offerì, et in tal maniera l'espose:

“Ogni animale ragionevole è homo,

Clinia è animale ragionevole,

Dunque Clinia è homo,

ove [217] si scorge che il mezo per raccogliere che Clinia sia homo, è l'essere animale ragionevole, definitione dell'attributo della conclusione, cioè homo”.

Per il certo rimasi attonito che sapiente qual stimai fosse Aristotele, sì per la cognitione che possiede delle cose naturali, come per la varia eruditione delle più nobili discipline, tenisse approvato che tal silogismo sopra tutte le altre maniere di argomentare occupasse il più degno loco, e che fosse il maggiormente idoneo a produrre la scientia. Per il che interrogai Teofrasto:

"Stimi forse che giammai si ritrovasse alcuno così scioco che sapendo che Clinia sia animale ragionevole che dubbitasse che homo non fosse? Seppur questo tale 
rather with a greater number of contrary instances. The objections now brought against Archelaus, namely concerning the alleged causes producing knowledge in us, primarily arose in my mind. ${ }^{387}$ Indeed, since Aristotle presumed that these premises should encompass the causes of the conclusion and that one should [be able to] choose suitable premises to produce this syllogism from which the [expected] conclusion would be drawn, [I thought that] it was necessary to be already endowed with considerable knowledge. Therefore, science, before its birth, would already have been born and grown to an adult. However, as I was not fully informed about the aforementioned saying uttered by Theophrastus, namely about the way the definition of a proportion of the conclusion could have [already] been introduced into the premises, I begged him to explain this to me in detail.

Then, he answered:

"Aristotle was certain that it was necessary to inaugurate and begin the demonstration from the definition and to form a syllogism from it which collects and achieves the conjunction between the subject and the predicate, or attribute, as we prefer to say, that we are attempting to demonstrate. Yet if you investigate from which part of the conclusion the definition must be taken - although our friend has not clearly explained this - I would believe that it was the definition of the attribute of the conclusion, ${ }^{388}$ which shows the alliance and connection between the subject and the conclusion itself through the order of the syllogism."

I asked him to provide an example of this. He kindly set and expounded it in the following way -

"Every rational animal is a man,

Cleinias is a rational animal,

Therefore Cleinias is a man.

- where [217] we may see that the means for gathering that Cleinias is a man is that he is a rational animal as the definition of the attribute of the conclusion, namely man."

Certainly, I was astonished that such a wise man as I considered Aristotle to be, both for his cognition of the natural things and his varied erudition concerning the noblest disciplines, had agreed that this syllogism was the worthiest means of argument above all others and the most suitable for producing knowledge. Thus, I asked Theophrastus:

"Do you think that it would ever be possible to find someone who is so foolish that even if he knew that Cleinias was a rational animal, he would however doubt that he was a man? Even if that person, like a barbarian or a 
come barbaro e straniero ignorasse il significato del vocabolo homo, ché in tal caso a gramatici e dittionaristi espositori delle parole lo rimetteressimo, non a filosofi di demostrationi artefici, e piuttosto ad Aristarco e Palemono, che ad Aristotele ricorreressimo".

A ciò risposemi Teofrasto, che in altra maniera si poteva ciò eseguire cioè per mezo della difinitione del soggetto della conclusione.

Di novo l'instai che avaro non mi fosse in arrecarmi di ciò essempio, et egli tale mi appresentò:

"Ogni animale ragionevole è risibile

L'huom è animale ragionevole

Dunque l'homo è risibile."

Seguì egli con dire:

"Nel qual silogismo ecco che la definitione dell'homo soggetto della conclusione è il mezo della demostratione, che convince l'homo esser risibile".

Non potei ciò udendo rattenermi dal ridere, scorgendo io Teofrasto reiterare benché alquanto in diverso modo l'istesso assordo. Ma egli che mi attendeva, ricercomi instantemente della cagione di tal irrisione.

Al che io li dissi ch'era una esperimentativa approbatione ch'io volsi aggiungere alla sua elaborata demostratione.

Ma egli di ciò non [218] satisfat|to sospettando di quello ch'in effetto era, mi sollicitò che li palesasse la vera cagione di tal mio scherno e sbefegiamento, promettendomi di ciò giamai con Aristotele motegiarne, ché purtroppo l'osservava meco alterato lamentandosi di me, che espositore di nomi piuttosto ch'esploratore di dottrine l'appellassi.

$\mathrm{Al}$ che io sogionsi:

"Ottimo amico, non attendi che con tal tua posteriore dichiaratione ti sei di nuovo esposto a colpi della primiera mia oppositione, per il che ti sei fatto meritevole di provocare la mia derisione? Non advertisci che niuno di sano giuditio conoscendo ch'ogni animale ragionevole sia risibile, che non apprenda ch'anco l'homo risibile sia, purch'egli intenda il significato della voce homo e che sappia che l'istesso sia che l'animale ragionevole, e che questo espressamente e con giro di parole, e quello implicitamente e ristretamente il medesimo esprime? Onde avenire potrebbe, che la parola homo divenisse mezo termine per far riconoscere che l'animale ragionevole risibile sia, mentre che alcuno si trovasse meglio informato del vocabolo homo che dell'animale ragionevole. Il che stimo che appo il volgo sovente avenga". 
foreigner, was ignorant of the meaning of the term man, then in this case we would entrust him to grammarians and dictionarists, who explain words, but not to philosophers, who are authors of demonstrations; therefore, we would appeal to Aristarchus and Palaemon ${ }^{389}$ rather than Aristotle.”

Theophrastus replied to this that one could carry it out in another way, namely by means of the definition of the subject of the conclusion. ${ }^{390}$

I solicited him again to be unsparing in providing examples of this, and he set this one to me:

"Every rational animal can laugh,

Man is a rational animal,

Therefore man can laugh."

He continued, saying:

"In the syllogism, the definition of man, as the subject of the conclusion, is the middle term of the demonstration which convinces us that man can laugh."

Once I had heard this, I could not restrain myself from laughing. Indeed, I noticed that Theophrastus was repeating the same absurdity, although in a different way. However, he immediately addressed me, looking for the reason for this derision.

Hence, I told him that I wanted to add an experimental proof to his elaborated demonstration.

Yet he was not satisfied with this, [218] and, as he had his suspicions about it [i.e., Socrates's derision], he spurred me to tell him the true reason for my scorn and derision and promised me that he would never have joked about this with Aristotle. Unfortunately, he [i. e., Theophrastus] had noticed that he [i. e., Aristotle] was angry with me because he [i.e., Aristotle] had complained that I had called him an expounder of names instead of an explorer of doctrines.

I added to this:

"My very good friend, don't you see that with your later declaration you have once more exposed yourself to the blows of my first objection? This is why you became worthy of my derision. Don't you realise that anyone endowed with sane judgment in knowing that every rational animal is able to laugh does not [need to] apprehend that man is also able to laugh, as long as he understands the meaning of the term man and knows that he is the same thing as a rational animal? Besides, [don't you realise that] the latter - explicitly and via circumlocution - and the former - implicitly and briefly - express the same thing? Therefore, it could happen that the word man could become the middle term to make us acknowledge that a rational animal can laugh, in case one was better informed about the term man than about that of rational animal. I think that this is often the case among the vulgar." 
Inteso questo Teofrasto non si poté anco egli dal riso temperare et astenersi.

Ma instando io la vittoria continovai a dimostrarli le vanità di tal silogistica machina, e li soggionsi:

"Significare ti voglio che l'induttione da me tanto praticata, e dal nostro amico schernita, efficacissima si trova ad apportarci quel lume di sapere, che alla nostra conditione è permesso. E ciò tanto più volentieri teco hora eseguisco, quanto è grande l'obligo che tengo di difenderla dall'altrui ingiurie, havendomi essa renduto vittorioso in molte battaglie e conflitti che con importuni sofisti me occorssero, né giamai li suoi suffragi mi riuscirno scarsi e deficienti. Io stimai sempre che mentre si pronuntia che ogni animale ragionevole sia risibile, che giammai alcuno con il discorso della mente abbracciasse tutto l'ambito delli animali ragionevoli che nel mondo furno, sono, e [219] saranno, ma che havendo tal conditioni in molti di essi animali ragionevoli osservato habbia supposto ch’a tutti li animali convenga tale risibilità”.

Soggionse Teofrasto:

"Così al sicuro aviene".

Onde continovai:

"Per qual cagione dunque dal nostro amico debbo esser intanto ripreso, poiché dal raccogliere da molti individui deduco quello ch'al mio proposito attiene, conieturando, che quello che a molti accade, anco a quel mio particolar soggetto ad essi simile occorrere debba? Rittenendomi pertanto dal formare propositione universale, ché se ciò facessi non sarei perciò maggiormente sicuro di non incorrere in alcuno errore, affermando quello non ho assolutamente praticato, né sensatamente osservato".

Rimase Teofrasto affatto satisfatto, affermando ch'a suo credere l'induttione sola essere soficiente direttrice del nostro discorso, né altra norma et instruttione ci sia necessaria per formare e fermare la nostra speculatione, e che perciò qualunque desidera profitare in alcuna disciplina, provedere si deve della cognitione di molti esprimenti et osservationi per poter trarne a suo profitto utili induttioni. E seguì con animo veramente filosofico confessando che sempre sospetò della insuficientia e vanità che tale silogistica construttione, e sovente dubbitò che l'istesso Aristotele fosse conscio della deficientia di tale argomentatione, ma che a guisa di falito alchimista benché sia informato della mendacità della sua arte nondimeno attentando il resarcimento della iatura ad esso seguita, continua appo homo opulente celebrare la prestantia della sua professione, con fine di raderli dalla borsa altrettanto argento, che le sue vane speranze l'indussero a consumare. Ma dubitando che l'esperienza in breve non convinca la 
Once he had understood this, Theophrastus also could not control himself or avoid laughing. However, pursuing the victory, I continued to demonstrate the vanity of this syllogistic strategy to him, and I went on:

"I want to show you that induction - which I have practised a lot, even though our friend derided it - is very effective for providing us with the light of knowledge, as far as our condition permits. Furthermore, the more willingly I do this with you now, the greater the obligation I have to defend it from the insults of others will be. Indeed, it has made me victorious in many battles and conflicts with some rash sophists and it has never been sparing or insufficient in aiding me. When uttering that every rational animal can laugh, I always thought that nobody had ever embraced the whole range of rational animals which were, are, and [219] will be in the world with the discourse of the mind. Rather, as these conditions have been observed in many rational animals, one may have supposed that this capacity for laughter is proper to all animals.”

Theophrastus replied:

"It surely happens in this way."

Therefore, I continued:

\begin{abstract}
"Then why should I be reprimanded by our friend? Because I deduce what is pertinent to my matter by gathering [information] from many people, isn't that right? Indeed, I conjecture that whatever happens to many must likewise also occur to my particular subject, as it is like them. Hence, I hold myself back from forming any universal proposition, because if I did this, I would not be so certain that I had not been misled and I would be stating that which I had not completely practised and not even sensibly observed."
\end{abstract}

Theophrastus was satisfied and stated that in his opinion, induction was the only sufficient director of our discourse, while no other rule or instruction was necessary for us to form and consolidate ${ }^{391}$ our speculation. Therefore, whoever wishes to profit from a discipline must have cognition of many experiments and observations in order to be able to draw useful inductions to his advantage. He continued with a truly philosophical attitude by confessing that he had always been suspicious about the insufficiency and vanity of this syllogistic construction. Besides, he [confessed to] having often doubted whether Aristotle himself was aware of the deficiency of this argumentation, or rather whether he was acting like an unsuccessful alchemist: namely that although he was informed of the mendacity of his art, he was nevertheless attempting to compensate for the ensuing damage by continuing to celebrate the proficiency of his work among opulent men. His aim was to scrape as much silver from their purses as his vain hopes had already led him to consume. Indeed, as he wondered whether experience would quickly convince them of the 
falsità delle sue promesse e vantamenti, tante lunghe et odiose preparationi e stentate dilationi li propone, che giammai si capita all'ultima esecutione e finale tramutatione di metalli, onde infra tanto l'impoverito homo conservando il concetto appo quel riccone, [220] comprando a caro prezzo et a denari effetivi tante vane promesse e sterili speranze:

\footnotetext{
"A questo modo apunto stimo che Aristotele si diportasse circa il saper humano, che ritrovandosi appieno informato dell'imbecilità e fiachezza dell'humano sapere, e havendo infrutuosamente consumato molto studio per rinvenire la verità, propose tale silogismo pieno di tante difficoltà et ardue circonstantie, a modo tale che giamai a capo di esso devenire non si potesse, onde l'homini d'ingegno semplice attribuendo la difficoltà alla loro propria inettia, e non alle impossibiltà del fatto, conservassero appo loro illesa la conceputa stima dell'autore di tal silogismo.

Segno evidentissimo di ciò mi fu che giamai nel corso di tante sue speculationi non formasse silogismo tale, che adempiuto havesse tutti li suoi numeri, e che tante conditioni possedesse, quante che da esso proposte furno. Indicio di ciò parimente mi fu, che essemplificando egli tal suo silogismo ricorse al nostro greco alfabeto, onde con non proprii essempii rappresentò suoi silogismi, ché se con termini reali rafigurati l'havesse, immediate riconosciuta si harebbe l'invalidità di tali machine".
}

Havendo qui fatto fine Teofrasto al suo divisare, lo comendai d'ingegno sciolto e libero, e che la famigliarità che tenne con Aristotele non li arrecò quella tenacità che proprio è di suoi seguaci.

Hor dunque essendomi smarita anco quella speranza ch'io teniva nella famosa dottrina di Aristotele, non passò molto di tempo doppo il congresso havuto con Teofrasto che nella nostra città capitò un hospite italiano che fu molto domestico di Filolao pitagorico, del quale possedeva un libro per quello si diceva molto pregiato, per il quale Platone tre mille darici li offerse. Havendo dunque egli meco contratto amistà, mi ricercò che essendoli stato da Platone per il libro tre mille darici promesso, e volendo egli, seguito il contratto, in Italia condurre over rimettere il dinaro, mi richiese che l'informasse della lega di tali monete. Al qual risposi, che [221] di ciò io mi ritrovava ignaro, ma che ne harei con Calicle ragionato, che all'erario publico era deputato, onde io lo stimava di tal affare abbastanza pratico, ma che in ricompensa di tal servigio solo ricercava, che instruire mi dovesse se circa ciò che fosse il saper humano in tal libro, Filolao alcuna cosa ne dividasse.

Risposemi egli che egregiamente di ciò ne trattava il di cui raccolto è, che due fontioni praticava l'intelletto, l'una componendo le cose 
falsity of his promises and boasts, he offered so many long and odious preparations and uncertain deferments to them that he never reached the last execution and final transformation of the metals. Therefore, in the meantime, the impoverished man preserved his esteem through those rich men [220] who bought many vain promises and sterile hopes at high costs and with real money. [And Theophrastus continued:]

\footnotetext{
"I believe that this was the way Aristotle approached human knowledge. As he was fully informed of the imbecility and weakness of human knowledge and fruitlessly devoted so much study to finding out the truth, he submitted a syllogism full of so many difficulties and arduous circumstances that nobody could ever have understood it. Hence, those men of wit simply attributed the difficulty to their own ineptitude, and not to the impossibility of the fact, so as to keep the esteem they had for the syllogism's author fully intact.

"A clear sign of this was that during his great many speculations, he had never formed a syllogism that could fulfil all its possibilities and which was endowed with as many conditions as he had put forth. Similarly, a clue to this was that he exemplified his syllogism by appealing to our Greek alphabet. Thus, he did not express his syllogisms using appropriate examples, because if he had represented them in real terms, the invalidity of this machine would have immediately been acknowledged."
}

Here ended Theophrastus's consideration. I commended him for being an unfetterd and free intellect and because the familiarity he had shared with Aristotle had provided him with that obstinacy which was peculiar to his followers.

Now, having also lost that hope that I had held in the famous doctrine of Aristotle, not much time passed after my meeting with Theophrastus before an Italian guest ended up in our city. He was very close to Philolaus the Pythagorean, ${ }^{392}$ and he owned a book by him considered to be very valuable ${ }^{393}$ for which Plato had offered three thousand darics. ${ }^{394}$ As we became friends, he asked me to inform him about the alloy of these coins, since Plato had promised him three thousand darics for the book. Thus, after having concluded the contract, he wanted to carry and transport the money back to Italy. Hence, I answered him that [221] I did not know what it was, but that I would discuss it with Callicles, who was in charge of the public treasury and who, in my view, was quite experienced in this respect. And the reward for this service was only to inform me whether Philolaus had discussed anything in this book concerning human knowledge.

He answered me that it gave an excellent treatment of it, the result of which was that the intellect practised two functions: one was to 
Duodecima espositione del sapere.

sparse e divise, e l'altra dividendo le confuse et unite. Onde l'aviene a guisa di aritmetico che doi offitii esercita circa l'arte del numerare, cioè comporre e dividere, onde quando la mente alcuno attributo ad un soggetto arreca et afferma, compone, e quando nega, disgiunge e divide. Da ciò poi prende ansa Filolao conforme il dogma di Pitagora di esaltare sopra qualunque altra disciplina l'aritmetica, celebrandola più d'ogni dottrina giovevole e profittevole ad indrizzare il nostro discorso, dipendendo da questa tutto l'humano sapere. Né peraltro stima egli che l'homo meglio che tutti li altri animali con sentimenti interni discorre, che per esser perito dall'arte del numerare, aggiungendo l'hospite, che solamente per tal dottrina meritava il libro li tre mille darici che Platone li propone.

A tal ragionamento si ritrovò presente Xenocrate il quale non poco si rallegrò, che al suo dogma fosse apportato da sì lontano loco tanto di sufragio, havendo egli definito che l'anima humana fosse numero da se stesso movente, tenuto insino alhora che possedesse più del chimerico che reale.

Ma io ciò inteso, non l'autorità di Filolao, né l'offerta di tre mille darici di Platone, e né anco l'amicitia di Xenocrate poté rattenermi che io non cimentassi tal dottrina, e che al mio solito sindicato non la sottoponesse. Interrogai l'hospite qual fosse la ragione che havendoli Platone promesso li tre mille darici, et essendo egli certo del loro numero, tuttavia dubbitasse della loro lega, e qualità.

Risposemi che poco li giovava il [222] sa|pere il semplice numero delle monete ignorando il loro stesso valore.

Al che replicai:

\footnotetext{
"Per il certo oltremodo riesce ingordo il pretio del tuo libro, contenga egli qualsivoglia dottrina, mentre che asserisce che il sapere humano universalmente altro non sia che numerare, poiché con tal sapere, non si può penetrare nell'interno et essentiale delle cose numerate, ma solamente delibarne l'esterno non essendo altro l'annoverare che una riasuntione over difalcatione mentale delle unità. Onde il numero piuttosto nel numerante che nel numerato risiede. Hor dunque siccome, ottimo hospite, di nulla overo poca satisfattione ti riuscì lo sapere il numero del pretio offertoti da Platone, cioè li tre mille darici, mentre rimanghi non informato della loro qualità e valore, così anco nulla o poco curare ci dobbiamo di qualunque dottrina, mentre che di altro noi non siamo raguagliati da essa che del numero del scibile, non altrimente delle interne conditioni di esso".
}

Rimase confuso di tal mio divisare l'hospite. Ma Xenocrate per difesa del suo proprio dogma mi accorse, dicendomi: 
combine scattered and separate things, and the other was to divide what is mixed and joined. Therefore, it acted like an arithmetician Twelfth exposition of who carries out two functions within the art of enumerating, namely composing and dividing. Hence, when the mind provided the subject with an attribute and affirmed it, it was composing; however, when it negated it, it was disjoining and dividing it. From this, in accordance with Pythagoras's dogma, Philolaus took the opportunity to exalt arithmetic above any other discipline. He celebrated it for being beneficial and profitable in directing our discourse above every other doctrine and as the thing on which the whole of human knowledge depends. Furthermore, he considered human beings to be better than all the other animals not because of their [capacity for] reasoning thanks to their internal senses, but rather because of their expertise in the art of enumerating. The guest continued that because of this doctrine alone, the book deserved those three thousand darics that Plato had offered.

Xenocrates, ${ }^{395}$ who was present for this argument, greatly rejoiced that his dogma had obtained so much support from so far away. Indeed, he had defined the human soul as a number moving by itself, considered up until that time to be more chimeric than real. ${ }^{396}$

Yet once I had understood this, nothing, neither Philolaus's authority nor the offer of Plato's three thousand darics and not even Xenocrates's friendship, could prevent me from testing this doctrine and submitting it to my judgment as usual. Since Plato had promised to give him three thousand darics and he was certain of their amount, I then asked the guest why he doubted their alloy and quality.

He answered that he found it little of little benefit [222] simply to know the number of the coins when he was ignorant of their value.

Hence, I replied:

"Certainly, the price of your book turns out to be extremely attractive, whatever doctrine it contains, if it asserts that the sum of human knowledge is nothing but enumerating. Indeed, with this knowledge, one may not penetrate to the essence of the enumerated things, but may only sample their exterior, since enumeration is nothing other than a mental adding or subtracting of units. Therefore, the number consists in enumerating rather than in the enumerated. Now, excellent guest, you have found it almost or entirely unsatisfactory to know the price offered by Plato, namely three thousand darics, when you are ignorant of their quality and value. Likewise, we must pay little or no attention to a doctrine if it does not inform us about anything other than the amount of things we suppose to know or of their internal conditions."

The guest was confused by my argument. Yet Xenocrates, in defence of his own dogma, reacted by telling me: 
"Con ottimo proponimento rigetti, o Socrate, l'openione di Filolao e non consenti che il saper humano sia numerare, essendoti tanto inetto dimostrato in tal esercitio, quando nel raccogliere publicamente li voti di Ateniesi così scioccamente nell'annoverarli ti diportasti”.

Al che soggionsi:

"Se nel corso delle mie attioni fossi stato provido e solecito in procurare il concetto del volgo circa il mio sapere, con ragione ciò conieturaresti, ma essendo io banditore della propria ignoranza, sinistramente ciò deduci. Ma giacché il mio falire introducesti conviene che anco di nuovo ti richieda se conforme il tuo parere e di Filolao l'esercitio dell'annoverare tenga bisogno di alcuna peritia, overo anco a caso e trascuratamente si può ottimamente eseguire?”.

Risposemi, che per il certo il numerare non era attione tanto volgare che senza alcuna peritia decentemente esercitare si potesse, e perciò fu detto che il sapere fosse ottimamente numerare. A questo [223] replicai interrogandolo:

“In qual maniera ottimamente si annovera?".

Rispose egli:

“Sapendone l'arte".

Allhora soprendendolo li dissi:

"Non adverti, amico Xenocrate, che mentre indagamo ciò che sia sapere, e che del libro di Filolao ricercai apprenderlo, e che da voi prestanti homini mi è detto che sia il saper ottimamente numerare, pretendete con l'ignoto informarmi di quello stesso ch'io ricerco di modo tale, che il sapere diviene l'esponente e l'esposto?".

Tacque Xenocrate e volgendomi all'hospite, che per il mio ragionare alquanto smarito divenne, lo rincorai con dirli, che di tal mia altercatione, pregiuditio alcuno apportare non doveva alla vendita del libro, e che li libri non si stimano per l'esata verità, ma per l'eleganza et eruditione che contengono, e che l'Illiade di Omero era di molto maggior pregio appo il comune delli homini, che li versi di Empedocle e Parmenide, che le più recondite materie della natura spiegano. Qui terminò il divisamento che hebbi con l'hospite e Xenocrate. 
“A fortiori, oh Socrates, you now are refuting Philolaus's opinion, and you do not agree that human knowledge consists in enumeration. Indeed, you demonstrated yourself to be very inept in this practice when, having collected the public votes of the Athenians, you so foolishly enumerated them.”

Hence, I continued:

"If I had been careful and solicitous throughout my deeds in seeking to achieve the esteem of the vulgar concerning my knowledge, you could reasonably conjecture this. However, since I am declaring my own ignorance, then you are deducing it with great malice. Yet since you have raised the topic of my failure, it is appropriate that I ask you once again whether, according to your and Philolaus's opinion, the practice of enumeration requires any expertise or whether it may be carried out by chance or by accident.”

He answered that enumeration was certainly not so common an action as to be correctly carried out without any expertise; therefore, it was said that knowledge consisted of excellent enumeration. I replied to this [223] by asking him:

"How may one enumerate as best [as he can]?”

He answered:

"By knowing this art."

Then I caught him, telling him:

"During this inquiry concerning what knowledge is, which I was trying to apprehend from Philolaus's book, you distinguished men are saying to me that consists of excellent enumeration. Thus, don't you realise, dear Xenocrates, that you [i.e., distinguished men] are supposing to inform me about the very thing I am seeking through the unknown, so that the knowledge becomes both the exponent and what is expounded?" 397

Xenocrates kept silent and I turned to the guest - who had become rather lost because of my arguing - and reassured him by saying that my disagreement would not cause any prejudice to the sales of the book. Indeed, books cannot be evaluated on the grounds of the exact truth [they provide], but on the grounds of the elegance and erudition that they contain. [For instance], Homer's Iliad was held in much higher esteem among the majority of people than the verses of Empedocles and Parmenides, which explained the most recondite matters of Nature. My discussion with Xenocrates and the guest ended here. 
Terzadecima espositione del sapere.
Non affatto dissimile ragionamento mi accadè con Euclide, come sapete nelle matematiche eccellentissimo, il quale affermava che la mente humana fosse a guisa di misura overo bracciolare segnato di minute portioni di divisioni. Li veramente sapienti possiedono aggiustata misura, e di minutissime distintioni la tengono divisa. Ma quelli che a tal segno non arrivano, ma che probabilmente giudicano le cose e che quasi per certo barlume conieturano la verità, possegono tal misura di giusta divisione segnata, ma non così minutamente distinta. Ma quelli, che non solamente all'ingrosso non giudicano bene le cose, ma affatto erroneamente ciò eseguiscono, come sono li volgari e plebei, tengono misura falsa, e pravamente segnata. E concludeva che il sapere consisteva nel decentemente applicare la propria et aggiustata misura come si conviene alle cose che apprendere si devono.

Udito io ciò, altrettanto che mi piacque l'inventione del tripartito numero di caratteri d'ingegni legiadramente applicato all' [224] es|sempio, così non mi satisfece il redurre la cognitione humana a modo di semplice misura, avenendole l'istesso che occorse alla espositione di Filolao non vi essendo altra differenza dal numerare al misurare se non che questo appartiene alla quantità continova, e quello alla discreta, et ambidoi non attengono punto all'interno essentiale delle cose. Oltre che secondo la positione di Euclide si procedeva all'infinito, bisognando riconoscere l'aggiustamento di qualunque misura per altra misura precedente, il che accade in riconoscere se l'istessa mente decentemente segnata e terminata sia. La qual instanza tanto maggiormente riesce gagliarda poiché tali signature non furno da principio dalla natura poste nella mente, ma giornalmente dalla esperienza et osservatione vi sortirno. Oltre che il riconoscere l'istesso aggiustamento è diverso dalla misura et è il medesimo sapere che tuttavia si ricerca, e che sotto il giudice pende. Per tali instanze et obbiettioni rimase Euclide convinto, et io come prima perplesso e hesitante circa la mia antica inchiesta.

Avenne che vicino a quel tempo ritornasse Platone d'Egitto, al quale mi condussi per ricercarlo se circa il mio proponimento da sacerdoti di quel loco havesse raportato cosa di rilievo. Ad esso dunque capitai, e pigliai a dirli, per il certo diverso fu il fine che l'impulsò ad Egitto navigare, da quello è il scopo d'altri che colà si conducono, che per acquistar haveri intraprendono tal viaggio, ma egli per rapportarne dottrine certamente a quel verso s'incaminò, per il che sicuramente stimavo che pregiati tesori di scientie alla Grecia, oltremodo avida di tali 
A not-dissimilar argument occurred with Euclid, a very excellent mathematician, as you know, who stated that the human mind was like a measure or arm's breadth ${ }^{398}$ marked with minute divisions. The truly wise men own the correct measure, which is divided into very minute distinctions. However, those who do not go so far, who only judge things according to the probable and conjecture the truth by following an almost certain glimmer, own a measure marked with the correct divisions, but which is not so minutely distinct [in parts]. Yet those who judge things approximately do so not only not very well, but rather erroneously; they are like vulgar and plebeian people who own false measures which are incorrectly marked. Furthermore, he concluded that knowledge consisted in properly applying the appropriate and correct measure, as is required for the things which must be apprehended.

Once I had heard this, although I liked the invention of the three kinds of intellects that were elegantly applied to the example, [224] nevertheless, I was not satisfied by the reduction of human cognition to a simple measure. Indeed, the same had already happened to Philolaus's exposition. However, the only difference between enumerating and measuring was that the former pertained to a continuous quantity, while the latter [pertained] to a discrete one, ${ }^{399}$ but neither of them remotely referred to the inner essentiality of things. Moreover, according to Euclid's position, this would lead to an infinite regress, as we would acknowledge that any measure must be set by means of another pre-existing measure, and this would also be the case when we [tried to] acknowledge whether the mind itself is properly marked and defined. This instance results as even more credible [if we consider that] these signs were not originally placed in the mind by Nature, but come every day from experience and observation; in addition to this, acknowledging the adjustment is different from [acknowledging] the measure, and it corresponds with the very knowledge that we are seeking and on which a final judgment has not yet been passed. Because of these instances and objections, Euclid became convinced, while I was as perplexed and hesitant as before concerning my original inquiry.

It happened at that time that Plato returned from Egypt, and I went to ask him whether he had brought anything relevant to my subject from the priests of that place. Hence, I met him and I began to tell him that the aim which had motivated him to sail to Egypt was certainly different from the goal of others who had also been there. Indeed, while they undertook this journey in order to purchase goods, he, of course, had gone there in order to bring back doctrines. For this reason, I believed that he must have brought refined treasuries of science to Greece, as it
Thirteenth exposition of knowledge. 
Quartadecima espositione del sapere. merci, arrecato havesse. Ma io altro hora non lo richiedeva, se non che mi comunicasse quello che circa il saper humano dall'Egitto havesse adotto.

A ciò egli cortesemente rispose, che di ciò sovente con sacerdoti ne ragionò, e quello che d'essi rapportò fu, che impossibile stimavano conseguire la cognitione di alcuna cosa per mezo altrui ma che per se stessa riconoscere si doveva, ché perciò essi [225] sacer|doti reggettavano la speculatione delle cause che cotanto appresso li Greci era stimata, dicendo essi che dalla esistentia del fuoco, si può bene dedurre che vi sia anco il fumo sua prole, ma non perciò si conosce ciò che sia esso fumo. Per il che raccoglievano che la vera scorta che ci conduce all'interni penetrali e recessi delle cose, e che al vivo all'intelletto le rapresenta, altro non esser che la definitione dell'istesse. Questa è quella, secondo il loro parere che normando l'intelletto giamai permette che falisca, e tanto si trova questa al di sopra delli altri adminicoli che all'intelletto ministrano, quanto che essa definitione né da tempo né loco si trova terminata e ristretta, né ad alteratione alcuna soggetta, rimanendo sempre appresso l'intelletto invariabile.

Lo ringratiai di sì nobile regalo da paese tanto remoto arrecatomi, et insieme lo solicitai che mi esplicasse la conditione di questa cotanta preclara definitione, ch'essendo tanto prestante giudicavo che non sia di volgare artifitio il construirla.

Risposemi egli che non tutte le definitioni riescono idonee a tal affare, cioè a rappresentare l'interna essentia delle cose, ma solamente quella che conforme il precetto della logicale scientia è formata, e che allhora sortisce ottimamente, quando che di due portioni del definito è composta, cioè di genere e differenza. La prima ci dimostra in che il diffinito con altri alquanto è simili e corrisponde, e l'altra in che si trova diverso e distinto, come per essempio volendo noi diffinire ciò che sia l'homo, si dice ch'egli è animale ragionevole. La primiera particola ci dinota la convenientia che tiene con li altri animali, l'altra ci instruisce di quello che esso è dalli altri differente, cioè l'esser ragionevole, advertendo di più essi sacerdoti che tali componenti della definitione conviene che siano intrinsichi et essentiali, non adventitii et accidentali. Inteso io ciò non si poté a tal espositione dell'humano sapere il mio inquieto genio fermare et ancorarsi, benché Amone, et Iside, over anco il bue Apis l'havesse a sacerdoti Egittii rive|lata. [226]

Primieramente mi offendeva che convenendo nel formare la definitione scegliere accuramente le portioni essentiali che la compongono, ciò non si può eseguire senza il retto discorso, onde ne sortirebbe che inanzi che la diffinitione fosse construtta già le sue parti integranti 
was extremely greedy for these kinds of wares. Yet I now asked him for nothing except to inform me what he had learned in Egypt concerning human knowledge.

He kindly answered that he had often argued with priests about this, and what he reported from them was that they considered it impossible to achieve cognition of one thing through another; on the contrary, one must acknowledge it through itself. Therefore, these priests [225] rejected the speculation concerning the causes that was so highly esteemed among the Greeks. Indeed, they said that from the existence of fire, one may well deduce that there is also smoke, as its offspring, but one may not know what smoke is because of it. Hence, they gathered that the true guide which leads us to the inner meanderings and recesses of things and presents them to the intellect with strict adherence to the truth ${ }^{400}$ was nothing other than the definition of things themselves. "This one is that one," ${ }^{401}$ according to their opinion, which ruled the intellect and meant that it never failed. Furthermore, it was above all the other instruments which assisted the intellect, as it was not limited or restricted by time or space or subject to any alteration, remaining always invariable alongside the intellect.

I thanked him for such a noble present, brought to me from such a remote country. Furthermore, I urged him to explain the condition of this illustrious definition to me, which was so remarkable that I believed it could not have been made through common artifice.

He answered me that not all definitions were appropriate for this affair, namely to represent the inner essence of things, but only one which was formed according to the precept of logic. In this case, it would best succeed when it was composed of two parts of the defined, namely its genus and its difference. ${ }^{402}$ The former would demonstrate to us that what was defined was sufficiently similar and corresponding to others, while the latter was [how it was] different and distinct in this respect. For instance, if we wanted to define what a man is, it would say that he was a rational animal. The first particle would show us his conformity with the other animals, and the second would instruct us concerning how he differed from the others, namely in being rational. These priests further realised that these components of the definition needed to be intrinsic and essential, not temporary and accidental. Once I had heard this, my restless genius could not stop or anchor at such an exposition of human knowledge, although it was revealed to the Egyptian priests by Amon, Isis, and the bull Apis.

[226] Primarily, I was bothered by the fact that in order to form a definition, one had to accurately choose the essential portions which would compose it, and this could not be carried out without the correct discourse. Therefore, it would result that before constructing the defi-
Fourteenth exposition of knowledge. 
fossero da noi conosciute e sapute. Per il che ne seguirebbe, non esser propria fontione della definitione l'additarci et insegnarci le essentie delle cose e produrre l'humano sapere, come che Platone e suoi sacerdoti suposero.

Di più mi si rendeva strano che il riconoscere l'assomiglianza che tiene una cosa con l'altra producesse in noi cognitione di alcuno rilievo, si come diceva il nostro Euclide megarense, li simili in quanto tali, ci riescono al pari intelligibili overo incompresibili. Onde il dire che questo sia a quello simile non produce in noi alcuna importante dottrina, e doi ritratti benché affatto simili, non argomentano che all'originale corrispondano e si aggiustino, né doi tiri per esser eguali, ci accertano che nel nero del bersaglio colpischino.

E la differenza, seconda portione della definitione, non è parimente priva delle sue difficoltà. Mi riusciva essa insufficiente rivelatrice delle cose, essendo infinite le diferenze che caduna di esse cose tiene con l'altra, e l'ultime sono stimate comunemente ignote, e non ritrovabili. Oltre di ciò restavo non mediocremente impedito nel deliberarmi da quale di correlativi diferenti, dovesse principiare la speculatione, non potendosi apprendere l'uno di essi senza riconoscere l'altro, né insieme nell'istesso tempo rappresentare si possono, ché si confonderebbe la nostra intelligenza, come fu molte volte detto. A questa difficoltà si aggiunge, siccome conieturo, pretendono l'autori di tale difinitione produtrice dell'humano sapere, che delle semplici portioni di essa ch'incomposti e simplici sono, non si tenga propriamente scientia. Ma stante ciò non poteva io concepire che quel composto le cui parti non cadono sotto scientia, riesca il proprio e germano [227] og|getto del nostro sapere.

In qual modo essendoci ignote le lettere del nostro greco alfabeto, il construtto di esse, dico le sillabe, possono essere esatamente conosciute? Ma di più supposto come hora fu detto che le mere portioni delle diffinitioni per se stesse non apportassero alla mente scientia, per cagione della loro simplicità, in qual guisa ci può la definitione tutta unita e come incomplessa sugerire scientia? Ma se come sciolta e nelli suoi parti integranti divisa, e non come una tal formalità l'oggettamo, ritorna la medesima difficoltà, e si rende non idonea a produrre la scientia. Ma di più lasciamo a parte li argomenti contra essa diffinitione dal discorso intentati, seguire dobbiamo l'esperienza, cimento d'ogni discorso, che certamente ci dimostra la vanità di tali difinitioni, ché lambendo queste solamente l'esterno apparente delle cose, non 
nition, we would need to acknowledge and know its integral parts already. Hence, it would follow that it was not the proper function of definitions to point out and teach us about the essences of things or to produce human knowledge, as Plato and his priests supposed it to be.

Furthermore, I found it strange that acknowledging the similarity of one thing to another could produce any relevant cognition in us, as our Euclid from Megara said, since the similar [things], as such, turn out to be either both intelligible or both incomprehensible. Therefore, to say that this one was like that one would not produce any relevant doctrine in us. Likewise, although two portraits are similar, nevertheless, they do not provide any proof of correspondence or conformity to their original. And two shots are not [necessarily] equal, even if we are certain that they have both hit the black part of the target.

Besides, difference, as the second part of the definition, was similarly not lacking in difficulties. It seemed to me to be insufficient to reveal things, since the differences between each thing were infinite and the latter ones were commonly considered to be unknown and impossible to find out. In addition to this, I was somewhat hindered from deciding which of the different correlatives should begin the speculation, since it was not possible to apprehend one of them without acknowledging the others, nor even to represent them together at the same time. The reason for this was that our understanding would become confused, as has been said many times. As I may conjecture, there was also another difficulty, namely that the authors of this definition which produces human knowledge claimed that one could not have any appropriate knowledge of its simple portions even though they were uncompounded and simple. Yet in these circumstances, I could not conceive that that compound, whose parts could not be known, could be the proper and authentic [227] object of our knowledge.

If the letters of our Greek alphabet were unknown to us, how could their combinations - I mean the syllables - be known in detail? Moreover, once we have assumed that the mere portions of the definitions, as was now said, do not provide the mind with any knowledge by themselves because of their simplicity, how does the definition, as it is so unified and simple, promote science? Yet if we present it to our understanding as unbound and divided into its integral parts and not as this sort of formal structure, the same difficulty will occur again and it will turn out to be unsuitable for producing knowledge. However, let us leave aside the arguments promoted by the discourse against this definition; now we must follow experience, the proof of every discourse, which will certainly demonstrate the vanity of these definitions to us. Indeed, since they only brush up against the external appearances of things, 
ci somministrarno giammai alcuna soda cognitione, ma ombratile e vana.

Da quindi è, che le maggiormente celebri deffinitioni, che da sapienti sono celebrate, altro non ci arrecano che superficiale espositioni di semplici nomi. E la natura che con tanta incombenza fu da savii ricercata la sua definitione, alla fine uno de' più stimati di essi, con acclamatione di suoi seguaci pronontiò, che fosse un principio interno di moto e quiete, non advertendo l'autor di essa, che se alcuno curioso addimandasse altrui, qual fosse la cagione impulsiva, che move l'horologio overo altro automato, e che a ciò li fosse risposto, che derivasse da principio che entro di lui risiede, che provocarebbe con tal risposta il sibilato e riso de' auditori. Come anco se alcuno peregrino capitato nella nostra città e che richiedesse con instanza, qual è colui che a suo talento ragira e volve la Republica ateniese, invece di significarli che Pericle è quel tale, li fosse detto ch'è un tale che si trova nel corpo di essa Republica, che hora move et impulsa li suoi concittadini all'eseguire alcuno affare, e hora li ratiene, et impedisce, al sicuro che ridicolo riuscirebbe quel tale che [228] risposto arrecasse.

Né meno incongrua è la definitione del motto benché comunemente sia accetata, cioè che sia un atto del mobile in quanto si trovi in potenza, ché conscio il suo autore delle dificoltà che s'incontrano nel concepir il motto, poiché in esso complicano li contraditorii, cioè l'esser e non esser, con il scapatoio di vocaboli di potenza et atto presunse evitare l'assordo, o piuttosto occultarlo.

Al pari delle antedette apparisce vana la definitione del bene, scopo e bersaglio delle nostre attioni, il quale fu definito che sia quello che per la sua perfettione si rende al genere humano desiderabile. La qual esplicatione non riesce meno indecente che se fossimo ricercati di esporre ciò che fosse l'oro, rispondessimo esser quello che per la sua perfettione al di sopra di tutti li altri metalli è da noi appretiato e desiato, non esplicando noi con tal diceria la di lui bellezza, splendore, peso, incorutibilità, flessibilità, et estensione, conditioni sue proprie, non come l'esser appretiato dalli homini, non essendo ciò che un segno e carattere esterno per il quale si discerne qual sia l'oro over il bene, come apunto occorrerebbe a colui che tentasse di fare riconoscere fra le meretrici Taide, per la turba e satelitio di suoi insani amanti.

Ma troppo tedioso riuscirei se hora compilare et amassare volessi la farragine delle definitioni schioche e vitiose, che per bocca delli homini pravamente sono pronontiate. Bastami le già dette per dimostrare li difetti di tali definitioni. Ma Platone, accorgendosi che la 
they will never provide us with a stable cognition, but only with a vain and shadowy one.

Therefore, the main well-known definitions, praised by the wise men, provide us with nothing other than a superficial exposition of mere names. Furthermore, [the same happens] concerning Nature, whose definition was sought from the sages with so much commitment. Lastly, one of the most esteemed among them uttered, with the acclamation of his followers, that it was an inner principle of motion and rest. ${ }^{403}$ Yet this [definition's] author did not realise that if a curious person had asked what impulsive cause moved a clock or any other mechanical device and he had answered that it was derived from a principle that dwelt in it, he would have provoked whistling and laughter from his listeners with this answer. Similarly, if a pilgrim ended up in our city and insistently asked who was skilfully ruling and controlling the Athenian republic, and, instead of explaining to him that Pericles was that person, one said that there was someone in the body of the republic who on the one hand moved and spurred his citizens to carry out their business and on the other hand restrained and hindered them, surely whoever provided this answer would [228] be ridiculous.

No less incongruous is the definition of motion, although it is commonly accepted, namely that it is the activity of a potentially moving object. ${ }^{404}$ The author of this was aware of the difficulties arising from conceiving motion, because contraries, namely being and non-being, are combined in it. Therefore, he presumed to avoid any absurdity, or rather to hide it, by using the easy means of the terms "potency" and "act."

Like the aforementioned things, the definitions of good, as the end and goal of our actions, defined as [the most] desirable for humankind because of its perfection, also appear to be vain. This explication is no less improper than attempting to expound what gold is by saying that it is what is appreciated and desired above all other metals because of its perfection. With this speech, we do not explain its beauty, splendour, weight, incorruptibility, flexibility, or extension as its own conditions. On the contrary, being appreciated by humankind is only an external sign and feature through which one may discern what gold or good are. Similarly, this would occur to whoever attempted to cause Thaïs to be acknowledged among the meretricious because of her insane crowd and mass of lovers.

Yet I would be too tedious if I now wanted to list and amass the medley of foolish and incorrect definitions which are erroneously uttered from the mouths of human beings. It is sufficient to recall the ones already mentioned to demonstrate the defects of these definitions. However, Plato realised that the wares brought from Egypt had been 
Quintadecima espositione del sapere. merce dall'Egitto condotta rimaneva per le mie confutationi avilita, e di nulla overo di pochissimo pregio riusciva, mi advertì, siccome già inanzi la sua navigatione mi ricordò, mentre che io li suoi universali abbateva, che circonspetassi che in gran pericolo io poneva l'humana scientia, trahendo da tali definitioni da loco e tempo libere e sciolte, li suoi permanenti e saldi fondamenti, e che queste demolite et abbatutte, tutta la filosofia rimaneva impedita et estinta. Et io costante [229] nel mio proponimento poco di ciò mi curavo ché havendomi di già in gran parte scaricato dal peso delle dottrine, poco mi importava si crolavano li aerii edifitii dell'humano intelletto.

Ma lasciando Platone alquanto afflitto in Cratilo mi abbatei, il quale si trovava in openione delli homini sapienti non meno aveduto esploratore di arcani della natura che egregio espositore di vocaboli e loro etimologie. Con costui adunque presi a ragionare circa il sapere humano, e raccontandoli compendiosamente tutto quello ch'in tali affari mi occorse, lo richiesi circa ciò del suo parere, il quale in tal guisa favellomi:

"Vano affatto (secondo il mio stimare) è per riuscirti circa tal proponimento ogni tuo tentativo, e mi stupisco, che invece di redarguire altrui, non emendi te stesso, perché ramentare ti conveniva delle primiere dificoltà che al sapere incontravano, mentre che ti rassembrava che li oggetti, senso, intelletto, contra esso sapere per la precedenza nell'esame, apportavano. E massime ignorando tu ciò che siano li oggetti, sensi, et intelletto, dovevi anco giudicare che meno potevi rinvenire ciò che sia l'istesso sapere, siccome impossibile ci riuscirebbe riconoscere quello che fosse amore mentre ci fosse interdetto l'apprendere ciò che sia l'amante, e l'amabile, di esso amore basi, e fondamenti. Di più essendo il sapere relatione e raportamento che verte tra il sciente e scibile, e tante sono le difficoltà, e ch'alla intelligenza della relatione incontrano, che anco il sapere resta anco egli invilupato et obtenebrato. Inoltre di ciò in che modo con il sapere l'istesso sapere attenti comprendere? Non ti accorgi che a guisa dell'infelice Ixione ruoti te stesso? Il sapere che giudica il primiero sapere, perché deve esser immune e libero di sottomettersi anco egli all'essame? Ma se il secondo sapere al terzo si sottopone perché non questo al quarto, e così all'infinito?

Per [230] li quali motivi parmi vano e frustatorio tal tuo ricercamento, cioè di indagare ciò che sia il sapere, ma che contentare ti dovresti di quel primo lume di cognitione che egli ti appresta, mentre che di passagio l'incontri et assaggi, e non procurare con concetti da lui diversi, di nuovo riconoscerlo, essendo qualunque nostro risentimento et intendimento appieno espressivo e significativo di se stesso, né per altrui da sé diferente si può aggiustatamente rapresentare. Per il che giudico che prudentemente si diportò Diogene, nostro comune amico, benché d'altri fosse stato schernito, che mentre nell'Accademia si disputava circa il dolore tenendosi da accademici diverse openioni circa la sua essenza:

- Platone asseriva che fosse effetto della dissolutione del continuo,

- altri settatori di Democrito il dedussero dal slocamento delli atomi nel vacuo, 
degraded by my confutations, turning out therefore to have little or no value. Then he warned me - as he had done before his navigation - to be careful, because by demolishing his universals, I was endangering human knowledge, which gathered its permanent and stable foundations from these definitions, free and unfettered from space and time. So, if they were demolished and defeated, then all philosophy would be hindered and extinguished. Yet I did not care much about [229] this and I stayed consistent to my aim. Indeed, since I had already been relieved of the weight of the doctrines, I did not mind whether the aery edifice of the human intellect was collapsing.

However, after leaving Plato rather afflicted, I came across Cratylus, who, according to the opinion of wise men, was as careful an explorer of Nature's arcana as he was an excellent expositor of terms and their etymology. Therefore, I began discussing human knowledge with him, and I summarily told him all that had occurred to me in such matters. I asked him his opinion concerning this and he spoke to me in this way:

"According to my consideration, each of your attempts concerning this subject will indeed turn out to be vain, and I am astonished that you do not emend yourself instead of reprimanding others. Indeed, you should remember the first difficulties concerning knowledge, caused - in your opinion - by objects, senses, and the intellect looking for precedence above knowledge in your examination..$^{405}$ Moreover, as you were ignorant of what objects, senses, and the intellect are, you must have judged it to be equally impossible to find out what knowledge itself is. Likewise, it would be impossible for us to acknowledge what love is if we were forbidden to apprehend what the lover and the lovable are, as they are the basis and foundation of love. Furthermore, since knowledge is a relation and connection between the knower and the knowable and there are many difficulties encountered in understanding relation, knowledge consequently also remains entangled and obscured. Besides, how do you attempt to comprehend knowledge through knowledge itself? Don't you realise that, like the unfortunate Ixion, you are going in circles? Why must the knowledge which judges the previous knowledge be itself also exempt and free from being examined? Yet if the second knowledge is examined by the third, why is this one also not [examined] by the fourth, and so on to infinity?

[230] "For these reasons, your research, namely to investigate what knowledge is, seems vain and frustrating to me. On the contrary, you should be pleased with that first light of cognition that it offers you when you encounter and experience it in passing. Furthermore, [you should not] reattempt to acknowledge it through concepts that are different from it, because each of our affections and understandings is fully expressive and revelatory of itself and cannot adequately be represented through another that is different from it. Hence, I think that Diogenes, our common friend, behaved prudently, although he was scorned by others, when there was a debate in the Academy regarding pain, since the Academicians held different opinions concerning its essence:

- Plato asserted that it was the effect of the dissolution of the continuum;

- Other followers of Democritus deduced it from the displacement of atoms into the void;
Fifteenth exposition of knowledge. 
- altri aggiunsero per cagione del dolore, l'alteratione d'interna qualità,

- Diogine percuotendo con la verga che in mano teniva Platone, prorupe dicendo: 'Dolore è ciò che Platone hora per cagione della percossa patisce'.

Con le quali parole significare volse che tutte le passione o resentimenti dell'animo nostro sono in tal modo in se stessi terminati, che con niuno altro concetto non si può rappresentarli. Per il che né anco Democrito solenne derisore delle humane attioni, riuscì punto ridicolo, mentre che essendo interrogato di ciò che fosse l'homo, stando egli con l'animo alquanto sospeso, rispose che fosse quel tale che si vede, mosso, per il certo della ragione hora accennata, cioè che niuna cosa per mezo di altra meglio al vivo rappresentare si può che per se medesima”.

\section{Al che soggionsi:}

"Dunque se il riconoscere ciò che sia sapere ci è impedito, in che maniera si diportaremo in prevalersi per nostro profitto delle cose che ci coasistono, e che invitan il nostro intendimento a contemplarle? Dunque rimaneremo privi di sì nobile trattenimento e dilettevol studio a cui la nostra mente si trova tanto propensa et inclinata?”.

\section{Accorsemi egli:}

"Anzi da cotesto [231] nostro amichevole congresso pretendo che resti affatto tranquillato, e che ormai ponghi fine e meta a questo tuo lunghissimo mentale divagamento, che insino al presente tanto ti affaticò et infestò. E stimarei che per l'avenire per il mio ragionare declinare e desistere dovessi da questo desio di sapere, dalli admiratori delle cose vane tanto affetato, il qual tanto più molesto e noioso ci riesce che questo nell'interno dell'animo annidandosi in ogni tempo e loco ci accompagna e stimola. Il curioso sapere che s'impiega circa l'humani affari, non meno ci travaglia per la cognitione delli avenimenti passati, overo che per l'avenire ci possono soprastare, che di quelli che di presenti ci molestano. Onde il tempo che tiene potestà sopra tutte le occorenze sublunari rendendole al pari di esso labili et flussibili, dalla contumacia del nostro animo a danno suo è domato, arrestando et affissando il nostro pensamento le preterite emergenze, e formalizando et ideando l'eventi che per l'avenire potrebbono essere, come se reali et esistenti fossero.

Ma se alla cognitione delle cose naturali l'humano intelletto incombe, fra li altri tormenti a cinque oggetti crudeli e sempre flagellanti egli si comette: all'infinito che lo distrahe, al minimo indivisibile che lo comprime, al motto che l'agita, al tempo che lo consuma, et al loco over vacuo che l'inanisce, materie tanto piene di spinosità ch'infelice per il certo è colui mentre che in esse invilupato, presume venire a capo della loro intelligenza. E quello è peggio che altro disastro ci occorre, che siccome il mare da contrarii venti comandato e 
- Others added that the cause of pain was the alteration of an inner quality.

- Diogenes beat Plato with his cane and exclaimed: 'Pain is what Plato is undergoing now, because of my blows.'

"This is how he wanted to express that all the passions or affections of our minds were determined by themselves and could not be represented through any other concept. Therefore, not even Democritus, a renowned mocker of human actions, turned out to be more ridiculous when he was asked what a man was, and, after initial uncertainty, he answered that he was a person that one sees. He was surely motivated by the reason I mentioned just now, namely that nothing can be more truthfully represented through another thing than through itself."

\section{Hence, I continued:}

"Then, if we are prevented from acknowledging what knowledge is, how will we act in order to take advantage of the things which coexist with us and which invite our understanding to contemplate them? And will we remain lacking in this noble entertainment and delightful study to which our minds are so prone and inclined?”

\section{He responded to me:}

"Rather, I demand [231] that you will indeed be reassured by this friendly exchange of ours and that you will now terminate this very long mental digression, which up to the present time has so strained and absorbed you. I further think that in future, you should cease and desist from this desiring to know, so displayed by admirers of vain things, because of my argument. This results as even more annoying and tedious for us because it accompanies and spurs us in every time and place, sheltering within our minds. The curious knowledge that one applies to human matters troubles us concerning either the cognition of past events or that of those which can threaten us in the future, as well as that of those which annoy us in the present time. Therefore, time, which has power over all sublunary events, making them similarly labile and flexible to itself, is tamed by the obstinacy of our minds, to its detriment. Indeed, we stop and fix past occurrences with our thinking, as well as formalising and conceiving the events which could happen in the future as though they were existent and real.

"Yet if the human intellect's task is the cognition of natural things, it will always become embroiled, among its other torments, in five cruel and constantly flagellating things: the infinite, which distracts it; the indivisible minimum, which burdens it; motion, which agitates it; time, which consumes it; and space or the void, which reduce it to nothing. These are such thorny matters that anyone who presumed to have finally intelligised them while he was entangled in them would certainly be unfortunate. Furthermore, what is even worse is that another disaster also occurs to us, namely that just as the sea is commanded 
percosso, non sa a qual di essi obedire, così la mente molte fiatte distratta da contrarie evidenze, e da repugnanti instanze diversamente raguagliata, non sa né può deliberare a quale di esse prestare debba la sua credenza et assenso.

Il nostro senso scorge apparente diversità e varietà nell'esser mondano. La mente di Xenofane, Melisso e Parmenide nega che vi sia in esso alcuna diferenza, ma instantemente afferma che l'esser in [232] quan|to tale, sia affatto eguale. E similmente l'occhio esprimenta che la luce che più lontana e remota si trova di maggior ambito apparisca. Onde una picciola fiacola mentre che lontana sia posta, grande incendio ci rassembra, tuttavia la mente con chiare dimostrationi ci instruisce, che cento e settanta cinque volte incirca il Sole sia maggior della terra. Alla ragione repugna, che da portioni indivisibile il continuo sia composto, ché se ciò fosse il diametro del quadrato non solamente sarebbe al suo lato comensurabile, ma di più, eguale. Ma se per il contrario all'infinito il continuo si divide, e non ad atomali portioni si riduce, accade non minor difficoltà, che non producendo la divisione le portioni nel continuo, ma solamente le separa e distrahe, da ciò ne segue che realmente infinite portioni si ritrovano in qualunque continuo per picciolo che sia. E perché non si può admettere infinito che sia dell'altro maggiore, ne segue che tutti li continui siano eguali, il che repugna ad ogni evidenza.

Così anco ne seguirebbe altro assordo che qualunque picciola dimensione riuscirebbe impertransibile, non potendosi le portioni infinite che la compongono trapassare. Repugna all'intelletto per un verso che l'indivisibile movere da un loco all'altro si possa, poiché per la sua indivisibilità non può ritrovarsi parte nel termine dal quale, e parte nel termine al quale, come è proprio di qualunque motto, nondimeno non si ritrova alcuno impedimento all'indivisibile in qualunque corpo inserto, che non si mova. Onde anco per se stando non si rinviene la cagione di tal impossibilità. Apparisce assordo alla retta ragione che trapassar si possa dal minore al maggiore senza prima pervenire alla equalità, tuttavia la geometria insegna ciò possibile essere in certo caso di angoli prodotti entro al circolo e fuori di lui.

Così anco il giudicio gagliardamente contrasta in admettere, che due quantità l'una maggiore, e l'altra minore continuamente al possibile augumentandosi questa, che alla fine una [233] fiatta non accada che si ritrovino eguali, e che vicendevolmente la minore venga maggiore, e l'altra minore. $\mathrm{E}$ nondimeno la dimostratione matematica insegna che in certo caso la minore rimanga sempre minore e l'altra continuamente maggiore. Rassembra affatto impossibile et incomprensibile, che un punto indivisibile sia eguale ad una amplissima superficie, eppure si dimostra che ciò occorre, mentre che certa figura tagliandosi insieme con altra orbicolare, le portioni che rimangono di ambe sortiscono eguali, onde all'ultimo procedendo, dell'una resta un punto, $\mathrm{e}$ dell'altra amplissima superficie. Che il centro della gravità del cono sia diverso dal centro del triangolo che constituisce esso cono rassembra impossibile, essendo questo formato dal girarsi di quello in se stesso, eppure la demonstratione rende ciò necessario. 
and beaten by contrary winds and does not know which one it should obey, so the mind is often diverted by contrary evidence and differently reported instances, nor can it know or decide which of them to believe and to give its assent.

"Our senses see the apparent diversity and variety within mundane being. [However,] our minds, in the view of Xenophanes, Melissus, and Parmenides, deny that there is any difference in it, but at the same time state that being [232] as such is indeed [always] the same. Similarly, our eyes experience that the further and more remote a light is, the greater extension it seems to have. Therefore, when a small torch is placed far away, it seems to us to be a great fire. Nevertheless, our minds, with clear demonstrations, instruct us that the sun is about one hundred and seventy-five times larger than the earth. Reason refuses [to accept] that the continuum could be composed of indivisible portions, because if this was true, then the diagonal of a square would not only be commensurable to its side, but also equal to it. ${ }^{406}$ Yet if, on the contrary, the continuum was infinitely divided and not reduced to atomic portions, a similar difficulty would occur, namely that the division would not produce the portions within the continuum, but would merely separate and distance them. From this, it follows that there truly are infinite portions in a continuum, ${ }^{407}$ however small it may be. Besides, since one cannot permit that [one] infinity may be larger than another, it follows that all continuums are equal, which may be disproved by any evidence.

"Likewise, another absurdity would also follow, namely that a small dimension would be impenetrable as it would be impossible to go beyond the infinite portions composing it. On the one hand, it is repugnant to the intellect that the indivisible could move from one place to another, since because of its indivisibility, we cannot find a portion that is the starting point or a portion that is the end point, as is specific to any motion. In any other body joined to it, but which does not move, one cannot find any hindrance to the indivisible. Therefore, even when it [i.e., an indivisible body] does not move, the cause of this impossibility cannot be found. It appears to be absurd to right reason that one may move from the lesser to the greater without first reaching equality. Nevertheless, geometry teaches that this is possible in the case of angles produced inside or outside a circle..$^{408}$

"Similarly, [our] judgment also strongly refuses to admit that when [there are] two quantities, one greater and the other lesser, the latter will continuously increase itself as much as possible until it finally becomes equal [to it], [233] and in turn, the lesser will become the greater and the other [will become] lesser. Nevertheless, mathematical demonstration teaches that in a certain case, the lesser always remains the lesser, while the other [becomes] continuously greater. It indeed seems to be impossible and incomprehensible that an indivisible point could be the same size as a very large surface. Yet it is demonstrated that this occurs when a specific shape and an orbicular [figure] are cut, for then the resulting portions of both of them turn out to be equal. Therefore, proceeding to the end, there remains a point from one and a very large surface from the other, as it seems to be impossible that a cone's centre of gravity may be different from the centre of the triangle which constitutes this cone, since the latter is made by the former turning in a complete circle. Yet the demonstration makes this necessary. 
Che il cono horizontalmente tagliato, la superficie del fragmento inferiore sia maggiore del superiore, par che sia necessario. Ma poi considerando che tutto il cono sia formato dalla giratione del triangolo in se medesimo, repugna che vi sia tal graduatione e scalamento. Che l'angolo sia il concorso di due linee in un punto, la definitione di esso angolo ci lo insegna, nondimeno esso angolo dividere si può in quante portioni desideramo, et all'infinito procedere, com'anco il centro di circolo che dividere si può, e da infinite linee che dalla circonferentia si dipartiscono può esser toccato. Che di sotto l'unità si trovino più minuti et incomprensibili numeri trascende ogni nostra imaginatione, eppure li numeri appellati comunemente irrationali sono della unità minori. Né si può negare che tali siano, sommando, moltiplicando, sottrando, devidendosi fra loro come li altri numeri che al di sopra dell'unità si trovano.

Che un numero quadrato possa haver più d'una radice che in se stessa moltiplicandosi lo produca, rassembra assordissimo e falsissimo, come anco che diversi quadrati tengono l'istessa radice, nondimeno in tali numeri irrationali la scientia matematica dimostra [234] ciò avenire. Che uno indivisibile tenga diversi e come contrarii visaggi, ogni ragione la repugna, nondimeno la linea circolare benché impartibile tiene in sé il convesso et il concavo. Il transitare dal finito all'infinito par che sia passaggio impossibile, tuttavolta con l'intervallo d'un punto indivisibile si scorre dall'uno all'altro, siccome accade fra l'ultimo allargare di linea circolare che immediate in linea retta si converte, questa all'infinito progredisce, e quella per lungo tratto di giro alla fine in se medesima s'incontra e ritorna.

E l'istesso aviene all'ombra che da corpo opaco rotondo si produce, che opposto a corpo luminoso di lui maggiore getta l'ombra finita in conica figura, ma occorrendoli luminoso ad esso eguale all'infinito la produce, eppure nel far passagio dal maggiore all'eguale con l'aggiunta di un sol punto indivisibile ciò si eseguisce. Che due linee in molte guise all'infinito accostandosi giamai insieme non si uniscono, è già divenuto volgare proponimento, né hormai tiene punto del paradosso. Si dimostra ragionevole ad ogni discorso che le linee spirali che circondono cilindro finito e terminato si possino all'infinito sempre allungare, per altro verso appare che qualsivoglia di esse finita sia, poiché l'istesso cilindro è finito e terminato. Che l'infinito non si possa percorrere ogni sano intendimento lo recusa, nondimeno conforme quelli che stimano il tempo passato sia stato sempiterno et infinito, fu dimenso e trapassato. Onde accozzano insieme queste due propositioni, cioè che principiando scorrere dal presente all'insù, cioè contra il flusso del tempo passato progredendo, giammai non si può divenire a total trapasso dell'infinito, nondimeno per l'altro verso, cioè dal passato al presente scorrendo conforme il progresso del tempo preterito è stato transitato e valicato l'infinito.

Mentre che da alcuno non si dubbita che tanto sia la dimensione della via che ci conduce da Corinto ad Atene, quanto è quella istessa che si trova partendosi d'Atene, e verso Corinto inviandosi, [235] appa|risce chiaro al senso, che un moto sia più dell'altro veloce et accelerato, onde principiando l'uno a moversi inanzi all'altro, l'ultimo può giungere alla meta inanzi il primo. Tuttavia il nostro Zenone eleate con evidente demonstratione convince ciò essere impossibile, né che giamai veloce lepre possa arrivare, nemmeno trapassare lenta testudine prima mossa. Che li contraditorii insieme non possino cohabi- 
"It seems to be necessary that [in the case of] a horizontally cut cone, the surface area of the lower fragment must be larger than that of the higher one. However, considering then that the cone is made by a triangle turning in a complete circle, ${ }^{409}$ it cannot be accepted that there is such a graduated scale. That an angle is the encounter of two lines on one point is taught to us by the definition of the angle itself. Nevertheless, this angle can be divided into as many portions as we wish, and so on proceeding to infinity. Likewise, the centre of a circle can also be divided and touched by infinite lines departing from the circumference. That more minute and incomprehensible numbers may be found below the unit is beyond any of our imaginations, yet those numbers that are commonly called irrational are smaller than the unit. It cannot be denied that they become such by adding, multiplying, subtracting, and dividing themselves like the other numbers which are greater than the unit.

"That a square number can have more than one root which can be produced by multiplying it by itself seems to be very absurd and false, and likewise that different squares could have the same root, yet mathematical science demonstrates that this is the case. [234] That an indivisible has different and contrary aspects may be refuted by any reason; nevertheless, a circular line, even if it is indivisible, holds both the concave and the convex in itself. Passing from the finite to the infinite would seem to be an impossible journey; nevertheless, by the interval of an indivisible point, one may move from the former to the latter. Similarly, this happens when the final widening of a circular line converts itself into a straight line; indeed, the latter progresses to infinity, while the former, after a long rotation, finally encounters and returns to itself.

"Furthermore, the same happens to the shadow produced by a round opaque body which, when held against a luminous body that is larger than it, produces a finite shadow with a conic figure; however, when the luminous body is equal to it, it produces an infinite one [i.e., shadow]. Yet it executes this by adding a single indivisible point in passing from the larger [one] to the equal one. That two lines may approach each other to infinity in many directions without ever joining together has already become a common resolution and is no longer considered to be a paradox. It is demonstrated to be reasonable according to every discourse that the spiral lines that encircle a finite and determined cylinder can always be extended to infinity, despite whichever of these appear to be finite, since the cylinder itself is finite and determined. That the infinite cannot be crossed is refuted by every sane understanding; nevertheless, according to those who consider the past to be everlasting and infinite, it has been measured ${ }^{410}$ and crossed. Therefore, these two propositions clash with each other: in moving from the present upwards, namely advancing against the flow of past time, one will never come to completely cross the infinite. Not even in the other direction, namely moving from the past to the present according to the progression of time, has the infinite been transited or crossed.

"While no one doubts that the road leading us from Corinth to Athens is the same length as that departing from Athens in the direction of Corinth, [235] it appears to be clear to our senses that one motion may be faster and more accelerated than the other. Therefore, when one [person] starts moving before another, the later one can still reach the destination before the earlier one. Nevertheless, our Zeno of Elea proved [to us] that this is impossible by [putting forth] an evident demonstration that a fast hare will never reach or overtake a slow tortoise that moved first. ${ }^{411}$ That contradictories cannot live or be combined 


\section{Nequit oppressi luminis igne \\ Rerum tenues noscere nexus?}

Per [236] il che, amico Socrate, lasciamo hormai cotali anfratti e spinosità a quelli che per loro colpa li fu destinato tal faticoso impiego, e noi raccogliendo le vele del nostro discorso terminamo hormai questo nostro mentale viaggio, e nel probabile approdamo, ridotto se non al pari del porto della verità sicuro che solamente ad Iddio è appropriato, almeno esso è tale che vi potemo in esso alquanto ancorare e fermare, difendendoci alquanto dalla tempestosa flutuatione che in questa nostra travagliata vita ci occorre".

\section{Al che replicai:}

"Giacché abbondante di tanta egregia dottrina mi sei riuscito, pregoti che non rimanghi aggravato di informarmi delle conditioni di tale probabile, alla vita tanto proficuo e salutare, come hora mi attestasti”.

Et egli in aggradirmi punto tardo non mi si dimostrando pronontiò che altro non stimava che fosse il probabile, che quel subitaneo barlume che ci si appresenta in distinguer il bene dal male, offerendosi alla nostra mente senza che dal vehemente e spermuto discorso sia agitato e depravato, riuscendo egli a tutto il genere humano chiaro e sereno, se da nostri stentati cavilli non fosse oscurato et obtenebrato, accadendo ad esso probabile siccome avviene nell'effusione del vino, che quello che prima esce dal doglio è più sincero, ma ciò che nel profondo 
together may be stated by any simple intellect; nevertheless, to conceive the nature of motion without admitting this coupling is not possible. That there is an empty space outside the convex [vault] of the sky - if we imagine it to be finite - able to contain every being may be stated by any fantasy. Nevertheless, our minds cannot accept that dimensions are not supported by essence, and they cannot grant that there is an absolute void in the compositions of mundane things, yet if we deny this [i.e., the void], why do bodies not have equal weight and solidity? There are so many instances that I could put forth" - Cratylus continued - "that although I would not have enough time to narrate them, nevertheless, my rational discourse [would be enough] to observe that they imply [enough] intolerable and unacceptable oppositions and contradictions in themselves to ultimately reduce any speculation whatsoever to a cause of dispute and strife between the senses and the mind. Besides, this one often opposes and clashes with itself because of the contrary reasons challenging it:

What cause discordant breaks the world's compact?

What god sets strife so great

Between two truths,

That those same things which stand, alone and separate,

Together mixed, refuse to be so yoked?

Or is there no such discord between truths,

And do they ever each to other firmly cleave,

But is it the mind, eclipsed by the body's unseeing parts,

That cannot recognize, by its suppressed light's fire,

The world's fine fastenings? ${ }^{412}$

Boetius

bk. 5. metre 3.

Hence [236], dear Socrates, let us now leave these bottlenecks and thorny problems to those who were intended for such strenuous pursuits, while we will now end our mental journey by furling the sail of our discourse and landing on the probable, which, although it is not like the secure harbour of the truth, which belongs only to God, at least it is such that we may stop and anchor there. Therefore, we may sufficiently defend ourselves from the stormy wavering occurring to us in this troubled life."

Hence, I replied:

"Since you have turned out to be full of such excellent doctrines, I beg you to free yourself by informing me about the condition of this probable that is so profitable and salutary for life, as you have now attested."

And so he pleased me by showing me that he was not slow-witted; indeed, he said that the probable was nothing other than that instantaneous glimmer arising in us [allowing us] to distinguish between good and evil. As it appears in our minds without being agitated or corrupted by vehement and prolific discourse, it will result as clear and limpid to the whole of humankind, if it is not obscured and hidden by our laboured quibbles. That which occurs to the probable also occurs with the effusion of wine: namely that the first [of the wine] that flows from the jar is pure, while that which one finds at the bottom of the vase 
del vase si ritrova più fecioso e torbido riesce. Tale appunto occorre alla consideratione del bene, che il primiero lume che ci si apparisce stimare si deve che più al vero si avicina, ma che l'ultimo conato et esercitio della mente lo disperde e fa smarire. E ragionevolmente stimare si deve, che siccome quella miglior causa in tal ottima guisa constituì l'homo e li donò egregi organi per conseguire li suoi desii, così anco l'offerì et apprestò il probabile facile ad esser da lui conosciuto et appreso, siccome sono tutte le altre cose alla nostra vita alquanto necessarie.

"Concludo dunque", diceva Cratilo, "il mio ragionare. Se come occhiuto Argo non potemo riconoscere l'esata verità, contentare si dobbiamo ch'a guisa di monocolo Polifemo scorgere ciò che ad essa tiene alcuna assimiglianza, ché se [237] oltre|modo circa essa saremo curiosi deveniremo alla fine come il cieco Tiresia, affatto di lume e vista, privi e cassi”.

Qui posò e terminò il suo divisare Cratilo, ma non già hebbe fine il mio travagliare. Osservai che le maggiori dificoltà da Cratilo mosse, vertivano circa la cognitione delle cose esterne et a noi inatinenti, per il che meravigliare non mi doveva se ci riescono ignote et incomprensibili. Onde presi speranza che del modo di reggere l'usi della vita, et ordinare li nostri affari ne potiamo tenire alcuna più che mediocre cognitione, et estimai che tale fosse la comunemente appellata prudenza cotanto decantata e celebrata dalli periti delle humane emergentie, ché perciò deliberai, che per tenirne di essa cognitione ricercare dovessi il parere di Pericle, celebre sopra ogni altro della nostra età in moderare e reggere li maneggi urbani. Per il che al giardino di esso in tempo che conieturai che sfacendato era, mi condussi. Il quale ritrovai, che in compagnia di amici divisava, se vi era più bisogno di prudenza nel far acquisto di un Stato, overo in conservarlo.

Alcuni asserivano per l'acquisto, ma Pericle vivamente manteniva che nella conservatione, la prudenza maggiormente prevaleva, adducendo quel celebre detto che difficilius est, prouincias obtinere, qua facere. viribus parantur, iure retinentur. Quasi che l'istesso fosse che fortuna parantur, prudentia retinentur. Dilatossi poi in dimostrare quanto che superava la prudentia la fortuna.

Ma io verso tale conversatione in tal maniera favellai:

"Altro tanto che voi, ottimi amici, vi accordate in pregiare la prudenza, io son bramoso di sapere ciò che essa sia, e con suplichevoli instanze chiedo che me la dimostrate”. 
is revolting and turbid. This is what happens as far as the good is concerned, namely that the first light that appears to us must be considered to be closer to the truth, while the final effort and exercise of the mind dispels and loses it. Besides, one must reasonably consider that just as the best cause constituted human beings in the best way, offering them excellent organs to achieve their desires, so it also offered and provided them with the probable, which is easy for them to know and apprehend, like all the other things that are absolutely necessary for life.

"Here, I conclude my arguing," Cratylus said. "If we cannot acknowledge the exact truth like all-seeing Argus, we must be content with the fact that, like one-eyed Polyphemus, ${ }^{413}$ we may only see what resembles it. If [237] we are excessively curious about it, in the end we will become like blind Tiresias, devoid of light and sight.”

This was the end and conclusion of Cratylus's consideration, but not of my striving. I observed that the greatest difficulties that Cratylus had raised were about the cognition of those external things that were not pertinent to us, and hence I should not have been astounded that they resulted as unknown and incomprehensible to us. Therefore, I began to hope that we could have some relevant cognition of the way to rule our way of life, as well as of how to regulate our affairs. Then, I considered that this was what is commonly called prudence, so praised and lauded by the experts in human events. Hence, I decided that in order to get to know it, I had to seek the opinion of Pericles, who was renowned above any other of our time as far as moderating and ruling urban affairs was concerned. Thus, I went to his garden when I thought he would not be busy. I found him debating with some friends about whether prudence was more necessary for acquiring a state or for maintaining it.

Some asserted that [it was more necessary] for acquiring it, while Pericles strongly maintained that prudence was more valuable in maintaining it, adducing that well-known saying it is more difficult to retain than to create provinces; they are won by force, they are secured by justice. ${ }^{414}$ This is almost the same as they are won by fortune, they are secured by prudence. ${ }^{415} \mathrm{He}$ then spoke at length demonstrating how much prudence exceeded fortune. However, as far as this conversation was concerned, I spoke in this way:

"I am as eager as you are, excellent friends who are agreed in praising prudence, to know what it is, and I address an imploring request to you to demonstrate it." 
Prima espositione della prudenza.

Iuvenale.
Rispose a ciò Protagora delli altri il più provetto, et in tal modo pigliò a dire:

"Se tu, buon Socrate, havessi per il passato ordinata la tua vita conforme li precetti della prudenza, giudicarei che tale richiesta fosse una delle tue solite ironie e dissimulationi, ma il vederti in tal stato e conditione di fortuna m'indica esser tu veramente ignaro di ciò che sia prudenza. Per il che stimo che voglioso sei di conoscerla, accioché con il possesso di essa possi ordinare il residuo della tua [238] età. La prudenza che ricerchi è timoniera della humana vita, stella polare per mezo della quale si deve indrizzare il corso delle nostre attioni, moderatrice anzi regina delle morali virtù, auriga delli humani affetti, quella che ci raffrena nelle prosperità e che ci sostiene nelle adversità, e che tenendo l'animo in equilibrio non li permette vanamente insultare, né vilmente trabocare, rendendolo cauteloso, e sempre circonspetto nel deliberare, ardito nell'intraprendere. E per concludere il molto in poco, la prudenza è quella che garegiando con li dei, alquanto ci difende da colpi da essi aventatici, et arivandoci ce li fa riuscire tolerabili et insensibili. Onde quanto può, rende quasi simile l'humanità all'istessa divinità:

Nullus numen deest si est prudentia

Sed nos te facimus fortuna deam coeloque locamus”.

Stimava Protagora havermi appieno satisfatto con tale sua gonfia diceria. Ma io ad egli:

"Amico Protagora, egregiamente hai esposto l'effetti e consequenze della prudenza, ma non tieni dichiarato né affigurato la vera effigie et imagine di essa. Non altrimente ciò hai eseguito che se forestiero allettato dalla fama che per tutto corre del valore del nostro Pericle, e capitato in questa città procurasse di veduta riconoscerlo, li fosse additato li palagi, li teatri e le munite muraglie che di suo ordine sono stati nella città erretti. Ciò che io bramo d'esser instrutto, è il riconoscimento dell'istessa prudenza e non di suoi attinentie et effetti”.

A questo mio dire non replicò Protagora, onde a Pericle rivolgendomi l'instai che circa ciò il suo parere amichevolmente mi arrecasse. Al che punto non ritardando, prononciò che la prudenza fosse quella virtù

Seconda espositione della prudenza. che si esercita in ramemorarci le cose passate, instruirci delli presenti, acciò potiamo provedere [239] et ordinare le venture.

A tal esplicatione mi opposi dicendoli che io non indagava una particolare cognitione di tutte le cose, come egli accennò nel suo dire, ma solamente io ricercava la propria imagine, e formalità della prudenza che la rende distinta e diversa dalle altre dottrine e facoltà, onde il dire che ci ramembra le cose passate et instruisce delle presenti, tiene troppo del generale, interminato et indefinito. Oltre di ciò il provedere alle cose venture parevami come ch'impossibile, perché conforme il 
Protagoras, the most expert of all of them, answered this, and he began by saying:

"If in the past, good Socrates, you had ruled your life according to the precepts of prudence, I would judge that this request of yours was one of your usual ironies and dissimulations, but having seen the state and condition of your fortune, I see that you are truly unaware of what prudence is. Hence, I consider that you are eager to know it so that by possessing it, you may rule what remains of your life. [238] The prudence that you are seeking is the helmsman of human life; [it is the] Pole Star by means of which we must guide the development of our actions. It is the moderator, or rather the queen, of moral virtues, the charioteer of human affects; it is that which reins in [our excesses] when we live in comfort and which supports us through adversity. By maintaining the mind in balance, it does not allow it to make vain insults or vile outbursts, rendering it cautious and always circumspect in deliberating, as well as courageous in any undertaking. Furthermore, to cut a long story short, prudence is that which, when we compete with the gods, rather defends us from their blows, allowing them to appear tolerable or imperceptible to us. Therefore, as far as it can, it makes humanity almost like divinity itself:

Fortune, you'd have no power,

If we were sensible: it's we who make you a goddess, it's we who Give you a place in the sky." ${ }^{416}$

Protagoras considered that he had fully satisfied me with this pretentious discourse. Yet I [said] to him:

"Dear Protagoras, you have excellently expounded the effects and consequences of prudence, but you have neither disclosed nor depicted its true effigy and image. You have acted no differently from a foreigner attracted by the widespread fame of Pericles's valour who, once he had arrived in this city with the aim of discovering what he looked like, was shown the palaces, theatres, and fortified city walls erected in the city by his command. What I am eager to know is prudence itself, not what pertains to it or its effects."

Protagoras did not reply to what I had said, and therefore I turned to Pericles and urged him to amicably tell me his opinion concerning this. Hence, he did not delay in uttering that prudence was that virtue that one practises to remember past things and receive instruction about present ones so that we can arrange and provide for [239] future ones.

I objected to this explication by telling him that I was not searching for the cognition of particular things, as he had mentioned during his speech, but that I was simply seeking the proper image and formality of prudence that made it distinct and different from the other doctrines and faculties. ${ }^{417}$ Therefore, to say that it reminds us of past things and instructs us concerning the present ones was too general, indeterminate, and undefined. Moreover, it seemed impossible to me to provide
First exposition of prudence.

Juvenal.

Second exposition of prudence. 
mio intendimento non si può provedere, circa ciò che non si può prevedere, né prevedere parimente si può ciò che per anco non è né tiene esistentia alcuna, non potendosi di quello non è, conforme il calcolo di quasi tutti li sapienti, tenirne né senso, né openione, né concetto alcuno. Ma di più lasciando in tal affari le sottigliezze a parte, siccome in certo modo la pontuale conditione delli effetti della constantissima natura non si può presagire, tanto meno l'emergentie delli affari humani, che per il più dal pazzo caso sono sosopra rivolti e turbati.

A queste mie obbiettioni, rispose Pericle, che per il certo stringere si doveva la fontione della prudenza circa il ricordarsi delle cose passate et inspettione delle presenti per apportar profitto alle venture, solamente in quanto appartiene alli affari del vivere civile non alla medicina, agricoltura, et altre simili professioni, ma che in quanto al provedere per l'avenire, stimava che bastava appogiarsi sopra un certo probabile che ragionevolmente presagisce li eventi futuri.

Ma opponendomi alla prima evasione li significai che non mi sapeva per anco formalizare in che consisteva la prudenza, e ciò che fosse la sua peculiare fontione e proprio offitio circa l'humani affari, poiché intraprendendosi per gratia di essempio di munire la nostra città, all'architetto si capita. Se condurre uno esercito si vuole et ordinarlo in battaglia, al professore dell'arte militare. Se deliberare una guerra si attenta al perito delle nostre forze e del nemico si ricorre. E se parimente si [240] mini|strare la giustitia a cittadini vogliamo, a giurisconsulti si conduciamo.

Onde non resta al prudente in che esercitarsi essendo il tutto da altri professori occupato, et ad essi conviene se rettamente vuole operare che si riferisca. Et in quanto all'altra partita della sua risposta, cioè che basta al prudente probabilmente indovinare l'evento, e li mezi per conseguirlo, il redarguii con dire, che se l'effetti della natura sono tanto dubbiosi e perplessi innanzi che accadono come sono le pioggie, li venti, il freddo e caldo delle stagioni, che sarà poi di ciò che apporta l'insana fortuna, e produce il capricioso, e variabile humano arbitrio?

Replicò egli, che non intendeva giamai che li cultori della prudenza fossero egregiamente dottati di tutte le arti, dottrine, e discipline, perché se ciò fosse di mestiero converebbe al prudente rinontiare il dominio che pretende sopra li affari humani, e rassignarlo alli veri professori di caduna arte che serve al viver civile, come di già io divisai, ma che la prudenza era superiore regente e comandante a tutte le altre arti e dottrine, nell'istesso modo che accade al 
for future things, because according to my understanding, one cannot provide for what cannot be foreseen, and what does not yet exist also cannot be foreseen. ${ }^{418}$ Indeed, according to the assessment of almost all wise men, a thing that does not exist cannot have any perception, opinion, or conception. Furthermore, let us leave aside the details of this matter, as one cannot certainly foresee the punctual condition of the effects of most consistent Nature, and even less the occurrences of human matters, which for the most part are upset and turned upside down by mad Chance.

Then Pericles answered my objections [saying] that one should certainly restrict the function of prudence to the memory of past things and the inspection of present ones in order to benefit future ones as far as civil matters were concerned, but not concerning medicine, agriculture, and other similar professions. Yet as far as providing for the future was concerned, he considered it to be sufficient to lean on the probable, which reasonably foresees future events.

However, I objected to the first deflection by explaining to him that he could not yet allow me to conceive what prudence consisted in and what its peculiar function and proper task concerning human matters were. For example, to fortify our city, one would address an architect; if one wanted to lead and direct an army in a battle, [one would address] someone professing the military art. If one were attempting to deliberate in favour of a war, one would appeal to an expert in both our armed forces and our enemy. Similarly, [240] if we wanted to administrate justice for our citizens, we would go to the jurisconsults.

Thus, although there was no place where the prudent could intervene, as all [areas] were already occupied by other experts, nevertheless, it would be worth referring to them if he wanted to act in the correct way. Besides, I reprimanded him [i. e., Pericles] concerning the other part of his answer, namely that it was sufficient for the prudent to foresee ${ }^{419}$ both the event and the means to accomplish it just by following probability. Indeed, I told him that if the effects of Nature were so doubtful and perplexed before they actually occurred, like the rains, winds, and the cold and heat of the seasons, what then would happen about what was provided by insane fortune or produced by the capricious and changeable human free will?

He replied that he had never meant that the estimators of prudence were excellently endowed with every art, doctrine, and discipline, because if that was so, then it would be necessary for the prudent to waive any claim of control over human matters and to allocate it among the true experts of every art that was useful for civil life, as I had already considered. However, [Pericles replied] that prudence was the major ruler and commander above all other arts and doctrines. [It was] like 
capitano di esercito, che comanda a perito arciero che per molti avenimenti egregii nella sua professione fu riconosciuto, benché esso capitano non sia punto pratico nell'arte del saettare. Così parimente occorre alli prudenti che ordinano e comandano alle altre discipline benché di esse ne siano come che affatto ignari.

Ma io in tal modo l'incalzai:

"Stimi che la prudenza consista nel comandar a cui che al sicuro si conosce per la certa esperienza che si tiene della sua peritia e sufficientia, idoneo ad eseguire la tale attione, o piuttosto nell'imperare a colui che si tiene alcun dubbio della sua sufficientia, ma che tuttavia si conietura che in tal esercitio sia per riuscirne conforme il desio e bisogno di chi l'adopera et impiega?".

Rispose egli:

"Giammai non crederei che fosse fontione propria della prudenza tanto comendata, il sapersi prevalere di cui che appo qualunque benché volgare sia stimato habile ad eseguire tale effetto, ma [241] sì bene stimarei che essa prudenza si travagliasse nell'indagare e riconoscere quel tale che non è altrimente a tutti manifesta e notoria la sua attitudine e habilità. Il che essa prudenza per via di esato essame, et accurata disquisitione sceglie et approba".

Al che io:

"Egregiamente ti sei condotto senza molto mio faticare a quel posto che io desideravo. Dunque conviene che tal prudente saggiatore sia perito della professione ch'in altrui si ricerca e desidera che vi sia. Dal che ne segue ch'a riconoscere la suficientia del medico, mentre che per la lunga esperienza di suoi felici eventi nel medicare non si tenisse di lui buon concetto, converebbe che oltremodo della medicina fosse intendente colui che prudentemente di esso facesse scelta, e che approbasse il suo valore. E quello si è detto del medico applicare devi a qualunque altra professione rispetto alla prudenza. Ma di più circa l'humani affari non solamente basta alla prudenza l'esser aveduta circa la peritia di altrui nell'eseguire qual si sia effetto che attenta, ma le conviene parimente riconoscere la dispositione dell'altrui volontà tanto di natura astrusa, $\mathrm{e}$ di punto in punto variabile e mutabile".

Contra il mio dire di nuovo risorse Pericle dicendo che poiché convenga concedere che la prudenza sia distinta dalle particolari cogni-

Terza espositione della prudenza. tioni delle cose, e non può né anco esserne affatto ignara, come dal prossimo antedetto ragionare appare, ché affatto inetta riuscirebbe, è necessario stimare che la prudenza sia una mediocre peritia di tutte le professioni et arti, e che per tal sua universalità a tutte decentemente comanda, et ottimamente li humani affari regge e governa. 
the captain of an army commanding an expert archer whose value was acknowledged in his field thanks to his many illustrious undertakings, [which was possible] although this captain was not acquainted with the art of shooting with a bow and arrow. This would likewise be the case for the prudent, who would rule and command the other disciplines although he was indeed ignorant of them.

Yet I urged him in this way:

"Do you consider that prudence consists in commanding a person who definitely knows himself thanks to the solid experience he has collected from his expertise and his ability to adequately carry out his actions? Or rather in ruling a person who has some doubts concerning his capacity, but nevertheless believes that he is acting in compliance with the wishes and needs of the person who uses and employs him?”

\section{He answered:}

"I would never believe that the proper function of this so-praised prudence is to rely on someone who is considered able - by anyone, even by common people to obtain such a result. On the contrary, [241] I would rather consider this prudence to be working hard in seeking and acknowledging a person whose attitude and ability is not evident or known to all. This person is chosen and approved by prudence after an exact examination and accurate disquisition.”

Then, I [said]:

"You have excellently led yourself, without a great effort from me, where I was wishing you to go. Therefore, it is necessary for such a prudent assayer to be an expert in the profession sought and desired in another. Hence, it follows that in order to recognise a doctor's ability, if his long successful experience in treatment is not to be taken into consideration, it is necessary for the one who had prudently chosen him and acknowledged his value to be a great specialist in medicine. Besides, you must apply what is said about the doctor to any other profession in relation to prudence. Moreover, concerning human matters, prudence cannot only be careful about the expertise of other people in obtaining any result they seek, but it is likewise necessary for it to acknowledge the disposition of other people's wills, which are naturally so abstruse and continuously changeable and unstable."

Pericles reacted to my speech by telling me that one should grant that prudence is distinct from the cognition of particular things, but that it could not be completely unaware of them, as it appeared from the argument mentioned shortly before, because then it would indeed Third exposition of prudence. turn out to be inept. It was necessary to consider that prudence was a moderate expertise in all professions and arts and that it properly commanded all of them and optimally ruled and governed human matters because of its universality. 
Quarta espositione della prudenza.
Ma a ciò gagliardamente mi opposi, con dirli, che permettere non si deve che quella virtù che regge e modera le altre, et è arbitra delle humane emergentie, e come disse Protagora che tiene la comitiva e satelitio di tutti li dei, al di sotto di qualunque dottrina e arte si ritrovasse. E qual è quel principe che accadendoli guerra, rimanessi servito del consiglio di mediocre capitano, et [242] atte|ntando solcare con grave armata il mare, non facesse scelta di eccellente e pratichissimo nochiero? E cadendo in infermità non chiamasse a sé sapientissimo e consultissimo medico? Ma per il certo di tutte le professioni sceglierebbe l'egregio et ottimo. Onde se la prudenza fosse mediocrità rimarebbero sempre li cultori di essa rigetti, et ad altrui inferiori.

Al mio ragionare fermossi Pericle né altro circa la prudenza apportò. Ma Hippia, ch'ivi si ritrovò prese a lodare la sentenza di Chilone in via ne properato, dicendo, che in essa consisteva gran parte della prudenza, ma se si accopiava con altra, festina lente, sortiva perfettissima, ché adempiva tutti li suoi numeri. E da quindi egli si allargò in dimostrare che il principale fondamento della prudenza era una certa moderata lentezza nel deliberare, et acceleratione nell'eseguire, ché però l'Egittii la rapresentarno come se delfino ad àncora fosse avolto, l'uno sopra qualunque altro pesce veloce nel guizzare, e l'altra nell'afferare e ratenere accelerato legno tenacissima.

"E chi non sa”, seguiva egli, "che il tempo è della verità padre? Esso ci additta il vero visagio e circonstantie delli affari. Et è cosa certa che ove egli s'interpone giamai o di rado falire non si può".

Non potei tolerare che la prudenza cotanto celebrata alla fine si riducesse alla tardità, lentezza, e pigritia, et opponendomi li dissi, che giamai non harei stimato che perito aritmetico nel calcolare, lento esser dovesse, né pittore che stentatamente trattegiasse, di ciò pretendesse lode, e che oratore che nella pronontia hestitasse, riuscisse comendabile. Per il che si rende chiaro che la tardità e lentezza non essere l'interno essentiale della prudenza, ma che piuttosto certo freno e retinentia alli precipitosi et inaveduti ingegni, non meno che la catena e ceppi all'insani e pazzi.

A questo mio dire replicò Hippia, che per il certo per la mia instantia stimare si deve, che alla tardità e lentezza in quanto appartengono alla prudenza si deve aggiungere l'esata inspettione dell'affare sopra il qual si consulta, [243] consideran|do tutte le sue attinentie. 
However, I strongly objected to this by telling him that one should not allow that virtue - which ruled and moderated the others, was the arbiter of human occurrences, and had the complete support of all the gods, as Protagoras said - to be beneath any other doctrine or art. Furthermore, what prince in a state of war would continue to be served by the counsel of a merely average captain, just as [242] attempting to plough through the sea with a great army would not appeal to an excellent and most expert helmsman? And [what prince], once [he had] fallen ill, would not choose a very wise and [frequently] consulted doctor? For he would certainly choose the best and most excellent in every profession. Therefore, if prudence was middling quality, its estimators would always be rejected and inferior to others.

In the face of my argument, Pericles stopped without adding anything else about prudence. Yet Hippias, who was there, began to praise Chilon's maxim of let no one see you in a hurry, ${ }^{420}$ saying that this summarised what most of prudence was; and if it was combined with the other - make haste slowly ${ }^{421}$ - it would turn out to be completely perfect, as it fulfilled all of its potential. Then, he expanded on this by demonstrating that the main principle of prudence was a certain moderate slowness in deliberating and speed in executing. Therefore, it was represented by the Egyptians as a dolphin wound around an anchor; the former is the fastest darting fish, while the latter is extremely steadfast when catching and holding a swift boat.

Then, he continued:

"Who does not know that time is the father of truth?422 It discloses the true face and circumstances of matters to us. Besides, it is certain that when it elapses [between two events], a person always, or almost always, succeeds.”

I could not tolerate that this so-praised prudence should in the end be reduced to indolence, slowness, and idleness, so I objected to this, telling him that I would never consider that an expert arithmetician would be slow in calculating, nor that a painter who had difficulty drawing would be praiseworthy, nor that an orator who was hesitant in speaking would be commendable. Hence, it became clear that indolence and slowness did not constitute the inner essentiality of prudence, but rather that they were a certain brake and restraint for some rash and hasty wits, as well as chains and shackles for the insane and mad.

Hippias replied to my speech that certainly, thanks to my example, one should consider that the exact inspection of the matter on which one had been consulting and the consideration of all the things that were related to it should be added to this indolence and slowness as [243] characteristics of prudence.
Fourth exposition of prudence. 
Ma io di nuovo il sopresi che inavedutamente si era accapato nelli primieri inviluppi, essendo già d'accordo regetto l'attribuire alla prudenza quella fontione ch'è propria a caduna arte e professione, appartenendo a qualunque di esse tal inspetione secondo l'affare che le sottogiace. Oltre che la inspettione non pare che sia suficiente per sé sola a dirigere e normare le nostre deliberationi, perché il troppo oggettare nelli affari ci rende sovente perplessi et irresoluti, onde non sapendo a che attenersi, per la moltiplicità di repugnanti instanze, e contraindicanti, il nostro assenso rimane sospeso et in se stesso implicato. Oltre che l'inspettione per sé è piuttosto passione dell'animo che attione che appartenga alla buona deliberatione. Il linceo et aquila sono di egregia vista dottati, nulladimeno non crederei che meglio di qualunque altro animale deliberassero. Per il che oltre l'inspettione ci vuole altra norma che dia perfettione alla prudenza.

Ma di novo ripigliò egli con dire che alla inspettione si deve accompagnare alcune massime et universali concetti, che come norme apportino l'ultima perfettione al giuditio et il sommo alla prudenza.

Ma di ciò non restando io punto satisfatto, li narrai l'instanze già da me a Platone opposte mentre che nelle scientie attentava valersi di tali axiomi, dimostrandoli di più, che non meno riuscirebbe temerario ardire il dedurre certo presagio di alcuno avvenimento futuro da tali propositioni universali, che l'indovinare quale deve puntualmente essere e sortire l'imagine con tutta la sua perfettione, per il riguardare il di lei rude et informe abbozzo. E poi rivolgendomi verso tutta la compagnia che ivi si ritrovava, li dissi:

"Ottimi amici, quale massima politica fu maggiormente approbata, e da tutti noi acclamata, che quella che ci admonisce, che per la quiete della nostra Republica non solamente desiderare, ma procurare si dovesse la depressione e diminuitione della immensa potenza del Re di Persia, che havendo di già occupato [244] tutta l'Asia, alla Europa minacia porle il giogo di miserabile servitù. Onde da noi Ateniesi con il calcolo di tutti li ordini della città fu preso per espediente, che con ogni più occulta et accurata arte si attentasse infiacchire le loro smisurate forze, et attenuare la loro tanto accresciuta potenza. Per il che oltre che si procurò di porre discordia fra loro suditti con solevare nel loro vasto imperio alcuni popoli a manifesta ribelione, la fortuna o per meglio dire il tempo ancora secondò il nostro desio, havendo essi Persiani per il loro lungo otio e prosperità smarita l'antica loro militare disciplina. E perciò avenne, che siccome per il passato tutta la Grecia, Macedonia, Epiro e Peloponesso insieme uniti non li potevano fare resistentia, quasi la nostra città si trovò suficiente ad opporseli, e contra essi fare capo.

Noi di tal loro debollezza allegri e giocondi, accade hora che tal fiachezza 
However, I caught him as he rashly ended up in the original tangles: indeed, we were already agreed in refusing to attribute those functions which were proper to each art and profession, namely that each of them had this [function of] inspection depending on the matter it dealt with, to prudence. Furthermore, the inspection could not be considered sufficient to rule and guide our decisions by itself. The reason for this was that thinking too much about any matter often makes us perplexed and irresolute. Then, as we do not know which we may comply with because of the multiplicity of opposite and contradictory instances, our assent remains suspended and entangled in itself. Furthermore, inspection is a passion of the mind rather than an appropriate action [for making] a good decision. The lynx and the eagle are endowed with excellent eyesight; nevertheless, I would not believe that they could deliberate better than any other animals. Hence, beyond inspection one needs another rule which may equip prudence with perfection.

Yet he continued again, saying that inspection had to be associated with some maxims and universal concepts, which, like rules, must provide judgment with the ultimate perfection and prudence with the supreme one.

However, as I was indeed not satisfied by this, I told him the instances I had already raised as objections to Plato when he was attempting to adopt these axioms for knowledge. Indeed, I furthermore demonstrated to him that it would turn out to be no less reckless to dare to deduce any presage of future events from these universal propositions than to guess an exact and perfect image only from looking at a rough and shapeless sketch of it. Then, addressing all the company that was there, I said:

"My very good friends, the supreme politics that was most approved and acclaimed by all of us was that which warned us that one should not only wish for the weakening and decrease of the immense power of the king of Persia for the peace of our republic, but also [attempt to] cause it. Indeed, he had already occupied the whole of [244] Asia and was then also threatening to subjugate Europe by miserably enslaving it. Therefore, we Athenians, by including people of all classes in the city, took the following measure, namely to attempt to weaken their immeasurable forces and attenuate their greatly increased power through concealed and accurate art. Hence, in addition to causing discord among their subjects by urging some peoples in their vast empire to openly rebel against them, fortune - or, better to say, time - went along with our wishes; indeed, the Persians themselves lost their ancient military discipline because of their long leisure and prosperity. Therefore, it happened that while in the past the whole of Greece, Macedonia, Epirus, and the Peloponnese together could not resist [them], [now] our city was sufficient by itself to oppose and face them.

"While we were happy and cheerful about this weakness of theirs, it happened indeed that this weakness now resulted as much more harmful to us than 
Quinta espositione della prudenza.
Sesta espositione della prudenza. ci riesce oltremodo più dannevole, che la loro antica potenza, poiché accadendoci con essi gueregiare, havendoci per mare, e per terra assaltati, siamo da tutte le provincie sudette abbandonati, stimando esse noi soli senza l'altrui aiuto, esser bastevoli a diffenderci et a contrastarli l'oltra passare. Onde hora tutto il peso della guerra conviene noi soli sostenere. Ma se tal axioma che insegna che il nemico potente si deve indebolire ci riesce in la prattica hora falace, a qual altro documento politico prestaremo fede, e per norma delle nostre attioni seguiremo? Da quindi è, che se osservare vogliamo la riuscita delli humani avenimenti si trovarà che la violentia, che con loro universali regole, e massime, apportano li formalisti alla resolutione di particolari e gran affari, ben sovente attraversa il loro progresso, benché peraltro siano stati dal principio ben incaminati e diretti”.

Al mio dire altro non replicò Hippia. Ma Critia doppo esso continuò dicendo che per quello haveva appreso nella gran scola del mondo li appariva, che la prudenza, altro non fosse, che farsi l'homo, il suo proprio interesse centro sopra il quale si ravolge [245] la circonferenza di suoi pensieri, con moderatione tale, che faccia apparire che il commodo altrui sia il punto del bersaglio, al quale prendono mira li suoi attentati, e che l'esperienza instruisce, che anco li più petulanti homini del mondo che senza alcuno rispetto agognano le loro intraprese benché con qualche difficoltà, li conseguiscono, et al dispetto altrui li loro desii riescono.

Non mi piacque punto tale diceria, non essendo decente che l'imperatrice delle virtù, non oggetti altro che il profitto del soggetto particolare nel quale insiste, né meno riesce ciò sconvenevole che se gran Prencipe ad altro non mirasse che alla conservatione della sedia sopra la quale egli si trova assiso. Oltre che Critia, espose piuttosto il fin di questa sua interessata e vil prudenza qual è il proprio profitto, che la propria di lei essenza, et in che modo il professore di tal prudenza possa pervenire all'acquisto del proprio interesse. Il sapere che il fine del saetante sia il colpire nella mira e scopo, non ci dimostra et insegna il modo del saettare, così anco l'esporre, che la prudenza tenga per fine il proprio profitto di chi l'esercita, non ci instruisce ciò ch'essa sia e qual formalità in sé tenga.

Acquietatosi Critia al mio dire, li sucesse Tarsimaco il qual proferì, che la prudenza fosse una arte di mettere in stima li cultori di essa appresso il comune delli homini, facendoli apparire quello che veramente non sono. Onde per mezo del concetto che li concilia, tengono appo altrui somma autorità nel disporre a loro talento a pro loro e di altrui li più importanti affari e maneggi. Il qual concetto diceva egli sortire per lo splendore di alcune minute virtù, insieme comesse benché cadauna da per sé sia come che insensibile e priva di comendatione, e forse di nome, a guisa delle piccole stelle che formano la via lattea celeste, che essendo qualunque di esse insensibile, insieme 
their ancient power, namely that since we had had to fight them after being assailed by land and sea, we had been abandoned by all the aforementioned provinces, which considered us to be capable of defending ourselves and preventing them from advancing without any further help. Thus, we now needed to bear the whole weight of the war alone. ${ }^{423}$ Yet if this axiom teaching us that one must weaken a powerful enemy now turns out to be fallacious in practice, what other political teaching may we believe and follow as a rule of our actions? Hence, if we want to see human events be successful, we will find that violence, which the formalists put forth in addition to their universal rules and maxims for the resolution of great and particular matters, ${ }^{424}$ has very often hindered their development, although they began and were directed well.”

Hippias did not make any further reply to my speech. Yet after him, Critias continued by saying that prudence, as far as he had learned in the great school of the world, appeared to him to be nothing other than a man placing his own interest at the centre of [245] all his thoughts, ${ }^{425}$ yet doing this with such moderation that he allowed it rather to appear that other people's convenience, to which his deeds were addressed, was the centre of the target. Furthermore, experience also instructed that the most petulant men of the world, who desired success in their undertakings without any respect for anyone else, achieved them, albeit [sometimes] with some difficulty, and fulfilled their desires without caring about others.

I did not like what he had said, because it was inappropriate that the empress of the virtues [i.e., prudence] should target anything other than the profit of the particular subject in which it existed. Similarly, it would be improper if a great prince aimed only to maintain the throne on which he sat. Furthermore, Critias expounded the goal of this interested and vile prudence, which was its own profit rather than its own essence, as well as the way that one who professed prudence could attain his own interest. To know that an archer's goal is to hit the target does not teach us how to shoot with a bow, just as expounding that prudence's goal was the profit of the one who practised it did not instruct us concerning what it was and its formality. ${ }^{426}$

After Critias had been appeased by my speech, Thrasymachus uttered that prudence was the art of causing its esteemers to be held in high regard by the common people by making them appear different to how they truly are. ${ }^{427}$ Thus, thanks to this esteem, they would earn benevolence and obtain supreme authority among the people in disposing very important matters and affairs as they wished in favour of themselves and others. He said that this esteem was raised from the splendour of several minute virtues combined together, although each by itself was imperceptible and without praise, and perhaps without name, like the small stars forming the celestial Milky Way, each of which is imperceptible, but which
Fifth exposition of prudence.

Sixth exposition of prudence. 
aggregate ci rendono osservabile luce.

"Né si deve”, seguiva egli, "la prudenza sdegnare ch’io l’impieghi circa tali virtù piuttosto putatie et ideali che vere e reali, poiché non per il proprio peso delle cose, ma per li effetti e profitti, che producono si devono stimare e pregiare".

[246] Dicen|do di più che per tale esplicatione non occorreva incaricare la prudenza di moltiplicità di arti e discipline che rendesse stimato, et autorevole il professore di essa, bastandoli l'istesse cose che nella finta lettera inviata alla Accademia dalla ragione furno esposte, affermando che quelle rendevano l'autorità appo altrui signorile e maestosa.

Ma io nauseato da tal ragionamento, li dissi, che parevami che il suo prudente non fosse dissimile da insani amanti, che come suole dire il nostro Platone, non in loro stessi, ma nelle loro amate vivono. Così anco questo prudente in se medesimo alle dottrine e virtù è morto, ma solamente nella openione altrui vive, per il falso concetto e stima che di lui si tiene. Oltre che a mio parere riuscirebbe oltremodo infelice, non sapendomi imaginare il più miserabile di mercante, ch'essendo meschino, li conviene per mantenere il credito, apparire ricco et opulente, così senza dubbio accadarebbe all'ignorante vestito e mascherato da prudente.

Ma di più non mi saprei rappresentare in qual guisa colui che si trova ignaro di una arte possa dimostrarsi di essa perito. In qual modo si può imitare ciò che giamai non si ha scorto et osservato? Colui che non sa che cosa sia dottrina, in qual maniera può ad altrui rappresentarsi addottrinato? Chi mai non ha appreso gramatica potrà giamai ottimamente fingere esserne disciplinato? Chi non imparò rettorica potrà ad altrui dimostrarsi oratore facondo?

Tacque a tali instanze Tarsimaco. Ma invece di esso pigliò a dire Clinia:

Settima espositione della prudenza.
"Gran ardire", diceva egli, "sarebbe il mio mentre che da voi eminenti ingegni sfuge il riconoscimento della prudenza, che io attentasi di afferarla, se non fosse che con la scorta del celebre oracolo di Delfo vi proponessi in ciò il mio sentimento. Stimo dunque che la prudenza altro non sia che conoscere se stesso, non dico l'apprendere di ciò sia composto il nostro corpo, né qual essentia sia il nostro animo, ché questo a fisici non ad homini civili appartiene il riconoscere, ma il sapere a qual esercitio, incombenza e [247] fon|tioni, cadauno è inclinato e dalla natura chiamato, e parimente saper esatamente misurare l'ultimo grado della propria suficientia, accioché la temerità non più oltre ci spinga di quello conviene, e la pusilanimità a dietro non ci ritiri di quello si deve. 
make a visible light when aggregated together. ${ }^{428}$

He continued:

"Prudence must not feel disdained if I adopt it toward these virtues, which are alleged and ideal rather than genuine and real, since they must be esteemed and appreciated not because of their own importance, but [because] of their effects and profits.”

[246] Moreover, he said that according to this explication, one did not need to entrust prudence with a multiplicity of arts and disciplines in order to cause the one who professed it to be esteemed and authoritative, but that those same things expounded in the false letter sent by Reason to the Academy ${ }^{429}$ were sufficient - he stated - to cause others to view Authority as refined and majestic.

Yet nauseated by this argument, I told him that his idea of a prudent man seemed to me [to be] no different from those insane lovers who live not in themselves, but in their beloveds, as our Plato used to say. ${ }^{430}$ Likewise, this [version of a] prudent man was also dead in himself as far as doctrines and virtue were concerned, but lived only in other people's opinion through the false consideration and esteem in which they held him. According to my opinion, he would also be extremely unfortunate; indeed, I could scarcely imagine how it could be worthwhile for the most miserable merchant imaginable to appear rich and opulent, although he was poor, in order to keep his reputation. The same would undoubtedly happen to an ignorant man dressed up and disguised as a prudent one.

Yet furthermore, I could not represent how one who did not know an art could demonstrate himself to be an expert in it. How could one imitate something he had never seen or observed? How could one who did not know what a doctrine was show others that he was informed of it? How could one who had never learned any grammar convincingly pretend to be well-educated in it? How could one who had never learned rhetoric show others that he was a prolific orator?

Thrasymachus was quiet in the face of these examples. Yet instead of him, Cleinias began to say:

"As the acknowledgement of prudence is escaping you, eminent intellects, my attempt to catch it would be greatly daring, unless I proposed my opinion on this to you with the guidance of the well-known Oracle of Delphi. Well, I consider that prudence is nothing other than knowing oneself. I do not mean apprehending what our body is composed of, nor what the essence of our minds is. Indeed, to acknowledge that is the task of physicians and not laymen, while [it is the task of the latter] to know which activity, [247] task, and function every person is inclined and called to do by Nature, as well as to get an exact measurement of our self-sufficiency. This is to avoid recklessness pushing us beyond what is appropriate for us and pusillanimity holding us back from our duty.

Seventh exposition of prudence. 
Questo fu il sentimento dell'oracolo quando comette a cadauno di suoi initiati nosce te ipsum, ché per il certo colui che divenirà osservatore di tal egregio precetto, cioè che egli si giudichi puntualmente qual egli è, impossibile li riuscirà il falire. Come per il contrario comettendo in tal giuditio errore, tutto ciò che interprenderà improsperamente li sortirà".

Ma né anco Clinia parevami che nel nero colpito havesse, et in tal guisa ripigliai, che sebbene tal sua diceria dalla autorità dell'oracolo alquanto era spalegiata e protetta, io non poteva applauderla, opponendomeli che colui che pretende regger decentemente l'humani affari e massime li civili, ove maggiormente è bisogno della prudenza da noi ricercata, conviene che non solamente riconosca se medesimo, ma che anco oltremodo sia informato delle altrui conditioni. Onde il sapere ottimamente anatomizare l'animi delli homini e penetrando nelli ultimi recessi della loro mente, scuoprire ogni loro astrusità è proprio della prudenza.

A ciò replicò Clinia, che agevolmente si potrebbe con un poco di additamento rimediare alla espositione da esso addotta, cioè che la prudenza fosse una retta cognitione di se stesso, e di altrui.

Né di ciò rimasi punto satisfatto, per il che l'interrogai:

"Stimaresti forse, amicissimo Clinia, che spechio rispetto all'istesso oggetto rappresenti la medesima apparenza di imagine, benché curvo, convesso, over concavo sia?".

Rispose Clinia:

"Per il certo, non".

Repicai io:

"Così anco stimare si deve che giamai alcuno non si può aggiustatamente formalizare della apprensione e concetto altrui circa l'istesso proponimento, mentre che diversamente egli sia constituito, onde più facilmente il pazzo può indovinare il proponimento dell'altro ad esso simile, che il savio in diversa [248] dispo|sitione posto, et è molto probabile che li homini sono nell'interno delle loro cogitationi molto più che nel volto over nella voce diversi. Per tutto ciò riesce come impossibile che si possa tenere ferma cognitione della conditione dell'animo altrui, benché sinceramente si procurasse di renderlo evidente, non potendolo esporre se non con parole, non veri e propri ritratti del concetto dell'animo siccome che con l'istesse giamai non si può rappresentare l'altrui effigie.

Ma oltre di ciò qual ferma cognitione si può ottenere circa la conditione dell'animo delli homini che più che il favoloso Proteo in un subito si cangia? Il decorso della età, la mutatione della fortuna, il variare conversatione, la turbata temperatura del corpo, l'affissarsi ad uno oggetto, le nuove dottrine e studii sovente inducono stupende metamorfosi. Onde quando anco havessimo 
This is the opinion of the Oracle when she demands know thyself from each of her initiates, ${ }^{431}$ because certainly, if one observes this illustrious precept, namely by deeming himself to be precisely as he is, it will be impossible for him to fail. On the contrary, if he is mistaken in this judgment, everything he undertakes will turn out to be fruitless."

However, it seemed to me that not even Cleinias had hit the target, and I continued in the following way. Although what he had said was supported and protected by the Oracle, nevertheless, I could not applaud it. I objected that for one who supposed to properly rule human matters, and above all civil ones, in which there was much more need of the prudence we were seeking, it would be necessary not only that he knew himself, but also that he was extremely well-informed about the conditions of other people. Thus, prudence's tasks were to be able to know the anatomy of the minds of human beings, to penetrate up to the innermost recesses of their minds, and to discover their abstrusity.

Cleinias replied to this that with a small addition, he could remedy the exposition he had put forth, namely that prudence was a correct cognition of oneself and others.

Yet I was indeed not satisfied by this. Therefore, I asked him:

"Do you think, perhaps, dearest Cleinias, that a mirror, even if it is curved, convex, or concave, will always reflect the image of the same object in the same way?"

Cleinias answered:

“Certainly not."

I replied:

"Similarly one must consider that no person, as each of them is constituted differently from the others, has ever correctly conceived another person's perception and conception concerning the same resolution. Hence, a madman can more easily guess the resolution of another who is like him than that of a sage [248] who is of a different disposition. Besides, it is very probable that human beings are more different [from each other] in their internal cogitations than in their faces or voices. In respect of all of this, it is impossible to have firm cognition of the condition of another person's mind, even if one sincerely tries to make it evident. Indeed, one can only expound it in words and not in true and proper portraits of the concepts of the mind. Likewise, one can never represent another person's effigy in these same [words].

Yet in addition to this, what firm cognition may one obtain concerning the condition of a man's mind, which may change itself more quickly than the fabulous Proteus? Ageing, changes of fortune, variations of fellowship, alterations of body temperature, being focused on a single object, and new doctrines and studies often induce splendid metamorphoses. Therefore, even after having 
consumato un moggio di sale con l'amico havendo del suo animo fatta accurata disecatione, in meno di un baleno, altro e diverso da se stesso è divenuto".

In quanto poi alla cognitione di se stesso cioè di riconoscere il proprio sapere, e qualità del nostro animo ricordai a Clinia tutte l'instanze che oppugnano tale reflessiva cognitione.

Ma egli replicando disse, che in quanto quello che appartiene alla cognitione di se stesso facilmente poteva evadere le oppositioni fatteli, non ricercando egli per la fontione della prudenza una esata cognitione del nostro sapere siccome fu già da me, mentre che tutti li sapienti del secolo io agitava, e vessava, essendo tal cognitione da me indagata, piuttosto fisica che morale, ma per quello attiene alla prudenza, li bastava che al possessore di essa li fosse manifesto a che egli sia idoneo, et insino a qual grado e segno fosse valevole di arrivare, e che li sia contrastato dalla propria insuficientia l'oltrapassare in breve.

"La prudenza è quella che ci rende instrutti di quello sappiamo e di ciò che ignoramo, onde non occorre per tal mia dichiaratione addossare al prudente di tante dottrine e discipline, come che forse accaderebbe ad [249] alcune delle esplicationi già esposte”.

Non appagò al mio animo Clinia. Primieramente se l'attraversava quella instanza tante volte a satietà da me adotta, che siccome è impossibile vedere il vedere, così anco riesce inadmissibile sapere quello che si sa. Ma di più mi molestava che a mio credere molto si aviliva tal celebrata prudenza, facendola comune a qualunque homo per ignaro che fosse, perché conieturavo che giamai homo volgare et idiota, mentre che egli deliberò nel suo animo non falire, operi se non quello che a sua stima giudica che ottimo sia, ché se ciò non fosse in altra miglior maniera harebbe eseguito la sua attione, cioè conforme la miglior idea, che in sé concepisce. È ben vero che subito eseguito l'effetto con la cognitione che ritrahe dalla inspettione dell'opera, riconosce pravamente haver eseguito la sua fontione, ma perché tal nuova cognitione li perviene in un momento subito eseguito l'effetto, stima benché falsamente, che anco nel tempo dell'operare non habbia concepito altrimente, e che tenendo in sé migliore idea seguì la peggiore. Dal tutto hora divisato sortisce, che nel tempo dell'operare ognuno opera conforme l'ultimo grado e conato del suo sapere e non altrimente. 
consumed an almud ${ }^{432}$ of salt with a friend ${ }^{433}$ and thus making an accurate dissection of his mind, in less than a flash, he may become unlike and different to himself."

As far as the cognition of oneself was concerned, namely acknowledging what our knowledge and the quality of our minds were, I reminded Cleinias of all the instances which contradicted this reflexive knowledge. Yet he replied by saying that as far as the cognition of himself was concerned, he could easily avoid the objections raised against him. Indeed, he was not looking for an exact cognition of our knowledge through the function of prudence, because I had already investigated this cognition [and demonstrated it] to be physical rather than moral, thereby causing upset and irritation to all the wise men of the present time. Yet as far as prudence was concerned, it was sufficient for him that its possessor was aware of what he was capable of doing. Similarly, [it was sufficient for him to ascertain] up to what grade and point he [the possessor of prudence] was able to arrive, as well as how hindered he was by his own insufficiency from going even a little beyond it.

"Prudence is that which makes us aware of what we know and what we are ignorant of, therefore, according to my declaration, it is not necessary to attribute many doctrines and disciplines to the prudent, as would perhaps occur [249] in some of the explications already expounded."

Cleinias had not satisfied my mind. Firstly, because it was hindered by that instance that I had adduced so many times, that it is impossible to see sight just as it is not acceptable [to state that one] knows what one knows. Moreover, what was bothering me even more was that in my opinion, this so-praised prudence was very degraded in being made common to every person, even those who were unaware [of what they were ignorant of]. Indeed, I conjectured that a simple and idiotic man, if he was resolved in his mind not to fail, would always act according to what he deemed to be best. If this were not the case, he would carry out his deeds in another, better way, namely according to the best idea that he could conceive in himself. It is also true that immediately after obtaining the effect with the help of the cognition he gathered from inspecting the work, he would acknowledge having executed his function incorrectly. Yet as this new cognition would come to him very soon after he had obtained the effect, he would consider, although wrongly, that he had not conceived it otherwise even during acting, and that although he was maintaining the best idea in his mind, nevertheless, the worst had followed. From everything that we had considered now, it would turn out that while acting, every person acted according to the highest grade and attempt of his knowledge and not otherwise. 
Ottava espositione della prudenza.
A tal mio dire Clinia altro non vi aggiunse, il che mi diede segno che la vittoria alacramente mi concedeva. Si ritrovava a queste disquisitioni presente Alcibiade, di Pericle nepote, giovane di nobile indole e che nelli primi studii della humanità allora si tratteneva, il quale in questa guisa parlò, che sebbene non conveniva alla sua età in presenza di sì presentanti homini, di prudenza ragionare, e massime essendo tanto ventilata, nondimeno voleva riferire l'espositione del suo maestro Aristarco che dichiarando il principio dell'Odissea ove Omero celebra Ulisse molto pratico delli affari del mondo, pronontiò che la prudenza sia un habito d'operare conforme la ragione, cioè consigliandoci seguir le cose buone, e distolendoci dalle cattive, e che il bene consiste nel mezo virtuoso infra l'estremi vitiosi colocato, e posto, convenendo alla prudenza primieramente [250] indagare quali siano l'estremi et il mezo e doppo indurre il sensuale affetto a refiutare quello, et abbracciare questo.

La dicacità e tedio di tale descrittione da Alcibiade proposta, non solamente mi riuscì scarsa in apportare sufficiente lume alla mia inchiesta, ma piuttosto di nuovo l'obnubilò et offuscò. Primieramente non satisfece alla mia curiosità, poiché io non era tanto solecito di riconoscere ciò che sia la prudenza morale, quanto la civile e publica. Per il che tale definitone riuscì incongrua al mio principale proponimento. Repugna alla conditione della publica prudenza, di conditione facendosa e generosa, il titolo di habito, poiché questo significa una certa tenacità di dispositione acquistata per la reiteratione del medesimo atto, il che stimare si deve contrario e repugnante alla vivace civile prudenza, tutta flessibile alla mutabilità delle occasioni, versatile al vario manegio de negotii, e mutabile alla diferente qualità de persone con qual si tratta. Né peraltro li volgari virtuosi dalla morale prudenza domati, riescono per il più disaventurati che per il contumace loro habito, e non pieghevole modo del loro costume. Ma di più anco l'attribuire alla prudenza il constituire il mezo fra li estremi vitiosi parevami non convenirle. Li vitii non tengono estremità che li terminano, all'infinito si estendono, ché perciò non si ritrova il lor mezo, essendo li estremi di qualunque dimensione indici del suo mezo.

Ma di più questa mediocrità tanto affetata dalla privata prudenza, nulla o poco giudicai che fosse per giovare alla publica che il sommo solamente deve agognare, e desiare. E chi non sa che trattando con nemici è di mestiero o con somma piacevolezza accoglierli ammolendo il lor animo cangiandoli l'odio che ci tengono in amistà, overo con eccessivo rigore eccedente li termini della humanità affatto spegnerli e distrugerli? La via della mediocrità apparì sempre dannosa e nociva 
Cleinias did not add anything to my speech. This gave me a sign that he had promptly granted the victory to me. These disquisitions were being observed by Alcibiades, Pericles's nephew, a young man of a noble character who was at that time at his first studies of human nature. He spoke in this way: that although at his age it was not appropriate to argue about prudence before such distinguished men, and above all although it had already been examined so much, nevertheless, he wanted to recall the exposition of his master Aristarchus. Declaiming the beginning of the Odyssey, in which Homer celebrates Ulysses [for being] very experienced in the matters of the world, he said that prudence was a way of acting in accordance with reason, namely that it suggested that we follow good things and dissuaded us from evil ones, and that the good consisted of the virtuous middle located and set between the depraved extremes. ${ }^{434}$ Prudence should [250] first investigate what the extremes and middle were and only then induce the sensory affect to refute the former and embrace the latter.

The mordacity and nuisance of this description propounded by Alcibiades seemed to me not only unable to bring sufficient light to my inquiry, but rather to obnubilate and overshadow it again. Primarily, it did not satisfy my curiosity, because what was urging me was not to acknowledge what moral prudence was, but rather the civil and public one. Hence, this definition did not pertain to my main purpose. The condition of public prudence, which is busy and generous, would reject the title of habitus, as it means a certain obstinate disposition obtained by repetition of the same deed. This had to be considered as contrary and opposite to the lively civil prudence, which was entirely flexible to the changeability of events, versatile in the management of various businesses, and variable depending on the different qualities of the persons with whom it negotiated. However, when the virtuous common people were tamed by moral prudence, they were mostly unfortunate because of their obstinate habitus and inflexibility. Moreover, it seemed inappropriate to me to state that prudence was the medium between depraved extremes. The vices have no extremes defining them, but stretch to infinity. Therefore, it is not possible to find their middle, since the extremes of any dimension are signs of its middle.

Yet furthermore, I judged this middle way, so vaunted by private prudence, to be of little or no benefit to public [prudence], which must long and wish only for what is supreme. Besides, who would not know that in dealing with enemies, it was necessary either to welcome them with great pleasantness in order to soften their minds and change their hatred into friendship or to extinguish and demolish them with extreme severity going beyond the borders of humanity? ${ }^{435}$ The path of the middle way has always appeared damaging and harmful to the
Eighth exposition of prudence. 
a chi la calpestò accapandosi, in quella censura nec satis audet nec satis providet, così la neutralità, che per il più espone chi la segue alle ingiurie di ambe le nemiche fattioni. Ma [251] final|mente che diranno di tale esplicatione coloro che abhorendo qualunque transatione con vitii, non meno che la convalescenza nella dispositione del corpo? Non insurgerano contra tal prudenza, come quella che ci instruisce non l'assolutamente purgarsi dal vitio, ma in parte admetterlo et abbracciarlo, e di più con il nome di virtù honorarlo? Decretando questi che l'assoluto svellere e sradicare il vitio, sia il vero conato et intrapresa della virtù.

A tali ragioni si acquietò tutta la sessione, eccetto Pericle che pigliò la difesa del nepote dicendo che facilmente, in quanto questa ultima oppositione, si poteva sostenere tal espositione concedendo alla prudenza facoltà di non solamente rintuzzare li affetti vitiosi dell'animo, ma affatto esterminarli et eliminarli.

A tal scapatoio mi opposi, ché a tutti li modi non cosa di rilievo si attribuiva alla prudenza che perciò meritasse tanto di encomii e lodi, mentre che solamente si esercitasse ad abbattere e detrudere le passioni, e che non bastava ad ottimo Prencipe il distrugere li nemici, ma di più li conveniva apportare alli amici e proprii vassali alcun profitto e giovamento, come anco riuscirebbe inetto quel pedagogo che solamente emendando li discepoli li purgasse la mente de loro proprii errori e natii vitii, senza che giamai li arrecasse del suo alcuna dottrina e documento, e che parimente gran diversità si trovava fra il lavandaio che semplicemente purifica li panni da liture e macchie, et il tintore che li sugerisce vaghi e fioriti colori.

Ma di più ricercai Pericle, fautore della espositione di Aristarco, che mi dimostrasse la maniera e modo che tiene la prudenza nel scacciare e sbandire li affetti vitiosi dal nostro animo e ridurre l'apetitto ossequente alli di lei documenti. Non per modo di ragionevole discorso essendo tali affetti, e l'istesso apetitto incapaci di retta ragione! L'insani non con documenti et instruttioni, ma con le verghe si divertiscono dal mal operare. Ma se adopra la forza, con quali instrumenti et arme doma et opprime tali [252] contumaci et inossequenti vassali?

Rimanendo al mio parlare satisfatto Pericle, occorse che in quell'instante capitò a noi Anasagora per procurare favori da Pericle appresso l'Areopagiti, essendo stato di già accusato che publicamente havesse affermato che il Sole altro non fosse che pietra over ferro ignito, al quale io volgendomi li dissi: 
one who treads it, thanks to that censure neither adequate courage nor foresight. ${ }^{436}$ Similarly, most of the time, neutrality exposes the one who follows it to the insults of both the enemy factions. However, [251] lastly, what would those who abhor any agreement with vices as much as [they do] a state of convalescence in the body's disposition say to this explication? Would they not rise up against this prudence, as it was that which instructed us not to purge ourselves of vice absolutely, but to partially accept and embrace it, and moreover to honour it with the name of virtue, since they had established that the true attempt and undertaking of virtue is to uproot and eradicate vice?

These reasons appeased the whole gathering, except for Pericles, who defended his nephew by saying that one could easily support this exposition by granting prudence not only the faculty of refuting the depraved affects of the mind, but also of exterminating and eliminating them.

I denied this loophole, because in any case, prudence had never been attributed anything so relevant that it must be considered to be deserving of this much commendation and praise. Indeed, it was simply practised to defeat and destroy the passions. However, destroying his enemies would not be enough for an excellent prince, to whom, on the contrary, it would be worthwhile to benefit and support his friends and vassals. Likewise, a pedagogue who simply emended his disciples by purging their minds of mistakes and innate vices without ever providing them with any of his doctrine or teachings would turn out to be similarly inept. In the same way, there would be a great difference between a laundryman who simply purified the clothes of spots and marks and a dyer who supplied them with delightful and floral colours.

Moreover, I asked Pericles, a supporter of Aristarchus's exposition, to demonstrate to me prudence's way and manner of expelling and banishing depraved affects from our minds and of making the appetite obedient to its teachings. Not by way of rational discourse, as these affects and the appetite itself are incapable of right reason! Insane people will be diverted from acting wrongly not by means of teachings and instructions, but by being beaten. However, if it used force, then with what instruments and weapons would it tame and oppress such [252] obstinate and disobedient vassals?

Pericles was satisfied by my speech, and in the same instant, Anaxagoras came across us, seeking to obtain Pericles's favour among the Areopagites as he had earlier been accused of having publically stated that the sun was nothing other than a stone or a [piece of] red-hot metal. Then, I addressed him and told him: 
"O quanto meglio, amico Anasagora, ti sarebbe riuscito che il vigore del tuo ingegno impiegato havessi in riconoscere la conditione delli humani affari divenendo possessore, e cultore della prudenza, che intraprendere l'investigatione del sole, corpo tanto lontano da noi et inattinente a nostri impieghi. Eppure altra volta fui da te ripreso che io a vane dispute mi applicassi tutto dedito a debelare sofisti e demolire l'aerie machine dalla loro vanità erette. E sebbene nel mondo sei invechiato per anco non tieni osservato quanto più agevole sia lasciarsi dalla corrente acqua trasportare overo contra il suo flusso ascendere. La natura non applicò giamai li agenti se non a patienti disposti et ossequenti, né agricoltore giamai a caso gettò seme se prima non osservasse la natura e conditione del terreno a che egli sia idoneo, il frumento richiede una qualità, et il miglio un'altra. Ma voi homini sapienti nel communicare al mondo vostri libri e dottrine non teniate rispetto né consideratione alcuna alla conditione delli lettori et auditori, per il che incapace in travagliosi casi come hora a te accade".

\section{$\mathrm{Al}$ che rispose:}

"Non inconsiderata curiosità mi distrasse dall'impiego d'humane emergentie, e mi dedicò alla speculatione delle cose sublimi, ma l'osservare l'incertezza, vacilatione, vicissitudine e flutuante contigenza delle cose humane mi intruse in tali contemplationi e dottrine. E che di certo poteva io conieturare nelli nostri affari, havendo questi per efficiente la nostra volontà, solamente constante nelle alterationi [253] e varietà, et il forsenato caso ben spesso per guida e reggente? E la esperienza mi ha dimostrato che sovente la prudenza ad altro non vale che a infracidire l'animo et infievolire il suo vigore facendolo pieghevole, e perciò debole a sostener il peso de gran negotii. Simile in ciò la prudenza all'argento vivo che rendendo flessibili li più consistenti e saldi metalli e perciò habili ad esser lavorati et a molti usi idonei, nondimeno rintuzza in essi il lor naturale robore e forze, così appunto accade a questa che sebbene formi l'animo humano snodato e manieroso a trattare qualunque negotio, e maneggiare ogni qualità di homini, sapendo non solo patientare, ma anco secondare qualsivoglia costume e humore, tuttavia enerva e consterna li suoi cultori di siffatto modo che nelle attioni spiritose e generose al si sotto della mediocrità freddamente si diportano, rimanendoli sopiti quelli primi e naturali semi che incontrando in opportune occasioni havrebbero prodotto meravigliosi e stupendi effetti.

E perciò tali prudenti si possono assomigliare al vino alquanto inacetito, che né come vino alimenta, né come aceto condisce, così questi né a guisa di huomini valorosissimi sono habili al comando, né a modo di volgari pronti all'obedire et eseguire. Per tale discorso et esprimento praticato circa le cose humane, deliberai per trattenere l'otio della vita, applicarmi alla indagine della natura e massime alla cognitione de corpi celesti inalterabili nella loro essentia, e constanti ne loro motti”. 
"Dear Anaxagoras, instead of undertaking to investigate the sun, a body so far away from us and not relevant to our purposes, it would have been much better for you to apply the vigour of your intellect to acknowledging the conditions of human matters by becoming a possessor and estimator of prudence. Yet last time, you reprimanded me that I was applying myself to vain disputes fully devoted to destroying sophists and demolishing the aery machinations raised by their vanity. Besides, although you have aged in this world, you still did not notice that it is easier to let oneself be carried away by the water's flow than to advance upstream. Nature has always made agents apply only on well-disposed and obedient patients. ${ }^{437}$ Likewise, a farmer never sows any seed by chance, but he [always] first observes whether the nature and condition of the land are suitable for it; indeed, wheat needs a specific quality, while millet [needs] another one. Yet you, wise men when communicating your books and doctrines to the world, do not respect or take into account the condition of your readers and audience; therefore, [you turn out to be] incompetent in many difficult cases, as is now happening to you.”

\section{Hence, he answered:}

"It was not rash curiosity which distracted me from the pursuit of human occurrences and [convinced me] to devote myself to speculation on sublime things, but rather my observation of the uncertainty, vacillation, vicissitudes, and wavering contingency of human things that pushed me to these contemplations and doctrines. Furthermore, what could I conjecture that was certain concerning our matters, since they have our will as an efficient cause, which is constant only in alterations [253] and varieties, and very often mad Chance as a guide and ruler? Besides, experience has demonstrated to me that often prudence is only useful for causing the mind to rot and weakening its vigour by making it pliant and thus [too] weak to bear the weight of great issues. Prudence is like quicksilver in this respect, ${ }^{438}$ in that it makes the most solid and stable metals flexible so that they can be wrought and be made suitable for many uses and [also] restrains their natural forces and strengths. The same is the case for this [i.e., prudence], which, although it makes the human mind bendable and ductile in dealing with issues or handling human qualities by learning not only to be patient, but also to go along with any custom or state of mind, it nevertheless discourages and dismays its estimators in such a way that they place themselves coldly below the average concerning courageous and generous actions. Indeed, those original and natural seeds, which would have produced marvellous and splendid effects on the appropriate occasions, are lying dormant in them.

"Thus, these prudent ones can be considered to be like wine once it has become rather sour, as it can neither be drunk as wine nor season as vinegar. Similarly, they are neither able to command like the most valorous men nor are they ready to obey and execute like common people. Because of this discourse and experimentation practised on human things, in order to maintain a life of leisure, I decided to apply myself to investigating Nature, and particularly the cognition of the heavenly bodies, as they are inalterable in their essence and constant in their motions." 


\section{Al che soggionsi:}

"Giacché scorgo che de fatti humani sei oltremodo informato, desidero da te conseguire alcuno documento circa la prudenza cotanto decantata appresso l'homini, se realmente si trova et esistente sia, o piuttosto annoverare si deve fra le favolose larve e poetiche fintioni, nome non meno di oggetto che di concetto privo".

\section{Et egli a me:}

"Circa [254] essa prudenza altro dire non ti saprei, se non che sebbene da molti con divini encomii sia celebrata, io altro di essa giudico, se non che sia fra le arti divinatrici la meno mendace, e che fra aruspici, auguri, auspici, giuditiarii, matematici, geomantici e hidromantici, nel conieturare il futuro tenga il primo loco, non allontanandomi in tal credenza da Omero, che volendo rappresentare la prestanza dell'augure Calcante, pare che di prudenza lo comendasse:

Tum cunctis toto reticentibus ordine, solus

Calchas taestorides longe celeberrimus augur

Quaque nunc fierent, quae ventura tenebat,

Omero Liber I. Idem qui caneretque dudum facta fuissent.

Loda Calcante di prevedere le cose venture, ma imperò indrizzato dalle cognitioni delli avenimenti presenti e passati, eppur al di sopra di celebratissimo augure non lo soleva”.

Di più seguì Anassagora che:

"Se tu, Socrate, stimi che il caso come vuole Democrito il tutto agita, grande temerità cometterebbe la prudenza, mentre pretendesse presaggire ciò che per l'avenire fosse per disporre il pazzo et insano caso. Ma se l'ordine delle cose da decreti della Divina Mente dipendono (com'io credo) e che già una fiatta sia constituita e terminata la riuscita del tutto ch'è per seguire, ogni conato della prudenza in opporsi à ciò, riesce vano e ridicolo. Onde con il prevedere gli urgenti avenimenti che ci soprastano, nulla si può provedere. E seppure la humana prudenza s'infrapone ancor essa nella serie et incatenamento delle cause, le conviene senza alcuna renitenza permettersi al transporto della altrui condotta, seguendo piuttosto alacramente il corso delle cause moventi, che con affetto renitente e repugnante presumere resisterle, seppur l'istesso affetto non è anco esso dall'altrui forza mosso e guidato, mentre che falsamente crede contrastare con chi più puô”.

Qui hebbe fine la discussione praticata da me circa l'humana [255] prudenza. Per il che conieturai che non meno la cognitione de' nostri proprii affari, che l'apprensione delli esterni et alieni oggetti ci sia 


\section{Hence, I continued:}

"As I realise that you are very well-informed about human matters, I wish you to teach me whether prudence, so praised among human beings, really exists or rather whether it must be included among fabulous spectres and poetical illusions because it is a name lacking both object and concept.”

And he [said] to me:

"Concerning [254] prudence, I cannot say anything else except that although many people have celebrated it with divine commendations, nevertheless, I deem it the least mendacious of the divinatory arts, and it is at the forefront of conjecturing the future among haruspices, ${ }^{439}$ augurs, ${ }^{440}$ auspices, ${ }^{441}$ judicial astrologists, ${ }^{442}$ mathematicians, ${ }^{443}$ geomantics, ${ }^{444}$ and hydromantics. ${ }^{445}$ Concerning this belief, I am not distant from Homer, who, in wishing to represent the skill of the augur Calchas, ${ }^{446}$ seemed to commend him for his prudence:

\section{Among them rose}

Up Calchas, son of Thestor, far the best of diviners,

Who had knowledge of all things that were, and that were to be, and

That had been before. ${ }^{447}$

"He praises Calchas for predicting future events, but although he maintained his unquestioned authority guided by his cognition of present and past events, nevertheless, he rated him no more highly than a celebrated augur."

\section{Anaxagoras furthermore continued:}

"If you, Socrates, consider that according to Democritus, Chance agitates the whole, then prudence would be enacting a great temerity if it supposed to predict what mad and insane Chance intended to dispose in the future. Yet if the order of things (as I believe) depends on the decrees of the Divine Mind, [then] the whole of what is going to happen has already been successfully made and completed once before, [and] therefore prudence's every attempt to oppose this will turn out to be vain and ridiculous. Therefore, [even if prudence] predicts the imminent events hanging over us, we cannot take action. Besides, even if human prudence comes between the series and concatenations of things, it should nevertheless rely on the guidance of others without resistance; namely, [it should] promptly follow the course of the driving causes, instead of presuming to resist them with a reluctant and opposing affect, were it not for the fact that the affect itself is moved and led by another force, while it wrongly believes that it is opposing it as much as it can."

Here ended the discussion that I addressed to human [255] prudence. Hence, I conjectured that we had been as prevented from obtaining cognition of our own matters as we had from apprehending external and 
impedita, e che il tutto con folta tenebre di ignoranza si trova ingombrato.

Qui sortì il fine e meta del mio lungo e travaglioso viaggiare, et approdò la mia stanca et affaticata mente, occorendomi quello suole accadere a viandante che ricco da casa sua partendosi, essendo nel viaggio svaligiato, nel fine del suo camino meschino è divenuto. Così io nel principio del mio divagamento opulente di molte dottrine mi stimavo, e havendo intrapreso di nuovo viaggiare per maggiormente farne acquisto per l'incorso d'huomini prestantissimi, affatto spogliato d'ogni sapere fui, onde nel fine del mio mentale camino meschino e tapino, mi ritrovo d'ogni sapere privo. Né di ciò punto mi attristo e doglio, essendomi per tal iattura e perdita liberato dal timore che continuamente mi infestava, il dubbio che tenivo, che l'oblivione sorititiamente mi furasse tal pregiato tesoro. Ma hora ritrovandosi il mio animo posto in libertà non più come prima con tanta ansiosa cultura me stesso travaglio, et invece che per il passato con circonspetta timidità alli assalti di captiosi sofisti mi esponeva, hora con risoluta alacrità a combattere con essi m'offerisco, non temendo di riportarne da essi perdita alcuna, rassomigliandomi a quel mendico, che incontrandosi in rapaci ladroni punto non si smarisce, ma sicuro per la sua povertà verso loro danza e festegia:

Iuvenal. Cantabit vacuus coram latrone viator.

Insomma la messe che tengo raccolto da sì lunga e laboriosa disquisitione circa l'humano sapere fu, che egli s'assomiglia ad una bene intesa scenografica pittura, e che conforme alli precetti della prospetiva sia egregiamente scorciata, ché ingannando la vista, come se fosse una profonda lontananza apparisce, ma avicinandosele riesce piana superficie [256].

In tale stato ritrovandomi affetto circa la cognitione della verità, risoluto di sospendere e retenire il mio assenso né a caso dispensarlo, sortì nel mio animo non lieve dubbio circa il propalare tale mia hesitantia e perplesità. E ciò fu, che essendo sempre stato mio instituto, indrizzare ogni mia attione al comune et universale bene del mio genere mi posi a considerare se fosse profitevole partito il publicamente discreditare il nostro preteso sapere, manifestando le sue difalte e mancanze, over che sia piuttosto all'humano genere giovevole mantenerlo in lena e concetto, perché non sempre la scoperta verità con il commodo nostro s'incontra et aggiusta, anzi siccome la nudità a nostri corpi non conviene sebbene che li loro membri con ogni maggior maestria siano stati dalla miglior natura construtti, così anco sovente indecente riesce, che la verità priva di addobamenti fra l'homini volgari apparisca. 
foreign objects, and that everything was occupied by the dense obscurity of ignorance. This was the end and goal of my long and difficult journey, and my fatigued and exhausted mind had arrived at this point. There had occurred to me that which usually happens to a wayfarer who was rich when he left his home, yet became poor by the end of his road following a robbery during the journey. Likewise, at the beginning of my digression, I considered myself rich in many doctrines, but once I undertook a new journey to acquire more of them by coming across very skilful men, I was stripped of all knowledge. Hence, poor and miserable at the end of my mental path, I found myself lacking in all knowledge. Yet this did not sadden me at all and I did not regret it, because thanks to this misfortune and loss, I had freed myself from the fear that was continuously haunting [my mind]: namely, the doubt I had had that oblivion would surreptitiously steal this precious treasure. However, as my mind was now released, I was not troubling myself with as much restless culture as before. Furthermore, while in the past, with cautious timidity, I had exposed myself to the sophists' assaults, now I promptly offered myself to fight them. Indeed, I was not worried about my losses, since I was like a mendicant who does not feel dismayed by encountering a rapacious thief, but on the contrary, dances and celebrates as his poverty makes him feel secure: ${ }^{448}$

So, the harvest of such a long and laborious disquisition concerning human knowledge was that it resembled a scenographic painting which displays an excellent illustration of the rules of perspective. Therefore, it deceives the eyesight by appearing as though it has depth from a distance, but as soon as one comes closer, it turns out to have a flat surface.

[256] Once I had found myself in this state concerning the cognition of the truth, convinced to suspend and withhold my assent and not to dispense it by chance, I began to have some doubts about whether to spread my hesitation and perplexity. Thus, as it was always my principle to direct all my actions in favour of the common and universal good of humankind, I began to consider whether it would be a profitable decision to publicly discredit our alleged knowledge by showing its mistakes and deficiencies, or rather whether it would be beneficial for humankind to hold it in high esteem, because disclosing the truth does not always fit or adjust it to our interests. Just as nudity is not appropriate for our bodies although their members were masterly constructed by excellent Nature, so often it turns out to be indecent that the truth should appear to vulgar people without any orna- 
Eccellenza dell'homo contemplativo.

Ovidio Met.
E come il diamante più di notte che al chiaro scintila e barlumi, nell'istessa guisa la verità fra le tenebre di misterii, e simboli più risplende. Sarei per liberarmi da tal dubbio all'oracolo occorso, ma essendomi interdetto l'importunarlo se prima tentato non havessi la comune sapienza delli homini che dalla cortese e libera mano d'Iddio li fu dispensato. Presi espediente alli savii del secolo ricorrere e capitare, ricercando il loro parere se il palesare l'imbecilità del nostro sapere sia al volgo delli homini giovevole, overo nocivo.

Accadé nell'istesso tempo che Hippia in Atene dimorasse, homo celebre per il possesso di varia dottrina, onde conferitoli tutto quello che mi occorse circa l'esame da me instituito circa l'humano sapere, lo richiesi se giudicava convenevole il propalare la fiachezza del nostro intendimento. Al che Hippia in tal guisa rispose:

"Per il certo, o Socrate, attenti di oltremodo rendere l'homo a se stesso rincrescevole e molesto, quando lo privassi della openione e concetto che egli tiene circa il pregio del proprio sapere, unica [257] sua consolatione fra tante altre calamità et angoscie, che continuamente l'affligono. Et al sicuro fra tutti li altri animali, sortirebbe il più miserabile, quando che con l'ali della speculatione lungi da questa ima sentina, e vile cloaca non si solevasse, et a cieli sormontando insino all'altura et eminentia della primiera e più nobile causa non pogiasse. Onde poi con generosa despicientia abhorendo l'angusto recinto della sua abietta, o per dire meglio fetida carcere, con il mezo della sua acre contemplatione contrahe famigliarità con li più nobili enti che l'universo adornano. Né per il certo per altro fine dalla più efficace causa fu eretto l'homo con la facia al cielo, se non per eccitarlo al vaghegiare quelli splendenti e lucidi globi, che sono non meno lumieri a nostri andamenti, che ossequenti ministri di chi li guida e ravolve:

Pronaque cum spectent animalia caetera terram Os hominis in sublime, dedit coelumque videre Iussit, et erectos ad sydera tollerentur vultus.

Fu posto l'homo nel mezo di questo gran teatro come giudice a cui incomba con il suo mirabile ingegno determinare nobilissimi quesiti, e svelare profondi arcani: se nel primordio di questa universale construttione, si ritrovava materia pregna d'infiniti e repugnanti embrioni, e ch'alla fine annoiata di portare in seno tal conflitante mescuglio, primieramente diformi et inesistenti aborti pro- 
ment. ${ }^{450}$ Besides, just as a diamond sparkles and twinkles more in the night than in the daylight, so the truth shines among the darkness of mysteries and symbols. I would have gone to the Oracle in order to free myself from such doubt, but I had been forbidden to bother her before having first tested the common wisdom of human beings which was dispensed by the free and generous hand of God. I had now found the way to address and appeal to the sages of the day in looking for their opinion on whether it would be beneficial or harmful to the masses to show the weakness of our knowledge.

At that time, Hippias, a man renowned for his extensive doctrine, was dwelling in Athens. Therefore, after having told him all that had occurred to me concerning the examination of human knowledge that I had instituted, I asked him whether he judged it worthwhile to broadcast the weakness of our understanding. Hence, Hippias answered in such a way:

"Certainly, Socrates, you would succeed in making man extremely unpleasant and annoying to himself if you deprived him of the opinion and concept that he holds concerning the worth of his own knowledge. Indeed, it is the only [257] consolation he has among the many adversities and anguishes which continuously torment him. Besides, he would surely turn out to be the most miserable of all the animals if he did not raise himself on the wings of speculation far above this low bilge and mean cloaca to surmount the heavens and come to rest on the height and eminence of the first and most noble cause. Thus, then with generous disfavour, abhorring the narrow enclosure of his despicable - or, better to say, fetid - prison, he becomes acquainted with the noblest beings adorning the universe by means of his incisive contemplation. Certainly, man was raised with his face to heaven by the most effective cause for no other reason than to incite him to long for those splendid and polished globes. They are both lights for our development and obedient ministers for the one who guides them and causes them to rotate.

And, though all other animals are prone, and

Fix their gaze upon the earth, he gave to man an uplifted face and

Bade him stand erect and turn his eyes to heaven..$^{451}$

"In the midst of this great theatre, man was placed as a judge with the task of determining the noblest questions thanks to his admirable intellect, as well as that of disclosing deep arcana. However, if [we admit that] at the dawn of this universal construction there was a matter pregnant with infinite and opposite embryos that finally became tired of carrying such a conflicting mixture in its breast, and thus first produced deformed and non-viable entities, then, as it
The excellence of the contemplative man.

Ovid Metamorphoses. 


\section{Lucretius Liber V.}

dusse, non potendo poi tale incongrue sconciature, et assorde progenie continuare,

\section{Multaque cum tellus etiam portenta creare} Conatast, mira facie, membrisque coorta

Androgynum, neutrum, inter utrunque ab utroque remotum, etc. Multaque tum interiisse animantum secla necesse est Nec potuisse propagando procedere prolem.

Ma alla fine essa materia havendo la necessità per ostetrice, sortirno li suoi parti nel modo che hor si trovano; overo conviene pronontiare, che al detto chaos assistesse mentre del bono e bello capace, che per la di lei virtù e scientia fosse distribuita in guisa tale, che ad un tratto ne sortì l'ottima dispositione delle cose, per cui l'universo ci si rende ornato et admirabile; o piuttosto riesce ragionevole che da causa efficiente non [258] sola|mente di sapienza e bontà, ma d'infinita potenza dottata, il tutto assolutamente sortì e derivò, non essendo maggiormente impossibile il creare il tutto dal niente, che dare legge a quella materia, che essendo eterna, possiede il suo essere e constitutione da necessità ad essa interna, e da niuno dependente.

A noi homini mediante la speculatione della nostra mente parimente appartiene definire se quattro sono li anziani elementi, incorottibili et inalterabili, dal qual vario mescolamento procede la diversità di tante spetii d'enti, overo piuttosto si rende probabile, che la prima intrapresa del maggiore efficiente fu, la conditura di varii e minutissimi semi che poi sparsi per tutto l'ambito del mondo, sopra li quali come invariabili principii, e fondamenti, la natura quotidianamente si esercita, e giornalmente erige li suoi temporanei edifitii, overo rassembra più credibile, che si trova certa tale materia di ogni attuale forma priva, ma tutta idonea a ricevere, o per meglio dire con vicendevole alternatione transformarsi, e come licentiosa meretrice hora abbracia l'una forma, e hora detrudendo e regettandola, altra accoglie.

Ma non solamente a tali disquisitioni è dalla sua energia chiamata la nostra mente, ma di più dal proprio talento è impulsata a spatiare con il discorso insino l'essere sempre eterno, inalterabile, et imutabile, e sebbene questo interminato oggetto interdetto sia a qualunque intelletto affatto apprenderlo, nondimeno non l'è impedito tenuamente assagiarne, lambendo piuttosto, che penetrandovi, satolarsene, e più facilmente riconoscere ciò che quella sublime essentia abhorisce seco mescolarsi, che riconoscere quello che se l'addati, onde in tal affare più s'assomigliamo a scultore che scalpella e recide l'incongruo, che pittore che con il penello colori apporti, et aggiunga. 
could not give continuity to these incongruous deformities and absurd progenies -

Many were the portents also that the earth then tried to make, Springing up with wondrous appearance and frame: the

Hermaphrodite, between man and woman yet neither, different From both, etc. ${ }^{452}$

Lucretius bk. 5.

And many species of animals must have perished at that time, Unable by procreation to forge out the chain of posterity. ${ }^{453}$

"Yet in the end, this matter, with necessity as its midwife, gave birth to what can now be found in the world. Therefore, it is appropriate to say that it was present during the aforementioned chaos, the container of goodness and beauty, which were shared out thanks to its virtue and knowledge; and suddenly the perfect disposition of things, whereby the universe appears decorated and admirable to us, emerged from it. Or rather, it is reasonable [to state] that the whole emerged and was derived from an efficient cause [258] absolutely endowed not only with wisdom and goodness, but also with infinite power, as to create the whole from nothing is no more impossible than to rule that matter which, as it is eternal, has a being and constitution ruled by an inner necessity and is dependent on no one else.

"Similarly, to us, as human beings, belongs [the task] of defining whether the primal elements, incorruptible and inalterable, are four [in number] through our mental speculation. The diversity of many species of beings is drawn from their various mixtures; or rather, it is probable that the first undertaking of the major efficient [cause] was the preparation of various very minute seeds [which were] then scattered all over the world. Nature works and raises its temporary constructions on them every day, as its invariable principles and foundations. Alternatively, it seems to be more believable that there is a certain matter lacking in any actual form, but entirely suitable to receive it, or better to say, to transform itself in alternation; namely, like a licentious meretrix, it first embraces one form and then receives another after having detruded and rejected the previous one.

"Our minds are called by their own energy not only to these disquisitions, but also by their own talent for letting their discourse wander through the everlasting, inalterable, and unchangeable being. Besides, although every intellect is indeed forbidden to apprehend this infinite object, nevertheless, it is not prevented from tenuously tasting it, lightly brushing it rather than penetrating it and becoming satiated. Furthermore, it is easier to acknowledge what that sublime essence abhors to mix with than to acknowledge what is suitable for it. Therefore, as far as it is concerned, we are more like a sculptor who chisels and cuts off the incongruous parts than a painter who adds colour with a paintbrush. 
Profitti che si trahe dalla speculatione delle cose mondane.

Da Iddio.

Profitti che si trahe dalle speculationi de cieli.
L'istessa nostra mentre intraprende l'indagare, se quel felice ente primiera causa del tutto, doppo che sugerì al mondo l'esser, e lo provide di tutto quello li fu di mestiero, si ritirasse e ristrinse a se medesimo [259] vagheggiando se stesso, non ritrovando alcuno oggetto fuori di lui che adequare possa alla capacità della sua intelligenza, non rimanendo perciò in certo modo di non apprendere tutto quello che fuori di lui esiste, ritenendo appo sé le radici e fondamenti di tutto il creato, overo è meglio dire che vibrando fuori di sé li raggi della sua Providenza non sdegni rimirare ciò che gratiosamente già una fiatta produsse e formò.

Al nostro giuditio soggiace riconoscere, se la serie delle cose mondane sia una decretata constituitione di concatenata successione di cause, con la quale ordinatione non ci lece accozzare, e tenzonare, overo piuttosto stimare si deve, che sia lasciato loco alla contingenza, per il che sia permesso alla nostra prudenza sciegliere il bene che le aggrada, et evitare il male che l'offende. Con tali e simili esercitii trattenimo il corso di nostra vita, che non ci si renda per tante altre sciagure noioso. E di più si difendiamo dal rodimento del vorace tempo che affatto non ci estingua, raccomandando la reliquie della nostra memoria alla seguente, et indefinente età, riuscendoci ciò molto più avantagioso, che la rimembranza del semplice nostro nome, overo dell'effigie del nostro volto in duro et insensibile marmo scolpito, overo della continuatione della sovente degenere nostra prole, procurandoci la sempiternità con la vera idea et imagine del nostro animo di mirabili dottrine ornata, e non in materia insensata, ma in animo a noi simile vivo et animato impressa.

Ma anco quando la fama che si tenga di noi doppo la nostra morte nulla ci importasse, nondimeno non pochi sono li documenti che da tali speculationi per l'uso della nostra vita ne trahemo. Principalmente dall'apprendere che quella sublime causa senza alcun proponimento e fine di ricompensa e retribuitione il tutto produsse, et in ottima maniera construsse, e tuttavia conserva e regge, sono li homini eccitati e massime li maggiormente aggiati et opulenti, a socorrere li bisognosi, benché affatto fossero privi di speme di premio e [260] remu|neratione.

Dalla speculatione de motti celesti apprese l'humana prudenza l'ottima administratione della republica, havendo osservato da essi, che la retta ragione di Stato non deve solamente oggettare la publica utilità, e rigorosamente ricercare da ministri del governo l'esato comune profitto, ma con moderata conivenza lasciare che mediocremente appouechiano al loro privato avantagio, essendosi sempre osservato che la esata et esquisita procuratione del ben publico, riuscì 
"The mind itself undertakes to investigate whether that fortunate being, the first cause of the whole, has retired and withdrawn into itself [259] for self-contemplation after having supplied the world with being and providing it with all that was necessary for it. As it did not find any object outside itself that could match the possibilities of its intelligence, and as there was somehow nothing left outside it to be apprehended, it holds the roots and foundations of the whole of creation in itself, or better to say that in letting the rays of its Providence vibrate outside itself, it does not disdain to look at what it once gracefully produced and formed.

"It is the task of our judgment to acknowledge whether the series of mundane things is an established constitution of a concatenated sequence of causes, which we should neither collide with nor struggle against, or rather that one must consider that it has allowed space for contingency and therefore that our prudence has been allowed to choose the good that pleases us and avoid the evil that hurts us. Through these and similar exercises, we manage the course of our lives so as to make it not hateful to us because of its many other misfortunes. Moreover, by entrusting the relics of our memory to the endless years to come, we defend ourselves from the erosion [made by] voracious time, so that it does not indeed extinguish us. This turns out to be much more advantageous for us than the simple memory of our names or effigies of our faces sculpted in hard and insensitive marble, or the continuation of our oft-degenerated offspring. Therefore, we provide ourselves with sempiternity through the true idea and image of our minds, decorated with admirable doctrines, impressed not on insensitive matter, but on a mind which, like us, is living and animated.

"Yet even if we do not care about our fame after death, nevertheless, there are many lessons we may draw from these speculations on our life's purpose. Firstly, by learning that the sublime cause produced everything and optimally constructed it, [and that although it did this] without the purpose or final goal of being rewarded and remunerated it nevertheless preserves and rules it, human beings, especially the most wealthy and opulent, are spurred to help the needy without having any hope of receiving reward or [260] remuneration.

"From speculation on heavenly motions, human prudence has learned the best way to administrate the republic. Indeed, through them, it has observed that the fair reason of state must not only take the public utility into account and rigorously demand the requested common profit from the government ministers, ${ }^{454}$ but that it must also allow them to take something for their own advantage with moderate connivance. Indeed, it has always been observed that the exact and thorough administration of the public good turns out to be a
Advantages one gathers from speculation on the mundane things.

From God.

Advantages one gathers from speculation on the heavens. 
seminario di contese, archivo di discordie, promptuario d'ingiurie fra cittadini, e scaturigini di attraversamenti di più importanti affari, essendo il ben proprio quasi sempre il vehicolo et incentivo dell'universal profitto. Tale instruttione dico, da motti celesti agevolmente fu delibata, e riconosciuta, che conspirando tutti li orbi sublimi nel motto diurno da oriente all'occidente, motto universale e comune a tutti li ministri celesti, nondimeno tolera il primo e generale impulsore, che qualunque di essi tenga il suo motto proprio e contrario all'universale, dall'occidente in oriente, e con andamenti suoi particolari e proprii diversi dalli altri di lui compagni, il che accade senza alcuno sconcio e sconcerto dell'universale sistema.

Ma di più è notabile, che l'orbi che si trovano più vicini al primo mobile, che impulsa li suoi inferiori al motto universale dall'oriente all'occidente, con più tardo passo il loro motto speciale e contrario, dall'occidente in oriente, eseguiscono. Ma li più remoti da esso, e maggiormente inferiori con più vehemenza, e celerità al loro proprio camino incombono. Nobile documento, che quelli che più principi si avicinano, e che maggiormente nelle republiche al sommo si accostano, devono con più tardo e lento passo a loro particolari interessi incaminarsi, e che perciò alla plebe che affatto nell'estremo lontano da sommi reggenti è posta nulla disdice se affatto a suoi individuali profitti si impiega senza punto curarsi del publico [261] et universale bene.

Così la Terra il più basso e fecioso elemento sublunare, non tiene altra natura che con moto retto diverso affatto dal circolare celeste al centro piombare.

Ci amaestrano parimente li cieli et instruiscono che quattro modi di governi sono: il primo ottimo, il secondo buono, il terzo cativo, il quarto pessimo. Alcun orbe sopra il proprio centro irregolarmente, ma circa quello dell'universo, ordinatamente si move. Tal è il governo di Principe che più agevolmente si desidera che si trova, che anteponendo il publico profitto de popoli al di suo proprio gira con le sue attioni decentemente sopra il centro dell'universal bene, ancorché ridonda in alcun suo proprio dispendio e detrimento.

Seconda maniera di motto è di quelli orbi che il centro sopra il qual si ravolgono è loro proprio, et anco comune con l'universo. In tal guisa si ravolgono il primo mobile, e le stelle fisse. Così fortunati sono quelli Stati che il centro del loro interesse incontra et è l'istesso con quello del Prencipe che li regge. 
ground for sowing disputes, an archive of discords, a storage place for citizens' insults, and a source of opposition concerning the most important matters, because one's own good is almost always the means and incentive for universal profit. From the heavenly motions, I say, the following instruction has been easily examined and acknowledged: although every day all the sublime orbs move together from Orient to Occident in accordance with a universal motion common to all heavenly ministers, nevertheless, the first and general mover allows each of them to keep its own motion, even if it is contrary to the universal one, namely from Occident to Orient, and likewise [they may keep] their own particular course that is different from those of their other companions. This happens without any concern or disconcertion to the universal system.

"However, it is even more remarkable that the orbs which are closer to the first mover, which propels its inferiors in the universal motion from Orient to Occident, carry out their special and contrary motion from Occident to Orient more slowly [than the others], yet those that are very remote from it or inferior follow their own paths faster and more vehemently. This is a noble lesson for those who approach princes and the heads of the republic: namely, they must head for their particular interests more slowly and unhurriedly. Thus, the plebians, who are at the other extreme, far from the supreme rulers, do not protest against anything that indeed concords with their own individual profits, not remotely caring about the public [261] and universal good. Similarly, the earth, as it is the lowest and most feculent sublunary element, according to its nature can only sink into the middle, following a rectilinear motion different from the heavenly circular one.

"The heavens likewise teach and instruct us that there are four forms of governance: the first is excellent, the second is good, the third is bad, and the fourth is awful. Some orbs move irregularly around their own centre while they move around that of the universe in an orderly fashion. The prince's governance that is most easily desired is such that by putting the public profit above his own, he appropriately guides his deeds to the centre of the universal good, and moreover even exceeds himself by consuming himself and wearing himself out.

"The second manner of motion pertains to those orbs which revolve around a centre that is both their own and shared with the universe. Both the first mover and the fixed stars revolve in this way. Those states whose centre of interest matches that of the prince who rules them and is even the same [as it] are very fortunate. 
Profitti dalli cieli in particolare.
Terzo modo si movono quelli orbi che regolatamente sopra al proprio centro, ma irregolarmente sopra il centro dell'universo, a questi sono simili li tiranni, che sempre circolando sopra il punto del loro interesse non mirano punto a quello del publico e de loro vassali.

Quarta guisa sono li orbi che né sopra il loro centro, né sopra quello dell'universo ordinatamente si movono, ma circa un centro diverso di certo orbe fititio, equante appellato regolarmente si ravolgono. Tali appunto sono quelli inaveduti, e malamente avisati imperanti, che né sopra il centro del proprio profitto, né circa quello del publico bene si ragirano, ma sì bene intorno quello de loro consiglieri e privati circolando, indrizzano ad esso disordinate attioni, riuscendo non meno a se stessi, che a loro vassali dannevoli e nocivi.

Ci sugeriscono li cieli anco altro documento, che essendo le stelle fisse una moltitudine quasi innumerabile, tutte si movono con uniforme traino e camino, ma li pianeti principali ministri della natura, hora retrogradi, hora accelerati, e hora stationarii appariscono, come anco alle fiatte [262] vicini, et alle volte lontani dalla Terra si ritrovano, egregio insegnamento al politico governo, che siccome la numerosa turba di vassalli deve osservare leggi eguali, et uniformi, così alli principali ministri del governo et agenti di gran affari, è concesso deviare dal comune sentiero et ordinarii decreti per mantenimento dello stato universale.

Dal regimento celeste si apprende, che siccome le stelle conforme il parere di alcuni savii, solamente con il motto e luce, e non con altri influssi assistono al governo del mondo sublunare, cosi li prencipi con il lume della loro prudenza, e motto della vigilante et efficace esecutione devono reggere i loro suditi, et acquistarne la benevolenza, non già con la profusione de tesori conseguire il loro ossequio, et obedienza. Ma siccome dall'universal moto e viaggiare di corpi celesti non poche instruttioni sortiscono per amaestramento della vita civile, così dalla particolar inspettione circa tali corpi e loro andamenti molte osservationi a pro nostro ne potiamo delibare e rapportare.

Li famosi congressi del Sole e della Luna ci sugeriscono non dispregiabili advertimenti. La Luna riceve la luce dal Sole e mentre che si trova vicino ad esso in congiuntione laterale, non solo non ecclissa il Sole, ma anco conseguisce alcun lume benché a noi invisibile, ma quando s'interpone diametralmente fra noi et esso Sole apporta ecclisse a questo, e la facia di essa a noi rivolta affato rimane oscura. Documento a grandi e favoriti de Principi, che sebbene si li accostano, approsimansi a loro Signori, in modo che rimangano essi in parte 
"The third manner is that of those orbs which move regularly around their own centre, but [move] irregularly around the centre of the universe: tyrants, who always revolve around their own interests without paying any attention to the public ones or those of their vassals, are like this.

"The fourth manner is that of orbs which do not move in an orderly way either around their own centre or around that of the universe, but only rotate around an alternative centre, that of a certain fictitious orb called the equant. ${ }^{455}$ Those rash and incautious rulers who revolve neither around their own profit nor the public good are like this. On the contrary, they gravitate towards that of their own counsellors and individuals and address disorderly actions to it that turn out to be as harmful and detrimental to themselves as to their vassals.

"The heavens also provide us with another lesson, namely that since the fixed stars are an innumerable multitude, they all follow their paths and ways in a uniform manner, while the principal planets, as ministers of Nature, sometimes appear to be moving backwards, sometimes accelerated and sometimes stationary, and sometimes near the earth [262] and sometimes far from it. This is an excellent lesson for political governance: just as the numerous crowd of vassals must observe equal and uniform laws, so the principal ministers of governance and agents in great affairs are allowed to deviate from the common path and ordinary decrees for the preservation of the universal state.

"From heavenly governance, one learns that just as the stars - according to the opinion of some sages - assist the governance of the sublunary world only through motion and light and not by influencing it in other ways, so princes must rule their subjects and gain their benevolence through the light of their prudence and the vigilant and effective execution of their actions, not by trying to earn their reverence and obedience through a profusion of treasures. Yet just as there results no small amount of instruction for the education of civil life from the universal motion and path of the heavenly bodies, so from the particular inspection of these bodies and their courses, we can sample and relate many observations to our own advantage.

"The famous conjunctions of the sun and moon put forth valuable warnings. The moon receives light from the sun, and when it is close to it in a lateral conjunction, not only does it not eclipse the sun, but it also produces some light even though it is not visible to us. Yet when it is diametrically placed between us and the sun, it eclipses the latter while the face of the moon that is towards us indeed darkens. A lesson for the greats and favourites of the princes is that although they draw near to the princes, nevertheless, they must approach their lords in such a way that they should respectfully stand apart [from the prince]

Advantages from the heavens in particular. 
riguardevoli e li dominanti con loro decoro e maestà conspicui, ma levandoli la reciproca veduta mettendosi fra imperanti e suditi, si ecclissa il governo e riesce il tutto ottenebrato e confuso. Dalli istessi congressi si apprende che siccome la Luna quando che nella maggior lontananza che può essere dal Sole discosta è tutta luminosa e rassembra un ritratto di esso, ma mentre [263] che si li avicina depone il suo splendore, e nella congiuntione con esso rimane come invisibile, così anco li ministri e rapresentanti de Principi mentre si trovano in governi di eserciti, legationi appo Principi stranieri, et adminstrationi di provincie remote, conviene che con ogni pompa e decoro possibile, rappresentino l'absente maestà de loro Signori, ma mentre che sono alla loro presenza divenuti, depongano ogni fasto e grandezza, e che a vita privata si riducano.

Di più ci amaestra l'istessi viaggiamenti del Sole e Luna, essere vero non solamente nel corpo humano, ma nel civile ancora, quel detto del nostro celebre vecchio Hippocrate, che la natura in noi sta sempre in moto e progresso over regresso, e giunti che siamo al sommo della sanità subito essa retrocede: In exercitantibus boni habitus ad summum progressio periculosi sunt si in extremo fuerint, non nam manere possunt in eodem, neque quiescere. Quum vero non quiescant non amplius in melius augescere possunt, reliquum est igitur et ut in deterius. Così anco aviene nelli favori de Principi che giunto che sia alcuno all'ultimo suo grado, non havendo più il Principe ciò che dare né il privato ciò che desiderare, subito cominciano a decrescere la gratia nell'uno, e l'ossequio nell'altro. Anzi come doppo la maggior luce della Luna, subito diminuisce, e nella esata oppositione al Sole, ritrovandosi puntualmente nella ecclitica ad esso diretta, per la interpositione della Terra le accade deliquio et oscurità, così sovente nel maggior grado di gratia che favorito si trova, per l'incorsione di altro suo emulo fra esso, et il Prencipe, rimane egli privo di honore et autorità.

$\mathrm{Ci}$ insegnano anco l'andamenti di tali pianeti che chi semina ingiurie, raccoglie messe di offese, e che anco all'inferiore non li è denegato provedere vendetta al suo maggiore. La Luna è assai inferiore della Terra in trigesima sesta proportione, questa ponendosi tra quella et il Sole l'impedisce la luce, e la rende corpo oscuro. L'istessa Luna vendicandosi di ciò alle fiatte [264] metten|dosi tra la Terra, et il Sole, la priva della veduta di esso, et impedisce, che non riceva li influssi de suoi prolifici, e benigni raggi. 
while their superiors [should be] visible to all with their decorum and majesty. However, if they impede their view of each other by placing themselves between the rulers and the subjects, then the governance will be eclipsed and everything will be clouded and unclear. From the same conjunctions, one may learn that the moon is entirely bright and appears to be a likeness of the sun when it is in the farthest position from it, but when it [263] comes nearer, it loses its splendour, as well as being invisible when they are in conjunction. Likewise, the ministers and representatives of princes should represent the absent majesty of their lords with as much pomp and decorum as possible when they govern armies and legations among foreign princes and administrate remote provinces, yet as soon as they are in their presence, it is necessary that they set aside every splendour and grandeur, taking on the role of a private individual.

"Furthermore, the same movements of the sun and moon teach us that that saying of our renowned old Hippocrates is true not only for the human body, but also for the civil one. Indeed, [he taught that] Nature [is] always in motion in us, as much in progress as in regression, but that once we arrive at the peak of our health, this is immediately reversed: In athletes a perfect condition that is at its highest pitch is treacherous. Such conditions cannot remain the same or be at rest, and, change for the better being impossible, the only possible change is for the worse. ${ }^{456}$ Similarly, this happens as far as the favours of princes are concerned: indeed, as soon as someone has achieved the highest position and the prince has nothing more to give and the private individual nothing to wish, immediately both the former's benevolence and the latter's obedience begin to be reversed. Furthermore, after its brightest moment, the moon's light immediately decreases when it is exactly opposite the sun, perfectly on its ecliptic; indeed, the interposition of the earth makes it vanish and darken. Likewise, it often happens that a favourite, once [he has] achieved the highest grade of benevolence, then remains without honour and authority because of the intrusion of someone else, who emulates him, between him and the prince.

"The movement of these planets teaches us furthermore that whosoever sows affronts gathers a harvest of offences, and [that] even an inferior is allowed to take revenge against his superior. When it [i. e., the earth] is placed between the moon and the sun, since the moon is considerably smaller than the earth, namely thirty-six times in proportion to it, the earth hinders the moon from receiving light by making it a dark body. Then the moon itself sometimes takes revenge for this by placing itself [264] ${ }^{457}$ between the earth and the sun so that it deprives it [i.e., the earth] of the view of the sun and prevents it from receiving the influence of its prolific and benign rays. 
Profitti che si trahe dalla contemplatione delle cose sublunari.
Né dalla regione sublunare mancano l'instruttioni ad erudire la civile prudenza, onde principiando dalla Terra nostra altrice, essa sospesa, e pendola nel mezo, sopra il centro dell'universo si sostiene. La cagione ch'in tal sito si mantenga comunemente si dice che sia, overo perché egualmente da tutti li lati del cielo è attratta, overo respinta, e perciò nel suo posto si conserva. Documento a mediocri Stati che oltra modo sicuri s'attrovano stando situati fra Principi molto più di loro potenti, mentre che questi siano di forze eguali et equilibrate, e siccome la Terra al volo di una mosca d'un loco di essa ad altro movendosi, variandosi perciò il centro della gravità, si ripone essa di nuovo in equilibrio, nell'istesso modo chi di minori forze si trova proveduto, nel mezo si rimetta, acciocché acostandosi ad uno lato più che all'altro, non sia da questo per la distanza abbondonato e dall'altro affatto attratto et oppresso.

L'acqua parimente sostenendo il lieve e somergendo il ponderoso, ci arreca notabile documento, che gli ingegni gravi e constanti amici della sincera verità, dalla flutatione del mondo sovente sono tirati al basso e s'affogano, ma li sventati et aerii non di rado emergendo, al sommo delle cose sono portati e solevati, avanzandosi li homini, più con l'apparente, che con l'essentiale.

Laria medesimamente ci sugerisce altro non inutile essempio, cioè che riceve dalle viscere della terra alle fiatte vapori pregni di fecondi influssi, e hora maligne esalationi, di impetuosi venti e horribili folgori gravide. Così aviene fra noi homini che alcune volte si solevano al sublime delle dignità alcuni che procurano emendare la difalta del loro nascimento con l'esercitio delle virtù, onde ottimi ne loro governi riescono, e sovente altri volendo vendicarsi delle ingiurie ricevute con molta offesa dell'universale, satiano il loro maligno genio e pessimo talento. Onde quasi sempre quelli che sono oscuramente nati e poi solevati, riescono all'estremo buoni, overo [265] pravi, renuntiando alla mediocrità e transatione della virtù con il vitio.

Il fuoco medesimamente ci dimostra, che non quel stato che ci apparisce di lontano splendido e bello sia accompagnato di quel bene che si stima il maggiore. La fiamma del fuoco fra tutte le mondane cose forse alla vista, è la più vaga, ma avicinandosele è la maggiormente tormentosa e dolorifica, ché se ciò fosse comunemente osservato, meno homini infarfalati fra noi si trovarebbero che volando a tal apparente lume, non solo se li accorciano le ale della lor fortuna, ma sovente, perdendovi anco la vita, s'inceneriscono. Si 
"Even from the sublunary region, one may gather instructions for educating civil prudence. Therefore, we may begin with the earth, our nourisher, which is suspended and dangling in the middle, self-sustaining at the centre of the universe. It is commonly said that the reason that it is sustained here is that it is equally attracted and repelled by all sides of the heavens and so preserves itself in its position. This is a lesson for the middle states, which are extremely secure, with their equitable and balanced forces, in being placed among princes much more powerful than them. Because of the flight of a single fly from one of its locations to another, the earth moves and changes its centre of gravity, then places itself in balance once more. In the same way, the weakest should stay in the middle and not nearer to one side than another, so that they will not be abandoned by the latter because of the distance, or indeed attracted and oppressed by the former.

"Likewise, water, in supporting a light thing and submerging a heavy one, supplies us with a remarkable lesson: that grave and stable intellects, as they are friends of the sincere truth, are often pulled down by the wavering of the world and then drowned, while the rash and aery ones not infrequently emerge and are raised and carried up to the peak of things. Indeed, human beings advance thanks more to the apparent than to the essential. ${ }^{458}$

"The air similarly supplies us with another useful example, namely that the earth sometimes sends it a vapour full of fecund influences and at other times malign emissions full of impetuous winds and horrifying lightning. This is also the case when we human beings try to emend our simple origins by raising ourselves up to the sublime dignity through exercising virtue and becoming excellent in our governance. Yet often others vindicate themselves for their received offences by satisfying their malign genius and worst desires to the great detriment of the whole. Therefore, those who have unknown origins and then achieve higher positions almost always turn out to be either extremely good or [265] [extremely] evil by renouncing the middle way and a compromise between virtue and vice.

"Similarly, fire demonstrates to us that that which appears to us to be splendid and beautiful from afar does not show what may be considered the greatest good. A fire's flame is perhaps the most beautiful thing to see of all the mundane things, but as soon as one approaches it, it turns out to be the most tormenting and painful. If this was commonly taken into account, there would be fewer people among us who would be mistaken in the same way as moths, who fly towards an apparent light and end up not only shortening the wings of their fortune, but often losing their lives through incineration. Moreover, one
Advantages gathered from the contemplation of sublunary things. 
advertisce di più circa l'istesso fuoco, che la di lui fiamma mentre è visibile non si può spicare e solevarsi da quella vil materia che l'alimenta, ma rilasciandola invisibile divenendo, si soleva alla sua sublime regione, e senza detrimento, e nutrimento emulo de cieli si ravolge e si conserva inalterabile. Il che instruire ci dovrebbe che quando sarà che l'animo nostro, rilasciarà et abbandonarà la corporale spoglia, da noi affatto sparendo, pervenire debba a loco tranquillo e sereno, et esso di ogni turbatione immune e libero esisterà.

Dal continuo litigio e contrasto delli elementi che l'uno con l'altro esercita, apprendiamo che la conservatione et augumento della republica dipende piuttosto da temperata e moderata discordia, che da tepida pace, e neghitosa quiete, poiché dall'altercatione sortisce l'emulatione, e garegiamento delle virtù fra cittadini. Onde per il contrario l'esquisita unione amorza li spiriti più generosi in alcuni, e rende più baldanzosi li maggiormente arditi all'offesa de privati, et espilatione del publico. E siccome detti elementi solamente nelle loro estremità contendono, rimanendo illesi nelle portioni più interne, così anco non può fare che fra Principi appo li confini non avenga alcuna tenzone, e sortita, restando sempre fermo, et inalterato il sodo et essentiale del Stato.

Constituì medesimamente la natura che li elementi parti [266] mag|giori del mondo sublunare perseverino sempre inalterabili, ma che li minuti misti in continua vicissitudine e cangiamenti si travagliassero. Così parimente vuole la bona politica che li grandi e per lunga serie di natali potenti, che non decadano dalla loro sublime conditione, acciò non tengano occassione et impulso, per riparare il loro cadente stato, di movere turbolenze e seditioni:

Ma per il contrario pare che sia giovevole che fra la gente volgare sia l'alteratione di ricchezze e cangiamento di loro stato, ché in tal maniera si mantengono vive le speranze de poveri, e dalla fortuna abbatutti che al miglior stato privato, e non al publico aspirino, e di più si rintuzza l'orgoglio di più opulenti che alla maggior potenza non agognino. Di più, s'advertisce nelle operationi della natura la destrità che pratica et osserva nell'accrescere le piante et animali eseguendo ciò insensibilmente et in corso, rispetto alla loro età, di longhissimo tempo, ma nel destrugerli, ci adopera prestezza e celerità, corpora lente augescunt, cito extinguuntur. Il che serve ad ottimo consiglio a grandi, che nel solevare li suoi favoriti devono lentamente procedere, e non ad un tratto colmarli con la maggior dignità, essendo sovente più riverita la dubbiosa speranza che 
may notice in the fire itself that when its flame is visible, it cannot be separated or raised from that vile matter which nourishes it, yet as soon as it releases it [i. e., the flame], it becomes invisible and rises up to the highest region without damage or advantage, and in imitation of the heavens, it spins around itself and keeps itself unalterable. This should teach us that when our soul ${ }^{459}$ leaves and abandons our bodily remains, departing from us, it will come to a calm and serene place where it will exist freely and immune to every disturbance.

"From the continuous quarrel and conflict of the elements with one another, we learn that the preservation and advancement of the republic depends rather on temperate and moderate disagreement than on tepid peace and indolent rest. The reason for this is that dispute causes the citizens to vie and compete with each other to see who can be the most virtuous. Therefore, on the contrary, a thorough union sometimes dampens the most generous spirits and makes the most daring ones more self-confident in damaging the private [citizens] and robbing the public. Furthermore, just as only the extremities of the aforementioned elements fight while the most internal portions remain unharmed, so also conflict and sortie between princes at borders cannot be avoided by allowing the foundation and essence of the state to remain always stable and unchanged.

"Nature established that the elements [266] [which constitute] most of the parts of the sublunary world always remain unchangeable, while the mixed and tiny particles are troubled by continuous vicissitudes and changes. Similarly, good politics requires that those who have been great and powerful for many generations do not fall from their sublime condition, so as not to have the opportunity and impulse to cause tumults and seditions in order to remedy their decline:

Hence came devouring usury and interest that looks greedily to the day of Payment; credit was shattered, and many found their profit in war. ${ }^{460}$

"Yet on the contrary, among the common people it seems to be useful for there to be alterations of wealth and changes in their state. The reason for this is that in this way, the hopes of the poor are kept alive: as they are made despondent by their fortunes, they wish for better private conditions and not public [positions]. Furthermore, it dampens the pride of the most opulent people so that they do not yearn for greater power. Moreover, among Nature's operations, one may observe the ability it practises and follows in allowing plants and animals to grow, as it carries this out imperceptibly and over a very long time according to their age, while it is fast and rapid in destroying them; the body itself is slow to grow and quick to decay. ${ }^{461}$ This is very good advice for the great ones, who must proceed slowly in advancing their favourites rather than suddenly presenting them with lavish rewards, because people often revere an uncertain hope more 
riconosciuta la certa benificientia, e sono maggiormente ampliate dalla imaginatione li beni venturi, che per anco non sono, che li presenti dalla reale esistentia oltremodo impiccioliti. Ma per il contrario l'abbattere et opprimere altrui, ad un colpo si deve eseguire, in modo che la lentezza non li porga aviso e sugerisce occasione di evitarlo, e forse anco regettarlo sopra l'oppressore.

Dall'advertire che fra le cose naturali, giamai non si trova cosa affatto semplice, e di [267] una sincera et incomposta conditione, e l'istessi nostri volgari elementi di alcuno mescuglio sono construtti, onde qualunque metallo ha della scoria, et alimento dell'escremento, e liquore del fecioso, onde l'homo prudente deve patientare se alcuno al possibile humanato tenga alquanto portioncella di ferità, e che le egregie virtù si associano alle fiatte con enormi vitii. $\mathrm{E}$ siccome che nelli misti mentre la forma principale di essi signoregia, rimangono ascose, et occulte le portioni escrimentitie, ma emergono et apriscono quando la si deprava, così li vitii con le virtù inestati, alterandosi il stato dell'homo, per la lusuriante, overo oppugnante fortuna, si rendono evidenti e manifesti.

Ma per il certo mirabile osservatione è quella che si trahe dal modo che tiene la natura quando intraprende la dissolutione del misto che volgarmente putrefattione si appella, il che in tal guisa eseguisce. Ė il suo calore che mantiene il misto unito, e che rende disposti li suoi integranti all'ossequio della forma dominante. Attenta la natura per servirsi ad altro uso della materia di tal misto, con il calore esterno che lo circonda lambire l'interno di lui, e l'alletta et invita ad uscire et abbandonar il misto, onde perciò dissolvendosi affatto lo disfa e demolisce.

Come quando per il contrario in esso vuole conservarlo, adopera il freddo, che con l'antiperistasi riconcentra il natio calore, in modo che reprima l'interna seditione, imponendo alle tumultuarie portioni del misto che siano alla dominante forma uniti e concordi. L'istesso apunto accade a Stati che tengono confini con più potenti di eguali costumi e consuetudini, che facilmente per la conformità di usi, attragono l'animi di popoli ad essi prossimi e li seducono ad abbandonare li propri loro Principi et ad essi assogettarsi. Ma essendo vicini a gente di diverse leggi et instituti, tanto più si rinfrancono, et al loro naturale Signori si uniscono. 
than they acknowledge a certain beneficence. Indeed, future goods, which do not even exist yet, are much expanded by the imagination, while present ones are made much smaller by their real existence. Yet on the contrary, others must be defeated and oppressed with a single blow, in order that a slow reaction does not offer them advice, suggest them opportunities to avoid it, or perhaps even send it back against their oppressor.

"Then I realised that one would indeed never find any simple thing [267] with a sincere and uncomposite condition among the natural things, and [I also realised] that our common elements themselves were made of a mixture [of several things]. Therefore, just as in any metal there is also slag, in any nourishment some waste materials, and in any liquid some discharged matter, then [I concluded that] a prudent person must also tolerate that a person may still have some small amount of brutality, albeit he is as civilized as he can be, and that excellent virtues are sometimes connected to some wicked vices. As far as the mixed [bodies] are concerned, the main form of them predominates, while the discharged portions remain hidden and concealed, but they emerge and appear as soon as it is corrupted. Likewise, although the vices are grafted into the virtues, nevertheless, they become evident and manifest once a man's state becomes altered by a propitious or adverse fortune.

"Certainly, one admirable observed rule is that which may be gathered from the way in which Nature undertakes the dissolution of a mixed [body], commonly called putrefaction, which is carried out in this way: indeed, it is heat that maintains a mixed [body] in a joined state and disposes its integral parts in accordance with the dominant form. In order to use the matter of this mixed [body] for other purposes, Nature attempts, through the surrounding external heat, to lightly touch the inner part of it so as to entice and invite it to leave and abandon the mixed [body]. Thus, as it is in decay, it decomposes and demolishes it.

"However, when it wishes to preserve it, it uses cold, which, according to antiperistasis, ${ }^{462}$ gathers the original heat in order to repress the internal sedition so as to force the tumultuous parts of the mixed [body] to remain joined and in agreement with the dominant form. The same indeed happens to states which border on others with the same customs and consuetudes, but which are more powerful. Thanks to their similar habits, the latter easily attract the spirits of people close to them and seduce them to abandon their own princes, as well as to bow to their will, yet when they are close to people with different rules and institutions, then they are much stronger and more united with their natural lords. 
Profitti che s'estrahe dalla speculatione del sistema humano.
Non fu parimente scarsa in sugerirci alcuno documento civile, la naturale constitutione del nostro humano sistema: tre sono le officine e sortite [268] principali della nostra vita. Il fegato distribuisce il sangue per mezo di vene per alimentare il nostro corpo. Il cuore sparge per la condotta delle inquiete arterie il sangue vitale a tutti li membri. Il celebro per mezo di nervi infonde il senso e moto per tutto il nostro ambito. A questo obediscono per mezo di muscoli l'ossi, principal nostro robore, e fortezza. E la saggia natura talmente dispose le vene, arterie, nervi, che sempre insieme uniti si trovano, dipendendo la vita nostra da tale società.

Così parimente il corpo politico tiene tre fonti da cui scaturisce il suo mantenimento. La copia di vetovaglie simile al fegato per conservare la moltitudine quieta e pacifica, annona pelexere. L'erario il cuore che sparge quel sangue spiritoso del danaro, che si distribuisce per mantenimento del Stato, et in particolare nella soldatesca et in altri adminicoli del governo, milites donis allicere. E l'archivo delli consigli, stratageme, arcani dell'imperare, e publici provedimenti, è quello che a guisa di celebro dà il moto a tutta la machina. Onde mentre che questi tre membri principali si trovano concordi, felice riesce la civile construtione, e sanissimo il corpo politico.

Di più dall'edifitio del nostro corpo si advertisce altro amaestramento di Stato, cioè che la sagace natura fra li più duri e vicini ossi, che al continuo motto sono destinati, pose flessibile e pieghevole cartilagine, ché se altrimente operato havesse, per il perseverante motto si attritarebbero e frangerebbero. Così parimente conviene a Stati potenti se in pace e quiete vogliono perseverare, che fra essi alcuno Stato debole, e di minor forze sia posto, acciocché destramente ceda alli soliti insulti che fra vicini e confinanti accader sogliono, rimanendo quelli illesi et inoffesi. Ma troppo lungo sarei a raccogliere tutte l'instruttioni che la prudenza civile dalla speculatione della natura prese e delibò, lasciando hora anco a parte l'amaestramenti che la medicina, agricultura, navigatione, edificatoria, tessetrice, et altre arti e professioni dall'istessa natura appresero et impararno, non vergognandoci di confessarci [269] disci|plinati da alcuni vili et abietti animali.

$\grave{E}$ ben vero che se non come il bombice che trahe dalle sue proprie viscere la nobile seta, siamo affatto inventori delle arti, tuttavia non s'assomigliamo alle formiche che semplicemente aggregano la loro raccolta, ma a guisa di api che da fiori pigliando la dolce rugiada nelle loro fauci migliorandola le porgono 
"The natural constitution of our human system has likewise not been scarce in providing us with some civil teachings: indeed, there are three main laboratories and outlets [268] of our lives. The liver distributes the blood through the veins in order to nourish our bodies. The heart spreads the blood to all the members through the ducts of the restless arteries. The brain, by means of nerves, introduces sense and motion throughout our [bodies], and the bones, as they are our main strength and fortitude, obey it by means of the muscles. Furthermore, wise Nature has disposed the veins, arteries, and nerves to be permanently joined together, since our lives depend on this society.

"Similarly, the political body has three sources of maintenance. [Firstly,] an abundance of provisions, like the liver, to keep the crowd calm and peaceful, [the populace] conciliated by corn. [Secondly,] the treasury is the heart, which spreads the spirited blood, that is to say money, which is shared out for the maintenance of the state, and especially for the army and other instruments of governance, to entice the army by gratuities. ${ }^{463}$ [Thirdly,] furthermore, the archive of advice, stratagems, arcana of reigning, and public interventions corresponds to that which puts the whole machine in motion, like the brain. Thus, if these three main members agree, the civil construction turns out to be successful and the political body very healthy.

"Moreover, from the structure of our body, one may observe another lesson for the state, namely that sagacious Nature has put a flexible and pliant cartilage between the hardest and most proximal bones, which are designed for continuous motion. Indeed, if it had worked otherwise, they would exhaust and smash themselves from perseverant motion. Similarly, if powerful states wish to persevere in peace and quiet, they should put a weak and less powerful state between them, so that the latter will cleverly surrender to the usual attacks that those who are close and neighbouring to each other are in the habit of making, while the former will remain unharmed and unhurt. However, I would be taking too long if I were to collect all the instructions taken and sampled by civil prudence from speculating on Nature. [Therefore,] I will now also leave aside the lessons that medicine, agriculture, navigation, [the art of] building, [the art of] weaving, and other arts and professions have apprehended and learned from Nature itself, without feeling ashamed to confess [269] that we have been disciplined by vile and abject animals.

"Although it is true that we are not inventors of arts - unlike the silkworm, which obtains the noble silk from its own viscera - nevertheless, we do not resemble ants, which simply aggregate what they collect, but rather bees. Just as they indeed take the sweet dew from flowers and improve it in their jaws,
Advantages gathered from speculation on the human system. 


\section{S'apprende la giustitia.}

\footnotetext{
S'apprende la temperanza.
}

l'ultimo condimento e perfettione, così dalla natura instrutta la nostra mente di molte osservationi, a miglior uso sono digeste et ordinate.

Ma questo basta circa l'humana prudenza. E siccome a questa abbondò la natura di ottimi precetti, così alle altre virtù non fu scarsa. L'istessa insegnoci l'administratione della giustitia distributiva e comutativa. La prima ci fu offerta dall'osservare la proportionata partitione ch'esercita la terra nell'alimentare le piante, et il ventricolo nel nutrire le portioni del nostro corpo tanto diferenti. Homogenea aparisce la terra, e similare il ventricolo. Tuttavia questo distribuisce a nervi, vene, arterie, ossi, cartilagini, ligamenti, tendini, membrane e carne l'alimento loro spetiale et appropriato, e quella offerisce a piante di repugnanti qualità dottate il suo assignato nutrimento, non confondendo punto che quello ad una appartiene all'altra distribuirlo. Onde dall'istessa terra attrahe il frumento, l'aconito, e napello, documento a Prencipi a non promiscuamente scialaquare, et a caso gettare li beni che li furno posti in loro balia, ma giuditiosamente dividerli: ad alcuni ricchezze, ad altri apparenti honori, et ad altri sopraintendenza et autorità compartire, et in somma il tutto conforme il genio, e capacità di cadauno distribuire.

Così anco la giustitia comutativa dalla istruttione della istessa natura fu appresa. Nella regione sublunare essercita essa un decreto universale, che qualunque misto doppo certo tempo da essa constituito, debba restituire alli comuni elementi tutto quello che gratuitamente li fu imprestato et impartito. Dal che impararno tutti li legislatori come base de' loro decreti, che senza rispetto di età, dignità, e di autorità, caduno deve restituire tutto quello che d'altrui tiene. La moderatione delle nostre passioni da progressi della migliore natura fu osservata, ché [270] sebbene essa natura può la sua prole molto aggrandire, e che tenga incentivi all'infinito estendere le sue attioni, non deficiendole la virtù né mancandole la materia, nondimeno impone moderata meta alle sue operationi.

Né poco giova all'animo nostro per renderlo forte a tolerare li colpi di fortuna, l'osservare non esservi portione dell'universo che alle fiatte non rimanga offesa. È travagliata la terra dal mare e sovente è assalita et ingoiata, $\mathrm{e}$ da esalationi over da incendii nelle parti nitrose di essa è scossa e sconvolta. Il mare da coluvione di terreni da fiumi apportati è occupato et oppresso. L'aria da impetuosi venti è infestata, e non di rado da pestilenti haliti è vessata, il Sole si ecclissa, e la Luna patisce deliquio, e li cieli conforma la più evidente ragione da infauste comete sono strisciati e sfregiati. Onde l'homo prudente di tutto ciò 
giving it the finest seasoning and perfection, so the mind is instructed by Nature with many observations, but they are then set out and disposed for a better purpose.

"Yet this is enough about human prudence. Nature has as great an abundance of excellent precepts concerning this as it does concerning the other virtues. It has taught us the administration of distributive and commutative justice. We received the former by observing the proportionate distribution the earth makes in feeding plants, just as the ventricle nourishes very different parts of our bodies. The earth appears consistent, and so, likewise, is the ventricle. The latter gives nerves, veins, arteries, bones, cartilage, ligaments, tendons, membranes, and flesh their special and appropriate nourishment, and the former supplies plants endowed with opposing qualities with the nourishment that they require without any confusion in distributing to one what pertains to the other. Therefore, [the fact that] wheat, aconitum, and napellus are all drawn from the same earth should teach princes not to promiscuously squander the goods that have been placed at their mercy or give them out at random, ${ }^{464}$ but to judiciously share them out: riches to some people, apparent honours to others, and superintendence and authority to still others, and in short, to distribute everything according to each person's disposition and capacity.

"Similarly, we have learned commutative justice from the teaching of Nature itself. It brings a universal law to the sublunary region, namely that any mixed [body], after a certain period of time that it [i.e., Nature] establishes, must give everything that was freely lent and assigned to it back to the common elements. From this, all rulers may learn as a foundation of their decrees that without considering age, dignity, or authority, each person must return everything that he has received from others. We maintain the moderation of our passions from the development of this excellent Nature: indeed, although Nature can [270] considerably increase its offspring and has an incentive to extend its actions indefinitely, since it is lacking neither in virtue nor in matter, it nevertheless imposes moderate goals on its operations.

"In order to strengthen our minds in tolerating the adversities of fortune, it is also worth noting that every part of the universe is sometimes struck [by the adversities of fortune]. The earth is tormented by the sea and often assailed and swallowed [by it], and it is shaken and upset by emissions of fire in its nitrous regions. The sea is occupied and oppressed by clusters of soil brought by rivers. The air is infested by impetuous winds and frequently oppressed by pestilential breezes, the sun is eclipsed, the moon swoons, ${ }^{465}$ and the heavens, according to the most evident reason, are streaked and slashed by unfavourable comets.

Temperance is apprehended. 
conscio, non li conviene né anco sospirare delle sciagure che l'incontrano, e sempre nella mente tenere fisso il detto del poeta:

Muoiono le città, muoion li Regni, Et l'homo di esser mortal par che si sdegni.

E per il certo colui, che havendo advertito l'inevitabile corso delle cause, e concatenata serie della fatalità, et invece di renderli ossequio con volontariamente seguirle, e vuole piuttosto esserne strascinato, è meritevole, che per pena della sua tergiversatione che con noie volontarie e continovate esiga da se medesmo il congruo suo castigo.

E senza dubbio che il considerare la caducità universale del mondo sublunare, rende l'homo dispregiatore della vita, e poco curante della imminente morte, che per servigio della patria seguire li debba. Cangia facia il mondo, muoiono e rinascano le cose in esso contenute, per servigio nostro, et un homo individuo e particolar spetattore di tali metamorfosi, ricuserà per servigio della patria perdere la vita e socombere alla morte? La [271] su|perbia et alterigia parto della humanità per il certo rimane fiaca, e rintuzzata dal considerare et osservare l'ampiezza di cieli, e vera grandezza delle stelle, divenendo conscia che l'ambito della Terra rispetto alli antedetti, riesce per la sua minimità a guisa di insensibile grano d'arena.

Sormonti l'homo con il discorso del suo intendimento alla sommità del più eminente cielo e scorga il globo terrestre e mira l'homini che il calpestano, che appena li rassembrino minutissime formiche che sopra esso s'affacendano, e che contendono per il possesso d'insensibile fragmento di grano, che per il certo questo tale che aventuroso fu di cotanto solevarsi, rattenere non si potrà, verso tale reclamare:

'O forsenata turba, o insana caterva questa piciolissima gleba, il cui maggior spatio occupa il mare, ingombra li tumori di sterili montagne, tengono vessato inculti selve, e paludosi laghi e regioni deserte, o per il rigore d'implacabile freddo o per l'ardore di fervente caldo infestano; parvi sia degno premio a tanti vostri faticosi esercitii, e che merita, che con il ferro, e foco ve l'usurpate? Onde aviene che per il cui acquisto, della humanità vostro proprio possesso vi private? Rassembravi decente che quella dispositione d'ingegno che dalla somma liberalità della superiore causa vi fu donata a fine che l'animo vostro riesca ornato et abbelito di egregia dottrina, impiegarlo in ignominia del vostro genere, et in detrimento dell'humana società? Ma siate certi che anco ottenute le vostre intraprese, altro non conseguirete ch'esporvi alla rapacità di più potenti, odio di eguali, et invidia d'inferiori, non dovendovi alla fine della nostra vita, l'amassamento di vostre immoderate richezze arrecarvi altro che 
Thus, a prudent person aware of all of this should not even sigh because of the misfortunes he comes across, and should always keep in mind the saying of the poet:

So dies each city, so each realm declines, And mortal man to see it sighs and pines. ${ }^{466}$

"Certainly, anyone who becomes aware of the inevitable course of causes and concatenate series of fatality and wishes rather to be dragged by them instead of obeying them by willingly following them deserves to expect adequate chastisement from himself through his willing and continuous sorrows as punishment for his tergiversation.

"Undoubtedly, considering the universal caducity of the sublunary world makes man a despiser of life and little caring about the imminent death to which he is destined in serving his homeland. The world changes its face, the things contained within it die and are born again to serve us, and why should a singular and particular man, as a spectator of these metamorphoses, refuse to lose his life and die serving his homeland? ${ }^{467}$ [271] Pride and arrogance, which are humanity's offspring, will certainly remain weak and held back from considering and observing the largeness of the heavens and the actual size of the stars, which would make them aware that the range of the earth, in comparison with the above-mentioned ones, is like an insensible grain of sand because of its smallness. ${ }^{468}$

"As soon as a person, with his rational faculty, reaches the summit of the most eminent heaven, sees the globe, and watches the other people walking on it, then they will appear to him to be barely the tiniest ant $\mathrm{s}^{469}$ bustling about on it and competing [with each other] to take possession of an imperceptible fragment of grain. Certainly, this person who was so adventurous as to raise himself to such a height would not restrain himself from addressing such a complaint to them:

'Oh mad crowd, oh insane horde, this tiny clod of earth, whereof the main space is occupied by the sea, is encumbered by the reliefs of sterile mountains, vexed by wild woods, swampy lakes, and desert regions, and infested either by the severity of implacable cold or by the ardour of fervent heat. Does it seem to you [to be] worthy of many of your strenuous exercises or to deserve that you usurp it with fire and sword? Hence, does it happen that you deprive yourself of your own humanity in order to acquire it? As the intellect's disposition has been granted to you by the supreme liberality of the superior cause, in order to decorate and embellish your mind with excellent doctrine, does it seem appropriate to you to use it to dishonour humankind and to the detriment of human society? However, you must be sure that even once your endeavours are accomplished, you will attain nothing other than to be exposed to the rapacity of the most powerful people, the hatred of their equals, and the envy of their inferiors. Indeed, the clustering of your immoderate wealth may cause you nothing other than 
impacio e vessatione d'animo apportandovi maggior molestia la distributione delle pravamente raccolte opulentie, che l'iminente e minuto comparto, che si deve fare del vostro composito, non sapendo ove le maggiormente essentiali portioni di esso capitare devono, et a qual loco siano destinate.

Ma di più se all'altura antedetta giammai si solevò con il suo mirabile ingegno [272] De|mocrito che fu delle humane insanie destro schernitore, crederei che al suo solito ismascelasse scorgendo che quello acervo di formiche stimasse che le vastissime ruote celesti, e li splendidi corpi in esse inserti con indefessi et aceleratissimi rivolgimenti anhelassero per apportare a quello lume e vitali influssi e che il Sole ch'eccede conforme l'opinione più moderna quattro mille volte incirca la Terra, giornalmente con tanta velocità si rivolve, per illuminare li formicaii che qui a basso sono, e con altro contrario et annuale moto dall'occidente all'oriente, circolando per arrecare alli istessi varietà di stagioni e diversa temperatura d'aria. E meno assordo egli giudicarebbe, che se vile et infarinato toparello stimasse, che l'edificio del molino, il girare di ruote, l'influsso continuo dell'acqua, l'assistenza del mugnaio, fossero destinati per renderli più agevole e macinato il cibo.

Non rimane però che se giamai tali formiconi cacciassero fuori l'ale, e che con il valore del loro intelletto al pari di lui alla regione celeste sormontassero, il di lui sbefegiamento in admiratione si cangiarebbe, e ben degni li reputarebbe che sì gran machina per loro servigi fosse stata eretta e construtta'.

Dal tutto insino hora detto", seguiva egli, "si raccoglie, che la natura non meno fu solicita in sugerirci documenti bastevoli a renderci quanto che può arivare la nostra conditione felici, di quello fu liberale in soministrarci ciò che appartiene alli nostri corporali bisogni e commodi. Onde essendoci la natura ottima maestra, e direttrice, e che giamai non falisce nelle sue operationi se non per superfluità o deficientia over contumacia della materia, che incontra, e che alle mani li perviene, mentre che noi seguiamo li suoi vestigi e constantemente insistiamo nelle sue orme, ci riesce impossibile il falire, e dal retto deviare. Per il che egregio e spiritoso poeta volendo descrivere li costumi di homo al sommo virtuoso li attribuì:

\section{[273] Serva/ri modum}

Lucano Naturamque sequi, patriae pendere vitam

Liber III. $\quad$ Nec sibi sed toto genitum mundo.

Cioè che conviene all'homo benché sopra ogni altro egregio, porre meta alle sue intraprese, seguire le pedate della natura, e preporre al proprio profitto il servitio non solamente della sua patria particolare, ma anco della universale, cioè di tutto l'humano genere, il che anco nel seguire li documenti della natura 
obstacles and mental oppression at the end of your lives. For the distribution of the opulence you have wickedly collected will cause you more trouble than the imminent and detailed subdivision that must be done with what you have put together, because it is not known where the most essential portions of this must be allocated and for which place they are designed.

'Furthermore, if Democritus, who was a skilful taunter of human insanities, were to rise to such a high position with his admirable [272] intellect, I would believe that as usual he would laugh very hard to observe that this jumble of ants considered the extremely vast celestial spheres and the splendid bodies in them to be longing to bring light and vital influences to them with their indefatigable and very rapid revolutions; and, moreover, that the sun, which according to the most modern opinion is about four thousand times larger than the earth, made its daily revolution so rapidly in order to illuminate the anthills below and revolved in another contrary and annual motion from Occident to Orient in order to provide them with a variety of seasons and different air temperatures. Furthermore, he would judge this no less absurd than a vile and small flour-covered mouse's belief that a mill, the turning of wheels, the continuous flux of water, and the assistance of a miller were intended to make the grain more accessible and finer for him.

'However, if those large ants ever gained wings and surmounted the celestial region through the value of their intellect, as he did, his taunting would turn into admiration. Furthermore, he would consider that they deserved to have such a great machine erected and constructed for their purposes.'

\section{He [Hippias] continued:}

"From what has been said until now, one may gather that Nature was as attentive in suggesting lessons to us that are sufficient to make us happy, as far as our condition allows, as it was liberal in supplying us with what is required by our corporeal needs and leisure. Therefore, Nature, which has never failed in its operations except for superfluity, deficiency, or reluctance in matter that occurs when it comes into its hands, is our greatest teacher and director. Thus, it is impossible that we may fail and divert from the right path while we are following its vestiges and remaining steady in its footsteps. Hence, an excellent and witty poet described the customs of a supremely virtuous man by attributing to him:

\section{[273] To observe moderation}

To follow nature, to give his life for his country, to believe that

He was born to serve the whole world and not himself..$^{470}$

Lucan bk. 3.

"This is, a person, even if he is more excellent than anything else, should limit himself in his endeavours, follow in Nature's footsteps, and put not only serving his particular homeland, but also the universal one - namely that of all humankind - before his own profit. Furthermore, he can also learn and acknowledge this by following Nature's teachings. ${ }^{471}$ When the rivers, with their vehement 


\section{Contemplatione delle} cose fa riconoscer apprende e riconosce. Li fiumi con vehemente corso nel mare imergendosi, perdono non solo la dolcezza delle loro acque, ma anco il proprio nome, e ciò per soccorrere all'oceano loro comune patria, che per li continui vapori che in alto ascendono, sia ciò per il sotteraneo fuoco che li spinge over il superiore celeste che l'attrahe, non venga meno e che non s'esausti, et inanisca.

Ma facendo regresso al punto principale del mio divisamento, concludo che senza la speculatione et osservatione delli andamenti della natura, cieca sarebbe l'humana prudenza. Ma quello che maggiormente nobilita tal impiego, è l'haverci soministrato la cognitione di quella eminentissima causa, che il tutto a miglior fine dispone et indrizza, che di gran lunga supera lo profitto che trahemo da tal apprensione, che qualunque giovamento che da qual si sia altra speculatione ci risulta. L'advertire il regolato motto de cieli, l'ordinato regimento delle cose sublunari, ci sugerì l'intendimento che teniamo di una suprema cagione, il cui sapere admiramo, potenza riverimo, e bontà amamo, e per il certo perciò siamo molto al di sopra di bruti, per tal apprensione affatto distratti et alieni. La traditione che si tiene di portenti e memoria di miracoli può dal continuato flusso del tempo rimanere estinta, overo da scelerati miscredenti temerariamente schernita, ma il certo et evidente giudicio che faciamo circa Iddio e sua Providenza, s'esime affatto dalle ingiurie del tempo e rigetta lo scherno d'empii. E di più riesce l'humana scientia o filosofia che dire la vogliamo, simile ad industre agricoltore, che procura svelere e sradicare l'inutile, e troppo lusuriante fecondità.

[274] Detru|se primieramente essa filosofia la dannata e scelerata impietà di ogni vitio solecita notrice, preparando l'animo humano al sentimento della vera religione. Ma di più s'impiegò a rintuzzare la pazza superstitione, che a guisa di germogliante lolio, opprime la pregiata messe della veneranda religione, havendole essa Sapienza reciso e mutilato quelli diformi cenci et appendici che la insana superstitione l'attacò et ingiunse, inducendo l'homini saggi a rendere al Supremo Autore et Opefice quella degna estimatione che se li deve, havendolo essa superstitione indegnamente finto hora troppo flessibile et indulgente, e però meno riverito, et alle fiatte lo rappresentò in eccesso rigoroso, e per ogni minuta transgressione implacabile et inesorabile, e perciò piuttosto temuto che amato.

Ma la Sapienza a guisa di vigoroso e perito guerriero, con ambe le mani di arme proviste, ad un tratto duoi diversi e fieri nemici abbatè e prostrò, dico l'impietà e superstitione. E per il certo non meno tiene la Sapienza merito per il fugare questa che per lo scacciare quella. L'impietà conoscendo la sua turpitudine, dall'aspetto dell'homini s'invola, e con l'addobamento dell'istessa superstitione mascherandosi, sconosciuta nella scena del mondo esercita 
courses, are submerged into the sea, they lose not only the sweetness of their waters, but also their names. However, they do this to aid the ocean as their common homeland, so that it will not disappear, become exhausted, or annihilate itself because of the continuous vapours which rise up, either pushed by subterranean fire or attracted by the heavens above.

"Yet to return to the main point of my consideration, I will conclude that without speculation and observation of Nature's course, human prudence would be blind. However, this pursuit is greatly ennobled by the fact that it has provided us with cognition of that very eminent cause which disposes and directs the whole to the best aim. Besides, the profit we will draw from this apprehension far exceeds whatever advantages may result from any other speculation. When we observed the regulated motion of the skies, the ordered government of sublunary things suggested the understanding of a supreme cause to us, whose knowledge we admire, whose power we revere, and whose goodness we love. Therefore, we are certainly far above brute animals, to whom the ability of this apprehension is alien and unattainable. Tradition, which maintains itself thanks to the wonders and memories of miracles, may be extinguished by the continuous flow of time or by being recklessly taunted by wicked unbelievers, but the certain and evident judgment we have concerning God and his Providence is exempt from the ravages of time and rejects the scorn of impious people. Furthermore, human knowledge, or, we should say, philosophy, tries to be more like an industrious farmer, attempting to remove and eradicate a useless and excessive fecundity. ${ }^{472}$

[274] "Primarily, philosophy destroyed that damned and wicked impiety, a solicitous nurturer of every vice, in order to prepare the human mind for the sense of true religion..$^{43}$ Moreover, it attempted to refute mad superstition, which, like germinating weeds, oppresses the refined harvest of venerable religion. ${ }^{474}$ Once wisdom had cut off and mutilated those deformed rags and attachments joined and attached to it by insane superstition, it induced sage men to have the due respect for the Supreme Author and Architect. Indeed, superstition unworthily supposed Him to be sometimes too flexible and indulgent, and therefore less revered, and sometimes represented Him as extremely rigorous, implacable, and inexorable because of every minute transgression, and thus [to be] feared rather than loved.

"Yet wisdom, like a vigorous and expert warrior provided with weapons in both hands, defeated and subdued two proud and different enemies in one fell swoop; I mean impiety and superstition. Certainly, wisdom has the merit of putting the latter to flight and of chasing away the former. Impiety, aware of its turpitude, escapes from the view of human beings and disguises itself with the adornment of superstition. In this way, as it remains unknown to the world, it
The contemplation of things leads to the acknowledgement of God. 
quelli tragici avenimenti che desertano le città et inaniniscono le provincie, e che l'homo divenga al suo genere lupo e tigre. Ma non resta però che odiosa non riesca all'altrui apparenza, poiché la imagine della superstitione tanto maggiormente riesce difforme, quanto che donna vecchia, monocola, guinza, e bavosa, più attrista la nostra vista, che l'aspetto di bue o cavallo affatto dalla nostra spetie diverso, essendo l'empii privi di alcun sentimento della deità, a guisa d'animali irragionevoli dalla classe delli homini distratti et esclusi, e li superstitiosi non essendo di religione privi, ma in modo distorto e depravato sortiscono in diformi et abominevoli sembianti.

Ma la Sapienza debelato che hebbe tali monstri et assordità, che con la retta religione ferocemente tenzonavano e gueregiavano la [275] richiamò al suo regal seggio, havendole preparato honorevole albergo, e degno tempio nella humana mente, più egregio loco che nella regione sublunare si ritrova. Questi sono li maggiori profitti che l'homo trahe dalla speculatione delle cose mondane, che nonostante le tue argutie e cavilli stimo che siano manifesti et evidenti, ma quando anco fosse come contendi quello che giammai io non son per affermare, che nulla di certo da tanto laborioso mentale esercitio, si conseguisce, essendoci la verità inattingibile et inaccessibile, tuttavia negare non puoi che grande noia arrecaresti all'humano genere in descreditarli il suo sapere. E stimo che verso di te in tal maniera reclamarebbe: qual ingiuria giamai dalli huomini tuoi consorti hai ricevuto, che con avilirli et annientarli il proprio sapere procuri privarli dal più sincero e durabile piacere che possegono, cioè del diletto che conseguiscono per la contemplatione dell'universo?

Non è questo come le volutà del corpo che velocemente pongono termine, e sovente quello è peggio inanzi che arivino al sommo, ci finiscono, ma principiando esso nella pueritia, ci accompagna nella vecchiaia, e non ci abbandona insino all'ultimo anhelito e respiratione. Né accade al piacere che dal sapere ci sortisce quello occorre alle altre volutà che con l'altrui ingiuria over danno ben spesso si conseguiscono, ma il contemplativo diletto senza noia et iattura di alcuno sempre ci si appresenta agevole e pronto.

Il gran teatro dell'universo al senso et intelletto di tutti li homini tanto nobili come plebei, ricchi come poveri egualmente è aperto e spalancato, e con liberale indiferenza li suoi mirabili spettacoli espone et offerisce, et in qualunque tempo alternando li suoi visaggi, diletta et instruisce. Molti de suoi arcani rivelò alli nostri antenati, non pochi al presente secolo svelò, ma in maggior copia è per manifestar alla ventura posterità. 
may pursue those tragic events which depopulate cities and empty provinces as well as making human beings become wolves or tigers to humankind itself. ${ }^{475}$ It appears to be simply hateful to other people, since the image of superstition turns out to be as deformed as a one-eyed, shrivelled, and slobbering old woman, which saddens us more than the sight of an ox or horse, as they are of a different species to us. Indeed, as impious people lack any sense of deity, ${ }^{476}$ they are like irrational animals, separate and excluded from the class of human beings. Yet the superstitious ones turn out to have deformed and abominable appearances, as they are not lacking in religion, but are rather endowed with a distorted and perverted one.

"However, wisdom, once it had defeated these monsters and absurdities which ferociously strive and fight against the true religion, [275] called it back to its royal seat, preparing an honourable accommodation and worthy temple for it in the human mind, the most refined place that may be found in the sublunary region. These are the greatest profits that human beings may gather from speculating on mundane things, which I consider to be manifest and evident despite your sharpness and quibbles. Yet even if it was as you argue - although I would never state this - namely that after such an industrious mental exercise, one would not achieve anything certain because the truth is not attainable or accessible to us, nevertheless, you cannot deny that you would cause a great inconvenience to humankind by discrediting its knowledge. Furthermore, I think that it will complain to you in this way: what affront have you ever received from human beings, as they share the same destiny with you, as by disheartening and annihilating their own knowledge you seek to deprive them of the most sincere and lasting pleasure they own, namely the delight they achieve from contemplating the universe?

"This is not like the sensual pleasures of the body, which end quickly, and what is even worse, they often finish before achieving their full potential. On the contrary, it begins in childhood, accompanies us through our old age, and does not abandon us until our last gasp and breath. Pleasure, as it emerges from knowledge, is not subject to the same thing that occurs with other sensual pleasures, which are often achieved by affronting or damaging other people: on the contrary, contemplative delight appears to us to be always easy and ready, without any inconvenience or harm to anyone.

"The great theatre of the universe is equally open and gaping to the senses and intellects of all human beings, the nobles as much as the plebeians, the rich as much as the poor. With liberal indifference, it displays and offers its admirable performances, and it may please and instruct at any time by altering its aspects. Many of its mysteries which have been somewhat revealed to us in the present time were disclosed to our ancestors, but a greater quantity will be shown to the world to come. 
In publicar

la debolezza

dell'ingegno

discredita la con-

scientia.
Onde, o Socrate, se il teatro che novamente Pericle eresse, acciocché con ludicri spettacoli l'otiosa plebe si trattenga, attentassi diruppare e demolire, senza dubbio incorreresti nella publica [276] indignatione, e per il certo severissimi castighi ne saresti per ricevere. Così anco riesci degno di rigorosissimi flagelli, mentre attenti di annientare il comune et universal teatro mondano che tanti piaceri e diletti a tanta moltitudine di homini continuamente appresta e sugerisce, il che certo seguirebbe quando che divolgassi, che mendace, vano, et illusorio fosse tutto quello che in esso apparisce e ci dimostra. E senza dubbio la pretensione che cadauno tiene del proprio sapere, è quel potente narcotico che lo adormenta nel renderlo insensato alle proprie miserie, et è quello fascino che prevertendo il giuditio, cagiona che ognun si appaga di se medesimo.

Ma di più diroti, che se publichi tal tuo parere circa l'imbecilità dell'humano giuditio, non poco offenderesti la buona moralità che tiene associato il nostro genere. Le publiche leggi agevolmente da scelerati si possono con la secretezza di delitti eludere. E la falsa openione che tengono l'impii della conivenza d'Iddio, e li volutuosi della sua indulgenza, rende questi confidenti, e quelli arditi nel comettere clandestinamente le sceleratezze e l'enormità. Ma l'horrore che ci impone severissimo magistrato nel più interno recesso di noi, dall'istessa natura eretto, è di tanta efficacia che non solamente ci reprime dalle prave attioni, ma anco da maligni pensamenti ci ritrahe, esigendo dalli homini in ogni tempo e loco le pene di loro misfatti e delinquenze. Questo magistrato è la conscientia, cioè la ragione che ci rimorde di nostre difalte, e che subito comesse che siano ci acusa, ci punge e flagella. Tale maestoso tribunale per cagione di tuoi insegnamenti rimarebbe affatto dispregiabile e vilipeso, mentre che manifesti la sua imbecilità e debolezza.

Qual rispetto, amico Socrate, e qual riverenza prestato sarebbe per l'avenire alla veneranda conscientia over ragione, mentre che mendace e fallace la promulghi? Al sicuro schernite sarebbero le sue admonitioni, e sbefati li suoi rimproveri e l'humano genere incorrerebbe di [277] nuovo in quelle sciagure che cadé nel tempo di Deucalione: 
"Therefore, oh Socrates, if you attempted to destroy and demolish the theatre that Pericles has newly erected in order to entertain the idle plebes with ludicrous shows, you would undoubtedly incur public [276] indignation and you would certainly receive extremely harsh punishments. Similarly, you would be worthy of the most rigorous chastisements if you attempted to annihilate the common and universal theatre of the world, which continuously provides and puts forth many pleasures and delights to such a great multitude of people. This would certainly follow if you decide to spread that everything that appears in it and is displayed to us is mendacious, vain, and illusory. Furthermore, the pretension that every man has concerning his own knowledge is that undoubtedly powerful narcotic that anesthetises by making [every man] unaware of his own miseries and that fascination that subverts judgment and causes every person to be satisfied with himself. ${ }^{477}$

"However, I will tell you further that if you broadcast your opinion concerning the weakness of human judgment, you will cause no little damage to the good morality that keeps humankind together. Wicked people can easily avoid the public laws by keeping their crimes secret, and the false opinion of impious people concerning the connivance of God, and [that of] libidinous people concerning His indulgence, makes the latter confident and the former daring in clandestinely committing wickedness and vileness. Yet the terror imposed by the strict magistrate [located] in the innermost recess of us, appointed by Nature itself, is so effective that it not only holds us back from [committing] evil deeds, but also pulls us away from malicious thoughts. It demands punishments from human beings for their misdeeds and crimes in every time and place. This magistrate is the conscience, namely reason, which prickles because of our mistakes and accuses, pricks, and then chastises us as soon as they are committed. This majestic court would indeed be despised and vilified because of your teachings if you revealed its incapacity and weakness.

"What respect, dear Socrates, and what reverence would be held for venerated conscience or reason in the future if you were to spread that it is mendacious and fallacious? Surely its admonitions would be taunted, its reproaches would be scorned, and humankind would once more incur [277] those disgraces that occurred in the time of Deucalion: ${ }^{478}$
By spreading the weakness of the intellect, he will discredit the conscience. 
Fugere pudor, verumque, fidesque:

In quorum subiere locum, fraudesque, dolique,

Insidiaeque, et vis, et amor sceleratus habendi.

Onde sarebbe Iddio solicitato purgare il mondo con altro diluvio come già eseguì, perché le nude leggi siano minacievoli quali furno quelli che Dracone a noi Ateniesi instituì, vane riuscirebbero quando alla loro difalta non suplissero quelle della occulta conscientia sopra tutte le altre in domarci validissime. Et a qual infamia si ridurebbero l'homini se come debitori di pessima qualità, non pagassero li loro creditori se non fossero le scritture e testimonii rimproveri de loro debiti, così anco s'essi non si astenessero dal mal operare se non fosse il freno de' castighi dell'humane leggi o flagelli della Divina Providenza? Questo sarebbe l'avantagio che conseguitasse il comune delli homini dalla publicatione della retentione dell'assenso e sospensione di giuditio.

Per il che, amico Socrate, se Gorgia ti convertì come mi narrasti in testugine, io t'admonisco che in vernale lumaca ti cangi che a guisa che essa de tuoi suchi, cioè di proprii discorsi e meditationi ti alimenti. E seppure di essi sei talmente pregno che non li puoi reprimere che fuori non prorompino, solamente a saggi e prudenti li comunicarai, con cautela tale, che l'orechio del volgo non feriscono, e con il poeta sempre susarare:

Procul o procul este profani”.

Ricorre Socrate a

Timone.

Profitti circa la religione.
In ciò terminò il ragionare di Hippia, ma io conforme il mio già intrapreso instituto, che sospende il giuditio, pertanto ratteni l'assenso, e deliberai di non inclinare al parere di Hippia, se prima non ricercassi ciò che Timone in tal proposito consigliasse. Costui come ben sapete prese irreconciliabile nemistà con l'humano genere per l'aversione che teniva con li sapienti del secolo, alla dottrina de quali li homini del nostro tempo pareva che inclinassero, e perciò risolse di evitare la loro famigliarità, et ad un suo podere vicino alla nostra città [278] et in vita solitaria si tratteneva, nella quale sua habitatione offeriva gratis recapito a quelli che importunati dal tedio del loro vivere procuravano da questo mondo accomiatarsi. Onde io alla sua maggione transferitomi, con proponimento di migliorare non di terminare la mia vita, egli con benigno sembiante mi raccolse, et in tal guisa pigliò a ragionare: 
Modesty and truth and faith

Fled the earth, and in their place came tricks and plots and snares,

Violence and cursed love of gain. ${ }^{479}$

"Therefore, God would be urged to purge the world with another flood, as has already happened, in order to make the simple laws as threatening as those instituted by Draco for us Athenians. ${ }^{480}$ These would turn out to be vain if their failure was not compensated by those [laws] of the hidden conscience, which are the most valid than any of the others for taming us. To what state of infamy would human beings be reduced if they did not abstain from committing evil deeds because the chastisements [coming from] human laws or the punishments of Divine Providence provided no restraints? [They would be] like the worst debtors, who do not pay their creditors when there are no writings or witnesses to reproach them with their debts. This would be the benefit that the common people would attain from publicising the withholding of assent and the suspension of judgment.

"Hence, dear Socrates, if Gorgias turned you into a tortoise, ${ }^{481}$ as you told me, I invite you to turn into a spring snail, and in this way to be nourished by your own secretions, ${ }^{482}$ namely to feed yourself with your own discourse and thoughts. Besides, although you are so full of them that you cannot restrain them or prevent them from overflowing, nevertheless, you shall only communicate them to sage and prudent people, so cautiously that they will not hurt the masses' ears, and together with the poet, you shall always whisper:

Away! Away! You that are uninitiated!"483

Hippias ended his argument thus, but according to my already undertaken proposal to suspend my judgment, I then withheld my assent and decided not to incline to Hippias's opinion without having first pursued what Timon might advise concerning this matter. This person, as you well-know, harboured an irreconcilable hostility towards humankind because of his aversion to the wise men of the time, towards whose doctrine men nowadays seem to be inclined. Therefore, he decided to avoid acquaintance with them and withdrew to a solitary life in a plot [278] of his close to our city. At his home, he freely offered an abode to those who, bothered by the tedium of their lives, wanted to take their leave of this world. Thus, as I moved to his dwelling with the purpose of improving my life and not ending it, he kindly received me

Advantages of religion. and continued his argument in this way: 
"Se la noia di vivere come a sicuro posto, qui ti condusse, con opportuna occasione sei qui capitato, havendo io ad offerirti pregiato regalo di dolcissimo liquore, che con laboriosa industria dall'oppio tengo estratto. Il quale in tal maniera è condito, che sebbene apporta a chi l'assagia accelerata morte, nondimeno è preparato in guisa, che garegia con qualsivoglia saporito vino, inducendo soavissimo sonno ch'alla morte tranquilamente et inavedutamente transmette e consegna.

Né di ciò mediocramente ringratiare mi devono l'homini della vita infastiditi, ché siccome si rimane obligato alla ostetrice che ci educe et estrahe dalle viscere materne alla luce del mondo, così parimente non poco di merito deve tenere appo essi, colui che l'appresta maniera di agevolmente et agiatamente estrahere le anime loro da tenebroso e noioso carcere, e senza alcuna passione e tormentoso sentimento le sviluppi. E siccome colui che alli affaticati viaggianti arreca generoso vino, che inducendoli sonnolenza che per tempo supisce li loro languori è lodevole, tanto più è degno di comendatione et è meritevole di elogio colui che alli travagliati et affannati da sciagure del mondo li sugerisce se non piacere e godimento, almeno perpetua et imperturbata indolenza. Per il che riconoscendomi invalido ad aportare alcuno giovamento alla altrui vita, ho procurato di rendere meno dolorosa l'agonia della morte insino hora stimata fra mali la più tormentosa.

Ma se tu, Socrate, qui ti sei tranferito non per mettere fine alla vita, ma per meco dimorare, benché peraltro io sia alieno di qualunque conversatione e famigliarità, tuttavia havendo rispetto alla tua indole e probità di costumi, volentieri sono per [279] comportarti e teco convivere, mentre però che ti compiaci purgarti affatto dalla infettione dell'hodierna filosofia, di buoni costumi corrutrice, la quale se insino hora non ti guastò, sono certo che in breve è per depravarti”.

Inteso che hebbi ciò io ringratiandolo del suo regalo, li dissi, che non tedio di vita, né desio di seco cohabitare, mi haveva alla sua stanza indotto, ma solamente per tale fine io colà mi condussi, per rendermi informato quali fossero li motivi che lo fecero tanto alieno e nemico alla scientia morale da filosofi del secolo divolgata, e che perciò delli homini in universale divenne nemico, che alli insegnamenti di essa prestano orechie. E di più, voleva io seco comunicare quello tenivo praticato circa l'humano sapere, havendolo ritrovato dubbioso e falace, e se propalando ciò alli homini l'havessi apportato alcuno giovamento, e forsi perciò con essi homini egli si sarebbe reconciliato e riamicato.

Risposemi, che ciò prontamente eseguirebbe, et in tal guisa favellò:

\footnotetext{
"Negare non si può che alcune dottrine dall'humano sapere derivate, habbino promosso grandi profitti alla vita humana, non riuscendo in ciò inferiori a veneni, che alle fiatte ottimi rimedii alla infermità de nostri corpi sugeriscono, ma di gran lunga sopravanzano li nocumenti, che tali speculationi l'apportano
} 
"If the troubles of life have led you here as to a secure place, you have ended up here at the right moment, since I may offer you, as a refined gift, a very sweet liqueur that I have extracted from opium with laborious industry. ${ }^{484}$ It is seasoned in such a way that although it quickly leads to death for the one who tastes it, it is nevertheless prepared so that it may compete with any flavourful wine, and therefore it induces a very gentle sleep, which, tranquilly and without him realising it, sends and delivers him to death.

"People who are weary of life should greatly thank me for this, because just as one should have a debt of gratitude to his obstetrician, who pulled us out and extracted us from the maternal viscera [and brought us] to the light of day, so too should a person who provides an easy and comfortable way to extract their souls from this dark and hateful prison, releasing them without any suffering or tormenting sensation, have great merit among them. Likewise, a person who offers a generous [quantity] of wine to tired travellers, which, causing drowsiness, temporarily calms their fatigue, is praiseworthy; but a person who submits, if not pleasure and enjoyment, at least a perpetual and unperturbed indolence to those who are troubled and worried because of the miseries of the world, is even more worthy of commendation and deserving of praise. Hence, since I recognised myself to be unable to provide any benefit to the lives of others, I sought to make the agony of death, so far considered the most tormenting of evils, less painful.

"Yet Socrates, if you came to me not in order to end your life, but to live with me, despite the fact that I am alien to any conversation or acquaintance, nevertheless, I will gladly [279] tolerate you and live with you, as I respect your nature and probity of customs, though [this is possible] only if you indeed wish to purge yourself from the infections of the present philosophy, a corrupter of good customs, which - although it has not spoiled you yet - I am sure will shortly debase you."

Once I had heard this, I thanked him for his gift and told him that neither boredom with life nor the desire to live with him had led me to his home, but that I had come there only because of this: namely that I wanted to know the reasons that had made him so removed from and such an enemy of the moral knowledge spread by the philosophers of the time and why he had universally become the enemy of the people who paid attention to its teachings. Furthermore, I wanted to tell him what I had experienced concerning human knowledge, namely that I had found it doubtful and misleading, and that if I were to benefit humankind by spreading it [i.e., that Socrates had found knowledge doubtful and misleading], then perhaps he would be reconciled and be brought back to friendship with it.

He answered me that he would do this immediately, and he spoke to me as follows:

"One cannot deny that some doctrines derived from human knowledge have promoted great benefits to human life. In this, they have turned out to be like poisons that sometimes offer excellent remedies for the infirmity of our bodies, although the damage they produce and cause is far greater than the [bene- 
et arrecano. Primieramente la contemplatione circa oggetti a noi esterni et inattinenti, richiama la nostra mente dalli humani affari de quali perciò rimaniamo affatto ignari, e contendendo di abbraciare il cielo, perdiamo la Terra, incorrendo in quella celebre riprensione ch'incontrò Talete, dalla sua serva rimproverato, che tenendo li occhi a cieli per spiare li loro andamenti, in una fetida cloaca cadè. Per il che dalla serva fu rampognato, che mentre con vana curiosità attendeva ad esplorare li viaggi delle stelle non scorgeva ciò che haveva in terra avanti ai piedi.

Né saprei ritrovare impiego, che maggiormente offendesse la civile prudenza, che la pratica e famigliarità che la humana mente tiene con le cose dalla natura prodotte e governate, e [280] massi|me li corpi celesti. Questi sono sempre con ordine costante et uniforme retti, ma per il contrario l'humani affari sempre variabili, e la volontà che li maneggia più che Proteo cangiabile, combattuta sempre da mutabili desii, intemperati amori, fanatici timori, insane speranze, furibondi odii, et altri affetti che la sconvolgono. Onde l'homo assuefato alla contemplatione delle cose naturali, riesce affatto inetto al trattamento delle materie civili, e massime quelli che nelle scientie matematiche sono esercitati, ricercando essi in qualunque cosa ferma demonstratione, onde nelle materie urbane al di sopra di probabili conieture non possono ascendere. E chi può nelli secreti recessi dell'animo humano penetrare e condursi, ricoperto et impedito da tante simulationi e fintioni? E l'esperienza sempre dimostrò che li homini che si dedicarno al studio della natura, chiamati al governo civile, talmente si diportaro, come che se in altro emispero appresso li antipodi vissuti et educati fossero.

Né molto mi cale di quello mi narrasti di Hippia, che in favore delle speculationi della natura addusse, che in quanto a quella ardita ascesa e temerario volo, che insino al cielo l'intelletto humano sormonti. Appo me tal intrapresa mi rende l'homo piuttosto ridicolo, che admirabile, e novello Icaro me lo rappresenta, tanto sono li pareri che circa l'essentia, situatione e moti di cieli da sapienti del secolo divolgati. Et inanzi che fosse stata fatta la disecatione dell'animale, quante openioni furno circa il principio della vita e moto di esso. Né giamai alcuno indovinò per molta speculatione che vi usasse, qual fosse tale esordio et origine di vita, ma doppo fatta la desecatione con stupore d'ognuno fu trovato, che tal fosse un picciol membro di conica figura, residente in un folicolo che contiene alquanto di certa acqua, che continuamente allargandosi e restringendosi, assorbe dalle vene il sangue e lo rigetta già elaborato e perfetionato alle arterie. Questo è il cuore primordio e conservatore della vita, primo a vivere et ultimo a morire.

"Stante ciò mi [281] meraviglio che vi sia alcuno che intraprende investigare la cagione impulsiva e motrice delli cieli, corpi tanto lontani da noi e mi stupisco, che se senza l'anatomica et occulata osservatione, giamai alcuno conieturò qual sia il principio della vita di noi stessi, agogna di riconoscere qual sia la vera cagione di moti celesti. E per il certo mentre l'homo si trova ignaro di tal cagione stimarei, lieve dottrina l'apprendere quali siano li viaggiamenti di essi orbi overo stelle, e non degna di tanti milantamenti, siccome anco li condottieri di invogli e bagaglieri che accompagnano l'eserciti, stimare non si devono per il semplice osservare li loro marchiamenti e posate, mentre che ignorano l'impulsi e fini di tali diverse attioni. 
fits] they cause. Firstly, the contemplation of the objects that are external and not relevant to us diverts our minds from human matters, whereof we indeed remain unaware. Then, by trying to encompass the sky, we lose the earth and encounter that well-known reprimand that Thales received from his servant, namely that he fell down into a fetid sewer because he was keeping his eyes on the skies in order to attentively observe their courses. Hence, the servant reproached him that while he was attempting to explore the courses of the stars with vain curiosity, he did not see what was on the ground along his path. ${ }^{485}$

"Besides, I cannot find a pursuit which causes more offence to civil prudence than the experience and acquaintance that the human mind has with the things produced and ruled by Nature, and [280] above all with the celestial bodies. These are ruled with constant and uniform order, while human matters, on the contrary, are always variable, and the will handling them is more changeable than Proteus. It is always afflicted by changeable desires, intemperate loves, fanatical fear, insane hope, furious hatred, and other affects upsetting it. Therefore, a man accustomed to the contemplation of natural things turns out to be indeed inept in treating civil matters, and above all those who are experts in mathematical sciences [are of this type]. Indeed, they search for firm demonstration of things, but they cannot advance beyond probable conjectures within urban matters. Furthermore, who can penetrate and go into the recesses of the human mind if he is hindered and impeded by so many simulations and fictions? Moreover, experience has always demonstrated that people who are applied to the study of Nature behave as if they had been living and educated on opposite sides of another hemisphere once they are called to civil government.

"I do not mind what you told me about Hippias, who adduced in favour of speculations on Nature, namely that arduous ascent and reckless flight committed by the human intellect up to the sky. This endeavour makes human beings appear ridiculous rather than admirable to me, and he appears to me like a new Icarus, as there are so many opinions concerning the essence, place, and motions of the skies spread by wise men nowadays. Furthermore, before dissections of animals were performed, there were many opinions concerning the principle of life and its motion. In spite of this great speculation, nobody had ever guessed the beginning and origin of life. Yet once dissections had been carried out, it was discovered, to the amazement of all, that [the origin of life] was a small limb of a conical figure, residing in a follicle containing a type of water, which, by expanding and contracting, absorbed the blood from the veins, and, once it had perfected and elaborated it [i.e., the blood], rejected it into the arteries. This was the heart, that which begins and conserves life, the first to live and the last to die. ${ }^{486}$

"In such circumstances, [281] I am astonished that there would be anyone who would undertake to investigate the propellant and driving cause of the skies, as they are such faraway bodies from us. Besides, I am surprised that anyone would long to know the true cause of the celestial motions if [one thinks that] anybody could ever conjecture the principle of our life without the anatomical and autopsical observations made by their own eyes. Certainly, while people are unaware of this cause, I would consider it to be an unimportant doctrine to apprehend the courses of orbs or stars, and also not worthy of so much boasting. Similarly, those who are in charge of bringing the packages and suitcases that accompany armies must not be judged simply by observing the way they march and stop if the reasons and goals of these different deeds are unknown. Hence, 
Amore indifferente dannato.
Per il che concludere si può in quanto a questo capo, che tali speculationi sono infrutuose applicationi o per dir meglio otiosi esercitii e neghitose facende.

Ma quello che tali contemplationi tengono di peggio, che praticando li professori di esse con il discorso continuamente con li corpi celesti, li stimano come se fossero concittadini della universale republica mondana, nella quale stimano esservi arrolati, e perciò con altiera despicientia riguardare la loro propria patria, conforme disse Hippia, come che se fosse vil vespaio et abietto formicaio. E per il certo ottimamente decretarno alcuni legislatori, che per tenire meglio affetti li cittadini alla loro propria republica, che li fosse interdetto l'inestarsi et annoverarsi anco in altra ad essi aliena, essendo tali ordinanti sicuri, che se ciò li fosse permesso, si diminuirebbe il legitimo amore che verso la loro patria sono tenuti.

Tutto ciò accade a tale filosofo che cittadino del mondo s'appella, e con celebre elogio si vanta come disse il poeta allegato non sibi sed toto genitum mundo, onde rispetto all'universo del quale egli è patritio, non più della rovina della sua picciol patria si comoverebbe, di quello si alterarebbe un di nostri cittadini ateniesi se vil publica capanucia per ricorso di pochi pastori eretta, fosse a terra caduta; né a tal sapiente più li molestarebbe il disfacimento della sua città, di quello [282] altro si attristasse del frangimento di picciola pietruzza, che in vastissima montagna accadesse. Né maggiormente li offenderebbe l'oppressione di suoi popolari, di quello s'allegrasse della vitoria di quelli che li assogettassero, essendo l'uni e li altri cittadini della massima mondana republica. Et oltre di ciò delle sciagure di figlioli non più si risentirebbe, che del calpestio del proprio sputo, overo altro suo escremento. Né della violenza alla moglie usata, non più se addolorarebbe, che di casa da lui abbandonata che da altrui fosse habitata e goduta. Né della demolitione di sepolcri di suoi antenati e dispregio di loro cenere et ossa, più si lagnarebbe che di ritagli di unghie e capelli di suoi progenitori, che all'aria fossero sparsi e dissipati. Né della denigratione della propria fama non altrimente si currerebbe, che di fetida saliva dal volgo escreata. Né della delapidatione de suoi beni punto si lagnarebbe, mentre che tenisse appo sé nel secreto erario del suo animo il pregiato tesoro della sua sapienza, che lo rende, secondo la sua stima, trionfante possessore di tutte le cose mondane.

Queste sono le massime che si tengono per l'acquisto di questa cotanto comendata e lodata sapienza, fra quali è principale il rendere promiscuo et indiferente l'amore che si deve alli homini, non admettendo in esso graduatione e diversità, non advertendo questi, che siccome copioso et abbondante fiume, in moltissimi rami derivato, alla fine estenuandosi s'estingue et inaridisce, nell'istesso modo li nostri affetti essendo a molti oggetti distribuiti, al niente si riducono. E perciò volendo rinforzare l'amore verso li proprii cittadini fu instilato da alcuni legislatori certo odio et aversione contro l'alieni della republica, che per modo di antiperistasi s'invigorisca l'affetto verso li proprii cittadini. Dal divisato da me, puoi raccogliere che non sia di profitto all'homo civile il vagare con il discorso fuori del recinto della propria patria, non dirò allargarsi insino a cieli, ma né anco difondersi per tutto il nostro genere, ma nell'ambito della propria patria terminarlo. 
one may conclude on this point that these speculations are unfruitful applications, or, better to say, futile exercises and lazy activities.

"However, what is even worse concerning these contemplations is that those who profess them, entertaining a continuous discourse with the celestial bodies, [end up] considering them as though they were fellow citizens of the universal mundane republic, ${ }^{487}$ whereof they believe themselves to be a part. Therefore, they look at their own homeland with haughty disdain, according to what Hippias said, as though it was a vile wasps' nest or abject anthill. ${ }^{488} \mathrm{Cer}-$ tainly, some legislators decreed that in order to keep the citizens better attached to their own republic, it would be best to forbid them from establishing and including themselves in another one that was foreign to them. Indeed, these rulers were sure that if they were allowed to this, it would decrease the legitimate love due to their own homeland.

"All of this happens to such a philosopher who calls himself a citizen of the world and famously boasts, as was said by the poet hereafter, to believe that he was born to serve the whole world and not himself. ${ }^{489}$ Therefore, as a citizen of the universe, he would be no more affected by the ruin of his small city than one of our Athenian citizens would be touched by the fall of a vile communal hut erected by a few shepherds. Furthermore, this wise man would be as afflicted by the decline of his city as [282] he would be saddened by the smashing of a small stone on a huge mountain. Likewise, he would be as displeased by the oppression of his own people as he would be gladdened by the victory of those who subjugated them, because all of them would be citizens of the great mundane republic. He would furthermore be as affected by the miseries of his offspring as [he would be] by treading on his own spittle or any of his other secretions. Likewise, he would be as aggrieved by violence experienced by his wife as by his abandoned home being lived in and enjoyed by others. In the same way, he would complain about the demolition of his ancestors' sepulchres and contempt for their ashes and bones as much as [he would] about his progenitors' hair and nail clippings being scattered and dissipated into the air. Similarly, he would care as much about the denigration of his own reputation as he would about the fetid saliva that the masses spit out. Likewise, he would not remotely complain about the squandering of his wealth if he held the refined treasure of his wisdom in the secret treasury of his mind, which would make him, in his own opinion, the owner of all mundane things.

"These are the maxims concerning the acquisition of this praised and commended knowledge. The main one of them is to make the love due to humankind mingled and indifferent and so not to admit any graduation or diversity within it. They do not realise that just as the copious and abundant river that divides into many branches, once consumed, is then finally extinguished and dries up, so when our affects are addressed to many objects, they will be reduced to nothing. Thus, some legislators, in order to strengthen their love for their own citizens, instil hatred and aversion towards those who are foreign to the republic, so by means of antiperistasis, ${ }^{490}$ the affection for their own citizens will be strengthened. From what I have considered, you may gather that it is not profitable for a citizen to wander outside the borders of his own homeland with his discourse. [On the contrary,] I will say that it should not be extended up to the skies or expanded throughout all of humankind, but that it should end within his own homeland.

When love was indifferent, it vanished. 
Abuso della moderatione.
Assordi che circa la moralità risultano dal contemplar la natura.
E siccome s'ingannò Hippia circa la sapienza che [283] vertisce circa le cose della natura stimandola madre dell'humana prudenza, così parimente non colpì nel vero quando affermò che la cognitione della natura generi nell'animo humano moderatione e temperanza. Non è poco di tempo che essendo a Xerse potentissimo Re dell'Asia raportato il dogma di Democrito, ch'afferma ch'infiniti siano li mondi nell'immenso vacuo disseminati, non parendoli probabile ch'in vastissima campagna un grano di miglio solamente vi germogliasse, sospirando prorupe:

'O da poco e neghitoso ch'io sono, che per anco uno di questi mondi io non ho assogetato e acquistato!’.

Et immediate alla impresa della Grecia si accinse. Dal che ne successero li mali non meno ad esso che a noi notorii. E né anco la fortezza fra le virtù veramente la più virile, non solamente nella scola della natura non s'apprende, ma piuttosto la viltà et abiettione dell'animo s'impara. L'oggettare l'infinito e riconoscendolo inattingibile consterna talmente il nostro animo, che l'estingue il talento naturale che tiene di sempre proseguire et oltrapassare con suoi intraprese e conquiste, discorrendo in tal guisa il cultore della sapienza:

'Se l'infinito non si può conseguire, di qual pregio è la portione di lui per grande che sia, se rispetto ad esso, è meno che grano di miglio in riguardo all'ampiezza del cielo? Anheli la più egregia virtù per lasciare per alcun tempo memoria di sé appo la posterità, mentre che non è certa della sempiternità, quel lungo tratto di tempo che si prometta è spatio minimo et inconsiderabile rispetto alla interminata successione ventura. Quello che una fiatta è per finire è come se mai non havesse principiato'.

Onde da tal divisamento turbato il sapiente, scusa la sua scioperatezza e difende il suo otio. E né stimarei che quelli documenti ch'addusse Hippia per norma della vita morale e civile che da principio dalle osservationi naturali fossero dedoti, ma che ad essi avenisse quello accade ad aritmetici, che prima ritrovano con la pratica il loro proponimento e doppo a tali inventioni le demonstrationi vi addatono, onde [284] volgarmente rimangono admirati l'homini di ciò ignari, stimando oltrapassare l'ingegno humano le loro sottilissime deduttioni. Così anco li pittori prima con l'occhio advertiscono li risalti, profondità e scorciamenti, e doppo li prospetivi l'accomodono le ragioni dalla matematica derivate.

Nell'istesso modo io tengo, che tutte l'instruttioni apportate da Hippia, e da altri che a tal impiego si posero, fossero prima tali avertimenti da politici osservati dalle humane emergentie, e doppo da esso Hippia artificiosamente applicati alli naturali avenimenti. E non dubbito, se l'otio me lo concedesse, che in maggior numero ritrovarei l'assordi, che volendo assestare li progressi della natura alli humani andamenti, succederebbero. Ma tuttavia non voglio lasciare di farne racconto d'alcuno, acciò il mio favellare ti riesca alquanto credibile, omettendo per hora il ragionare circa la prudenza, poiché nel principio del mio divisamento ti accennai il discapito che ne succede per l'incombenza che circa le cose naturali frequenta. Ma circa la giustitia comutativa mostreroti quanto di scandalo ne segue deducendo dalla natura la sua genealogia. 
"Besides, just as Hippias was mistaken as far as wisdom [283] about the things of Nature was concerned, as he considered it the mother of human prudence, so he was not speaking the truth when he stated that cognition of Nature generates moderation and temperance in the human mind. Xerxes, ${ }^{491}$ a very powerful king of Asia, was recently told about the dogma of Democritus, which states that there are infinite worlds disseminated throughout the immense vacuum. Then, as it seemed improbable to him that only one grain of millet could germinate in all the vast countryside, he sighed and then burst out:

'I am so insignificant and negligent that I have not yet conquered and subjugated even one of these worlds! ${ }^{492}$

"He then immediately set about occupying Greece. There then followed the evils which he [i.e., Hippias] knows as well as we do. Furthermore, strength is not even the most robust of the virtues: indeed, it cannot be apprehended in Nature's school, where one rather learns vileness and abjectness. Conceiving the infinite and acknowledging that it is inaccessible dismays the mind so much that it extinguishes its natural skill to continually exceed itself in its undertakings and conquests. A person who esteems wisdom would speak in this way:

'If the infinite is unachievable, what value may a part of it have, even if it is large, if, when the two are compared, it is smaller than a grain of millet compared to the vastness of the sky? You long for the most excellent virtue in order to leave a memory of yourself to posterity for a while, while sempiternity itself is not certain. That guaranteed long period of time is a minimal and inconsiderable space compared to future indeterminate events. Something that will one day end is like a thing that never began.'

"Thus, this wise man, upset by this exposition, excuses his indolence and defends his leisure. Besides, I do not think that those pieces of evidence put forth by Hippias as rules for moral and civil life were originally deduced from natural observations, yet they may undergo the same thing that occurs to arithmeticians, who first find their resolution through practising and then adjust their demonstrations to these inventions. Therefore, [284] people who are unaware of this are commonly impressed by it, as they consider that their extremely fine deductions go beyond the human intellect. Similarly, painters also execute the highlighted areas, depth, and foreshortening first, merely by sight, and then adjust the perspectives to the rules derived from mathematics.

"In the same way, I think that all the instructions provided by Hippias and the others who pursued this work were first warnings observed by politicians from human occurrences which Hippias artfully applied to natural events. Besides, I cannot doubt - if my leisure would allow me to do so - that I would find an even greater number of absurdities which would occur if one attempted to adjust Nature's improvements to human advancements. Nevertheless, I do not want to neglect to mention some of them in order that my speech may result as sufficiently credible. I will omit debating prudence for the moment, because at the beginning of my examination, I mentioned to you the disadvantage following from its dealings with natural things. Yet concerning commutative justice, I will show you what great scandal follows when one deduces its genealogy from Nature.
The abuse of moderation.
The absurdities concerning morality result from contemplation of Nature. 
Non si può negare che nell'esigere la natura da minuti misti tutto quello che li è accomodato dall'elementi, si dimostra rigorosa, et oltremodo austera, e vuole che integramente li sia restituito. Non così diligente apparisce in eseguire la sua giustitia nelle portioni maggiori dell'universo, con quali si osserva praticare quella memorabile, ma dannata sententia dall'arrabiata politica pronontiata, sua retinere privatae domus, de alienis certare regiam laudem esse, onde circa l'usurpationi ch'esercitano li elementi l'uno contra l'altro, giamai la natura con suoi vigorosi stimoli indusse che l'uno all'altro restituisca quello che dell'altrui tiene e possiede.

Quando giammai l'Atlantico mare restituì alla terra quel grandissimo tratto che l'occupò e [285] somer|se? Come anco non le reintegrò quell'istmo che l'Italia con la Sicilia continovava. Né la terra parimente non ha renduto al mare quello li furò, quando con l'aluvione del Nilo, formò nel suo seno l'Egitto. Né l'aria tumultuando nelle viscere della terra, sconvolgendola con rovinosi terramoti giamai la rifece de danni cagionatile. Com'anco il fuoco con suoi impetuosi folgori abbrugiandole tratto di grandissime e spatiosissime selve, per alcuno tempo non la reintegrò.

Dall'istessa natura fu appreso quell'altro iniquo detto, id aequius, quod validius, osservandosi per tutto il corso di essa natura che sempre il più potente vince, et il debole soccombe e rimane oppresso. Ma oltre di ciò, quel fermo instituto della natura, di non generare alcuna cosa se non con la corrutione di altra, può esser abusato da questi che vogliono assestare li usi humani alli decreti della natura, con derivare da tale osservatione l'approvechiarsi et avanzarsi con il detrimento altrui, e fabricare li edifitii della propria fortuna, sopra le rovine di suoi consorti et amici, poiché anco la natura non trapassa nelle sue transmutationi da genere a genere, ma piuttosto da spetie all'altra prossima.

Da tali contemplationi presero ansa alcuni dalla virtù alieni di patrocinare alcuni enormi vitii. L'ingratitudine appo l'istessi vitiosi monstruosa e dannata, nell'ambito della natura trovò li suoi essempii, le esalationi nel seno della terra prodotte, e dal calore del Sole in alto solevate, et illuminate, ma nondimeno sovente et a questo l'impediscon la vista, e l'offuscano il lume, e quella folgorano. Di più mentre che la Luna maggiormente apporta luce alla Terra, essendo questa dal lume del Sole destituta, cioè ritrovandosi la Luna nel plenilunio, all'hora appunto la Terra la priva di luce et impedisce il vagheggiare il suo amante Sole.

Così anco l'avaritia che non riconosce legge alcuna per ritener quello [286] che una volta ha preso e stretto tiene nelle mani:

Virgilius. Quid non mortalia pectora cogis, auri sacra fames.

Nella scola della natura imparò li suoi depravati costumi. E che non eseguisce essa natura per rittenere quello che una fiatta tenga posseduto, se non di cosa equivalente sia reintegrata? Non solo ritiene il grave che contra la sua propria inclinatione al basso non discenda, ma di più lo fa ad alto salire insin tanto che non sia di altro corpo ricompensato, onde patienta l'universo che si frangano li suoi decreti, mentre non si inanisca alcuna portione di esso. Li violatori della 
"It cannot be denied that Nature demonstrates that it is rigorous and extremely austere in demanding from the minute mixed [things] that everything that was promised by the elements be fully returned to it [i.e., Nature]. [However,] it does not appear to be so diligent in executing its justice on the greater portions of the universe. Indeed, one may here observe that it practises that memorable but damned sentence uttered by angry politics: ${ }^{493}$ To retain its own possessions was the virtue of a private family: in contending for those of others lay the glory of a king. ${ }^{494}$ Therefore, concerning the elements' usurpations of one another, Nature has never, through its vigorous incentives, forced one of them to return to another that which they took from them.

"Has the Atlantic Ocean ever given the earth back that great stretch [of it] which it occupied and [285] submerged? Likewise, it has not restored the isthmus connecting Italy and Sicily, nor has the earth given back to the sea that which it stole when, after the flooding of the Nile, it formed Egypt in its bosom; nor has the air ever compensated the damage caused to the earth when, agitating itself violently in its bowels, it upset it with ruinous earthquakes. Similarly, fire, after burning a stretch of great and extremely wide wood with its impetuous lightning, does not restore it for a while.

"From Nature itself was learned that other unjust saying, with princes might was the only right, ${ }^{495}$ by observing that throughout Nature's course, the most powerful always win, while the weak succumb and are oppressed. However, in addition to this, Nature's firm principle of generating things only through the corruption of other things may be abused by those who wish to adjust human purposes to Nature's decrees. Indeed, from this observation, they would gather how to take advantage and advancement by damaging others and thus to construct the buildings of their fortune over the ruins of their fellows and friends, because Nature in its transmutations also does not move from kind to kind, but rather from one species to the next.

"From these contemplations, some people alien to virtue took the opportunity of defending some great vices. Ingratitude, which was monstrous and damned in the opinion of these same depraved people, took an example from Nature's realm. Indeed, the exhalations produced in the earth's bosom, once they are raised up by the sun's heat and illuminated [by it], are not only often [responsible] for obstructing the view of the latter and obscuring its light, but also for striking the former with lightning. Moreover, when the moon provides more light for the earth, namely when it is a full moon, and the latter is destitute of sunlight, then the earth deprives it of light and prevents it from contemplating its lover the sun. ${ }^{496}$

"Avarice does not acknowledge any rule in order to retain that which it [286] once took and held in its hands:

To what crime do you not drive the hearts of men, accursed hunger for gold ${ }^{497}$

Virgil.

"[Avarice] learned its depraved customs in Nature's school. What will it [i.e., Nature] not do in order to keep that which it once possessed, if it is not replenished with something equivalent? Not only does it restrain a heavy thing from its own inclination to descend, but it also causes it to ascend as long as another body is returned to it. Therefore, the universe tolerates its decrees being broken provided that none of its parts is destroyed. Those who violate 
Abuso circa l'amicitia.

\section{Contrarii li andamenti della natura alla moralità.}

Sapienza naturale offende la religione. amicitia sostegno e condimento della humana vita, da progressi della prima materia presero a paliare la loro scelerata iniquità.

Questa secondo il parere del nostro Aristotele, seguito dal satelitio di molti suoi settatori benché s'unisca in stretta allianza et amicissima congiuntione con una forma, tuttavia giamai con essa si stringe, che in breve tempo, rispetto alla duratione dell'universo, non la rigetta e abhorisce, et a guisa di infame meretrice ad altra inclina e si prostituisce. Dal che questi tali spregiatori dell'amicitia prendono pravo documento et eseguiscono delli loro amici, quello si suole fare di vestiti, molti haverne, un goderne e cangiare spesso infiniti. Altri pravi costumi all'homo dannati facilmente si contrahe dal troppo oggettare con la mente le cose esterne. Da tal pratica riportò Aristippo a noi homini, che il piacere sia l'ultimo fine al quale tutte le nostre attioni si devono indrizzare, havendo li Persiani anco nelli irragioneuoli animali osservato l'infame concubito di figliuoli con le madri. Li Egittii da bruti dedussero anco il giacersi con le sorelle, e tu, Socrate, mentre che seriamente vanegiavi, d'indi raportasti l'instituire nella tua republica la comunità di mogli e figliuoli. Come anco Diogine da tali essempi dedusse la nudità di corpi, habitatione del doglio, fierezza di costumi, rudità di vita, e despicientia di ogni civile cultura. Intrapresa veramente indegna [287] di chi professa il nome di filosofo cioè l'attentare di rimettere l'homini nella classe di bruti riuscendo con tal loro intrapresa inferiori a publici giocoleri che per dilettare il volgo, procurano di amaestrare li più sciochi animali che con lor attigiamenti imitino li nostri gesti. Ma tali filosofi s'impiegano a disumanarci e che ad essi bruti simili diveniamo.

Da ciò che hora teco ho divisato, stimarei, o Socrate, che a sufficientia dimostrato rimane, di quanto diversi anzi contrarii siano li andamenti della natura con quali si mantiene la vastissima machina dell'universo, dalli ordini et instituti con quali si governa il nostro genere, picciolissima portione di quello. L'uguagliarli non meno assordo che se la nostra Attica picciola parte della Grecia volesse reggersi con li ordini che si governa tutta l'Asia al re di Persia sogetta.

Da ciò parimente scorgi, quanto lungi dalla verità se discostò Hippia, mentre affermò che il mondo fosse una publica scola et accademia nella quale si aprendono li precetti della moralità e rudimenti della politica. Restami a dimostrarti che anco vanamente si affaticò il medesmo in dare ad intendere che la filosofia naturale habbia aperto l'adito alla religione e pietà. Io per il certo tengo parere a ciò contrario! Anzi credo che alla filosofia sia avenuto ciò che sovente accade alla pratica della medicina, che mentre imprende scacciare dall'infermo li depravati humori che l'offendono, insieme con essi detrude l'istessa vita. Così anco questa temeraria Sapienza non diretta da maggior lume, pretendendo distrugere la superstitione, fuga la istessa religione.

Et io non sono tale che approbbi la superstitione! Anzi io la condanno e regetto! Ma dirò ben questo, che piuttosto essa ridicola e dispregiabile che maligna e scelerata riesce mentre però non è pigliata per pretesto, et addobamento della istessa impietà, falce d'ogni virtù devastatrice dell'humana società. E stimo che la superstitione è a guisa di quelli veneni che alle fiatte apporta alli infermi alcuna sanità, poiché l'esperienza, vera nostra maestra, 
friendship, the support and seasoning of human life, gathered [the capacity] to dissimulate their wicked iniquity from the advancements of the primal matter.

"According to the opinion of our Aristotle, together with a group of many of his supporters, although it [i. e., matter] forms a close alliance and very favourable conjunction with a form, it nevertheless only draws close to it for a short time compared with the duration of the universe, and it never rejects or abhors it, but, like an infamous harlot, ${ }^{498}$ rather inclines to others and prostitutes itself. These despisers of friendship take an evil example from this and do to their friends what one usually does with clothes, namely to have many of them, but to enjoy only one, and to often alternate between an infinite number of them. By excessively thinking about external things, other evil customs might be easily acquired [which are] damned among humankind. From this practice, Aristippus reported to us human beings that pleasure was the final goal to which we should direct all our deeds. Indeed, the Persians observed that the infamous concubinage between sons and their mothers even occurred among irrational animals. The Egyptians drew [the practice] of lying with their very sisters from these brutes, ${ }^{499}$ and you, Socrates, while you were raving, seriously referred to them in order to establish the community of wives and sons in your republic. ${ }^{500}$ Likewise, from these examples, Diogenes deduced bodily nudity, [the use of] a barrel as a home, ${ }^{501}$ ferality of customs, crudity of life, and disdain for every civil culture. It is truly an unworthy [287] undertaking for whosoever professes the name of philosopher to attempt to place human beings back into the class of brutes. In their endeavour, they turn out to be inferior to a public juggler, who tries to train the silliest animals to imitate our gestures with their behaviour in order to delight the masses. Indeed, these philosophers seek to dehumanise us so that we become like brutes.

"From what I have now considered with you, I would think, oh Socrates, that it has been sufficiently demonstrated that the course of Nature, thanks to which the enormous machine of the universe is maintained, is very different, or even contrary, to the orders and principles which rule humankind, which is a very small part of it. To compare them would be as absurd as if our Attica, a small part of Greece, wished to be ruled by the same orders that rule the whole of Asia, subjects of the king of Persia.

"From this, you may similarly see how far Hippias diverted from the truth when he stated that the world was a public school or academy where one learns the precepts of morality and rudiments of politics. I still have to demonstrate to you that the same man strove in vain to make others believe that natural philosophy opened the path to religion and piety. I certainly have a contrary opinion! Rather, I believe that there occurred to philosophy the same thing that often occurs within the practice of medicine, namely that when it undertakes to chase the degenerated humours away from the sick person whom they are harming, it also [ends up] detruding life itself along with them..$^{502}$ Likewise, this reckless wisdom, when it is not led by superior light, dispels religion itself while believing that it is destroying superstition.

"And I am not the sort of person who approves of superstition! Rather, I condemn and refute it! However, I will say that it turns out to be ridiculous and despicable rather than malicious and wicked if it is not used as a pretext and ornament of that same impiety, which is a scythe to every virtue and destructive to human society. Furthermore, I consider superstition [to be] like those poisons which sometimes bring health to the sick. This is because experience,
Those who violate

friendship.

The course of Nature is contrary to morality.

Natural wisdom hurts religion. 
ci dimostrò che sovente ad inanimire un popolo alla difesa della propria [288] patria et ad incontrare con lieto sembiante l'horrore della morte, riesce più efficace l'osservare il cibare, garire, e volare, di ucelli, come anco l'inviluppati responsi di infuriata donna, che meditato ragionemento di erudito filosofo che del dispregio della vita e della gloria dottamente divisasse, non riuscendo vero quello che Ipocrate ci lasciò scritto, che contraria contrariis curantur, ma piuttosto come altri più moderni tengono che similia similibus curantur.

Cioè al mio proposito che li vitii prodotti dalle stoltitie del popolo alle fiate si emendono e curano con altre simili, riuscendo vero il comune proverbio che clavus clavo eiicitur, accadendo ciò non in diverso modo di quello si pratica nel purgare li machiati panni, che con il sapone composto di oglio, liquore sopra tutti li altri infetivo, si levano le loro lordure. Così apunto nelli animi plebei le liture di alcuni vitii con altri si spingono e purgano. E ciò dico circa quella vana superstitione che consiste in superflue et esterne attioni e mendaci openioni, non già appellando con tal nome il culto mentale che si pratica verso Iddio, benché eccessivo egli fosse, non potendo giamai ciò riuscire superfluo, mentre tiene oggetto infinito et interminato. Per il che non può sortire esorbitante et intemperato il suo interno culto, e siccome nelle materie morali la mediocrità è decente, così in questo l'immoderato è il comendabile.

Ma voglio hormai lasciare a parte il discorrere circa la speculatione delle cose a noi esterne, et inclinare voglio il ragionare a quella tanto stimata dal volgo di sapienti proficua e giovevole contemplatione. Dico la morale scientia, quella che si milanta di haver revocato li homini dalle solitarie selve, deserte spelonche, e da quella maniera di vita raminga e roza e ridotteli al vivere civile e sociabile, havendoli admoniti ad erigire città, fondare popolationi, instituire regni, formare republiche, promulgare leggi et instilare nelli nostri animi li primi semi di virtù. Per il che si rende cotanto felici li suoi cultori, che le rendono ossequio et obedienza, havendoli dimostrato [289] li termini che fra li estremi vitiosi essa virtù si trova:

Oratius.

\section{Est modus in rebus sunt certi denique fines}

Quae ultra citraque nequit consistere rectum.

Ma nondimeno con tanti vantamenti se tale scientia esaminare vogliamo, non solamente riesce deficiente a tante comendationi, ma non priva da nocumento et offesa, e massime quando oltremodo cavillando trapassa il segno circa li principii della virtù. Sovente accade a questa quello aviene ad alcuni Prencipi oltremodo curiosi di riconoscere la lor antica stirpe, e genealogia, che tanto

Assordo che segue, dal troppo investigare li principii delle virtù morali. oltrapassano, che s'incontran in alcuno sciagurato sbirro. E come parimente occorre a quelli che profondando per rinvenire li fondamenti di nobile e riguardevole palagio che alla fine vi ritrovano roze pietre e lordo fango, così parimente a questi fuori di ordine sacenti incontra, che tanto si internano con il loro caviloso discorso verso li primi esordii e ressorti della virtù, che alle fiatte nell'istesso vitio s'attopano, rendendosi costoro che seguono tal dottrina simile a quelli che nella loro infantia, e primiera indole riverirno li loro educatori come legitimi loro padri, ma in progresso di tempo riconosciuto che hanno esserli 
our true teacher, has demonstrated to us that the feeding, twittering, and flying of birds, as well as the confused responses of frenzied women, often turn out to be more effective to encourage people to defend their own [288] homeland and to go joyfully towards the dread of death than the carefully weighted reasoning of an erudite philosopher who learnedly argues in favour of the disregard of life and glory. Therefore, what Hippocrates wrote, that the opposite is cured with the opposite, ${ }^{503}$ turns out not to be true, but rather the like is cured with the like, ${ }^{504}$ as is maintained by other more modern [thinkers].

"As far as my subject is concerned, namely that the vices produced by the foolishnesses of common people can sometimes be emended and cured by others [that are] like them, the common proverb that one nail can be driven out by another turns out to be true; ${ }^{505}$ the same happens in the practice of purging stained clothes, which can be cleaned with a soap made of weeds, the most staining liquid of all. Likewise, in plebeian souls, the stains of some vices are indeed expelled and purged by others. I am talking about that vain superstition consisting of superfluous and external actions and mendacious opinions, and by this name I do not mean the intellectual worship of God. Indeed, although this is excessive, it will never be useless, since it has an infinite and indeterminate object. Hence, His internal worship could never turn out to be exorbitant or immoderate, and just as moderation is appropriate within moral matters, so in this one, the immoderate is commendable.

"Yet I now want to leave aside further debate concerning speculation on things external to us and rather argue in favour of contemplation, esteemed as so profitable and useful by many wise men; I mean moral philosophy, that which boasts of having called humankind back from the lonely woods, desert caves, and rough and wandering lives. Furthermore, it boasts of having led them to civil and social life and having exhorted them to build cities, lay the foundation of populations, institute realms, form republics, promulgate laws, and instil the first seeds of virtue in our minds. Therefore, it [i. e., moral philosohy] makes its estimators so fortunate - as it has demonstrated [289] to them that virtue is placed between the extremes of vices - that they respect and obey it:

There is measure in all things. There are, in

Short, fixed bounds, beyond and short of which right can find no place..$^{506}$

Horace.

"However, if we want to examine this such-praised knowledge, it turns out to be not only lacking in many commendations, but also to be a cause of injury and harm, especially when it [i. e., moral philosophy] goes too far by frequently and excessively quibbling over the principles of virtue. There often occurs to this the same thing that occurs to some princes, who are so curious to know their ancient ancestry and genealogy that they go so far as to run into a wicked official of justice. Likewise, just as it happens to those who, in lowering themselves to discover the foundations of a noble and remarkable palace in the end find only rough stones and dirty mud, so it is the case for these extraordinarily arrogant people who sometimes come across vice itself when they are moving towards the origins and outcomes of virtue with their quibbling discourse. Those who follow this doctrine make themselves like those who [show] a primaeval inclination to revere their pedagogues as their legitimate fathers during their infancy, but then over time, once [they have] acknowledged that they are

Absurdities that follow from excessively investigating the beginnings of moral virtues. 
Esame circa le cagioni della beneficientia. putatitii genitori, altrotanto che da principio l'honoravano doppo li dispregiano e sviliscono.

Ma che ciò sia avenuto alle virtù, rispetto il troppo sofisticare di costoro, dimostrerotelo primieramente esser ciò accaduto alla beneficientia, di tutte le virtù madre e corifea. Circa questa dunque s'esercitarono in riconoscere li suoi primordii et anziani principii, e da strane origini dedussero li suoi natali. Fu detto che fosse avantagioso trafico e usuratica mercantia, che fra li homini sovente si esercita di offerire il poco per conseguire il molto, e perciò da vil interesse trarre origine. Da altri fu detto che fosse oppiato regalo, che li più accorti al volgo offerisce per [290] addormen|tarli insino che conseguiscono li loro attentati, e perciò dalla fraude trahesse li suoi natali. Da altri fu dedota d'impatiente conditione d'animo inetto a resistere alla petulanza di dimandanti, essendole piuttosto estorti li benefitii che da essa conferiti. Sovente anco essa beneficientia derivare da lubrica rilassatione, che non sa né godere, né rattenere li beni che possiede, onde senza alcun diletto, promiscuamente a qualunque li prostituisce.

Altri attribuirno la sua origine in quanto appartiene alla profusione di proprii haveri, alla otiosità e scioperatezza liberandosi dall'impacio e briga di conservare illeso, ciò che continuamente le viene d'altrui insidiato. Altri dissero che ben spesso è paliamento e coperta di enormi vitii, essendo questa l'anello che regge e rende invisibile li vitiosi che in dito la tengono, et il vero fascino che incanta li animi anco più attenti e risvegliati. Altri la stimarono che sebbene che anco sincera di ogni interesse e fraude fosse, non di rado è figlia di cieco amore, et effetto d'indiscreto giuditio. Altri tirarno la sua genealogia da perversa malignità, ché non rare volte prendono li grandi diletto d'inalzare alcuno con li favori, per poi abbassarlo, trastulandosi del spettacolo di salti mortali e croli repentini che il sgratiato favorito li rappresenta. Et altri, per trattenere il loro otio, e per adempire in uno sogetto le tre fontioni che appartengono ad essi grandi, cioè il fare, disfare, e dare ad intendere.

Non mancono altri che stimano li favori et autorità che ad altrui si appresta, hanno per fine l'interessare li suoi privati nel sostegno della cadente fortuna del loro principe, dovendo caminare a pari passo la prosperità del beneficiato, con la grandezza del benefattore. Accade anco dicono altri, che la distributione di grandi favori, non procede da amore, ma per dare contrapeso ad altro favorito, onde oppresso questo cade parimente quello. Affermano parimente alcuni, che la straordinaria beneficentia, da intenso odio deriva, e non per altro è praticata, che per rendere il favorito maggiormente invidiato e che se li accendi tanto più agevolmente [291] contra l'ira de' suoi arrabiati emuli e malevoli. Advertiscono altri, che sovente s'accresce alcuno di autorità per dar ad intendere al volgo, che li effetti enormi che nel Stato occorono, dalle difalte del ministro avengono, nella cui balia è riposto il peso e somma delle cose, onde sacrificandolo poi all'odio universale, il supremo dominante riacquista l'affetto e l'amore de suoi vassali. E quando ciò non succedesse, almeno il privato a guisa di antemurale si trova primo esposto al populare furore. 
only alleged parents, disdain and debase them, while at the beginning they honoured them.

"Yet I will demonstrate to you that this happened to the virtues because of their [i. e., the arrogant people who praise knowledge] excessive sophist ication, and that this first occurred to beneficence, as the mother and coryphaeus of all virtues. They applied themselves to it with the aim of acknowledging its beginnings and primaeval principles, and they then deduced that it had strange origins. It has been said that it is like advantageous trade or usurious wares, because it is often the custom among human beings to offer little and attain more, and thus that it emerges from a vile interest. Others have said that it is an opium-based gift that is offered to the masses by the most careful people with the aim of [290] making them fall asleep while they accomplish their attempts, and therefore that it draws its origin from fraud. Others deduced it from an impatient condition of the mind that is incapable of resisting the insistence of askers, and thus benefits are extorted rather than bestowed from it. Often beneficence was a result of lascivious licentiousness, able neither to enjoy nor to retain the possessed goods; hence without any delight, it promiscuously prostitutes them to anyone.

"As it is a profusion of one's own wealth, others have attributed its origin to leisure and laziness in order to escape the awkwardness and difficulty of preserving unharmed that which is continuously undermined by others. Others have said that it is very often a cover and blanket for enormous vices, because it is like that ring that rules the depraved people who wear it on their finger and makes them invisible ${ }^{507}$ and that it is the true fascination which enchants even the most aware and careful minds. ${ }^{508}$ Others considered that although it is [only] sincerely [moved] by interest and fraud, it is often the daughter of blind love and the result of rash judgment. Others have gathered its genealogy from a perverse malignity, because often the great delight themselves in raising a person with their favours and then in bringing him down, enjoying the spectacle offered by the somersaults and sudden falls of this miserable favourite. Still others [thought that its purpose was] to withhold their leisure and thus to fulfil the three functions proper to the great in a sole subject, namely to do, to undo, and to bring about beliefs.

"There were also others who considered that the only goal of the favours and authority given to others was that of turning the attention of a prince's private individuals to supporting his falling fortune, because the prosperity of the beneficiary must go hand in hand with the greatness of the benefactor. Others have said that it also happens that the distribution of great favours does not come from love, but [from the wish] to counterbalance [the position of] another favourite; therefore, as soon as the latter is oppressed, then the former also falls. Likewise, some have stated that extraordinary beneficence is derived from intense hatred and that it is practised only to make a favourite so envied as to make it much easier [291] for the rage of his angry imitators and ill-wishers to be unleashed against him. Others have warned that often a person increases his authority by giving the masses the impression that the terrible consequences occurring in the state are the fault of a minister who has the weight and totality of things at his mercy. Thus, by sacrificing him to the hatred of all, the supreme ruler regains his vassals' affection and love. However, in the cases where this does not happen, [his] private [goods], like an antemural, ${ }^{509}$ are the first to be exposed to the people's fury.

Examination
of the causes of
beneficence. 
Altri tengono che più delle volte la beneficientia scaturisce non da amore che si tenga verso li homini, ma da urgente et intensissimo desio di gloria, essendo la fama della beneficentia, la più espedita nel volo, e di più chiara voce che il sussuro che balbotiscono l'altre virtù, et ad essa come farfale alla luce, vi accorrono tutti li bisognosi over avidi di alcun beneficio. Alcuni dissero, che ben spesso nasce da ostentatione di potenza, emulando li grandi l'istesso Iddio, nel dar esser al nulla, e perciò alcune volte è praticata piuttosto in solevare l'indegni, che li meritevoli, sospettando che il merito tenendo parte in tale esaltatione, non li sminuisca la stima della loro plenipotentia. Altre cause e ressorti hanno li morali attribuito alla beneficientia, al pari delli antedetti indegni, che troppo tedioso riuscirei se hora annoverare te li volessi, ché tutti però ridondono in renderla interessata, fraudolente, inetta, malitiosa, e disgiunta dalla vera e sincera virtù.

Difesa dell'ingratitudine.

Oppongono alla prudenza.

Oppongono

alla definitione della giustitia.

Altra definitione della giustitia.
Da questa divolgata dottrina prese ardire l'ingratitudine abominevole vitio, di vantarsi esser una esquisita filosofia, indagatrice delle vere cause e primi esordii delle gratie, rinvenendo con il suo speculare quali siano li primi impulsi che reggono la beneficientia. Da questo il nostro Aristotele nella materia morale tanto perito, assignando le conditioni al suo ideato magnanimo, prese a dire, che tale semideo si trova oblivioso di favori da altrui ottenuti. Non meno infelice incontro, occorse alla prudenza con questi sottilissimi e curiosi ricercanti della genealogia delle virtù che oltremodo [292] ven|tilata, vano e chimerico nome et improficua virtù la divolgarono, siccome dalle discussioni circa essa esercitati (come mi narrasti) si è reso manifesto.

Né la giustitia benché al volgo dell'homini sia formidabile, non fu bastevole a difendersi dalli costoro affronti. Da principio dalla sincera gente fu definito che sia una ferma volontà di rendere a cadauno ciò che è suo. Ma da questi cavillatori in tal guisa fu assaltata. Primieramente suposero che l'ignoranti non siano differenti da pazzi, se non in quanto il più et il meno, che essendo tutti essi al pari esclusi dal posseso della verità, simili stimare si devono circa quelli proponimenti che ambi deviano et errano. Secondariamente, affermarno, che non meno è nocivo il libero uso delle ricchezze a pazzi, che delle arme, anzi che con quello si può procacciare più numeroso stuolo di malefici per eseguire l'insani loro attentati. Da ciò dedussero che siccome a pazzi è interdetto il maneggiar delle armi, così anco le loro richezze convenga per mezo di curatori trattare, e siccome quelle non è lecito restituirle, così anco alli ignoranti nella classe de pazzi già intrusi, non se li deve lasciar libero l'uso de loro opulentie, ma li savii o filosofi che dir li vogliamo, devono di queste prenderne custodia et esercitarvi il loro talento e voglia.

E perciò mutando tale definitione pronontiarno, fontione della giustitia essere che cadauno posedesse ciò che li conviene. Onde dedussero, che il pedagogo di Ciro meritava piuttosto le stafilate ch'il discepolo, ché havendo questo giudicato che fosse lecito al grande e proceroso pigliare al breve di statura il proprio lungo vestito, contracambiandolo con il suo, se al picciolo s'assesta, seguitando piuttosto in ciò la convenevolezza e decentia, che la proprietà, per tal decisione fu dal maestro severamente battuto detestandoli oltremodo tale sentenza. Aggiungendo essi, che conforme la primiera esplicatione, la giustitia comutativa seguendo la imperfetta proportione 
"Others hold the opinion that beneficence mostly arises not from the love of humankind, but from an urgent and extremely intense desire for glory. Indeed, the fame [coming from] beneficence is the quickest to stand out and has a clearer voice in comparison with the whispers mumbled by the other virtues. Furthermore, all those people who are needy or greedy for profit rush up to it like moths to a flame. Some have said that this often comes from a display of power: indeed, the great people imitate God Himself by creating out of nothing. Therefore, this is sometimes practised in promoting the unworthy instead of those who deserve it, because they suspect that if merit played a role in this promotion, the esteem for their plenipotency would decrease. Moral people have attributed other unworthy causes and effects to beneficence similar to those mentioned before, and I would be too tedious if I wished to enumerate them now. However, many [of them] make it [i.e., beneficence] out to be self-interested, fraudulent, inept, malicious, and separate from true and sincere virtue.

"From this disseminated doctrine, ingratitude, an abominable vice, began to dare to boast of being a thorough philosophy, an investigator of the true causes and the first beginnings of graces, able, through speculation, to discover what the first impulses ruling beneficence were. Hence, our Aristotle, so expert in moral matters, in attributing [these] conditions to whomsoever he had conceived to be magnanimous, began to say that this demigod forgot the favours obtained by others. No less unfavourable was the encounter between prudence and those very subtle and inquisitive researchers into the genealogy of virtue, [292] who debated about it extensively and spread that it was a vain and chimeric name as well as a useless virtue. This was evident from the discussions that were held about it, as you told me.

"Not even justice, although the common people feared it, could defend itself from their affronts. In the beginning, sincere people defined it as the firm will to return to every man that which is due to him. Yet these quibbling people then assaulted it in this way: first they supposed that the ignorant were more or less no different from the insane; indeed, as all of them were equally excluded from possessing the truth, they should be considered similar concerning those resolutions that both divert [from the truth] and are mistaken. Secondly, they stated that the free use of riches made by the mad was no less harmful than that of weapons; rather, with the former, an even greater number of wicked deeds could be produced to pursue their insane attempts. They inferred from this that just as mad people were forbidden to use weapons, so it was also necessary for their riches to be looked after by administrators. Furthermore, just as it was not licit to return them [to mad people], so one should not allow the ignorant, already added to the class of the mad, the free use of their riches. For [only] the sages - or philosophers, as we prefer to say - must guard them [i.e., riches] and, through them, exercise their talent and desire.

"Thus, changing this definition, they uttered that the function of justice was that each person would have what was appropriate for him. Therefore, they deduced that Cyrus's pedagogue, ${ }^{510}$ and not his disciple, deserved the lash. Indeed, the latter deemed that a tall and slender person was allowed to a short person's longer clothing ${ }^{511}$ and to offer his own [clothing] in exchange, if it was suitable for the short person. In this regard, he abided by decorum and decency rather than by ownership. Because of this decision, he was severely beaten by his master, who greatly despised this sentence. They continued that according to the first explication, commutative justice, abiding by imperfect arithmetical propor-

\section{Defence of \\ ingratitude.}

\section{Objection to}

prudence.

Objection to the

definition of justice.

Other definition of

justice. 
Oppongono alla clementia.

Oppongono alle leggi.

Contra l'incostanza. aritmetica, riusciva monocola et incirconspeta, non riguardando se non la cosa che si restituisce, non il renditore, né a cui si restituisce. Di più accusandola, che se pur voleva seguire la aritmetica proportione, doveva osservare li decreti [293] dell'istessa aritmetica che dell'aggregato delle unità constituisce il numero, giudicando questo altro non essere che accumulatione di quelle.

Ma la giustitia comutativa trascura l'agregatione di piccioli usurpationi, come se fosse il composito di essi, bench'aggrandito, affatto di diversa natura da suoi componenti, ma solamente circa la grande et evidente usurpatione che ad un tratto sortisce, s'esercita e travaglia. Di più fu censurata di corta vista, ché solamente all'iniquo posesso presente abbadi, non riguardando all'antico originale e primordiale, affatto ingiusto e tirannico, ma oltre di ciò caluniandola che le sue leggi ripugnano a quelle della amicitia, essendo tanto questa più nobile che quella, quanto la medecina perservativa, eccede la curativa: questa dubbiosa, e che sovente invece di vita apporta morte all'infermo, e quella sempre sicura, et infine opponendole che ad essa giustitia accade quello non aviene ad alcuna altra cosa mondana, che il sommo, e perfetto di essa sia pravo e dannato, e che nel suo contradittorio si converta, d'onde derivò quella volgare sentenza summum ius summa iniuria. Ma non perché da questi fosse vilipesa la giustitia, però fu lodata la clementia che non poco da quella declina, anzi accusandola che senza circonspettione mira solamente il presente e particolare individuo, non oggetando l'universalità dell'homini e l'infinito avenire, e che essendo pieghevole e pietosa verso pochi, e benefica ad alcuni particolari, riesce crudele et atroce verso ad innumerabili, poiché il terrore delle inflessibili leggi, rattiene infiniti dal mal operare, et altrui offendere. Ma non perciò le leggi da questi furno comendate, anzi l'appellarno imperfetti e rudi abbozzi che giamai si addattano et aggiustano alla vera imagine d'affari, ritrovandosi sempre discrepanza notabile tra la legge, e l'emergentia che la fortuna rapresenta, riuscendo esse leggi, piuttosto ostacoli all'iniqui che non operino sceleratamente, che norma alla giustitia.

Né la fortezza benché sia di conditione invitta poté evitare di costoro l'offese essendo da questi, li forti comparati alli fanciulli, che l'ombre nocturne li metton paura, e tuttavia dispregiano li grandi et evidenti pericoli della vita, così parimente essi forti non [294] s'inhoridi|scono della presenza della morte, ma sì bene prendono terrore del cicalare del volgo e saliva della plebe, reclamando anco di lei, che sia indegna di annoverarsi fra le più nobili virtù, trahendo ben spesso li suoi natali dalla stupidità et inhumanità, et anco dall'istessa pazzia, deliberando di perdere se stessa per conservare mediocri commodi di quelli, che come insana la disprezzano, e scherniscono.

Né la costanza benché tanto affine alla fortezza, dalle mani di costoro poté scapare, appellandola dell'animo contumace usciera, ché sovente ostacola et impedisce l'adito alle più opportune occasioni e benigni incontri, divolgando che l'homo constante non esser diverso di imprudente nochiero, che invece di destragiare et orzare, con il vento e flutti marini vuole accozzare. $E$ che se li vitii sono spetii di insanie, questa è la più biasimevole per essere maggiormente durabile, siccome che le manie sono per la loro continuatione più nocivi, che le frenesie insultorie e brevi. 
tion, turned out to be one-eyed and not circumspect, because it paid attention neither to what needed to be returned, nor to the one returning, nor to whom it was returned. They furthermore charged it that if it wanted to abide by arithmetical proportion, it had to observe the decrees [293] of arithmetic itself, which constitutes the numerical [sequence] of the aggregation of units, because they judged it to be nothing other than the accumulation of them.

"For commutative justice overlooks the aggregation of small usurpations as if the combination of them was not only larger, but of a different nature to its components, yet it only handles and applies itself to the great and evident usurpation that suddenly occurs. Moreover, it has been criticised for being shortsighted, because it cares only about the current unjust possession and does not pay attention to the ancient original primaeval one, which was indeed unfair and tyrannical. In addition to this, people have slandered it saying that its laws are contrary to those of friendship, as the latter is much nobler than the former, just as a preventive medicine surpasses a curative one: the latter is doubtful and often causes death instead of [saving the] lives of the sick, while the former is always reliable. ${ }^{512}$ Lastly, it has been argued that there occurs to this justice that which does not happen to any other mundane thing, namely that the highest and most perfect [point] of it is [so] wicked and evil as to be converted into its opposite. Therefore, that common sentence more law, less justice derives from this. ${ }^{513}$ The fact that they scorn justice does not mean that they praise clemency, which is somewhat different from it. They rather accuse it of observing only the present and particular individual without circumspection and of not conceiving the universality of human beings or the infinite future. Furthermore, while it is flexible and compassionate to a few people and beneficial to some particular ones, it is cruel and atrocious to innumerable people, since the fear of inflexible laws restrains an infinite [number of people] from acting badly and harming others. Nevertheless, they do not commend the laws, and rather call them imperfect and rough sketches which never conform to the true image of matters. Indeed, as there has always been a remarkable discrepancy between laws and the occurrences put forth by fortune, the laws turn out to be an obstacle to unjust people's wicked deeds rather than a rule of justice.

"Nor could strength, although it is invincible, avoid the offences of those who compared the strong to children who fear night-time shadows, but scorn the great and evident dangers of life. Similarly, these strong people are not horrified [294] by the presence of death, but they are frightened by rumour among the masses and by plebs foaming at the mouth. Thus, they claimed that it [i.e. strength] was also unworthy of being included among the noblest virtues, since it often arose from stupidity and inhumanity and even from madness itself, deciding to lose itself in order to preserve the mediocre interests of those who despised it and sneered at it as though it was insane.

"Not even perseverance, although it is so similar to strength, could escape from the hands of those who called it a reluctant usher of the mind because it often hinders and obstructs the path to the most opportune occasions and benign encounters. Indeed, they have spread that a perseverant man is no different from an imprudent helmsman who, instead of manoeuvring and luffing, wants to clash with the wind and marine waves. Furthermore, if the vices are species of insanity, this one is the most blameworthy, because it is more lasting. Likewise, manias, because of their duration, are more harmful than frenzies, which are occasional and short.
Objection to clemency.

They make objections against the laws.

Against the lack of perseverance. 
Contra la gloria.

Oppongono alla temperanza.
Da quindi sortì, che la gloria fine et oggetto di ambe queste due preclare virtù, incontrò da questi l'istesso strapazzo. E che non dissero contro essa? Appelandola oggetto di sogno di vigilanti, e spettro di sani deliranti, a che fine dicono questi pravamente sapienti, lasciarsi dalla fortezza e constantia persuadere di pericolare anzi perdere la vita? Forsi per l'acquisto della memoria appo li posteri? Ma qual acquisto può esservi, mentre che l'acquistante non vi sia? Ma questa tal memoria ove deve rimanere impressa? Nell'animo delli ignoranti arrolati da noi nella classe di menticati e pazzi? Onde il ritrovarsi ivi l'imagine della virtù delineata, non diverso sarebbe, che il disiare che il ritratto della nostra imagine, fosse dipinta sopra quei vasi ch'a contenere abominevoli escrementi sono dedicati. Nemmeno possono sperare tali homini forti e costanti, scialacquatori e prodighi della propria vita che il simulacro della loro virtù risieda nella mente de veramente savii, havendo questi per instituto di non admettere nel lor animo alcuna admirabilità, e stupore, essendo tali alterationi [295] prole della ignoranza dal loro animo affatto sbandita, havendo sempre in bocca:

\section{Nil admirari prope res una numici \\ Solaque quae potest facere, et servare beatum.}

Da quindi è, che tali sapienti lontani sono di arischiare la loro vita, overo la fortuna, per il commodo altrui, anzi stimano che la codardia publicamente sia tiro di somma prudenza e degna di comendatione, ché se lodato fu Prencipe che per salvare una egregia pittura d'Apelle elaborata, perdonasse ad una grande città contra d'esso iniquamente infelonita, appregiando più quella superficiale pittura et opera di virtù, che la vendetta di molti scelerati ribelli, tanto maggiormente contendono questi che sia scusabile la loro codardia, ché antepongono la conservatione di se stessi, in cui vi risiede la loro dotta mente, ritratto nel quale vi è dipinto non solamente quello di presente nel mondo si ritrova, ma mediante la memoria, quello vi fu, et anco ciò che vi sarà, se attentamente osserva il passato et il presente, e non solamente conserva le superficiali lineamenti e colori, ma l'idee delle interne essentialità.

Stante ciò secondo il lor dogma, non fuor di proposito dissero, che il filosofare altro non sia, ch'il meditare la morte, parendoli che oltra modo terribile sia, che perciò a renderla facile con la imaginaria frequenza e pratica, riesce meno spaventevole. E per il certo le grandi preparationi che li filosofi apportarno per patientare la morte, è inditio manifesto del gran timore che ne concepiscono, siccome che l'armarsi straordinariamente di corsaletto, braciali, gambieri, elmo e visiera, dinota tenire del nemico straordinario timore e horribile spavento. $\mathrm{E}$ quello che ho detto del dispregio della gloria che tali tengono, bastarebbe a manifestarti in quanto poca stima hanno le virtù, essendo vero che contempta gloria contemnuntur virtutes. Ma tuttavia giacch'il tempo me lo concede, voglio proseguire in narrarti [296] quel|lo circa alcune altre virtù fu da essi divolgato.

Hor dunque dicoti, che né anco verso la temperanza l'antedetti sapienti punto moderati sortirno, imponendole che sia occulatissima interessata et avantagiosa calculatrice di piaceri, spiando accuratamente quali siano li diletti più durabili e perseveranti, anteponendo questi alli vehemennti ma transitorii, onde da essi fu concluso, che intemperantia temperantes sumus. 
"Hence, it transpired that glory, as the aim and object of both of these eminent virtues, was similarly mistreated by them. And what did they not say against it? As they called it a dream object for the awake and a spectre for the raving sane, why did these wicked wise men say that they allowed strength and perseverance to persuade them to face danger and even to die? Perhaps in order to be remembered by posterity? However, what can be acquired if there is no one acquiring it? And where must this memory be impressed? In the minds of the ignorant, whom we have enrolled in the class of the half-witted and mad? Therefore, if the image of virtue were to end up as has now been outlined, it would be no different from wishing a representation of our image to be painted on those pots used for containing abominable excrements. These strong and perseverant people cannot even hope, as they are squanderers and wasteful of their own lives, that the simulacrum of their virtue lies in the mind of the truly sage. Indeed, the latter follow the rule of not admitting any marvel or astonishment into their minds, since these alterations [295] are the offspring of ignorance, which is banned from their minds, ${ }^{514}$ as they always say: ${ }^{515}$

'Marvel at nothing' - that is perhaps the one and only thing,

Numicius, that can make a man happy and keep him so. ${ }^{516}$

"Hence these wise men are far from risking their lives, or fortunes, for the interests of others; rather, they consider cowardice to be public proof of the utmost prudence and to be worthy of commendation. A prince who wanted to save an illustrious painting by Apelles forgave a great city for having become unjustly furious with him; indeed, he appreciated that painted surface and work of virtue more than taking revenge against many wicked rebels. ${ }^{517}$ So, they demand to be excused for their cowardice even more, because they put the preservation of themselves first. Indeed, their learned mind rests [in them] like a portrait in which is painted not only what is in the world at the present time, but, through memory, that which has been, and also what will be, if it carefully observes the past and present. Besides, it not only preserves the superficial lines and colours, but also the ideas of their inner essentiality.

"In these circumstances, according to their dogma, they said - not without reason - that philosophising was nothing other than meditating on death, which appears extremely formidable to them. Therefore, it would have been less frightening if they had frequently imagined and dealt with it. Certainly, the great preparations provided by the philosophers for coping with death are a manifest sign of the great fear they feel for it. Likewise, thoroughly arming oneself with a cuirass, armguard, leg guard, helmet, and visor signifies being affected by an extreme fear and horrible dread of the enemy. Furthermore, what I have said about the disregard of glory that they maintain would be enough to show you the little esteem in which they hold virtues, as it is true that in the scorn of glory was implied the scorn of virtue. ${ }^{518}$ Nevertheless, as I still have time, I wish to continue and tell you [296] what they have spread concerning some other virtues.

"Therefore, I will tell you that the aforementioned wise men were indeed not even moderate towards temperance. They established that it was very attentively interested in calculating pleasures for its own advantage. As it carefully spied what the most durable and perseverant delinquencies were and then put them They objected to temperance. above the vehement but transitory ones, they concluded that we are becoming

Against glory.

?


Filosofi amici del piacere.

False calunnie dell'amicitia.
Ma di più tanto oltre si condussero nel caluniarla, che immeritevole del nome di virtù la giudicorno, e che piuttosto falce di vitii e freno di sceleragini appellare si deve, essendo la temperanza semplice espulsiva di vitii non apportatrice di alcuna egregia virtù com'anco il sonno da essi ci disvia, e distolle, seguendo di più che non meno assordo comette colui che arrola la temperanza nelle virtù, di colui, che la privatione fra li principii delle cose naturali annoverò.

Onde l'habito di essa secondo questi, non in diverso modo si diporta con l'humano animo, che le catene e ceppi con li forsenati e pazzi, aggiungendo essi di più che il solo fugire dalli piaceri per timore di non essere da essi sconvolto e superato, indica piuttosto codardia e pusilanimità, che carettere d'animo valoroso e virtuoso. Ma tale pare che sia quel tale, che tenendo pratica e famigliarità con li piaceri non si lascia da essi dominare et opprimere. E perciò alli compagni di Ulisse li fu otturato l'orecchi, acciò non udissero le lusinghevoli e micidiali cantilene delle sirene, ma egli bene le ascoltava e non l'offendevano, essendo legato all'antene della ragione, che governava la nave, cioè la sua persona.

E di più dicono questi, che l'animi capaci di risalti et eccessi, riescono conspicui nel proseguire le più eccelse et eminenti virtù e che l'innestamento del vitio nella virtù produce effetti mirabili, onde per il contrario li spiriti dalla temperanza assolutamente domati, e da scossi et impeti gagliardi non agittati, il più delle volte nell'operare languiscono. Per il che appare che sovente alcuni vitii siano li vehicoli e promotori delle grandi virtù, e per il certo dimostrano con effetti non [297] meno che con le parole, questi tali ingiusti dileggiatori della temperanza, quanto le sono nemici et al piacere a tutta briglia sono inclinati, mentre che tali sapienti si distragono da loro proprii et attinenti affari, per un lieve prorito, e fievole titilamento de piacere che sentono nel speculare d'onde derivi lo strepito della cicala, con quali muscoli saltella il pulce, e per qual cagione l'ape con esagonale figura formi la sua meliflua cella.

E tanto più riesce ad essi pregiudiciale tal piacere, quanto che non come le altre volutà tiene li suoi limiti e periodi, poiché l'istesso nostro corpo che tanto di esse si trova avido e le concede amorevole hospitio, alla fine osservando le loro offese, overo la sua invalidità, da sé le discaccia e detrude. Ma li diletti mentali una fiatta che ci habbino sorpresi, giamai ci lasciano, né da essi sbrigare si potiamo, et in ogni tempo e loco ci insidiano et infestano, non prendendo da noi comiato se non all'ultimo anhelito.

Né l'affabile amicitia poté con suoi benigni accoglimenti contrahere con costoro alcuna domestichezza, et evitare li di loro colpi, asserendo questi che fra le fintioni di poeti essa annoverare si dovesse, non possedendo real esistentia se non in voce e parole, cavillando l'istessi che fra simili l'amicitia trovare non si può, dimostrando l'esperienza che piuttosto nemistà fra tali vertisce per la emulatione e garegiamento che vi accade, che ad occupare il medesimo fine ambi li simili attentano. Oltre che pare che non si possa formalizare qual sia il diletto e piacere che il simile dall'altro simile carpisca e prenda, siccome anco l'unisuono non genera alcuna dilettevole consonanza: 
moderate through intemperance. ${ }^{519}$ Yet they went so far in defaming it that they judged it to be unworthy of the name of virtue and that it rather had to be called the 'scythe of vices' and the 'restraints of wickedness.' The reason for this was that temperance simply expels vices, but does not provide any excellent virtue, just as sleep does by diverting and dissuading us from them [i. e., vices]. They continued, moreover, that anyone who listed temperance among the virtues committed no less an absurdity than the one [i. e., Aristotle] who included privation among the principles of natural things.

"Therefore, in their opinion, its [i. e., temperance's] habitus is, in relation to the human mind, no different from chains and shackles for the frenzied and mad. They furthermore continued that escaping from pleasures only because of the fear of being upset and overwhelmed by them showed cowardice and pusillanimity rather than a valorous and virtuous spirit. Yet it seems to be the case that a person who is acquainted and familiar with pleasures does not allow himself to be dominated or oppressed by them. Thus, while the ears of Odysseus's companions were plugged so that they could not hear the flattering and fatal songs of the Sirens, he listened attentively to them without being harmed, since he was tied to the mast of reason which steered the ship, namely his own personality. ${ }^{520}$

"Moreover, they say that minds that are capable of redundancies and excesses remarkably succeed in pursuing the most important and eminent virtues, and that when vice is grafted upon virtue, it produces admirable effects. Therefore, on the contrary, those spirits which are absolutely dominated by temperance and not agitated by jolts or strong impulses are - most of the time unsuccessful in their actions. Hence, it seems to be the case that some vices are often vehicles and promoters of great virtues. Certainly, those who unjustly sneer at temperance have demonstrated as much with facts [297] as with words how much they are averse to it and how inclined they are to unbridled pleasure. Indeed, these wise men are used to diverting from their proper and pertinent matters for merely a light itch or feeble titillation of pleasure perceived in speculating on whence the clamour of the cicada comes, by means of which muscles the flea jumps, or why the bee makes its honeyed cells hexagonal.

"This pleasure turns out to be even more harmful to them because, contrary to the other sensual pleasures, it has no limit or duration of time. As our body itself is so greedy for them, it grants them loving hospitality, but as soon as it beholds the damage they cause or their want of strength, it casts them out of itself and expels them. Yet once mental delights catch us, they will never leave us. We can never release ourselves from them; indeed, they will threaten and infest us in any time and place and bid farewell to us only at our last breath.

"Not even affable friendship, with its benevolent acceptance, could become acquainted with them or avoid their blows. Indeed, they have asserted that it must be included among the pretences of poets, since it has no real existence, but only [exists] in speech and words. Thus, they quibble that there cannot be friendship among similars, as experience has demonstrated that there is rather hostility between them because of emulation and competition. Indeed, both similars are attempting to achieve the same goal. Moreover, it seems to be impossible to conceive what delight and pleasure one of the similars may catch and gather from the other similar. Similarly, this monotony does not generate any delightful consonance:
Philosophers, friends

of pleasure.

False slanders against friendship. 
Falsa instanza contra l'amicitia.

Instanze contra l'humiltà.
Cum est sicca terra, ips a certe cum imbre amat

Cum turget ether imbre cum coelum tumet

Affectat ut telluris in sinus cadat.

Ma né anco fra li dissimili può esservi amicitia, poiché non pare admissibile che essendo la dissimilitudine e diversità [298] prin|cipio et origine della nemistà, onde non può essere comune madre anco all'amicitia, e però non è imaginabile ch'il dissimile in quanto tale sia cagione di corrispondentia e repugnanza.

Ma non trovandosi li natali dell'amicitia né fra simili né dissimili, presero a calunniare l'istesso amore, publicandolo spurio, nato da certo incestuoso matrimonio seguito fra la copia e bisogno, perché chi fra noi non ha bisogno di alcuna cosa, non l'ama, e chi affatto non ne tiene nella mente alcuna fissa idea non la conosce, né sa che li sia attinente. Colui che ama un oggetto bello, ne possiede nell'animo alcuna imaginaria participatione, ma anco si sente bisognoso di affatto possederlo. Ma di più verso l'amicitia presero a dire, che accordandosi anco li più sinceri morali che l'amor proprio sia l'architipo originale di tutti li altri amori che si tiene verso altrui, decantandolo legitimo, antico, et immortale padre di tutti li altri amorini che alla giornata si producono, e periscono, conviene dunque per il certo alla bene morigerata sua prole regolarsi sempre conforme li paterni profitti et utili.

Di più l'istessi dileggiatori imposero alla amicitia, che tenga leggi diverse da quelle della giustitia che comunemente reggono l'humano mondo: queste vigilanti, occulate, rigorose et inflessibili, quelle coniventi, trascurate, piacevoli, e pieghevoli alla voglia dell'amico. Onde perciò contendono questi, che sia anco giovevole lo stimarla ideale e priva di vera esistentia, adducendo di più che segno di ciò è, che per la lunga serie dell'antichità non s'annovera altro che Damone e Fithia, che siano stati sinceri amici, ché essendo l'uno di essi da crudele tiranno condannato a morte, e volendo ire alquanto lontano dalla città per accomodare i suoi affari, propose al tiranno di darli per malevadore et assicuratore del ritorno, il suo compagno, che se non adempiva la promessa, sopra questo cadesse la rigorosa sentenza; et essendo non meno dal re accettato, che dal vero e cordial amico eseguito il partito, avenne che nel giorno terminato al regresso, il [299] dannato per liberare l'amico, si constituì e ripose nelle mani del re.

E chissá se ciò fosse piuttosto figmento de scrittori per dilettare con alcuna admirabilità i lettori, che racconto per informare altrui della verità. Alla fine a tal segno si ridussero, che non si arrossirono di affermare, che essendo li sapienti a se stesso sufficiente, il culto della amicitia li sia indecente, adducendo che li animali più deboli sono gregali, li potenti e vigorosi, solitarii et insociabili.

Né l'innocente humiltà scansò l'ingiurie, dicendo questi, che s'è pratticata verso li maggiori, è debito, con li eguali, è discapito, et offesa usata contro chi l'esercita, se rispetto l'inferiore, sconvenevoleza repugnante al natural corso, che il maggior e più vigoroso supera, e l'inferiore socombe. E di più divolgarno, 
When dried up, Earth yearneth for the rain

And the majestic Heaven when filled with rain

Yearneth to fall to Earth. ${ }^{521}$

"However, there cannot even be friendship among dissimilars, as it seems to be inadmissible that dissimilarity and diversity [298], as they are the principles and origins of hostility, could also be common mothers of friendship. It is, however, unimaginable that dissimilarity in itself could be a cause of [both] correspondence and opposition.

"Yet as it was not possible to find the origin of friendship either among similars or among dissimilars, they began to defame love itself, saying that it was spurious, born of an incestuous marriage between plenty and poverty. ${ }^{522}$ This is because anyone among us who has no need of a single thing cannot love anything, and whosoever has no stable idea of this thing in his mind cannot know it and cannot even know what is pertinent to it. A person who loves a beautiful object has an imaginary participation with it in his mind, but he also indeed needs to own it. Moreover, they began to say concerning friendship that also the sincerest moral people would agree that self-esteem was the original archetype of all other loves felt for others. Yet as they praised it as the legitimate, ancient, and immortal father of all the other small loves, which are born and die in a day, then it was necessary for its well-moderated offspring to always rule itself in accordance with its paternal profits and advantages.

"In addition to this, these same sneerers established that friendship follows different laws from those of justice which commonly rule the human world: the latter are watchful, attentive, rigorous, and inflexible; the former are conniving, careless, pleasant, and pliant to the wishes of friends. Thus, they argued that it was also useful to consider it [i. e., friendship] as ideal and lacking in actual existence. They furthermore put forward as proof of this that throughout the whole of antiquity, one could only count Damon and Pythias as having been sincere friends. ${ }^{523}$ This was because when one of them had been sentenced to death by a cruel tyrant and wanted to go some distance from the city to settle his affairs, he suggested to the tyrant that he could give him his friend as a guarantor and ensurer of his return. If he did not fulfil the pledge, then he [i.e., the friend] would be severely sentenced. Once the condition had been accepted by both the king and the true and sincere friend, it befell that at the end of the day of his return, [299] the sentenced one turned himself [over to the king] and gave himself up into the king's hands in order to free his friend.

"Who knows whether this was [only] a writer's pretence intended to delight his readers through something that could amaze rather than a tale to inform others of the truth? Finally, they came to such a point that they did not blush to say that as wise men were self-sufficient, the worship of friendship was indecent for them. [In order to support this opinion], they put forth that while the weakest animals are gregarious, the powerful and vigorous ones are solitary and unsociable.

"Not even innocent humility can avoid being insulted, as they said that it turns into a debt when it is practised towards greater people and becomes a detriment or offence to the one who uses it towards people of the same level. [If it is practised] towards inferior people, it turns out to be improper because it is contrary to the natural course in which the superior and more powerful person prevails while the inferior one surrenders. Furthermore, they spread that just

False instance against friendship.

Instance against humility. 
False difese di vitii.

Difesa della superbia.

Falsa difesa dell'avaritia.

Falsa difesa della prodigalità.

Falsa difesa della invidia.

Falsa difesa della discordia. che siccome il proietto che con maggiore forza verso la terra è cacciato, con più alto rimbalzo ascende, così sovente quello che maggiormente s'abbassa, aspira a più sublime grado sollevarsi. E l'esperienza volgare dimostra, che li formalisti cerimonieri, riescono li più puntuali osservatori delle altrui inadvertenze, che verso loro si comettono.

Ma non havrebbero a sufficientia adempito questi calunniatori tutti li numeri della loro malitia, se non havessero preteso anco di comendare li più horrendi vitii. La superbia intrattabile, e fra vitii il più odioso, fu da questi lodata espultrice delli altri vitii, ché nell'animo ove essa allogia conviene a quelli pigliare congedo et esilio. Detrude da sé anco l'ambitione, con la quale essa tiene tanta allianza, dovendo quella per via della humiltà e somissione progredire nelli honori e pervenire al fine di suoi attentati.

Né dissimile incontro accadè alla avaritia, celebrata da questi, nemica del lusso, temperata, mansueta, tolerante dell'ingiurie, alle fatiche patiente, provida dell'avenire, ratenuta nelle intraprese, circonspetta nelli affari, timorosa delle comuni leggi in quanto non contrastano a suoi progressi, offitiosa se non nella profusione, almeno nelle semplici attioni, et insomma delle republiche vigilante conservatrice, poiché ove essa regna li [300] tiran|ni non sorgono, ché questi senza le fattioni languiscono, né queste senza la prodiga profusione de danari esistono. E nelli regni anco che li dominanti sono avari, se non difondono del suo, non prendono di quello d'altri per reintegrare li loro mancamenti. Né perciò la prodigalità alla avaritia contraria, fu priva delle sue comendationi, celebrandola vera medicina delle disordinate repletioni. Questa con salutare flebotomia leva il superfluo, e deprime il turgido, e riduce il genere humano ad una eguale e salutare temperie.

Oltre di ciò l'invidia, benché disconcia di vista, e d'occhio losco, non trovò appo li sudetti maligno, e bieco sguardo. Anzi riportò da essa lode, essendo comendata che sia stimolo alla virtù, et eccitante alli animi tiepidi, riuscendo più efficace nell'animo humano il suo tacito parlare ad invitarlo alle attioni egregie, che tutta l'eloquenza del nostro Isocrate, e la dottrina del tuo discepolo Platone. E sebbene che sovente attraversa li fatti egregi, et impedisce la remuneratione a chi si deve, ciò non accade alcune volte senza profitto notabile della republica, esercitando essa un salutare ostracismo, poiché quasi sempre l'eminente et immoderatamente insigne virtù, riuscì sospeta al ben comune, e non rare fiatte nociva all'universale commodo, essendo ben spesso solito, che colui che apprestò al publico alcuno notabile servigio, con esorbitante et illegitima usura ne pretende la ricompensa. Oltre che la invidia serve per cimento e saggio per riconoscere la vera e sincera virtù, repurgata da ogni feciosa scoria.

E la discordia benché rissosa e sempre contendente, da tali turbatori come ad essa conformi ne riportò elogio, lodandola, che come il mare mentre che sia quieto, et in bonacia, riesce inhabile alla navigatione, e l'aria non agitata da venti, si deprava e corrompe, cosi la humanità quando da turbini di discordie non fosse alterata, devenirebbe affatto inetta e scioperata. Onde fu detto che la guerra fosse la scola della virtù, e l'otiosità della pace, nutrice di vitii. 
as the harder the projectile is thrown on the earth, the higher it can bounce, so often one who lowers himself the most aims to raise himself up to the sublimest level. Common experience demonstrates that the ceremonious formalists turn out to be the most precise observers of the inadvertences committed on their behalf. 524

"Yet these slanderers would not have sufficiently carried out all of their malice to its full potential if they had not demanded that even the most horrible vices be commended. They praised pride, unmanageable and the most odious of the vices, for being able to expel the other vices, because in a mind where it dwells, they should bid farewell and depart from it. It even expels ambition, with which it has a close alliance, by itself, since this must advance in gathering honours and achieve its attempts through humility and submission.

"It was no different for avarice, which they praised as the enemy of luxury, moderate, docile, tolerant of injustices, withstanding of toils, cautious concerning the future, restrained in undertakings, circumspect in businesses, and fearful of common laws, as long as they do not hinder its advancements. [It] was not [considered] profusely thoughtful, but was at least so in simple actions, and, in short, watchful in preserving the republics. Indeed, tyrants could not rise where it reigned, [300] because just as the former languish without factions, so the latter cannot exist without a generous profusion of money. When the rulers of kingdoms are also avaricious, if they do not spread their own [wealth], they cannot take anything from others in order to replenish what they are lacking. Not even prodigality, although it was contrary to avarice, missed out on their commendations, as they praised it as a true medicine for disorderly repletion, which removed surpluses, decompressed swelling, and brought humankind to an equal and salutary constitution through a salutary phlebotomy.

"In addition to this, the aforementioned people did not look contemptuously or askance at envy, albeit it is short-sighted and blind in one eye. Rather, it received praise from them, as it was commended as a stimulus to virtue and an incitement to tepid spirits. Indeed, its tacit speech has turned out to be more effective in spurring the human mind to perform excellent deeds than all the eloquence of our Isocrates or the doctrine of your disciple Plato. ${ }^{525}$ Besides, although it often prevents illustrious events and hinders remuneration to the one to whom it is due, nevertheless this often causes a remarkable profit for the republic, as it practices a [kind of] beneficial ostracism. The reason for this is that the eminent and immoderately distinguished virtue almost always turns out to be of questionable value for the common good and often harmful to the universal interest. Indeed, it is quite usual for a person who provides the community with a noteworthy service to demand a reward with exorbitant and illegitimate usury. Furthermore, envy is used as evidence and proof for recognising true and sincere virtue, purged of any revolting dregs.

"Moreover, discord, albeit quarrelsome and always ready to bicker, was praised by these disturbers, as they were in accordance with it. They commended it [by saying] that just as the sea turns out to be unsuitable for navigation when it is unruffled and absolutely calm, and the air is foul and corrupted when it is not agitated by winds, so humanity would indeed become inept and lazy if it were not altered by a whirlwind of discords. Thus it has been said that war was the school of virtue, while leisure [was the school of] peace, which is the wet-nurse of vices.
False defence of

vices.

Defence of pride.

False defence of avarice.

False defence of prodigality.

False defence of envy.

False defence of discord. 
Falsa difesa della crudeltà.

Falsa difesa dell'infedeltà.

Varie opinioni circa l'ultimo fine dell'homo.
E chi direbbe che anco la crudeltà, vitio piuttosto ferino che humano, trovasse chi la scusasse? Divolgando essi che sia una ottima purga delli [301] animi. Li strani essempii sono quelli che profondamente s'imprimono et affissano nella memoria. At quidam insontes peribunt, nam ex effuso exercitu cum decimus quisque fuste feritur etiam strenui sortiuntur. Habet aliquid ex iniquo omni magnum exemplum, quod contra singulos, utilitate publica rependitur.

Ma quello avanza ogni credenza, che insino l'infedeltà fra li vitii a mio credere il più infame, ritrovò appo costoro recapito et alcuna protettione, cicalando essi che la privata infedeltà sia vigilante custode della publica fede, ché se quella sicura si trovasse fra li minuti homini, infinite sortirebbero nelle republiche e regni le coniurationi e seditioni, ché assistendo l'infedeltà con linceo occhio tratiene et impedisce che l'uno con l'altro non comunichi et affidi li suoi scelerati pensieri.

Ma troppo importuno sarei se compilare volessi tutti l'eccessi che da hodierni filosofi si sono introdotti, et in particolare nell'imporre nome di virtù a vitii, e così per il converso. Ma solo voglio aggiungere a tale divisamento quello che publicarno circa l'ultimo fine al quale devono l'homini incaminare il traino delle loro attioni, e quale sia la mira alla quale indrizza il suo riguardo la mente, per scopo di tanto anhelare. Et è degno di osservatione, che giammai fra medici fu contraversato intorno il fine della medicina, accordandosi tutti unanimi, esser la sanità de nostri corpi. Fra l'homini militari fu parimente aggiustato, che il fine della guerra sia la vittoria. Tuttavia fra filosofi morali non è questione più inviluppata, e dubbiosa, che quella che si travaglia circa il riconoscere qual sia l'ultimo scopo delle humane intraprese, overo sommo bene che dir lo vogliamo. Né giamai fu da gramatici tanto acramente altercato circa la patria di Omero, e la navigatione di Ulisse, quanto da questi sapienti in proposito dell'ultimo fine dispetosamente fu digladiato.

- Vi furno che asserirno, che esso fosse il piacere, a cui collimare dovessero tutti li nostri attentamenti. Questi si divisero in due classi, l'una ponendo per fine non solamente li piaceri presenti, ma li passati, e venturi, che aspettano. Altri si restrinssero alle instanti volutà, rifiutando l'altre come aerie e vane.

- Altri posero il fine nella indolenza.

- Altri nell'honesto.

- $\quad$ Ad [302] altri piacque l'estirpatione totale delli nostri affetti.

- Ad altri bastò la loro moderatione.

- Ad altri parve, che il seguire il dettame della semplice e sincera natura, fosse la mira de' nostri proponimenti, né più oltre conveniva trapassare.

- Altri credettero che la speculatione circa le cause de mirabili effetti della natura, fosse il bersaglio di nostre intraprese.

- Ad altri piacque che piuttosto fosse la cognitione di noi medesimi.

- Altri stimarono che la mira a che dobbiamo indrizzare tutto il nostro sapere, sia l'indurci a tal conditione che il tutto ci riesca indiferente, tanto le cose 
"And who would say that even cruelty, a beastly rather than human vice, could find someone who would excuse it? They spread that it was an excellent purge [301] of the mind. Indeed, it is the unusual examples which deeply impress and fix themselves in the memory. 'But some innocent lives will be lost!' - Even so; for when every tenth man of the routed army drops beneath the club, the lot falls on the brave as well. All great examples carry with them something of injustice - injustice compensated, as against individual suffering, by the advantage of the community. ${ }^{526}$

"Yet what is not possible to believe is that even infidelity, in my opinion the wickedest of the vices, has been welcomed and upheld among them. Indeed, they foolishly said that private infidelity was the watchful guardian of public faithfulness, because if the latter was taken for granted by people of a lower social status, then infinite conspiracies and seditions would occur in republics and kingdoms. Indeed, as infidelity watches these with an eagle eye, it holds people back and prevents them from communicating or entrusting their wicked thoughts to others.

"However, I would be too fastidious if I wished to compile all the excesses introduced by current philosophers, especially in imposing the name of virtues on vices and vice versa. Yet I only want to add to this consideration that which they have spread concerning the final goal to which human beings must direct their actions and the aim to which the mind [must] address its attention as the goal of so much yearning. Besides, it is noteworthy that the final goal of medicine has never been discussed among doctors, as they all agree that it is the health of our bodies. Soldiers similarly agree that the final goal of war is victory. Nevertheless, among moral philosophers, there is no issue more convoluted and doubtful than that of striving to acknowledge the final goal of human endeavours, or the supreme good, depending on how we prefer to call it. Grammarians have never quarrelled so harshly concerning the homeland of Homer or the voyage of Odysseus as these wise men have spitefully disputed concerning the final goal:

- There were those who asserted that it was pleasure towards which all of our attempts should be directed. These were divided into two classes: one [of them] set not only current pleasures, but also past and future ones, which they awaited, as the final goal. The other only considered instantaneous sensual pleasures and refuted the others as aery and vain. ${ }^{527}$

- Others set indolence as the final goal.

- Others honesty.

- Others [302] preferred a complete uprooting of our affects. ${ }^{528}$

- According to others, self-moderation alone was sufficient. ${ }^{529}$

- It seemed to others that following the dictate of sincere and simple Nature was the aim of our resolutions, and that it was necessary not to overcome it. ${ }^{530}$

- Others believed that speculation on the causes of the marvellous effects of Nature was the target of our endeavours.

- Others preferred it to be rather self-cognition. ${ }^{531}$

- Others considered the aim to which we should address all our knowledge to be to achieve such a condition that we should turn out to be indifferent
False defence of cruelty.

False defence of infidelity.

Variety of views concerning the final goal of human beings. 
Bene si trova nel convenevole. a noi esterne, come anco l'oggetti del nostro animo, di modo tale, che si potiamo ad ogni caso della fortuna accomodare, et a qualunque openione asestare et aggiustare.

- Alcuni proferirono che l'ultimo bene humano consista nell'esercitio delle morali virtù, e nell'attualmente praticarle.

- $\quad$ Altri di più mite et indulgente ingegno li bastò il loro semplice habito.

- Altri posero il fine, nella sanità del corpo.

- Altri vi aggiunsero quella dell'animo.

- Altri nel dominio et imperio.

- Altri si contentarno che almeno ad altri non assogettarsi, et alla libera vivere. Altri nell'accopiarsi con un certo intelletto agente che c'illumina nelle nostre speculationi constituirno la nostra ultima felicità.

- Altri pensarno che non vi fosse alcuno ultimo fine, ma che ogni nostra attione sia a se stessa meta, e che perciò l'homo sapiente vivere debba alla giornata, havendo sempre per meta il tempo instante, giudicandolo possibile termine della sua vita.

- Ma altri essendo in tutto incerti e flutuanti non riconoscendo, né ciò che sia fine, né mezo che ad esso ci conduca, promulgarono, che non si deve ad alcun fine indrizzarsi, ma seguire il calpestio, e frequentare li vestigi della comune folla delli homini.

Non mancano altri pareri circa l'ultimo fine delle humane attioni, a segno tale, che nella nostra città di Atene, nel medesimo tempo s'anoverarno al di sopra di doi cento e nonanta openioni circa tal proponimento. Né di ciò molto mi meraviglio, poiché tutti questi stimarno che il bene consista nel conseguire [303] certa convenevolezza che tengono le cose l'una con l'altra. Da ciò ne segue, che esso bene conforme questo, non tenga una ferma e stabile essentia, ma mobile e variabile secondo la diversa dispositione delli homini e diferente incontro che nelle cose da essi desiderabili occorre, siccome il grande è tale, abbatendosi nel minore, ma se in maggiore di lui, picciolo di novo appare.

Nell'istessa guisa moltiplice riesce l'aspetto del bene, siccome che ad alcuno sortisce convenevole e da altrui l'istesso è regetto, come ad esso indecente. E per il certo tu, Socrate, tieni esprimentato, ch'essendo stata a mio credere la tua dottrina a tutti li tuoi scolari e famigliari uniforme, nondimeno essi a diverso stile di vita si appigliarno.

- Platone alle dottrine filosofiche et ad una guisa di sublime eloquenza si applicò.

- Aristippo a piaceri e vita sontuosa si dedicò.

- Xenofonte all'arte militare, et ad un placido e moderato modo di scrivere, tutto s'impiegò.

- Antistene, la rudità di costumi e libertà di vita seguì. 
to everything, as much to the things that were external to us as to the objects of our minds. In this way, we could accommodate ourselves to every circumstance of fortune and adapt and adjust ourselves to any opinion. ${ }^{532}$

- Some said that the final human good consisted in the exercise of moral virtues and in the concrete practice of them.

- According to others of milder and more indulgent intellects, it was sufficient simply to have them as habits. ${ }^{533}$

- Others set the final goal as the health of the body. ${ }^{534}$

- Others added that of the mind. ${ }^{535}$

- Others [set it] on dominion and sovereignty.

- Others were merely pleased not to be subject to others and to live freely.

- Others constituted our ultimate happiness in joining with a certain agent intellect which enlightens us in our speculations.

- Others thought that there was no final goal, but that each of our actions was an aim in itself; therefore, that a wise man should live day to day and always be focused on every single moment, because it could potentially be the end of his life. ${ }^{536}$

- Yet others, uncertain and wavering about everything, declared neither what the final goal was nor what the means whereby we are led to it were, and that instead of addressing any final goal, one must rather follow in the footsteps of the masses of common people and stay on the path that they have traced..$^{537}$

"There are also [so many] other views concerning the final goal of human actions that in our city of Athens, one could simultaneously count more than two hundred and ninety opinions concerning the resolution of this issue. I am not particularly astonished about this, because all of them deemed that the good consisted in achieving [303] a certain fittingness ${ }^{538}$ that things should hold with one another. From this, it follows that the good has no fixed or stable essence, but rather is fickle and changeable according to the diverse dispositions of human beings and the different relationships between the things that they desire; indeed, a large thing is so when it comes across a smaller one, but if [the larger one comes across] something greater than itself, it will appear small again.

"Similarly, the appearance of the good turns out to be [so] various that the same thing may be suitable for one person and rejected by another as inappropriate to him. Certainly, Socrates, you have already experienced that although your doctrine, in my opinion, has been the same for all your disciples and acquaintances, they have nevertheless all followed different ways of life:

- Plato applied himself to philosophical doctrines and to a sublime form of eloquence;

- Aristippus devoted himself to pleasures and a sumptuous life;

- Xenophon fully dedicated himself to the military art and to a placid and moderate way of writing;

- Antisthenes followed the crudity and freedom of life;

Good consisted in a certain fittingness. 
Si deve gettarsi nelle mani della natura.

Reprobatione della sentenza che li Re recasse filosofare over li filosofi regnare.
- $\quad$ Tehetetto scielse la vita civile.

- $\quad$ Euclide alle matematiche si sequestrò.

- $\quad$ Et Alcibiade alcuno spetiale instituto di vita non abbraciò, ma dispose il suo animo talmente snodato e sciolto, che può facilmente prendere qualunque maniera di vita, che la volubile et insultoria fortuna l'appresentasse.

Onde, Socrate, con essempii domestici puoi conieturare quanti varii visagi possiede il bene, e che conforme che il volgo delli homini si propone, agevolmente il concetto di esso sia cangiabile e transformabile. Ma se la scorta del nostro anhelante, et affaticato intendimento, in additarci l'ultimo scopo delle nostre intraprese, ci riesce tanto dubbiosa et incerta, quanto meglio ci avenirebbe se ommettendo tali cavillose dottrine, di nuovo nelle braccia della natura ci restituissimo che con suoi taciti instinti et occulti semi lievamente coltivati, è per riuscirci non meno nostra pedagoga e maestra nella maniera del vivere, che produtrice et alimentatrice. Onde secondo il mio conieturare, l'homo da essa disciplinato è per divenire come prima retto nel giudicare, incolpabile nell'ellegere et [304] inno|cente nell'operare, e sempre unito e concorde con se stesso.

Da ciò che insino hora tengo divisato, apprendere puoi quanto sortisce reprobata quella sententia dalli homini volgari celebrata, cioè che allhora, beato il genere humano divenirebbe se li filosofi regnassero, overo che li $\mathrm{Re}$ filosofassero ché per il certo se tale disaventura accadesse, a mio stimare, non solamente senza alcun rispetto da questi con lor cavilli sarebbero spallegiati li vitii, e senza l'addobbamento e vestito delle virtù si renderebbero palesi e manifesti, ma insieme rimarebbe oppressa ogni cultura della vita civile.

Rappresentati, di gratia, Diogine sopra il dorso del suo doglio assiso, di vili cenci addobato, e con il suo ruvido bastone invece di gemmato scetro in mano, che dispensi leggi, promulghi decreti a popoli, prohibendoli con grave pena qualunque minutia et atomo di affetti, e scrupulo di piaceri, a quali assordità et indecentie capitarebbe il nostro genere?

La terra rimarebbe in gran parte priva di cultori, riducendosi all'antiche ghiande et all'insipida acqua. Onde non più si edificarebbero città, erigirebbero palagi, coltivarebbero hortagi, e l'istesso homo con la total mutilatione de suoi naturali affetti, e privatione di corporali diletti, non diverso rassembrarebbe che ruvido tronco di arbore, reciso di rami, spogliato di foglie, sbarbicato di radici, e denudato di cortecia. Rafiguratilo senza alcun talento di ambitione, alletamento di speranza, stimolo d'ira, comottione di misericordia, attrattione d'amore, prorito di piaceri, e gusto di qualunque diletto tenendolo con il dolore indiferente. Non si ridurebbe egli alla classe delle pietre, e forse al di sotto di esse, ritrovandosi la magnete da incentivi di amore et odio ingombrata?

Ma di più chi non osserva che eliminati et estirpati da noi assolutamente li affetti, per conseguenza si accomiatarebbero da noi le virtù, tanto da essi filosofi acclamate, a quali incombe li affetti reggere e moderare? Nelli governi civili spenti che siano li nemici, conviene a quelli che manegiano l'armi deporle, et a capi della militia renontiare al militar [305] co|mando. Così parimente per necessità ne segue, che abbatutte et estirpate le perturbationi che il nostro animo infestano, che cessi parimente l'esercitio della virtù, e siccome nave posta in tranquillo e calmato mare, il di lei timone punto non la regge né 
- Theaetetus chose the civic life;

- Euclid concentrated on mathematics;

- Alcibiades did not embrace any particular principle of life, but disposed his mind in such a free and flexible way that he could easily adopt any way of life provided by fickle and changeable fortune.

"Therefore, Socrates, you can infer from familiar examples how many various faces the good has and that the concept of it is easily changeable and convertible according to the desires of the common people. However, if the guide of our panting and fatigued understanding turns out to be so doubtful and uncertain in pointing to the final goal of our endeavours, it would be better to omit such quibbling doctrines and to return ourselves to Nature's arms. Thanks to its tacit impulses and hidden faintly cultivated seeds, it turns out to be as much a pedagogue and mentor for us as it is a producer and nourisher. Thus, according to my inference, a man who has been disciplined by it will, as rapidly as possible, become fair in judging, blameless in choosing, and [304] innocent in acting, and always coherent and in agreement with himself.

"From what I have considered so far, you can apprehend how much that sentence that is praised by vulgar people - namely that humankind will only come to bliss if philosophers reign, or rather if kings philosophise ${ }^{539}$ - turns out to be disproved. Certainly, if this misfortune did befall, in my opinion, they would unrestrainedly support the vices through their quibbles and they would clearly and evidently appear as they really are, without the decoration or clothing of virtues. In addition to this, any cultivation of civil life would be oppressed.

"Please try to imagine Diogenes sitting on top of his barrel, dressed in vile rags and with his rough stick in his hand instead of a gemmed sceptre, proclaiming laws, issuing decrees to populations, and prohibiting them any minutia or atom of affect or scruple of pleasure with threats of serious punishments. ${ }^{540}$ What absurdities and indecencies would then occur to humankind?

"The land would most of all be lacking in cultivators, reduced to ancient acorns and insipid water. ${ }^{541}$ Thus, no city would be edified anymore, no palace raised up, no vegetable cultivated, and because of the mutilation of the natural affects and privation of corporal delights, the people themselves would look no different from a rough trunk, hewn of its branches, divested of its leaves, torn up from its roots, and stripped of its bark. Try to imagine a human being without any aptitude for ambition, any enticement of hope, any impulse to rage, any merciful disposition, any attraction of love, any yearning for pleasure, or any taste for pleasure because he does not consider it to be any different to pain. He would be reduced to the category of stone, and perhaps even beneath it, as even a magnet is pervaded by incentives of love and hate, would he not? ${ }^{542}$

"Yet who does not furthermore observe that once the affects are entirely eliminated and eradicated from us, then the virtues will consequently [also] take their leave of us? [The same virtues] which were highly applauded by the philosophers, which have the task of ruling and moderating affects? In civil governments, once the enemies have been subdued, it is necessary for those who bear arms to lay them down and for the chief of the army to renounce his military [305] command. Likewise, it necessarily follows that once the perturbations infesting our minds have been defeated and eradicated, the exercise of virtue also stops. Just as a ship in a tranquil and calm sea does not [need] to be guided or ruled

To throw himself into the arms of Nature.

Reprimand of the sentence which says that kings should philosophise and philosophers should reign. 
Ad homo senza passione la virtù inutile.

Utilità de piaceri per l'humano consortio.

L'homo antepone l'apparente all'essentiale.

Non conoscere se stesso utile.

Ovidio

De arte amandi. la governa, ma sì bene mentre che si trovi in corso e da venti spinta, e da flutti marini agitata, ch'allora agevolmente alla poca inclinatione di esso obedisce e si volge. Così anco la virtù timoniera dell'homo, poco o nulla vale, quando esso homo con la totale privatione di passioni sia affatto quieto et intorpedito, e come affisso se ne stia.

Per il che si è osservato che l'homo essendo agitato da vehemente moto d'ira, dall'impulso dell'interno dettame, overo d'esterna persuasione, essersi condotto all'estrema meta di clemenza, a guisa di inalzato pendolo, che quasi che altrotanto che ad un lato si solieva, all'altro contrario si conduce et ascende. Ma oltre di ciò dico, che in quanto a piaceri, che profligati che questi fossero, l'humano consortio si discioglierebbe, perché il diverso genio che tengono li homini in seguire diversi diletti, risveglia la cultura di varie arti, da che sorgono differenti maniere di procacciarsi il vitto, cessando l'invidiose emulationi che sono fra quelli che tragono il loro mantenimento dalla istessa professione.

Ma di più non saprei imaginare, in che modo lo sfugire li piaceri, et abhorire i lussi, si aggiusta e possa seguire con il regnare di filosofi, over filosofare di Re. La bellezza dell'oro, lo scintillare delle gemme, la vaghezza della porpora, lo splendore della seta, la sontuosità de palagi, la comitiva del satelitio, la copia et esquisitezza di cibi, il scialaquamento della cucina, sono quelli, che admirati dalla scioca plebe, e riescono più efficaci ad attrahere la riverenza dal minuto popolo maggiore portione, che li dotti ragionamenti, e gravi sentenze, che sortiscono invalidi ad impulsarlo all'obedienza et ossequio di legitimi comandanti. Il più delli homini discorrono con l'occhi, et il meno di essi con la mente. Sovente il posessore per il posseduto, l'interno essentiale per l'esterno[306] adven|titio, il vero per il fititio, si tiene in veneratione e stima. Il volgo circa l'appreggiare li homini, pratica il contrario di ciò che nel riconoscere li generosi cavalli s'osserva: questi volendoli mercare, spogliati di selle, et altro arnese procura mirarli, ma nel giudicare il valore del suo congenere non altrimente, che infagotato di ricchezza, et ornato di honori e nobilità lo considera.

Ma quello è peggio che non solamente nel riconoscere altrui si comette tal difalta, ma nel rimirare se stesso sì pravamente s'inganna e delude, che pure riflettendo l'animo sopra se medesimo tali oggetti non vi s'infrapongono. Ma da tali illusioni che noi pratichiamo circa il proprio riconoscimento, ne potrebbe derivarci per mio aviso salutare documento, et è, che essendo l'homo ignaro di se stesso, e ciò al mio credere riesce impossibile per le ragioni da te narratemi, rimane parimente sopito e come estinto l'inordinato amore, che verso se stesso il comune delli homini tiene, essendo tal intemperata philautia, origine e seminario de irregolati affetti et enormi vitii che si comettono. Tal consequenza da ciò sortisce, che l'amore sempre supone il riconoscimento dell'oggetto amato, che altrimente esistere non può:

Quod latet ignotum est, ignoti nulla cupido. 
by its helm, but, as soon as it is underway and being pushed by the wind and agitated by the waves, it easily obeys and turns at its slightest inclination, so also virtue, as the helmsman of the people, counts for very little or nothing when they, entirely deprived of passions, indeed remain quiet, numb, and motionless.

"Hence, it has been observed that a man, even if he is agitated by a fit of anger, leads himself to an extreme point, [that] of clemency, thanks to an impulse coming either from an internal dictate or an external persuasion, like a raised pendulum which, as soon as it has been displaced sideways, steers itself towards the contrary side and swings up to it. ${ }^{543}$ Yet in addition to this, I will say as far as pleasures are concerned that if they were destroyed, human society would be broken up. The reason for this is that the different attitudes of human beings in following several delights reawaken the cultivation of a variety of arts, from which there arise different ways to earn one's livelihood. Thus, it prevents envious emulations from existing among those who earn their maintenance from professing the same thing.

"Furthermore, I could not imagine how escaping pleasures and abhorring luxury could follow and conform with the government of philosophers or the philosophising of kings. The beauty of gold, the sparkling of gems, the pleasantness of purple, the splendour of silk, the sumptuousness of palaces, the retinue of supporters, and the abundance of exquisite food to squander in the kitchen are things which, admired by the foolish plebs, succeed more effectively in obtaining the reverence of the majority of lower class people than learned reasonings and severe sentences do. These turn out to be unable to push them to obey and respect legitimate commands. The majority of people analyse with their eyes, and a smaller number [of them] with their minds. Often, the owner is held in veneration and esteem instead of what he possesses, the temporary exterior [is held in veneration and esteem] instead of the essential, [306] and the fictitious [is held in veneration and esteem] instead of the truth. The masses, in appraising people, practise the contrary of what is taken into account in acknowledging well-bred horses: if one wants to trade them, he will try to observe them stripped of saddles and other tools, yet when deeming the value of one of his congeners, he will only consider him when he is wrapped up in wealth and decorated with honours and nobility.

"However, what is worse is that not only does one commit this error in acknowledging others, but he deceives and disappoints himself so badly in observing himself that even while the mind is reflecting on itself, these objects get in the way. Yet from these illusions that we experience in acknowledging ourselves, we could gather, in my opinion, a salutary teaching, namely that just as man is unaware of himself - and I believe that this is impossible because of the reasons you told me about - so the unbridled love that the common people feel for themselves remains soothed and extinguished. [On the contrary,] this immoderate "self-love ${ }^{544}$ is the origin and seedbed of the unbridled affects and extraordinary vices that may be committed. This consequence comes from the fact that love always presupposes the acknowledgement of the loved object, because otherwise it cannot exist:

What is hidden is unknown; what is unknown none desires. ${ }^{545}$
Virtue is useless

for a man without passions.

Utility of pleasure for human society.

Human beings held in esteem fictitious thing instead of the essential.

Not knowing himself is useful.

Ovid

The Art of Love. 
Homo da principio retto, e doppo depravato.

Non si deve dubbitare che si svilisce la coscientia

Affanno di Socrate in destrugere le sue openioni.
Onde ignorandosi se medesimo, riesce impossibile che vi sortisca né anco mediocre amore tra l'homo e se stesso. Ma tali ingannati inamorati amati, invece di loro stessi, certa altra aliena fantasma e strano spettro prima admirano, e doppo irregolatamente amano et idolatrano, seppur l'animo invece d'esso medesimo, amoregia non dirò la sua carcere, ma almeno il suo addobamento e domicilio cioè il corpo che li appresta hospitio e vestito.

Da quello ch'insino hora teco ho divisato, facilmente apprendere e raccogliere puoi, che non despicientia che io tenga con il nostro genere, né aversione ch'io professi contra la società civile, mi indusse a questa [307] solitudine, ma l'havere esprimentato qual sia l'indole di hodierni homini dalla moderna filosofia depravati e sconci, benché dal volgo sinistramente ciò sia interpretato e da esso odiatore dell'homini son appellato. Ma la verità è, che io implacabile adversario solamente sono de loro ignoranze e vitii! E se a questa mia diserta magione alcuno incontaminato ingegno, non punto depravato da aliene dottrine, capitasse, ma tale quale dalle mani della sincera natura scapò e ritenessi quelli primi semi di humana ragione che li fu da essa sugerito, assagiarebbe qual fosse la mia piacevole urbanità e grata cortesia da fuci et inganni affatto remota.

Onde non come che l'idioti mi infamarebbero con l'improperio di misanthropus, ma piuttosto con l'encomio di philantropus, cioè amator dell'homo mi honorarebbero, procurand'io ridurli a quella conditione di eccellenza, che già egregio homo non nella Grecia nato né con nostri costumi educato nelli suoi divini monumenti espresse: Deus fecit hominem rectum, et ipsi requiserunt cogitationes multas.

Né a caso e per errore incorse in discordanza gramatichale, prononciando primieramente hominem singulare et ipsi plurale, ma con somma prudenza ciò comise, volendo significare che l'homo spicato dalle mani di Iddio, overo dalla natura sua serva, non solamente fu retto, ma con se medesimo concorde et unito, ma poi depravato dalla curiosità del troppo immoderato sapere, e cavilloso indagare, divenne in se stesso diviso, moltiplice, e con se stesso repugnante.

Stimarei, o Socrate, che rimani a satietà persuaso, a comunicare al genere delli homini di cui ti mostri tanto amico, la fiachezza del suo intendimento, e perciò admonirlo alle retentioni dell'assenso, e sospensione del proprio giuditio, dal che ne seguirà l'evitatione e scansamento di tanti incommodi, come dal mio ragionare tieni appreso. Né punto dubbitare devi, che rendendosi il proprio giuditio discreditato, et incolpato di falsità, che perciò il tribunale della conscientia al quale assiste la mente humana rimanerebbe avilito e privo di autorità, poiché invece di essa, [308] è per subintrare la maestà della natura, che con maggior decoro è per additare il sentiero del bene e revocare dal male.

Ma prima che tu, Socrate, tanto di salute apporti ad altrui convienti deporre la grave salma delle apprese da te dottrine, che tengono aggravato et incurvato il tuo animo ché oltre il discaricarti da tal peso, ti liberarai da continua noia et affanni, che stimo non poco ti affligono: cioè che producendo continuamente il tuo intelletto copiosa prole di dogmi, doppo haverla per tratto di alcun tempo educata, sforzato dalla evidenza riconoscendola falsa e monstruosa, nella 
"Thus, if one is ignorant of himself, it will turn out to be impossible for him to find even a modicum of self-love in a person. For these deceived enamoured ones do not love themselves, but first admire a certain foreign phantom and extraneous spectre and then immoderately love and idolise it. However, instead of itself, the soul ${ }^{546}$ will love, I will not say its prison, but at least its ornament and dwelling, namely the body, which supplies it with accommodation and garments.

"From what I have considered with you so far, you can easily apprehend and gather that I do not feel disdain for humankind, and it is not the aversion I profess against civil society that has induced me to this loneliness, [307] but the experience of the current nature of human beings, as it is corrupted and spoiled by modern philosophy. Although this has been maliciously interpreted by the masses and thus they have called me a hater of humankind, nevertheless, the truth is that I am only an implacable opponent of their ignorance and vices! And if an uncontaminated intellect ended up in my forsaken dwelling - not at all corrupted by foreign doctrines, but as it was when it was made by the sincere hands of Nature - and preserved those first seeds of human reason that it provided, it would taste my pleasant urbanity and my grateful courtesy, indeed distant from pretences and deceptions.

"Therefore, they would not defame me, as idiots do, with the insult of 'misanthrope,' but rather with the commendation of 'philantropist,' that is, they would honour me as a lover of humankind. I indeed sought to lead them to that condition of excellence which an illustrious man, neither born in Greece nor educated in our customs, already expressed in his divine warnings: God made man upright; but they have sought out many inventions. ${ }^{547}$

"Nor did he end up in a grammatical discordance by saying first man, singular, and then they, plural, by chance, but rather he did this with supreme prudence. Indeed, he meant that man came from the hands of God - or Nature, as it is his servant - not only righteous, but unanimous and in agreement with himself. Yet as he was then corrupted by curiosity for immoderate knowledge and quibbling investigation, he became divided in himself, plural, and in disagreement with himself.

"I consider, oh Socrates, that you are sufficiently persuaded to communicate to humankind, to whom you show yourself to be such a friend, the weakness of their understanding, and thus to warn them to withhold their assent and suspend their judgment. From this, there will follow the avoidance and eschewing of many inconveniences, as you will have apprehended from my argument. You must not even doubt that in discrediting its own judgment and accusing it of falsity, the court of conscience attended by the human mind would be debased and lacking in authority, because it will be [308] replaced by the majesty of Nature, which will lead the way more decorously towards the good and remove the evil.

"Yet Socrates, before you provide so much salvation to others, it will be appropriate for you to lay down the heavy burden of the doctrines you have apprehended, as they are weighing down and warping your mind. Thus, you will not only be discharged of this weight, but you will also be free from the continual bothers and worries which, I think, are greatly troubling you; namely, as your intellect continuously produces an abundant offspring of dogmata, after having raised it for a period of time, as it is compelled by the evidence, it then
Human beings are originally righteous and then become corrupted.

One must not doubt that the conscience will be debased.

Socrates worries about destroying his opinions. 
Timone persuade

Socrate a pigliarsi trastullo della vanità degli homini.

Lucretius.

Timone repulsa

Socrate di cohabitar

seco e fine del ragionare di Timone.

Conferisce Socrate insieme il parlare di Hippia, e Timone, et inclina Timone. guisa che ordinasti nella tua ideale republica circa li assordi e sconci parti, con ferina crudeltà la destrugi et annienti, divenendo homicida di tuoi proprii figliuoli.

Ma per meglio habituarti in sì proficuo proponimento, consiglioti che meco dimori, godendo ambi noi qui in comune quelli soavi frutti, che la natura aiutata dalla nostra industria, liberamente ci produce et offerisce, et alle fiatte trattenere il nostro otio, insieme, trastulandoci nel rafigurarci con la mente quelli ludicri spettacoli che nel teatro del mondo l'homini, e particolarmente quelli che del loro sapere più si appaga, gratis ci rappresentano. Onde noi a guisa di quelli che in loco sicuro trovandosi, mirano il battagliare di insana gente, che il suo sangue difonde per cui giammai non vide né conobbe, over simili diveniremo a colui che sopra rupe marina stando, scorge la pericolosa flutuatione di nave, che per far acquisto di superflua merce, alli assalti di rabbiosi venti et indiscreto mare s'espose:

Suavi, mari magno turbantibus equora ventis

E terra magnum alterius spectare laborem.

Ma se contumace in seguire il camino intrapreso perseveri, calpestando il sentiero che ti additano l'hodierne discipline, e che ricusi doppo l'havere fatto meco alcuna dimora [309], manifestare all'homini l'imbecilità del loro ingegno et incertezza di dottrine, avisoti che hora accomiatarti da me ti devi, e non apportare disturbo alla mia pacatissima quiete, ché sebbene riguardando a tuoi buoni costumi, odiarti non mi lece, mentre che sei imbevuto dalli volgari amaestramenti et usi, conforme il mio preso instituto, teco vivere mi è interdetto et impedito".

Qui fece termine il favellare di Timone. Onde io con brevi parole li soggionsi, che non poco mi aggradì il suo libero parlare, e saggia instrutione, e che molto lo ringratiava del suo cortese invito, offerendomi il meco famigliarmente cohabitare, ma che il tratenermi seco, e seguire il suo instituto, non me lo permetteva il mio genio, sempre a giovare altrui propenso, ma che da indi partendomi, conforme li suoi documenti e persuasioni, harei alli amici e miei famigliari propalato il suo ragionare, et admonitili conforme il suo parere alla retentione dell'assenso e sospetione del giuditio, e che seco prendere diletto dal vanegiare delli homini come che in pericolosa battaglia e turbolente mare travagliassero, punto non approbavo, ma che la naturale carità che ad altrui si deve, mi chiamava a prestarli aiuto e sufragio.

In tal guisa da Timone presi congedo. Onde ruminando e riasumendo di novo il ragionare di Hippia e Timone, e conferendo l'uno con l'altro, ad esso Timone, et alla sua proficua instruttione inclinai. Per il che stimai essere spetie di dannata avaritia rattenere appo me quello che giovare potesse a miei consorti, et amici, tanto più che facendolo comune io non ne pativa alcun detrimento e danno. 
acknowledges it to be false and monstrous. Likewise, in your ideal republic, as far as absurdities and deformed offspring are concerned, you would order that they be destroyed and annihilated with brutal cruelty, becoming the murderer of your own children..$^{548}$

"However, to make you accustomed to such a profitable resolution, I will suggest that you dwell here with me; thus together, we will both enjoy those pleasing fruits that Nature freely produces and offers us with the help of our industry. Furthermore, we will sometimes enjoy our leisure together and we will amuse ourselves imagining those ludic plays freely performed for us by people in the theatre of the world, especially by those who are more satisfied with their knowledge. Therefore, we will be like those who, from a safe place, watch insane people battle and shed their blood for something they have never seen or known; namely, we will become like a person on a seaside cliff who sees the dangerous fluctuation of a ship exposed to the assaults of raging winds and the insolent sea in the attempt to acquire unnecessary goods:

Pleasant it is, when on the great sea the winds trouble the waters, To gaze from shore upon another's great tribulation. ${ }^{549}$

"Yet if you obstinately persevere in following this path and treading the way indicated by the current disciplines, and if, after having dwelt with me, [309] you refuse to show people the weakness of their intellects and the uncertainty of their doctrines, then I shall warn you that you must bid farewell to me right now and not disturb my most placid quiet. Although, thanks to your good manners, I cannot hate you, nevertheless, according to the principle I follow, I am forbidden and prohibited from living with you as long as you are imbued with common teachings and customs."

Here ended Timon's words. Thus, I briefly said that I greatly appreciated his free speech and wise instruction and that I was very thankful for his courteous invitation, namely that he had invited me to dwell intimately with him, but that my genius, always inclined to benefit others, would not allow me to stay with him and follow his rule. Nevertheless, on departing from there, I would spread his argument to my friends and those familiar to me and warn them, following his opinion, to withhold their assent and suspend their judgment in accordance with his teachings and persuasions. Furthermore, [I would tell them] that I did not at all approve of being amused by the vanity of human beings, who are troubled as though in a dangerous battle or a turbulent sea, but that the natural charity due to others called me to offer them my help and support.

In this way, I bade farewell to Timon. Thus, after ruminating and summarising the reasoning of Hippias and Timon once more, in comparing one with the other, I inclined towards Timon and his profitable teaching. Hence, I considered it a form of wicked avarice to keep anything that could help my companions and friends to myself, all the more so since I would not suffer any detriment or damage in making it
Timon persuades

Socrates to mock the vanity of humankind.

Lucretius.

Timon does not accept that Socrates will live with him and this is the end of Timon's argument.

Socrates compares the speeches of Hippias and Timon, and inclines to that of Timon. 
Non si deve abbandonarsi alla ignoranza ma seguire il probabile.

Admonisce al seguire il probabile.
Onde tutto quello che in sì lungo e travaglioso mentale discorso mi occorse, che circa l'esame di me stesso e dell'humano sapere mi accadé, a miei famigliari avisai, e che l'incertezza del sapere et imbecilità del nostro intendimento fosse la messe e raccolto da tal stentato e laborioso impiego. Ma l'aggiunsi che l'abbandonarsi affatto alla cecità dell'ignoranza, come già fu esposto, io bene stimava che non poco di nocumento apportarebbe al [310] nostro genere.

Admonii alli miei domestici, che nell'attioni all'uso della vita attinenti, seguire dovessero la direttione del probabile, non punto testarecio e cavilloso, alle opportune occorenze pieghevole, e più esecutivo che discorsivo, il quale nell'uso della vita morale, non allontanandosi per molto intervallo da primi semi che la natura nel nostro animo instilò, ché se non colpisce affatto nella verità, almeno non incontra nella insana contumacia, e pazza ostinatione, dovendosi stimare, che la migliore natura che fu tanto propitia all'homo nel concederli l'organi materiali tanto vicini alla perfettione, con li quali così agevolmente potesse conseguire li comuni usi della vita, li fosse riuscita meno liberale in prestarli alcuna norma, con la quale agevolmente indrizzare dovesse il corso della istessa vita, ché siccome non mediocre errore cometterebbe colui, che havendo fabricato nave con ogni maggior diligenza, et in tutto punto corredata, e provista di marinari, nochiero, e pedota, e si fosse poi trascurato nell'apprestarle carta navigatoria, e bossolo magnetico con quali dovesse normare il suo viaggio, e nondimeno a solcare l'immenso oceano l'esponesse, così anco rassembrarebbe assordo, che essendo stato constituito l'homo con tanto artificio e magisterio, e ch'a viaggiare nel mondo, non meno che mare scogliato e turbolentissimo destinato, che non li fosse infuso il dettame del probabile, indice che nel suo camino li mostri il bene che deve seguire, et il male che li conviene evitare. Ma piuttosto stimare si deve, che tacitamente la istessa natura ci sussura e con invisibile cenno ci addita quello che convenga tracciare e scansare:

$$
\begin{aligned}
& \text { Heremus cuncti superis; temploque tacente } \\
& \text { Nil agimus non sponte dei, non vocibus ullis } \\
& \text { Numen eget, dixitque, semel nascentibus auctor } \\
& \text { Quidquid scire licet, steriles nec legit arenas } \\
& \text { Ut caneret paucis, mersitque hoc pulvere verbum. }
\end{aligned}
$$

[311] Que|sto è quel genio, che da miei calunniatori mi è opposto che come Iddio partiale dicono ch'io lo reverisca, et adori, e che mi vanto che continuamente m'assista, e che nelli più gravi et importanti urgentie mi consiglia, in modo che mentre io li fui ossequente sempre li suoi avisi mi sortirno prosperi, e quando non l'acconsentii il tutto a rovescio et infelicemente mi riuscì. 
public. Therefore, I informed those familiar to me of everything that had happened to me during this long and troubled mental discourse in the harvest and crop of such laborious and arduous work. However, I continued that I considered it to be very harmful to [310] humankind to yield to the blindness of ignorance, as I have already shown.

I warned my close friends that they should follow the guidance of the probable for actions connected to the purpose of life, as it is not obstinate or quibbling, but adaptable to opportune necessities, and more executive than discursive. In the practice of moral life, it has not deviated much from the first seeds that Nature instilled in our minds, since if it does not grasp the truth, at least it does not encounter insane contumacy or mad obstinacy. One must hence consider that great Nature was [on the one hand] most propitious to human beings in granting them material organs so close to perfection through which they could easily achieve the common customs of life, but [on the other hand] it turned out to be less liberal in providing them with rules thanks to which they could easily guide the course of life itself. It would be no small mistake for a man, once he had most diligently made a fully equipped ship provided with sailors, a helmsman, and a pilot, to neglect to supply it with a nautical chart and magnetic compass with which he could guide his voyage and be ready to sail the immense ocean. Likewise, it would be absurd if the dictate of the probable was not instilled in humankind, [which was] created with so much skill and mastery, destined to travel the world as well as the rocky and most turbulent sea. It is indeed like a sign along its path, which shows them the good they must follow and the evil they must avoid. Yet one must rather consider that this same Nature tacitly whispers to us and shows us, through invisible signs, what should be followed and avoided:

We men are all inseparable from the gods, and, even if the oracle
Be dumb, all our actions are predetermined by Heaven. The gods
Have no need to speak; for the Creator told us once for all at our
Birth whatever we are permitted to know. Did he choose these
barren sands, that a few might hear his voice? Did he bury truth in this desert? ${ }^{550}$

[311] This is that genius which my slanderers argued that I revere and adore like a demigod. [They also argued] that I boast of his continuous assistance and that he advises me with the most serious and important urgency. For that reason, when I obey him, his advice always turns out to be prosperous, but as soon as I do not agree with him, everything ends up inverted and unhappy.
One must not yield to ignorance, but must follow the probable.

He admonished them to follow the probable. 
Che il probabile non si può affermare che sia verisimile.

Si deve seguire il probabile sebbene non sa ciò che sia.

Socrate divien né amico a dotti né amico alli volgari.

Genio l'accenna che non sarà dannato.
Ma se interrogato fossi a che grado di certezza tal probabile arivasse, e che mi fosse opposto con dire che se la sincera verità ci è impedito il conseguirla, in qual maniera potrassi dire che il probabile sia almeno verisimile? Poiché mentre che l'originale e l'assimigliato ci è occulto et inaprensibile, non potiamo a modo alcuno affermare che altro li sia simile et alquanto conforme. Pittore che non conosce Pericle giamai non potrà dipingere il di lui ritratto.

A tal obbiettione risponderei, che qual grado di certezza ottenga il probabile circa l'esata verità, et in qual maniera ci la rappresenti essendone di quella non informato, ch'io ne sia ignaro, ma ben conietturo ch'egli ci sia proficuo et oltremodo salutare, pervenendoci dalle mani della natura, più solecita con li effetti a giovarci, che con le discipline adottrinarci. E l'esperienza ci insegna, che quelli attioni che per il lungo habito meno intendiamo, più espeditamente eseguimo, ma quando che con il discorso le attentiamo, stentatamente, e non senza errore operiamo. Onde bastare ci deve, il sentire che la natura a tali attioni ci impulsa, benché del perché e del come siamo ignari. Non altrimenti dovemo esser disposti, che buon soldato che de fini e consiglii del capitano non inquirisce, ma solamente con alacrità l'ossequio li presta.

Questo è quello, ottimi Giudici, che con amici e famigliari ho conferito, dal che ne seguì contra di me l'odio quasi universale di tutte le classi delli hodierni homini. E hora esprimento quanto fosse vero il detto del nostro Pericle, che nelle fattioni e guerre, la neutralità e via di mezo, quasi sempre riesce nociva a chi la segue, rimanendo alla fine questo, ad ambe le fattioni, poco amico e sovente acramente odiato. Il che senza [312] dubbio l'istesso a me accade, essendo da addottrinati odiato perché io dispregiai l'admiranda loro sapienza, né al volgo parimente amico, né hora da esso difeso, non havendoli io approbato la sua cieca e crassa ignoranza, ma antepostole il probabile e sommamente da esso volgo per la pessima consuetudine e licentiosa dissolutione corrotto, e depravato. Né perciò, ottimi Giudici, desperare debbo la mia assolutione, mentre che sotto l'auspicii della vostra integrità mi ricovro. E tanto maggiormente mi rincoro, et in essa mi confido, che il genio che giamai nelli più dubbiosi et ardui pericoli con suoi avisi non mi riuscì mendace, havendomi accennato che nel presente caso dannato non riuscirei. E di più anco fui confortato che sebbene arduo, e laborioso fu il principio di tal mio instituto, alla fine honore e gloria mi è per risultarne. 
Yet if one asked me what degree of certainty this probable may achieve, and objected by saying that we were prevented from achieving the sincere truth, how could one say that the probable at least resembles the truth? ${ }^{551}$ Since the original and the like are hidden and inapprehensible, there is no way to affirm what else is similar and conformable [to the truth]. A painter who does not know Pericles will never paint his portrait.

To these objections, I would answer that I am not aware of the degree of certainty that may be obtained by the probable as far as the exact truth is concerned, or how it may present it to us, since it is not informed of it. However, I certainly believe that it is profitable and extremely salutary, since it comes from the hands of Nature, which is more solicitous to help us through its effects than to indoctrinate us through disciplines, and experience teaches us that those actions which we understand the less because of their continuous use are carried out more quickly. Yet when we attempt [to understand] them through discourse, we act with difficulty, and not without mistakes. Hence, it must be sufficient for us to feel that Nature gives us the impulse for these actions, although we are not aware of why or how. We must be disposed like a good soldier, who does not inquire about his captain's aim or advice, but only quickly offers his obedience.

Excellent judges, this is what I discussed with friends and people close to me and whence there follows towards me the almost universal hatred of all classes of people nowadays. Only now am I experiencing how true the saying of our Pericles was, namely that in factions and wars, neutrality and the middle way were almost always harmful to the one who followed them; indeed, he ends up being unfriendly with both factions and often bitterly hated by them. Undoubtedly [312] the same has happened to me: I am hated by the learned ones, because I despised their admired wisdom, and likewise, I am not a friend of the masses, who do not defend me now because I did not approve of their blind and coarse ignorance. Yet I put the probable, highly corrupted and depraved by the masses themselves through the worst custom and licentious dissolution, above this. Nor, therefore, shall I despair of my absolution, excellent Judges, if I console myself under the auspices of your integrity. And I hearten myself even more and rely on this because my genius, who has never turned out to be untruthful with his advice in the most doubtful and arduous dangers, has told me that I will not be sentenced in the present case. Furthermore, I am comforted by the fact that although the beginning of my proposal was arduous and laborious, it will result in honour and glory for me in the end.
The probable cannot be defined as resembling the truth.

One must follow the probable, although it is not known what it is.

Socrates became an enemy of learned and of common people.

His genius says that he will be not sentenced. 
Si difende che non attentò abbattere le vere virtù.

Si discolpa della deficientia della religione.
Stimo ch'a satietà io habbia non meno esposto la cagione che m'indusse a tale retentione di assenso, che difesomi dalle colpe che circa ciò principalmente li miei malevoli mi hanno iniquamente accusato avanti il Vostro spettabilissimo Tribunale. Ma perché a questa loro principale accusa, hanno aggiunte alcune altre indoglienze, conviene che di esse alcuna cosa brevemente io ne dica.

Fui incolpato che io attentassi distrugere le morali virtù. Il che tanto è lontano, quanto io li promulgai figliole del probabile, legitime nepoti dell'istessa natura, onde che trahendo da questa li loro natali, non dissimili da essa li stimo, invincibili et immortali, ché perciò dalla oppugnatione di qual si sia acre disputa, rimangono inflessibili et invitte. E seppure dal pravo uso alcuna fiatta si piegano, di novo dalla natura invigorite, risorgono. Ma siccome queste legitime e nobili virtù celebrai, così le adulterine e fucate, che da cavilose argomentationi, stentate e false dottrine sono prodotte, non niego esserne stato sempre publico nemico e caluniatore, essendosi queste dalla natura tanto divertite che non tengono con essa alcuna allianza et affinità.

In quanto poi a quello mi è opposto della deficientia della commune religione stimo, [313] che li miei accusatori, dall'attestato de voi, Signori Giudici, rimangono affatto confusi e mendaci, bastandomi per mia difesa, che habbiate in ogni tempo osservato li ragionamenti publici e privati che ho tenuto circa la riverenza che si deve alla primiera, e più degna causa, che il tutto move e regge, havendo io sempre promulgato che la cognitione che di essa si tiene, e la veneratione che si li deve, non solamente da sottili e lontane dedotioni derivare, ma dall'istessa natura insieme con il latte ci fu imbevuto. Dal che procede che l'animo humano è tanto proclive e propenso alla religione, e divino culto, anzi che privato che fosse di tal impiego, non troppo discosto dalli bruti animali si trovarebbe.

Né le cerimonie et instituti, dalla nostra città ordinati, circa l'osservanza della religione giamai dispregiai, né omessi, ma sempre conforme li riti patrii, nelli lochi convenevoli, tempi opportuni, e con modi legitimi publicamente sacrificai. E se alcuna fiatta all'homini ignoranti m’opposi, riprendendoli della loro ridicola superstitione, o depravata religione, non perciò a guisa di giganti attentai detrudere Giove dal cielo, ma sì bene procurai levarli dall'animo quelli dispregiabili concetti che deturpano la bellezza e formosità della vera religione. 
I think that I have sufficiently expounded the reason why I was induced to withhold my assent as much as I have defended myself from the faults whereof the malevolent have iniquitously accused me before Your very respectable Court. Yet since they have added some other remonstrations to this main charge, it will be useful that I briefly say something about them.

I was accused of having attempted to destroy moral virtues. Yet this is very far away [from what I said], because I proclaimed them the daughters of the probable, the legitimate grandchildren of Nature itself. Therefore, since they have their origin from it, I consider them to be no different from it, and thus invincible and immortal, because they remain inflexible and unbeatable after the struggle of every harsh dispute. And although they sometimes warp because of this ill use, they then rise again, reinvigorated by Nature. However, just as I praised these legitimate and noble virtues, so I cannot deny having been a public enemy and slanderer of those adulterous and erroneous ones produced by quibbling argumentations and laborious and false doctrines. Indeed, they are so divergent from Nature that they do not have any alliance or affinity with it.

Then, as far as that which has been brought as a charge against me, namely that I believe in the deficiency of the common religion, is concerned, I think [313] that my accusers indeed remain confused and untruthful because of what you have attested, Lord Judges. For it is sufficient for my defence that you observe the public and private reasonings that I have always delivered concerning the reverence due to the first and worthiest cause, which moves and rules everything. Indeed, I have always promulgated that the cognition that one has of it and the veneration that is due to it come not only from subtle and wide-ranging deductions, but were also given to us along with milk by Nature itself. Hence, it follows that the human mind is so inclined and favourably disposed to religion and divine worship that if it were deprived of such a pursuit, it would not be very different from brute animals. ${ }^{552}$

I have never despised or omitted [to perform] ceremonies or institutions ordered by our city for the observance of religion, but I have always publicly offered sacrifices in accordance with the rites of my homeland, in appropriate places, at the right moment, and in a legitimate manner. ${ }^{53}$ And if I sometimes took a position against the ignorant by reprehending them for their ridiculous superstition or degenerate religion, I was not then attempting, as the Giants did, to expel Jupiter from the sky, but rather trying to remove those despicable concepts which disfigured the beauty and grace of the true religion in their minds.
He defends himself because he was not attempting to destroy the true virtues.

He defends himself from [being accused of affirming] the deficiency of religion. 
Per il che alli affatti prudenti sovente nelle orecchie intonai, che custodire si debbino dalla infettione della superstitione, epidemio e grave morbo popolare, e che advertiscano che non rare volte la religione del vil volgo, è del sapiente esecranda blasfemia e che il vero tempio d'Iddio è l'animo del sapiente, nel quale con holocausti di amore e sacrificii di veneratione è adorato. Ma che però li riti da urbani magistrati ordinati in honoranza di Iddio, con ogni maggior esterno culto si devono osservare, e nondimeno le ridicole credenze, e vane cerimonie della plebe patientare si dovessero, insino che emergesse alcuna opportunità, che senza alcuna offesa eradicarle si potessero, riuscendo sempre più salutare con l'openione del volgo destregiare che accozzare, temporeggiare [314] che affrontare.

Per mia discolpa altro non mi resta, se non che ramemorare vi dobbiate l'innocenza della mia passata vita, e sincerità di costumi, da qualunque illusoria simulatione aliena, e da ciò dedurre la fallacia e mendacità de' miei malevoli ingiuriatori. Pertanto, Signori Giudici, tal concetto nel Vostro animo di Socrate formarete, che pure s'egli con il discorso della mente, come homo in molte cose errato havesse, nondimeno la dispositione della sua volontà, al bene comune delli homini fu sempre inclinata. Per il che non solamente si trova immeritevole de calunnia, ma piuttosto degno di comendatione e lode.

Ma già il genio mi accenna che ponga fine alla mia discolpa, e di nuovo mi riaccerta e riassicura che non sono per riportare danno né nocumento alcuno, dal vostro giusto giuditio. 
Therefore, I have often solemnly said to those who were truly prudent that they must protect themselves from the infection of superstition, an epidemic and serious disease of the people. They [must] be aware that often the religion of the vile common people is abominable blasphemy for wise men and that the true temple of God is in the wise man's mind, where He is adored through offerings of love and sacrifices of veneration. Yet the rites ordered by the city magistrates for honouring God must be observed with a greater external worship. Likewise, we must tolerate the plebeians' ridiculous beliefs and vain ceremonies as long as we have the opportunity to uproot them without [causing] any damage. Indeed, it is always more salutary to dexterously manage the opinion of the masses instead of clashing with it, and to temporise [314] instead of confronting it.

For my defence, all that remains for me to do is to urge you to remember the innocence of my past life and the sincerity of my custom, which was alien to any illusory simulation; and from this, you will deduce the fallacy and mendacity of those malevolent people who have defamed me. Therefore, Lord Judges, you will form in your minds this opinion of Socrates: that although he as a man has mistaken many things in the discourse of his mind, nevertheless, the disposition of his will was always inclined to the common good of humankind; thus, he is not only undeserving of calumny, but rather worthy of commendation and praise.

Yet my genius suggests that I should end my defence, and it confirms and reassures me that I will not receive any harm or detriment from your correct judgment. 